Luís FLÁVIO NETO

\title{
OS “CONTEXTOS” NA INTERPRETAÇÃO E APLICAÇÃO DE ACORDOS DE BITRIBUTAÇÃO
}

\section{TESE DE DOUTORADO}

Orientador: Professor Titular Dr. Luís Eduardo Schoueri

Faculdade de Direito da Universidade de São Paulo São Paulo - 2015 
LUÍS FLÁVIO NETO

\section{OS “CONTEXTOS” NA INTERPRETAÇÃO E APLICAÇÃO DE ACORDOS DE BITRIBUTAÇÃO}

Tese apresentada a Banca Examinadora do Programa de Pós-Graduação em Direito, da Faculdade de Direito da Universidade de São Paulo, como exigência parcial para obtenção do título de Doutor em Direito, na área de concentração de Direito Tributário, sob a orientação do Professor Titular Dr. Luís Eduardo Schoueri.

Faculdade de Direito da Universidade de São Paulo

São Paulo - 2015 
Banca Examinadora: 


\section{AGRADECIMENTOS}

São muitos os agradecimentos a serem feitos. Agradeço não apenas aos que colaboraram diretamente para o desenvolvimento do estudo ora apresentado, mas aos que participaram do fantástico ciclo de doutorado encerrado por esta tese. Registro aqui apenas alguns, mas tenho guardada a gratidão por todos.

A professores, funcionários e todos os amigos da FACULDADE DE DIREITO DA UNIVERSIDADE DE SÃo PAULO.

Ao InSTITUTO BRASILEIRO DE DiREITO TRIBUTÁRIO - IBDT, por agregar a todos em sua nobre missão de promover a pesquisa e o ensino do Direito Tributário.

A Universidade São Judas Tadeu (USJT), a cada um de meus alunos. Ao Prof. FERnANDo Aguilar, competente Diretor da Faculdade de Direito, pelo sincero incentivo de minha licença para as pesquisas desta tese.

Ao INSTITUTE FOR AUSTRIAN AND INTERNATIONAL TAX LAW, WiRTSCHAFTSUNIVERSITÄT WIEN - WU (Áustria), pela singular oportunidade de pesquisas durante todo o ano de 2014, bem como para a participação em tantos eventos, simpósios, conferências e aulas. Ao Prof. MichAEL LANG, sempre disponível e interessado, por toda a sua contribuição. A todos os professores e colegas, a quem agradeço dirigindo-me especialmente a uma pessoa: Vielen Dank, Frau Renée Petuska!

A UNIVERSiTAT DE VALÈnCIA (Espanha), pela oportunidade de apresentação e discussão preliminar desta tese em seu "Seminar on International and EU Tax Law". Aos professores debatedores, EkKeHARt ReImer, Francisco Alfredo García Prats e Gianluigi BIZIOLI, pelo altíssimo nível de suas provocações e contribuições.

A UPPSALA UniVESITET (Suécia), pela oportunidade de apresentação e discussão preliminar desta tese em seu "Doctorate Seminar on Comparative Tax Law". Aos professores debatedores, BERTIL WIMAN e JOHN AVERY JONES, pelo altíssimo nível de suas provocações e contribuições.

Ao Prof. João Francisco Bianco e ao Prof. Roberto França Vasconcellos, pelas inestimáveis contribuições como componentes da banca de qualificação desta tese.

Aos colegas do escritório Neto Sociedade de Advogados, em especial Luis EduARdo Neto e TAMARA Hellen, pelo mais completo apoio.

A Prof. LIA DUARTE, pelas valiosas observações ao texto desta tese.

A toda minha família (Netos e Britos), pelo constante incentivo e amor incondicional. Em especial, a minha mãe, pelas raízes acadêmicas e asas para a vida.

A minha linda Thamara Brito Neto, por todos os dias, noites e madrugadas de apoio e paciência.

Em especial, ao Prof. Luís EdUARDo SCHOUERI, por sua orientação exemplar, incentivo, oportunidades acadêmicas e, acima de tudo, contagiante euforia docente e rigor técnico. 
Para Thamara Brito Neto, por todo o nosso amor, companheirismo, cumplicidade, alegria e energia. Como se não bastasse toda a sua beleza e inteligência... 
"Still the question remains. Is the statement of the ILC correct; is interpretation an art, and not a science? If this is true, then this would mean that judicial certainty is just a utopian dream; that academics, lawyers and judges alike, are artists and not legal scientists; that judicial decisions, the articles in the present volume are works of art not products of legal science; most importantly, since interpretation is a key element of legal science, the latter would be just a fiction, a mirage obstructing the true nature of an 'art of law' from shining through".

PANOS MERKOURIS (2010) ${ }^{1}$

\footnotetext{
${ }^{1}$ MERKOURIS, Panos. Introduction: Interpretation is a Science, is an Art, is a Science, in Treaty Interpretation and the Vienna Convention on the Law of Treaties. Leiden : Martinus Nijhoff, 2010, p. 12-13.
} 


\section{RESUMO}

Luís Flávio Neto. Os "contextos" na interpretação e aplicação de acordos de bitributação. 2015. 514 pgs. Doutorado. Faculdade de Direito da Universidade de São Paulo, São Paulo.

O tema da presente tese é o "contexto" referido no art. 3 da CM-OCDE para a interpretação e aplicação de termos não definidos nos textos de convenções fiscais. $\mathrm{O}$ Brasil e os seus acordos de bitributação são adotados como referenciais, embora também seja investigada a jurisprudência de uma série de outros países quanto à interpretação e aplicação de suas convenções fiscais. A Introdução apresenta o tema, o problema, a hipótese, o objetivo e as principais questões analisadas na tese, seguidas de considerações propedêuticas necessárias ao desenvolvimento de todo o trabalho. O Capítulo I se ocupa: (i) do sentido de "contexto" referido no art. 3 da CM-OCDE; (ii) do seu relacionamento com a cláusula de reenvio ao Direito doméstico prevista no mesmo dispositivo e; (iii) dos critérios formais, funcionais e materiais de reconhecimento de evidências sob o escopo do "contexto". O Capítulo II analisa o chamado "contexto intrínseco" e identifica: (i) quais evidências seriam abrangidas pelo contexto intrínseco, a exemplo do texto do acordo de bitributação, seu preâmbulo e anexos, documentos elaborados em conexão com o tratado, protocolos e acordos posteriores celebrados pelos Estados contratantes, bem como; (ii) quais técnicas seriam úteis à exploração de tais evidências, como métodos sintáticos, semânticos de interpretação do texto do acordo como um todo, testes comparativos da função e do sentido dos termos no acordo de dupla tributação como um todo, a identificação dos objetivos e propósitos do acordo a partir de detalhes de cada uma de suas partes. O Capítulo III analisa o chamado "contexto extrínseco primário", especialmente com vistas aos procedimentos amigáveis, às práticas seguidas pelos Estados (autoridades fiscais, judiciárias e legislativas) para a aplicação de acordos de dupla tributação e aos parallel treaties. O Capítulo IV aborda o chamado "contexto extrínseco secundário", que compreende as decisões de Cortes nacionais de terceiros Estados, a doutrina dos publicistas mais qualificados das diferentes Nações, a Convenção Modelo da OCDE e os seus respectivos Comentários, os trabalhos preparatórios, os atos unilaterais quanto à intenção dos Estados contratantes e as circunstâncias relacionadas à conclusão da convenção fiscal.

Palavras-chave: contexto; interpretação; aplicação; acordos de bitributação; dupla tributação; Direito tributário internacional; Convenção Modelo da OCDE; artigo 3. 


\begin{abstract}
Luís Flávio Neto. The "contexts" to the interpretation and application of tax treaties. 2015. 514 pages. Doctoral degree. Faculty of Law, University of São Paulo, São Paulo, Brazil.

This thesis deals with the "context" referred to in the art. 3 (2) of the OECD Model Tax Convention to interpretation and application of terms not defined in tax treaties. It adopts the Brazilian system and its tax treaties as reference, although it also analyzes the cases law from a number of other countries regarding the interpretation and application of its tax treaties. The Introduction presents the theme, the problem, the hypothesis, the goal and the key issues addressed by the thesis, followed by propaedeutic considerations needed to develop the whole study. The Chapter I deals with: (i) the meaning of "context" referred to in the art. 3 (2) of the OECD Model Tax Convention; (ii) the precedence between the "context" and the domestic law (general 'renvoi' clause) and; (iii) the formal, functional and material criteria for recognition of evidences under the scope of the "context". The Chapter II examines the so-called "intrinsic context", in order to: (i) identify some evidences under its scope, such as the tax treaty text, its preamble and annexes, materials prepared in connection with the convention, protocols and subsequent agreements concluded by the Contracting States, as well as; (ii) which methods would be useful to handle such materials, such as syntactic and semantic methods, comparative tests of the function and meaning terms' at the whole treaty, as well the identification of the objectives and purposes of the agreement from the details of each of its parts. The Chapter III analyses the so-called "primary extrinsic context", which includes mutual agreement procedures, practices followed by the fiscal, judicial and legislative authorities for the application of tax treaties and the parallel treaties. The Chapter IV deals with the so-called "secondary extrinsic context", which comprises decisions of national courts of third States, the teachings of the most highly qualified publicists of the various nations, the OECD Model Tax Convention and their Commentaries, preparatory works, unilateral materials about the intention of the parts and circumstances occurred at the time of the conclusion of the tax treaty.
\end{abstract}

Keywords: context; interpretation; application, tax treaties; double taxation; international tax law; OECD; article 3. 


\title{
ESTRATTO
}

\author{
Luís Flávio Neto. I "contesti" nell'interpretazione e nell'applicazione dei \\ trattati contro la doppia imposizione. 2015. 514 p. Dottorato. Facoltà di \\ Giurisprudenza, Università di Sao Paolo, Sao Paolo, Brasile.
}

La tesi dottorale verte sul concetto di "contesto" riferito all'articolo 3 (2) del modello OCSE contro la doppia imposizione nell'interpretazione e nell'applicazione dei termini non definiti nei trattati. Essa adotta il sistema brasiliano e i suoi trattati come riferimento, nondimeno analizza anche la giurisprudenza di altri stati riguardo l'interpretazione e l'applicazione dei relativi trattati. L'introduzione presenta il tema, il problema, l'ipotesi, l'obiettivo e i concetti chiave in merito alla tesi, seguiti da considerazioni propedeutiche necessarie per lo sviluppo di tale studio. Il Capitolo I tratta: (i) il significato del "contesto" riferito all'articolo 3 (2) del modello OCSE; (ii) il precedente tra il "contesto" e la legislazione nazionale (clausola generale del "renvoi") e; (iii) i criteri formali, funzionali e materiali per l'individuazione delle evidenze nell'ambito del "contesto". Il Capitolo II esamina il contesto intrinseco ("co-testo"), in modo tale da: (i) identificare alcune evidenze all'interno del suo ambito, come il testo del trattato, i suoi preamboli e i relativi allegati, lavori preparatori in relazione alla convenzione, protocolli e accordi successivi tra gli stati contraenti, così come (ii) quali metodi sono utili per trattare tali materiali, ad esempio metodi sintattici e semantici, tests comparativi della funzione e dei significati dell'intero trattato, così come l'identificazione degli obiettivi e dei propositi dell'accordo derivanti dai dettagli di ogni sua parte. Il Capitolo III analizza il contesto primario estrinseco, che include le procedure amichevoli, le pratiche seguite dalle autorità fiscali, giudiziarie e legislative nell'applicazione dei trattati e dei trattati paralleli. II Capitolo IV tratta con il contesto secondario estrinseco, che comprende decisioni di corti nazionali di stati terzi, gli insegnamenti della dottrina più qualificata di varie nazioni, il modello OCSE e il suo Commentario, i lavori preparatori, documenti unilaterali sulle intenzioni delle parti e delle circostanze occorse al momento della conclusione del trattato.

Parole chiave: contesto, interpretazione, applicazione, trattati, doppia imposizione, fiscalità internazionale, OCSE, articolo 3. 


\section{LISTA DE ABREVIATURAS}

Art.: Artigo

Asain: Assessoria de Assuntos Internacionais.

CAF-OCDE - Comitê de Assuntos Fiscais da Organização

CARF: Conselho Administrativo de Recursos Fiscais.

CDAA: Comunidade para o Desenvolvimento da África Austral.

CDAA: Convenção modelo de acordos de dupla tributação da Comunidade para o Desenvolvimento da África Austral.

CEDH: Corte Europeia de Direitos Humanos.

CF: Constituição Federal do Brasil, de 1988.

CIJ: Corte Internacional de Justiça.

CM-Alemanha: Convenção modelo de acordos de dupla tributação da Alemanha.

CM-Bélgica: Convenção modelo de acordos de dupla tributação da Bélgica.

CM-EUA: Convenção modelo de acordos de bitributação dos Estados Unidos da América

CM-Países Baixos: Convenção modelo de acordos de bitributação dos Países Baixos.

CM-ILADT: Organização para a Cooperação e Desenvolvimento Econômico Instituto Latinoamericano de Derecho Tributario.

CM-OCDE: Convenção modelo de acordos de bitributação da Organização para a Cooperação e Desenvolvimento Econômico.

CM-ONU: Convenção modelo de acordos de bitributação da Organização das Nações Unidas.

COFINS: Contribuição para o Financiamento da Seguridade Social.

CORIN: Coordenação de Relações Internacionais da Receita Federal do Brasil

COSIT: Coordenação de Tributos sobre a Renda e o Patrimônio da Coordenação-Geral do Sistema de Tributação

CTN: Código Tributário Nacional brasileiro

CVDT: Convenção de Viena Sobre o Direito dos Tratados

ECIJ: Estatuto da Corte Internacional de Justiça

ECtHR: European Court of Human Rights

EUA: Estados Unidos da América.

GATT: Acordo Geral Comercial.

IATJ: International Association of Tax Judges 
IFA: International Fiscal Association.

ILADT: Instituto Latinoamericano de Derecho Tributario.

ILC-ONU: International Law Commission da Organização das Nações Unidas

LOB: Limitation on benefits.

no: Número.

OCDE: Organização para a Cooperação e Desenvolvimento Econômico.

OECD: Organisation for Economic Co-operation and Development.

OEEC: Organisation for European Economic Cooperation.

OMC: Organização Mundial do Comércio.

ONU: Organização das Nações Unidas.

PGFN: Procuradoria Geral da Fazenda Nacional.

PICJ - Permanent Court of International Justice.

PUC-RS: Pontifícia Universidade Católica do Rio Grande do Sul.

PUC-SP: Pontifícia Universidade Católica do Rio Grande do Sul.

RFB: Receita Federal do Brasil.

TRF-2: Tribunal Regional Federal da $2^{\mathrm{a}}$ Região.

TRF-4: Tribunal Regional Federal da $4^{\mathrm{a}}$ Região.

UE: União Européia.

UFPR: Universidade Federal do Paraná.

UnB: Universidade de Brasília.

USP: Universidade de São Paulo.

WCO - World Customs Organization.

WTO - World Trade Organization. 


\section{SUMÁRIO}

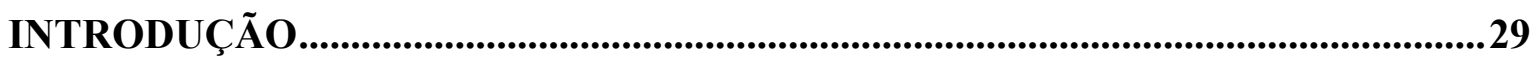

1. Tema, problema, hipótese, objetivo e principais questões analisadas na tese..........29

2. Direito Internacional e direito tributário internacional...............................................34

2.1. Direito Internacional público................................................................................................334

2.2. Direito tributário internacional................................................................................39

2.3. Direito tributário internacional do Brasil. ..................................................................46

2.4. Os acordos de dupla tributação e a CM-OCDE: protagonistas do

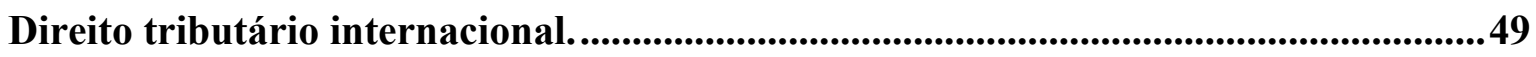

2.4.1. Além da CM-OCDE: outros modelos de acordos de bitributação.............................. 54

2.4.1.1. Convenção Modelo da Organização das Nações Unidas ("CM-ONU”) ..................55

2.4.1.2. Convenção Modelo dos Estados Unidos da América ("CM-EUA”).......................56

2.4.1.3. Outros modelos de acordos de dupla tributação .....................................................57

3. Interpretação e aplicação do Direito tributário internacional (brasileiro) ...............59

3.1. A interpretação e aplicação do Direito Internacional antes da CVDT ..................62

3.2. A interpretação e aplicação do Direito Internacional após a CVDT. ......................66

3.2.1. A única e combinada operação de interpretação prevista pela CVDT. ..................... 69

3.2.2. As normas de interpretação da CVDT e o sentido contextualizado,

o sentido consentido, o sentido comum e o sentido especial. ............................................ 72

3.2.2.1. Exemplo: Os tribunais canadenses e a busca pelo sentido contextualizado das

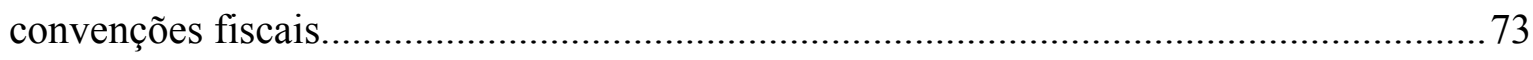

3.2.3. O contexto interpretativo dos acordos de dupla tributação almejado pelas normas de

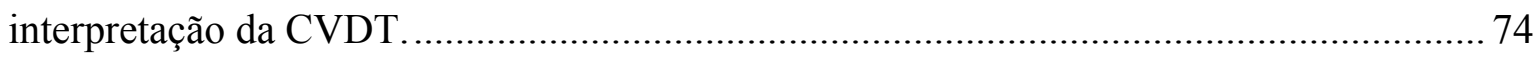

3.3. A interpretação e aplicação do Direito tributário internacional.............................75

3.3.1. A CVDT tutela a interpretação dos acordos de dupla tributação?.............................. 77

3.3.2. As regras de interpretação veiculadas pela CVDT seriam suficientes

para solucionar todas as questões relacionadas aos acordos de dupla tributação? ............... 81

3.3.3. As normas gerais da CVDT podem ser excepcionadas como

decorrência da fragmentação do Direito Internacional? .................................................... 81

3.3.4. A autonomia dos conceitos, categorias e métodos de

interpretação do Direito tributário internacional e do Direito doméstico............................ 85

3.3.4.1. A influência de concepções monistas e dualistas para a solução das questões. .....86 
3.3.4.2. A autonomia dos conceitos e categorias do Direito tributário internacional e o Direito doméstico.

3.3.4.2.1. Exemplo: o conceito de "residente" para o Direito doméstico

e para o Direito tributário internacional.

3.3.4.2.2. Exemplo: a autonomia do conceito de "dividendos" no

Direito doméstico brasileiro e no Direito tributário internacional.

3.3.4.2.3. Exemplo: A autonomia do Direito tributário internacional

nos tribunais ingleses.

92

3.3.4.3. A autonomia dos métodos de interpretação do Direito

tributário internacional e do Direito doméstico.

3.3.4.3.1. Exemplo: o caso espanhol da construção de sentido de

"royalty" do art. 12 da CM-OCDE conforme os métodos de

interpretação do Direito doméstico. 95

3.3.4.4. Os conceitos, categorias e normas de interpretação do sistema

jurídico brasileiro em face de seus acordos de dupla tributação. 96

3.3.4.4.1. Exemplo: a (não) aplicação das normas do CTN para a interpretação dos acordos fiscais brasileiros.

3.3.5. A norma especial de interpretação do art. 3 da CM-OCDE 100

3.3.5.1. O reenvio ao Direito doméstico dos Estados contratantes. 101

3.3.5.2. A cláusula da interpretação conforme o "contexto". 105

3.3.5.3. Outros termos polêmicos do art. 3 (2) da CM-OCDE. 107

3.3.5.4. A cláusula de interpretação conforme o "contexto" do

art. 3 (1) da CM-OCDE. 108

3.3.6. Dispositivos similares ao art. 3 (2) da CM-OCDE em

outros modelos de acordos de bitributação.

3.3.6.1. O art. 3 (2) da CM-ONU e os seus respectivos Comentários. 109

3.3.6.2. O art. 3 (2) da CM-EUA e os seus Comentários.

3.3.6.3. O art. 3 (2) em outros modelos de acordos de dupla tributação.

3.3.7. As versões do "art. 3 (2)" adotadas nos acordos de dupla tributação celebrados pelo Brasil. 


\section{CAPÍTULO I}

CONTEXTO INTERPRETATIVO: SELEÇÃO E UTILIZAÇÃO DE EVIDÊNCIAS QUANTO AO SENTIDO DOS TERMOS DE ACORDOS DE BITRIBUTAÇÃO..115

1. A definição e a amplitude do "contexto" referido no art. 3 da CM-OCDE...........115

\subsection{Revisão doutrinária quanto à definição e amplitude do "contexto" dos}

acordos de dupla tributação referido no art. 3 (2) da CM-OCDE................................116

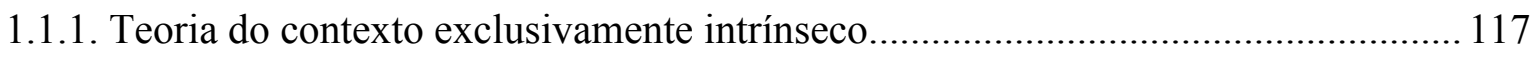

1.1.1.1. Críticas à teoria do contexto exclusivamente intrínseco..................................... 118

1.1.2. Teoria da posição oficial do CAF-OCDE quanto ao "contexto"

referido no art. 3 da CM-OCDE.

1.1.2.1. Críticas à posição oficial do CAF-OCDE quanto ao "contexto"

referido no art. 3 da CM-OCDE.

1.1.3. Teoria da correlação do "contexto" com os Comentários à

CM-OCDE e demais materiais do CAF-OCDE.

1.1.3.1. Críticas à teoria da correlação do "contexto" com os

Comentários à CM-OCDE e demais materiais do CAF-OCDE.

1.1.4. Teoria do "contexto" internacional amplo.

1.1.4.1. Críticas à teoria do "contexto" internacional amplo:

os riscos da interpretação liberal.

1.1.4.1.1. Exemplo: A “interpretação liberal” dos tribunais australianos......................... 130

1.1.4.1.2. Exemplo: A “interpretação liberal” dos tribunais canadenses......................... 131

1.1.5. Teoria da cumulação dos "contextos" internacional e nacional. .............................. 132

1.1.5.1. Críticas à teoria da cumulação dos "contextos" internacional e nacional. ............ 133

2. A ordem de precedência entre o "contexto" e o reenvio ao direito doméstico. .......133

2.1. A corrente da precedência do Direito doméstico em face do "contexto". ............136

2.1.1. Exemplo: o caso brasileiro da construção de sentido

de "lucro da empresa" ("business profit") do art. 7 da CM-OCDE

conforme o Direito doméstico.

2.1.2. Exemplo: o caso brasileiro da construção de sentido do termo

“dividendos" ("dividends") do art. 10 da CM-OCDE conforme o Direito doméstico. ..... 140

2.1.3. Exemplo: o caso espanhol da construção de sentido de "royalty"

do art. 12 da CM-OCDE conforme o Direito doméstico.

2.1.4. Exemplo: o caso canadense de interpretação das convenções

fiscais conforme o seu Direito doméstico. 
2.1.5. Exemplo: a consideração do art. 3 (2) como norma puramente de reenvio ao Direito doméstico.

2.1.6. Exemplo: a interpretação dos termos "beneficial owner" nos acordos de bitributação.

2.2. A teoria da precedência do "contexto" face ao Direito doméstico.

2.3. A teoria mista ou comparativa (Direito doméstico vs. "contexto").

2.3.1. Exemplo: o caso espanhol da construção de sentido de "royalty" do art. 12 da CM-OCDE conforme o Direito doméstico.

2.3.2. Exemplo: O termo "enterprise" na CM-OCDE

3. Uma teoria funcional sobre o sentido ordinário contextualizado

dos termos dos acordos de dupla tributação 154

3.1. A definição e a amplitude do "contexto" referido no art. 3 da CM-OCDE. .155

3.2. A relação de precedência entre o "contexto" e o Direito doméstico

na norma do art. 3 (2) da CM-OCDE.

4. A identificação das evidências sob o escopo do "contexto" referido

no art. 3 (2) da CM-OCDE: critérios formais, funcionais $e$

materiais de reconhecimento.

4.1. Critérios formais de reconhecimento: a validade das evidências

conforme os critérios do Direito Internacional.

4.1.1. Fontes formais e fontes materiais dos acordos de dupla tributação (ou: onde procurar por evidências?).

4.1.2. Normas domésticas de fundamental relevância a cada um

dos Estados contratantes.

4.2. Critérios funcionais de reconhecimento: a promoção

do efeito útil e da interpretação harmônica dos acordos de dupla tributação.

4.2.1. A promoção do efeito útil dos acordos de dupla tributação.

4.2.1.1. Exemplo: Os tribunais canadenses e o princípio pacta sunt servanda.

4.2.1.2. Exemplo: O CAF-OCDE e o princípio pacta sunt servanda.

4.2.1.3. Exemplo: o caso brasileiro da construção de sentido de

"business profit" do art. 7 da CM-OCDE conforme o Direito doméstico.

4.2.1.4. Exemplo: Os tribunais ingleses e a promoção do efeito útil das

convenções fiscais.

4.2.2. Os objetivos e propósitos de acordos de dupla tributação.

4.2.2.1. Objetivos e propósitos pressupostos dos acordos 
de dupla tributação: coordenação, cooperação e reciprocidade internacionais. 178

4.2.2.1.1. Exemplo: A reciprocidade na troca de informações.

4.2.2.2. Os objetivos e propósitos específicos do acordo de dupla tributação.

4.2.2.2.1. Exemplo: um caso brasileiro de interpretação contrária ao

objetivo e propósito de evitar a dupla tributação.

4.2.2.2.2. Exemplo: Os tribunais australianos e os objetivos e propósitos

técnicos do art. $7^{\circ}$ da CM-OCDE.

4.2.2.3. Objetivos e propósitos técnicos.

4.2.2.3.1. Exemplo: os objetivos e propósitos técnicos do art. 15 da CM-OCDE. 187

4.2.2.3.2. Exemplo: os objetivos e propósitos técnicos de oposição

a planejamentos tributários considerados abusivos.

4.2.2.4. A influência dos objetivos e propósitos dos acordos de dupla

tributação em seu processo de interpretação.

4.2.2.4.1. A negação da influência dos objetivos e propósitos

dos acordos de dupla tributação para a interpretação de seus termos.

4.2.2.4.1.1. Exemplo: Cautelas para a consideração dos objetivos

e propósitos das convenções fiscais.

4.2.2.4.1.2 Exemplo: a irrelevância dos objetivos e propósitos

na interpretação do art. 13 da CM-OCDE

4.2.2.4.2. A aparente aceitação da influência dos objetivos e propósitos

dos acordos de dupla tributação, sem atribuição de efeitos práticos na interpretação de seus termos.

4.2.2.4.3 A efetiva influência dos objetivos e propósitos dos acordos

de dupla tributação na interpretação de seus termos.

4.2.2.4.3.1. Exemplo: Os objetivos e propósitos das convenções

fiscais nos tribunais canadenses

4.2.2.4.3.2. Exemplo: o sentido do termo "payable" diante dos objetivos

e propósitos técnicos do acordo de dupla tributação Reino Unido-França.

4.2.3. A promoção da interpretação harmônica dos acordos de bitributação.

4.2.3.1. As consequências de uma interpretação devem influenciar no trabalho de intérprete?

4.2.3.2. A interpretação harmônica é realmente exigida pelo

Direito tributário internacional?

4.2.3.2.1. Exemplo: a promoção da interpretação harmônica 
nos tribunais australianos. 200

4.2.3.3. Dificuldades e objeções empíricas na aplicação da interpretação harmônica .....200

4.2.3.4. Interpretações divergentes suportadas pelo Direito tributário internacional. .......202

4.3. Critério mateiral de reconhecimento: a plausividade da interpretação........................ 204

4.3.1. Exemplo: o caso brasileiro da construção de sentido de

"business profit" do art. 7 da CM-OCDE conforme o Direito doméstico. 204

\subsection{Linguagem tributária internacional: requisito fundamental} para a seleção de evidências do sentido contextualizado?

\section{CAPÍtUlo II}

O CONTEXTO INTRÍNSECO DOS ACORDOS DE DUPLA TRIBUTAÇÃO ......208

1. Notas introdutórias. ..............................................................................................208

2. Hierarquia de fontes: a relação de prevalência entre

evidências intrínsecas e extrínsecas.........................................................................211

\subsection{A corrente da consideração lexical e da suficiência do} sentido literal "claro".

2.1.1. Exemplo: O Caso Falcão.

2.1.2. Exemplo: A consulta de dicionários nos tribunais britânicos................................. 214

2.1.3. Exemplo: O uso comercial dos termos dos acordos de bitributação. ....................... 215

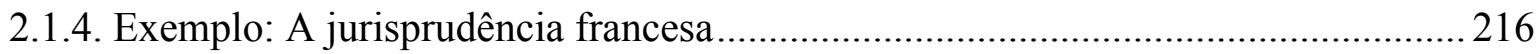

2.1.5. Críticas à corrente da consideração lexical e da suficiência do sentido literal "claro".

2.1.6. A utilidade de dicionários na interpretação de acordos de dupla tributação.

2.1.7. A recusa da aplicação da teoria da consideração lexical dos termos dos acordos de bitributação pelos tribunais.

2.1.7.1 Exemplo: A experiência brasileira e os riscos da consideração lexical dos termos das convenções fiscais.

2.1.7.2. Exemplo: Os tribunais canadenses e a rejeição da consideração

lexical dos termos das convenções fiscais.

2.1.7.3. Exemplo: a rejeição do sentido lexical do termo "payable"

do acordo de dupla tributação Reino Unido-França.

2.1.7.4. Exemplo: o sentido do termo "exchange" referido

no 26 (3) do acordo de bitributação Canadá-França.

\subsection{A corrente da suficiência do sentido "claro" provido}


por elementos do contexto intrínseco....................................................................226

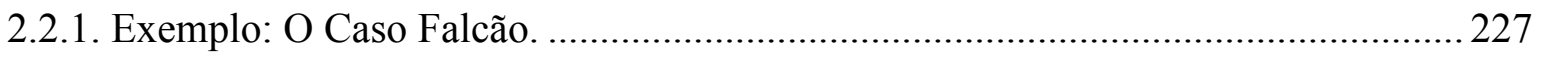

2.2.2. Exemplo: Os tribunais ingleses e a rejeição da corrente da suficiência

do sentido "claro" provido por elementos do contexto intrínseco.....................................228

2.2.3. Exemplo: o sentido do termo "person" referido no

art. 26 (3) do acordo de bitributação EUA-Reino Unido......

2.3. O contexto intrínseco como apenas um dos estágios da investigação. ....................230

2.3.1. Exemplo: A interpretação holística nos tribunais australianos ................................ 232

3. A identificação de evidências do contexto intrínseco: o ponto de partida

para a construção do sentido contextualizado dos termos de acordos

de dupla tributação.................................................................................................................233

3.1. O texto do acordo de dupla tributação, seu preâmbulo e anexos...........................234

3.1.1. Exemplo: Evidências levantadas a partir do preâmbulo do acordo

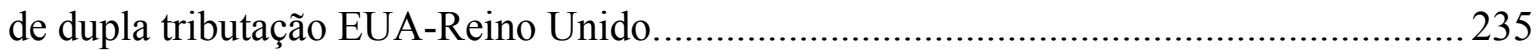

3.1.2. Exemplo: Evidências levantadas a partir do preâmbulo do acordo

de dupla tributação Reino Unido-França.

3.1.3. Exemplo: Evidências levantadas a partir do preâmbulo do acordo

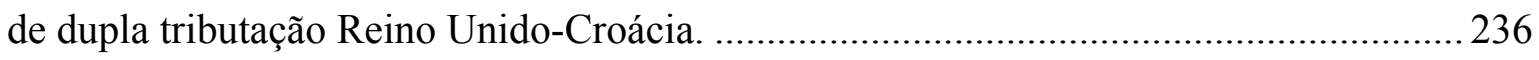

3.2. Documentos elaborados em conexão com o acordo de dupla tributação. ............236

3.2.1. Protocolos anexados aos acordos de dupla tributação............................................ 238

3.2.1.1. Exemplo: O sentido de "pessoa" no acordo Brasil-Canadá,

conforme o seu protoloco.

3.2.1.2. Exemplo: O sentido de "residente de um Estado contratante"

referido no art. 14 dos acordos celebrados pelo Brasil.

3.2.1.3. Exemplo: O sentido de "royalties" no acordo Brasil-Hungria,

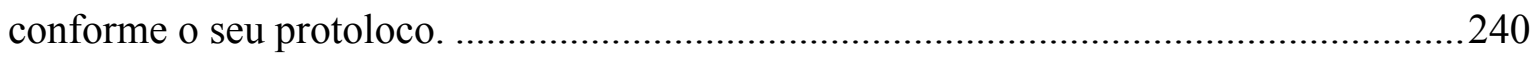

3.2.1.4. Exemplo: A adoção de protocolos para a alteração da convenção fiscal. .............241

\subsection{Acordos posteriores celebrados pelos Estados contratantes}

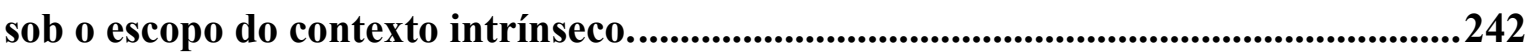

3.3.1. Memorandos de entendimentos quanto ao acordo de dupla tributação................... 243

3.3.1.1. Exemplo: o “Joint Explanatory Memorandum” ao acordo

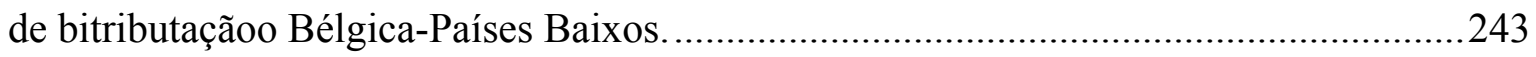

4. A exploração das evidências do contexto intrínseco.......................................................2244

4.1. Adoção de métodos sintáticos e semânticos na interpretação 
do texto do acordo como um todo.

4.1.1. Exemplo: o termo "income" e os métodos sintáticos e semânticos

de interpretação textual do acordo de dupla tributação Canadá-Alemanha.

4.1.2. Exemplo: os tribunais canadenses e o métodos de dedução indireta.

\subsection{Testes comparativos: a função e o sentido dos termos}

no acordo de dupla tributação como um todo

4.2.1. Exemplo: A experiência brasileira da interpretação de termos

das convenções fiscais comparando a sua utilização em diferentes dispositivos.

4.2.2. Exemplo: a comparação do "tax", nos art. 2, 23, 24, 26 e 27 da CM-OCDE

4.2.3. Exemplo: a comparação dos termos "enterprise", "person" e

"business" para a interpretação da CM-OCDE.

4.2.4. Exemplo: A experiência australiana da interpretação de termos

das convenções fiscais comparando a sua utilização em diferentes dispositivos.

4.2.5. Exemplo: a comparação do termo "income" em dispositivos

do acordo de bitributação Canadá-Alemanha.

4.2.6. Exemplo: a comparação da função dos enunciados para a interpretação

do acordo de dupla tributação EUA-Reino Unido.

4.2.7. Exemplo: a comparação do termos "beneficial owner",

"beneficiário efetivo" no art. 10, 11 e 12 da CM-OCDE.

\subsection{A identificação dos objetivos e propósitos do acordo a partir de detalhes}

de cada uma de suas partes: análise do texto do acordo como um todo

4.3.1. Exemplo: A experiência norte-americana de identificação dos objetivos e propósitos do acordo a partir de detalhes de cada uma de suas partes.

4.3.2. Exemplo: A identificação do treaty entitlement pela análise

de diferentes dispositivos da convenção fiscal.

4.3.3. Exemplo: a interpretação do termo "tax" com base nos objetivos e

propósitos do acordo desvendados a partir de detalhes de cada uma de suas partes

4.3.4. Exemplo: a interpretação da expressão "borne by a permanent

establishment" com base nos objetivos e propósitos do acordo

desvendados a partir de detalhes de cada uma de suas partes 


\section{CAPÍTULO III}

O CONTEXTO EXTRÍnSECO PRIMÁRIO DOS ACORDOS DE DUPLA TRIBUTAÇÃ O .................................................................................................................258

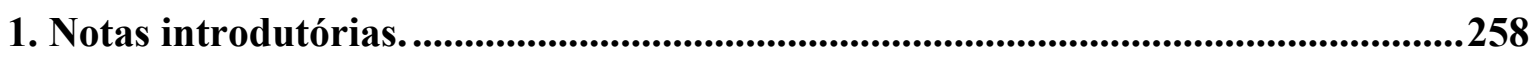

2. Procedimento amigável: evidências extrínsecas no Direito tributário internacional? ..................................................................................260

2.1. Os procedimentos amigáveis previstos na CM-OCDE...........................................2261

2.2. O procedimento amigável previsto na CM-ONU.................................................264

2.3. O procedimento amigável previsto na CM-EUA............................................2264

2.4. Critérios formais de reconhecimento: a validade e a eficácia dos procedimentos amigáveis perante o Direito tributário internacional...........................265

2.4.1. A corrente da invalidade dos procedimentos amigáveis, com vistas à Constituição.

2.4.2. A corrente da validade dos procedimentos amigáveis,

à revelia da Constituição.

2.4.3. A corrente da validade dos procedimentos amigáveis, com vistas à Constituição.

2.4.4. O status dos procedimentos amigáveis entre as evidências do "contexto" referido no art. 3 (2) da CM-OCDE.

2.5. Critérios funcionais e materiais de reconhecimento dos procedimentos amigáveis como "contexto".

3. Práticas seguidas pelos Estados para a aplicação de acordos de dupla tributação.

3.1. Funções, perfil e posição das práticas subsequentes

no Direito Internacional público.

3.2. As práticas subsequentes no Direito tributário internacional.

\subsection{Decisões e normas enunciadas por autoridades fiscais}

sobre a aplicação de acordos de dupla tributação.

3.3.1. Exemplo: o caso brasileiro da construção de sentido de "lucro da empresa" ("business profit") do art. 7 da CM-OCDE pelas autoridades fiscais.

3.3.2. Exemplo: A consideração de decisões de autoridades fiscais sobre

a aplicação de acordos de dupla tributação no Canadá.

3.3.3. Exemplo: A consideração de decisões de autoridades fiscais sobre a aplicação de acordos de dupla tributação nos EUA. 
3.4. Decisões judiciais do outro Estado contratante.

3.4.1. Critérios formais de reconhecimento de evidências:

decisões judiciais do outro Estado contratante.

3.4.2. Critérios funcionais de reconhecimento de evidências:

decisões judiciais do outro Estado contratante

3.4.3. Critérios materiais de reconhecimento de evidências:

decisões judiciais do outro Estado contratante

3.4.4. O efetivo processo de comunicação entre as Cortes nacionais.

3.4.4.1. Exemplo: A consideração de decisões judiciais do outro Estado contratante por tribunais da Austrália.

3.4.4.2. Exemplo: A consideração de decisões judiciais do outro Estado

contratante por tribunais do Reino Unido.

3.4.4.3. Exemplo: A consideração de decisões judiciais do outro Estado contratante por tribunais do Canadá.

3.4.5. Dificuldade de acesso às decisões de Cortes nacionais de outros Estados.

3.4.6. Lege ferenda: medidas para a facilitação do acesso às informações

quanto à interpretação do acordo de dupla tributação por parte do

outro Estado contratante.

\subsection{Alterações no Direito doméstico dos Estados contratantes}

como práticas subsequentes à conclusão do acordo: seu status de evidência

do sentido de termos dos acordos de dupla tributação.

3.5.1. Exemplo: A consideração de alterações legislativas subsequentes

como evidências para a interpretação de convenção fiscal celebrada pelos EUA

4. Parallel treaties: O princípio da integração sistêmica dos acordos

internacionais e as evidências extrínsecas primárias....................................................306

4.1. O recurso a parallel treaties nos Tribunais internacionais....................................308

4.2 Parallel treaties no Direito tributário internacional................................................309

4.2.1. Parallel treaties: outros acordos de dupla tributação como pares

de comparação.

4.2.1.1. Exemplo: O recurso aos parallel treaties em julgados do CARF.

4.2.1.2. Exemplo: O recurso aos parallel treaties nos tribunais dos EUA. ........................ 314

4.2.1.3. Exemplo: O recurso aos parallel treaties nos tribunais do Reino Unido...............314

4.2.1.4. Exemplo: O recurso aos parallel treaties nos tribunais do Canadá.

4.2.2. Parallel treaties: outros acordos internacionais que afetam a 
matéria tributária como pares de comparação.

4.2.2.1. Exemplo: O recurso a outras espécies de tratados internacionais

em matéria tributária para a interpretação do termo "tax" utilizado na CM-OCDE.

4.2.3. Parallel treaties: acordos internacionais em matéria não tributária

como pares de comparação.

\section{CAPÍTULO IV}

O CONTEXTO EXTRÍNSECO SECUNDÁRIO DOS ACORDOS DE DUPLA

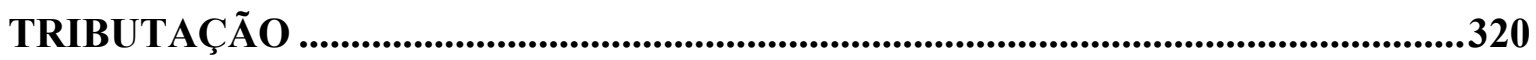

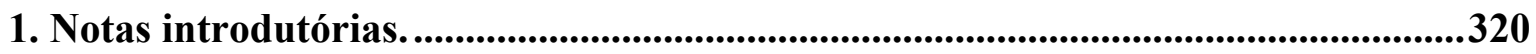

2. A admissibilidade de evidências extrínsecas secundárias no processo

de construção de sentido de termos dos acordos de dupla tributação.

2.1. A corrente da admissibilidade irrestrita, fundada na ineficácia técnica da CVDT.

2.2. A corrente da não admissibilidade de evidências do contexto extrínseco secundário.

2.3. A corrente da admissibilidade condicionada a situações restritas e

com propósitos limitados, fundada na norma da CVDT.

2.4. A corrente da admissibilidade condicionada a situações restritas e com propósitos amplos, fundada na norma da CVDT.

2.5. Corrente da admissibilidade e propósitos amplos, com atenção à CVDT.

2.6. Positivo: é pertinente a investigação de evidências extrínsecas secundárias.

3. Decisões de Cortes nacionais de terceiros Estados como

evidências do contexto extrínseco secundário.

3.1. Critérios formais de reconhecimento..............................................................331

3.2. Critérios funcionais de reconhecimento. ...............................................................332

3.3. Critérios materiais de reconhecimento...........................................................334

3.3.1. Exemplo: A consideração de decisões de terceiros Estados

por tribunais do Canadá.

3.3.2. Exemplo: A consideração de decisões de terceiros Estados

por tribunais da Austrália.

4. A doutrina dos publicistas mais qualificados das diferentes Nações

como evidência indireta do sentido de termos de convenções fiscais.

4.1. Quem produz os elementos referidos no art. 38 (1) “c”" do ECIJ: “a doutrina 
dos publicistas mais qualificados das diferentes Nações"? ..............................................340

4.1.1. Quem são os publicistas mais qualificados das diferentes nações?.

4.1.1.1. Exemplo: A influência da doutrina na interpretação de acordos de bitributação pelo CARF.

4.1.2. Instituições podem produzir "a doutrina dos publicistas mais qualificados das diferentes Nações"?

5. A CM-OCDE, os Comentários à CM-OCDE e outros materiais

como evidências do sentido contextualizado de termos de convenções físcais.

5.1. Modelos de tratado como pares de comparação: parallel treaty impróprio.

5.1.1. A CM-OCDE como par de comparação.

5.1.1.1. Exemplo: Os tribunais ingleses e a adoção da CM-OCDE

como par de comparação.

5.1.1.2. Exemplo: Os tribunais canadenses e a adoção da CM-OCDE

como par de comparação.

5.1.2. Reservas à CM-OCDE e as suas consequências para a interpretação dos acordos de bitributação

5.1.3. Outros modelos de outras espécies de acordos internacionais

em matéria tributária como pares de comparação.

5.1.3.1. Exemplo: Outros modelos de outras espécies de acordos internacionais para a interpretação do termo "tax" da CM-OCDE.

\subsection{Comentários à CM-OCDE e Reports publicados pelo CAF-OCDE:}

breve retrospecto.

5.2.1. Exemplo: $\mathrm{O}$ recurso aos Comentários à CM-OCDE pela PGFN.

5.2.2. Exemplo: $\mathrm{O}$ recurso aos Comentários à CM-OCDE nos tribunais australianos....... 353

5.2.3. Exemplo: O recurso aos Comentários à CM-OCDE nos tribunais canadenses....... 354

5.2.4. Exemplo: O recurso aos Comentários à CM-OCDE pelo próprio

CAF-OCDE (circularidade).

\subsection{A natureza jurídica dos Comentários à CM-OCDE entre as evidências} admitidas para a construção do sentido ordinário contextualizado dos termos da CM-OCDE.

5.3.1. Os Comentários à CM-OCDE como acordo multilateral (CVDT, art. 31)............. 356

5.3.2. Os Comentários à CM-OCDE como declarações interpretativas unilaterais. .......... 358

5.3.3. Os Comentários à CM-OCDE como instrumentos estabelecidos

em conexão com cada acordo de dupla tributação (CVDT, art. 31 (2)). 
5.3.3.1. Exemplo: Os Comentários á CM-OCDE sob o art. 31 (2) da CM-OCDE 359

5.3.4. Os Comentários à CM-OCDE como sentidos especiais atribuídos pelas partes (CVDT, art. 31 (4)).

5.3.5. Os Comentários à CM-OCDE como trabalhos preparatórios (CVDT, art. 32)....... 361

5.3.6. Os Comentários à CM-OCDE como circunstâncias em que

os acordos de dupla tributação são celebrados (CVDT, art. 32).

5.3.6.1. Exemplo: Os tribunais do Canadá e a consideração dos Comentários à

CM-OCDE como circunstâncias em que as convenções fiscais são celebradas.

5.3.7. Os Comentários à CM-OCDE como práticas ou acordos subsequentes

(CVDT, art. 31 (3)).

5.3.8. Os Comentários à CM-OCDE como "soft law".

5.3.9. Os Comentários à CM-OCDE como elemento da integração sistêmica

(CVDT, art. 31 (3) “c").

5.3.10. Os Comentários à CM-OCDE como doutrina dos publicistas mais qualificados das diferentes nações (CVDT, art. 31 (3) “c”, c/c ECIJ, art. 38 (1) “c”)....

5.3.11. Os Comentários à CM-OCDE como um contexto extrínseco sem paralelo na CVDT.

5.3.12. Conclusões e uma questão a mais: a mutação do status dos

Comentários à CM-OCDE entre as evidências admitidas para a

interpretação dos termos das convenções fiscais.

5.3.12.1. Exemplo: O caso mexicano de mutação do status dos

Comentários à CM-OCDE.

5.4. Oposição de observações aos Comentários à OCDE: consequências

sobre o seu status de evidência do sentido de termos dos acordos de

dupla tributação.

5.4.1. Exemplo: A relevância de observações aos Comentários à

CM-OCDE para os tribunais da Espanha.

\subsection{A natureza jurídica dos Comentários à CM-OCDE perante}

um Estado não membro e que não o adota integralmente em seus

acordos de dupla tributação: Brasil.

5.6. Critérios funcionais: a promoção do efeito útil e da interpretação

harmônica pelos Comentários à CM-OCDE. 
5.6.1. Exemplo: A consideração dos Comentários à CM-OCDE pelos

tribunais ingleses como forma de promover o efeito útil e a interpretação

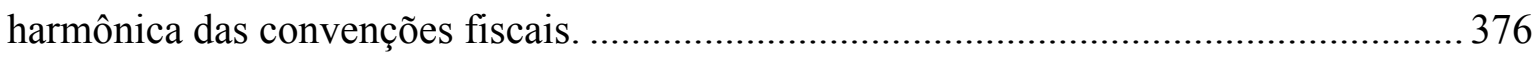

5.7. $O$ critério material: a plausibilidade dos Comentários à CM-OCDE....................377

5.8. Revisões nos Comentários à CM-OCDE e a sua influência na

construção de sentido dos termos dos acordos de dupla tributação.

5.8.1. A política de revisões frequentes dos Comentários à CM-OCDE.

5.8.1.1. Exemplo: nem todos os Comentários à CM-OCDE são constantemente revisados.

5.8.2. A perda de credibilidade dos Comentários em função de suas

constantes revisões.

5.8.2.1. Revisão dos Comentários à CM-OCDE para amplificar interpretações

que desde sempre seriam possíveis a partir do texto dos acordos de dupla tributação

5.8.2.1.1. Exemplo: revisões amplificadoras de interpretações

desde sempre possíveis.

5.8.2.2. Revisão dos Comentários à CM-OCDE para o preenchimento

de lacunas dos acordos de dupla tributação.

5.8.2.2.1. Exemplo: revisões dos Comentários à CM-OCDE para

o preenchimento de lacunas no art. 17 dos acordos de bitributação.

5.8.2.3. Revisão dos Comentários à CM-OCDE para a reversão de posições

anteriores do CAF-OCDE.

5.8.2.3.1. Exemplo: revisões dos Comentários à CM-OCDE para a

reversão de posições sobre o art. 15 dos acordos de bitributação.

5.8.2.3.2. Exemplo: outras revisões dos Comentários à CM-OCDE para

a reversão de posições nos acordos de bitributação.

5.8.2.4. Revisão dos Comentários à CM-OCDE para alinhamento

às novas práticas dos Estados.

6. Trabalhos preparatórios como evidências sob o escopo do contexto extrínseco dos acordos de dupla tributação.

6.1. A identificação de trabalhos preparatórios dos acordos de dupla tributação.

6.2. A eficácia jurídica de trabalhos preparatórios dos acordos de dupla

tributação. 392

6.3. Critérios funcionais de reconhecimento de trabalhos preparatórios 
dos acordos de dupla tributação.

6.4. Critérios materiais de reconhecimento de trabalhos preparatórios

dos acordos de dupla tributação.

7. Atos unilaterais quanto à intenção dos Estados contratantes.

7.1. Os efeitos jurídicos dos atos unilaterais dos Estados

perante as Cortes Internacionais.

7.2. Os atos unilaterais dos Estados contratantes como expressão

do Direito tributário internacional.

7.3. Exposições de motivos, memorandos e "technical explanations" utilizados

pelo Poder Legislativo no processo de ratificação do acordo de dupla tributação. 402

7.3.1. Exemplo: o recurso a materiais unilaterais por tribunais norte-americanos........... 404

7.3.2. Exemplo: o recurso a materiais unilaterais por tribunais canadenses..................... 406

7.3.3. Exemplo: o recurso a materiais unilaterais por tribunais australianos..................... 406

7.4. Testemunho pessoal dos negociadores. .............................................................407

7.4.1. Exemplo: a importância do testemunho dos negociadores para os

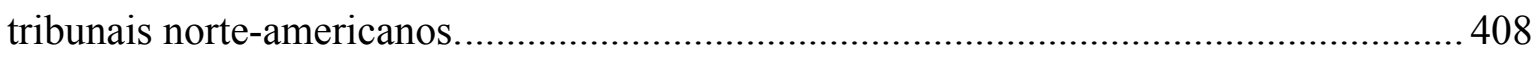

7.5. Atos normativos das autoridades administrativas.................................................408

8. Circunstâncias relacionadas à conclusão do acordo de dupla tributação como evidências do sentido de seus termos...............................................409

8.1. Circunstâncias fáticas ocorridas no período das negociações e da celebração do acordo de dupla tributação.

8.1.1. Exemplo: Os tribunais ingleses e a consideração de circunstâncias

fáticas ocorridas no período das negociações da convenção físcal.

8.1.2. Exemplo: Os tribunais canadenses e a consideração de circunstâncias

fáticas ocorridas no período das negociações da convenção fiscal.

8.1.3. Exemplo: Os tribunais australianos e a consideração de

circunstâncias fáticas ocorridas no período das negociações da convenção fiscal.

8.2. Acordos de dupla tributação anteriormente celebrados entre os mesmos Estados.

8.2.1. Exemplo: A análise do texto original para a compreensão do texto

do acordo modificado por protocolo.

8.3. O Direito doméstico dos Estados contratantes no momento da

celebração da convenção fiscal. 
8.3.1. Exemplo: Os tribunais canadenses e a consideração do Direito doméstico dos Estados contratantes no momento da celebração da convenção físcal.

8.3.2. Exemplo: Os tribunais norte-americanos e a consideração do Direito doméstico

dos Estados contratantes no momento da celebração da convenção fiscal......

8.4. A origem histórica do termo utilizado no acordo de dupla tributação.

8.4.1. Exemplo: A origem dos termos beneficiário efetivo ("beneficial owner").

8.4.2. Exemplo: a distinção entre sistemas jurídicos de tradição no common law e no civil law.

8.4.3. Exemplo: O termo "enterprise" na CM-OCDE.

8.5. A participação de um ou de ambos os Estados contratantes

em grupos econômicos

8.6. A celebração de acordos entre países industrializados

e países em desenvolvimento.

8.7. A política adotada por parte dos Estados contratantes em relação aos acordos de dupla tributação.

8.8. O idioma no qual as negociações foram conduzidas.

CONCLUSÕES

APÊNDICE 01.

A REDAÇÃO DO “ART. 3 (2)” NOS MODELOS DE CONVENÇÕES

FISCAIS E NOS ACORDOS DE BITRIBUTAÇÃO BRASILEIROS

1. O "art. 3 (2)" nos variados modelos de convenções fiscais.

2. O “art. 3 (2)" nos acordos de bitributação celebrados pelo Brasil.

APÊNDICE 02.

DESCRIÇÃO DE CASOS DE APLICAÇÃO DE ACORDOS DE DUPLA TRIBUTAÇÃO POR TRIBUNAIS BRASILEIROS

CITADOS NO TRABALHO. 445

1. "Caso Alubar". 445

2. "Caso BBA". 446

3. "Caso Air France". 448

4. "Caso Copesul". 449

5. "Caso Falcão" 451 
APÊNDICE 03. 453

DESCRIÇÃO DE CASOS DE APLICAÇÃO DE ACORDOS DE DUPLA TRIBUTAÇÃO POR TRIBUNAIS ESTRANGEIROS

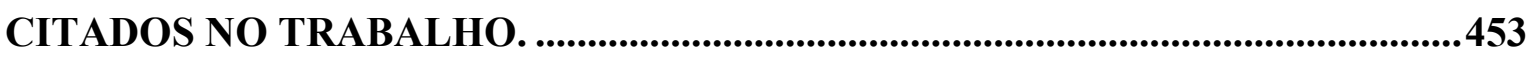

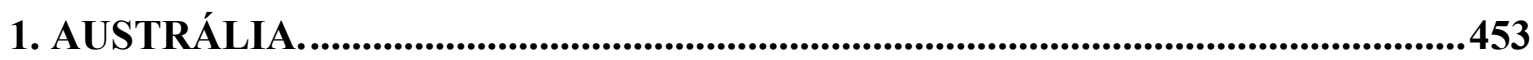

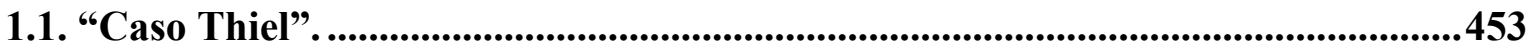

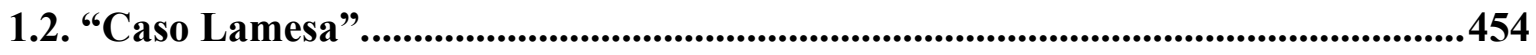

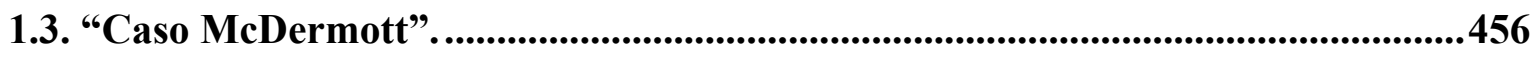

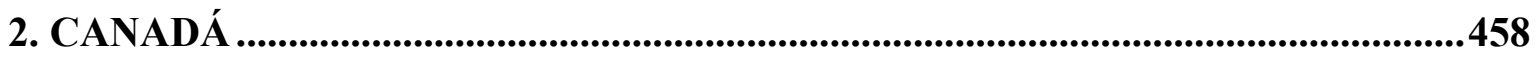

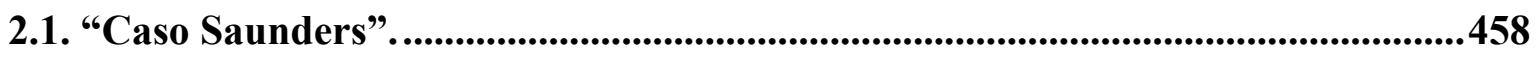

2.2. "Caso Ezra".........................................................................................................................459

2.3. "Caso Cruikshank" .............................................................................................................461

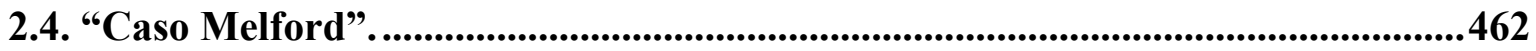

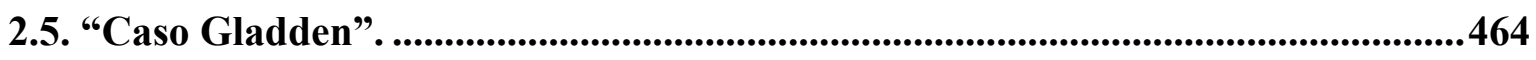

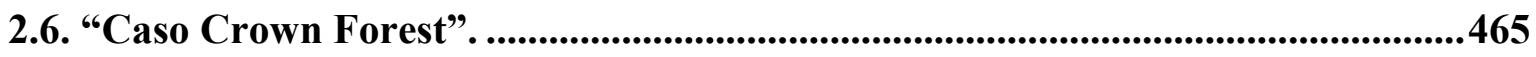

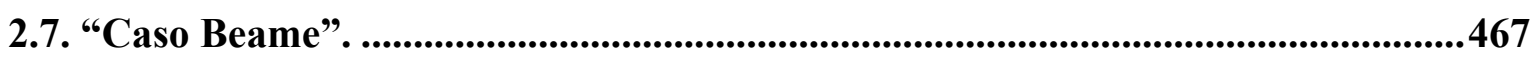

2.8. Caso Pacific Network ....................................................................................468

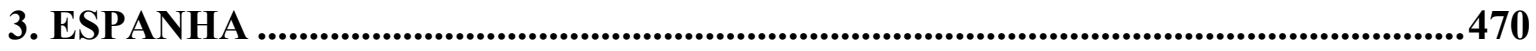

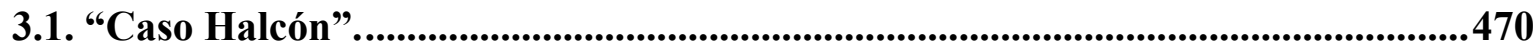

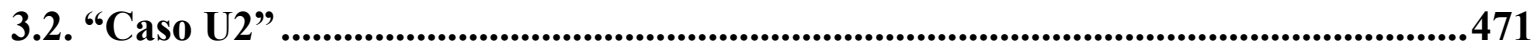

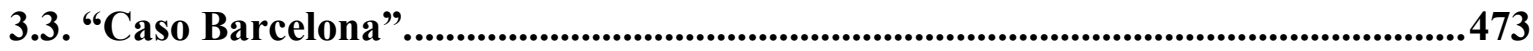

3.4. "Caso Televisió de Catalunya"..................................................................................474

4. ESTADOS UNIDOS DA AMÉRICA (EUA) ...................................................476

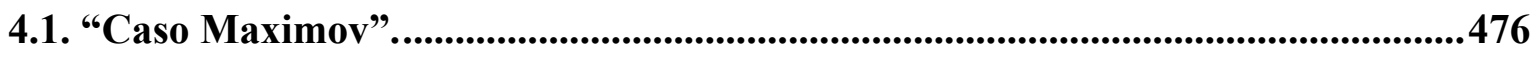

4.2. "Caso Johansson". ...............................................................................................................478

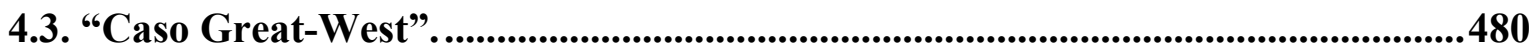

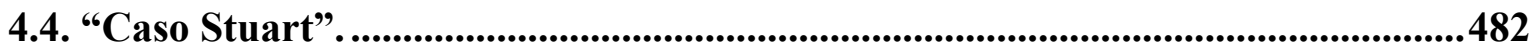

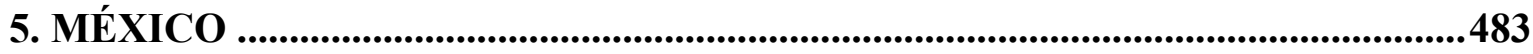

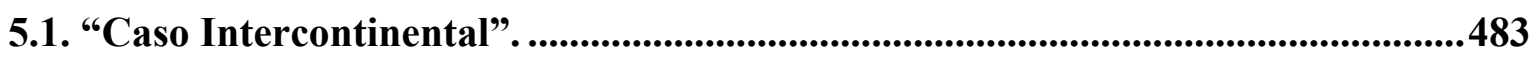

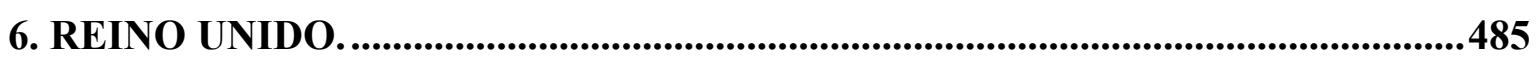

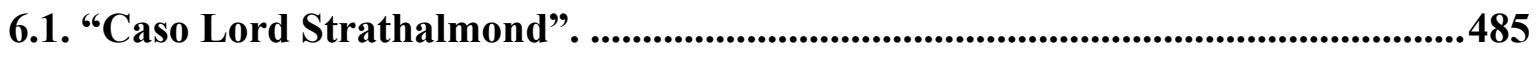

6.2. "Caso Ostime"'..................................................................................................................4486

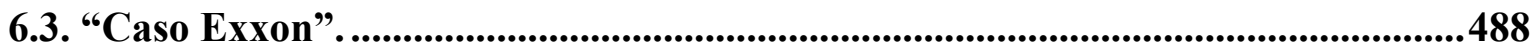


6.4. "Caso Vas", ................................................................................................................................489

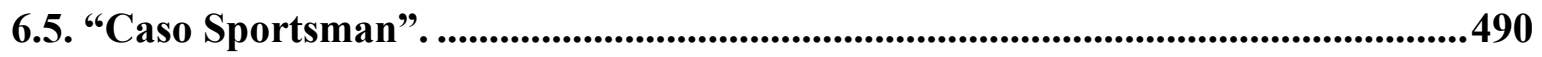

6.6. "Caso Banco do Brasil/Commerzbank"...........................................................491

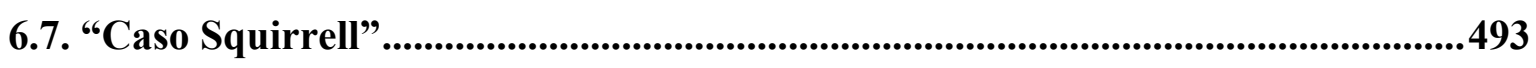

REFERÊNCIAS BIBLIOGRÁFICAS............................................................................497

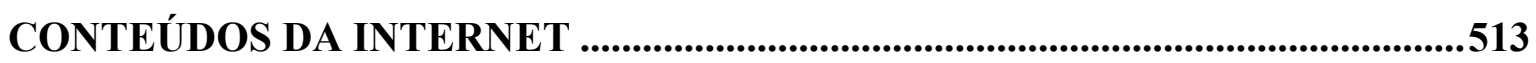




\section{INTRODUÇÃO}

\section{TEMA, PROBLEMA, HIPÓTESE, OBJETIVO E PRINCIPAIS QUESTÕES ANALISADAS NA TESE.}

"On the one hand, there are those who are seeking, as it were, to describe the process of interpretation and who are seeking, as it were, attention upon the materials to be which the would-be interpreter should consult: and, on the other hand, there are those who are seeking to establish certain principles or rules as to the relative value or weight to be attributed to the materials to be taken into consideration". IAN SINCLAIR $(1973)^{2}$

O Direito tributário internacional é repleto de temas intrigantes, entre os quais destacam-se a interpretação e a aplicação dos acordos internacionais para evitar a dupla tributação.

Geralmente, tais acordos de bitributação possuem dispositivos cujos termos são definidos em seu texto, como sugerido no art. 3 (1) da Convenção Modelo da Organização para a Cooperação e Desenvolvimento Econômico (“CM-OCDE”). Assim, para a aplicação das convenções físcais, tais termos devem ser interpretados conforme as acepções descritas em seu texto, a não ser que o "contexto" requeira um sentido diverso.

Também é comum que tais acordos de bitributação possuam cláusula segundo a qual os seus termos, quando não definidos expressamente, sejam interpretados conforme o sentido que lhes for atribuído pela legislação do Estado que os aplica, a não ser que o "contexto" exija um sentido diverso. Trata-se do art. 3 (2) da CM-OCDE 3 , o qual ocupa papel central no presente estudo. O “Apêndice 01" apresenta quadros comparativos da redação do "art. 3 (2)" nos variados modelos de convenções físcais e nos acordos de bitributação brasileiros, aos quais serão feitas referências no decorrer de todo este trabalho.

Nesse seguir, a presente tese de doutorado tem o propósito de contribuir para o tema da interpretação dos acordos de dupla tributação, com a investigação do sentido, conteúdo e forma de utilização do "contexto" referido no art. 3 da CM-OCDE. Em tal análise, serão consideradas as diferentes versões desse dispositivo já sugeridas pelo Comitê

${ }^{2}$ SINCLAIR, Ian M. The Viena Convention on the Law of Treaties. Manchester University Press : Manchester, 1973, p. 73.

${ }^{3}$ Vide: “Apêndice I - A redação do 'art. 3 (2)' nos modelos de convenções fiscais e nos acordos de bitributação brasileiros". 
de Assuntos Fiscais daquela instituição (“CAF-OCDE”) e adotadas em acordos de dupla tributação efetivamente celebrados por diferentes Estados, especialmente pelo Brasil.

O problema que se apresenta para análise consiste na existência de uma série de termos não definidos nos acordos de dupla tributação, ou mesmo definidos nestes, em relação aos quais os operadores do Direito tributário internacional devem questionar a existência de sentidos consentidos aplicáveis à relação jurídica mantida pelos Estados contratantes, construídos a partir de seu "contexto" e não necessariamente colhidos do Direito doméstico.

No decorrer deste trabalho, será investigado como o "contexto" pode contribuir para a interpretação e aplicação dos acordos de bitributação, utilizando-se como exemplo de importantes termos, como "imposto" ("tax"), lucro das empresas ("business income"), "beneficiário efetivo" ("beneficial owner") e "artistas e desportista" ("artistes and sportsmen", pago (“paid”), pensões (“pension”).

Não se pode dizer tratar-se de tema novo. Sua atualidade, no entanto, decorre dos latentes questionamentos e dificuldades que tornam turva a própria concepção de "contexto" no art. 3 da CM-OCDE. Há uma série de dúvidas, ainda hoje existentes na doutrina e na jurisprudência, se o "contexto" realmente poderia de fato colaborar para a construção de sentido de termos utilizados nas convenções fiscais ou se o reenvio ao Direito doméstico seria a solução a ser adotada na generalidade dos casos.

Sejam os acordos internacionais causa ou consequência do fenômeno da globalização ${ }^{4}$, os últimos cinquenta anos foram marcados pelo crescimento estrondoso de convenções fiscais, dado o reconhecimento universal de que a bitributação da renda deve ser evitada para o desenvolvimento da atividade econômica mundial ${ }^{5}$. A criação de tratados dessa espécie fez surgir importantes dúvidas e divergências relacionadas à sua interpretação que prejudicam o seu bom funcionamento. Nesse cenário, o tema ora analisado apresenta importância teórica e prática. Avanços na compreensão da norma de

\footnotetext{
${ }^{4}$ Sobre a discussão se os acordos de dupla tributação configuram causa ou consequência da globalização, vide: VASCONCELLOS, Roberto França. Aspectos Econômicos dos Tratados Internacionais em Matéria Tributária, in Revista de Direito Tributário Internacional n. 1. São Paulo: Quartier Latin, 2005, p. 147 e seg. ${ }^{5}$ Cf. BIANCO, João Francisco. A CIDE sobre royalties e os tratados internacionais contra a dupla tributação, in Grandes Questões Atuais do Direito Tributário vol. 8 (Coord. Valdir de Oliveira Rocha). São Paulo : Dialética, 2004, p. 244.
} 
interpretação e aplicação desses acordos internacionais podem trazer significativos retornos à sociedade ou, como preferem alguns, à "sociedade internacional" 6 .

O tema da interpretação e aplicação dos acordos de bitributação deve ser bem compreendido, como premissa para a cumprimento das obrigações assumidas pelo Brasil perante outras nações, tal como deve se comportar um gigante internacional ungido pela boa-fé (pacta sunt servanda).

O processo de interpretação jurídica envolve etapas mutuamente influentes, em que os fatos para os quais a norma será aplicada ensejam questões, deduções e induções perante o texto a ser interpretado: o intérprete se volta aos enunciados normativos para verificar qual a norma soluciona as questões formuladas.

Pode-se dizer que a construção das normas dos acordos de bitributação igualmente demanda fases mutuamente influentes. Conforme as particularidades do caso concreto e dos rendimentos envolvidos, o intérprete procura entre as normas do acordo de dupla tributação alguma que se mostre aplicável. A partir daí, inicia-se um processo de justificação, em que são apresentados argumentos quanto à aplicação (ou não) de algum dispositivo de um acordo de bitributação ao caso concreto. Nesse processo, argumenta-se que a aplicação do acordo ao caso concreto seria suportada pela mútua expectativa dos Estados contratantes, o que justifica o valor de evidências quanto ao consentimento destes a respeito do tema, apuradas no "contexto" do acordo de dupla tributação celebrado.

Nesse seguir, assumindo-se por hipótese que aos termos das convenções de bitributação devem ser atribuídos os sentidos consentidos pelos Estados signatários, então a interpretação de suas normas deve se basear em evidências de tal consentimento, levantadas a partir de seu "contexto" e legitimadas pelo Direito Internacional. Se assim for, o "contexto" referido no art. 3 da CM-OCDE poderia ser definido como repertório de evidências quanto ao sentido dos termos de acordos de dupla tributação, cujo reconhecimento, admissibilidade e consideração por juizes e outros operadores do Direito

\footnotetext{
${ }^{6}$ Cf. D'ASPREMONT, Jean. The Systemic Integration of International Law by Domestic Courts: Domestic Judges as Architects of the Consistency of the International Legal Order, in The Practice of International and National Courts and the (De-) Fragmentation of International Law (Nollkaemper, A.; Fauchald, O. K., eds). Hart Publishing : Oxford, 2012, p. 143-144; 153.
} 
tributário internacional são mandatórios para o cumprimento de boa-fé de tais convenções internacionais.

Para que a referida hipótese se confirme, parece ser necessário que o "contexto" seja apto a fornecer evidências para que o intérprete construa, de forma efetiva, o sentido de termos dos acordos de bitributação. Assim, como fonte de investigação para testar tal hipótese, o presente trabalho recorre, por exemplo, a materiais doutrinários, documentos históricos, estudos de entidades como Organização das Nações Unidas ("ONU”) e Organização para a Cooperação e Desenvolvimento Econômico (“OCDE”). Em especial, este estudo investigada decisões de tribunais de uma série de países quanto à interpretação e aplicação de acordos de dupla tributação.

As decisões de Cortes nacionais analisadas nesta tese foram preponderantemente coletadas do banco de dados do International Bureau of Fiscal Documentation (IBFD), que conta atualmente com aproximadamente 5.500 decisões originárias de mais de 200 países. A pesquisa utilizou palavras chave "interpretation" e "context" para a seleção de decisões relevantes, mas também foi expandida para a coleta de decisões que, ao se deter com outros dispositivos de acordos de dupla tributação, interpretou e aplicou a cláusula do "contexto" do art. 3 da CM-OCDE. Privilegiou-se a análise do acórdão original de cada decisão e não do resumo fornecido pelo IBFD, a fim de que importantes nuances não fossem desconsideradas.

As decisões coletadas foram analisadas considerando, em especial, as seguintes questões: (i) quais métodos de interpretação foram adotados? (ii) quais evidências foram consideradas relevantes pelos juízes para a construção do sentido dos acordos de dupla tributação? (iii) os juízes recorreram ao "contexto" ou imediatamente se valeram de sentidos providos por seus respectivos sistemas jurídicos domésticos? (iv) há atribuição de pesos entre as evidências quanto ao sentido de termos da convenção fiscal, de forma que algumas possuam apenas valor relativo, a exemplo dos trabalhos preparatórios?

A questão de mérito, analisada em tais decisões, possui o papel de pano de fundo, a fim de demonstrar o recurso às evidências analisadas na tese sob a perspectiva teórica de ferramentas para a construção do sentido contextualizado de termos de acordos de dupla tributação. Como estratégia expositiva, a tese apresenta aspectos relevantes das referidas 
decisões em diversos subtópicos sempre intitulados como "Exemplo" e, a fim de não cansar o leitor com a repetição de informações sobre cada caso, foram elaborados apêndices que se ocupam da descrição detalhada de cada um destes e, quando tal recurso se mostrar didaticamente recomendável, com a sua ilustração gráfica. O "Apêndice 02" apresenta a descrição de casos de aplicação de acordos de dupla tributação por tribunais brasileiros citados no trabalho. Já o "Apêndice 03" se ocupa da descrição dos casos de aplicação de acordos de dupla tributação por tribunais estrangeiros citados no decorrer da tese.

O objetivo deste trabalho, então, consiste na investigação do repertório de evidências sob o escopo do "contexto" referido no art. 3 da CM-OCDE para a construção de sentido dos termos de acordos de bitributação. Para tanto, o trabalho procura identificar critérios para o reconhecimento de tais evidências, o que será objeto do Capítulo I. Por sua vez, os Capítulos II, III e IV se dedicam à análise de evidências em espécie quanto ao sentido dos termos das convenções fiscais, organizando-as, respectivamente, no contexto intrínseco, contexto extrínseco primário e contexto extrínseco secundário.

Como se analisará no tópico "2" desta introdução, não se pode olvidar que peculiaridades de cada sistema nacional ou, ainda, de cada acordo de dupla tributação, exigem que se considere a existência de uma série de Direitos tributários internacionais particulares. Em especial, por adotar o Brasil como referencial, esta tese abordará as peculiaridades do Direito tributário internacional brasileiro. O tópico “3”, por sua vez, se dedica ao exame de detalhes da interpretação e aplicação do Direito tributário internacional relevantes a todos os capítulos deste trabalho.

É importante sublinhar que a investigação empreendida não procurou encontrar fórmulas matemáticas, como se duas evidências somadas sempre conduzissem a um determinado resultado, ou melhor, a um sentido contextualizado. Isso não seria possível ao menos por três razões, que serão abordadas em diversas oportunidades deste trabalho: (i) não é possível controlar as variáveis dos elementos culturais que influenciam cada um dos intérpretes (como juízes) nas mais variadas jurisdições, o que não é possível sequer dentro de um único sistema jurídico nacional; (ii) cada objeto pode ser descrito de formas variadas, sem que essas sejam necessariamente divergentes ou equivocadas; (iii) é preciso reconhecer a falência da teoria do único sentido correto para cada termo de um acordo 
internacional ${ }^{7}$. Parece necessário admitir como premissa que, no âmbito da argumentação jurídica, procura-se por sentidos passíveis de justificação ${ }^{8}$ e não únicos sentidos corretos.

Nos tópicos seguintes, serão expostas algumas consideraçães propedêuticas, todas elas relacionadas com questões analisadas nos Capítulos I, II, III e IV desta tese.

\section{DIREITO INTERNACIONAL E DIREITO TRIBUTÁRIO INTERNACIONAL}

Compreender o "contexto" referido no art. 3 (2) da CM-OCDE exige que se compreenda o sistema jurídico dúplice em que tal dispositivo está inserido, composto pelo Direito Internacional e pelo Direito doméstico ${ }^{9}$. Nesse seguir, os subtópicos seguintes cuidam da questão da fragmentação do Direito Internacional, especialmente para abordar elementos do Direito tributário internacional fundamentais para a presente tese.

\subsection{Direito Internacional público.}

"Violations of this law are certainly frequent. But the offenders always try to prove that their acts do not contain a violation, and that they have a right to act as they do according to the Law of Nations, or at least that the rule of the Law of Nations is not against their acts.

Has a State ever confessed that is was going to break the Law of Nations or that it ever did so?

The fact is that States, in breaking the Law of Nations, never deny its existence, but recognise its existence througt the endeavour to interpret the Law of Nations in a way favourable to their acts".

LASSA OPPENHEIM (1912)

A disciplina jurídica que já se preferiu denominar de Direitos das Gentes ("le droit des gens") ou Direito nas Nações ("Law of Nations")" 11 chamamos hoje de "Direito

\footnotetext{
${ }^{7}$ Contra, vide: AVERY JONES, John. The "one true meaning” of a Tax Treaty, in 55 Bulletin for International Fiscal Documentation - Tax Treaty Monitor - Junho 2001. IBFD : Amsterdã, p. 220-224. A favor, vide: RAAD, Kees van. Interpretation and Application of Tax Treaties by Tax Courts, in European Taxation - January 1996. IBFD : Amsterdã, 1996.

${ }^{8}$ Nesse sentido, vide: ROCHA, Sergio André. Interpretação dos tratados para evitar a dupla tributação. São Paulo : Quartier Latin, 2013, p. 133; BROEKHUIJSEN, Dirk M. A Modern Understanding of Article 31(3)(c) of the Vienna Convention (1969): A New Haunt for the Commentaries to the OECD Model?, in Bulletin for International Taxation, volume 67, n. 9. Amsterdã : IBFD, 2013, p. 3.

${ }^{9}$ Vide: BAKER, Philip. Double taxation conventions and international tax law. Londres : Sweet \& Maxwell, 1994, par. C-02; ROCHA, Sergio André. Interpretação dos tratados para evitar a dupla tributação. São Paulo : Quartier Latin, 2013, p. 46 e seg.

${ }^{10}$ OPPENHEIM, Lassa. International Law. A treatise. Volume I (of 2) - Peace. Longmans : Londres, 1912 (Kindle), Introduction Foundation and Development os the Law of Nations, $\S 10$.
} 
Internacional Público" ("Public International Law") 12. Embora o complemento "público" seja utilizado como distinção ao Direito Internacional privado ${ }^{13}$, também é bastante comum referir-se simplesmente a "Direito Internacional" (“International Law") 14 .

Não apenas sua denominação experimentou variações, mas também significativas evoluções marcam tal disciplina ${ }^{15}$. Há tempos o Direito Internacional deixou de governar apenas relações mantidas entre Estados, passando a regular também questões internas que afetam indivíduos. ${ }^{16}$ Modernamente, essa seara do Direito pode ser definida como um conjunto de normas jurídicas pertencentes à comunidade internacional que se presta à cooperação entre os seus sujeitos, sejam eles Estados, organizações internacionais ou, ainda que menos frequentemente, indivíduos. ${ }^{17}$

No entanto, séculos de existência não foram suficientes para suplantar contestações quanto à sua juridicidade: nenhuma outra disciplina jurídica tem sido compelida a justificar a sua existência por tanto tempo e, para DAVID J. BADERMAN ${ }^{18}$, realmente o Direito Internacional parece estar condenado a fazê-lo perpetuamente. Em especial, questiona-se com frequência o seu caráter cogente ou mesmo o seu status de "Direito"19.

${ }^{11}$ Cf. OPPENHEIM, Lassa. International Law. A treatise. Volume I (of 2) - Peace. Longmans : Londres, 1912 (Kindle), Cap. 1, § 1.

${ }^{12}$ Nesse sentido, vide: BEDERMAN, David. The Spirit of International Law. The University of Georgia Press : Athens, Georgia : 2002, p. 1.

${ }^{13}$ Sobre a "dicotomia atenuada" entre o Direito Internacional "publico" e "privado", vide: AMARAL JÚNIOR, Alberto do. Curso de Direito Internacional Público. Atlas : São Paulo, 2013, p. 17-20.

${ }^{14}$ Nesse sentido, vide: BESSON, Samantha. Theorizing the Sources of International Law, in The Philosophy of International Law. Oxford : Oxford, 2010, p. 167-168.

${ }^{15}$ Cf. SCHARF, Michael P. Customary International Law in Times of Fundamental Charge - recognizing Grotian Moments. Cambridge University Press : Cambridge, 2013.

${ }^{16}$ Nesse sentido, vide: D’ASPREMONT, Jean. The Systemic Integration of International Law by Domestic Courts: Domestic s as Architects of the Consistency of the International Legal Order, in The Practice of International and National Courts and the (De)Fragmentation of International Law (Nollkaemper, A.; Fauchald, O. K., eds). Hart Publishing : Oxford, 2012, p. 142.

${ }^{17}$ Nesse sentido, vide: BESSON, Samantha. Theorizing the Sources of International Law, in The Philosophy of International Law. Oxford : Oxford, 2010, p. 164-166.

${ }^{18}$ BEDERMAN, David. The Spirit of International Law. The University of Georgia Press : Athens, Georgia : 2002 , p. 1.

${ }^{19}$ Referindo-se às objeções suscitadas por HoBBES, PUfENDORF e Austin, vide: OPPENHEIM, Lassa. International Law. A treatise. Volume I (of 2) - Peace. Longmans : Londres, 1912 (Kindle), Cap. 1, § 2. 
Ocorre que o Direito Internacional encontra desafios geralmente inexistentes nos sistemas jurídicos nacionais, em que há um poder constituído, um órgão legislativo centralizado e instituições vocacionadas a fazer valer "a lei"20.

Enquanto os sistemas internos são geralmente centralizados e unitários, com hierarquia das fontes ou mesmo entre as searas do Direito doméstico ("domestic law" ou “municipal law" $)^{21}$, o Direito Internacional obedece a uma ordem plural e verticalizada devido à ausência de hierarquia entre as suas fontes. Além disso, possui um caráter plural e horizontal, devido à sua fragmentação ${ }^{22}$ para a tutela de diferentes temas, como comércio internacional, direitos humanos, meio ambiente, questões tributárias, entre muitos outros. A ausência de autoridade central, capaz de impor aos governos nacionais o cumprimento coercitivo de suas obrigações no Direito Internacional, faz com que sejam feitas referências à existência de uma "anarquia internacional"23, que poderia conduzir à equivocada concepção da inexistência de uma ordem jurídica.

A emancipação do Direito Internacional como conjunto de normas jurídicas (e cogentes), contudo, encontra farto respaldo doutrinário e jurisprudencial. Para reconhecer o seu caráter jurídico do "Direito" Internacional, HUGH THIRLWAY ${ }^{24}$ assume como "Direito" um sistema de preceitos que governa relações entre sujeitos que podem escolher entre cumprir ou não os seus deveres, mas que não têm o controle sobre a consequência de tais atos devido à cogência das normas jurídicas. RICHARD K. GARDINER ${ }^{25}$ vê o Direito Internacional como um conjunto autônomo de normas, reconhecido e observado pelos Estados, que são fortemente influenciados por este na elaboração de normas domésticas.

Ao rejeitar a anarquia do Direito Internacional, ALBERTO DO AMARAL JÚNIOR ${ }^{26}$ suscita que a ausência de um poder centralizado não impede a existência de normas comuns observadas por diferentes Estados soberanos, mas enseja a discussão sobre uma

\footnotetext{
${ }^{20}$ Nesse sentido, vide: ROTHMANN, Gerd W. Interpretação e aplicação dos acordos internacionais contra a bitributação. Tese de doutorado. São Paulo : Faculdade de Direito da Universidade de São Paulo (USP), 1978, p. 135.

${ }^{21}$ Cf. GARDINER, Richard K. International Law. Pearson : Harlaw, 2003, p. 9.

${ }^{22}$ Nesse sentido, vide: BESSON, Samantha. Theorizing the Sources of International Law, in The Philosophy of International Law. Oxford : Oxford, 2010, p. 164.

${ }^{23}$ Sobre o tema da "anarquia internacional" e as discussões relacionadas, vide: AMARAL JÚNIOR, Alberto do. Curso de Direito Internacional Público. Atlas : São Paulo, 2013, p. 1-2.

${ }^{24}$ THIRLWAY, Hugh. The Sources of International Law. Oxford : Oxford, 2014, p. 1-2.

${ }^{25}$ GARDINER, Richard K. International Law. Pearson : Harlaw, 2003, p. 13.

${ }^{26}$ AMARAL JÚNIOR, Alberto do. Curso de Direito Internacional Público. Atlas : São Paulo, 2013, p. 8-25.
} 
ordem internacional, especialmente com a "formação de regularidades empíricas e de comportamentos rotinizados". A ordem internacional surgiria como um padrão de previsibilidade nas relações jurídicas, de forma a permitir a gestão da política internacional. Desde sua origem, o Direito Internacional buscaria justamente reduzir a anarquia pela adoção de regras de conduta capazes de estabelecer relações entre os Estados, satisfazendo as necessidades e os interesses destes, em uma dialética entre cooperação e coexistência variável em diferentes momentos históricos. As funções do Direito Internacional, sustenta aquele professor, seriam: (i) "definir o princípio normativo supremo de organização da política mundial"; (ii) "estabelecer regras de coexistência e de cooperação entre os atores internacionais"; (iii) "discriminar competências, atribuir direitos e obrigações, bem como especificar a sua natureza e extensão" e; (iv) "mobilizar obediência em relação às regras de coexistência e cooperação".

Embora o reconhecimento da vigência e cogência de um Direito Internacional baseado em costumes internacionais possa apresentar maiores dificuldades, é necessário reconhecer que o fim da Segunda Guerra Mundial, acompanhado do estabelecimento da ONU, representa um marco importante: o Direito Internacional passou a basear-se preponderantemente em acordos internacionais, ao que se pode referir à era dos tratados ${ }^{27}$, em que hoje vivemos.

Em 1949, a codificação do Direito Internacional foi assumida como prioridade pela International Law Commission da Organização das Nações Unidas ("ILC-ONU"), que atribuiu a missão da elaboração de seu projeto a HERSCh LAUTERPACHT, GERALD FitzMAurice e Humphrey Waldock. Em 1961, a ideia inicial de um código foi reformulada, decidindo-se por uma convenção multilateral. ${ }^{28}$ As inúmeras reuniões diplomáticas que se seguiram culminaram na celebração de uma convenção multilateral sobre o Direito dos tratados, na Viena de 1969. A Convenção de Viena sobre o Direito dos Tratados ("CVDT") representa um marco jurídico pelo qual os Estados formalmente

\footnotetext{
${ }^{27}$ A respeito da utilização dessa expressão e do crescente processo de celebração de tratados, vide: FONTOURA, Jorge. A era dos tratados. Último acesso em 1/09/2014, por meio do endereço eletrônico http://www.gazetadopovo.com.br/colunistas/conteudo.phtml?id=1421372); TORRES, Heleno Taveira. $O$ combate à evasão e à elisão tributária de caráter internacional, in Revista Internacional de Direito Internacional - ABRADT, vol. 1, n. 2. Del Rey : Belo Horizonte, 2004, p. 155.

${ }^{28} \mathrm{Cf}$. ONU. Yearbook of the International Law Commission. Documents of the fourteenth session including the report of the Commission to the General Assembly. ONU, 1962; ONU. Yearbook of the International Law Commission. 1966. Records on the 866th meeting. ONU, 1966, p. 173 e seg.
} 
reconhecem o dever de respeitar as obrigações decorrentes dos tratados e, ainda, dos costumes internacionais ${ }^{29}$.

Em seu art. 84, a CVDT previu que sua vigência teria início no trigésimo dia que se seguisse à data do depósito do trigésimo quinto instrumento de ratificação ou adesão, o que se deu em 27.01.1980. Atualmente, são poucos os Estados que não ratificaram a CVDT, como é o caso dos EUA, o que não necessariamente afasta a obediência às suas normas, como se verá adiante.

O Brasil foi representado por seus diplomatas em toda a elaboração da CVDT. Contudo, o Congresso Nacional apenas a aprovou em 17 de julho de 2009, por meio do Decreto Legislativo $\mathrm{n}^{\circ}$ 496. Ato subsequente, em 25 de setembro de 2009, o Governo brasileiro depositou o seu instrumento de ratificação junto ao Secretário-Geral das Nações Unidas. Finalmente, a referida Convenção foi publicada no Diário Oficial da União por força do Decreto n. 7.030, de 14.12.2009.

O caráter excepcional do descumprimento puro e simples do Direito Internacional pode ser explicado pela "teoria dos regimes". Conforme essa teoria, a cooperação entre os Estados se mantém com base no autointeresse, nos benefícios que cada Estado pode obter com a existência de um sistema organizado e no fortalecimento de sua reputação perante os atores internacionais. LASSA OPPENHEIM ${ }^{30}$ já advertia que violações a tais normas por um Estado o estigmatizariam perante a opinião pública e os governos dos demais Estados.

Modernamente, como observa AlBERTO DO AMARAL JÚNIOR ${ }^{31}$, a teoria dos regimes é demonstrada pelo fato de países recém-independentes descobrirem rapidamente que a concordância com as normas internacionais é essencial para que sejam reconhecidos como Estados soberanos. Para esse professor, as regras de Direito Internacional seriam obedecidas especialmente pela aceitação dos fins ou valores subjacentes aos tratados, pela coerção exercida por grandes potências e pela existência de interesses recíprocos.

\footnotetext{
${ }^{29}$ Brasil. Decreto n. 7.030/2009 (CVDT), preâmbulo.

${ }^{30}$ OPPENHEIM, Lassa. International Law. A treatise. Volume I (of 2) - Peace. Longmans : Londres, 1912 (Kindle), Introduction Foundation and Development os the Law of Nations, § 10.

${ }^{31}$ AMARAL JÚNIOR, Alberto do. Curso de Direito Internacional Público. Atlas : São Paulo, 2013, p. 15$16 ; 25$.
} 
Outro fenômeno intensificado com a era dos tratados consiste na fragmentação do Direito Internacional ${ }^{32}$, pela qual temas específicos que emergem das relações internacionais exigem que se considerem peculiaridades que cada uma de suas searas especializadas ("self-contained regime”) possam assumir. À presente tese interessa o estudo do Direito tributário internacional.

\subsection{Direito tributário internacional.}

“O ponto de partida é a necessidade de não sobrecarregar os agentes econômicos com um excesso proibitivo de tributos quando eles atuam ultrapassando as fronteiras. (...) Tributasse o Estado rigorosamente tudo o que a ele é possível nos limites de sua territorialidade, seria paralisado o tráfico econômico internacional."

KLAUS TIPKE \& JOACHIM LANG ${ }^{33}$

A proposta de WiLLIAM PITT, para um embrionário imposto sobre a renda destinado às despesas com a guerra então mantida com a França, foi aprovada pelo Parlamento inglês em 1799, contagiando rapidamente outros países europeus até se tornar a regra permanente na generalidade dos Estados ${ }^{34}$. Não tardou, contudo, para que todos percebessem o óbice criado pela dupla tributação de uma mesma renda por dois ou mais Estados.

A concepção de um ramo autônomo dedicado à questão tributária apenas teria surgido na doutrina no raiar do século XIX. Alessandro GARELli ${ }^{35}$, professor de "Scienza dele finanze $i$ diritto finanziario" da Universidade de Turim, teria sido o primeiro $^{36}$ a escrever uma obra para a consideração de uma disciplina autônoma, publicada em 1899. Hoje, sabe-se que a existência dessa disciplina decorre da soberania dos Estados para a autolimitação de suas jurisdições fiscais, tendo como objeto o estudo do conjunto de normas jurídicas que tutelam a tributação de fatos econômicos em que haja ao menos um elemento de estraneidade. ${ }^{37}$

\footnotetext{
${ }^{32}$ Vide: ONU. Reports of the Study Group of the International Law Commission - General Assembly. Fragmentation of International Law: Difficulties Arising from the Diversification and Expansion of International Law, 2006.

${ }^{33}$ TIPKE, Klaus; LANG, Joachim. Direito tributário (Steuerrecht). Volume 1. Tradução da 18a edição alemã, totalmente refeita, de Luíz Dória Furquim. Porto Alegre : Sergio Antonio Fabris Editor, 2008, p. 102.

${ }^{34}$ Nesse sentido, vide: GROSSFELD, Bernhard; BRYCE, James. A Brief Comparative History of the Origins of the Income Tax in Great Britain, Germany and the United States, in The American Journal of Tax Policy. Vol. 2, p. 214.

${ }^{35}$ GARELLI, Alessandro. Il Diritto Internazionale Tributario. Torino, Roux Frassati, 1899.

${ }^{36}$ Cf. ROTHMANN, Gerd W. Interpretação e aplicação dos acordos internacionais contra a bitributação. Tese de doutorado. São Paulo : Faculdade de Direito da Universidade de São Paulo (USP), 1978, p. 5.

${ }^{37}$ Cf. SCHOUERI, Luís Eduardo. "Direito tributário internacional. Acordos de bitributação. Imposto de Renda: Lucros auferidos por controladas e coligadas no exterior. Disponibilidade. Efeitos do art. 74 da
} 
A soberania é uma pré-condição da jurisdição, pela qual se define o âmbito de incidência das leis do Estado soberano. Embora nem todas as normas de um Estado se estendam por toda a sua jurisdição, nenhuma delas a ultrapassa, pois fora desta o Estado não pode impor a sua força. Como ensina Luís EDUARDO SCHOUERI ${ }^{38}$, aplicando-se ao Direito tributário tais concepções de soberania e jurisdição, é possível compreender que o poder de tributar dos Estados apenas pode ser exercido até os limites de sua jurisdição, não podendo ultrapassá-los.

Nesse seguir, da soberania fiscal dos Estados irradia o princípio da territorialidade, que pode ser compreendido com base em seus aspectos formais ou materiais. O princípio da territorialidade formal corresponde ao poder de império de um Estado dentro de sua jurisdição e à inexistência de poder para a prática de atos coercitivos fora de tais mourões. A territorialidade material, por sua vez, faz com que as riquezas materializadas no exterior possam ser objeto de tributação pelo Estado de residência. Seria o caso, por exemplo, de um Estado ("A") tributar os seus residentes (sujeitos, portanto, aos seus atos de império) que obtenham rendimentos decorrentes de investimentos realizados em outro Estado ("B"), ainda que tais rendimentos permaneçam do território daquele outro Estado ("B") ${ }^{39}$.

Exige-se, portanto, certa conexão de um Estado com os rendimentos tributados, a fim de que o exercício dessa potestade seja legítima ou mesmo factível ${ }^{40}$. Para que um Estado esteja legitimado a tributar um determinado signo de riqueza deverá, de alguma maneira, conectar-se a ele. A eleição dos chamados elementos de conexão deve evidenciar que uma determinada situação se encontra sob a jurisdição de um ou mais Estados soberanos, possibilitando a esses o exercício da tributação.

Medida Provisória n. 2.158-35 - Parecer.”, in Revista de Direito Tributário Atual n. 16. São Paulo : IBDT/Dialética, 2001, p. 162.

${ }^{38}$ SCHOUERI, Luís Eduardo. Preços de transferência no direito tributário brasileiro. São Paulo : Dialética, 2013, p. 415-419.

${ }^{39}$ Sobre tal concepção de territorialidade formal e material, vide: TIPKE, Klaus; LANG, Joachim. Direito tributário (Steuerrecht). Volume 1. Tradução da 18a edição alemã, totalmente refeita, de Luíz Dória Furquim. Porto Alegre : Sergio Antonio Fabris Editor, 2008, p. 103-104; SCHOUERI, Luís Eduardo. Tratados e Convenções Internacionais sobre Tributação, in Revista de Direito Tributário Atual n. 17. São Paulo : IBDT/Dialética, 2003, p. 20-50.

${ }^{40}$ Cf. ROTHMANN, Gerd W. Interpretação e aplicação dos acordos internacionais contra a bitributação. Tese de doutorado. São Paulo : Faculdade de Direito da Universidade de São Paulo (USP), 1978, p. 2. 
Os elementos de conexão presentes no Direito tributário internacional estabelecem uma relação entre objetos, fatos e ordenamentos tributários. ${ }^{41}$ Assim, por exemplo, os rendimentos auferidos por pessoa física não-residente no Brasil, provenientes de fontes situadas no exterior, não se sujeitariam à tributação do imposto de renda brasileiro ${ }^{42}$, pois não estariam de nenhuma forma conectados ao País. No caso, diferentes teorias ${ }^{43} \mathrm{e}$ sistemas jurídicos domésticos conduzem geralmente ao binômio dos elementos de conexão fonte dos rendimentos e residência do titular da renda ${ }^{44}$, embora seja possível segregá-los com vistas às específicas situações tuteladas, como domicílio e residência, sede e direção, estabelecimento permanente, situação do bem, fonte do rendimento, país de origem ou destino. ${ }^{45}$ Os EUA constituem um caso de exceção, por tributar em bases mundiais tanto as pessoas físicas residentes em seu território quanto os seus cidadãos, ainda que residentes no exterior ${ }^{46}$. No Caso Cook v. Tait $^{47}$ (EUA, 1924), a Suprema Corte norte-americana decidiu que os cidadãos daquele país fariam jus à sua proteção em qualquer região do mundo, razão pela qual não perderiam a condição de contribuintes.

A questão da dupla tributação da renda decorre justamente de tais elementos de conexão. Como bem observa JOÃo FrANCISCO BIANCO ${ }^{48}$, os problemas de bitributação surgem porque, enquanto alguns Estados adotam a residência como elemento de conexão, outros podem adotar a fonte, de modo que o contribuinte seria tributado em ambos. Caso apenas um critério fosse adotado de forma uniforme pelos Estados, não haveria problemas de bitributação de um mesmo evento de substrato econômico. Também suscita Luís EDUARDO SCHOUERI ${ }^{49}$ que, como os Estados são livres para descrever as hipóteses em que

${ }^{41}$ Cf. ROTHMANN, Gerd W. Interpretação e aplicação dos acordos internacionais contra a bitributação. Tese de doutorado. São Paulo : Faculdade de Direito da Universidade de São Paulo (USP), 1978, p. 50 e seg.).

${ }^{42}$ Nesse sentido, vide pronunciamentos da administração fiscal brasileira, ao solucionar consultas de contribuintes, como: BRASIL, Receita Federal do Brasil. SOLUÇÃO DE CONSULTA nº 61 de 23 de julho de 2002.

${ }^{43}$ Sobre esse debate, vide: ROTHMANN, Gerd W. Interpretação e aplicação dos acordos internacionais contra a bitributação. Tese de doutorado. São Paulo : Faculdade de Direito da Universidade de São Paulo (USP), 1978, p. 2-4.

${ }^{44}$ Sobre o tema, vide: AVI-YONAH, Reuven. International Tax as International Law. New York, Cambridge University Press, 2007, p. 64 e seg.

${ }^{45}$ Cf. ROTHMANN, Gerd W. Interpretação e aplicação dos acordos internacionais contra a bitributação. Tese de doutorado. São Paulo : Faculdade de Direito da Universidade de São Paulo (USP), 1978, p. 54-57.

${ }^{46}$ Também as Filipinas adotam tal critério.

47 Disponível no site da Internet: http://supreme.justia.com/cases/federal/us/265/47/. Último acesso em $10 / 06 / 2014$.

${ }^{48}$ BIANCO, João Francisco. Transparência fiscal internacional. São Paulo : Dialética, 2007, p. 137 e seg.

${ }^{49}$ SCHOUERI, Luís Eduardo. "Direito tributário internacional. Acordos de bitributação. Imposto de Renda: Lucros auferidos por controladas e coligadas no exterior. Disponibilidade. Efeitos do art. 74 da Medida 
haverá tributação em seu sistema doméstico, bem como que uma mesma realidade fática pode ser apreendida por diferentes prismas, nada impediria que dois ordenamentos jurídicos distintos, com a descrição de fatos geradores completamente diversos, atinjam uma mesma situação fática, ensejando a bitributação internacional.

Ainda sobre o tema, KLAUS VOGEL ${ }^{50}$ aponta ser possível identificar a dupla tributação jurídica em três situações: $i$ ) quando um país adota o princípio da residência e outro adota o princípio da fonte para tributar o mesmo rendimento auferido pelo mesmo contribuinte; ii) quando um contribuinte é considerado residente em dois ou mais Estados ou quando um mesmo rendimento é considerado como tendo sido auferido em dois ou mais Estados; iii) quando um país adota o princípio da nacionalidade para fundamentar a tributação de rendimentos e o outro país adota o princípio da residência. A dupla tributação econômica ocorreria quando o mesmo rendimento sofresse a tributação de dois ou mais Estados, durante o mesmo período, mas em relação a contribuintes diferentes. Segundo ALBERTO XAVIER $^{51}$, a dupla tributação jurídica pode ser identificada pela presença de quatro identidades, quais sejam: i) a identidade do contribuinte; ii) a identidade de pressuposto, que pode ser entendido como o critério material da hipótese de incidência tributária $^{1}$; iii) a identidade do tributo e iv) a identidade de período de tempo. Já a dupla tributação econômica ocorreria com a presença apenas de três dessas identidades: i) a identidade do pressuposto, ii) a identidade de tributo e iii) a identidade do período. Para Vogel e XAVIER, então, a ausência de identidade do contribuinte é discriminem para diferenciar a dupla tributação econômica da jurídica. Somente quando um mesmo contribuinte sofrer a imposição tributária de dois Estados distintos sobre um evento por ele praticado (identidade do aspecto material, espacial e temporal da hipótese de incidência), ter-se-á a bitributação jurídica. O Direito tributário internacional, em geral, se volta contra essa bitributação jurídica ${ }^{52}$.

Provisória n. 2.158-35 - Parecer.”, in Revista de Direito Tributário Atual n. 16. São Paulo : IBDT/Dialética, 2001, p. 164.

${ }^{50}$ VOGEL, Klaus. Double Taxation Convention, Kluwer : London, 1997, p. 9 e seg.

${ }^{51}$ XAVIER, Alberto. Direito Tributário Internacional do Brasil: tributação das operações internacionais. 5. Ed., atualizada. Rio de Janeiro: Forense, p. 33.

${ }^{52}$ Cf. BIANCO, João Francisco. A CIDE sobre royalties e os tratados internacionais contra a dupla tributação, in Grandes Questões Atuais do Direito Tributário vol. 8 (Coord. Valdir de Oliveira Rocha). São Paulo : Dialética, 2004. 
Os Estados, contudo, não exercem em sua plenitude a competência tributária de que dispõem. Como na passagem em epígrafe, ensinam KLAUS TiPKE \& JOACHIM LANG ${ }^{53}$ que uma série de fatores conduz para a adoção de medidas unilaterais ou para a celebração de acordos internacionais que estabelecem hipóteses em que um Estado - da residência, por exemplo - deixe de exercer tal tributação ou a exerça de forma mais amena, a fim de que a tributação exercida por outro Estado - da fonte, por exemplo - não sobrecarregue ou mesmo elimine a capacidade contributiva.

Há algum debate quanto à real necessidade de convenções fiscais, sustendando Agostinho TAvOlaro que medidas unilaterais tornariam despiciendos os acordos internacionais. ROBERTO FRANÇA VASCONCELLOS ${ }^{54}$ sustenta o contrário, sob a perspectiva de que a harmonização da tributação da renda por medidas unilateriais seria inatingível, exigindo a adoção de convenções fiscais. Ainda nos lindes desta introdução, o subtópico seguinte se dedica à análise de tais acordos de dupla tributação.

A necessidade econômica de impulsionar as trocas comerciais e incrementar a participação no mercado internacional ${ }^{55}$ requer do Direito Internacional tributário três funções jurídicas básicas ${ }^{56}$ : (i) demarcatória, em que são estabelecidas as hipóteses em que determinado Estado tributará riquezas conectadas com fontes estrangeiras; (ii) resolutória de colisão, em que são adotados mecanismos para evitar ou aliviar a dupla tributação pelos métodos de isenção ou de crédito e (iii) harmonizadora, relacionada com os princípios da igualdade tributária e da neutralidade concorrencial. Como explicam KLAUS TIPKE \& JOACHIM LANG ${ }^{57}$, quanto maior for a atuação internacional, maior será a pressão sobre os Estados para que preservem tais princípios e harmonizem os seus sistemas tributários. Para esses professores, o desafio seria estabelecer a medida ideal em que tais atos de império devem ser exercidos: "depende o desenvolvimento das economias políticas nacionais e

${ }^{53}$ TIPKE, Klaus; LANG, Joachim. Direito tributário (Steuerrecht). Volume 1. Tradução da 18a edição alemã, totalmente refeita, de Luíz Dória Furquim. Porto Alegre : Sergio Antonio Fabris Editor, 2008, p. 102.

${ }^{54}$ VASCONCELLOS, Roberto França. Aspectos Econômicos dos Tratados Internacionais em Matéria Tributária, in Revista de Direito Tributário Internacional n. 1. São Paulo: Quartier Latin, 2005, p. 182.

${ }^{55}$ Sobre os obstáculos à circulação internacional de mercadorias, serviços, capitais e pessoas criados pela dupla tributação, vide: ROTHMANN, Gerd W. Interpretação e aplicação dos acordos internacionais contra a bitributação. Tese de doutorado. São Paulo : Faculdade de Direito da Universidade de São Paulo (USP), 1978, p. 4.

${ }^{56}$ A respeito dessas três funções dos Direito tributário internacional em sentido amplo, vide: TIPKE, Klaus; LANG, Joachim. Direito tributário (Steuerrecht). Volume 1. Tradução da 18a edição alemã, totalmente refeita, de Luíz Dória Furquim. Porto Alegre : Sergio Antonio Fabris Editor, 2008, p. 103-112.

${ }^{57}$ TIPKE, Klaus; LANG, Joachim. Direito tributário (Steuerrecht). Volume 1. Tradução da 18a edição alemã, totalmente refeita, de Luíz Dória Furquim. Porto Alegre : Sergio Antonio Fabris Editor, 2008, p. 111. 
mundial basicamente do fato de se saber, se e até que ponto o desempenho das potestades tributárias é afetado pelo princípio da consideração internacional ${ }^{, 58}$.

Desse modo, a soberania fiscal dos Estados deve ser compatibilizada com as regras de Direito Internacional, em um processo de autolimitação. Tal fenômeno não representa qualquer ofensa à soberania fiscal do Estados, mas a sua afirmação: ao limitar o exercício de seu poder de tributar por meio de concessões entre as partes contratantes, o Estado determina a sua vontade e conserva a sua soberania. ${ }^{59}$ Como suscita PAUlo BorbA CASELLA $^{60}$, em nome da proteção de seus interesses, os Estados aceitam negociar e limitar parcela de sua capacidade de tributar em troca de segurança, ainda que se possa argumentar que esta seja apenas relativa.

De maneira geral, os acordos de bitributação descrevem hipóteses abstratas, nas quais um dos dois Estados contratantes se compromete a não exigir o tributo de forma parcial (método do crédito fiscal ou da tributação reduzida no Estado da fonte) ou total (método da isenção) $^{61}$. Para KLAUs VoGEL ${ }^{62}$, o Direito Internacional privado se propõe a identificar se as normas domésticas de um determinado Estado ou se normas produzidas por Estados estrangeiros serão aplicáveis em casos de conflito. Nessa relação, compete a cada sistema jurídico legislar ("conflict rules") as hipóteses em que os seus tribunais devem aplicar a legislação estrangeira. O Direito Internacional público trabalha de forma diversa. Como bem observou o professor alemão, os acordos de dupla tributação não veiculam regras de conflito tal como no Direito Internacional privado, mas regras de limitação de competência ("rules of limitation of law") ou, ainda, regras de distribuição do exercício dessa competência ("distributive rules"), já que os Estados mutuamente se obrigam a não exigir tributos em determinadas situações ou a exigí-los de forma limitada. Note-se que as regras dos acordos de bitributação não autorizam ou legitimam a jurisdição fiscal entre os Estados contratantes, já que estes já possuíam, antes da celebração do acordo, a competência plena para o exercício da tributação.

\footnotetext{
${ }^{58}$ Cf. TIPKE, Klaus; LANG, Joachim. Direito tributário (Steuerrecht). Volume 1. Tradução da 18a edição alemã, totalmente refeita, de Luíz Dória Furquim. Porto Alegre : Sergio Antonio Fabris Editor, 2008, p. 104.

${ }^{59}$ SCHOUERI, Luís Eduardo. Tratados e Convenções Internacionais sobre Tributação, in Revista de Direito Tributário Atual n. 17. São Paulo : IBDT/Dialética, 2003, p. 21.

${ }^{60}$ CASELLA, Paulo Borba. Direito internacional tributário brasileiro. São Paulo : LTR, 1995, p. 24.

${ }^{61}$ Cf. SCHOUERI, Luís Eduardo. Planejamento Fiscal Através de Acordos de Bitributação (Treaty Shopping). São Paulo: Ed. Revista dos Tribunais, 1995, p. 20.

${ }^{62}$ VOGEL, Klaus. Klaus Vogel on Double Taxation Conventions. Kluwer : London, 1999, p. 20-21.
} 
É importante que se compreenda essa relação entre o Direito Internacional e o Direito doméstico em matéria tributária. Ensina Luís EdUARdo SCHOUERI ${ }^{63}$ que, como o alcance do exercício da tributação se limita à jurisdição dos Estados, um acordo de dupla tributação seria "um muro de contenção referente ao poder-dever dos legisladores internos de disciplinar questões que constem em tais tratados, normas de direito internacional que fixam os limites das jurisdições dos Estados contratantes". Não há relação de hierarquia entre normas tributárias domésticas e as normas dos acordos de dupla tributação, pois não tratam da mesma matéria. Enquanto aquelas primeiras, em geral, impõem a tributação, os acordos internacionais cuidam da "autolimitação recíproca de duas soberanias fiscais" com a delimitação da jurisdição das normas dos respectivos Estados. ${ }^{64}$

Tais discussões, é bom que se diga, são tão recentes quanto é jovem o processo de emancipação dessa disciplina, intensificado com a era dos acordos de dupla tributação. Até os anos 90, KEES VAN RAAD ${ }^{65}$ observou a existência de pouco material doutrinário efetivamente disponível a respeito da tributação internacional em geral ou, ainda, da interpretação dos tratados. Não muito tempo atrás, observou o professor de Leiden, muitos tribunais nacionais ainda encaravam as convenções fiscais como normas exóticas.

Não obstante, os últimos anos foram marcados por um crescente número de decisões de Cortes nacionais e pela progressão geométrica de trabalhos doutrinários quanto à matéria. Atualmente, são efervescentes os centros de excelência no estudo do Direito tributário internacional em diversas localizações ao redor do mundo e o debate entre acadêmicos ou mesmo julgadores de diferentes nações é uma realidade sem volta.

\footnotetext{
${ }^{63}$ SCHOUERI, Luís Eduardo. Preços de transferência no direito tributário brasileiro. São Paulo: Dialética, 2013, p. 415-419.

${ }^{64}$ Cf. SCHOUERI, Luís Eduardo. Preços de transferência no direito tributário brasileiro. São Paulo: Dialética, 2013, p. 418-419.

${ }^{65}$ RAAD, Kees van. Interpretation and Application of Tax Treaties by Tax Courts, in European Taxation January 1996. IBFD : Amsterdã, 1996, p. 3-4.
} 


\title{
2.3. Direito tributário internacional do Brasil.
}

\author{
“As convenções em matéria de bitributação e evasão fiscal cristalizam, \\ no ordenamento jurídico pátrio, a expressão mais concreta do ramo da ciência jurídica \\ denominado direito tributário internacional ou direito internacional tributário. \\ Por meio e através destas são ordenadas e reguladas as relações tributárias internacionais entre a \\ República Federativa do Brasil e seus co-contratantes estrangeiros, \\ conforme estipula cada texto convencional." \\ PAulo Borba CASElla (1995) ${ }^{66}$
}

A obra de LASSA OPPENHEIM ${ }^{67}$, do início do século XX, distingue duas espécies de Direito Internacional: universal e particular. A primeira congregaria normas decorrentes de costumes internacionais e de tratados que vinculariam a todas as nações civilizadas, sem exceção. Já o Direito Internacional particular ("particular Internacional Law") seria obrigatório apenas a dois ou mais Estados em razão de acordos que tenham formalizado entre si.

Modernamente, também Hugh THIRLWAY ${ }^{68}$ observa que a aceitação dos Estados em firmar um tratado e contrair deveres que de outra forma não existiriam, cria um regime jurídico especial entre tais partes o qual não se estende a terceiros, ao que se poderia, então, chamar de Direito internacional "particular". Conforme será exposto com mais detalhes adiante, a análise desse sistema exige a consideração de normas domésticas de fundamental importância de cada um dos Estados contratantes, normas de Direito Internacional público e, ainda, das normas estabelecidas por acordos de dupla tributação celebrado entre tais Estados. Convenções internacionais devem ser válidas perante as normas de Direito Internacional e de Direito doméstico. Não é o que se daria, por exemplo, no caso de acordos que afrontassem jus cogens e, portanto, sem validade perante o Direito Internacional, ou de tratados legítimos perante o Direito Internacional, mas inválidos para um dos Estados contratantes por força de suas limitações constitucionais.

O Direito tributário internacional parece partir dessa concepção: marcado pela tônica da tutela dos mais variados sistemas jurídicos domésticos - o que faz com se atribua relevo ao seu título "tributário" antes de "internacional" - a sua regência se dá por meio de convenções internacionais, cada qual com a sua peculiaridade.

${ }^{66}$ CASELLA, Paulo Borba. Direito internacional tributário brasileiro. São Paulo : LTR, 1995, p. 23.

${ }^{67}$ OPPENHEIM, Lassa. International Law: A treatise. Volume I (of 2) - Peace. Longmans : Londres, 1912 (Kindle), Introduction Foundation and Development os the Law of Nations, $\S 1$.

${ }^{68}$ THIRLWAY, Hugh. The Sources of International Law. Oxford : Oxford, 2014, p. 43. 
A era dos tratados e a crescente fragmentação ${ }^{69}$ do Direito Internacional torna-o “cada vez menos universal”, como observa ALBERTO DO AMARAL JÚNIOR ${ }^{70}$. A constatação desse professor, de que a tônica atual do Direito Internacional é a diferença e a desigualdade conforme os variados fatores e acordos celebrados, demonstra que esse caráter "particular" do Direito tributário internacional, capaz de se tornar peculiar para cada acordo celebrado entre dois Estados, está longe de ser uma exclusividade da seara fiscal. Muito ao contrário, para um pesquisador do Direito tributário internacional, o estudo da teoria geral do Direito Internacional público pode ensejar ao menos dois sentimentos: (i) satisfação, diante da grande quantidade de discussões úteis à sua área de concentração e (ii) decepção, pela desconsideração quase que completa de temas tributários por seus autores $^{71}$. Por sua vez, tal como a doutrina de Direito Internacional público deixou de olhar para os acordos de dupla tributação, muitos tributaristas também têm deixado de se ater às obras daquela seara: embora seja amplamente aceito na doutrina especializada que a interpretação dos acordos de dupla tributação esteja sujeita às regras da CVDT (ou seja, ao Direito Internacional público), não é realmente comum que um tributarista se aprofunde nesses estudos $^{72}$. Esta tese buscará não cometer a mesma falta, não simplesmente para prestigiar a doutrina do Direito Internacional, mas porque suas investigações se mostram de grande utilidade à análise de problemas do Direito tributário internacional.

As peculiaridades que o Direito tributário internacional possa vir a assumir em cada um dos Estados não depõem contra a tese da existência de um sistema de Direito tributário internacional, dotado de cogência e de todas as características de uma ordem jurídica. Se por um lado o Direito Internacional reconhece expressamente que "uma parte não pode invocar as disposições de seu direito interno para justificar o inadimplemento de um tratado" (CVDT, art. 27), há ressalva para a hipótese do consentimento em obrigar-se por

\footnotetext{
${ }^{69}$ Vide: ONU. Reports of the Study Group of the International Law Commission - General Assembly. Fragmentation of International Law: Difficulties Arising from the Diversification and Expansion of International Law, 2006.

${ }^{70}$ AMARAL JÚNIOR, Alberto do. Curso de Direito Internacional Público. Atlas : São Paulo, 2013, p. 24.

${ }^{71}$ Sobre o fato de o Direito tributário internacional ser ignorado na literatura de Direito internacional Público, vide: EDWARDES-KER, Michael. Tax Treaty Interpretation - The International Tax Treaties Service. InDepth Publishing : Athlone, 1995, p. 1, Capítulo 1.

${ }^{72}$ Com conhecidas exceções, como: SCHOUERI, Luís Eduardo. Tratados e Convenções Internacionais sobre Tributação, in Revista de Direito Tributário Atual n. 17. São Paulo : IBDT/Dialética, 2003, p. 27; ROCHA, Sergio André. Interpretação dos tratados para evitar a dupla tributação. São Paulo : Quartier Latin, 2013, p. 41; ENGELEN, Frank. Interpretation of Tax Treaties under International Law. Doctorial series n. 7. IBFD : Amsterdam, 2004.
} 
um tratado ter sido expresso em violação de uma disposição do Direito interno dos Estados contratantes que se mostre manifesta e de importância fundamental (CVDT, art. 46).

Como o Direito tributário internacional reconhece como inválido dispositivo de acordo de dupla tributação que ofenda Direito interno de importância fundamental $e$ manifesta, a avaliação quanto à validade de uma norma relativa a um acordo de dupla tributação deve levar em consideração fatores de Direito Internacional e, em especial, normas constitucionais dos Estados contratantes ${ }^{73}$. O intérprete deve realizar, portanto, duas análises, paralelas ou em conjunto, de forma a verificar se a norma é válida perante o Direito Internacional e, ainda, perante o Direito doméstico.

De forma panorâmica, é possível observar que, no Direito tributário internacional brasileiro, rendimentos como aqueles decorrentes de atividades independentes, pensões e lucros de empresas, inclusive de navegação, são tributados no Estado de residência de seus beneficiários. Os lucros de empresas os rendimentos de atividades independentes atribuíveis, respectivamente, a um estabelecimento permanente e a instatação fixa no Estado da fonte devem ser, por sua vez, tributáveis nestes. ${ }^{74}$

Os acordos de dupla tributação celebrados pelo Brasil geralmente preveem que rendimentos como dividendos, juros e royaties podem ser tributados pelo Estado da fonte à alíquota máxima de 15\%, restando ao Estado de residência exigir apenas o percentual previsto em sua legislação doméstica que exceder tal montante. ${ }^{75}$

Importantes rendimentos, a exemplo dos ganhos de capital, podem ser tributados tanto pelo Estado da fonte quanto pelo Estado de residência. Nesse caso, a maior parte dos acordos de bitributação celebrados pelo Brasil prevê que esse último reconheça como crédito o imposto cobrado pelo primeiro. Algumas convenções fiscais celebradas pelo Brasil, contudo, adotam o método da isenção e não o método do crédito para evitar a bitributação em tais situações, de forma que Argentina, Países Baixos, República Tcheca,

\footnotetext{
${ }^{73}$ VOGEL, Klaus. Klaus Vogel on Double Taxation Conventions. Kluwer : London, 1999, p. 38.

${ }^{74}$ Cf. CASELLA, Paulo Borba. Direito internacional tributário brasileiro. São Paulo : LTR, 1995, p. 34.

${ }^{75}$ Cf. CASELLA, Paulo Borba. Direito internacional tributário brasileiro. São Paulo : LTR, 1995, p. 34-35.
} 
República Eslovaca, Áustria, Bélgica, França, Hungria, Luxemburgo e Noruega devem isentar rendimentos tributados na fonte brasileira. ${ }^{76}$

\subsection{Os acordos de dupla tributação e a CM-OCDE: protagonistas do Direito tributário internacional.}

"O crescimento das relações internacionais insere-se em cenário de uma concorrência internacional entre os países, que, qual agentes num mercado altamente competitivo, buscam de todas as maneiras atrair investimentos internacionais. Nesse sentido, a celebração de tratados internacionais inclusive aqueles em matéria tributária - já não mais se apresenta como uma opção, mas uma necessidade das nações inseridas no cenário internacional." Luís EDUARDO SCHOEURI (2003) $)^{77}$

Embora não seja difícil reconhecer que a dupla tributação da renda castigue a capacidade contributiva do indivíduo ${ }^{78}$, muitos autores não compreendem que disso decorra qualquer costume internacional que, por si, torne a priori ilegítima a bitributação $^{79}$. Distoa o magistério de LUís EDUARDO SCHOUERI ${ }^{80}$, quem acompanha HARALD SCHAUMBURG na concepção de que a bitributação se tornaria irregular sempre que implicar excesso de exação em afronta ao princípio da igualdade e ao seu corolário da capacidade contribuinte (geralmente aceitos pelas nações civilizadas). Sob essa perspectiva, conclui o professor que a proteção à dupla tributação da renda pode ser compreendida como Direito fundamental do ser humano, cuja não observância seria incompatível com o Direito Internacional.

\footnotetext{
${ }^{76}$ Cf. CASELLA, Paulo Borba. Direito internacional tributário brasileiro. São Paulo : LTR, 1995, p. 35.

${ }^{77}$ SCHOUERI, Luís Eduardo. Tratados e Convenções Internacionais sobre Tributação, in Revista de Direito Tributário Atual n. 17. São Paulo : IBDT/Dialética, 2003, p. 20.

${ }^{78}$ Nesse sentido, vide: GRUPENMACHER, Betina Treiger. Tratados internacionais em matéria tributária e ordem interna. São Paulo : Dialética, p. 90.

${ }^{79}$ No sentido de que não há norma no Direito Internacional que, independentemente de acordos internacionais, repudiaria a dupla tributação, vide: TIPKE, Klaus; LANG, Joachim. Direito tributário (Steuerrecht). Volume 1. Tradução da 18a edição alemã, totalmente refeita, de Luíz Dória Furquim. Porto Alegre : Sergio Antonio Fabris Editor, 2008, p. 108-109; VOGEL, Klaus. Klaus Vogel on Double Taxation Conventions. Kluwer : London, 1999, p. 12; ROTHMANN, Gerd W. Interpretação e aplicação dos acordos internacionais contra a bitributação. Tese de doutorado. São Paulo : Faculdade de Direito da Universidade de São Paulo (USP), 1978, p. 2 e 71; ROTHMANN, Gerd W. A denúncia do acordo de bitributação BrasilAlemanha e suas consequências, in Grandes Questões Atuais do Direito Tributário vol. 9 (Coord. Valdir de Oliveira Rocha). Dialética : São Paulo, 2005, p. 146; GRUPENMACHER, Betina Treiger. Tratados internacionais em matéria tributária e ordem interna. São Paulo : Dialética, p. 92.

${ }^{80}$ SCHOUERI, Luís Eduardo. O princípio do não retrocesso como nova perspectiva à denúncia de acordos de bitributação, in Revista de Direito Tributário Atual n. 29. São Paulo : IBDT/Dialética, 2013, p. 237-245; SCHOUERI, Luís Eduardo. Tratados e Convenções Internacionais sobre Tributação, in Revista de Direito Tributário Atual n. 17. São Paulo : IBDT/Dialética, 2003, p. 22.
} 
Ensina LUÍs EDUARDO SCHOUERI ${ }^{81}$, ainda, que acordos de dupla tributação seriam os instrumentos de Direito Internacional público utilizados pelos Estados para aliviar ou eliminar o fenômeno da bitributação da renda e para combater a evasão fiscal, mediante concessões de ambas as partes. Com a celebração de uma convenção fisscal, busca-se, então, afastar o risco de ofensa à capacidade contributiva do contribuinte. Embora geralmente celebrada entre dois Estados, tais convenções fiscais estabelecem uma "relação trilateral", considerando-se os contribuintes que se sujeitam às suas normas e que podem buscar nestas os instrumentos hábeis para a concretização do "Direito Humano de não Bitributação".

Quanto à sua terminologia, tais instrumentos são geralmente chamados ${ }^{82} \mathrm{de}$ convenções internacionais contra a dupla tributação, tratados internacionais em matéria tributária, concenções contra a dupla tributação, acordos de bitributação e outros semelhantes. Para GERD W. ROTHMANN ${ }^{83}$, por sua vez, seria mais adequado o termo "acordo", como distintivo de tratados com objeto econômico, financeiro, comercial e cultural.

Independentemente das preferências doutrinárias quanto aos rótulos utilizados, não parece haver prejuízo à exposição desta tese a utilização dessa variedade de títulos, desde que se tenha claro o objeto a que se refere o discurso: instrumentos do Direito Internacional pelo qual dois ou mais Estados assumem compromissos e criam mútuas expectativas de coordenação, cooperação e reciprocidade na adoção de medidas para evitar a dupla tributação, prevenir a evasão fiscal e cumprir outros objetivos e propósitos nele estabelecidos.

Se a tributação direta da renda teria surgido da iniciativa inglesa na última quadra do século XIX, os primeiros acordos de dupla tributação foram celebrados antes mesmo da

\footnotetext{
${ }^{81}$ SCHOUERI, Luís Eduardo. Preços de transferência no direito tributário brasileiro. São Paulo: Dialética, 2013, p. 409; SCHOUERI, Luís Eduardo. O princípio do não retrocesso como nova perspectiva à denúncia de acordos de bitributação, in Revista de Direito Tributário Atual n. 29. São Paulo : IBDT/Dialética, 2013, p. 240 .

${ }^{82}$ Para um levantamento doutrinário das preferências terminológicas na doutrina brasileira e estrangeira, vide: VASCONCELLOS, Roberto França. Aspectos Econômicos dos Tratados Internacionais em Matéria Tributária, in Revista de Direito Tributário Internacional n. 1. São Paulo: Quartier Latin, 2005, p. 148-152.

${ }^{83}$ ROTHMANN, Gerd W. Interpretação e aplicação dos acordos internacionais contra a bitributação. Tese de doutorado. São Paulo : Faculdade de Direito da Universidade de São Paulo (USP), 1978, p. 15.
} 
virada para o século XX. KLAUS VoGEL ${ }^{84}$ noticia, como primeiros acordos conhecidos relacionados à tributação direta, aqueles celebrados entre Prússia e Saxônia (1869), Áustria e a Hungria (1869/70) e Áustria e Prússia (1899).

Após o fim da Primeira Guerra Mundial ${ }^{85}$, diversos países deixaram de adotar exclusivamente o princípio da territorialidade formal ${ }^{86}$ - em que a soberania fiscal do Estado se volta apenas para a tributação de rendimentos auferidos dentro de seu território e passaram a conceber a tributação em bases mundiais ou universais ("world wide taxation" $)^{87}$, cuja gênese teria sido concebida por Wagner ${ }^{88}$. Diante da intensificação das relações comerciais internacionais e da aloção de atividades no exterior, os Estados passaram a adotar o princípio da territorialidade material. O cenário se tornou, então, propício à dupla tributação da renda.

Os primeiros esforços para a elaboração de um padrão eficaz de medidas vocacionadas a aliviar ou mesmo evitar a dupla tributação da renda foram conduzidos pela Liga das Nações ${ }^{89}$. Em 1921, por meio de seu Comitê de Assuntos Fiscais, os especialistas em finanças públicas Bruins (Roterdã, Países Baixos), EINAUdi (Turim, Itália), SELIGAN (Nova Iorque, EUA) e STAMP (Londres, Inglaterra) foram convidados para elaborar um relatório sobre as questões relativas à dupla tributação e à evasão fiscal internacional. Tal relatório foi apresentado em 1923, seguindo-se de duas recomendações, em 1925, sobre como lidar com aquelas duas problemáticas por meio de tratados internacionais. O grupo de notáveis não trabalhou sozinho, com a nomeação de um grupo técnico para trabalhar na questão. Nesse seguir, então, quatro modelos para tratados foram elaborados em 1926 e 1927, os quais foram revisados e adotados em 1928 por representantes de 28 estados (alguns dos quais não eram membros da Liga das Nações) em uma conferência convocada

\footnotetext{
${ }^{84}$ VOGEL, Klaus. Klaus Vogel on Double Taxation Conventions. Kluwer : London, 1999, p. 17.

${ }^{85}$ Nesse sentido, vide: UCKMAR, Victor. Double Taxation Conventions, in International Tax Law (Ed. Andrea Amatucci). Klumer : Netherlands, 2006, p. 150.

${ }^{86}$ Sobre o tema da territorialidade, vide: SCHOUERI, Luís Eduardo. Tratados e Convenções Internacionais sobre Tributação, in Revista de Direito Tributário Atual n. 17. São Paulo : IBDT/Dialética, 2003; GRUPENMACHER, Betina Treiger. Tratados internacionais em matéria tributária e ordem interna. São Paulo : Dialética, p. 43.

${ }^{87}$ VOGEL, Klaus. Klaus Vogel on Double Taxation Conventions. Kluwer : London, 1999, p. 12.

${ }^{88}$ Cf. VASCONCELLOS, Roberto França. Aspectos Econômicos dos Tratados Internacionais em Matéria Tributária, in Revista de Direito Tributário Internacional n. 1. São Paulo: Quartier Latin, 2005, p. 154.

${ }^{89}$ A respeito de acordos comerciais com reflexos tributários, que não são tratados nesta tese, vide: GRUPENMACHER, Betina Treiger. Tratados internacionais em matéria tributária e ordem interna. São Paulo : Dialética, p. 90 e seg. A respeito dos acordos internacionais relacionados aos impostos de impostortação, vide: HILÚ NETO, Miguel. Imposto sobre importações e imposto sobre exportações. São Paulo : Quartier Latin, 2003.
} 
pelo Secretário-Geral da Liga das Nações. Ainda em 1928, então, o Conselho da Liga das Nações designou uma comissão permanente sobre tributação e, no ano seguinte, esta apresentou dois tratados modelo alternativos, que substituíram os anteriores. ${ }^{90}$

Foi apenas após o fim da Segunda Guerra Mundial, contudo, que a celebração de acordos internacionais para evitar a dupla tributação tornou-se realmente intensa, acompanhando a gradual remoção de barreiras comerciais e a negociação de uma série de acordos comerciais, como o GATT (1947). ${ }^{91}$

Em 1943, a Liga das Nações voltou a se reunir para tratar do tema. No México, com a presença principalmente de países latino-americanos, foram realizadas revisões e apresentou-se um novo modelo, mais benéfico aos países em desenvolvimento. Logo em 1946, aquela organização voltou a se reunir, agora com a presença dos Estados industrializados, publicando então o modelo de Londres, que restabeleceu as vantagens aos países industrializados.

Nos anos 60, contudo, os principais trabalhos sobre a temática passaram a ser conduzidos por outra organização. Constituída em 1960 para suceder a então Organisation for European Economic Cooperation (“OEEC”), a OCDE publicou, em 1963, seu primeiro esboço de um modelo (acompanhado de comentários) para a celebração de acordos de dupla tributação por seus Estados membros, incentivando que, aos pares, estes entrassem em negociação e formalmente as celebrassem. Em 1971, o modelo passou a ser reanalisado pela CAF-OCDE, especialmente diante de demandas e constatações práticas surgidas. Em 1977, por sua vez, foi publicado um modelo mais completo e revisado, acompanhado de Comentários a respeito de cada um de seus dispositivos. A partir de 1992, o CAF-OCDE passou a publicar periodicamente - e cada vez com mais frequência - revisões pontuais à CM-OCDE e aos seus comentários, sob a sistemática de folhas soltas, ou seja, sem que se aguarde a conclusão de estudos para alterações em seu texto como um todo ${ }^{92}$. Assim, seguiram-se revisões à CM-OCDE e aos seus Comentários, publicadas em 1992, 1994,

${ }^{90}$ Cf. RAAD, Kees van. The term 'Enterprise' in the Model Double Taxation Conventions - Seventy Years of Confusion, in Intertax 1994/11. Intertax, 1994, p. 494 e seg.; VOGEL, Klaus. Double Taxation Convention, Kluwer : London, 1997, p. 17.

${ }^{91}$ Nesse sentido, vide: VANN, Richard J. International Aspects od Income Tax, in Tax Law Design and Drafting (Ed. THURONYI, Victor). Londres : Kluwer, 1998, p. 719 e seg.

${ }^{92}$ Sobre o tema e o histórico da CM-OCDE, vide: VOGEL, Klaus. Double Taxation Convention, Kluwer : London, 1997, p. 18 e seg. 
1995, 1997, 2000, 2003, 2005, 2008, 2010 e 2014 ${ }^{93}$. Note-se que, desde 1997, a posição oficial de Estados não-membros da OCDE (convidados), manifestada por meio de reservas e observações, passou a acompanhar a CM-OCDE e os seus respectivos Comentários ${ }^{94}$, o que é especialmente relevante ao Brasil, que assume o papel de país não-membro observador convidado naquela organização.

Há uma rede em crescimento, com milhares de acordos de dupla tributação celebrados basicamente a partir da CM-OCDE. Não é demais frisar que a CM-OCDE é um modelo e não uma convenção internacional em si. Cada acordo de bitributação mantém suas próprias peculiaridades, decorrentes de uma série de variáveis culturais, políticas, econômicas, entre outras. Outros modelos de acordos de dupla tributação, como a CMONU e a CM-EUA analisados no subtópico seguinte, refletem algumas dessas variações.

Os acordos de dupla tributação elaborados a partir da CM-OCDE possuem cerca de 100 a 120 disposições, distribuídas entre aproximadamente 30 artigos. As normas veiculadas nos acordos de dupla tributação não possuem um caráter único, mas podem ser segregadas da forma sugerida por GERD W. ROTHMANN ${ }^{95}$ : (i) como normas de conflito, ao indicar qual das duas legislações nacionais seria a aplicável e; (ii) como normas materiais, que alterariam as normas tributárias da ordem interna dos Estados contratantes. As normas materiais contidas em tais acordos internacionais poderiam ainda ser dividas em outras 5 categorias, quais sejam: (a) cláusulas de isenção; (b) cláusulas de redução de alíquota; (c) cláusulas de crédito; (d) cláusula de reserva de progressão; (e) cláusula de troca de informação.

Sob outro prisma, ROBERTO FRANÇA VASCONCELLOS ${ }^{96}$ suscita que o compromisso assumido pelos Estados com a celebração de um acordo conforme a CM-OCDE poderia ser reduzida a três itens: $i$ ) cada Estado permanece legitimado à tributação da renda

\footnotetext{
${ }^{93}$ Vide: OCDE. Model Tax Convention on Income and on Capital 2014 (Full Version), OECD Publishing, 2014.

${ }^{94}$ Sobre o tema, vide: VOGEL, Klaus. Double Taxation Convention, Kluwer : London, 1997, p. 18; ENGELEN, Frank; DOUME, Sjoerd. Conference position paper: the quest for the holy grail in international tax law - the legal status of the Commentaries on the OECD Model Tax Convention on Income and on Capital, in The legal status of the OECD Commentaries. Amsterdã : IBFD, 2008, p. 255 e seg.

${ }^{95}$ ROTHMANN, Gerd W. Interpretação e aplicação dos acordos internacionais contra a bitributação. Tese de doutorado. São Paulo : Faculdade de Direito da Universidade de São Paulo (USP), 1978, p. 41-49.

${ }^{96}$ VASCONCELLOS, Roberto França. Aspectos Econômicos dos Tratados Internacionais em Matéria Tributária, in Revista de Direito Tributário Internacional n. 1. São Paulo: Quartier Latin, 2005, p. 155-156.
} 
derivada de atividades desenvolvidas em seu território; ii) cada Estado permanece legitimado à tributação da renda de seus residentes; iii) diante da possibilidade de cumulação dos dois itens antecendentes, cabe ao Estado da fonte restringir a tributação em algumas hipóteses, bem como deverá o Estado da residência insentar rendimentos ou conceder crédito em relação ao imposto pago àquele primeiro, nas hipóteses em que também lhe couber a tributação. A questão, contudo, reside nos limites adequados para a tributação pelo país da fonte.

Tal como concebida, a estrutura da CM-OCDE privilegia o Estado da residência, importador de capitais: (i) a renda do trabalho ou de serviços pode ser tributado no Estado em que estes são executados; (ii) a renda passiva, como juros e dividendos, podem ser tributados pelo Estado da fonte até um determinado limite; (iii) o lucro das atividades empresariais serão tributadas no Estado da residência, salvo no que se refere aos lucros atribuíveis a um estabelecimento permanente no Estado da fonte. ${ }^{97}$

O Brasil possui, atualmente, 31 (trinta e um) acordos internacionais em vigor $^{98}$, abrangendo 32 (trinta e dois) países. Como analisado no subtópico seguinte e em outras passagens desta tese, embora os acordos de dupla tributação celebrados pelo Brasil em geral se alinhem à CM-OCDE, possuem traços da CM-ONU e peculiaridades próprias, o que torna cada um deles único.

\subsubsection{Além da CM-OCDE: outros modelos de acordos de bitributação.}

A estrutura da CM-OCDE exerce considerável influência sobre os acordos de dupla tributação efetivamente celebrados pelos Estados e, ainda, na elaboração de outros modelos: há uma série de outros modelos de acordos de dupla tributação, cada qual com suas peculiaridades, mas com estruturas semelhantes à CM-OCDE.

A seguir, serão analisados alguns desses outros modelos, elaborados por outras organizações ou por países.

\footnotetext{
${ }^{97}$ VASCONCELLOS, Roberto França. Aspectos Econômicos dos Tratados Internacionais em Matéria Tributária, in Revista de Direito Tributário Internacional n. 1. São Paulo: Quartier Latin, 2005, p. 155-156.

${ }^{98}$ Vide "Apêndice 1", tópico 2, ao final do presente trabalho.
} 


\subsubsection{Convenção Modelo da Organização das Nações Unidas ("CM-ONU")}

A CM-ONU (1980-2011) ${ }^{99}$ assume atualmente especial importância, sendo geralmente considerada na negociação com países em desenvolvimento. EDUARDO BAISTROCCHI ${ }^{100}$ observa que a CM-ONU se posiciona entre a CM-Comunidade Andina (favorável ao Estado da fonte) e a CM-OCDE (favorável ao Estado de residência), distinguindo-se desta última em 27 adaptações pontuais, a exemplo de conceitos mais amplos de estabelecimento permanente e royalties.

Diversos acordos de dupla tributação celebrados pelo Brasil possuem traços da CM-ONU, embora em geral se alinhem à CM-OCDE, sem repetir qualquer desses modelos em sua integralidade ${ }^{101}$. Alguns exemplos demonstram tal cenário. As convenções celebradas com Chile, México, Peru e Ucrânia seguem a CM-OCDE, adotando o "lugar de incorporação" ( "place of incorporation") como critério de residência, como sugere o art 4 da CM-ONU). É possível observar que a maior parte dos acordos de dupla tributação brasileiros ${ }^{102}$ adota a cláusula do art. 5 (3) da CM-OCDE para a definição de estabelecimento permanente, temperada a previsão do período de seis meses (183 dias) colhida da CM-ONU, a qual, na CM-OCDE, é de doze meses. O acordo Brasil-China, embora único nesse sentido, adota em sua integralidade a cláusula do art. 5 (3) da CM$\mathrm{ONU}^{103}$. Por sua vez, a maior parte dos acordos brasileiros ${ }^{104}$ adota o art. 5 (6) da CMONU, atinente ao estabelecimento permanente de companhias seguradoras, sem correspondente na CM-OCDE, embora também possua dispositivos semelhantes ao art. 5 (5), (6) e (7) desta. A segunda sentença do art. 5 (7) da CM-ONU, ausente na CM-OCDE,

\footnotetext{
${ }^{99}$ Vide: United Nations. Model Double Taxation Convention between Developed and Developing Countries. Nova Iorque : ONU, 2011. Último acesso em 01/11/2014, no endereço eletrônico http://www.un.org/esa/ffd/documents/UN_Model_2011_Update.pdf.

${ }^{100}$ BAISTROCCHI, Eduardo A., The Use and Interpretation of Tax Treaties in the Emerging World: Theory and Implications. British Tax Review n. 4. Londres : Thomson, 2008, p. 372.

${ }^{101}$ Para um panorama completo deste cenário, vide: SCHOUERI, Luís Eduardo; SILVA, Natalie Matos. Brazil, in The Impact of the OECD and UN Model Conventions on Bilateral Tax Treaties. (Editores: LANG, Michael; PISTONE, Pasquale; SCHUCH, Josef; STARINGER, Claus). Cambridge : Cambridge University Press, 2012, p. 171 e seg.

${ }^{102}$ Vide, por exemplo: BRASIL, Decreto ${ }^{\circ} 355$, de 2 de dezembro de 1991. Acordo Brasil-Países Baixos, art. 5 (3).

${ }^{103}$ Vide, por exemplo: BRASIL, Decreto n ${ }^{\circ} 762$, de 19 de fevereiro de 1993. Acordo Brasil-China, art. 5 (3).

${ }^{104}$ Vide, por exemplo: BRASIL, Decreto $\mathrm{n}^{\circ}$ 75.106, de 20 de dezembro de 1974. Acordo Brasil-Dinamarca, art. 5 (5).
} 
foi adotada nos acordos celebrados com Chile, China, Índia e México ${ }^{105}$. Entre outros exemplos, é possível notar que todos os acordos celebrados pelo Brasil ${ }^{106}$ seguem o art. 12 da CM-ONU, que autoriza a tributação dos royalties também pelo Estado da fonte, divergindo da política da CM-OCDE de tributação exclusiva pelo Estado de residência.

\subsubsection{Convenção Modelo dos Estados Unidos da América ("CM-EUA")}

"Desde o início do projeto de tratados tributários, os tratados dos Estados Unidos seguiram rigorosamente o Modelo da OCDE. Não é de se surpreender, considerando o papel central dos Estados Unidos e de seus representante em funções chaves no Comitê de Assuntos Fiscais da OCDE. Os Estados Unidos geralmente aceitam as 'regras do jogo', apesar de sua retórica forte em defesa da não padronização dos tratados tributários e a visão de que cada tratado verdadeiramente é fruto de negociações sérias e efetivo 'toma-lá-dá-cá'. No entanto, os Estados Unidos vêm continuamente dando o tom ao Modelo da OCDE, com ênfases próprias".

YARIV BRAUNER (2011) ${ }^{107}$

Os EUA sempre participaram ativamente na elaboração de modelos para celebração de convenções, desde o projeto da Liga das Nações até os trabalhos atuais do CAF-OCDE. Como observa o professor ${ }^{108}$ da passagem em epígrafe, posições adotadas particularmente por aquele país justificaram a publicação de um modelo próprio, tornandoas mais transparentes aos seus potenciais parceiros internacionais.

Desde 1976, então, passou a ser publicada a CM-EUA, consistindo basicamente na CM-OCDE, alterada em alguns pontos. Embora inspirada na CM-OCDE, não devem ser ignorados os importantes pontos que as distinguem, a exemplo de cláusulas de limitação de benefícios dos acordos ${ }^{109}$ e a adoção exclusivo do método da imputação ${ }^{110}$.

\footnotetext{
${ }^{105}$ Vide, por exemplo: BRASIL, Decreto n 6.000 , de 26 de dezembro de 2006. Acordo Brasil-México, art. 5 (7).

${ }^{106}$ Vide, por exemplo: BRASIL, Decreto $\mathrm{n}^{\circ}$ 75.106, de 20 de dezembro de 1974. Acordo Brasil-Dinamarca, art. 12 .

${ }^{107}$ BRAUNER, Yariv. Por que os Estados Unidos firmam Tratados Tributários? E por que não têm Tratado Tributário com o Brasil?, in Revista Direito Tributário Atual n. 26. São Paulo : IBDT/Dialética, 2011, p. 114.

${ }^{108}$ BRAUNER, Yariv. Por que os Estados Unidos firmam Tratados Tributários? E por que não têm Tratado Tributário com o Brasil?, in Revista Direito Tributário Atual n. 26. São Paulo : IBDT/Dialética, 2011, p. 115 e seg.

${ }^{109}$ Nesse sentido, vide: SCHOUERI, Luís Eduardo. Tratados e Convenções Internacionais sobre Tributação, in Revista de Direito Tributário Atual n. 17. São Paulo : IBDT/Dialética, 2003, p. 30.

${ }^{110}$ VASCONCELLOS, Roberto França. Aspectos Econômicos dos Tratados Internacionais em Matéria Tributária, in Revista de Direito Tributário Internacional n. 1. São Paulo: Quartier Latin, 2005, p. 166.
} 
Acompanha essa publicação uma explicação técnica elaborada pelo Tesouro norteamericano, semelhante à que é apresentada ao Senado no processo de aprovação de convenções fiscais efetivamente celebradas.

Como quaisquer modelos, YARIV BRAUNER ${ }^{111}$ observa que a CM-EUA é negociável inclusive em seus pontos mais peculiares em relação à CM-OCDE. Há propósito, não há uniformidade nos acordos atualmente existentes nos EUA ou mesmo clareza e transparência na política adotada na negociação de cada um deles.

\subsubsection{Outros modelos de acordos de dupla tributação}

Em relação à CM Comunidade Andina (1971) ${ }^{112}$, KLAUs VogEL ${ }^{113}$ observou tratar-se de modelo que se propõe à melhor consideração dos interesses específicos dos países em desenvolvimento, privilegiando o princípio da fonte. A Comunidade Andina, formada em 1971 pela aliança entre Bolívia, Chile, Equador, Colômbia e Peru, passou a contar, a partir de 1973, também com a Venezuela. No entanto, o Chile abandonou o grupo em 1977 e, a Venezuela, em 2006. Como observa EdUARdo BAISTROCCHI ${ }^{114}$, não há notícia da utilização desse modelo por acordos firmados com países desenvolvidos. Apenas dois acordos entre países em desenvolvimento o teriam adotado: o acordo Argentina-Chile e o acordo Argentina-Bolívia.

Mais do que não ter obtido adesão internacional, ROBERTO FRANÇA VASCONCELlOS ${ }^{115}$ aduz que a política sustentada pelos Estados componentes do Pacto Andino, de observação rigorosa do princípio da territorialidade, os levou ao isolamento e ao afugentamento do investimento estrangeiro.

\footnotetext{
${ }^{111}$ BRAUNER, Yariv. Por que os Estados Unidos firmam Tratados Tributários? E por que não têm Tratado Tributário com o Brasil?, in Revista Direito Tributário Atual n. 26. São Paulo : IBDT/Dialética, 2011, p. 115. ${ }^{112}$ Andean Community Income and Capital Model Tax Treaty. Último acesso em 01/11/2014, no endereço eletrônico

http://online.ibfd.org/kbase/\#topic=doc\&url=/collections/ttmodel/html/tt_a1_02_eng_1971_mo_td1.html\& WT.z_nav=Navigation\&colid $=4933$.

${ }^{113}$ VOGEL, Klaus. Double Taxation Convention, Kluwer : London, 1997, p. 18-19.

${ }^{114}$ BAISTROCCHI, Eduardo A., The Use and Interpretation of Tax Treaties in the Emerging World: Theory and Implications. British Tax Review n. 4. Londres : Thomson, 2008, p. 372.

${ }^{115}$ VASCONCELLOS, Roberto França. Aspectos Econômicos dos Tratados Internacionais em Matéria Tributária, in Revista de Direito Tributário Internacional n. 1. São Paulo: Quartier Latin, 2005, p. 173-174.
} 
Em 2011, a Comunidade para o Desenvolvimento da África Austral (“CDAA”) publicou sua convenção modelo (“CM- CDAA”). Como expõem os seus Comentários, trata-se de um modelo que em geral incorpora a CM-OCDE de 2010, mantendo alguns dispositivos de versões anteriores e aderindo a algumas propostas da CM-ONU. ${ }^{116}$

Alguns países também possuem os seus próprios modelos, customizados para refletir suas posições em relação à política tributária internacional. Cite-se, por exemplo, a CM-Alemanha $(2013)^{117}$, a CM-Bélgica (2010) ${ }^{118}$, a CM-EUA (2006) ${ }^{119}$, a CM-Países Baixos (1988) $)^{120}$ e a CM-Rússia $(2010)^{121}$.

Por fim, vale nota a CM-ILADT $(2012)^{122}$. Fruto do trabalho conjunto de acadêmicos e profissionais, a CM-ILADT apresenta uma alternativa à questão da melhor distribuição das competências tributárias entre os Estados da fonte e da residência, bem como transparece a preocupação em remediar conhecidas dificuldades de interpretação e aplicação dos demais modelos. Quanto àquele primeiro aspecto, quando comparada com a CM-OCDE, é possível observar que a CM-ILADT reserva maior fatia da tributação ao Estado da fonte, adota a isenção como método prevalente (salvo para rendimentos passivos, para a qual se reservou uma única regra distributiva), valendo-se do método do

\footnotetext{
${ }^{116}$ SADC Model Tax Agreement on Income. Último acesso em 01/11/2014, no endereço eletrônico http://online.ibfd.org/kbase/\#topic=doc\&url=/collections/ttmodel/html/tt_sad_01_eng_2011_mo_td1.html\& WT.z nav=Navigation\&colid $=4933$.

${ }^{117}$ Germany Income and Capital Tax Treaty. Último acesso em 01/11/2014, no endereço eletrônico http://online.ibfd.org/kbase/\#topic $=$ doc\&url=/collections/ttmodel/html/tt_de_02_eng_2013_mo_td1.html\& WT.z_nav=Navigation\&colid $=4933$.

${ }^{118}$ Belgium Income and Capital Model Convention. Último acesso em 01/11/2014, no endereço eletrônico http://online.ibfd.org/kbase/\#topic=doc\&url=/collections/ttmodel/html/tt_be_02_eng_2010_mo_td1.html\& WT.z nav=Navigation\& colid $=4933$.

${ }^{119}$ UNITED STATES MODEL INCOME TAX CONVENTION. Último acesso em 01/11/2014, no endereço eletrônico http://www.irs.gov/pub/irs-trty/model006.pdf.

${ }^{120}$ The Netherlands Income and Capital Model Convention. Último acesso em 01/11/2014, no endereço eletrônico

http://online.ibfd.org/kbase/\#topic $=$ doc\&url=/collections/ttmodel $/ \mathrm{html} / \mathrm{tt} \_\mathrm{nl}$ 02_dut_1998_mo_td1.html\&

WT.z_nav=Navigation\&colid=4933.

${ }^{121}$ Russia Russian Income and Capital Model Convention. Último acesso em 01/11/2014, no endereço eletrônico

http://online.ibfd.org/kbase/\#topic $=$ doc\&url=/collections/ttmodel $/ \mathrm{html} / \mathrm{tt} \_$ru_02_rus_2010_mo_td1.html\& WT.z_nav=Pagination\& colid=4933.

${ }^{122}$ Modelo ILADT de Convenio Multilateral de Doble Imposición para América Latina, in Cuaderno Tributario ICDT, Agosto. Santiago de Compostela : ILADT, 2012. Último acesso em 31/10/2014, por meio do endereço eletrônico http://www.iladt.org/frontend/DocumentPage.aspx.
} 
crédito apenas para a aplicação de tax sparing clauses $^{123}$. Não se tem notícia, contudo, de qualquer acordo de dupla tributação que já tenha considerado tal modelo.

No decorrer desta tese, serão feitas referências correntes à CM-OCDE, sob o pressuposto de que as considerações em questão se aplicam, em geral, também aos acordos de dupla tributação celebrados considerando outros modelos devido à semelhança entre esses. Por sua vez, particularidades desses outros modelos serão evidenciadas em diversas passagens do texto, quando necessário.

\section{INTERPRETAÇÃO E APLICAÇÃO DO DIREITO TRIBUTÁRIO INTERNACIONAL (BRASILEIRO)}

"Numerous rules, canons, and principles have been laid down by international tribunals, and by writers to be used as tools in the interpretation of treaties, and to serve as useful, indeed necessary, guidelines to the drafting of treaty provisions. These rules, canons, and principles, although sometimes invested with the sanctity of dogmas, are not absolute formulae, but are in every sense relativerelative to the particular text, and to the particular problem that is in question. To some extent, like presumptions in the law of evidence, their weight may depend on the cumulative application of several, rather then the application of one singly.", J.G. STARKE \& I.A. SHEARER (1994) ${ }^{124}$

A interpretação é tema caro a qualquer disciplina jurídica, desde a teoria geral do Direito até as mais especializadas searas jurídicas. A interpretação no Direito pode ser compreendida como a construção de sentido de uma determinada norma jurídica ${ }^{125}$. Tal concepção se contrapõe à interpretação enquanto ato de mero resgate de um sentido ínsito aos signos de linguagem. A atividade criadora do intérprete está vinculada ao contexto em que ele e o objeto interpretado se encontram imersos, o que explica a possibilidade de comunicação e entendimento entre os operadores de tal sistema jurídico.

Entre as questões que rondam o Direito tributário, discute-se há tempos se o ato de "interpretar" deve ser distinguido do ato de "aplicar" determinada norma jurídica. Para justificar a segregação dos institutos, seria necessário relacionar “interpretar” com o

\footnotetext{
${ }^{123}$ Cf. SCHOUERI, Pedro. Comparison of the OECD and ILADT Model Conventions, in Bulletin for International Taxation - Agosto, volume 68, n. 9. Amsterdã : IBFD, 2014.

${ }^{124}$ STARKE, Joseph Gabriel; SHEARER, I.A. Starke's international law. Butterworths : Canada, 1994, p. 435.

${ }^{125}$ Cf. CARVAlHO, Paulo de Barros. Curso de Direito Tributário. São Paulo : Saraiva, 2000, p. 94; $107-$ 108.
} 
processo de conhecimento do sentido de determinada norma e, "aplicar", com a subsunção de tal norma a determinado fato concreto. ${ }^{126}$

A teoria jurídica parece ser mais bem explicada por autores que, embora não distinguam temporalmente os atos de "interpretar" e de "aplicar" o Direito, admitam a segregação teórica de tais movimentos. Como ensina LUís EdUARDo SCHOUERI ${ }^{127}$, há um processo em que o aplicador do Direito realiza a interpretação, integração e aplicação de forma simultânea: "no lugar de etapas diversas e sucessivas, o conhecimento da norma e do fato se revelam mutuamente influentes, de modo que o operador do direito não poderá deixar qualquer um deles de lado na construção do resultado de seu trabalho".

Já no início dos anos 80 , GERD W. ROTHMANN ${ }^{128}$ assumia que a opinião prevalente consistiria em considerar a interpretação como um estágio, um "problema parcial do ato de aplicação do direito global, que funcionalmente é integrado na relação de implicação entre situação de fato e norma". Ocorre que o ato de aplicação consistiria em um processo de raciocínio amplo, que se iniciaria com a interpretação da norma e terminaria com a solução jurídica de um caso concreto.

Alguns autores ${ }^{129}$ consideram relevante distinguir a interpretação da aplicação do acordo de dupla tributação, de modo a atribuir a este último um rótulo especial: qualificação. Assim, para AlBerto XAVIER ${ }^{130}$, o ato de interpretar "cifra-se em definir por via geral e abstracta todos os possíveis conteúdos de um dado conceito, enquanto a qualificação, incidindo sobre um quid concreto e traduzindo-se por uma decisão de espécie, contende já com a aplicação da norma de direito.” A qualificação seria um problema posterior à interpretação, que teria lugar com a aplicação da norma jurídica e consistiria "na subsumibilidade de um quid (objeto de qualificação) num conceito utilizado por uma norma (fonte da qualificação)". A “qualificação" consistiria, para o autor, no ato cognoscente de enquadrar um determinado rendimento em alguma das categorias econômicas estabelecidas pelos Estados contratantes, no ato de subsumir um fato a uma

\footnotetext{
${ }^{126}$ Sobre a identidade dos atos de "aplicar" e "interpretar" o Direito, vide, ainda: ROCHA, Sergio André. Interpretação dos tratados para evitar a dupla tributação. São Paulo : Quartier Latin, 2013, p. 130.

${ }^{127}$ SCHOUERI, Luís Eduardo. Direito Tributário. Saraiva : São Paulo, 2013, p. 679.

${ }^{128}$ ROTHMANN, Gerd W. Interpretação e aplicação dos acordos internacionais contra a bitributação. Tese de doutorado. São Paulo : Faculdade de Direito da Universidade de São Paulo (USP), 1978, p. 95-96.

${ }^{129}$ Além de Alberto XAVIER, vide: BELLAN, Daniel Vitor. Direito tributário internacional. Rendimentos de pessoas físicas nos tratados internacionais contra a dupla tributação. Saraiva : São Paulo, 2010, p. 107.

${ }^{130}$ XAVIER, Alberto. Direito tributário internacional do Brasil. Forense : Rio de Janeiro, 2010, p. 140 e seg.
} 
norma do acordo de bitributação. A aplicação do acordo seria, assim, identificada com o momento em que o rendimento é enquadrado, ou melhor, qualificado, em alguma das cédulas de rendimentos (conceitos-quadro).

No entanto, a expressão "qualificação" também é utilizada, por outros autores, com referência a um fenômeno distinto. Assim, para SERGIO ANDRÉ ROCHA ${ }^{131}$, a "qualificação" consistiria na "remissão, à regra de conflito, do resultado da interpretação/aplicação do direito interno de cada um dos países aos quais determinada situação se encontra vinculada por elementos de conexão". Empresta-se, nessa perspectiva, o instituto da "qualificação" do Direito Internacional privado ${ }^{132}$.

Como se pode observar, para ALBerto XAVIER ${ }^{133}$, o art. 3 (2) da CM-OCDE não trata da questão da "qualificação", pois se volta à interpretação, que seria um momento anterior. Já para outros autores ${ }^{134}$, o dispositivo versa precisamente sobre o tema, dando ensejo, então, aos conflitos de qualificação. Assim, SERGIO ANDrÉ RoCHA ${ }^{135}$ sustenta que a qualificação propriamente dita não decorreria dos acordos de dupla tributação, "mas sim da interpretação do direito interno dos Estados contratantes quando o mesmo for relevante para a integração do texto convencional, na forma prevista no item 2 do artigo 3 da Convenção Modelo”.

Para os propósitos desta tese, serão reservadas as expressões "qualificação" e "conflitos de qualificação" com referência, respectivamente, à caracterização dos rendimentos na legislação interna dos Estados contratantes e aos problemas decorrentes do reenvio ao Direito doméstico responsáveis pela dupla tributação ou mesmo dupla não tributação da renda.

${ }^{131}$ ROCHA, Sergio André. Interpretação dos tratados para evitar a dupla tributação. São Paulo : Quartier Latin, 2013, p. 231.

${ }^{132}$ Cf. SCHOUERI, Luís Eduardo. Preços de transferência no direito tributário brasileiro. São Paulo: Dialética, 2013, p. 412.

${ }^{133}$ XAVIER, Alberto. Direito tributário internacional do Brasil. Forense : Rio de Janeiro, 2010, p. 134 e seg.

${ }^{134}$ SCHOUERI, Luís Eduardo. Preços de transferência no direito tributário brasileiro. São Paulo: Dialética, 2013, p. 412; ROTHMANN, Gerd W. Interpretação e aplicação dos acordos internacionais contra a bitributação. Tese de doutorado. São Paulo : Faculdade de Direito da Universidade de São Paulo (USP), 1978.

${ }^{135}$ ROCHA, Sergio André. Interpretação dos tratados para evitar a dupla tributação. São Paulo : Quartier Latin, 2013, p. 231-235. 
Tal questão é útil para esclarecer a delimitação da presente tese, que não investiga necessariamente o problema da "qualificação" ou mesmo do "conflito de qualificação". Neste estudo, não se procura solucionar o dilema do reenvio ao Direito doméstico apenas do Estado da fonte ou do Estado de residência, como forma de dirimir conflitos de qualificação. Na verdade, em contraste, procura-se investigar uma alternativa para que o problema dos conflitos de qualificação sequer venham a existir.

Desse modo, para a investigação ora proposta, é relevante conhecer os mecanismos de interpretação existentes no Direito Internacional e, ainda, a norma especial de interpretação do Direito tributário internacional, veiculada pelo art. 3 da CM-OCDE. Esse é precisamente o objeto dos subtópicos seguintes.

\subsection{A interpretação e aplicação do Direito Internacional antes da CVDT}

"There are few topics in international law which have given rise to such extensive doctrinal dispute as the topic of treaty interpretation. The passion which is generated among jurists on this one issue is such that, whith MacNair, your lecturer confesses that 'there is no part of law of treaties which [he] approaches with more trepidation than the question of interpretation'."

IAN SINCLAIR (1973) $)^{136}$

No Direito Internacional, princípios e máximas de interpretação foram gradualmente construídos, baseados em experiências anteriores e demandas de casos concretos $^{137}$.

Em 1935, a Universidade de Harvard publicou estudos para a elaboração de um acordo multilateral sobre o Direito dos tratados ("Harvard Draft Convention on the Law of Treaties"), os quais se opunham à codificação de normas vocacionadas a conduzir a interpretação de acordos internacionais. Compreendeu-se que a interpretação seria uma ciência natural, que não poderia ser confinada em regras mecânicas. Sob tal perspectiva, uma convenção multilateral - como aquela celebrada mais tarde em Viena - não deveria conter qualquer dispositivo a respeito da interpretação dos tratados. ${ }^{138}$

${ }^{136}$ SINCLAIR, Ian M. The Viena Convention on the Law of Treaties. Manchester University Press : Manchester, 1973, p. 69.

${ }^{137}$ MERKOURIS, Panos. Introduction: Interpretation is a Science, is an Art, is a Science, in Treaty Interpretation and the Vienna Convention on the Law of Treaties. Leiden : Martinus Nijhoff, 2010, 5.

${ }^{138}$ Cf. BECERRA, Andrés González. The interpretational approaches to the Vienna Convention application to (tax) treaty analysis, in Bulletin for International taxation - setembro 2011. IBFD : Amsterdam, 2011, p. 2. 
A passagem em epígrafe demonstra as dificuldades que o tema enfrentava quando da celebração da CVDT, em 1969. Os relatórios da ILC-ONU ${ }^{139}$ evidenciam que tal convenção multilateral foi celebrada em um franco ambiente de dilemas e dúvidas, relacionadas especialmente a questões como: i) se seria ou não possível o controle do ato interpretativo por meio de normas jurídicas e ii) qual seria o objetivo da interpretação e se haveria um método mais adequado para alcançá-lo.

Durante as discussões para a elaboração da CVDT, parte dos membros da ILC-ONU defendia que não lhe fosse incluído nenhum dispositivo para a tutela da interpretação dos tratados. Entre os embaixadores que sustentavam tal posição, LAUTERPACHT, antes mesmo da oficialização dos primeiros esforços para a elaboração da CVDT, já suscitava que diversas máximas de interpretação existentes seriam mutuamente excludentes, não se podendo esperar que uma simples listagem dessas pudesse compor um coerente sistema normativo. Como exemplo, aquele autor citava que a máxima "in dubio pro mitius" poderia se chocar com a máxima "ut res magis valeat quam pereat". ${ }^{140}$ Por sua vez, a codificação de regras de interpretação também não seria de todo aconselhável, já que poderiam se tornar instrumentos rígidos, perdendo a flexibilidade que lhes seria naturalmente necessária ${ }^{141}$. No ambiente acadêmico e político existente à época em que a CVDT foi negociada, colocava-se em dúvida a legitimidade ou mesmo pertinência da positivação de normas para a interpretação dos acordos internacionais.

A segunda questão em franca discussão ao tempo da elaboração da CVDT - e que ainda hoje permanece presente em uma série de debates - se refere a quais os objetivos da interpretação e quais métodos devem ser adotados para concretizá-los. Nas décadas que antecederam a conclusão da CVDT (1969), ao menos três teorias quanto à interpretação dos acordos internacionais disputaram a preferência da doutrina e dos Tribunais: textual, subjetiva e teleológica.

\footnotetext{
${ }^{139}$ ONU. Yearbook of the International Law Commission. 1966. Records on the 866th meeting. ONU, 1966, vol. II, p. 173 e seg.

${ }^{140}$ Cf. BECERRA, Andrés González. The interpretational approaches to the Vienna Convention application to (tax) treaty analysis, in Bulletin for International taxation - setembro 2011. IBFD : Amsterdam, 2011, p. 3.

${ }^{141}$ Cf. BROWNLIE, Ian. Principles of public international law. Clarendon : Oxford, 1998, p. 632.
} 
Enquanto a corrente da interpretação subjetiva (ou voluntarista) defendia que a interpretação de um acordo internacional teria o propósito de verificar a intenção original dos Estados contratantes, a corrente textual assumia que a interpretação consistiria na identificação de sentido do texto do acordo, pois a intenção das partes somente poderia ser averiguada a partir de elementos intrínsecos ao texto ${ }^{142}$ e com uma postura muitas vezes eminentemente lexical ${ }^{143}$.

A teoria da interpretação subjetiva (ou voluntarista) se aproxima da interpretação textual ao sustentar que o objetivo da interpretação é a descoberta da vontade das partes; o que afasta tais teorias é o repertório de elementos a que o intérprete pode recorrer para identificar a intenção dos Estados contratantes, como os trabalhos preparatórios, aceitos pela primeira e rejeitados pela segunda. ${ }^{144}$ Observa GERD W. ROTHMANN ${ }^{145}$ que, até a Segunda Guerra Mundial, a interpretação subjetiva (ou voluntarista) encontrava acolhida da jurisprudência internacional, sendo possível identificar, desde então, inclinações ao entendimento de que o texto seria a única expressão da vontade das partes.

Um terceiro grupo sustentaria, ainda, que o objetivo da interpretação seria evidenciar os objetivos e propósitos do acordo internacional celebrado (corrente teleológica). ${ }^{146}$ Para essa corrente, o objetivo da interpretação seria atribuir efeito aos objetivos e propósitos dos acordos internacionais, ainda que o resultado obtido não fosse suportado por seu texto. Os objetivos e propósitos de um acordo internacional não seriam apenas mais um elemento a ser considerado no processo interpretativo, mas o mais importante de todos: sua função seria auxiliar o juiz a remediar deficiências e lacunas existentes no texto do acordo internacional, a fim de transparecer o que as partes pretendiam expressar, embora não o tenham feito com eficiência. ${ }^{147} \mathrm{Com}$ a chamada

\footnotetext{
${ }^{142}$ EDWARDES-KER, Michael. Tax Treaty Interpretation - The International Tax Treaties Service. InDepth Publishing : Athlone, 1994, p. 1, Capítulo 4.

${ }_{143}$ Nesse sentido, vide: GARDINER, Richard K. International Law. Pearson : Harlaw, 2003, p. 80-81.

${ }^{144}$ BECERRA, Andrés González. The interpretational approaches to the Vienna Convention - application to (tax) treaty analysis, in Bulletin for International taxation - setembro 2011. IBFD : Amsterdam, 2011, p. 2.

${ }^{145}$ ROTHMANN, Gerd W. Interpretação e aplicação dos acordos internacionais contra a bitributação. Tese de doutorado. São Paulo : Faculdade de Direito da Universidade de São Paulo (USP), 1978, p. 139.

${ }^{146}$ Nesse sentido, vide: SINCLAIR, Ian M. The Viena Convention on the Law of Treaties. Manchester University Press : Manchester, 1973, p. 70.

${ }^{147}$ Nesse sentido, vide: BROE, Luc De. International tax planning and prevention of abuse (doctoral series $\mathrm{n}$. 14). Amsterdã : IBFD, 2007, p. 248.
} 
"emergent purpose school" ${ }^{148}$, passou ainda a ser levantada a questão de que um tratado deveria ser interpretado não apenas com vistas aos seus objetivos e propósitos presentes no momento de sua contratação, mas também àqueles desenvolvidos durante a existência do acordo e perceptíveis no momento de sua aplicação.

Como observa RiCHARD K. GARDINER ${ }^{149}$, o método literal, o teleológico e o subjetivo se propõem à interpretação do texto e, portanto, têm este como objeto. O mesmo se pode dizer quanto aos métodos histórico e sistemático. A interpretação histórica observa fatores como a evolução normativa ocasionada pela introdução do dispositivo interpretado. ${ }^{150}$ Já a integração sistemática considera que nenhum elemento jurídico está isolado, mas integra um conjunto que deve considerado para a compreensão de cada um de seus elementos. $^{151}$

Além disso, para autores como IAN SINCLAIR ${ }^{152}$, essas três correntes não seriam mutuamente excludentes e nenhuma delas deveria ser observada com exclusividade. No entanto, cada um desses métodos, quando utilizados isoladamente, passa a se sujeitar a críticas variadas.

Em trabalho publicado em 1967, um ano após a conclusão (1966) do que viria a ser a minuta final da CVDT celebrada, MYRES S. MCDOUGAL ${ }^{153}$ direcionou críticas à corrente que defendia a tese da interpretação textual dos tratados. Para o autor, aquela teoria corresponderia ao exercício de um primitivo e potencialmente destrutivo formalismo, ignorando o fato de que as partes contratantes se comunicam para a troca de suas expectativas quanto às obrigações estabelecidas no acordo internacional por meio de muitos outros sinais e atos de colaboração.

\footnotetext{
${ }^{148}$ Sobre a referida "emergent purpose school”, vide: BECERRA, Andrés González. The interpretational approaches to the Vienna Convention - application to (tax) treaty analysis, in Bulletin for International taxation - setembro 2011. IBFD : Amsterdam, 2011, p. 2; BROE, Luc De. International tax planning and prevention of abuse (doctoral series n. 14). Amsterdã : IBFD, 2007, p. 248.

${ }_{149}$ GARDINER, Richard K. International Law. Pearson : Harlaw, 2003, p. 80.

${ }^{150}$ Cf. ROTHMANN, Gerd W. Interpretação e aplicação dos acordos internacionais contra a bitributação. Tese de doutorado. São Paulo : Faculdade de Direito da Universidade de São Paulo (USP), 1978, p. 109.

${ }^{151}$ Cf. ROTHMANN, Gerd W. Interpretação e aplicação dos acordos internacionais contra a bitributação. Tese de doutorado. São Paulo : Faculdade de Direito da Universidade de São Paulo (USP), 1978, p. 109-110. ${ }^{152}$ SINCLAIR, Ian M. The Viena Convention on the Law of Treaties. Manchester University Press : Manchester, 1973, p. 70.

${ }^{153}$ MCDOUGAL, Myres S. The International Law Commission's Draft Articles Upon Interpretation: Textuality Redivivus, in Faculty Scholarship Series - paper 2581. Yale : Yale Law School Legal Scholarship Repository, 1967, p. 992.
} 
A compreensão do modo como a CVDT tutela os métodos de interpretação é relevante ao tema desta tese. Como o que verdadeiramente difere tais métodos são as evidências a que o intérprete poderá recorrer para a construção de sentido dos acordos sob interpretação, se a CVDT for aplicável sobre os acordos de dupla tributação, então o repertório de evidências a que o intérprete pode recorrer para construir o sentido de seus termos a partir do "contexto" referido no Art. 3 CM-OCDE será influenciado pelas normas daquela convenção multilateral.

A solução adotada pela CVDT quanto aos métodos de interpretação dos tratados pode ser decisiva quanto às espécies de evidências que advogados, juízes e quaisquer intérpretes devem investigar e apresentar em disputas sobre a interpretação de termos não definidos em acordos de dupla tributação. Assim, por hipótese, caso se reconheça o método literal como o único apto à interpretação de um acordo de dupla tributação, de nada adiantaria a tais operadores dispensar atenção a trabalhos preparatórios que trouxessem informações a respeito da questão discutida, pois estariam compelidos aos lindes das evidências textuais disponíveis.

\subsection{A interpretação e aplicação do Direito Internacional após a CVDT.}

"So how can we respond to the question of whether interpretation is an art or a science? Interpretation is a science, that is artful, an art that is scientific; a science that has characteristics that transform it into art, which art in turn partakes of such scientific elements that make it science, and so on and so forth." PANOS MERKOURIS (2010) ${ }^{154}$

A elaboração da CVDT foi fruto de um longo processo ${ }^{155}$, em que os interesses dos Estados membros das Nações Unidas tiveram de ser equacionados. A sequência de discussões que culminou, em 1966, no texto final da CVDT, finalmente aprovado na assembleia de Viena em 1969, demonstra que a ILC-ONU tentou lidar com a tensão das questões expostas no subtópico anterior, assumindo que a interpretação dos tratados é tal como uma arte e, ao mesmo tempo, estabelecendo regras para o seu exercício. ${ }^{156} \mathrm{~A}$

\footnotetext{
${ }^{154}$ MERKOURIS, Panos. Introduction: Interpretation is a Science, is an Art, is a Science, in Treaty Interpretation and the Vienna Convention on the Law of Treaties. Leiden : Martinus Nijhoff, 2010, p. 12-13.

${ }^{155}$ A respeito de detalhes históricos da elaboração da CVDT, vide: ENGELEN, Frank. Interpretation of Tax Treaties under International Law. Doctorial series n. 7. IBFD : Amsterdam, 2004, p. 41-43.

${ }^{156}$ Nesse sentido, vide: ARNOLD, J. Brian. The interpretation of tax treaties: myth or reality, in Bulletin for international Taxation (tax treaty monitor) - january of 2010. IBFD : Amsterdã, 2010, p. 7.
} 
aparente contradição da tutela de uma arte pode ser justificada com a compreensão da oposição de arte e ciência em que parece ter se baseado a CVDT.

Imerso na teoria jurídica da década de 60 em que a ILC-ONU se inseria, nos ensinou Miguel REALE ${ }^{157}$ que a interpretação do Direito seria dotada de peculiaridades, pois "enquanto que as leis físico-matemáticas têm um rigor e uma estrutura que não dão lugar a interpretações conflitantes, as leis jurídicas, ao contrário, (...) exigem um esforço de superamento de entendimento contrastantes". Também RUY BARBOSA NoGUEIRA ${ }^{158}$, em seu Curso de Direito Tributário, ensinava que "o Direito, como ciência social, não pode, quer por meio de leis ou da doutrina, equacionar e dar soluções a priori para todos os casos imprevisíveis, porque não é ciência matemática”.

Ao consignar que a interpretação é mais uma arte do que uma ciência, a ILC-ONU aderiu à lição clássica da teoria jurídica, de que a aplicação de "regras" de interpretação não garante mecanicamente a construção de um único sentido correto ${ }^{159}$. Nessa conhecida assertiva histórica da ILC-ONU - observa o autor da passagem em epígrafe ${ }^{160}$ - seus membros teriam partido da premissa de que uma ciência propriamente dita apresenta conjuntos de regras capazes de prever os precisos efeitos dos eventos sob sua tutela, em uma relação de causalidade. O conceito de "ciência", sob tal perspectiva, não refletiria o processo de interpretação do Direito Internacional que, tal como em todas as outras searas do conhecimento, não seria determinista.

Diante da relutância de alguns membros da ILC-ONU para tutelar a arte da interpretação, foi questionado se, ainda que arte fosse, alguma espécie de norma poderia existir para a sua regulação. Como réplica a tal provocação, é possível indagar o próprio acerto da distinção entre arte e ciência em que se apoiavam alguns dos membros da ILCONU. Para PANOS MERKOURIS ${ }^{161}$, caso se considere que sequer a física ou a matemática

\footnotetext{
${ }^{157}$ REALE, Miguel. Lições Preliminares de Direito. São Paulo : Saraiva, 1995 (22a ed.), p. 167-168.

${ }^{158}$ NOGUEIRA, Ruy Barbosa. Curso de Direito Tributário. São Paulo, Saraiva, 1995, p. 96.

${ }^{159}$ Nesse sentido, vide: GARDINER, Richard K. International Law. Pearson : Harlaw, 2003, p. 158-159; MERKOURIS, Panos. Introduction: Interpretation is a Science, is an Art, is a Science, in Treaty Interpretation and the Vienna Convention on the Law of Treaties. Leiden : Martinus Nijhoff, 2010, p. 10; ROCHA, Sergio André. Interpretação dos tratados para evitar a dupla tributação. São Paulo : Quartier Latin, 2013, p. 133-135; 143.

${ }^{160}$ MERKOURIS, Panos. Introduction: Interpretation is a Science, is an Art, is a Science, in Treaty Interpretation and the Vienna Convention on the Law of Treaties. Leiden : Martinus Nijhoff, 2010, p. 8 e seg.

${ }^{161}$ MERKOURIS, Panos. Introduction: Interpretation is a Science, is an Art, is a Science, in Treaty Interpretation and the Vienna Convention on the Law of Treaties. Leiden : Martinus Nijhoff, 2010, p. 12-13.
} 
possuem métodos capazes de determinar absolutamente em 100\% das situações os efeitos de certos eventos, pode ser colocado em dúvida o próprio conceito de ciência exata, adotado pela ILC-ONU para excluir a interpretação e elevá-la ao estandarte de arte. Caso se considere, ainda, que há obras de artes - tal como A Monalisa, A Última Ceia e especialmente $O$ Homem Vitruviano, de LEONARDO DA VINCI - que também podem ser analisadas como obras da ciência com os seus padrões de simetria, a separação hermética de tais conceitos se mostra menos absoluta.

Nesse seguir, Panos Merkouris ${ }^{162}$ opõe, tal como também o faz EKKEHART REIMER ${ }^{163}$, que a interpretação do Direito Internacional é regulada por regras vocacionadas a lhe atribuir certo grau de certeza, o que constitui o principal objetivo das ciências jurídicas.

De todo modo, a questão foi tratada pela ILC-ONU sem que necessariamente tenha sido concedida a vitória aos defensores de uma codificação detalhada ou, ainda, aos que rejeitavam qualquer dispositivo sobre a questão. Tanto a teoria textual quanto as teorias subjetiva e teleológica foram prestigiadas ${ }^{164}$, procurando-se por um meio termo, com a positivação de regras gerais em tese aplicáveis a todos os casos ${ }^{165}$.

\footnotetext{
${ }^{162}$ MERKOURIS, Panos. Introduction: Interpretation is a Science, is an Art, is a Science, in Treaty Interpretation and the Vienna Convention on the Law of Treaties. Leiden : Martinus Nijhoff, 2010, p. 10-11.

163 REIMER, Ekkehart. Interpretation of tax treaties - Germany. European Taxation. IBFD, 1999 (December).

${ }^{164}$ Nesse sentido, vide: BROE, Luc De. International tax planning and prevention of abuse (doctoral series n. 14). Amsterdã : IBFD, 2007, p. 239.

${ }^{165}$ Nesse sentido, vide: BECERRA, Andrés González. The interpretational approaches to the Vienna Convention - application to (tax) treaty analysis, in Bulletin for International taxation - setembro 2011. IBFD : Amsterdam, 2011, p. 4.
} 


\subsubsection{A única e combinada operação de interpretação prevista pela CVDT.}

"The Commission, by heading the article 'General rule of interpretation' in the singular and by underlining the connexion between paragraphs 1 and 2 and again between paragraph 3 and the two previous paragraphs, intended to indicate that the application of the means of interpretation in the article would be a single combined operation. All the various elements, as they were present in any given case, would be thrown into the crucible, and their interaction would give the legally relevant interpretation. Thus, article 27 [sic] is entitled 'General rule of interpretation' in the singular, not 'General rules' in the plural, because the Commission desired to emphasize that the process of interpretation is a unity and that the provisions of the article form a single, closely integrated rule. In the same way the word 'context' in the opening phrase of paragraph 2 is designed to link all the elements of interpretation mentioned in this paragraph to the word 'context' in the

first paragraph and thereby incorporate them in the provision contained in that paragraph. Equally, the opening phrase of paragraph 3 'There shall be taken into account together with the context' is designed to incorporate in paragraph 1 the elements of interpretation set out in paragraph 3."

ILC-ONU (1966) ${ }^{166}$

Ao acolher todas essas teorias existentes, a CVDT estabeleceu, em seus arts. $31 \mathrm{a}$ 33, uma única e combinada operação de interpretação ("a closely integrated single rule of interpretation" 167 ): o texto do acordo deve influenciar a identificação de seu objetivo e propósito para evitar que a interpretação redunde em extremos da perspectiva teleológica, bem como deve o objetivo e propósito iluminar o acesso ao texto, a fim de evitar os excessos de uma rigidez equivocada ${ }^{168}$. RICHARD K. GARDINER ${ }^{169}$ leciona que, ao se deparar com as teorias (1) literal, (2) teleológica e (3) subjetiva, a ILC-ONU equacionou a norma de interpretação dos tratados da seguinte forma: “(1) + (2) = (3)", o que significa que a intenção dos Estados contratantes “(3)” deverá ser construída pelo intérprete a partir dos métodos textuais “(1)" e teleológicos “(2)".

Nessa mesma linha, LUC DE BROE ${ }^{170}$ observa que a CVDT previu o recurso a sete elementos no processo de interpretação, além do texto do tratado: i) o princípio da boa-fé; ii) o objeto e o propósito do acordo; iii) o contexto do acordo, incluindo acordos e

${ }^{166}$ ONU. Yearbook of the International Law Commission. 1966. Records on the 866th meeting. ONU, 1966, vol. II, par. 9.

${ }^{167}$ ONU. Yearbook of the International Law Commission. 1966. Records on the 866th meeting. ONU, 1966, vol. II, par. 9.

${ }^{168}$ Nesse sentido, vide: BECERRA, Andrés González. The interpretational approaches to the Vienna Convention - application to (tax) treaty analysis, in Bulletin for International taxation - setembro 2011. IBFD : Amsterdam, 2011, p. 2-4.

${ }^{169}$ GARDINER, Richard K. International Law. Pearson : Harlaw, 2003, p. 80-81; BROEKHUIJSEN, Dirk M. A Modern Understanding of Article 31(3)(c) of the Vienna Convention (1969): A New Haunt for the Commentaries to the OECD Model?, in Bulletin for International Taxation, volume 67, n. 9. Amsterdã : IBFD, 2013.

${ }^{170}$ BROE, Luc De. International tax planning and prevention of abuse (doctoral series n. 14). Amsterdã : IBFD, 2007, 239, nota de rodapé n. 31. 
instrumentos interpretativos contemporâneos, elaborados por uma parte e aceitos pela(s) outra(s); iv) acordos interpretativos subsequentes; $v$ ) práticas subsequentes que conduzam ao consentimento quanto à determinada interpretação; vi) regras relevantes de Direito internacional e; vii) meios suplementares de interpretação. $\mathrm{O}$ autor ${ }^{171}$ destaca que, ao exigir do intérprete a consideração dos objetivos e propósitos dos tratados na construção do sentido contextualizado de seus termos, a CVDT não justifica a adoção de uma interpretação teleológica pura, mas propõe que tal fator seja considerado em conjunto com os demais. Não estariam em conformidade com as mútuas expectativas dos Estados contratantes interpretações apoiadas em supostas intenções presentes na mente de seus negociadores, mas que não pudessem ser demonstradas por evidências presentes em seu contexto intrínseco ou extrínseco.

Assim, essa única e combinada operação de interpretação vem sendo construída de forma bastante coerente por grande parte da doutrina do Direito Internacional. Para IAN SINCLAIR $^{172}$, espera-se que um intérprete acesse todos os materiais que se apresentem como "evidência" quanto aos termos utilizados no texto de um acordo internacional, o que incluiria, por exemplo, trabalhos preparatórios e circunstâncias em torno de sua conclusão. RICHARD GARDINER ${ }^{173}$, na mesma linha, adota como premissa fundamental que os acordos internacionais, embora participem na formação de significativa parcela do atual Direito Internacional, não constituem a sua única fonte, bem como não o cobrem por completo. Normas gerais de Direito Internacional (reconhecidas por costumes internacionais ou por princípios gerais), decisões de Tribunais e a doutrina seriam, para o professor inglês, evidências do Direito Internacional ("evidence of international law"). Sendo assim, seria imperativo que o operador do Direito Internacional empreendesse acurada pesquisa nos documentos do histórico das transações diplomáticas, práticas dos Estados, decisões de Cortes Internacionais e nacionais, trabalhos acadêmicos e publicações de organismos internacionais.

A forma encontrada para organizar os enunciados dessa norma de interpretação foi a sua distribuição em três sucessivos dispositivos, que assumiram na última reunião da

\footnotetext{
${ }^{171}$ BROE, Luc De. International tax planning and prevention of abuse (doctoral series n. 14). Amsterdã : IBFD, 2007, 245-255.

${ }^{172}$ SINCLAIR, Ian M. The Viena Convention on the Law of Treaties. Manchester University Press : Manchester, 1973, p. 72-73.

${ }^{173}$ GARDINER, Richard K. International Law. Pearson : Harlaw, 2003, p. 8; 50-51.
} 
ILC-ONU, em Viena, a posição dos artigos 31, 32 e 33. O art. 31 (1) aponta que os tratados devem ser interpretados de boa-fé e segundo o sentido contextualizado (sentido consentido, "sentido comum", "ordinary meaning") atribuível aos termos em seu contexto, à luz de seu objetivo e finalidade. Os demais enunciados indicam quais elementos podem ser acessados pelo intérprete para a construção do referido sentido contextualizado. No caso, o art. 31 (2) faz referência às evidências intrínsecas quanto ao sentido contextualizado dos termos adotados em acordos internacionais, enquanto que o art. 31 (3), 32 e 33 trazem referências a evidencias extrínsecas.

As explicações da ILC-ONU ${ }^{174}$ para a redação final da CVDT, que indicam a adoção dessa única e combinada operação de interpretação ("a closely integrated single rule of interpretation"). Explicitam os embaixadores que a disposição dos enunciados da CVDT não conduzem a qualquer ordem de preferência ou importância no processo de interpretação: a ordem de apresentação adotada buscaria inspiração apenas por considerações lógicas, sem qualquer pretensão hierárquica ${ }^{175}$. Todos esses elementos devem ser levados em consideração na interpretação dos acordos internacionais, sem que qualquer superioridade seja estabelecida a priori. Nesse cenário, IAN BROWNLIE ${ }^{176}$ observa que a CVDT consagra o princípio da integração como forma de construção do sentido ordinário contextualizado dos termos dos tratados: tal sentido deve emergir do contexto do acordo como um todo, à luz dos objetos e propósitos deste.

Note-se que foram propostas pelos embaixadores dos EUA alterações ao texto da CVDT, a fim de remover essa segregação tripartite e a aparência de hierarquia que daí pode decorrer, de forma que as evidências dos artigos 31 e 32 fossem combinadas em um único dispositivo. A proposta, contudo, obteve pouca simpatia, prevalecendo a opinião de que o texto final da CVDT não afastaria a ideia de que todos os seus elementos devem interagir, sem hierarquia a priori $^{177}$. A posição prevalente considerou que a disposição explicitaria que, como a interpretação corresponde a atribuir sentido ao texto, este deveria ser o primeiro a ser referido. A "lógica”, em sua acepção vulgar, e não atributos de valor, justificaria a ordem em que os elementos se apresentam na CVDT. Também seria "apenas

\footnotetext{
${ }^{174}$ Vide: ONU. Yearbook of the International Law Commission, 1966, vol. II, par. 9, Commentaries.

${ }^{175}$ Em sentido oposto, vide: STARKE, J.G.; SHEARER, I.A. Starke's international law. Butterworths : Canada, 1994, p. 435.

${ }^{176}$ BROWNLIE, Ian. Principles of public international law. Clarendon : Oxford, 1998, p. 634.

${ }^{177}$ Tratando da proposta norte-americada e a hierarquia das evidências no processo de interpretação na CVDT, vide: BROWNLIE, Ian. Principles of public international law. Clarendon : Oxford, 1998, p. 633.
} 
a lógica" a responsável pela separação dos elementos extrínsecos referidos no parágrafo 3, não havendo qualquer mensagem ou estipulação se estes seriam mais ou menos relevantes que os seus antecedentes.

Caso a proposta dos EUA houvesse sido aceita pela ILC-ONU, é possível que a ideia de hierarquia entre os elementos dispostos nos artigos 31 e 32 da CVDT houvesse sido desbaratinada, o que não se pode, atualmente, afirmar por completo. Como será analisado adiante, é questão em debate se há hierarquia entre tais elementos ${ }^{178}$.

\subsubsection{As normas de interpretação da CVDT e o sentido contextualizado, o sentido consentido, o sentido comum e o sentido especial.}

O operador do Direito tributário internacional não está livre para atribuir aos termos de um acordo internacional o sentido que lhe aprouver. Sua missão é delinear um sentido contextualizado, consentido pelos Estados contratantes.

Como ensina LUís EDUARDo SCHOUERI ${ }^{179}$, por "sentido normal" ou "especial" entende-se aquele que os Estados atribuiriam ao termo, tendo em vista os objetos e propósitos do acordo internacional. Para alcançá-los, contudo, caberia ao intérprete procurar por interpretações que expressassem o entendimento comum entre tais Estados, que conduzissem à finalidade do acordo de afastar a dupla tributação da renda.

Tanto o "sentido ordinário" quanto o "sentido especial" devem ser contextualizados com a relação jurídica estabelecida pelos Estados e, portanto, consentidos por estes.

Assim, o "sentido comum" ou o "sentido especial” somente podem ser construídos conectados ao "contexto", razão pela qual SERGIO ANDRÉ RochA ${ }^{180}$ suscita que “desconectado do contexto do tratado e do momento histórico em que foi promulgado é até

\footnotetext{
${ }^{178}$ Entre os autores que adotam critérios de hierarquia, ainda que diversos, vide: STARKE, Joseph Gabriel; SHEARER, I.A. Starke's international law. Butterworths : Canada, 1994, p. 437-438.

${ }^{179}$ SCHOUERI, Luís Eduardo. Preços de transferência no direito tributário brasileiro. São Paulo: Dialética, 2013, p. 411.

${ }^{180}$ Cf. ROCHA, Sergio André. Interpretação dos tratados para evitar a dupla tributação. São Paulo : Quartier Latin, 2013, p. 146-147.
} 
mesmo difícil determinar o sentido comum ou o sentido especial dos termos ali empregados".

Também é corrente na doutrina ${ }^{181}$ a afirmação de que o consenso entre os Estados para a adoção de determinados sentidos pode ser manifestada de forma explícita ou implícita. Tal assunção traz consigo a questão da evidenciação da própria norma do acordo internacional, cujo sentido deverá ser construído a partir de dispositivos expressos em seu próprio texto (evidências intrínsecas) ou, quando implícitas no texto, por meio de evidencias extrínsecas. IAN BROWNLIE ${ }^{182}$ aponta que a ILC partiu da presunção de que os Estados fariam prova dos sentidos especiais que desejassem atribuir a determinados termos insertos nos tratados que tenham celebrado. Existiriam ainda, para o professor de Oxford, outras presunções aceitas no Direito Internacional. A máxima ejusdem generis operaria a presunção de que termos gerais, que sigam ou que antecedam termos especificos em uma relação ou composição de um grupo, representam um gênero relacionado ao termo especifico $^{183}$. Outra presunção apontada pelo professor da Universidade de Oxford se refere à máxima expressio unius est exclusio alterius, pela qual quando determinados elementos de uma classe são expressamente citados, todos os demais omitidos não são abrangidos pela norma.

\subsubsection{Exemplo: Os tribunais canadenses e a busca pelo sentido contextualizado das convenções fiscais.}

"That being so, the illustrations must be taken in the context of the ordinary usage of $t$ he language at the time of the Agreement, in which case one can find no justification in any of the four words for excluding a fee in the nature of a guaranty fee from the previously exempted industrial and commercial profits". Juiz EsteY. Suprema Corte do Canadá Caso Melford (1982)

No Caso Melford (Canadá, 1982), para a aplicação do acordo de bitributação Canadá-Alemanha, o tribunal canadense precisou decidir se os pagamentos anuais para a contratação de uma fiança bancária ( "garantee fee") estariam compreendidos no conceito

\footnotetext{
${ }^{181}$ Vide, por exemplo: SILVEIRA, Rodrigo Maitto da. Aplicação de Tratados Internacionais Contra a Bitributação - Qualificação de Partnership Joint Ventures. IBDT/Quartier Latin : São Paulo, 2006, p.120.

${ }^{182}$ BROWNLIE, Ian. Principles of public international law. Clarendon : Oxford, 1998.

${ }^{183}$ Como ilustração, seriam a questão de saber se uma relação constante em uma norma incluindo automóveis, tratores, motocicletas e outros veículos automotores abrangeria, neste gênero, aeronaves e embarcações maritimas motorizidas.
} 
de juros ("interest") ou lucros de atividades comerciais ou industriais ("industrial or commercial profits of').

O caso chama a atenção para dois fatores relevantes ao tópico em análise: (i) o sentido dos termos em questão deveria ser harmônico a ambos os Estados contratantes, não sendo permida a alteração unilateral de seu conteúdo e; (ii) tais sentidos seriam aqueles ordinários à época em que a convenção fiscal foi celebrada, pois não haveria evidências de que sentidos extraordinários, especiais, teriam sido convencionados pelas partes.

A Suprema Corte canadense recusou o reenvio ao Direito doméstico canadense e a consequente alteração unilateral do sentido contextualizado que se harmonizaria com as expectativas de ambos os Estados contratantes com a celebração da convenção físcal. Para delinear qual seria o sentido contextualizado dos termos da convenção fiscal, o tribunal recorreu à evidência dos contextos intrínseco e extrínseco, como será oportunamente exposto no decorrer deste estudo.

\subsubsection{O contexto interpretativo dos acordos de dupla tributação almejado pelas normas de interpretação da CVDT.}

O processo interpretativo exigido pela CVDT, como bem observa MiCHAEL EDWARDES-KER ${ }^{184}$, nos remete ao contexto interpretativo amplo ("tax treaty's general context").

Ainda que integradas, há nas normas da CVDT três diferentes fontes para as quais o intérprete pode recorrer para a construção do sentido contextualizado dos tratados em geral, que podem ser consideradas separadamente para investigações analíticas. Argutamente, CARLO GARBARINO ${ }^{185}$ as nomeia como “co-testo", “contesto in senso stretto" e "contesto in senso lato". Ensina o professor italiano que, enquanto o "co-testo" (CVDT, art. 31, parágrafo 2) relaciona elementos textuais (acordo e outros instrumentos conectados à sua conclusão), o "contesto in senso stretto" (CVDT, art. 31, parágrafo 3)

\footnotetext{
${ }^{184}$ EDWARDES-KER, Michael. Tax Treaty Interpretation - The International Tax Treaties Service. InDepth Publishing : Athlone, 1995, Capítulo 7, p. 6-8.

${ }^{185}$ GARBARINO, Carlo. Manuale di tassazione Internazionale. Milão : Kluwer, 2005, p. 175-185.
} 
iria além, compreendendo os seus procedimentos de aplicação, práticas subsequentes e o Direito internacional. Já a interpretação conforme o "contesto in senso lato" (CVDT, art. 32) somente seria possível quando a interpretação com base no "contesto" e no "contesto em senso stretto" conduzissem a sentidos ambíguos ou obscuros, bem como a resultados manifestamente absurdos ou desarrazoados.

A organização dos capítulos da presente tese considera a disposição dos contextos apreendida por CARLO GARBARINO, ainda que se adote nomenclatura diversa, adequada ao idioma em que a monografia é redigida, bem como se questione, no decorrer deste trabalho, as hipóteses progressivas de acesso a tais fontes sugeridas pelo professor italiano. Assim, serão adotados como rótulos para tais categorias, respectivamente, as expressões "contexto intrínseco" (Capítulos II), "contexto extrínseco primário" (Capítulos III) e “contexto extrínseco secundário" (Capítulos IV).

Note-se que a organização das evidências em intrínsecas e extrínsecas não é necessariamente uma novidade trazida por esta tese. IAN SINCLAIR ${ }^{186}$, seguindo o trabalho de VISSCHER dos idos de 1970, distinguia elementos intrínsecos, os quais estariam contidos no próprio tratado, dos elementos extrínsecos, que seriam externos ao referido texto.

\subsection{A interpretação e aplicação do Direito tributário internacional}

"International law is a 'universe of inter-connected islands', a house with many rooms. Each room/island is a different area of international law, and depending on its area of focus, be it environmental law, trade law etc. it might have developed a terminology that could differ from the generally acceped one."

PANOS MERKOURIS (2010) ${ }^{187}$

Em matéria tributária, o debate quanto à necessidade de normas especiais de interpretação, bem como à sua efetiva adoção, é uma constante ${ }^{188}$. Embora muitos considerem superadas as teorias que sustentam métodos especiais de interpretação, aplicáveis exclusivamente ao Direito tributário ${ }^{189}$, ao menos é certo que o operador do

${ }^{186}$ SINCLAIR, Ian M. The Viena Convention on the Law of Treaties. Manchester University Press : Manchester, 1973, p. 70.

${ }^{187}$ MERKOURIS, Panos. Introduction: Interpretation is a Science, is an Art, is a Science, in Treaty Interpretation and the Vienna Convention on the Law of Treaties. Leiden : Martinus Nijhoff, 2010, p. 7.

${ }^{188}$ Vide: VANONI, Ezio. Natureza e interpretação das leis tributarias. Trad. Rubens Gomes de Souza. Rio de Janeiro : Edições Financeiras, 1932, p. 11-13.

${ }^{189}$ Vide: RIBEIRO, Ricardo Lodi. Justiça, Interpretação e Elisão Tributária. Rio de Janeiro: Editora Lumen Juris, 2003, p. 91. 
Direito tributário doméstico já está prevenido quanto aos dilemas que enfrentará ao expandir o seu objeto de análise para o Direito tributário internacional.

Os acordos de bitributação possuem peculiaridades em relação às normas domésticas de incidência tributária que não podem ser ignoradas em seu processo de interpretação. Tratam-se as convenções fiscais de "normas sobre a aplicação de normas" ${ }^{190}$, pois delimitam as situações em que as legislações domésticas serão ou não aplicáveis para a tributação de determinados rendimentos conectados a ambos os Estados contratantes. Dai porque LUís EdUARDo SCHOUERI ${ }^{191}$ leciona que, "se a descrição da hipótese de incidência, pela legislação interna, já é um processo de abstração, então o emprego das mesmas expressões pelos acordos de bitributação constitui abstração de segundo grau". Quanto maior o grau de abstração de determinado conceito, mais realidades fáticas podem estar sob o seu escopo, o que pode explicar o sucesso da adoção de um único modelo de convenção fiscal pelos mais variados sistemas jurídicos.

As peculiaridades e semelhanças das convenções fiscais em relação ao Direito mantêm acesas diversas questões na doutrina do Direito tributário internacional, com reflexos sobre pontos importantes abordados nos Capítulos I, II, III e IV desta tese. Em especial, permanece em disputa na literatura especializada: (i) se as regras de interpretação veiculadas pela CVDT seriam suficientes para solucionar todas as questões relacionadas aos acordos de dupla tributação ou se, por outro lado, sua generalidade as tornariam supérfluas; (ii) se acordos de dupla tributação requerem métodos de interpretação diversos daqueles aplicáveis aos tratados em geral, ainda que não houvesse qualquer cláusula especial em seu texto nesse sentido ; (iii) qual a norma de interpretação veiculada pelo art. 3 da CM-OCDE, especialmente em relação à sua cláusula do "contexto"; (iv) se a cláusula do art. 3 da CM-OCDE estabelece norma especial em relação àquelas previstas na CVDT, capaz de estabelecer distinção entre a forma pela qual deve ser aplicado um acordo de dupla tributação e tratados em geral; (v) se há normas especiais de interpretação distintas do art. 3 (2) da CM-OCDE em outras convenções modelo para acordos de dupla tributação, como a CM-ONU ou a CM-EUA; (vi) se os métodos de interpretação prescritos pelo sistema jurídico doméstico em relação às suas normas tributárias internas, ainda que

${ }^{190}$ VOGEL. Problemas na interpretação de acordos de bitributação, in Direito Tributário - Homenagem a Alcides Jorge Costa (Coord. Luis Eduardo Schoueri). São Paulo: Quartier Latin, 2003. v. 2, p. 964 e seg.

${ }^{191}$ SCHOUERI, Luís Eduardo. Tratados e Convenções Internacionais sobre Tributação, in Revista de Direito Tributário Atual n. 17. São Paulo : IBDT/Dialética, 2003, p. 36. 
diversos daqueles previstos pela CVDT, devem ser adotados para a interpretação dos acordos de dupla tributação.

Há intenso debate acadêmico quanto à norma do art. 3 da CM-OCDE, referido nos itens "(iii)", "(iv)" e "(v)" do parágrafo anterior, o qual traz consigo o tema central da presente tese: (a) qual o sentido e amplitude do "contexto" referido naquele dispositivo; (b) se há ordem de precedência entre o aludido "contexto" e o Direito doméstico dos Estados contratantes e, em caso positivo, qual seria essa ordem. Tais questões, introduzidas nos subtópicos seguintes, serão analisadas em todo o decorrer desta tese.

\subsubsection{A CVDT tutela a interpretação dos acordos de dupla tributação?}

"Accordingly, in my opinion, Art 31 of the Vienna Convention requires the courts of this country when faced with a question of treaty interpretation to examine both the 'ordinary meaning' and the 'context ... object and purpose' of a treaty'. Juiz BuRCHETT. Caso Lamesa (1997).

É preciso saber se a interpretação e aplicação dos acordos de dupla tributação devem ou não considerar as regras da CVDT. Caso a resposta a essa indagação seja $a$ priori negativa, seriam injustificáveis maiores esforços para a consideração daquela convenção multilateral nesta tese.

Sob uma primeira perspectiva, alguns consideram que a CVDT não teria eficácia para tutelar a interpretação de acordos de dupla tributação ou mesmo de quaisquer outros. Após quase 50 anos de sua elaboração, os enunciados da CVDT sobre a interpretação dos tratados não enfrentam apenas críticas teóricas, mas aferições pragmáticas, sobre a eficácia técnica e social de tais dispositivos, isto é, quanto ao seu acatamento pela comunidade jurídica $^{192}$.

$\mathrm{Na}$ "Klaus Vogel Lecture" de 2009, Brian J. ARNOLD ${ }^{193}$ defendeu que a interpretação, como atividade humana intuitiva, seria desempenhada da mesma forma em relação aos tratados internacionais, ao Direito doméstico ou a quaisquer outros textos, não podendo ser reduzida a regras formais. Seria um mito a ideia de que a interpretação de

${ }^{192}$ Sobre o conceito de eficácia social, vide: CARVALHO, Paulo de Barros. Curso de Direito Tributário. São Paulo : Saraiva, 2000, p. 81-82.

${ }^{193}$ ARNOLD, J. Brian. The interpretation of tax treaties: myth or reality, in Bulletin for international Taxation (tax treaty monitor) - january of 2010. IBFD : Amsterdã, 2010, p. 2-9. 
acordos internacionais, especialmente os tributários, deveria ser conduzida com alguma especialidade em relação à interpretação da legislação doméstica ou mesmo de situações da vida: a interpretação de discursos ou textos escritos ocorreria sem o auxílio de quaisquer regras, não sendo diferente com o Direito tributário internacional. A interpretação, na verdade, seria uma fundamental, universal e intuitiva ação humana que não pode e não precisa ser controlada por regras ou fórmulas: o sentido de qualquer termo deve sempre ser determinado com referência ao seu contexto, o que inclui o propósito para o qual a palavra é utilizada.

Nesse seguir, para BRIAN J. ARNOLD ${ }^{194}$, seria necessário considerar que, na prática, autoridades fiscais, advogados e juízes interpretam os textos (por exemplo, os Comentários da OCDE) de forma natural, sem sofrimentos em relação a como fazer isso e sem a necessidade de qualquer regra de interpretação positivada. Observa o autor, ainda, que o art. 31 (1) da CVDT deixa sem resposta questões relevantes, como o peso a ser atribuído ao propósito de um tratado (ou seja, se este é ou não sempre subsidiário ao sentido ordinário e ao contexto), se deve ser analisado o propósito de um dispositivo especial do acordo ou do tratado como um todo e, ainda, como o propósito deve ser determinado.

Por sua vez, aceitando a potencial eficácia técnica de tais normas, RICHARD K. GARDINER ${ }^{195}$ sustenta que, embora os arts. 31 e 32 da CVDT requeiram a aplicação sucessiva de seus dispositivos, com uma sistemática progressão por meio de seus diversos elementos, tal ritual não seria usual: geralmente, identificado o problema interpretativo a ser enfrentado, evidências julgadas úteis são apresentadas de forma esparsa, sem qualquer ordem. Para esse professor, a consideração e aplicação da CVDT pelas Cortes nacionais não seriam sistemáticas, mas incidentais e ocasionais: em geral, os juízes não teriam o costume de fundamentar os passos seguidos em sua interpretação, ou mesmo indicariam qual norma da CVDT estaria sendo aplicada no caso concreto, restando apenas referências específicas a evidências admitidas para a interpretação. As mesmas conclusões são obtidas por BRIAN J. ARNOLD ${ }^{196}$, quando suscita que a abordagem da CVDT seria tão artificial que não seria de se estranhar que os juízes não a utilizassem. Também pondera esse autor que a

\footnotetext{
${ }^{194}$ ARNOLD, J. Brian. The interpretation of tax treaties: myth or reality, in Bulletin for international Taxation (tax treaty monitor) - january of 2010. IBFD : Amsterdã, 2010, p. 2-9.

${ }^{195}$ GARDINER, Richard K. International Law. Pearson : Harlaw, 2003, p. 79-83.

${ }^{196}$ ARNOLD, J. Brian. The interpretation of tax treaties: myth or reality, in Bulletin for international Taxation (tax treaty monitor) - january of 2010. IBFD : Amsterdã, 2010, p. 8.
} 
CVDT não teria estabelecido nenhuma novidade: a interpretação de quaisquer materiais escritos, sejam eles jornais, livros, memorandos ou instrumentos legais, requer que as palavras sejam lidas com cuidado, considerando-se que qualquer sentido é dependente do "contexto".

A ausência de novidade, contudo, é referida como qualidade da CVDT por PANOS MERKOURIS ${ }^{197}$. Após a análise de decisões de organismos internacionais de julgamento, como a World Trade Organization ("WTO"), produzidas no decorrer dos trinta anos da celebração dessa convenção multilateral, esse autor conclui que suas regras se mostram flexíveis o suficiente para se adaptar à generalidade dos casos, mas rígidas o bastante para que não se tornassem inúteis, bem como aptas a evoluir para se conformar às mudanças da sociedade.

Assim, sob uma segunda perspectiva, mais difundida, as normas da CVDT são consideradas aplicáveis e eficazes em relação aos tratados em geral. Em relação aos acordos de dupla tributação ${ }^{198}$, tais normas assumiriam o papel de norma geral de interpretação. ${ }^{199}$

Não é incomum que Cortes nacionais ${ }^{200}$ não diferenciem os acordos tributários dos demais para eleger os recursos necessários à sua interpretação. Em tais jurisdições, as mesmas regras de interpretação aplicáveis aos tratados em geral devem ser aplicadas para a interpretação de acordos de dupla tributação. Os Tribunais australianos geralmente observam como precedente para a interpretação de acordos de dupla tributação o Caso Applicant A, no qual a Suprema Corte daquele país interpretou e aplicou um acordo internacional relacionado a refugiados.

\footnotetext{
${ }^{197}$ MERKOURIS, Panos. Introduction: Interpretation is a Science, is an Art, is a Science, in Treaty Interpretation and the Vienna Convention on the Law of Treaties. Leiden : Martinus Nijhoff, 2010, p. 12-13.

${ }^{198}$ Nesse sentido, vide: BAKER, Philip. Double taxation conventions and international tax law. Londres : Sweet \& Maxwell, 1994, par. C-02 e C-04; GARBARINO, Carlo. Manuale di tassazione Internazionale. Milão : Kluwer, 2005, p. 172 e seg.; WIJNEN, Wim. Some Thoughts on Convergence and Tax Treaty Interpretation, in Tax Treaty Monitor - Bulletin for International Taxation (November 2013). IBFD: Amsterdã, 2013, p. 575; VANN, Richard J. International Aspects od Income Tax, in Tax Law Design and Drafting (Ed. THURONYI, Victor). Londres : Kluwer, 1998, p. 722 e seg.; ROHATGI, Roy. Basic International taxation. Volume 1: principles. Nova Deli : Taxmann, 2005, p. 2-3; XAVIER, Alberto. Direito tributário internacional do Brasil. Forense : Rio de Janeiro, 2010, p. 134-135.

${ }^{199}$ Nesse sentido, vide ROTHMANN, Gerd W. Interpretação e aplicação dos acordos internacionais contra a bitributação. Tese de doutorado. São Paulo : Faculdade de Direito da Universidade de São Paulo (USP), 1978, p. 145-146;

${ }^{200}$ Vide, por exemplo: Case Lamesa, e Case Thiell,
} 
Por fim, é amplamente aceito o entendimento de que os elementos contidos nos arts. 31 a 33 da CVDT apenas declaram costumes internacionais pré-existentes a essa convenção multilateral. Tal posição é especialmente adotada por organismos internacionais de julgamento, como a $\mathrm{CIJ}^{201}$. No entanto, há também aqueles que se recusam a afastar de plano a discussão quanto à aplicação das normas interpretativas da CVDT em relação aos países que não ratificaram tal convenção internacional, cujos exemplo mais eloquente provavelmente seja dos EUA. Ocorre que autores como IAN BROWNLIE ${ }^{202}$ suscitam que a CVDT não possui como vocação exclusivamente declarar normas já existentes no Direito Internacional consuetudinário, com dispositivos capazes de inovar o Direito Internacional anterior a 1980.

Sob essa perspectiva, como relator dos EUA para o Congresso da IFA de 1993, STANLEY I. KATZ ${ }^{203}$ sustentou que ao limitar o acesso a evidências da intenção dos Estados contratantes, a CVDT teria estabelecido norma não pré-existente no Direito Internacional consuetudinário. Assim, como tal convenção multilateral não foi ratificada pelos EUA, ainda que a interpretação dos acordos de dupla tributação naquele país em muito se alinhe com as regras da CVDT, tais questões poderiam justificar distinções.

Desde que a CVDT foi finalmente ratificada pelo Brasil, em 2009, a questão colocada no sistema jurídico brasileiro deixou de ser se tais normas seriam aplicáveis ou não aos acordos de dupla tributação e passou a ser como essas devem ser aplicadas. É importante, assim, ter claro que esta tese adota como premissa a aplicabilidade da CVDT sobre os acordos de dupla tributação, sendo necessária a aplicação consistente de tal premissa do início ao fim da análise ora proposta.

\footnotetext{
201 Vide, por exemplo: Kasikili/Sedudu Island. Disponível em: http://www.icjcij.org/docket/index.php?p1=3\&p2=3\&code=bona\&case=98\&k=b7, último acesso em 10.04.2014.

${ }^{202}$ BROWNLIE, Ian. Principles of public international law. Clarendon : Oxford, 1998, p. 508.

${ }^{203}$ KATZ, Stanley I. United States National Report. Cahiers de Droit Fiscal International by the International Fiscal Association (studies on international tax law), volume LXXVIIIa - Subject I. Interpretation of double taxation conventions. Kluwer Law and Taxation Publishers / IFA : Rotterdam, 1993, p. 624.
} 


\subsubsection{As regras de interpretação veiculadas pela CVDT seriam suficientes para solucionar todas as questões relacionadas aos acordos de dupla tributação?}

"Va subito precisato che i metodi per l'interpretazione dei trattati internazionali non sono norme direttamente precettive, bensi principi e criteri regolativi. Nella trattazione che segue ci si riferisce, dunque, a linee di tendenza piuttosto che a norme vincolanti relative alla interpretazione (e peraltro anche le norme sull'interpretazione sono oggetto di interpretazione). I canoni interpretativi nel diritto tributario internazionale sono quindi tanto importanti quanto non definibili a priori: ogni fattispecie concreta implica un problema interpretativo che può essere variamente risolto in base a criteri anche diversi", CARLO GARBARINO $(2005)^{204}$

Ao considerar-se que as normas de interpretação da CVDT são aplicáveis aos acordos de bitributação, surge uma questão subsequente: elas seriam suficientes?

Embora WIM WIJNEN ${ }^{205}$ assuma que os juízes nacionais estejam compelidos a observar a CVDT, considera que esta não seja capaz de prover elementos suficientes para uma interpretação harmônica, de tal forma que os Estados contratantes compreendessem com clareza a forma como devem interpretar os acordos de dupla tributação.

A generalidade da CVDT e a sua incapacidade para tratar de nuances inerentes a searas específicas, a exemplo do Direito tributário internacional, como observou KLAUS VOGEL $^{206}$, não afasta o seu valor para a solução de uma série de questões relacionadas à interpretação de acordos de dupla tributação, inclusive por Estados que não são seus signatários ou que a ratificaram.

\subsubsection{As normas gerais da CVDT podem ser excepcionadas como decorrência da fragmentação do Direito Internacional?}

Nos idos de 1932, EZIO VANONI ${ }^{207}$ dava por pacificada a discussão quanto à necessidade de normas especiais de interpretação para ramos específicos do Direito. Para o professor italiano, embora diferentes disciplinas pudessem apresentar regras de interpretação aplicáveis a todas as searas jurídicas, seria essencial que o intérprete

\footnotetext{
${ }^{204}$ GARBARINO, Carlo. Manuale di tassazione Internazionale. Milão : Kluwer, 2005, p. 173.

${ }^{205}$ WIJNEN, Wim. Some Thoughts on Convergence and Tax Treaty Interpretation, in Tax Treaty Monitor Bulletin for International Taxation (November 2013). IBFD: Amsterdã, 2013, p. 575.

${ }^{206}$ VOGEL, Klaus. Klaus Vogel on Double Taxation Conventions. Kluwer : London, 1999, p. 35.

${ }^{207}$ VANONI, Ezio. Natureza e interpretação das leis tributarias. Trad. Rubens Gomes de Souza. Rio de Janeiro : Edições Financeiras, 1932, p. 11-13.
} 
observasse a natureza particular das relações reguladas. No caso de normas de Direito tributário, sua natureza exigiria métodos próprios, o que ensejaria o debate a respeito de quais seriam os mais apropriados.

A discussão quanto à pertinência de normas especiais de interpretação, contudo, não terminaria por ali. Ainda hoje se discute se o Direito tributário exigiria métodos de interpretação específicos e, em especial, se a interpretação e aplicação do Direito tributário internacional estariam sujeitas a regramentos especiais. Tal como é tema em debate se a CVDT seria suficiente para tutelar a interpretação e aplicação dos acordos de dupla tributação, é possível perquirir se seria necessário ou mesmo legítimo que normas especiais, celebradas entre os Estados, excepcionassem aquelas normas gerais da CVDT. Para que qualquer esforço investigativo quanto à existência de normas especiais de interpretação aplicáveis aos acordos de bitributação se justifique, é necessário antes saber quão livres são os Estados para se afastarem das normas da CVDT por meio de cláusulas especiais. Afinal, se não houver possibilidade de qualquer desvio da CVDT, então apenas a análise dessa convenção multilateral já seria suficiente, sendo despiciendo investigar a cláusula do art. 3 (2) da CM-OCDE.

O tema da fragmentação do Direito Internacional traz consigo a discussão quanto à necessidade de normas especiais de interpretação diante das peculiaridades dos segmentos especializados ('self-contained regime'). O Direito Internacional, fundado ele próprio na soberania dos Estados, não rejeita que estes contratem cláusulas que divirjam da CVDT ou de outras normas gerais, desde que não contrariem normas peremptórias (jus cogens), o que não é o caso. É possível compreender que os Estados soberanos possuem autonomia para estabelecer cláusulas especiais de interpretação em seus tratados. No Direito tributário internacional, por sua vez, os acordos de dupla tributação celebrados pelos Estados podem prever cláusulas especiais de interpretação, desde que não violem normas peremptórias ("jus cogens") ou, ainda, o Direito interno de importância fundamental e manifesta de cada um dos Estados contratantes (CVDT, art. 27 e 46).

Na elaboração da CVDT, a ILC-ONU adotou normas gerais capazes de se adequar às peculiaridades de cada um dos segmentos do Direito internacional. O Fragmentation 
Report publicado pela ILC-ONU em $2006^{208}$, 40 anos após a celebração da CVDT, observa que aquele acordo multilateral não impede que os Estados estabeleçam regras especiais de interpretação para satisfazer possíveis exigências dos variados segmentos do Direito Internacional, de forma a estabelecer critérios diversos ou mesmo atribuir maior peso a alguns dos elementos referidos pela norma geral. A ILC-ONU suscitou, ainda, que os recursos que devem ser adotados diante de conflitos de interpretação não poderiam ser solucionados, a priori, a favor da CVDT ou de regras especiais existentes em selfcontained regimes (ou vice-versa), sendo necessária a análise de cada caso concreto.

Como marca de sua fragmentação, o Direito tributário internacional desenvolveu cláusulas especiais de interpretação, que podem ser segregadas em três categorias: (i) normas de interpretação autêntica de termos e dispositivos específicos; (ii) normas de interpretação de termos específicos, com remissão ao Direito doméstico e; (iii) normas de interpretação de termos em geral, nomeadamente o art. 3 (2) da CM-OCDE.

A função das normas relacionadas à interpretação e aplicação do tratado de dupla tributação é estabelecer acordo entre os Estados quanto às fontes formais e materiais de sentido a que os operadores destes podem recorrer (cláusulas especiais de interpretação de termos em geral ou específicos) ou, ainda, veicular interpretações autênticas. Interessa à presente tese a última categoria citada: a norma de interpretação de termos em geral não definidos no acordo, nos moldes do art. 3 (2) da CM-OCDE, pela qual o sentido destes deverá ser colhido do Direito doméstico dos Estados contratantes (reenvio), a não ser que o "contexto" requeira interpretação diversa. A cláusula é de importância ímpar, não apenas porque os termos não definidos nos textos dos acordos de dupla tributação são a maioria, mas também porque muitos desses termos são de grande relevância.

A discussão quanto às cláusulas especiais de interpretação dos acordos internacionais não é um caso isolado da seara tributária; pelo contrário, o relatório da ILCONU sobre a fragmentação do Direito Internacional sequer faz referência à questão tributária. Muitos outros segmentos do Direito Internacional têm procurado por métodos alternativos para garantir a interpretação harmônica e o efeito útil de seus acordos

${ }^{208}$ ONU. International Law Commission Fifty-Eighth Session. Geneva, 2006. Fragmentation Of International Law: Difficulties Arising From The Diversification and Expansion of International Law - Report of the Study Group of the International Law Commission, p. 9-11. 
internacionais. Alguns desses, inclusive, têm verificado que o reenvio ao Direito doméstico pode se mostrar meio eficaz para a interpretação dos tratados celebrados. Em acordos internacionais de Direito Comercial, por exemplo, em geral há referências ao Direito doméstico dos Estados contratantes para definição de termos como "loan", "interest" e “assets".

No entanto, não há notícia de segmentos do Direito Internacional que adotem o Direito doméstico dos Estados contratantes como fonte material de sentido, por meio de cláusula geral de interpretação inserida em seus acordos internacionais. Cláusulas gerais de reenvio ao Direito doméstico são, na verdade, muito excepcionais no Direito Internacional público.

Por outro lado, são numerosos os exemplos de interpretação autônoma nos acordos internacionais em matérias não tributárias. EDWIN VAN DER BRUGGEN ${ }^{209}$ cita o caso dos tratados de pesca, de promoção de investimentos e de livre comércio. Os tratados de pesca limitariam as leis e regulamentos das partes contratantes, mas ainda assim não seria usual o recurso às suas leis internas para a definição de expressões como exercício da pesca, recursos naturais, processamento do peixe ou qualquer outro termo encontrado em tais acordos internacionais. Convenções para a promoção e proteção dos investimentos teriam, por sua vez, claramente impacto restritivo sobre muitas leis e regulamentos do país de acolhimento e poderiam afetar a propriedade de estrangeiros; ainda assim, expressões como "know-how", "semiconductor mask works" e "spot transactions" seriam interpretadas sem o reenvio para qualquer sistema jurídico doméstico em particular. Por fim, também acordos de livre comércio poderiam impor grande impacto sobre barreiras tarifárias e não-tarifárias previstas em leis e regulamentos dos Estados contratantes, mas os termos utilizados em tais acordos também seriam interpretados sem o recurso à lei interna dos Estados que os aplicam.

${ }^{209}$ BRUGGEN, Edwin van der. Unless the Vienna Convention Otherwise Requires: notes on the relationship between Art. 3 (2) of the OECD Model Tax Convention and art. 31 and 32 of the Vienna Convention on the Law of Treaties, in European Taxation of May 2003. IBFD : Amsterdam, 2003, p. 152. 


\title{
3.3.4. A autonomia dos conceitos, categorias e métodos de interpretação do Direito tributário internacional e do Direito doméstico.
}

\author{
"Illustratively expressed: the treaty acts like a stencil \\ that is placed over the pattern of domestic law and covers over certain parts".
} KLAUS VOGEL (1999) $)^{210}$

A conhecida lição de KLAus Vogel, em epígrafe, explica de forma bastante clara o funcionamento da relação entre o Direito tributário internacional e o Direito doméstico.

Os acordos de dupla tributação são vocacionados a cobrir o sistema jurídico de dois diferentes Estados. No entanto, há independência entre o Direito tributário internacional e o Direito tributário doméstico de tais Estados, bastando que os conceitos e categorias do primeiro sejam capazes de se sobrepor total ou parcialmente aos conceitos e categorias do segundo, levando-os, nessa parcela de contato, à sombra (ou melhor, à não aplicação). As normas domésticas de incidência tributária que permanecerem iluminadas serão aplicadas normalmente, tal como acordado entre ambos os Estados contratantes por meio do tratado de bitributação.

No entanto, a ideia de que as convenções fiscais compõem tanto o Direito Internacional quanto o sistema jurídico doméstico dos Estados contratantes ${ }^{211}$ divide a doutrina em questões relevantes para o tema em análise, em especial: (i) se os conceitos e categorias do Direito doméstico seriam aplicáveis para a interpretação do Direito tributário internacional e; (ii) se a interpretação dos termos dos acordos de bitributação deve ser governada por normas do Direito doméstico dos Estados contratantes ${ }^{212}$ ou por normas do Direito Internacional $^{213}$.

\footnotetext{
${ }^{210}$ VOGEL, Klaus. Klaus Vogel on Double Taxation Conventions. Kluwer : London, 1999, p. 31-32.

${ }^{211}$ Nesse sentido, vide: EDWARDES-KER, Michael. Tax Treaty Interpretation - The International Tax Treaties Service. In-Depth Publishing : Athlone, 1995, Capítulo 1, p. 1-2; ROTHMANN, Gerd W. Interpretação e aplicação dos acordos internacionais contra a bitributação. Tese de doutorado. São Paulo : Faculdade de Direito da Universidade de São Paulo (USP), 1978, p. 32-33; UCKMAR, Victor. Double Taxation Conventions, in International Tax Law (Ed. Andrea Amatucci). Klumer : Netherlands, 2006, p. 149; ROHATGI, Roy. Basic International taxation. Volume 1: principles. Nova Deli : Taxmann, 2005, p. 1718.

${ }^{212}$ Cf. LENZ, Raoul. General Report. Cahiers de Droit Fiscal International by the International Fiscal Association (studies on international tax law), volume XLII - Subject II: The interpretation of the Double Taxation Convention/IFA : Rotterdam, 1960, p. 296; UCKMAR, Victor; CORASANITI, Giuseppe; VIMERCATE, Paolo de'Capitani; OLIVA, Caterina Corrado (aspectos gerais); GRECO, Marco Aurélio; ROCHA, Sérgio André (sistema brasileiro). Manual de Direito Tributário Internacional. Dialética : São Paulo, 2012, p. 45.

${ }^{213}$ Nesse sentido, vide: SCHOUERI, Luís Eduardo. Planejamento Fiscal Através de Acordos de Bitributação (Treaty Shopping). São Paulo: Ed. Revista dos Tribunais, 1995, p. 37.
} 


\subsubsection{A influência de concepções monistas e dualistas para a solução das questões.}

Concepções monistas $^{214}$ podem levar à conclusão de que apenas as normas do Direito tributário internacional seriam relevantes na escolha dos métodos de interpretação dos acordos de dupla tributação: como o operador aplicaria diretamente o acordo de dupla tributação, sem considerar normas domésticas como intermediárias, então apenas o recurso aos métodos de interpretação típicos de acordos internacionais seriam justificáveis. Nessa ordem de ideias, LUC DE BROE ${ }^{215}$ sustenta que a aprovação dos acordos de dupla tributação pelo Poder Legislativo belga seria apenas formal e não normativo, de forma que, ao qualificar-se como um sistema monista, a Bélgica deve interpretar tais convenções conforme as regras do Direito Internacional e não de seu Direito doméstico.

Concepções dualistas ${ }^{216}$, por sua vez, poderiam conduzir à ideia de que a interpretação dos acordos de dupla tributação seria governada exclusivamente por normas do Direito doméstico dos Estados contratantes: como o operador aplicaria uma norma jurídica emanada por fontes internas e não o acordo internacional que serviu de base para a sua produção, os métodos de interpretação comuns a todas as demais normas domésticas seriam pertinentes.

Assim, pela teoria da "transformação", típica das concepções dualistas, o tratado internacional celebrado entre os Estados não poderia ser diretamente aplicado pelos Tribunais nacionais, sendo necessária a sua incorporação à ordem interna pelos meios adequados. Concluída a "transformação", aquele tratado internacional passaria a ter a natureza de Direito doméstico e, assim, sujeito aos mesmos critérios de interpretação aplicável às demais normas internas. Em contraposição à teoria da "transformação", a

\footnotetext{
${ }^{214}$ Sobre o tema, vide: SCHOUERI, Luís Eduardo. Planejamento Fiscal Através de Acordos de Bitributação (Treaty Shopping). São Paulo: Ed. Revista dos Tribunais, 1995, p. 37.

${ }^{215}$ BROE, Luc De. International tax planning and prevention of abuse (doctoral series n. 14). Amsterdã : IBFD, 2007, 244-260-262.

${ }^{216}$ Sobre tema do dualismo, vide: SCHOUERI, Luís Eduardo. Planejamento Fiscal Através de Acordos de Bitributação (Treaty Shopping). São Paulo: Ed. Revista dos Tribunais, 1995, p. 37
} 
teoria da "adoção" sustenta que a aplicação do acordo internacional no sistema jurídico doméstico dos Estados contratantes não lhe retiraria a natureza internacional. ${ }^{217}$

A discussão está presente na literatura do Direito Internacional público e não apenas no Direito tributário internacional: com a incorporação de um acordo internacional à legislação doméstica de determinado Estado, cujo texto utiliza termos que possuem um sentido único e peculiar, devem ser desconsiderados os sentidos que tais termos assumem no Direito Internacional e acolhidas as definições do sistema interno? Ou, ainda: poderia o intérprete abandonar os conceitos, categorias e métodos de interpretação do Direito Internacional com a incorporação do tratado ao Direito doméstico? RICHARD K. GARDINER $^{218}$ aponta que os Tribunais do Reino Unido, em geral, ainda não teriam solucionado a questão do relacionamento entre o Direito Internacional e o Direito doméstico, especialmente quanto aos métodos de interpretação a serem adotados, tendo em vista que muitas vezes não resta claro aos julgadores se o objeto sob interpretação pertence ao Direito Internacional ou ao Direito doméstico.

$\mathrm{Na}$ doutrina brasileira, atualmente prevalece o entendimento de um sistema monista moderado ${ }^{219}$. Luís EdUARDO SCHOUERI ${ }^{220}$ identificou na "teoria da execução" a melhor descrição para o sistema brasileiro, rejeitando a teoria da transformação. $\mathrm{O}$ ato do Presidente da República seria mera ordem de execução do acordo de dupla tributação, não o desconectando da ordem internacional de que é originário, mas apenas o adotando na ordem interna. Como argumento mais contundente para se refutar a teoria da transformação diante do sistema jurídico brasileiro, o professor $^{221}$ suscita que a denúncia do tratado por um dos Estados contratantes faz com que este cesse os seus efeitos. Como se poderia explicar que tal revogação, concretizada no âmbito do Direito Internacional, retiraria uma regra do Direito doméstico?

${ }^{217}$ Cf. SCHOUERI, Luís Eduardo. Preços de transferência no direito tributário brasileiro. São Paulo : Dialética, 2013, p. 409.

${ }^{218}$ GARDINER, Richard K. International Law. Pearson : Harlaw, 2003, p. 153-154; 161.

${ }^{219}$ Nesse sentido, vide: ROCHA, Sergio André. Interpretação dos tratados para evitar a dupla tributação. São Paulo : Quartier Latin, 2013, p. 53; SCHOUERI, Luís Eduardo. Preços de transferência no direito tributário brasileiro. São Paulo : Dialética, 2013, p. 419-420.

${ }^{220}$ SCHOUERI, Luís Eduardo. Planejamento Fiscal Através de Acordos de Bitributação (Treaty Shopping). São Paulo: Ed. Revista dos Tribunais, 1995, p. 70, 111; Preços de transferência no direito tributário brasileiro. São Paulo: Dialética, 2013, p. 409 e seg.

${ }^{221}$ SCHOUERI, Luís Eduardo. Preços de transferência no direito tributário brasileiro. São Paulo: Dialética, 2013, p. 409-410. 
Nos subtópicos seguintes, tais questões serão analisadas sob a perspectiva da autonomia dos conceitos, categorias e métodos de interpretação do Direito tributário internacional.

\subsubsection{A autonomia dos conceitos e categorias do Direito tributário internacional e o Direito doméstico.}

"Da autonomia dos momentos de exame do direito interno e do acordo de bitributação decorre, de um lado, a possibilidade de se examinarem um acordo ou o outro, sem qualquer ordem de preferência e, como corolário, a independência na aplicação de conceitos e categorias de direito tributário."

LUÍS EDUARDO SCHOUERI $(2013)^{222}$

Há independência a priori dos conceitos e categorias componentes do Direito doméstico e dos acordos de bitributação. Nessa mesma linha, ensina MiCHAEL LANG ${ }^{223}$ que a adequada aplicação dos acordos de bitributação exige que os seus termos sejam interpretados sem a consideração do Direito doméstico dos Estados contratantes, de forma autônoma.

Evidentemente, quando a convenção fiscal consignar expressamente que os Estados devem interpretar determinado termo conforme os seus sistemas jurídicos domésticos, esse deverá ser o caminho trilhado pelo operador do Direito tributário internacional. No entanto, é especialmente importante neste estudo compreender que essa dependência entre o Direito doméstico e o Direito tributário internacional não é a regra, mas uma opção dos Estados contratantes. Em regra, o sentido dos termos adotados nos acordos de bitributação é definido por seu texto (contexto intrínseco) ou por seu contexto extrínseco.

Tal independência decorre de uma questão bastante pragmática. As legislações nacionais que os acordos de dupla tributação são vocacionados a cobrir muitas vezes são diversas entre si, bem como extensas e detalhadas. Por tal razão, as convenções fiscais devem ser elaboradas a partir de fórmulas com maior grau de generalidade e abstração, capazes de servir a ambos os Estados contratantes. Assim, as normas de Direito tributário internacional nem sempre refletem perfeitamente as legislações nacionais, com a

222 SCHOUERI, Luís Eduardo. Preços de transferência no direito tributário brasileiro. São Paulo: Dialética, 2013, p. 414.

${ }^{223}$ LANG, Michael. Introduction to the law of double taxation conventions. Vienna : Linde, 2013, p. 42. 
autonomia dos conceitos e categorias do Direito tributário internacional em relação ao Direito doméstico.

Algumas considerações são importantes a respeito.

Primeiro, é fora de dúvida que, quando um acordo de dupla tributação consignar expressamente a definição de um termo nele utilizado, esse sentido acordado por ambos os Estados contratantes deverá - para fins de aplicação da referida convenção - ser adotado independentemente dos conceitos e categorias do Direito interno de seus respectivos sistemas jurídicos domésticos.

Segundo, quando o acordo de bitributação não definir expressamente um termo utilizado em seu texto, deverá ser verificado se há evidências em seu contexto (intrínseco e extrínseco) quanto aos sentidos consentidos pelos Estados. Com o delineamento destes, mantém-se a independência dos conceitos e categorias do Direito doméstico e da convenção fiscal.

Terceiro, os sentidos mutuamente atribuídos pelos Estados contratantes aos termos de um acordo de bitributação não podem ser desvirtuados ou alterados unilateralmente pelas partes. Alterações na legislação doméstica dos Estados contratantes não interferem $a$ priori na aplicação dos acordos de bitributação celebrados.

Alguns exemplos, expostos nos subtópicos seguintes, ilustram bem essas questões.

\subsection{Exemplo: o conceito de "residente" para o Direito doméstico e para o Direito tributário internacional.}

Ser "residente" pode significar coisas diferentes perante o sistema jurídico interno de um Estado e os acordos de dupla tributação celebrados por este. De um lado, exclusivamente com a finalidade de reconhecer os sujeitos aos quais as regras de um acordo de dupla tributação são aplicáveis, o sentido de "residente" deve ser construído a partir desse instrumento internacional. Por sua vez, para a aplicação das normas de 
incidência tributária de um Estados contratates, devem ser observados as normas domésticas de tal sistema jurídico relativas à residência fiscal.

Geralmente, cada sistema jurídico doméstico possui os seus próprios critérios de reconhecimento de residência fiscal, para a finalidade específica da aplicação de suas regras internas de tributação. Tal conceito é usualmente determinado pelas legislações nacionais por critérios exclusivamente objetivos, especialmente com base no parâmetro da simples presença física em território nacional por um período mínimo de tempo, normalmente 183 dias. Alguns sistemas jurídicos, por sua vez, possuem testes de domicílio fiscal com fatores mais subjetivos, como o "local principal de repouso", "laços familiares", "ânimo definitivo", "centro vital de interesses", "laços duráveis". Podem os Estados adotar, ainda, critérios mistos, que levem em consideração tanto fatores objetivos quanto subjetivos. $^{224}$

O que importa notar é que, como leciona Luís EDUARDo ScHOUERI ${ }^{225}$, há autonomia entre o momento de exame do Direito doméstico e do acordo de dupla tributação, bem como há independência entre os conceitos e categorias de ambos. Para aplicar uma convenção internacional em matéria tributária (“A-B”), o intérprete deveria verificar se um determinado sujeito (“ $\beta$ ”) deve ser considerado "residente" de um dos Estados contraentes ("A") conforme os critérios estabelecidos exclusivamente para a aplicação da norma desse acordo "e, nesse momento, 'esquecer-se-á' de que o contribuinte é, internamente, residente" desse Estado (“A”). Não há objeções, então, que tal indivíduo (“ $\beta$ ") seja residente de um certo Estado (“A”) para fins de sua legislação doméstica, mas seja considerado residente não deste, mas de outro Estado ("B”), para fins de aplicação de um acordo de dupla tributação (“A-B”).

Se dois Estados desejam que um tratado de bitributação adote o sentido de "residente" colhido de seus respectivos sistemas jurídicos domésticos, depende exclusivamente de cláusula expressa ou implícita de reenvio acordada por eles.

\footnotetext{
${ }^{224}$ Nesse sentido, vide: SCHOUERI, Luís Eduardo. Residência fiscal da pessoa física, in Revista de Direito Tributário Atual n. 28. São Paulo : IBDT/Dialética, 2012.

${ }^{225}$ SCHOUERI, Luís Eduardo. Preços de transferência no direito tributário brasileiro. São Paulo: Dialética, 2013, p. 414-415.
} 


\subsection{Exemplo: a autonomia do conceito de "dividendos" no Direito doméstico brasileiro e no Direito tributário internacional.}

Da análise de todos os acordos de bitributação brasileiros, PAUlo BorBA CASElla $^{226}$ e AlBerto XAVIER ${ }^{227}$ observam que o conceito de dividendos, juros e royalties nas convenções fiscais seria mais amplo que no Direito doméstico brasileiro.

O sentido de dividendos estabelecido nos acordos de bitributação brasileiros celebrados geralmente é amplo o suficiente para abarcar rendimentos provenientes de ações, ações ou direitos de fruição, ações de empresas mineradoras, partes de fundador ou outros direitos de participação nos lucros, excluídos os créditos contra a empresa e ainda os rendimentos de outras participações no capital, que, para efeitos tributários, sejam tratadas, pela legislação do país onde reside a empresa que efetua a distribuição, como rendimentos de ações.

Tal conceito seria bastante amplo para abranger não apenas aquilo que se classifica como "dividendos" no Direito brasileiro. Conforme a definição estabelecida para fins de aplicação das convenções fiscais brasileiras, seriam abrangidas pelo conceito de "dividendos" aquilo que na legislação brasileira possui sentidos diversos, como rendimentos de "partes beneficiárias" (Lei 6.404/76, arts. 46 a 51) e a distribuíção lucros em razão de debêntures (Lei 6.404/76, arts. 52 a 74)

Para a aplicação dos acordos de bitributação, CASELlA e XAVIER ponderam que devem ser adotados esses conceitos mais amplos colhidos das convenções fiscais.

${ }^{226}$ CASELLA, Paulo Borba. Direito internacional tributário brasileiro. São Paulo : LTR, 1995, p. 36-40.

${ }^{227}$ XAVIER, Alberto. Direito Tributário Internacional do Brasil. Rio de Janeiro: Forense, 2010, p. 588 e seg. 


\subsection{Exemplo: A autonomia do Direito tributário internacional nos tribunais ingleses.}

No Caso Banco do Brasil (Reino Unido, 1990), o tribunal inglês reafirmou a autonomia dos termos adotados nos acordos internacionais em relação ao Direito doméstico.

O tribunal britânico consignou que a linguagem adotada em convenções internacionais não seriam escolhidas unilateralmente pelo parlamento daquele país: não se tratariam de textos redigidos no convencional idioma inglês e nem seriam aplicados exclusivamente por juízes do Reino Unido. Os acordos de dupla tributação deveriam ser considerados de forma mais ampla e com variações que não seriam encontradas no Direito doméstico, concluíram os juízes.

\subsubsection{A autonomia dos métodos de interpretação do Direito tributário internacional e do Direito doméstico.}

É bastante difundida a ideia de que as convenções de bitributação possuem natureza dupla: são celebradas em meio ao Direito Internacional (tributário) e operam perante o Direito doméstico dos Estados contratantes ${ }^{228}$. Surge daí a pergunta se seriam ou não relevantes aos acordos de dupla tributação as normas de interpretação do Direito doméstico: Se um Estado privilegia em seu sistema jurídico doméstico a interpretação literal, deverá adotar o mesmo método na interpretação de seus acordos de dupla tributação? Ou, justamente por adotar em seu Direito doméstico a interpretação literal, deve tal Estado interpretar os acordos de dupla tributação de forma distinta?

Suscita CARlo GARBARINO ${ }^{229}$ que, no Direito tributário internacional, a adoção do método literal de interpretação pode indicar a adesão à corrente formalística, que equipara os acordos de dupla tributação à lei doméstica e, tal como se daria em relação a esta, o

\footnotetext{
${ }^{228}$ Nesse sentido, vide: BAKER, Philip. Double taxation conventions and international tax law. Londres : Sweet \& Maxwell, 1994, par. C-02.

${ }^{229}$ GARBARINO, Carlo. Manuale di tassazione Internazionale. Milão : Kluwer, 2005, p. 173-174.
} 
recurso a elementos extrínsecos apenas seria permitido quando aqueles intrínsecos ao texto se mostrassem insuficientes.

Para RoY RoHATGI ${ }^{230}$, a interpretação das normas tributárias domésticas e daquelas contidas nos acordos de dupla tributação devem obedecer a roteiros distintos, pois: (i) aos acordos internacionais aplicam-se as regras de interpretação da CVDT, que se baseiam no Direito Internacional consuetudinário; (ii) o Direito doméstico adota linguagem altamente técnica, moldada às necessidades de uma específica jurisdição, enquanto que acordos de dupla tributação devem ser mais gerais para comportar entendimentos de ao menos dois Estados contratantes, em mais do que um idioma; (iii) os acordos de dupla tributação se prestam a afastar ou aliviar a tributação, enquanto que a legislação doméstica é vocacionada à imposição tributária em situações específicas, além do que, diante da longa duração dos acordos de dupla tributação, devem ser flexíveis o suficiente para que suportem as mudanças de ambos os sistemas jurídicos contratantes; (iv) acordos de dupla tributação tendem a ser menos precisos, requerendo a adoção de métodos mais liberais, interpretações mais amplas com vistas à substância sobre a forma e; (v) a interpretação dos acordos de dupla tributação deve ser compreendida por si só, mantendo-a o mais afastada possível das regras de interpretação do Direito doméstico.

Como se pode observar, na defesa da tese de que a interpretação dos acordos de dupla tributação não deve coincidir com tal método literal aplicável às normas tributárias domésticas, vêm sendo utilizados argumentos relacionados às diferenças entre essas duas espécies normativas, como o processo de formação, sujeitos, objeto, caráter contratual e estilo de redação.

Argumentos que atribuem a tais fatores a causa para a distinção dos métodos de interpretação de dispositivos do Direito doméstico e de acordos de dupla tributação vêm sendo bastante criticados por BRIAN J. ARNOLD ${ }^{231}$. Para o autor, haveria um mito de que tratados de dupla tributação devam ser interpretados de forma mais ampla ou liberal que a legislação tributária doméstica, cuja interpretação seria mais literal. Para esse autor, ainda que geralmente os tratados sejam elaborados de forma mais aberta, em diversos casos a

${ }^{230}$ ROHATGI, Roy. Basic International taxation. Volume 1: principles. Nova Deli : Taxmann, 2005, p. 3839.

${ }^{231}$ ARNOLD, J. Brian. The interpretation of tax treaties: myth or reality, in Bulletin for international Taxation (tax treaty monitor) - january of 2010. IBFD : Amsterdã, 2010, p. 5-14. 
situação se inverte e o Direito doméstico prescreve regras mais genéricas e o acordo de dupla tributação veicula normas com considerável nível de detalhamento. Além disso, sustenta o autor que também a legislação doméstica, por mais detalhada que seja, estaria sujeita a ambiguidades e obscuridades que conduzem a disputas entre fisco e contribuintes, o que vem reclamando, em diversas jurisdições, por uma interpretação teleológica, similar à proposta pela CVDT. Assim, para ARNOLD ${ }^{232}$, ainda que se aceite que a linguagem adotada nos acordos de dupla tributação seja distinta daquela utilizada pela legislação doméstica, tal fator não conduz necessariamente à conclusão quanto ao específico método de interpretação que deveria ser aplicado a cada qual.

Assim, não seria suficiente identificar diferenças entre as regras do Direito doméstico e aquelas que compõem os acordos de dupla tributação: seria necessário perquirir se tais distinções geram reflexos na escolha dos métodos de interpretação e nos sentidos construídos a partir dos textos dos acordos de dupla tributação. ${ }^{233}$ A questão seguinte à constatação de divergências seria, então, saber se os juízes de tais jurisdições devem alterar os métodos de interpretação geralmente adotados para questões domésticas, a fim de adequá-los a uma postura internacionalmente aceitável (“internationally acceptable approach") ${ }^{234}$.

A questão, então, não deve ser colocada em termos absolutos, de tal forma que a interpretação dos acordos de dupla tributação sempre seja conduzida de forma idêntica ao Direito doméstico ou, ainda, que sempre seja conduzida de forma diversa deste. Tal afirmação também decorre do fato que os métodos adotados na interpretação das normas domésticas de um determinado Estado sejam coincidentes com aqueles adotados pelo Direito Internacional, de modo que não haveria maiores problemas, como se daria geralmente na opinião de KLAUS VOGEL. ${ }^{235}$ As discussões surgem quando há divergência de métodos.

\footnotetext{
${ }^{232}$ ARNOLD, J. Brian. The interpretation of tax treaties: myth or reality, in Bulletin for international Taxation (tax treaty monitor) - january of 2010. IBFD : Amsterdã, 2010, p. 13-14.

${ }^{233}$ ARNOLD, J. Brian. The interpretation of tax treaties: myth or reality, in Bulletin for international Taxation (tax treaty monitor) - january of 2010. IBFD : Amsterdã, 2010, p. 9-10.

${ }^{234}$ Nesse sentido e, ainda, favorável à alterações dos métodos de interpretação por Cortes nacionais, vide: EDWARDES-KER, Michael. Tax Treaty Interpretation - The International Tax Treaties Service. In-Depth Publishing : Athlone, 1995, p. 3-4, Capítulo 1.

${ }^{235}$ VOGEL, Klaus. Klaus Vogel on Double Taxation Conventions. Kluwer : London, 1999, p. 34 e seg.
} 
O dilema entre acompanhar ou divergir dos métodos adotados para a interpretação de normas tributárias domésticas pode ser comum em sistemas do common law, como Reino Unido, Austrália e Canadá. ${ }^{236}$ Nesses, tradicionalmente os julgadores assumiriam uma postura voltada à interpretação literal, em que o acesso a elementos extrínsecos (como trabalhos preparatórios) não seria permitido. No entanto, a questão também pode surgir em países com tradição no civil law. LUC DE BROE ${ }^{237}$ aponta que a interpretação literal de isenções tributárias no sistema jurídico belga, notadamente de tradição no civil law, atrairia diversos autores a sustentar que igual método deveria ser aplicado também em relação aos acordos de dupla tributação. No Brasil, cujo sistema jurídico também está fundado no civil law, a discussão também está presente, como se poderá observar a seguir.

Em países como Japão e Coreia, a discussão parece não haver pertinência em absoluto, pois há disposições constitucionais que dão prioridade aos tratados sobre as leis internas, o que serve como argumento para que os métodos de interpretação do Direito Internacional sejam considerados prioritários em relação aos métodos domésticos ${ }^{238}$.

\subsection{Exemplo: o caso espanhol da construção de sentido de "royalty" do art. 12 da CM-OCDE conforme os métodos de interpretação do Direito doméstico.}

No Caso Televisió de Catalunya (Espanha, 2011), o Tribunal Supremo considerou que o sentido do termo "cánones" ("royalties”), presente no art. 12 do acordo de dupla tributação Espanha-Países Baixos, deveria ser construído em conformidade com as normas interpretativas da Ley General Tributária, que proibe o recurso à analogia em seu art. 23 (3).

Para os juízes espanhóis, apenas com o recurso à analogia seria possível incluir no sentido do termo "cánones" ("royalties") o uso ou a cessão de uso de direitos de imagem.

\footnotetext{
${ }^{236}$ Nesse sentido, vide: KATZ, Stanley I. United States National Report. Cahiers de Droit Fiscal International by the International Fiscal Association (studies on international tax law), volume LXXVIIIa - Subject I. Interpretation of double taxation conventions. Kluwer Law and Taxation Publishers / IFA : Rotterdam, 1993, p. 616-628, 632, nota de rodapé n. 65; EDWARDES-KER, Michael. Tax Treaty Interpretation - The International Tax Treaties Service. In-Depth Publishing : Athlone, 1995, p. 2-3; 7 e seg., Capítulo 3.

${ }^{237}$ BROE, Luc De. International tax planning and prevention of abuse (doctoral series n. 14). Amsterdã : IBFD, 2007, 260-262.

${ }^{238}$ Cf. ARNOLD, J. Brian. The interpretation of tax treaties: myth or reality, in Bulletin for international Taxation (tax treaty monitor) - january of 2010. IBFD : Amsterdã, 2010, p. 9.
} 
A Ley Orgánica espanhola, de 1982, tutelaria o Direito à imagem como um Direito fundamental e irrenuncíavel inerente à pessoa, embora o seu titular pudesse cedê-lo a terceiros para fins publicitários, comerciais ou semelhantres, como se um bem material fosse. Ocorre que, ao ser cedido como um bem, perderia a sua natureza de "Direito de imagem" e, assim, apenas analogicamente a contraprestação por seu uso assumiria a acepção de royalties.

Não se pode deixar de registrar as críticas que vêm sendo suscitadas em face de decisões dos tribunais espanhóis. ANDRÉs BÁEZ MORENO ${ }^{239}$ suscita que tais decisões se tornaram exemplo corrente na doutrina de como os acordos de bitributação não devem ser aplicados.

\subsubsection{Os conceitos, categorias e normas de interpretação do sistema jurídico brasileiro em face de seus acordos de dupla tributação.}

No Brasil, o tema é relevante. O Código Tributário Nacional (“CTN”), elaborado coincidentemente à mesma época da CVDT, tutelou a forma de interpretação das normas tributárias. Há enunciados no CTN especialmente dedicados à interpretação da "legislação tributária" ${ }^{240}$, o que compreende "as leis, os tratados e as convenções internacionais, os decretos e as normas complementares que versem, no todo ou em parte, sobre tributos e relações jurídicas a eles pertinentes" ${ }^{241}$. Ocorre que as regras previstas no CTN supostamente aplicáveis aos "tratados" - não coincidem com as normas gerais veiculadas pela CVDT.

O CTN dispõe sobre a interpretação das normas tributárias em seu Capítulo IV (“Interpretação e Integração da Legislação Tributária”). O art. 108 do CTN, entre outras coisas, autoriza o recurso à analogia para situações específicas, proibindo-a expressamente para a exigência de tributo não previsto em lei. O art. 109 do CTN prevê que os "princípios gerais de direito privado utilizam-se para pesquisa da definição, do conteúdo e do alcance

\footnotetext{
${ }^{239}$ MORENO, Andrés Báez. Contract Splitting and Article 17 of the OECD Model: Is Source Taxation of Artistes and Sportsmen a New Dummensteuer?, in Bulletin for International Taxation vol. 68, n. 3. Amsterdã :2014, p. 1.

${ }^{240}$ BRASIL. CTN, art. 107.

${ }^{241}$ BRASIL. CTN, art. 96.
} 
dos institutos, conceitos e formas, mas não para definição dos respectivos efeitos tributários". O art. 111, ainda, prevê a interpretação literal da legislação tributária que trate da "suspensão ou exclusão do crédito tributário", "outorga de isenção" ou "dispensa do cumprimento de obrigações tributárias acessórias". ${ }^{242}$ Diversos conceitos do Direito tributário brasileiro, vale então frisar, devem ser investigados a partir de seu Direito privado doméstico.

Esse seria o roteiro para a interpretação dos acordos de dupla tributação celebrados pelo Brasil? Não obstante o debate na doutrina brasileira ${ }^{243}$, a resposta parece ser negativa.

Embora inicialmente tenha compreendido que os acordos de dupla tributação, assim que incorporados ao sistema jurídico brasileiro, deveriam ser interpretados conforme os arts. 107 a 112 do CTN, GERD W. ROTHMANN ${ }^{244}$ reviu sua posição. Em seus últimos trabalhos, assume o professor que a ausência de transformação do acordo em Direito doméstico - que permanece como parte do Direito Internacional Público, tal como em sua origem - faz com que sejam aplicáveis exclusivamente os métodos de interpretação previstos neste, salvo exceção expressa no texto do acordo. É importante analisar os fundamentos para tal mudança de posição, a fim de que se compreendam as duas correntes doutrinárias existentes sobre o tema.

Ambas as conclusões de Gerd W. Rothmann parecem partir da premissa de que os acordos de dupla tributação pertencem a duas ordens: (i) internacional, na qual há um acordo firmado entre dois ou mais Estados soberanos e; (ii) nacional, na qual o referido acordo é "adotado", "aprovado", "incorporado" pelo respectivo Poder Legislativo interno. No Brasil, a incorporação do acordo internacional decorrente de sua promulgação por decreto presidencial o transformaria em lei e, ainda, "superior às demais leis" devido ao seu caráter de lex specialis.

\footnotetext{
${ }^{242}$ Sobre a questão da interpretação no CTN, vide: NOGUEIRA, Ruy Barbosa. Curso de Direito Tributário. São Paulo, Saraiva, 1995, p. 100 e seg.

${ }^{243}$ Adotam o entendimento da aplicação das regras de interpretação do CTN sobre as convenções fiscais, por exemplo: CASELLA, Paulo Borba. Direito internacional tributário brasileiro. São Paulo : LTR, 1995, p. 25.

${ }^{244}$ ROTHMANN, Gerd W. Interpretação e aplicação dos acordos internacionais contra a bitributação. Tese de doutorado. São Paulo : Faculdade de Direito da Universidade de São Paulo (USP), 1978, p. 31 e seg; ROTHMANN, Gerd W. Prefácio, in Interpretação dos tratados para evitar a dupla tributação (Autor: ROCHA, Sergio André). São Paulo : Quartier Latin, 2013, p. 14-15.
} 
Ocorre que, em uma primeira fase, representada pela conclusão de sua tese de doutorado nos idos 1978, compreendia GERD W. ROTHMANN que as convenções físcais deveriam ser interpretadas conforme os métodos próprios ao Direito internacional, "tendo em vista sua natureza de tratado no plano internacional", bem como "conforme as regras de interpretação das leis, considerando sua natureza de lei especial interna". Nessa ordem doméstica, seria "de competência dos tribunais nacionais interpretar os tratados assim incorporados, podendo os contribuintes invocá-los diretamente”. As regras interpretativas de Direito Internacional público, por sua vez, só teriam aplicação subsidiária.

Ainda hoje, tal posição encontra acolhida doutrinária. Em 2010, BRIAN J. ARNOLD $^{245}$ publicou trabalho no qual sustenta que, em países nos quais os acordos de dupla tributação devem ser incorporados ao sistema jurídico interno, as normas domésticas de interpretação aplicáveis a todas as demais normas internas pertencentes a esse sistema seriam aplicáveis para a interpretação do referido acordo. ARNOLD ainda opõe que, mesmo na ausência do argumento da transformação, o fato de os acordos de dupla tributação serem celebrados com vistas aos sistemas jurídicos domésticos dos dois Estados contratantes seria decisivo: acordos de dupla tributação seriam apenas pontes entre os tais sistemas internos e, assim, acessórios desses, de modo que não poderiam assumir métodos de interpretação independentes e diversos daqueles aplicáveis nos regimes domésticos. Nesse seguir, divergindo de outros autores ${ }^{246}$, ARNOLD ${ }^{247}$ conclui que não seria realístico imaginar que um juiz alteraria seu método de interpretação quando lidasse com termos inseridos no contexto de acordos de dupla tributação.

A mudança de posição de Gerd W. Rothmann, por sua vez, permite identificar a outra corrente doutrinária sobre o tema: os acordos de dupla tributação são celebrados em meio ao Direito Internacional e devem ser interpretados considerando esse seu contexto, ainda após a sua incorporação ao ambiente jurídico interno.

\footnotetext{
${ }^{245}$ ARNOLD, J. Brian. The interpretation of tax treaties: myth or reality, in Bulletin for international Taxation (tax treaty monitor) - january of 2010. IBFD : Amsterdã, 2010, p. 9-12.

${ }^{246}$ Em sentido contrario, vide: EDWARDES-KER, Michael. Tax Treaty Interpretation - The International Tax Treaties Service. In-Depth Publishing : Athlone, 1995, p. 3-4, Capítulo 1.

${ }^{247}$ ARNOLD, J. Brian. The interpretation of tax treaties: myth or reality, in Bulletin for international Taxation (tax treaty monitor) - january of 2010. IBFD : Amsterdã, 2010, p. 14.
} 
Nessa mesma direção, para Luís EdUARDo SCHOUERI ${ }^{248}$, os acordos de dupla tributação devem ser interpretados conforme as regras do Direito Internacional, veiculadas pela CVDT. Como exemplo, por tratar-se o treaty shopping de assunto atinente à interpretação de acordos de bitributação, tal questão apenas poderia ser analisada a partir das normas dos tratados internacionais e não daquelas colhidas da legislação doméstica.

\subsection{Exemplo: a (não) aplicação das normas do CTN para a interpretação dos acordos fiscais brasileiros.}

A questão da aplicação das normas do CTN para a interpretação dos acordos de bitributação apenas recentemente entrou na pauta dos tribunais brasileiros.

No Caso Falcão (Brasil, 2009), ao considerar que o sentido dos termos "participantes em diversões públicas" referidos no art. 15 do acordo Brasil-Japão comportariam técnicos de futebol, consignou a Min. Eliana CALMON, do Superior Tribunal de Justiça ("STJ") que com isso estaria cumprida a interpretação restritiva requerida pelo art. 111 do $\mathrm{CTN}$.

No Caso Air France (Brasil, 2008), o Tribunal Regional Federal da $2^{\text {a }}$ Região (“TRF-2") precisou delinear se a COFINS estaria compreendida no escopo de "impostos futuros de natureza idêntica ou análoga", presente no art. 2 (2) do acordo Brasil-França.

O tribunal julgou que, como o acordo Brasil-França estabeleceria hipóteses de exclusão do crédito tributário (CTN art. 175, I), deveria ser interpretado literalmente (CTN, art. 111) e não de forma extensiva.

É interessante notar que ambos os casos poderiam ser igualmente solucionado com o recurso a meios de interpretação fornecidos pelo Direito tributário internacional, sem a necessidade da aplicação de normas do CTN.

${ }^{248}$ SCHOUERI, Luís Eduardo. Planejamento Fiscal Através de Acordos de Bitributação (Treaty Shopping). São Paulo: Ed. Revista dos Tribunais, 1995, p. 70, 111; Preços de transferência no direito tributário brasileiro. São Paulo: Dialética, 2013, p. 409 e seg. 


\subsubsection{A norma especial de interpretação do art. 3 da CM-OCDE}

Qual a norma de interpretação veiculada pelo art. 3 da CM-OCDE, especialmente em relação à sua cláusula do “contexto”? O art. 3 da CM-OCDE veicula norma especial em relação àquelas previstas na CVDT, capaz de estabelecer distinção entre a forma pela qual deve ser aplicado um acordo de dupla tributação e tratados em geral?

$\mathrm{O}$ art. 3 (2) da CM-OCDE é um excelente exemplo de quão peculiar é o Direito tributário internacional: diante das normas gerais de interpretação da CVDT aplicáveis a todos os tratados, o dispositivo tras uma cláusula especial de interpretação de termos não definidos no texto dos acordos de dupla tributação, que não encontra similar em outros seguimentos do Direito Internacional. A questão, então, é saber se o art. 3 (2) da CMOCDE, restringe, amplia ou de alguma forma altera as normas gerais da CVDT, ainda que seja para atribuir hierarquia diversa aos meios de interpretação já previstos nessa convenção multilateral.

O dispositivo pode ser considerado cláusula especial de interpretação em relação às normas gerais de interpretação veiculadas pela $\mathrm{CVDT}^{249}$. Tal caráter, contudo, não poderá ser utilizado como coringa para justificar inobservâncias àquelas normas gerais. Normas especiais, por definição, prevalecem sobre normas gerais nas situações específicas de que tratam, mantendo intactos os demais pontos não abordados. Dessa forma, deve-se verificar em quais pontos a norma especial do art. 3 (2) da CM-OCDE se sobrepõe à única e combinada operação de interpretação da CVDT e, em caso de divergências, quais os novos esquemas interpretativos seriam estabelecidos.

O dispositivo também pode ser considerado cláusula geral de interpretação, por se prestar à interpretação de termos em geral da $\mathrm{CM}_{-} \mathrm{OCDE}^{250}$, em contraposição ao art. 3 (1) da CM-OCDE, que cuida da interpretação de termos específicos. Pelo critério da especialidade, teriam precedência sobre o art. 3 (2) da CM-OCDE, geralmente afastando a sua aplicabilidade: (i) cláusulas de interpretação autêntica de termos utilizados no texto da

\footnotetext{
${ }^{249}$ VOGEL, Klaus. Klaus Vogel on Double Taxation Conventions. Kluwer : London, 1999, p. 209.

${ }^{250}$ Nesse sentido, vide: VOGEL, Klaus. Klaus Vogel on Double Taxation Conventions. Kluwer : London, 1999, p. 209-210.
} 
convenção, a exemplo do art. 11 (3), em que se define o sentido a ser atribuído ao termo juros (“interest”), ou do art. 12 (2), que veicula a definição de "royalties"; (ii) claúsulas com remissão expressa ao Direito doméstico de um dos Estados contratantes, a exemplo do art. 4 (1), que define a expressão "residente de um Estado Contratante", do art. 6 (2), que trata dos termos "bens imóveis" e do art. 10 (3), que cuida do termo "dividendos", aos quais deve ser aplicado o sentido conforme a legislação do Estado contratante; (iii) cláusulas que não tratam do tema da interpretação, mas que requerem a aplicação do próprio Direito doméstico dos Estados contratantes, como por exemplo o art. 23 (A e B), que remete ao Direito doméstico a questão de como o crédito em relação ao imposto pago no outro Estado contratante será concedido.

É curioso e importante sublinhar que o próprio exercício de interpretação do art. 3 (2) da CM-OCDE deve ser realizado necessariamente com base nas normas gerais da CVDT: sem isso, nega-se de início a ideia de qualquer ordem no Direito Internacional, vende-se fácil o que não teria preço e, no caso do Brasil, nega-se cogência à decisão do Congresso Nacional ${ }^{251}$, promulgada pelo Presidente da República ${ }^{252}$, de reconhecer à CVDT o caráter de "lei" do sistema jurídico brasileiro.

\subsubsection{O reenvio ao Direito doméstico dos Estados contratantes.}

"The operation of Article 3 (2) raises several difficulties. The paragraph provides that domestic tax law definition can be used. Apart from the exceptional situation where domestic definitions are identical, this would seem to imply an acceptance that the Convention will mean diferente things in the two Contracting States". PHILIP BAKER (1994) $)^{253}$

Em todas as suas versões - de 1963, 1977 e 1995 - o art. 3 (2) da CM-OCDE prevê duas diferentes fontes para as quais o operador do Direito tributário internacional deve recorrer para a construção de sentido dos termos não definidos nos acordos de dupla tributação: (i) o reenvio ao Direito doméstico do Estado que aplica o acordo ou; (ii) o "contexto". Ainda que a doutrina naturalmente se ocupe de ambas as fontes, suas atenções

${ }^{251}$ BRASIL. CONGRESSO NACIONAL. Decreto Legislativo ${ }^{\circ}$ 496, de 17 de julho de 2009.

${ }^{252}$ BRASIL. PRESIDÊNCIA DA REPÚBLICA. Decreto ${ }^{\circ}{ }^{7.030}$, de 14 de dezembro de 2009.

${ }^{253}$ BAKER, Philip. Double taxation conventions and international tax law. Londres : Sweet \& Maxwell, 1994, par. C-19. 
geralmente se voltam à primeira delas, ou seja, ao reenvio ao Direito doméstico dos Estados contratantes.

A previsão de reenvio ao Direito doméstico já se encontrava presente no antigo acordo de dupla tributação EUA-Reino Unido, que inaugurou a sua utilização em 1945. No entanto, essa claúsula considerada inusitada no Direito Internacional público parece ter sido adotada pela primeira vez em regulamentos do imposto de renda norte-amerinado ${ }^{254}$. Em 1940, logo após celebrar um acordo de bitributação com a Suécia (1939), o Governo dos EUA o regulamentou internamente. De acordo com esse regulamento, os termos definidos naquela convenção deveriam ser interpretados conforme tais definições; contudo, termos adotados no texto da convenção, mas não definidos neste, deveriam ser interpretados conforme as definições do regulamento do imposto de renda norte-americano (“Internal Revenue Code").

Se alguma aproximação teórica é necessária, essa alternativa ao "contexto" referida pelo art. 3 (2) da CM-OCDE assemelha-se - mas não se confunde - com o que ocorre no Direito Internacional privado, em que o juiz deve aplicar a legislação estrangeira para a solução de um determinado caso sob a sua jurisdição. O chamado reenvio ao Direito doméstico ("renvoi") do Direito Internacional privado têm semelhanças, mas é distinto do previsto na cláusula do art. 3 (2) da CM-OCDE.

Para compreender como se dá o "reenvio" no Direito Internacional privado, suponha-se, por exemplo, que a legislação doméstica de um Estado (“A”) preveja que o Direito de herança sobre determinada propriedade seria regido pela legislação atinente ao local do último domicílio do de cujus, no caso, um outro Estado ("B”). Seria necessário àquele Estado (“A”), então, analisar a legislação desse outro Estado (“B”) para encontrar a solução. Se esse sistema jurídico estrangeiro ("B”) possuísse a previsão de que o Direito de regência fosse daquele primeiro Estado (“A”), então esta seria aplicada. ${ }^{255}$

\footnotetext{
${ }^{254}$ Cf. BAKER, Philip. Double taxation conventions and international tax law. Londres : Sweet \& Maxwell, 1994, par. C-18.

${ }^{255}$ GOTHENBURG, K. Ahlm. National Report of Sweden. Cahiers de Droit Fiscal International by the International Fiscal Association (studies on international tax law), volume XLII - Subject II: The interpretation of the Double Taxation Convention. / IFA : Rotterdam, 1960, p. 257.
} 
Não se pode dizer, contudo, que ocorreria o mesmo fenômeno tanto no Direito Internacional privado quanto no Direito tributário internacional. AlBERTO XAVIER ${ }^{256}$ suscita que, naquele primeiro, entram em contato normas de conflito internas e normas materiais estrangeiras, enquanto que no Direito tributário internacional estão envolvidas "regras de colisão convencional" e normas domésticas de um dos Estados contratantes.

Na qualidade de relator geral do Congresso IFA de 1960, RAOUL LENZ ${ }^{257}$ relatava que a crescente adoção da general renvoi clause, especialmente nos acordos de dupla tributação entre países Anglo-saxões e, celebrados por Estados como Países Baixos e Suécia. Em sua essência, tais cláusulas continham a fórmula hoje presente no art. 3 (2) da CM-OCDE. Embora se tornasse cada vez mais comum, a cláusula já não era isenta de discussões. Enquanto SPITALER, relator nacional da Alemanha, relacionava à referida cláusula de reenvio a suposta vantagem de prover aos contribuintes segurança jurídica com o prévio conhecimento quanto à aplicação de suas leis domésticas em relação aos termos não definidos no teto do acordo de dupla tributação, AHLM (Suécia), REUVERS (Holanda) e WIDMER (Suíça) opunham que uma cláusula geral de reenvio ao Direito doméstico restringiria de forma injustificada a discricionariedade na aplicação do acordo e conduziria à dupla tributação.

Para EDWIN VAN DER BRUGGEN ${ }^{258}$, ao se referir apenas ao Direito doméstico de um dos Estados, enquanto a interpretação harmônica claramente envolve o engajamento de ambos, tal possibilidade se mostra tão irregular e fora de sintonia com vários princípios gerais e regras de interpretação do Direito Internacional que o art. 3 (2) da CM-OCDE enseja consideráveis dúvidas quanto à sua aptidão para servir de cláusula geral interpretativa.

Entre as inúmeras discussões que a cláusula de reenvio suscita, algumas podem ser destacadas. Apenas normas relacionadas ao imposto sobre a renda seriam relevantes? Ou normas relacionadas a outros tributos ou mesmo do Direito civil poderiam ser acessadas?

\footnotetext{
${ }^{256}$ XAVIER, Alberto. Direito Tributário Internacional do Brasil. Rio de Janeiro: Forense, 2010, p. 145.

${ }^{257}$ LENZ, Raoul. General Report. Cahiers de Droit Fiscal International by the International Fiscal Association (studies on international tax law), volume XLII - Subject II: The interpretation of the Double Taxation Convention. / IFA : Rotterdam, 1960, p. 296-297.

${ }^{258}$ BRUGGEN, Edwin van der. Unless the Vienna Convention Otherwise Requires: notes on the relationship between Art. 3 (2) of the OECD Model Tax Convention and art. 31 and 32 of the Vienna Convention on the Law of Treaties, in European Taxation of May 2003. IBFD : Amsterdam, 2003, p. 144.
} 
Devem ser consideradas as normas existentes no momento da celebração do acordo de dupla tributação? Ou aquelas vigentes no momento de aplicação do acordo?

Foram questões como essas que motivaram a alteração da CM-OCDE em 1995, que passou a expressar que, caso o "contexto" não requeira outro sentido, termos não definidos no acordo de dupla tributação devem ter o sentido construído a partir da legislação dos Estados contratantes vigente no momento de sua aplicação - e não de sua celebração. O CAF-OCDE também inseriu no dispositivo cláusula que expressamente autoriza que se considerem normas domésticas não tributárias, embora os sentidos providos pelas normas domésticas de regência dos tributos abrangidos pelo acordo tenham prevalência $^{259}$. A revisão do art. 3 (2) da CM-OCDE foi observada pelos negociadores dos acordos de dupla tributação celebrados pelo Brasil, conforme exposto no subtópico "3.3.7" desta introdução.

Outras questões relacionadas às fontes domésticas poderiam ser ainda suscitadas, mas provavelmente o conflito de qualificação seja a mais relevante. Tais questões, relacionadas à clausula do reenvio, já vêm sendo sobejamente analisada por abalizada doutrina pelo próprio CAF-OCDE. As soluções propostas para problemas e indagações da cláusula de reenvio, como os conflitos de qualificação, geralmente dão ensejo a uma série de novos questionamentos. Tema bastante representativo desta assertiva envolve a qualificação de partnerships sob o escopo dos acordos de dupla tributação, para o qual o CAF-OCDE dedicou um estudo ${ }^{260}$ sugerindo fórmulas bastante questionáveis ${ }^{261}$ para a solução de problemas de interpretação criados pelo reenvio.

A presente tese, contudo, não se ocupa necessariamente do problema dos conflitos de qualificação ou de minúcias da cláusula de reenvio ao Direito doméstico previstas no art. 3 (2) da CM-OCDE. ${ }^{262}$ Este estudo investiga a outra fonte provedora de sentidos aos termos não definidos no texto do acordo de dupla tributação: o "contexto".

\footnotetext{
${ }^{259}$ Vide: OCDE, Model Tax Convention on Income and on Capital 2014 (Full Version), OECD Publishing, 2014, Comentários à CM-OCDE, art. 3 (2), par. 13.1, incluído na revisão de 1995.

${ }^{260}$ Vide: OCDE, The Application of the OECD Model Tax Convention to Partnerships, in Issues in International Taxation n. 6. Paris : OECD Publishing, 1999.

${ }^{261}$ Vide, em especial: LANG, Michael. The application of the OECD Model Tax Convention to Partnerships - A critical Analysis of the Report Prepared by the OECD Committee on Fiscal Affairs. Viena : Linde, 2000.

${ }^{262}$ Para diversos autores o art. 3 (2), da CM-OCDE tutelaria a questão da interpretação, mas não da qualificação. Nesse sentido, vide: XAVIER, Alberto. Direito tributário internacional do Brasil. Forense : Rio
} 


\subsubsection{A cláusula da interpretação conforme o "contexto".}

"Prof. Ellis brought it up, but the subject has been on my mind for decades. What is the meaning of the art. 3 (2) of the OECD Model, which provides that a term has the meaning it has in the domestic law of a state 'unless the context otherwise requires'?" FRANK VAN BRUNSCHOT (2005) ${ }^{263}$

Embora as normas veiculadas no art. 3 da CM-OCDE sejam vocacionadas a prover soluções à interpretação no Direito tributário internacional, elas próprias ensejam severas e inconclusivas divergências doutrinárias e jurisprudenciais. Com quase 70 anos de utilização e presente hoje em aproximadamente 5.000 acordos de dupla tributação, a cláusula do "contexto", vocacionada a conduzir a interpretação de termos dos acordos de dupla tributação, tem canalizado os esforços interpretativos para a sua própria compreensão, de tal modo que vem sendo questionada a sua aptidão para promover a interpretação harmônica entre os seus Estados contratantes ${ }^{264}$ ou, ainda, para veicular uma norma geral de interpretação dos acordos de dupla tributação.

$\mathrm{O}$ art. 3 da CM-OCDE requer o recurso ao "contexto" ou, ainda, do Direito doméstico dos Estados contratantes. Contudo, experientes operadores do Direito tributário internacional, como o juiz da Suprema Corte holandesa citado na passagem em epígrafe, ou o barister e professor inglês PHILIP BAKER ${ }^{265}$, não escondem suas dificuldades em compreender claramente qual o sentido do "contexto" referido no art. 3 (2) da CM-OCDE e a que deveriam recorrer antes do reenvio ao Direito doméstico.

Para EDUARDO BAISTROCCHI ${ }^{266}$, o art. 3 (2) da CM-OCDE seria o misto de regra ("rule”), com a previsão de resultados ex ante, e padrão jurídico ("standard”), cujos resultados apenas poderiam ser aferidos ex post. Sob tal concepção, a norma que prevê o

de Janeiro, 2010, p. 129; BELLAN, Daniel Vitor. Direito tributário internacional. Rendimentos de pessoas físicas nos tratados internacionais contra a dupla tributação. Saraiva : São Paulo, 2010, p. 67.

${ }^{263}$ BRUNSCHOT, Frank van. The Judiciary and the OECD Model Tax Convention and its Commentaries, in Bulletin - Tax Treaty Monitor of January 2005. IBFD, 2005, p. 8.

${ }^{264}$ Nesse sentido, WIM WIJNEN observa que quase todos os tratados fiscais contêm uma regra geral nos moldes do artigo 3 (2) da CM-OCDE, que não conduziria, contudo, à interpretação harmônica dos acordos de dupla tributação. (WIJNEN, Wim. Some Thoughts on Convergence and Tax Treaty Interpretation, in Tax Treaty Monitor - Bulletin for International Taxation (November 2013). IBFD: Amsterdã, 2013, p. 575).

${ }^{265}$ BAKER, Philip. Double taxation conventions and international tax law. Londres : Sweet \& Maxwell, 1994, par. C-20.

${ }^{266}$ BAISTROCCHI, Eduardo A., The Use and Interpretation of Tax Treaties in the Emerging World: Theory and Implications. British Tax Review n. 4. Londres : Thomson, 2008, p. 387-389. 
reenvio ao Direito doméstico seria uma regra, pois já seria possível saber previamente que a consequência seria o recurso a determinadas espécies de normas internas. Por sua vez, não seria possível antever as consequências da cláusula do "contexto", sendo necessário aguardar a aplicação da norma por um juiz. Muitos termos da CM-OCDE teriam esta última natureza, restando à rede descentralizada de julgadores domésticos construir o seu sentido.

O desafio da presente tese é atribuir traços mais claros ao "contexto" referido no art. 3 (2) da CM-OCDE, a fim de que possa ser utilizado de forma mais transparente pelos operadores do Direito tributário internacional.

Conforme exposto no Capítulo I, há ao menos cinco teorias quanto ao sentido e extensão do "contexto" referido no art. 3 (2) da CM-OCDE: (i) teoria do contexto exclusivamente intrínseco; (ii) teoria oficial do CAF-OCDE; (iii) teoria da correlação do “contexto" com os Comentários à CM-OCDE; (iv) teoria do contexto internacional amplo; (v) teoria da cumulação do "contexto" internacional e interno. Além do significado do "contexto", também será analisado no Capítulo I desta tese o relacionamento deste com a cláusula de reenvio do art. 3 (2) da CM-OCDE, o que é tão relevante quanto polêmico: será examinado se há ordem de precedência entre o "contexto" e o Direito doméstico dos Estados contratantes e, em caso positivo, qual seria esta.

Ao assumir-se por hipótese que se deve atribuir aos termos dos acordos de dupla tributação o sentido consentido pelos Estados signatários, então a interpretação de suas normas para a aplicação em casos concretos deve se basear em evidências de tal consentimento, levantadas a partir do "contexto". Assim, o Capítulo I desta tese se dedica, ainda, à análise de critérios de seleção das evidências que compõem o acervo sob o escopo do "contexto" referido no art. 3 (2) da CM-OCDE, às quais, como já se antecipou, são organizadas nesta tese em três segmentos, correspondentes aos Capítulos II, III e IV: evidências intrínsecas, evidências extrínsecas primárias e evidências extrínsecas secundárias, respectivamente. 


\subsubsection{Outros termos polêmicos do art. 3 (2) da CM-OCDE.}

Não apenas o "contexto", mas também outros termos referidos no art. 3 (2) da CMOCDE têm demandado a análise da doutrina do Direito tributário internacional. Como exemplo, podem ser citados os signos termo ("term"), requer, exige ("requires") e aplicação (“application”).

O "termo" ("term") sob interpretação para a aplicação do acordo de bitributação, referido no art. 3 (2) da CM-OCDE, compreende não apenas palavras unitárias de um acordo de dupla tributação, mas também palavras compostas e justapostas, expressões, orações ou mesmo períodos completos.

Note-se que a CM-OCDE é editada em dois idiomas oficiais: inglês e francês. Embora a sua versão na língua inglesa utilize o signo "term", a versão na língua francesa adota "terme ou expression". Além disso, LUC DE BROE ${ }^{267}$ observa que atribuir ao signo "term" o alcance apenas de palavras isoladas restringiria desnecessariamente o escopo do art. 3 (2) da CM-OCDE, em afronta ao princípio da promoção do efeito útil e da boa-fé com base nos quais os acordos internacionais devem ser interpretados. Estariam sob o escopo desse dispositivo, então, palavras como "alienation" e "paid", bem como expressões mais longas, a exemplo de "an enterprise of a Contracting State participates directly or indirectly in the management, control or capital of an enterprise of the other Contracting State".

Da mesma forma que não há uniformidade quanto ao sentido do termo "contexto", também não há em relação ao sentido ou a intensidade do termo "requires", referidos no art. 3 (1) e (2) da CM-OCDE, mas não definidos em seu texto. Para autores como KEES VAN RAAD ${ }^{268}$, tal termo seria determinante ao debate quanto à ordem de precedência entre o "contexto" e o Direito doméstico dos Estados contratantes, o que será exposto com mais detalhes no Capítulo I desta tese.

${ }^{267}$ BROE, Luc De. International tax planning and prevention of abuse (doctoral series n. 14). Amsterdã : IBFD, 2007, 264-265.

${ }^{268}$ Cf. RAAD, Kees van. The term 'Enterprise' in the Model Double Taxation Conventions - Seventy Years of Confusion, in Intertax 1994/11, Intertax, 1994, p. 493. 
Por sua vez, EDWIN VAN DER BRUGGEN ${ }^{269}$ suscita que o uso da palavra “application" e não (ou também) "interpretation" é bastante incomum em cláusulas gerais de interpretação de acordos internacionais. Chama a atenção daquele autor, ainda, que o art. 3 (2) da CM-OCDE se refere a "application of the convention by a contracting state" e não "by both contracting states". Vale ressaltar que algumas discussões relacionadas a esse termo interessam mais ao estudo dos conflitos de qualificação, que não é objeto da presente tese.

\subsubsection{A cláusula de interpretação conforme o "contexto" do art. 3 (1) da CM- OCDE.}

Não apenas o art. 3 (2) da CM-OCDE traz a ressalva do "contexto". O art. 3 (1) da CM-OCDE tutela a definição de termos específicos, como "person" "company", "enterprise", "enterprise of a Contracting State", "enterprise of the other Contracting State”, "international traffic", "competent authority", "national”, "business", ressalvando a possibilidade do "contexto" exigir um sentido diverso do delimitado naquele dispositivo.

Como será analisado com mais detalhes no Capítulo II desta tese, parece ser correto compreender que o que diferencia o art. 3 (1) do art. 3 (2) da CM-OCDE é que, em relação àquele primeiro, o intérprete parte de uma evidência intrínseca contundente: o sentido indicado para cada termo específico daquele dispositivo. Em relação ao art. 3 (2) da CM-OCDE, contudo, o termo sob interpretação se caracteriza precisamente por não possuir tal evidência intrínseca tão clara.

${ }^{269}$ BRUGGEN, Edwin van der. Unless the Vienna Convention Otherwise Requires: notes on the relationship between Art. 3 (2) of the OECD Model Tax Convention and art. 31 and 32 of the Vienna Convention on the Law of Treaties, in European Taxation of May 2003. IBFD : Amsterdam, 2003, p. 144-145. 


\subsubsection{Dispositivos similares ao art. 3 (2) da CM-OCDE em outros modelos de acordos de bitributação.}

Os outros modelos de acordos de dupla tributação analisados anteriormente, sugeridos por instituições ou países, veiculam dispositivos semelhalhantes ao art. 3 (2) da CM-OCDE. No entanto, alguns desses modelos possuem particularidades.

\subsubsection{O art. 3 (2) da CM-ONU e os seus respectivos Comentários.}

A CM-ONU, desde sua versão de 1980, acompanha as evoluções propostas pelo CAF-OCDE para o art. 3 (2). O CAF-ONU deixa isso claro ao reproduzir os Comentários à CM-OCDE relacionados a esse dispositivo. Assim, enquanto aquela primeira versão da CM-ONU copiou a redação do art. 3 (2) da CM-OCDE em sua versão de 1977, a versão revisada da CM-ONU, de 1996, replicou as mudanças propostas pelo CAF-ONU em 1995, bem como os respectivos Comentários. Desde então, acompanhando a posição do CAFOCDE, o art. 3 (2) da CM-ONU não sofreu mais qualquer modificação.

\subsubsection{O art. 3 (2) da CM-EUA e os seus Comentários.}

Desde a sua primeira versão, a CM-EUA propõe a inclusão, no dispositivo sugerido no art. 3 (2) da CM-OCDE, da previsão para que as autoridades promovam acordos quanto ao sentido dos termos não definidos no tratado de dupla tributação, por meio do procedimento amigável previsto em seu art. 25. Note-se que o CAF-OCDE acompanha o entendimento do Tesouro norte-americano, quanto à possibilidade da instauração de procedimento amigável nesse caso, mas o explicita por meio de seus Comentários à CMOCDE.

A "Technical Explanation" que acompanha a CM-EUA ${ }^{270}$ sugere que, se o sentido de um termo não puder ser prontamente determinado a partir do sistema jurídico doméstico

${ }^{270}$ EUA. Technical Explanation to the 2006 EUA Model Income Tax Convention. (Disponível em www.ibfd.org). 
dos Estados contratantes, ou se conflitos de qualificação criarem dificuldades na aplicação da Convenção, as autoridades competentes devem instaurar um procedimento amigável para a interpretação autônoma de tal termo. É importante dar destaque a esse ponto: os Comentários à CM-EUA consignam que o objetivo de tal procedimento amigável é estabelecer um sentido contextualizado (“common meaning”) capaz de prevenir a dupla tributação ou, ainda, concretizar quaisquer outros objetivos e propósitos da convenção. Tal sentido contextualizado, por decorrer de interpretação autônoma, não precisaria ser coincidente com o sentido colhido do sistema jurídico doméstico de quaisquer dos Estados contratantes ("This common meaning need not conform to the meaning of the term under the laws of either Contracting State"). Sob tal perspectiva, a meta final do art. 3 (2) da CM-EUA seria promover a interpretação harmônica e o efeito útil do acordo de bitributação.

Em 1996, a fim de acompanhar a revisão proposta pelo CAF-OCDE em 1995, o art. 3 (2) da CM-EUA também foi revisto, acolhendo expressamente a cláusula de reenvio dinâmico (“ambulatory' definitions") ${ }^{271}$ ao Direito doméstico dos Estados contratantes. A CM-EUA foi revisada pela última vez em 2006 e, acompanhando também a posição do CAF-OCDE, não propôs mais qualquer alteração ao art. 3 (2).

\subsubsection{O art. 3 (2) em outros modelos de acordos de dupla tributação.}

A última versão da CM-Alemanha (2013) e da CM-Bélgica (2010) também replicam o enunciado do art. 3 (2) da CM-OCDE, na versão mantida desde a revisão em 1995.

A CM-Asiática adota a redação da CM-OCDE de 1963/77 para o seu art. 3 (2), enquanto que o CM-SADC replica a redação da CM-OCDE de 1995 para esse dispositivo. A CM-Comunidade Andina, de 1971, sem razão aparente, contudo, destoou dos demais modelos, prevendo o reenvio imediato ao Direito doméstico dos Estados contratantes para a interpretação dos termos não definidos, sem a previsão expressa para o recurso ao "contexto".

\footnotetext{
${ }^{271}$ EUA. Technical Explanation to the 2006 EUA Model Income Tax Convention. (Disponível em www.ibfd.org).
} 
A CM-ILADT, por sua vez, propõe que, após uma longa relação de definições de termos específicos, os Estados adotem as seguintes cláusulas:

"2. Cualquier término contenido en el Convenio deberá ser interpretado, a menos que del contexto se infiera una interpretación diferente, a la luz de las definiciones establecidas en el Convenio, así como de su objeto y propósito, de conformidad con las disposiciones de la Convención de Viena sobre el Derecho de los Tratados. La interpretación de acuerdo con la ley interna sólo será posible como un mecanismo suplementario de interpretación.

3. Todo término o expresión no definido en el Convenio, o cuyo significado no pueda ser reconstruido a la luz del mismo, tendrá, a menos que de su contexto se infiera una interpretación diferente, el significado que en ese momento le atribuya la legislación del Estado de la fuente relativa a los impuestos que son objeto del Convenio, prevaleciendo el significado atribuido por la legislación fiscal sobre el que resultaría de otras ramas del Derecho de ese Estado".

Conforme expressam os Comentários à CM-ILADT, o art. $4^{\circ}$ - equivalente ao art. 3 da CM-OCDE - está dividido em três parágrafos que conteriam, respectivamente: (i) uma lista de definições de termos utilizados em seu texto, bastante ampla; (ii) os critérios para a interpretação autônoma dos termos, de forma direta e indireta, e (iii) os limites para o recurso do reenvio ao Direito doméstico dos Estados contratantes. Essa fórmula estaria vocacionada a conduzir à interpretação autônoma dos termos utilizados na convenção baseada nos objetivos e propósitos desta, seja em relação aos diversos termos definidos ou aos não definidos, relegando-se a legislação tributária doméstica dos Estados contratantes ao posto de fonte sedundária ${ }^{272}$.

Não hesitam os Comentários à CM-ILADT que o reenvio ao Direito doméstico dos Estados contratantes deve ser sempre evitado, privilegiando-se a interpretação autônoma, de tal modo que mesmo os termos definidos expressamente no texto do acordo poderiam ter o seu sentido reconstruído pelo intérprete à luz de seus objetivos e propósitos. A referência expressa à CVDT evidenciaria a forma como a interpretação deve ser

${ }^{272}$ Cf. Comentário à CM-ILADT. Comentário n. 1 e 2 ao art. 4. (Modelo ILADT de Convenio Multilateral de Doble Imposición para América Latina, in Cuaderno Tributario ICDT, Agosto. Santiago de Compostela : ILADT, 2012. Último acesso em 31/10/2014, por meio do endereço eletrônico http://www.iladt.org/frontend/DocumentPage.aspx.) 
conduzida, bem como o reenvio ao Direito doméstico seria um elemento componente do contexto extrínseco secundário, isto é, sob o escopo do art. 32 da $\mathrm{CVDT}^{273}$.

Os Comentários à CM-ILADT indicam a preferência a "reconstrucción indirecta", com referência à construção do sentido dos termos do acordo a partir de seu "contexto". Tal posição seria expressa por seu art. 4 (3), equivalente ao art. 3 (2) da CM-OCDE em sua versão de 1995, com a significativa peculiaridade de expressamente consignar que, na hipótese de reenvio, então a solução dos conflitos de qualificação se daria em favor do Estado da fonte, "puesto que este criterio corresponde a los objetivos del Modelo ILADT, es más fácil en su aplicación y permite evitar conflictos hermenéuticos". A CM-ILADT não seguiu a CM-EUA, com a previsão da solução de conflitos de interpretação por meio de procedimentos amigáveis, preferindo a forma adotada pelo CAF-OCDE, que omitiu tal remissão no texto do art. 3 (2), trazendo a recomendação em seus Comentários ${ }^{274}$.

\subsubsection{As versões do "art. 3 (2)" adotadas nos acordos de dupla tributação celebrados pelo Brasil.}

No momento em que esta tese foi elaborada, o Brasil possuía 31 (trinta e uma) convenções fiscais celebradas e vigentes, abrangendo 32 (trinta e dois) parceiros internacionais. Note-se que, destas, o acordo que hoje rege tanto as relações com a República Tcheca quanto com a República Eslovaca foi celebrado entre o Brasil e a então República Federativa Tcheca e Eslovaca. Por sua vez, o acordo de dupla tributação BrasilAlemanha foi denunciado por aquele país.

Destes, vinte e um acordos de bitributação, celebrados com Alemanha (sem efeito), Áustria, Bélgica, Canadá, China, Coreia, Dinamarca, Espanha, Filipinas, Finlândia, França, Hungria, Índia, Itália, Japão, Luxemburgo, Noruega, Países Baixos, República Eslovaca, República Tcheca e Suécia adotaram o padrão do art. 3 (2) da CM-OCDE de 1963/77.

${ }^{273}$ Cf. Comentário à CM-ILADT. Comentários ao art. 4 n. 29 a 31. (Modelo ILADT de Convenio Multilateral de Doble Imposición para América Latina, in Cuaderno Tributario ICDT, Agosto. Santiago de Compostela : ILADT, 2012. Último acesso em 31/10/2014, por meio do endereço eletrônico http://www.iladt.org/frontend/DocumentPage.aspx.)

${ }^{274}$ Cf. Comentário à CM-ILADT. Comentários ao art. 4 n. 33 a 36. (Modelo ILADT de Convenio Multilateral de Doble Imposición para América Latina, in Cuaderno Tributario ICDT, Agosto. Santiago de Compostela : ILADT, 2012. Último acesso em 31/10/2014, por meio do endereço eletrônico http://www.iladt.org/frontend/DocumentPage.aspx.) 
Todos esses acordos, com exceção do acordo Brasil-Finlândia (1996), foram celebrados antes da revisão da CM-OCDE, em 1995. Neste último acordo, celebrado com a Finlândia, por exemplo, o dispositivo assumiu a seguinte redação:

"3 (2). Para a aplicação do presente Acordo por um dos Estados Contratantes, qualquer expressão que não se encontre nele definida terá o sentido que lhe é atribuido pela legislação desse Estado Contratante relativa aos impostos que são objeto do Acordo, a não ser que o contexto imponha uma interpretação diferente" ${ }^{275}$.

Nove acordos de dupla tributação celebrados pelo Brasil, com África do Sul, Chile, Israel, México, Peru, Portugal, Trinidad e Tobago, Turquia e Ucrânia, adotaram o padrão do art. 3 (2) da CM-OCDE de 1995. Note-se que o antigo acordo Brasil-Portugal, de $1971^{276}$, havia sido redigido conforme a CM-OCDE de 1963/77. Contudo, o novo acordo Brasil-Portugal, de 2001, passou a adotar o padrão mantido pela CM-OCDE desde 1995, como segue:

"3 (2). No que se refere à aplicação da Convenção, num dado momento, por um Estado Contratante, qualquer termo ou expressão que nela não se encontre definido terá, a não ser que o contexto exija interpretação diferente, o significado que lhe for atribuido nesse momento pela legislação desse Estado que regula os impostos a que a Convenção se aplica, prevalecendo a interpretação resultante desta legislação fiscal, na definição dos respectivos efeitos tributários, sobre a que decorra de outra legislação deste Estado".

A convenção fiscal celebrada com a Venezuela (2005), por sua vez, adotou cláusula semelhate à CM-OCDE de 1963/77, com a adição de parte do modelo de 1995 atinente à possibilidade expressa de reenvio à legislação privada.

Por fim, dois acordos celebrados pelo Brasil, com Argentina (1980) e Equador (1983), adotaram cláusula semelhante ao art. 3 (2) da CM-EUA, com a previsão para que a interpretação harmônica de seus termos seja construída a partir de procedimento amigável celebrado entre as autoridades administrativas. Neste último, por exemplo, o dispositivo assumiu a seguinte redação:

\footnotetext{
${ }^{275}$ BRASIL. Decreto n ${ }^{\circ} 4.012$, de 13 de novembro de 2001. Acordo de dupla tributação Brasil-Portugal.

${ }^{276}$ BRASIL. Decreto $n^{\circ}$ 69.393, de 21 de outubro de 1971. Acordo de dupla tributação Brasil-Portugal.
} 
"3 (2). Para a aplicação da presente Convenção por um Estado Contratante, qualquer expressão ou termo que se encontre de outro modo definido terá o significado que lhe é atribuído pela legislação desse Estado Contratante no que respeita aos impostos que são objeto da presente Convenção, a não ser que o contexto imponha uma interpretação diferente. Caso os sentidos resultantes sejam opostos ou antagônicos, as autoridades competentes dos Estados Contratantes estabelecerão, de comum acordo, a interpretação a ser dada".

Como se pode observar, as peculiaridades das três versões do art. 3 (2) dos acordos de dupla tributação se referem especialmente à hipótese de reenvio e não influenciam na claúsula do "contexto", que se encontra indistintamente presente em todas as convenções fiscais brasileiras. Dessa forma, para os propósitos desta tese, serão feitas referências ao "contexto" aplicáveis a todos os acordos de dupla tributação celebrados pelo Brasil, independentemente do modelo adotado.

O tópico "2" do "Apêndice 1", ao final do presente estudo, apresenta a relação comparativa de todos as versões do "art. 3 (2)" adotadas nos acordos de bitributação celebrados pelo Brasil. 


\section{CAPÍTULO I \\ CONTEXTO INTERPRETATIVO: SELEÇÃO E \\ UTILIZAÇÃO DE EVIDÊNCIAS QUANTO AO SENTIDO \\ DOS TERMOS DE ACORDOS DE BITRIBUTAÇÃO.}

\section{A DEFINIÇÃO E A AMPLITUDE DO “CONTEXTO” REFERIDO NO ART. 3 DA CM-OCDE.}

$£ 16,50$. No Caso Fothergill (Reino Unido, 1980), um prejuízo insignificante e corriqueiro do cliente de uma companhia aérea provocou a House of Lords a firmar um dos mais importantes precedentes do Reino Unido quanto a um fator determinante para a interpretação e aplicação de seus tratados internacionais (de dupla tributação, inclusive): a definição e a utilidade do "contexto" interpretativo. Para construir o sentido do termo "damage", o tribunal inglês recorreu a evidências como a comparação do termo no texto, comparação das versões nos idiomas, dicionários, doutrina, decisões de Cortes estrangeiras, trabalhos preparatórios, bem como propósitos e objetivos do acordo.

O Caso Fothergill nos ajuda a compreender que as demandas na aplicação de acordos internacionais muitas vezes surgem devido à pluralidade semântica de seus termos, ao que se podem somar as variações culturais de seus intérpretes. Diferentes contextos podem ensejar variados sentidos a partir de um mesmo signo. Tal como ocorre na linguagem cotidiana dos mais variados idiomas, um termo adotado no texto de um acordo internacional pode possuir acepções variadas, a depender do contexto em que estiver inserido. A partir de tal premissa, DunCAN B. HoLlis ${ }^{277}$ adota a expressão "high seas" para demonstrar que esta pode possuir uma série de sentidos no ambiente doméstico ou no Direito Internacional. Além disso, demonstra o autor que uma mesma mensagem decorrente da expressão "high seas" pode ser transmitida por diferentes formulações, com destaque às constitutivas, diferenciais e funcionais.

\footnotetext{
${ }^{277}$ HOLLIS, Duncan B. Defining treaties, in The Oxford Guide to Treaties (Ed. HOLLIS, Duncan B.). Oxford University Press : Oxford, 2012, p. 11-13.
} 
Os termos de um acordo internacional não devem ser compreendidos fora do contexto em que estão inseridos, sob pena de abandonar-se a sua adequada interpretação à sorte do intérprete. A razão de ser de um tratado celebrado por Estados soberanos não se resume naturalmente ao ato de assinatura de um texto. Acordos internacionais são celebrados para o estabelecimento de códigos de conduta a serem observados a partir de então, em situações que, em muitos casos, ensejariam medidas jurídicas domésticas diversas não fosse o acordo internacional.

Com o reconhecimento da pluralidade semântica dos termos dos acordos internacionais, surge a necessidade de que sejam identificados instrumentos capazes de individualizar os sentidos de um termo em seu "contexto", a fim de que possam ser formuladas definições adequadas a um caso concreto. A questão chave da presente tese consiste precisamente na identificação do "contexto" referido no art. 3 (2) da CM-OCDE, com a investigação do repertório de evidências a que o operador do Direito tributário internacional pode recorrer para a construção do sentido contextualizado de termos insertos em acordos de dupla tributação. O primeiro passo consiste na definição do “contexto"dos acordos de dupla tributação.

Nos subtópicos seguintes, serão analisadas seis teses que geralmente disputam a preferência da doutrina e dos Tribunais nacionais quanto à definição e amplitude do “contexto" referido no art. 3 (2) da CM-OCDE. Após essa revisão doutrinária, serão apresentadas concepções quanto à definição e amplitude do "contexto" que mais influenciam a análise desenvolvida nos Capítulos II, III e IV desta tese.

\subsection{Revisão doutrinária quanto à definição e amplitude do "contexto" dos acordos de dupla tributação referido no art. 3 (2) da CM-OCDE.}

A revisão doutrinária quanto à definição e amplitude do "contexto", referido no art. 3 (2) da CM-OCDE, pode ser organizada ao menos em cinco diferentes posturas, ora nomeadas como: (i) teoria do contexto exclusivamente intrínseco; (ii) teoria oficial do Comitê de Assuntos Fiscais nos Comentários à CM-OCDE; (iii) teoria da correlação do “contexto" com os Comentários da OCDE; (iv) teoria do contexto internacional amplo; (v) teoria da cumulação do "contexto" internacional e interno. 
Como se poderá observar, algumas dessas posições podem ser consideradas verdadeiras bandeiras hasteadas por acadêmicos. Outras, contudo, podem apenas ser identificadas de forma mais sutil. Dessa forma, não pretende tal classificação segregar os acadêmicos ou juízes citados como precursores das teorias em questão, posto que não se pode atribuir uma posição a quem não a assumiu expressamente. Após o "brainstorm” de teorias quanto ao "contexto" referido no art. 3 (2) da CM-OCDE, será apresentado o modelo ao qual a presente tese se manterá coerente para o desenvolvimento dos Capítulos II, III e IV.

\subsubsection{Teoria do contexto exclusivamente intrínseco.}

"In the most narrow sense, 'context' is the text immediatelly before and after the term, preferably in the same sentence". ROY ROHATGI $(2005)^{278}$

A teoria do contexto exclusivamente intrínseco sustenta que apenas evidências intrínsecas ao texto do acordo de dupla tributação estariam sob o escopo do "contexto": o seu texto, o conjunto de signos linguísticos que lhe são próximos, preâmbulo, anexos, qualquer acordo, instrumento relativo ao tratado e feito entre todas as partes em conexão com a sua conclusão.

Sob tal perspectiva, o art. 31 (2) da CVDT ditaria o sentido do "contexto" referido no art. 3 (2) da CM-OCDE, isolando-se de todas as demais evidências providas pelo parágrafo (3) desse dispositivo, bem como do art. 32 e 33 da CVDT. Pode-se observar que o critério da identidade do signo linguístico seria fundamental para sustentar tal teoria: o "contexto" referido no art. 3 (2) da CM-OCDE seria exclusivamente o "contexto" definido no art. 31 (2) da CVDT.

Caso se aceite tal concepção restritiva do "contexto", haveria consequências muito claras: se os elementos textuais referidos pelo art. 31 (2) da CVDT não fornecerem um sentido razoável, o Direito doméstico dos Estados contratantes deverá ser acessado imediatamente, cumprindo, de tal modo, aquilo que supostamente demandaria o art. 3 (2)

\footnotetext{
${ }^{278}$ ROHATGI, Roy. Basic International taxation. Volume 1: principles. Nova Deli : Taxmann, 2005, p. 49, nota de rodapé 132 .
} 
da CM-OCDE. Não haveria escolha diversa daquela proposta pelo Direito doméstico, já que todas as evidências extrínsecas sob o escopo do art. 31 (3) e do art. 32 da CVDT (como os trabalhos preparatórios) estariam excluídas do campo de visão do intérprete de um acordo internacional que tenha como objeto evitar a dupla tributação.

Nessa linha, FrANK ENGELEN ${ }^{279}$ sustenta que o "contexto" referido no art. 3 (2) da CM-OCDE compreenderia o texto do acordo como um todo, incluindo o seu preâmbulo e anexos, bem como o seu objeto e propósito, mas excluiria qualquer elemento extrínseco. Para aquele professor de Leiden, ao utilizar o termo "zinsverband" em muitos de seus acordos de dupla tributação, como substitutivo do idioma holandês ao termo inglês “context", diversos acordos celebrados pelos Países Baixos reforçariam a teoria do contexto exclusivamente intrínseco. Ocorre que "zinsverband" teria sentido bastante estrito no idioma holandês, compreendendo basicamente o texto do acordo, de forma a não contemplar, sequer materiais como acordos relativos ao tratado e estabelecidos entre todas as partes em conexão com a conclusão do tratado.

\subsubsection{Críticas à teoria do contexto exclusivamente intrínseco.}

Diversas críticas vêm sendo opostas a essa teoria ${ }^{280}$. O argumento da identidade do signo linguístico é, em si, bastante frágil, já que termos idênticos, presentes em acordos de dupla tributação podem, sob perspectivas teóricas e empíricas, possuir sentidos e propósitos diversos. É bastante esclarecedor o trabalho de KEES VAN RAAD ${ }^{281}$ quanto à pluralidade de sentido do termo "enterprise" presente em uma série de dispositivos da CMOCDE. Parece aceitável que o sentido do termo "contexto", contido em um acordo para evitar a dupla tributação da renda, também possa assumir sentido diverso do mesmo termo (“contexto") utilizado no texto da $\mathrm{CVDT}^{282}$.

${ }^{279}$ ENGELEN, Frank. Interpretation of Tax Treaties under International Law. Doctoral series n. 7. IBFD : Amsterdã, 2004.

${ }^{280}$ Vide, por exemplo: BAKER, Philip. Double taxation conventions and international tax law. Londres : Sweet \& Maxwell, 1994, par. C-20; SILVEIRA, Rodrigo Maitto da. Aplicação de Tratados Internacionais Contra a Bitributação - Qualificação de Partnership Joint Ventures. IBDT/Quartier Latin : São Paulo, 2006, p. 125;

${ }^{281}$ RAAD, Kees van. The term 'Enterprise' in the Model Double Taxation Conventions - Seventy Years of Confusion, in Intertax 1994/11, Intertax, 1994, p. 492-493.

${ }^{282}$ Nesse sentido: BRUGGEN, Edwin van der. Unless the Vienna Convention Otherwise Requires: notes on the relationship between Art. 3 (2) of the OECD Model Tax Convention and art. 31 and 32 of the Vienna Convention on the Law of Treaties, in European Taxation of May 2003. IBFD : Amsterdam, 2003, p. 144. 
O critério da identidade do signo linguístico também não se mantém por fatores históricos. A cláusula do "contexto", tal como presente hoje no art. 3 (2) da CM-OCDE, tem como ancestral o art. 2 (3) do acordo de dupla tributação Reino Unido-Estados Unidos de $1945 .{ }^{283}$ A publicação da primeira CM-OCDE, a qual já contava com a cláusula do “contexto" em seu art. 3 (2), se deu em $1963^{284}$, o que se seguiu com a intensificação do número de acordos de dupla tributação entre os Estados, em geral com a adoção de tal fórmula. Embora o dispositivo tenha passado por alterações no decorrer dos últimos quarenta anos, a cláusula que prevê a interpretação dos termos do acordo a partir de seu "contexto" ("unless the contexto otherwise requires") se manteve substancialmente inalterada.

Assim, é possível observar que a cláusula de interpretação conforme o "contexto" já era utilizada em acordos de dupla tributação décadas antes da conclusão do texto (1966), celebração (1969) e início de vigência (1980) da CVDT. Teria o art. 31 (2) da CVDT o propósito de comandar o sentido do termo "contexto" já útilizado décadas antes em acordos de dupla tributação? A resposta parece ser claramente negativa. ${ }^{285}$

Além da aludida cronologia indicar que tal cláusula especial presente na maioria dos acordos de bitributação não possui como inspiração a norma geral da CVDT, dois outros fatores conduzem à mesma conclusão.

Primeiro, não é possível identificar no texto da CVDT ou mesmo nos trabalhos preparatórios do art. 31 (2) qualquer menção ao propósito dos embaixadores membros da ILC-ONU para regular o sentido do termo "contexto" referido em acordos de dupla tributação que, naquele momento, já haviam sido ou que viriam a ser celebrados por

\footnotetext{
${ }^{283}$ Acordo de dupla tributação Reino Unido-EUA, de 16/04/1945 (sem efeito, atualmente), art. 2 (3): 'In the application of the provisions of the present Convention by one of the Contracting Parties any term not otherwise defined shall, unless the context otherwise requires, have the meaning which it has under the laws of that Contracting Party relating to the taxes which are the subject of the present Convention". (Último acesso em $01 / 11 / 2014, \quad$ no endereço elrônico http://online.ibfd.org/kbase/\#topic=doc\&url=/data/treaty/docs/html/tt_ukus 01_eng_1945_tt_td1.html\&WT.z_nav=Navigation\&colid=4932.) ${ }^{284}$ expor

${ }^{285}$ Considerando tal fator histórico decisivo para refutar a tese do contexto exclusivamente intrínseco: RAAD, Kees van. Interpretation and Application of Tax Treaties by Tax Courts, in European Taxation January 1996. IBFD : Amsterdã, 1996, p. 3.
} 
inúmeros dos Estados ali representados ${ }^{286}$. Segundo, não haveria evidências de que as Cortes nacionais tenham alterado a sua postura quanto ao "contexto" dos acordos de dupla tributação após a celebração da $\mathrm{CVDT}^{287}$.

As críticas à teoria do contexto exclusivamente intrínseco não necessariamente rejeitam que a CVDT seja aplicável à interpretação dos acordos de dupla tributação, pelo contrário. A CVDT exige que os acordos de dupla tributação sejam interpretados conforme a única e combinada operação de interpretação ("a closely integrated single rule of interpretation") referida nos trabalhos da ILC-ONU, pela qual o acesso às evidências intrínsecas e extrínsecas do acordo internacional tem igual valor, resguardada a possibilidade de recurso a evidências extrínsecas secundárias.

Nessa linha, MichAel EdWARDES-Ker ${ }^{288}$ suscita que nada indicaria que o termo “contexto" no art. 3 (2) da CM-OCDE tenha o sentido estrito definido no art. 31 (2) da CVDT, mas tudo levaria à conclusão oposta. Para o autor inglês, o art. 3 (2) da CM-OCDE faria referência ao contexto do acordo internacional em geral ("tax treaty's general context"), muito mais amplo que o disposto no art. 31 (2) da CVDT. Dessa forma, a adoção do "contexto" referido no art. 3 (2) em termos tão estritos como do art. 31 (2) da CVDT conduziria a resultados contrários à própria CVDT, que requer que os tratados sejam interpretados considerando evidencias intrínsecas (art. 31(2) da CVDT) e extrínsecas (art. 31(3) (4) e art. 32 da CVDT).

Embora a tese de FRANK ENGELEN ${ }^{289}$ possa ser - como de fato vem sendo considerada referência na sistematização das discussões da ILC-ONU quanto às cláusulas de interpretação prescritas na CVDT, o autor deixa de considerar fatores como os anteriormente expostos, considerados na presente tese como essenciais para a compreensão dos reflexos das normas gerais daquele acordo multilateral ao Direito tributário internacional .

${ }^{286}$ ONU. Yearbook of the International Law Commission. 1966. Records on the 866th meeting. vol. II. ONU, 1966.

${ }^{287}$ Nesse sentido: EDWARDES-KER, Michael. Tax Treaty Interpretation - The International Tax Treaties Service. In-Depth Publishing : Athlone, 1995, Capítulo 7, p. 7-8.

${ }^{288}$ EDWARDES-KER, Michael. Tax Treaty Interpretation - The International Tax Treaties Service. InDepth Publishing : Athlone, 1995, Capítulo 7, p. 6-8.

${ }^{289}$ ENGELEN, Frank. Interpretation of Tax Treaties under International Law. Doctoral series n. 7. IBFD : Amsterdã, 2004. 
Também pode ser colocado em dúvida o argumento sustentado por ENGELEN quanto à adoção do termo "zinsverband" em acordos de dupla tributação redigidos em holandês. Tomando-se como exemplo o acordo de dupla tributação Brasil-Bélgica ${ }^{290}$, que adota como idiomas oficiais as línguas holandesa, francesa e portuguesa, pode-se observar que o termo em questão ("zinsverband") tem como equivalente, na versão brasileira, o termo "contexto". Nesse caso, conforme prevê o art. 33 (1) e (3) da CVDT, ambos os idiomas têm igualmente fé e presume-se que os termos "zinsverband" e "contexto" têm o mesmo sentido.

De acordo com o art. 33 (4) da CVDT, quando a aplicação dos arts. 31 e 32 desse tratado multilateral não for capaz de eliminar diferenças entre os idiomas oficiais, adotarse-á o sentido que, tendo em conta o objeto e a finalidade do tratado, melhor conciliar os textos. Assim, mesmo em face do acordo de dupla tributação Brasil-Bélgica, a questão não poderia ser solucionada pela interpretação literal do termo "zinsverband" sugerida por Engelen. Tal como se dá ao partir-se do termo "contexto" (português), "context" (inglês) ou "contexte" (francês), mostra-se necessária investigação ampla, tal como se propõe nesta tese.

A questão se torna ainda mais curiosa em face do acordo de dupla tributação Espanha- Países Baixos, redigido em três idiomas oficiais. Em sua versão elaborada na língua inglesa, o art. 3 (2) se refere a "context", enquanto que as versões espanhola e holandesa se referem, respectivamente, a "texto" e "zinsverband". No entanto, em conformidade com o art. 33 (1) da CVDT, o acordo de dupla tributação Espanha-Países Baixos dispõe que, em caso de dúvidas, adotar-se-á a sua versão na língua inglesa ("context").

${ }^{290} \mathrm{O}$ art. 3 (2) do acordo Brasil-Belgica apresenta a seguinte redação, em seus dois idiomas oficiais: Holandês: 3(2). "Voor de toepassing van de Overeenkomst door een overeenkomstsluitende Staat heeft tenzij het zinsverband anders vereist, elke niet anders omschreven uitdrukking de betekenis welke die uitdrukking heeft volgens de wetten van die Staat met de betrekking tot de belastingen die het onderwerp van de Overeenkomst uitmaken". Português: "2. Para aplicação da Convenção por um Estado Contratante, qualquer expressões não definida de outro modo terá, a não ser que o contexto exija interpretação diferente, o significado que lhe é atribuido pela legislação desse Estado Contratante relativo aos impostos que são objeto da Convenção." (grifamos) 
Note-se que LUC DE BROE ${ }^{291}$ sugere tratar-se de mero erro de tradução do termo "contexto" ao idioma holandês, não sendo tal questão significativa para a aplicação do art. 3 (2) do acordo de dupla tributação; sequer as autoridades fiscais belgas adotariam interpretação tão estreita daquele termo, declarando expressamente a opção por uma acepção mais ampla.

\subsubsection{Teoria da posição oficial do CAF-OCDE quanto ao "contexto" referido no art. 3 da CM-OCDE.}

Em sua versão original, de $1977^{292}$, o parágrafo $8^{\circ}$ dos Comentários ao art. 3 da CM-OCDE quanto ao seu art. 3 (2) se limitavam a atribuir-lhe o status de regra geral de interpretação de termos utilizados na Convenção, mas não definidos por esta. Em 1995, os Comentários à $\mathrm{CM}_{-} \mathrm{OCDE}^{293}$ foram reformulados, passando a expressar que o reenvio dinâmico ao Direito doméstico - isto é, o recurso às normas domésticas existentes no momento da aplicação do acordo - seria a regra, a não ser quando o "contexto" requeresse uma interpretação alternativa.

O "contexto", aponta o CAF-OCDE, consistiria na intenção dos Estados contratantes com a celebração do acordo internacional e no sentido atribuído ao termo em questão no Direito doméstico dos Estados contratantes, como uma forma de referência implícita ao princípio da reciprocidade em que o acordo de dupla tributação se baseia. Essa é a posição assumida por ALBERTo XAVIER ${ }^{294}$.

O CAF-OCDE assume como posição, ainda, que o art. 3 (2) da CM-OCDE atribuiria às autoridades fiscais certa discricionariedade ou margem de manobra em sua aplicação.

\footnotetext{
${ }^{291}$ BROE, Luc De. International tax planning and prevention of abuse (doctoral series n. 14). Amsterdã : IBFD, 2007, p. 276, nota de rodapé 134 e 137. O autor faz referência ao entendimento expressado pelas autoridades fiscais belgas na "Circular Letter, 16 January 2004, No. AFZ/2004/0053, 11".

${ }^{292}$ Vide: Raad, Kees van. Materials on International, TP and EU Tax Law 2014-2015. Leiden : International Tax Centre Leiden, 2014.

${ }^{293}$ OECD, Model Tax Convention on Income and on Capital 2014 (Full Version), OECD Publishing, 2014, Comentário n. 12 ao art. 3.

${ }^{294}$ XAVIER, Alberto. Direito Tributário Internacional do Brasil. Rio de Janeiro: Forense, 2010, p. 139.
} 
Note-se que Roy RoHAtgi ${ }^{295}$ abstrai dos referidos Comentários ao art. 3 (2) da CM-OCDE que, diante das condições ali estabelecidas, os Estados não estariam autorizados a recorrer aos seus respectivos sistemas jurídicos domésticos sem uma prévia investigação quanto ao sentido do termo em questão no sistema jurídico do outro Estado contratante, o que se mostraria como uma salvaguarda ao permanente cumprimento da convenção com boa-fé. De outra forma, observa o autor indiano, mudanças no sistema jurídico interno de um dos Estados contratantes poderiam tornar o acordo bilateral inoperante.

\subsubsection{Críticas à posição oficial do CAF-OCDE quanto ao "contexto" referido no art. 3 da CM-OCDE.}

A análise crítica de tais Comentários à CM-OCDE não pode deixar de observar que, de uma extensa lista de fontes materiais do Direito tributário internacional capazes de prover sentido aos termos utilizados nos acordos de dupla tributação (contexto intrínseco e extrínseco), o CAF-OCDE há mais de duas décadas indica que o "contexto" referido no art. 3 (2) seria composto apenas por: (i) um elemento o qual a ILC-ONU considerou relevante na elaboração da CVDT, mas cuja subjetividade fez com que o seu acesso restasse dependente de outros elementos, tornando o seu poder de evidência apenas indireto (a intenção das partes) e; (ii) um outro elemento presente no contexto extrínseco, possivelmente relacionado às circunstâncias em que o acordo foi celebrado (Direito doméstico dos Estados contratantes). Não há qualquer referência a uma série de evidências intrínsecas e extrínsecas que poderiam ser úteis aos operadores do Direito tributário internacional.

É curioso notar que o CAF-OCDE sequer faz menção aos seus próprios Comentários entre as evidências quanto ao sentido dos termos utilizados nos acordos de dupla tributação. Tal posição, assumida nos Comentários ao art. 3 (2) da CM-OCDE, pode no entanto ser confrontada com outras manifestações do CAF-OCDE, como se poderá observar na análise exposta no Capítulo IV.

${ }^{295}$ ROHATGI, Roy. Basic International taxation. Volume 1: principles. Nova Deli : Taxmann, 2005, p. 50. 
Os Comentários ao art. 3 (2) da CM-OCDE são considerados pela literatura especializada $^{296}$, de forma quase generalizada, de pouca valia, já que em nada colaboram para a compreensão da própria norma de interpretação dos acordos de dupla tributação. Além disso, os Comentários à CM-OCDE ignoram abertamente questões fundamentais, vastamente levantadas pela doutrina e jurisprudência do Direito tributário internacional (como o recurso à CVDT), de modo tal que expõe o maior de seus pontos fracos: a ausência de consistente fundamentação.

\subsubsection{Teoria da correlação do "contexto" com os Comentários à CM-OCDE e demais materiais do CAF-OCDE.}

Como se expôs no subtópico anterior, o CAF-OCDE não se compromete, em seus Comentários ao art. 3 (2), com a posição de que as definições veiculadas em seus relatórios e Comentários componham o "contexto". No entanto, é muito comum que, diante de controvérsias em torno de termos presentes nos acordos de dupla tributação, os operadores do Direito tributário internacional busquem solucioná-las tomando como argumento justamente os Comentários à CM-OCDE.

Não é raro que Comentários à CM-OCDE sejam lançados como argumentos de autoridade, como se houvesse uma correlação do "contexto", referido no art. 3 (2), com os próprios Comentários à CM-OCDE. Não apenas consultores tributários utilizam tal material com frequência: além de juízes de diversas Cortes nacionais declaradamente recorrerem aos Comentários em suas decisões ${ }^{297}$, o mesmo também ocorre nas mais corriqueiras discussões do meio acadêmico, como se esses comentários fossem, em si, a norma a ser observada. É exatamente essa a constatação empírica exposta no capítulo de introdução aos Comentários à $\mathrm{CM}-\mathrm{OCDE}^{298}$, que não deixa de consignar a sua expectativa para que tal hábito se expanda e se consolide cada vez mais.

\footnotetext{
${ }^{296}$ Nesse sentido: BROE, Luc De. International tax planning and prevention of abuse (doctoral series n. 14). Amsterdã : IBFD, 2007, 274-275.

${ }^{297}$ ARNOLD, J. Brian. The interpretation of tax treaties: myth or reality, in Bulletin for international Taxation (tax treaty monitor) - january of 2010. IBFD : Amsterdã, 2010, p. 7-8.

${ }^{298}$ OECD. MODEL TAX CONVENTION (FULL VERSION), 2012, Introduction. 29.1-29.3.
} 
Assim, quando se lê algum Comentário à CM-OCDE no dia a dia e imediatamente se forma uma concepção de como aplicar o Direito tributário internacional, assume-se como adequada a teoria ora em análise. Conforme será analisado no Capítulo IV, há diversas teses que buscam conferir juridicidade aos Comentários à CM-OCDE, embora o argumento em que tal postura se sustenta pareça ser mais pragmático do que jurídico. Geralmente, assume-se que os negociadores dos acordos internacionais também teriam adotado tais Comentários como referência ao negociarem o texto posteriormente ratificado pelos Poderes Legislativos nacionais, o que afastaria dúvidas quanto à sua pertinência.

\subsubsection{Críticas à teoria da correlação do "contexto" com os Comentários à CM- OCDE e demais materiais do CAF-OCDE.}

Conforme será analisado com maiores detalhes no Capítulo IV, são severas as objeções à juridicidade dos Comentários à CM-OCDE. Se não está isenta de dúvidas a aceitação dos Comentários à CM-OCDE entre as evidências admissíveis para a construção de sentido dos termos insertos nos acordos de dupla tributação, assumir que tais materiais produzidos pelo CAF-OCDE exerçam com a exclusividade o papel de "contexto" é altamente questionável.

\subsubsection{Teoria do "contexto" internacional amplo.}

“Il termine 'contesto' dell'art. 3 paragrafo 2 del Modello OCSE pertanto include il co-testo, il contesto in senso stretto e il contesto in senso lato". CARLO GARBARINO (2005) $)^{299}$

Considerável número de proeminentes autores ${ }^{300}$ do Direito tributário internacional, bem como juízes de diferentes jurisdições, assume que o "contexto", tal como referido no

${ }^{299}$ GARBARINO, Carlo. Manuale di tassazione Internazionale. Milão : Kluwer, 2005, p. 182.

${ }^{300}$ Vide: BAKER, Philip. Double taxation conventions and international tax law. Londres : Sweet \& Maxwell, 1994, par. C-20; BROE, Luc De. International tax planning and prevention of abuse (doctoral series n. 14). Amsterdã : IBFD, 2007, 272-283; EDWARDES-KER, Michael. Tax Treaty Interpretation The International Tax Treaties Service. In-Depth Publishing : Athlone, 1994 p. 7, Capítulo 4; KATZ, Stanley I. United States National Report. Cahiers de Droit Fiscal International by the International Fiscal Association (studies on international tax law), volume LXXVIIIa - Subject I. Interpretation of double taxation conventions. Kluwer Law and Taxation Publishers / IFA : Rotterdam, 1993, p. 636; BRUGGEN, Edwin van der. Unless the Vienna Convention Otherwise Requires: notes on the relationship between Art. 3 (2) of the 
art. 3 (2) da CM-OCDE, seria amplo o suficiente para abarcar o contexto intrinseco, o contexto extrínseco primário e o contexto extrínseco secundário, relacionados nos artigos 31, 32 e 33 da CVDT. Tal postura é assumida, ainda, como forma de oposição à corrente do contexto exclusivamente intrínseco.

Geralmente, a amplitude do "contexto" sustentada por essa corrente não extravasa a CVDT, nem o limita a qualquer dos elementos dispostos nos diversos enunciados dos arts. 31 a 33 daquele tratado multilateral. Para o autor da passagem em epígrafe, não fosse assim a CM-OCDE o limitaria de um modo contrário à própria CVDT. Nessa linha, LuC DE BROE ${ }^{301}$ aponta que o termo "contexto" referido no art. 3 (2) da CM-OCDE não se presta aos mesmos propósitos do "contexto" aludido no art. 31 (2) da CVDT, bem como teriam dimensões bastante distintas: enquanto este se limitaria ao contexto intrínseco ("internal context"), aquele primeiro comportaria tanto o contexto intrínseco ("internal context") quanto o contexto extrínseco ("external context"). Mais ainda, destaca o professor de Leuven que internal context referido no art. 31 (2) da CVDT não estaria vocacionado a ser aplicado de forma isolada, mas em uma operação combinada que deve envolver todos os demais elementos indicados nos arts. 31, 32 e 33 daquele acordo multilateral.

Para PHILIP BAKER ${ }^{302}$, por "contexto" se entenderia tudo que se pudesse levar em consideração para a interpretação de um tratado internacional, desde que legitimado pela CVDT. Como as cláusulas do "contexto" e do reenvio seriam alternativas, o "contexto" compreenderia quaisquer evidências de que o sentido provido pelo Direito doméstico não seria consistente com o acordo de dupla tributação, bem como evidências que demonstrassem qual sentido, então, seria o mais adequado. Sob tal perspectiva, a norma especial de interpretação veiculada pelo art. 3 (2) da CM-OCDE estabeleceria duas fontes de sentidos distintas e bem definidas: o contexto e o Direito doméstico dos Estados contratantes. Note-se que este último não consta entre os elementos do art. 31 a 33 da CVDT, que propiciam o acesso às evidências intrínsecas e extrínsecas do contexto internacional.

OECD Model Tax Convention and art. 31 and 32 of the Vienna Convention on the Law of Treaties, in European Taxation of May 2003. IBFD : Amsterdam, 2003, p. 147.

${ }^{301}$ BROE, Luc De. International tax planning and prevention of abuse (doctoral series n. 14). Amsterdã : IBFD, 2007, p. 273-274; 295.

${ }^{302}$ BAKER, Philip. Double taxation conventions and international tax law. Londres : Sweet \& Maxwell, 1994, par. C-20 e C-21. 
Note-se que, para Klaus VogeL ${ }^{303}$, o termo "contexto", referido no art. 3 (2) da CM-OCDE, deveria ser interpretado da forma mais ampla possível. A posição do professor alemão estaria apoiada basicamente em três argumentos: (i) a definição do art. 31 (2) da CVDT não teria qualquer influência na delimitação do termo "contexto" utilizado na CMOCDE; (ii) o argumento de que a restrição do "contexto" protegeria a soberania dos Estados contratantes não se manteria, já que haveria evidências de que o recurso ao Direito doméstico pode gerar a dupla não tributação (o que não seria, de forma alguma, vantajoso às soberanias) e; (iii) a análise histórica do dispositivo da CM-OCDE, que remonta ao Direito inglês, demonstraria o caráter amplo do dispositivo. Para VoGEL, o contexto seria tão amplo a ponto de incluir as relevantes previsões do Direito doméstico de ambos os Estados contratantes e, ainda, no caso de Estados membros da OCDE, a CM-OCDE e os seus respectivos Comentários, existentes quando da celebração do acordo.

Como se verá adiante, tal teoria admite ainda subdivisões, caso se atribua preferência aos sentidos providos pelo Direito doméstico ou àqueles construídos a partir do “contexto". Por essa segunda perspectiva, o reenvio ao Direito doméstico dos Estados contratantes para a colheita de evidências quanto ao sentido de termos não definidos no acordo de dupla tributação seria admissível caso as evidências intrínsecas e extrínsecas do contexto internacional não se mostrassem capazes de fornecer o sentido contextualizado requerido pela única e combinada operação de interpretação da CVDT. Caso se compreenda que o Direito doméstico tenha precedência nessa operação, as evidências do "contexto" apenas seriam acessadas caso aquele falhasse em fornecer sentido aos termos da convenção internacional.

\subsubsection{Críticas à teoria do "contexto" internacional amplo: os riscos da interpretação liberal.}

As críticas que se podem opor à teoria do contexto amplo se referem mais à sua deturpação que a ela própria. Decisões de Cortes nacionais ou mesmo trabalhos acadêmicos por vezes proclamam adesão a tal teoria, mas não lhe atribuem consequências

${ }^{303}$ VOGEL, Klaus. Klaus Vogel on Double Taxation Conventions. Kluwer : London, 1999, p. 214-215. 
efetivas no processo decisório ou, ainda, descaracterizam as normas da CVDT que dizem observar, com o extravasamento a uma interpretação liberal, extensiva ou mesmo analógica.

Como ensinou RUY BARBOSA NoGUEIRA ${ }^{304}$, a interpretação extensiva se dá quando a "situação de fato" se mostra clara, mas o pressuposto para a aplicação da norma jurídica se apresenta obscuro ou incompleto, agindo o intérprete de forma a iluminá-la para alcançar tais situações fáticas. "O intérprete procura fazer o texto alcançar a situação de fato; ele demontra que um caso que não parece estar incluído na norma, nem a está compreendido". A aplicação analógica, distinguiu o catedrático, se daria quando a "situação de direito" se mostrar clara, mas a situação de fato não se identifica formalmente aos pressupostos de aplicação da norma, embora seja análoga à descrição normativa; embora o caso não esteja compreendido no quadro da lei, a norma lhe seria aplicada por tratar-se de situação análoga.

Também observa RICARDO LODI RIBEIRO ${ }^{305}$, que diz-se “restritiva” a interpretação quando o intérprete, por concluir que o legislador disse mais do que teria pretendido, restringe a amplitude do texto justamente para traduzir a real intenção do legislador. A interpretação extensiva, por sua vez, partiria do pressuposto que o legislador teria utilizado signos de linguagem que expressariam menos do que se pretendia, cabendo ao intérprete estender a aplicação da lei a casos que, embora não pudessem ser abstraídos das palavras do texto, se adequassem à intenção do legislador.

Conforme GERD W. ROTHMANN ${ }^{306}$, pela interpretação declaratória, o intérprete simplesmente declararia o sentido léxico próprio aos termos interpretados, sob o escopo, então, de sua literalidade; pela interpretação restritiva, agindo de forma contra legem, o intérprete ficaria aquém do referido sentido lexical e; pela interpretação extensiva, para cumprir com o objetivo e finalidade da norma, o intérprete também agiria contra legem, a fim de ampliar as hipóteses que o texto em si permitiria. Contra a adoção dessa interpretação extensiva (ou liberal), parece suficiente o argumento da soberania, pelo qual

\footnotetext{
${ }^{304}$ NOGUEIRA, Ruy Barbosa. Curso de Direito Tributário. São Paulo, Saraiva, 1995, p. 100-101.

${ }^{305}$ RIBEIRO, Ricardo Lodi. Justiça, Interpretação e Elisão Tributária. Rio de Janeiro: Editora Lumen Juris, 2003, p. 96-97.

${ }^{306}$ ROTHMANN, Gerd W. Interpretação e aplicação dos acordos internacionais contra a bitributação. Tese de doutorado. São Paulo : Faculdade de Direito da Universidade de São Paulo (USP), 1978, p. 114 e seg.
} 
determinado Estado apenas se vincula no Direito Internacional até o ponto que tenha consentido $^{307}$.

Como se pode observar, diversas razões convergem para que sejam recusadas as interpretações extensivas, restritivas ou analógicas no Direito tributário internacional, pois tanto o esvaziamento quanto o extravasamento dos lindes da CVDT por um Estado contratante seriam danosos à relação internacional estabelecida entre os dois Estados. Por adotar a premissa de que o "contexto" referido no art. 3 (2) da CM-OCDE é tão amplo quanto são amplos os lindes das normas de interpretação da CVDT, a teoria em análise tem como pilar a eficácia técnica, jurídica e social desse acordo multilateral. Por premissa, então, a chamada interpretação liberal (ou extensiva) não seria admissível.

A referida interpretação extensiva (ou liberal), contra legem, foi repudiada pela ILC-ONU na elaboração da CVDT. Na ILC-ONU de $1966^{308}$, consignou-se que a máxima 'ut res magis valeat quam pereat' deveria ser observada na aplicação da CVDT, o que, de forma apropriada, não deveria culminar em interpretações "extensivas" ou "liberais", assim compreendidas aquelas que vão além do que está explícito ou mesmo implícito no texto do acordo internacional.

Nesse seguir, como critério de coerência, a teoria do contexto internacional amplo deve buscar promover a efetividade do acordo de dupla tributação celebrado entre os Estados, recusando posturas restritivas ou extensivas que conduzam a sentidos estranhos ao que os Estados harmonicamente obteriam.

Embora os tribunais de alguns Estados consignem adotar a "interpretação liberal" em relação às convenções fiscais, não fica totalmente claro quais os critérios seriam utilizados para a seleção de evidências sob o escopo do art. 3 (2) da CM-OCDE. A fundamentação débil quanto à interpretação liberal assumida por tais decisões as tornam pouco úteis para a análise da questão.

\footnotetext{
${ }^{307}$ ARNOLD, J. Brian. The interpretation of tax treaties: myth or reality, in Bulletin for international Taxation (tax treaty monitor) - january of 2010. IBFD : Amsterdã, 2010, p. 10-11.

${ }^{308}$ ONU. Yearbook of the International Law Commission. 1966. Records on the 866th meeting. ONU, 1966, p. $173 \mathrm{e}$ seg.
} 
É importante notar, contudo, que nem sempre a declaração do julgador quanto à adoção de uma "interpretação liberal" conduz àquela postura combatida pela ILC-ONU. Ocorre que sistemas jurídicos que se declaram adeptos de uma interpretação literal da legislação tributária podem considerar as normas de interpretação da CVDT mais liberais que aquelas adotadas internamente e, assim, consignar a interpretação liberal dos acordos internacionais.

\subsection{Exemplo: A “interpretação liberal” dos tribunais australianos.}

"Third, the mandatory requirement that courts look to the context, object and purpose of treaty provisions as well as the text is consistent with the general principle that international instruments should be interpreted in a more liberal manner than would be adopted if the court was required to construe exclusively domestic legislation".

Caso Lamesa (Austrália, 1997)

O Caso Lamesa (Austrália, 1997) demonstra qual diretriz é considera nos tribunais australianos como a mais adequada para a aplicação as convenções fiscais. Assim, diante do acordo de bitributação Austrália-Países Baixos, seria necessário recorrer a métodos de interpretação mais liberais do que seriam exigidos dos juízes na aplicação de normas exclusivamente domésticas.

É curioso observar a posição intermediária sustentada pelo julgador em relação à questão. Conforme o seu entendimento, embora acordos de bitributação devessem ser interpretados de modo mais liberal que as normas tributárias puramente domésticas, deveria ser menos ampla que a interpretação de outras espécies de acordos internacionais, como a Convenção de Refugiados das Nações Unidas. Ocorre que as convenções fiscais possuiriam peculiaridades que não estariam presentes em outras espécies, como tornar-se parte do Direito doméstico para interagir com a legislação nacional e, ainda, serem negociadas e celebradas por meio de um processo procedimento técnico de alto nível.

Essa posição intermediária, contudo, não foi de fato aplicada ao caso. Ocorre que o tribunal reconheceu que já seria tarde para se discutir a questão, já que a Suprema Corte canadense, no Caso Thiel, já teria estabelecido a regra vinculante de que os acordos de bitributação deveriam ser interpretados tal como quaisquer outros tratados internacionais. 
No Caso McDermott (Austrália, 2005), o tribunal australiano também julgou que o acordo de bitributação Austrália-Singapura deveria ser interpretado de forma liberal ("liberally"), pois convenções fiscais não seriam elaboradas de modo tão preciso quanto a legislação doméstica.

Embora a decisão tenha se autoconsiderado "liberal", não parece se afastar da única e combinada operação de interpretação requerida pela CVDT. Para a solução do caso, os juízes australianos consideraram necessário o exame do texto, do contexto, bem como dos objetivos e propósitos do acordo de bitributação. Isso porque, caso fosse necessário abandonar o sentido lexical (“natural meaning”) dos termos do art. 4 (3) do acordo Austrália-Singapura, tal construção deveria ser empreendida a partir de tais elementos, adotando-se o "contexto" em sua acepção ampla.

\subsection{Exemplo: A “interpretação liberal” dos tribunais canadenses.}

"Contrary to an ordinary taxing statute a tax treaty or convention must be given a liberal interpretation with a view of implementing the true intentions of the parties. A literal or legalistic interpretation must be avoided when the basic object of the treaty might be defeated or frustrated in so far as the particular item under consideration is concerned". Juiz ADDY. Caso Gladden (1985)

No Caso Gladden (Canadá, 1985), o tribunal canadense precisou construir o sentido dos termos "sale or exchange", adotados no art. 8 do acordo Canadá-EUA (1942), mas não definidos neste. O dispositivo, equivalente ao art. 13 da CM-OCDE, cuidava da tributação sobre ganhos de capital. O tribunal consignou ser necessário adotar uma interpretação liberal para a interpretação das convenções fiscais, o que não se daria em relação à legislação tributária doméstica.

No Caso Pacific Network (Canadá, 2002), o tribunal canadense novamente consignou que acordos de dupla tributação demandariam interpretação liberal e não literal. A decisão, contudo, também não parece divergir da única e combinada operação de interpretação requerida pela CVDT ou mesmo ser contra legem. A decisão considerou evidências intrínsecas e extrínsecas.

Os julgadores canadenses consideraram que o contexto intrínseco não seria suficiente para prover um sentido plausível, conduzindo a conclusões contraditórias, 
enquanto que o contexto extrínseco primário seria menos convincente que o contexto extrínseco secundário, fundamentando, então, porque se apoiariam basicamente nas evidências levantadas a partir deste último.

Bem compreendida, a decisão do Caso Pacific Network não parece merecer as críticas cabíveis às interpretações liberais propriamente ditas, mas sim ter assumido a teoria do contexto amplo, perfeitamente suportada pela CVDT e, como se viu anteriormente, pelo art. 3 (2) da CM-OCDE.

\subsubsection{Teoria da cumulação dos "contextos" internacional e nacional.}

"The 'ordinary meaning of a treaty term is determined by application of Article 3 (2) of the OECD Model".

KEES VAN RAAD (1994) ${ }^{309}$

Por essa teoria, às evidências acolhidas pela teoria do contexto internacional amplo deveriam ser somadas outras mais, provenientes do Direito doméstico dos Estados contratantes. Sob essa perspectiva, considera-se que o intérprete real está livre em sua atividade cognitiva e, como tal, certamente acessaria ao menos o seu sistema jurídico doméstico à procura de sentidos para os termos não definidos em um acordo de dupla tributação.

Como forma de justificar essa postura, argumentar-se-ia que o "contexto" em que o operador do Direito tributário internacional está imerso para a colheita de elementos que o auxiliem na composição do sentido de termos insertos em acordos de dupla tributação não está limitado pela CVDT. Assim, seria necessário aceitar que o intérprete age em um estado de arte, especialmente por conta da ineficácia técnica de qualquer norma jurídica para a tutela da interpretação humana.

Nesse sentido, Hugh AulT ${ }^{310}$ observou que a estrita delimitação do contexto e as condições restritivas para o acesso a meios suplementares de interpretação tornariam a CVDT inapropriada para a plena aplicação dos acordos de dupla tributação, já que todos os

${ }^{309}$ RAAD, Kees van. The term 'Enterprise' in the Model Double Taxation Conventions - Seventy Years of Confusion, in Intertax 1994/11, Intertax, 1994, p. 492-493.

${ }^{310}$ AULT, Hugh. The role of the OECD Commentaries in the Interpretation of Tax Treaties, in Intertax v. 22. Kluwer Law International : 1994, p. 145-146. 
materiais que se mostrem úteis para a sua interpretação devem ser considerados pelo intérprete. Não se pode deixar de observar, contudo, que o autor deixa expresso que tais considerações não afastam o fato de que a CVDT é juridicamente aplicável aos acordos de dupla tributação e, portanto, deve ser observada.

\subsubsection{Críticas à teoria da cumulação dos "contextos" internacional e nacional.}

Tal como todas as demais teorias, também essa pode estar sujeita a objeções, algumas delas bastante convincentes. Afinal, se o recurso ao Direito doméstico é autorizado pelo art. 3 (2) da CM-OCDE a não ser que o "contexto" requeira outra fonte, pode ser contraditório que o próprio Direito doméstico faça parte de tal "contexto".

Outra questão que tal teoria deve enfrentar se refere à aceitação das dinâmicas alterações a que a legislação doméstica está sujeita, o que poderia conduzir a modificações unilaterais no conteúdo do acordo internacional. Há um exemplo ilustrativo no Direito brasileiro: o art. $26, \S 1^{\circ}$, da Lei n. 12.249/2010, que trouxe uma definição aos termos “beneficiário efetivo". Toda a série de acordos de dupla tributação celebrados pelo Brasil passariam a ser necessariamente influenciada por essa definição veiculada pela novel norma doméstica? ${ }^{311}$

\section{A ORDEM DE PRECEDÊNCIA ENTRE O "CONTEXTO" E O REENVIO AO DIREITO DOMÉSTICO.}

Assim como a definição de "contexto", a ordem de precedência entre as duas alternativas previstas no art. 3 (2) da CM-OCDE - o "contexto" e o reenvio ao Direito doméstico - é questão em debate na doutrina do Direito tributário internacional.

O ponto decisivo é saber se, havendo um sentido construído a partir de evidências do "contexto" e outro a partir do Direito doméstico, qual deve prevalecer e, assim, ter precedência nesse processo de interpretação. A postura assumida pelo intérprete pode ser

${ }^{311}$ Em sentido positivo, vide: ROCHA, Sergio André. Interpretação dos tratados para evitar a dupla tributação. São Paulo : Quartier Latin, 2013, p. 83. 
determinante: se a precedência for do Direito doméstico, somente quando este não se mostrar capaz de prover sentidos aos termos dos acordos de bitributação é que seria pertinente investigar se o "contexto" poderia fazê-lo. Nesse cenário, a relevância do "contexto" restaria reduzida a situações residuais.

Alguns outros assuntos do Direito tributário internacioanal se aproximam da análise empreendida nesse tópico, mas com ela não se confundem. Inicialmente, é necessário esclarecer que o núcleo desta discussão não reside na questão de "como o Direito tributário internacional dirige o conhecimento do intérprete durante o processo de aplicação do acordo de dupla tributação". O foco da discussão não é esse, ao menos por duas razões: $i$ ) crê-se que não seria possível controlar o exercício cognitivo do intérprete ou desconsiderar inflluências culturais, predileções individuais e características investigativas de cada expert; $i$ i) ainda que se assuma que seja possível tal controle, disso não decorreria uma solução conclusiva, pois esse não é necessariamente o ponto decisivo da questão. ${ }^{312}$

Também são distintos temas como da ordem de aplicação das normas do acordo de dupla tributação e das normas tributárias domésticas em sentido estrito (ou seja, aquelas que preveem a incidência do tributo) ${ }^{313}$. Essa clássica questão está relacionada à verificação, no texto do acordo de dupla tributação, de qual regra de distribuição de competência e de alívio da dupla tributação seria aplicável ao caso concreto e, no Direito doméstico, se haveria em tese o exercício de tributação sobre a situação em análise e, em caso positivo, qual o ônus tributário ali imposto. Se o intérprete iniciar a sua análise pelo Direito doméstico de um determinado Estado e constatar que determinadas receitas não são tributadas, sequer precisaria visitar o texto do acordo de dupla tributação; mas no caso de tributação doméstica, deverá consultar se há limitação pelo acordo de dupla tributação e, caso encontre limites, deverá observá-los. Por sua vez, se o intérprete iniciar a sua análise pelo acordo de dupla tributação, poderá evidenciar que um dos Estados contratantes concordou em isentar certos rendimentos, dispensando, assim, a análise se o seu respectivo Direito doméstico os tributa ou não; se a este Estado competir limitada ou ilimitadamente

${ }^{312}$ EDWARDES-KER, Michael. Tax Treaty Interpretation - The International Tax Treaties Service. InDepth Publishing : Athlone, 1996, p. 11, Capítulo 7.

${ }^{313}$ A respeito desse tema, vide: TIPKE, Klaus; LANG, Joachim. Direito tributário (Steuerrecht). Volume 1. Tradução da 18a edição alemã, totalmente refeita, de Luíz Dória Furquim. Porto Alegre : Sergio Antonio Fabris Editor, 2008, p. 108.; VOGEL, Klaus. Klaus Vogel on Double Taxation Conventions. Kluwer : London, 1999, p. 31. 
tais rendimentos, restará verificar a tributação doméstica, para aplicar o seu ônus limitada ou ilimitadamente. Note-se que essa discussão não questiona se o Direito doméstico supera o Direito tributário internacional ou vice versa: a premissa da análise é que o acordo de dupla tributação será respeitado, limitando ou não a legislação doméstica, em quaisquer das ordens de precedência adotadas.

Essa discussão - que se considera encerrada no meio acadêmico pela constatação de que ambos conduzem ao mesmo resultado - trata de momento distinto e que não interessa diretamente ao tema em análise nesta tese. A questão discutida nesta tese, portanto, não se refere necessariamente à ordem de análise a ser considerada pelo intérprete para a aferição do ônus tributário incidente sobre o contribuinte.

Por fim, vale ressaltar que, como esta tese se volta ao "contexto" referido no art. 3 (2) da CM-OCDE, não estão em questão as hipóteses de que o acordo de dupla tributação expressa ou implicitamente ${ }^{314}$ faz remissão a sentidos contidos no sistema jurídico de um dos Estados contratantes. Em tais casos a norma do art. 3 (2) da CM-OCDE não é aplicável, tendo em vista que os próprios Estados contratantes livremente acordaram como exclusiva solução o reenvio ao Direito doméstico de um deles, o qual já conteria anteriores formulações quanto à sua definição. ${ }^{315}$

Assim, a análise exposta nesse tópico se volta a um aspecto bastante objetivo do processo de interpretação: aos termos não definidos de acordos de bitributação devem ser atribuídos os sentidos providos preferencialmente pelo "contexto" ou pelo Direito doméstico?

Os trabalhos acadêmicos e decisões de Cortes nacionais analisados sobre esse tema podem ser organizados em três grandes grupos, aqui nomeados como: (i) teoria da precedência do Direito doméstico; (ii) teoria de precedência do "contexto" e; (iii) teoria comparativa entre Direito doméstico e "contexto" (ou mista).

\footnotetext{
${ }^{314}$ Sobre tal possibilidade, vide: VOGEL, Klaus. Klaus Vogel on Double Taxation Conventions. Kluwer : London, 1999, p. 42.

${ }^{315}$ Sobre tal questão, vide: KATZ, Stanley I. United States National Report. Cahiers de Droit Fiscal International by the International Fiscal Association (studies on international tax law), volume LXXVIIIa Subject I. Interpretation of double taxation conventions. Kluwer Law and Taxation Publishers / IFA : Rotterdam, 1993, p. 625.
} 


\subsection{A corrente da precedência do Direito doméstico em face do "contexto".}

Sob a teoria da precedência do Direito doméstico, qualquer termo não definido no texto do acordo de dupla tributação deveria ter o seu o sentido construído diretamente a partir do Direito doméstico dos Estados contratantes, salvo situações excepcionalíssimas, em que o "contexto" exigisse algum sentido diverso. É ilustrativa a citação de MICHAEL EDWARDES-KER ${ }^{316}$, oponente dessa linha, segundo quem alguns materiais de treinamento nos EUA $^{317}$ chegariam a orientar que tais termos deveriam ser compreendidos imediatamente conforme a legislação norte-americana, sem fazer sequer referência ao "contexto".

Tal postura é adotada, ainda que implicitamente, por considerável parte da doutrina $^{318}$ e em decisões de Cortes nacionais ${ }^{319}$. Os argumentos que a acompanham são variados, como: (i) praticabilidade, já que seria mais simples ao operador investigar o seu sistema jurídico interno do que o repertório de evidências do "contexto" internacional" (ii) o termo "unless" evidenciaria que o reenvio ao Direito doméstico é regra geral, de forma que o recurso ao "contexto" seria a exceção ${ }^{321}$; (iii) também o termo "requires" teria forte influência na norma do art. 3 (2) da CM-OCDE, tornando o Direito doméstico a regra geral e o "contexto" a exceção ${ }^{322}$; (iv) o art. 3 (2) da CM-OCDE teria a função de resguardar a soberania dos Estados mesmo em face de suas obrigações contratadas no acordo de dupla tributação ${ }^{323}$; (v) o acordo de dupla tributação não teria sido negociado em

\footnotetext{
${ }^{316}$ EDWARDES-KER, Michael. Tax Treaty Interpretation - The International Tax Treaties Service. InDepth Publishing : Athlone, 1995, p. 3-4, Capítulo 1.

317 A referência é feita ao "International Issues for International Examiners", v. 01.

${ }^{318}$ Vide, em especial: BROE, Luc De. International tax planning and prevention of abuse (doctoral series n. 14). Amsterdã : IBFD, 2007, 277.

${ }^{319}$ Sobre tal tendência no jurisprudência norte-americana, vide: KATZ, Stanley I. United States National Report. Cahiers de Droit Fiscal International by the International Fiscal Association (studies on international tax law), volume LXXVIIIa - Subject I. Interpretation of double taxation conventions. Kluwer Law and Taxation Publishers / IFA : Rotterdam, 1993, p. 643.

${ }^{320}$ Nesse sentido: ARNOLD, J. Brian. The interpretation of tax treaties: myth or reality, in Bulletin for international Taxation (tax treaty monitor) - january of 2010. IBFD : Amsterdã, 2010, p. 13 e seg..

${ }^{321}$ Nesse sentido, vide: BROE, Luc De. International tax planning and prevention of abuse (doctoral series $\mathrm{n}$. 14). Amsterdã : IBFD, 2007, p. 277.

${ }^{322}$ Nesse sentido, vide: WIJNEN, Wim. Some Thoughts on Convergence and Tax Treaty Interpretation, in Tax Treaty Monitor - Bulletin for International Taxation (November 2013). IBFD: Amsterdã, 2013, p. 576577; BROE, Luc De. International tax planning and prevention of abuse (doctoral series n. 14). Amsterdã : IBFD, 2007, p. 277;

${ }^{323}$ Cf. VOGEL, Klaus. Klaus Vogel on Double Taxation Conventions. Kluwer : London, 1999, p. 208.
} 
um vácuo jurídico, mas tendo como referencial os sistemas jurídicos domésticos ${ }^{324}$; (vi) a adoção de termos no texto do acordo de dupla tributação com similares nacionais conduziria à adoção de tal sentido provido pelo sistema jurídico interno ${ }^{325}$; (vii) o acordo de dupla tributação, por ser aplicado em ambiente doméstico, deveria ser interpretado tal como as demais normas existentes nesse sistema ${ }^{326}$ e; (viii) haveria uma expectativa a priori muito baixa de que o "contexto" pudesse ser realmente útil na construção de sentido dos termos adotados nos acordos de dupla tributação, tornando a sua análise geralmente superficial e pouco produtiva.

A tese de Frank EngELEN ${ }^{327}$ defende a precedência do Direito doméstico e argumenta que o mero fato de que tal postura possa conduzir a interpretações divergentes dos Estados contratantes, tendo em vista as inerentes peculiaridades de cada um desses sistemas, não teria qualquer relevância. Em especial, seria determinante àquele autor que os acordos de dupla tributação não seriam celebrados em vácuos jurídicos, mas tendo como pano de fundo o Direito doméstico de cada um dos Estados contratantes, nos quais supostamente os negociadores teriam se pautado para a escolha dos termos utilizados na minuta do acordo celebrado.

É possível observar que tal postura muitas vezes redunda na consideração do art. 3 (2) da CM-OCDE em uma norma apenas de reenvio ao Direito doméstico. Isso se dá, por exemplo, quando o operador constata que não há termo correspondente à convenção na legislação interna dos Estados contratantes e daí conclui, então, pela impossibilidade completa de aplicação do art. 3 (2).

Também é importante notar que o reenvio ao Direito doméstico em diversas oportunidades pode se mostrar infrutífero, tendo em vista a inexistência de termos similares na legislação nacional. Assim, por exemplo, a expressão presente no art. 4 da CM-OCDE, "sede de direção" ("place of effective management"), não possui similar no

\footnotetext{
${ }^{324}$ Nesse sentido: ENGELEN, Frank. Interpretation of Tax Treaties under International Law. Doctoral series n. 7. IBFD : Amsterdã, 2004, p. 149 e seg.

${ }^{325}$ Nesse sentido: ARNOLD, J. Brian. The interpretation of tax treaties: myth or reality, in Bulletin for international Taxation (tax treaty monitor) - january of 2010. IBFD : Amsterdã, 2010, p. 13.

${ }^{326}$ Nesse sentido: GOTHENBURG, K. Ahlm. National Report of Sweden. Cahiers de Droit Fiscal International by the International Fiscal Association (studies on international tax law), volume XLII Subject II: The interpretation of the Double Taxation Convention. / IFA : Roterdã, 1960, p. 261.

${ }^{327}$ Cf. F. ENGELEN, Frank. Interpretation of Tax Treaties under International Law. Doctoral series n. 7. IBFD : Amsterdã, 2004, p. 149 e seg.
} 
sistema jurídico brasileiro, adotada como critério de residência à incorporação da pessoa jurídica no Brasil, conforme sua legislação. ${ }^{328}$

Note-se ainda que, por assumir a teoria da precedência do Direito doméstico, LUC DE BROE $^{329}$ aponta que caberia à parte que alega a pertinência dos sentidos providos pelo "contexto" o ônus da prova quanto à necessidade de se afastar dos sentidos providos pela legislação interna dos Estados contratantes.

Na jurisprudência das Cortes nacionais, não é raro encontrar decisões sem qualquer sinal de efetivo esforço na análise do contexto, com o reenvio imediato ao Direito doméstico dos Estados contratantes. Assim, no Caso Squirrell (Reino Unido, 2005), na qualidade de julgador, AVERY JONES foi bastante sintético em suas justificativas ao recurso exclusivo ao Direito inglês ("I cannot think of any reason why the context might otherwise require”).

A teoria da precedência do Direito doméstico, no entanto, está sujeita a uma série de críticas e questionamentos bastante coerentes, os quais serão analisados com a sua antítese (a teoria da precedência do contexto), no subtópico seguinte.

\subsubsection{Exemplo: o caso brasileiro da construção de sentido de "lucro da empresa" (“business profit”) do art. 7 da CM-OCDE conforme o Direito doméstico.}

Os argumentos suscitados por ARNOLD ${ }^{330}$, na defesa da teoria da precedência do Direito doméstico, trazem a triste lembrança da interpretação do fisco brasileiro mantida por mais de uma década quanto aos termos "business profit" ("lucro da empresa"), contidos no art. $7^{\circ}$ dos acordos de dupla tributação.

\footnotetext{
${ }^{328}$ Cf. SCHOUERI, Luís Eduardo; SILVA, Natalie Matos. Brazil, in The Impact of the OECD and UN Model Conventions on Bilateral Tax Treaties. (Editores: LANG, Michael; PISTONE, Pasquale; SCHUCH, Josef; STARINGER, Claus). Cambridge : Cambridge University Press, 2012, p. 174-175.

${ }^{329} \mathrm{BROE}$, Luc De. International tax planning and prevention of abuse (doctoral series n. 14). Amsterdã : IBFD, 2007, 277.

${ }^{330}$ ENGELEN, Frank. Interpretation of Tax Treaties under International Law. Doctoral series n. 7. IBFD : Amsterdã, 2004, p. 149-150.
} 
No Caso Copesul (Brasil, 2012), a administração fiscal brasileira sustentou que deveria ser observado o Ato Declaratório COSIT n. 1/2000, conforme o qual as remessas decorrentes de contratos de prestação de assistência técnica e de serviços técnicos sem transferência de tecnologia não estariam compreendidos no sentido do termo "lucros das empresas", adotados no art. 7 dos acordos de dupla tributação celebrados pelo Brasil, mas sim no art. 21 ("Rendimentos não Expressamente Mencionados"), sujeitando-se à tributação na fonte. Ocorre que, diferente da CM-OCDE, os acordos celebrados pelo Brasil tradicionalmente permitem que o Estado da fonte tribute os rendimentos sob o escopo do art. 21 .

No Parecer PGFN/CAT n. 776/2011, elaborado para ser apresentado ao STJ como memorial para o julgamento deste caso, compreendeu-se que, para a interpretação dos termos do art. $7^{\circ}$ "lucros da empresa", seria inevitável e necessário o reenvio ao conceito de "lucro" na legislação brasileira. Tal definição dependeria "assim, única $e$ exclusivamente do conceito de lucro dentro da legislação pátria"

O Tribunal Regional Federal da $4^{\text {a }}$ Região ("TRF-4") compreendeu que "é, portanto, pela aplicação do direito interno que devemos analisar a natureza daqueles valores remetidos". Não discordou aquele tribunal, portanto, quanto a pertinência do reenvio ao Direito doméstico, sustentada pelo fisco brasileiro. No entanto, as autoridades administrativas estariam equivocadas quanto a qual norma do Direito doméstico deveria ser considerada para a interpretação dos termos "lucro da empresa". No caso, o reenvio deveria ser realizado aos arts. 11 e 12 do Decreto-lei n. 1.598/77, que cuidam do "lucro operacional", calculado a partir da receita bruta da venda de bens e da prestação de serviços, e não ao art. $6^{\circ}$, que tutela o "lucro real", o "lucro líquido do exercício".

Ao julgar o caso, o STJ acompanhou a decisão decisão do TRF-4, afastando a interpretação do fisco brasileiro, sob os mesmos fundamentos do tribunal a quo. Preocupou-se o Ministro CASTRO MEIRA em consignar que a sua decisão não "desborda da legislação brasileira que consagra, expressamente, diversas modalidades de 'lucro'”, o que demonstra a sua preocupação em não afastar-se do reenvio ao Direito brasileiro para a interpretação das convenções fiscais. 
É importante observar que não há referências nas decisões do TRF-4 e do STJ às normas da CVDT ou, ainda, ao art. 3 (2) da CM-OCDE, presente em ambas as convenções fiscais envolvidas no caso.

Após a conclusão do julgamento pelo o STJ, foi emitido o Parecer PGFN/CAT n. 2363/2013, a partir do qual a administração fiscal brasileira finalmente passou a considerar que os que remessas decorrentes de contratos de prestação de assistência técnica e de serviços técnicos sem transferência de tecnologia estariam sujeitos à tributação apenas no Estado de residência de seus beneficiários, por força do art. 7 dos acordos de bitributação celebrados pelo Brasil.

O Parecer PGFN/CAT n. 2363/2013 relata que a reversão da posição da administração fiscal brasileira também estaria motivada em ofício do Ministério das Finanças da Finlândia, sobre a intenção daquele Estado em denunciar o acordo BrasilFinlandia caso fosse mantida a interpretação aduzida no Ato Declaratório COSIT n. $1 / 2000$.

Nesse cenário, o Caso Copesul demonstra como pode ser desastroso o recurso indiscriminado ao Direito doméstico dos Estados para a interpretação de termos das convenções fiscais, o que deve ser reprimido pelas Cortes nacionais.

\subsubsection{Exemplo: o caso brasileiro da construção de sentido do termo "dividendos" ("dividends") do art. 10 da CM-OCDE conforme o Direito doméstico.}

No Caso BBA (Brasil, 2006), o CARF precisou analisar se lucros não distribuídos estariam compreendidos no conceito de "lucro da empresa", sob o escopo do art. 7 do acordo Brasil-Portugal, ou no conceito de "dividendos" referidos pelo art. 10 dessa convenção.

Em seu voto, a julgadora SANDra MARIA FARONI acolhe a doutrina de AlbERTO XAVIER e reconhece que, no Direito tributário internacional, o termo "dividendos" seria mais amplo que no Direito doméstico brasileiro, de forma a abranger não apenas os lucros distribuídos por sociedades anônimas, mas também por sociedades em comandita por 
ações e por sociedades por quotas de responsabilidade limitada. O termo "dividendos" referidos no art. 10 do acordo Brasil-Portugal, que seguiu o padrão da CM-OCDE, teria então o sentido de "rendimentos oriundos de uma participação societária nos lucros de sociedades de capitais", bem como que "lucros pagos são dividendos, e se regem pelo artigo X".

A questão, então, seria definir o sentido de "lucros pagos". Como tais termos não foram definidos no texto do acordo Brasil-Portugal, compreendeu a julgadora que seria necessário observar a norma de seu art. 3 (2). Contudo, sem qualquer fundamentação quanto ao que poderia se colher do "contexto", compreendeu-se que o art. 3 (2) da convenção fiscal justificaria o reenvio ao Direito interno brasileiro, no qual "consideram-se pagos os lucros empregados por controlada/coligada no exterior em favor do investidor brasileiro beneficiário".

Concluiu-se, então, que os rendimentos em questão estariam compreendidos no escopo do art. 10 do acordo Brasil-Portugal (e não no art. 7, como sustentou o contribuinte), de forma a ser legítima a sua tributação no Brasil.

Ainda que se pudesse chegar à mesma conclusão a partir de evidências colhidas a partir do "contexto", é importante notar que nenhum questionamento em relação a isso foi realizado, o que fragiliza a decisão.

\subsubsection{Exemplo: o caso espanhol da construção de sentido de "royalty" do art. 12 da CM-OCDE conforme o Direito doméstico.}

No Caso Barcelona (Espanha, 2013), para a interpretação do termo “cánones” (“royalties") referido no art. 12 do acordo Espanha-Países Baixos, o tribunal espanhol adotou expressamente a teoria da precedência do Direito doméstico em face do "contexto", ignorando por completo quaisquer evidências providas por esse último.

Em julgado anterior, o Tribunal espanhol havia decidido que os pagamentos de direitos de imagem realizados pelo Fútbol Club Barcelona não se sujeitariam à retenção de imposto de renda, pois não estariam sob o escopo do termo "cánones" ("royalties"). 
Diante de tal decisão, a empresa Orotava Rocky Stone Media, residente nos Países Baixos, requereu ao Governo espanhol a restituição de impostos anteriormente retidos pelo Barcelona entre os anos de 2004 e 2007, em razão do pagamento de direitos de imagem relacionados a diversos jogadores. No entanto, o Tribunal espanhol rejeitou tal pedido de restituição sob o fundamento de que, desde a Ley 46/2002, que reformulou parcialmente a legislação do imposto sobre a renda na Espanha, o conceito de "cánones" ("royalties”) teria sido alterado.

O art. 3 (2) do acordo de dupla tributação Espanha-Países Baixos representaria, conforme a fundamentação apresentada pelo juiz FRANCISCO JOSE NAVARRO SANCHIS, um chamado para que o sistema jurídico espanhol estabelecesse o conceito de "cánones" (“royalties"). A Ley 46/2002, por sua vez, deveria ser compreendida como a interpretação autêntica do legislador espanhol e "integrada" ao art. 12 do acordo Espanha-Países Baixos, o qual deveria "interpretarse rectamente conforme a las definiciones legales contenidas en la legislación interna del Estado contratante (art. 3.2 del Convenio)”.

O exemplo espanhol também parece demonstrar quão perigosa pode ser a adoção da corrente da precedência do reenvio ao Direito doméstico em relação ao "contexto".

\subsubsection{Exemplo: o caso canadense de interpretação das convenções fiscais conforme o seu Direito doméstico.}

No Caso Beame (Canadá, 2004), um indivíduo residente na Irlanda (e não residente no Canadá) alienou ações que detinha em uma empresa canadense. Sob a perspectiva interna, o Direito canadense tributaria "taxable capital gain", que equivaleria a $3 / 4$ dos ganhos de capital efetivamente obtido pelo contribuinte.

Por sua vez, o art. 6(1) do antigo acordo Canadá-Irlanda (1966), que não possui equivalente na CM-OCDE, dispôs que: "[t] he rate of Canadian tax on income (other than income from carrying on business in Canada or from performing duties in Canada) derived from sources within Canada by a resident of Ireland shall not exceed 15 per cent". 
Foi, então, necessário ao tribunal canadense interpretar o termo "income", que não se encontrava definido naquela convenção, à qual continha cláusula semelhante ao art. 3 (2) da CM-OCDE. Para o físco canadense, o termo deveria ser interpretado de forma a incluir todo o ganho de capital auferido pelo contribuinte, não sendo equiparável aos “taxable capital gains" previstos na legislação doméstica.

No entanto, para o juiz MALONE e os seus pares, como haveria no Direito canadense norma pela qual aos termos não definidos no acordo internacional devem atribuídos de forma dinâmica os sentidos existentes no Income Tax Act, o termo "income", presente no art. 6(1) do antigo acordo Canadá-Irlanda, teria o sentido de "taxable capital gains". Assim, apenas $3 / 4$ dos ganhos de capital obtidos pelo contribuinte seriam tributados, adotando-se, ainda, a alíquota reduzida de $15 \%$ estabelecida pela convenção fiscal.

2.1.5. Exemplo: a consideração do art. 3 (2) como norma puramente de reenvio ao Direito doméstico.

No caso Caso Thiel (Austrália, 1990), foi consignado pelo juiz DAWSON que o art. 3 (2) do acordo de bitributação Austrália-Suíça (equivalente ao art. 3 (2) da CM-OCDE) não seria aplicável para a interpretação do termo "enterprise", especialmente por não haver uma definição específica para este no sistema jurídico australiano. Seria, então, necessário interpretar o termo a partir de evidências intrínsecas e extrínsecas à convenção em questão.

Tal afirmação do juiz DAWSON demonstra a concepção de que o art. 3 (2) seria uma norma exclusivamente de reenvio ao Direito doméstico dos Estados contratantes, sem a consideração que tal dispositivo prevê também o recurso ao "contexto", o qual compreende justamente evidências intrínsecas e extrínsecas ao texto referidas no voto daquele julgador.

\subsubsection{Exemplo: a interpretação dos termos "beneficial owner" nos acordos de bitributação.}

A interpretação dos termos "beneficial owner" nos ilustra outro exemplo de como a norma do art. 3 (2) da CM-OCDE pode vir a ser aplicada como uma norma puramente de 
reenvio ao Direito doméstico, que seria aplicável apenas nas hipóteses em que o legislação doméstica dos Estados contratantes pudessem contribuir para a construção de sentido de termos não definidos no tratado.

Nesse seguir, JoÃo Francisco BIANCO \& RAQUEL NEWTON ${ }^{331}$ questionam se o art. 3 (2) seria ou não aplicável para a interpretação dos termos "beneficial owner", em vista de posições doutrinárias que suscitariam a sua inaplicabilidade, pela inexistência de correspondente no Direito doméstico dos Estados contratantes. Os autores concluem pela aplicabilidade do dispositivo, evidenciando a existência de institutos semelhantes em países do common law e, tal como no caso do Brasil, do civil law.

No common law, observam BIANCO \& NEWTON ${ }^{332}$ que a expressão seria utilizada com sentido mais amplo que no âmbito dos acordos de bitributação, para excluir do conceito de beneficiário efeitivo: (i) aqueles que detêm a propriedade de um bem em nome de terceiros, como agentes, administradores e trustess; (ii) aqueles que têm a prerrogativa de se tornar beneficiários efetivos, mas que ainda não a exerceram, como detentores de opções de compra; (iii) aqueles que detêm direitos sobre um ativo, mas não tão relevantes quanto os detidos por terceiros, como locatários. Em especial, o sentido de "beneficial owner" adotado no common law norte-americano melhor se adequaria aos objetivos dos acordos de bitributação que aquele utilizado no Direito inglês. Na Inglaterra, tal expressão seria geralmente utilizada sob uma perspectiva mais formal, como distinção ao direito de propriedade, de forma que apenas esse último poderia ser considerado um direito real. Já no common law norte-americano, mais influenciado pela teoria da substância sobre a forma, a caracterização da "beneficial ownership" dependeria de fatores fáticos e não necessariamente formais, como o poder de utilizar o bem livremente, a fruição dos benefícios deles decorrentes e a assunção de seus riscos imanentes.

Em relação aos sistemas do civil law, BIANCO \& NEWTON ${ }^{333}$ observam que países como França e Holanda não possuem em suas codificações instituto semelhante ao beneficial owner, restringindo-se a tratar da propriedade legal e à possibilidade de

\footnotetext{
${ }^{331}$ BIANCO, João Francisco. NEWTON, Raquel. Beneficiário efetivo, in Revista Direito Tributário Atual n. 26. São Paulo : IBDT/Dialética, 2011, p. 258.

${ }^{332}$ BIANCO, João Francisco. NEWTON, Raquel. Beneficiário efetivo, in Revista Direito Tributário Atual n. 26. São Paulo : IBDT/Dialética, 2011, p. 258-264.

${ }^{333}$ BIANCO, João Francisco. NEWTON, Raquel. Beneficiário efetivo, in Revista Direito Tributário Atual n. 26. São Paulo : IBDT/Dialética, 2011, p. 258-264.
} 
transferência do direito de uso dos frutos a terceiros mediante contrato, seus tribunais podem admitir a distinção diante de situações fáticas específicas, em que a "direitos econômicos" se mostrem relevantes.

No Brasil, embora o Direito civil jamais tenha contemplado tal conceito, recentemente a legislação tributária passou a contemplá-lo no art. $26, \S 1^{\circ}$, da Lei n. 12.249/2010. Sob a perspectiva de que o art. 3 (2) da CM-OCDE conduz à interpretação dos termos "beneficiário efetivo" conforme o Direito doméstico dos Estados contratantes, os autores concluem seu estudo com a análise da acepção provida pelo Direito brasileiro ${ }^{334}$ a esse termo.

De modo semelhante, também SERGIO ANDRÉ RochA ${ }^{335}$ concluiu que o art. 26, $\S 1^{\circ}$, da Lei n. 12.249/2010 “deve ser considerado para fins de determinação do conceito de beneficiário efetivo para fins domésticos e de aplicação dos tratados internacionais brasileiros".

\subsection{A teoria da precedência do "contexto" face ao Direito doméstico.}

"It would be suficiente to recall the fundamental principle of international law that international law prevails over domestic law." ICJ. Applicability of the Obligationto Arbitrate under Section 21 of the United Nations Headquarters Agreement of 26 June 1947, Advisory Opinion. (1988)

O “princípio fundamental do Direito Internacional”, referido em epígrafe, aduz que evidências quanto ao sentido dos termos dos tratados sejam colhidas a priori do "contexto" e não pelo reenvio ao Direito doméstico. Tal regra há tempos é afirmada nas decisões da CIJ e de sua antecessora, a PICJ ${ }^{336}$.

Sob essa mesma perspectiva, o "contexto" referido no art. 3 (2) da CM-OCDE teria preferência sobre o Direito doméstico dos Estados contratantes na interpretação de termos não definidos no texto do acordo de dupla tributação. Apenas seria possível o acesso ao

\footnotetext{
${ }^{334}$ BIANCO, João Francisco. NEWTON, Raquel. Beneficiário efetivo, in Revista Direito Tributário Atual n. 26. São Paulo : IBDT/Dialética, 2011, p. 265-270.

${ }^{335}$ ROCHA, Sergio André. Interpretação dos tratados para evitar a dupla tributação. São Paulo : Quartier Latin, 2013, p. 83 .

${ }^{336}$ Vide, por exemplo: PICJ. Exchange of Greek and Turkish Populations,1923, p. 18-21.
} 
Direito doméstico dos Estados contratantes se um sentido contextualizado não pudesse ser construído de forma razoável a partir de evidências do "contexto".

Um número considerável de autores brasileiros ${ }^{337}$ e estrangeiros ${ }^{338}$ adere a essa linha de pensamento, em que o reenvio ao Direito doméstico se torna subsidiário. MiCHAEL LANG ${ }^{339}$ sustenta não haver razões para que os termos de um acordo de bitributação não possam ter o seu sentido construído diretamente a partir de seu "contexto". A posição do professor de Viena decorre também da constatação de que a origem dos termos das convenções fiscais não está, em geral, relacionada com a legislação interna dos Estados contratantes, posto que esses termos são originários do Direito tributário internacional.

A primazia das evidências colhidas no Direito Internacional em relação aos sentidos providos pelos sistemas domésticos encontra respaldo em uma série de argumentos, especialmente: (i) no Direito Internacional público, a regra geral é que não haja reenvio ao Direito doméstico dos Estados contratantes, o que é evidenciado pela ausência de qualquer menção ao Direito doméstico dos Estados contratantes nos arts. 31 a 33 da CVDT, que estabelecem a busca por um sentido contextualizado ${ }^{340}$; (ii) o princípio da boa-fé e pacta sunt servanda, que impedem que qualquer dos Estados contratantes deixe de cumprir uma obrigação acordada sob justificativas de seu Direito doméstico (CVDT, art. 27) 341 ; (iii) a modificação do Direito doméstico de um Estado contratante faria com que este alterasse unilateralmente o próprio acordo de dupla tributação e, tratando-se de um acordo internacional, não se poderia abandonar os princípios que regem o Direito

\footnotetext{
${ }^{337}$ Vide, por exemplo: XAVIER, Alberto. Direito Tributário Internacional do Brasil. Rio de Janeiro: Forense, 2010, p. 138-139; ROCHA, Sergio André. Interpretação dos tratados para evitar a dupla tributação. São Paulo : Quartier Latin, 2013, p. 194-195; TÔRRES, Heleno Taveira. Pluritributação internacional sobre as rendas das empresas. São Paulo : Revista dos Tribunais, 2001, p. 640-644; SILVEIRA, Rodrigo Maitto da. Aplicação de Tratados Internacionais Contra a Bitributação - Qualificação de Partnership Joint Ventures. IBDT/Quartier Latin : São Paulo, 2006, p. 122-124.

${ }^{338}$ Vide, por exemplo: LANG, Michael. Introduction to the law of double taxation conventions. Vienna : Linde, 2013, p. 41-64; HOFBAUER, Ines. Tax treaty interpretation in Austria, in Tax treaty interpretation. LANG, Michael (ed). LINDE : Vienna, 2001; ROHATGI, Roy. Basic International taxation. Volume 1: principles. Nova Deli : Taxmann, 2005, p. 50; EDWARDES-KER, Michael. Tax Treaty Interpretation - The International Tax Treaties Service. In-Depth Publishing : Athlone, 1996, p. 8-11, Capítulo 7.

${ }^{339}$ LANG, Michael. The application of the OECD Model Tax Convention to Partnerships - A critical Analysis of the Report Prepared by the OECD Committee on Fiscal Affairs. Viena : Linde, 2000, p. 23-24.

${ }^{340} \mathrm{Cf}$. ONU. Yearbook of the International Law Commission. Documents of the fourteenth session including the report of the Commission to the General Assembly. ONU, 1962; ONU. Yearbook of the International Law Commission. 1966. Records on the 866th meeting. ONU, 1966, p. 173 e seg.

${ }^{341}$ Cf. EDWARDES-KER, Michael. Tax Treaty Interpretation - The International Tax Treaties Service. InDepth Publishing : Athlone, 1994, p. 1, Capítulo 5.
} 
Internacional ("principles governing the interpretation of the law of nations") e que devem ser aplicados com precedência a quaisquer outros quando o texto não estiver claro ${ }^{342}$; (iv) alguns dos mais importantes propósitos e objetivos dos acordos de dupla tributação, como reciprocidade, coordenação e cooperação, apenas seriam devidamente cumpridos com a interpretação prioritária a partir do $\operatorname{contexto}^{343}$; (v) a adoção do sentido doméstico dos Estados contratantes para termos não definidos no acordo fiscal fragiliza o seu propósito de evitar a dupla tributação e objetivos dos sentidos providos pelo "contexto"344; (vi) nem todos os problemas podem ser solucionados pelo reenvio imediato ao Direito doméstico, pois este não possui a resposta para todos eles, de tal modo que ignorar as possibilidades semânticas providas pelo contexto seria um grande erro ${ }^{345}$.

Note-se que a assertiva de FRANK ENGELEN ${ }^{346}$, de que os acordos de dupla tributação não são celebrados em um vácuo jurídico, é incontestável; para tudo há um contexto. Os desdobramentos e conclusões obtidas por esse professor, no entanto, se enfraquecem por não considerarem o próprio Direito Internacional como contexto em que um acordo de dupla tributação é celebrado. De fato, os defensores da teoria da precedência do Direito doméstico precisam justificar, a partir da redação do art. 3 (2) da CM-OCDE, a desconsideração de todo o repertório de evidências ${ }^{347}$, sob o escopo do “contexto" referido em tal dispositivo.

Conforme a definição da CVDT $^{348}$ quanto aos "tratados" para os quais suas normas se destinam, “'tratado' significa um acordo internacional concluído por escrito entre Estados e regido pelo Direito Internacional”. A aceitação de que os acordos de bitributação estão sob o escopo da CVDT importa no reconhecimento consistente de que estes são governados pelo Direito Internacional e devem observar as suas regras. Vindo

${ }^{342}$ Cf. LENZ, Raoul. General Report. Cahiers de Droit Fiscal International by the International Fiscal Association (studies on international tax law), volume XLII - Subject II: The interpretation of the Double Taxation Convention. / IFA : Roterdã, 1960, p. 296.

${ }^{343}$ Cf. BRUGGEN, Edwin van der. Unless the Vienna Convention Otherwise Requires: notes on the relationship between Art. 3 (2) of the OECD Model Tax Convention and art. 31 and 32 of the Vienna Convention on the Law of Treaties, in European Taxation of May 2003. IBFD : Amsterdam, 2003, p. 149.

${ }^{344}$ Cf. BRUNSCHOT, Frank van. The Judiciary and the OECD Model Tax Convention and its Commentaries, in Bulletin - Tax Treaty Monitor of January 2005. IBFD, 2005, p. 8-9.

${ }^{345}$ Cf. LENZ, Raoul. General Report. Cahiers de Droit Fiscal International by the International Fiscal Association (studies on international tax law), volume XLII - Subject II: The interpretation of the Double Taxation Convention. / IFA : Roterdã, 1960, p. 296.

${ }^{346}$ ENGELEN, Frank. Interpretation of Tax Treaties under International Law. Doctoral series n. 7. IBFD : Amsterdam, 2004, p. 149-150.

${ }^{347}$ Vide Capítulos II, III e IV desta tese.

${ }^{348}$ CVDT, art. 2, (1), “a”. 
logo após a cláusula pacta sunt servanda (art. 26), o art. 27 da CVDT prescreve que "uma parte não pode invocar as disposições de seu direito interno para justificar o inadimplemento de um tratado". Além disso, o art. 46 (1) da CVDT também afasta a possibilidade do Estado de invocar a sua legislação doméstica como argumento para rejeitar obrigações assumidas por um acordo internacional, estabelecendo como única ressalva o caso de tal violação ser manifesta diante de "uma norma de seu direito interno de importância fundamental”. A violação em questão é considerada manifesta - prescreve o art. 46 (2) da CVDT - "se for objetivamente evidente para qualquer Estado que proceda, na matéria, de conformidade com a prática normal e de boa fé". 349

A questão quanto à relevância do Direito doméstico na interpretação e aplicação dos acordos internacionais é solucionada pela CVDT, assim, com a regra geral da relevância apenas do Direito interno de importância fundamental e manifesta. A regra de reenvio sugerida no art. 3 (2) da CM-OCDE é uma exceção.

A fragmentação do Direito Internacional permite que seus segmentos estabeleçam exceções, especialmente quando o recurso ao Direito doméstico for a solução mais indicada para dar eficácia às peculiaridades técnicas dos assuntos envolvidos, a exemplo das hipóteses expressas de reenvio previstas na CM-OCDE expostas anteriormente. Ainda que haja uma norma geral no Direito Internacional público que, a priori, recuse o reenvio ao Direito doméstico, a fonte formal representada pelo consenso dos Estados contratantes faz com que esta seja superada por essa norma especial do Direito tributário internacional. No entanto, a ausência de evidências intrínsecas quanto ao consenso entre os Estados contratantes para que uma regra de exceção seja adotada conduz à aplicação da regra geral de não reenvio a priori.

Tais fatores são relevantes. Se a regra geral do Direito Internacional (público) não for alterada pelo art. 3 (2) da CM-OCDE, no Direito tributário internacional o sentido comum deve ser construído a partir de evidências do "contexto" e não do Direito doméstico dos Estados contratantes. Parece ser realmente isso o que ocorre.

\footnotetext{
${ }^{349}$ Vide, por exemplo: Certain Questions of Mutual Assistance in Criminal Matters (Djibouti v. France), p. 124.
} 
Essa conclusão é reforçada pelos relatórios da ILC-ONU, quando apontam que, diante de duas interpretações igualmente possíveis, deve prevalecer a que melhor promova o efeito útil do acordo internacional. Ocorre que as particularidades inerentes aos variados sistemas tributários domésticos frequentemente conduziam a interpretações divergentes e, portanto, contrárias aos propósitos e objetivos - caso cada um dos Estados contratantes procedesse o reenvio pela lex fori.

A teoria da precedência do contexto internacional não coloca necessariamente em dúvida se tais acordos foram celebrados tendo como pano de fundo o sistema jurídico de cada um dos Estados contratantes. O texto da CM-OCDE traz referências e remissões expressas e implícitas ao Direito doméstico de um dos Estados contratantes em diversos de seus enunciados. Como os acordos de bitributação serão aplicados sobre o Direito doméstico dos Estados contratantes, naturalmente pode haver referências a este, o que não afasta o fato de que tais convenções pertencem ao Direito tributário internacional e, como regra geral, são interpretadas por seu "contexto".

Assim, como observa RoY RoHATGI ${ }^{350}$, ao adotar-se a teoria ora em análise, o recurso ao Direito doméstico para a construção de sentido dos termos dos acordos de dupla tributação seria possível, mas apenas: (i) se houver remissão expressa da convenção ao sistema jurídico interno dos Estados contratantes; (ii) em situações em que o "contexto" convincentemente conduzir ao Direito doméstico ou, ainda; (iii) se nenhum sentido razoável puder ser construído a partir do "contexto".

\subsection{A teoria mista ou comparativa (Direito doméstico vs. "contexto").}

Nas duas teorias anteriores, ou haveria o reenvio imediato ao Direito doméstico, independentemente da aptidão do "contexto" para o fornecimento de evidências quanto ao sentido dos termos adotados no acordo de bitributação (teoria de precedência do Direito doméstico), ou o Direito doméstico não seria acessado até que o "contexto" internacional se mostrasse de fato ineficiente para fornecer sentido a esses termos (teoria de precedência do "contexto"). Sob a teoria mista (ou comparativa), por sua vez, o operador de um acordo de dupla tributação deveria selecionar, entre os sentidos providos por fontes do

${ }^{350}$ ROHATGI, Roy. Basic International taxation. Volume 1: principles. Nova Deli : Taxmann, 2005, p. 49. 
“contexto" e do Direito doméstico, o sentido que conduza à aplicação mais razoável do acordo de dupla tributação ${ }^{351}$.

Por aceitar-se como premissa que o "contexto" seria capaz de prover sentidos razoáveis aos termos não definidos em um acordo de dupla tributação, na mesma medida em que o Direito doméstico de um dos Estados contratantes também poderia fazê-lo, o intérprete estaria compelido a investigar francamente os elementos disponíveis em ambos, ao mesmo tempo. Assim, a fórmula do art. 3 (2) da CM-OCDE suscitaria, para KEES VAN $\mathrm{RAAD}^{352}$, a comparação entre sentidos construídos em dois ambientes diversos, quais sejam, no Direito doméstico dos Estados contratantes e no contexto do acordo internacional.

Um dos argumentos de base da teoria da precedência do Direito doméstico e da teoria comparativa é que os acordos de dupla tributação são aplicados sobre a legislação interna dos Estados contratantes, bem como foram celebrados tendo tais normas internas como pano de fundo. De tais assertivas, então, sustenta-se que os termos não definidos nessas convenções deveriam encontrar o seu sentido no Direito doméstico desses Estados (completa ou comparativamente, respectivamente).

Assim, ao se verificar que um termo utilizado na CM-OCDE é estranho à legislação doméstica dos Estados contratantes, o "contexto" poderia se mostrar inevitavelmente mais útil para o fornecimento de sentidos. Expressões como "enterprise”, "effectively connected”, “movable property”, “imovable imovable”, “activities of an independente character", "agent of independent status" seriam alguns exemplos de termos ou expressões estranhas a uma série de sistemas jurídicos domésticos. Nesse caso, todas as teorias poderiam alcançar o mesmo resultado: aqueles que atribuem prioridade ao “contexto", ao se depararem com um sentido razoável neste, sequer questionariam se haveria outros sentidos providos pelo Direito doméstico dos Estados contratantes; já aqueles que atribuem prioridade ao Direito doméstico, ao evidenciarem a ausência de sentidos providos por este, também se viriam compelidos a recorrer ao "contexto".

\footnotetext{
${ }^{351}$ Nesse sentido, vide: ROHATGI, Roy. Basic International taxation. Volume 1: principles. Nova Deli : Taxmann, 2005, p. 51.

352 RAAD, Kees van. Interpretation and Application of Tax Treaties by Tax Courts, in European Taxation January 1996. IBFD : Amsterdã, 1996, p. 3.
} 
Também na situação inversa, parece que iguais resultados seriam obtidos: se o contexto não fosse capaz de fornecer um sentido razoável a um termo do acordo de dupla tributação, para quaisquer das três teorias, a consequência prática seria o reenvio ao Direito doméstico.

Contudo, a questão se torna intrigante quando houver algum sentido provido pelo Direito doméstico dos Estados contratantes e outro sentido diverso provido pelo contexto. Supondo-se que ambos os sentidos se mostrem a priori plausíveis, como a questão poderia ser solucionada? Aqueles que atribuem prioridade ao contexto, sequer questionariam se haveria outros sentidos providos pelo Direito doméstico dos Estados contratantes. Aqueles que atribuem prioridade ao Direito doméstico dos Estados contratantes, sequer questionariam se haveria outros sentidos providos pelo "contexto". Contudo, os adeptos da teoria comparativa, ao avaliar qual deles se mostraria mais razoável ao caso concreto, podem se deparar novamente com o dilema sobre qual das fontes ("contexto" vs. Direito doméstico) teria preferência, o que redunda em circularidade. Cria-se, então, outras questões em vez de solucionar-se o problema.

\subsubsection{Exemplo: o caso espanhol da construção de sentido de "royalty" do art. 12 da CM-OCDE conforme o Direito doméstico.}

No Caso Televisió de Catalunya (Espanha, 2011), para a interpretação do termo “cánones" ("royalties”), presente no art. 12 do acordo de dupla tributação Espanha-Países Baixos, o Tribunal Supremo espanhol recorreu tanto ao seu Direito doméstico quanto a evidências do "contexto" da referida convenção internacional, comparando os resultados obtidos em ambos. Ao assim fazer, o Juiz Oscar GonZalez GonZalez, acompanhado de seus pares, observou que a Ley Orgánica espanhola, de 1982, tutelaria o Direito à imagem como um Direito fundamental e irrenunciável inerente à pessoa, seguindo-se do reconhecimento de tal caráter por aquela Suprema Corte. Embora se tratasse de Direito fundamental, irrenunciável, a referida Ley Orgánica espanhola garantiria expressamente ao seu titular a possibilidade de ceder os seus Direitos de imagem a terceiros para fins publicitários, comerciais ou semelhantes, como se um bem material fosse. Concluíram os julgadores espanhóis, por fim, que tal bem cedido perderia completamente a sua natureza 
de "Direito de imagem", protegida pela legislação espanhola sob égide dos Direitos fundamentais.

Paralelamente, o Juiz OSCAR GONZALEZ GONZALEZ recorreu ao contexto intrínseco do acordo de dupla tributação Espanha-Países Baixos. O art. 12 (3) do referido acordo definia o termo "cánones" ("royalties"), relacionando-o a Direitos que, embora imateriais, se distinguem do irrenunciável Direito de imagem por se desprenderem de tal forma da personalidade do sujeito que adquiririam vida própria e independente, até um ponto que o seu autor perderia por completo a sua titularidade.

Desse dialógo entre o Direito doméstico e o "contexto" do acordo de dupla tributação resultaria, então, que os rendimentos cuja tributação estava em litígio não estariam compreendidos no sentido do termo "cánones" (“royalties”).

O mesmo foi realizado para a construção de sentido da expressão "rentas obtenidas por los profesionales del espectáculo, tales como artistas de teatro, cine, radiodifusión o televisión y los músicos, así como los deportistas", contida no art. 17 do acordo EspanhaPaíses Baixos.

No caso, a Televisió de Catalunya argumentou que a CM-OCDE deveria ser considerada como evidência para a construção de sentido daquela expressão. Ocorre que a CM-OCDE, em sua versão de 1992, passou a sugerir que os Estados adotassem cláusula de combate a estruturas abusivas, geralmente chamadas de star companies, incluindo nesse dispositivo um parágrafo $2^{\circ}$. Assim, a inexistência de cláusula semelhante ao art. 17 (2) da CM-OCDE no texto do acordo Espanha-Países Baixos evidenciaria que pagamentos a empresas holandesas pela cessão de Direitos de imagens de jogadores esportistas não estariam sob o escopo do art. 17 daquela convenção internacional.

O Juiz OsCar GonZalez GonZalez, contudo, recorreu ao Direito doméstico e às evidências extrínsecas secundárias para chegar à conclusão oposta à do contribuinte. Para o Tribunal Supremo espanhol, os Comentários à CM-OCDE seriam determinantes e deveriam ser considerados de forma dinâmica, a fím de que o acordo de Espanha-Países Baixos fosse interpretado como se possuísse a cláusula do art. 17 (2) da CM-OCDE. Ao mesmo tempo, as alterações introduzidas no Direito espanhol pelo Real Decreto 1841/1991 
permitiriam considerar diretamente o esportista, desconsiderando a empresa interposta, de forma a também justificar a aplicação do art. 17 (1) do acordo de dupla tributação Espanha-Países Baixos.

É bom esclarecer que o caso foi julgado sob o Direito doméstico espanhol anterior às alterações legislativas introduzidas para a nova tutela dos royalties no ambiente doméstico daquele país.

\subsubsection{Exemplo: O termo "enterprise" na CM-OCDE.}

Ao investigar o sentido do termo "enterprise" utilizado na CM-OCDE, KEES VAN $\mathrm{RAAD}^{353}$ demonstrou que, com o recurso a evidências do contexto intrínseco primário e com a comparação de diferentes dispositivos em que este era utilizado, seria possível identificar ao menos dois sentidos diversos: "person" e "business". Em uma primeira leitura, embora dois sentidos fossem possíveis, a aplicação estrita da regra de interpretação do art. 3 (2) da CM-OCDE afastaria o recurso ao Direito doméstico. Caso houvesse algum sentido provido pelo Direito doméstico, este seria irrelevante. Isso porque, se o sentido doméstico coincidisse com o sentido provido pelo "contexto", este seria aplicado sem contribuições do Direito doméstico. Por sua vez, se o Direito doméstico divergisse do sentido provido pelo "contexto", este deveria prevalecer. O "contexto" manteria uma relação de prevalência total em relação ao Direito doméstico (“"no win' situation”). Para o professor de Leiden, essa leitura estaria correta não fosse o termo "requires" presente na cláusula do art. 3 (2) da CM-OCDE.

O termo "requires" indicaria que nem todo sentido contextualizado teria preferência em relação ao Direito doméstico: o sentido provido pelo "contexto" deveria ter robustez suficiente para afastar sentidos por ventuda colhidos do Direito doméstico dos Estados contratantes ("It must have some force.") ${ }^{354}$. KEES VAN RAAD relacionou, então, a ideia de robustez ("force") do sentido construído a partir do "contexto" à clareza e à inexistência de ambiguidades por ele proporcionadas. Não lhe pareceu que o contexto

${ }^{353}$ RAAD, Kees van. The term 'Enterprise' in the Model Double Taxation Conventions - Seventy Years of Confusion, in Intertax 1994/11, Intertax, 1994, p. 492-493.

${ }^{354}$ Cf. RAAD, Kees van. The term 'Enterprise' in the Model Double Taxation Conventions - Seventy Years of Confusion, in Intertax 1994/11, Intertax, 1994, p. 493. 
intrinseco primário (no caso, a comparação de diferentes passagens do texto) do termo "enterprise" proporcionasse um sentido robusto o suficiente para afastar o recurso ao Direito doméstico dos Estados contratantes. Tal conclusão conduziria à uma situação problemática, pois nenhum sentido para o termo "enterprise" seria encontrado no sistema jurídico doméstico de uma série de Estados, especialmente naqueles de tradição no common law. Seria necessário, para KEES VAN RAAD, substituir tal termo da CM-OCDE.

Como se pode notar, a posição desse professor está entre a corrente da precedência do Direito doméstico e a teoria comparativa.

\section{UMA TEORIA FUNCIONAL SOBRE O SENTIDO ORDINÁRIO CONTEXTUALIZADO DOS TERMOS DOS ACORDOS DE DUPLA TRIBUTAÇÃO}

"Further, treaties are made in the context of generally applicable international law and whithin an international legal system. Though considerably different from that governing the international order of states, international law is an essential part of the system that constitutes international society. The history, sources and means of development of the law are important parts of the context in which treaties are made, interpreted and applied." RICHARD K. GARDINER (2003) $)^{355}$

Diante dessa multiplicidade de teorias quanto ao sentido do "contexto", o operador do Direito tributário internacional deve abstrair uma solução. No presente tópico, então, será apresentado o entendimento adotado nesta tese quanto ao sentido do “contexto"referido no art. 3 (2) da CM-OCDE e a ordem de precedência deste em relação Direito doméstico. Essa análise deve partir de critérios legítimos, os quais, coerência à própria concepção de Direito tributário internacional, devem ser obtidos nas normas de interpretação da CVDT $^{356}$, que possuem força de lei no Brasil e na generalidade dos Estados. A cláusula do "contexto" também possui um contexto interpretativo, o que é relevante para a compreensão de sua relação de precedência à cláusula de reenvio ao Direito doméstico presente no art. 3 (2) da CM-OCDE.

\footnotetext{
${ }^{355}$ GARDINER, Richard K. International Law. Pearson : Harlaw, 2003, p. 7.

${ }^{356}$ Vide: BROE, Luc De. International tax planning and prevention of abuse (doctoral series n. 14). Amsterdã : IBFD, 2007, p. 272; ROHATGI, Roy. Basic International taxation. Volume 1: principles. Nova Deli : Taxmann, 2005, p. 48.
} 
Como estratégia expositiva, o sentido do termo "contexto" será explorado por meio de formulações constitutivas (o que é), diferenciais (o que não é) e funcionais (para o que se presta). ${ }^{357}$ Dessa análise - antecipa-se - decorre que a teoria do contexto internacional amplo parece ser a que melhor explica o sentido e a extensão do "contexto" referido no art. 3 (2) da CM-OCDE, com a precedência deste em relação à cláusula de reenvio ao Direito doméstico.

\subsection{A definição e a amplitude do "contexto" referido no art. 3 da CM-OCDE.}

"In this regard, the notion of something's being evidence for something else seems comparable to the notion of an argument. (...) It is opposed to the idea many seem to at least initially have about evidence, to the effect that it should only be composed of 'hard facts', 'just the facts', or only os what can be directly seen or heard, or of observable events or physical objects. The new theory makes evidence seem like a more relational notion that has a lot to do whith chains of argumentation". DOUGLAS WALTON (2002) $)^{358}$

Adotando-se o roteiro da CVDT, a interpretação do signo "contexto" referido no art. 3 (2) da CM-OCDE pode ter início em seu contexto intrínseco, o que inclui a análise dos propósitos e objetivos dessa norma.

Note-se que a função assumida pelo "contexto" referido no art. 3 (2) da CM-OCDE é muito mais ampla que do "contexto" aludido no art. 31 (2) da CVDT ${ }^{359}$. Embora se trate do mesmo signo linguístico, o "contexto" referido no art. 3 (2) da CM-OCDE não expressa a mesma acepção do "contexto" aludido pelo art. 31 (1) e (2) da CVDT. Ocorre que aquilo que o art. 3 (2) da CM-OCDE trata como "contexto", a CVDT trata como todo o repertório de evidências intrínsecas e extrínsecas legitimadas pelo Direito Internacional para a construção de sentidos contextualizados ("ordinary meaning"), chamada pela ILC-ONU de única e combinada operação de interpretação ("a closely integrated single rule of interpretation").

\footnotetext{
${ }^{357}$ Sobre as diversas formulações possíveis para um mesmo sentido de um mesmo termo, vide: HOLLIS, Duncan B. Defining treaties, in The Oxford Guide to Treaties (Ed. HOLLIS, Duncan B.). Oxford University Press : Oxford, 2012, p. 11-13.

${ }^{358}$ WALTON, Douglas. Legal argumentation and evidence. Pennsylvania Satate Press : Pennsylvania, 2002, p. 202.

${ }^{359}$ Nesse sentido, vide: BRUGGEN, Edwin van der. Unless the Vienna Convention Otherwise Requires: notes on the relationship between Art. 3 (2) of the OECD Model Tax Convention and art. 31 and 32 of the Vienna Convention on the Law of Treaties, in European Taxation of May 2003. IBFD : Amsterdam, 2003, p. 147.
} 
A ILC-ONU utilizou o termo "contexto" como sinônimo de texto do acordo e textos a ele conectados, o que explica o trocadilho utilizado por CARLO GARBARINO ${ }^{360}$ ao referir-se ao art. 31 (2) da CVDT como "co-testo". Tal constatação fragiliza a teoria do contexto exclusivamente intrínseco, especialmente por infirmar o seu argumento central da identidade do signo linguístico.

Os julgados da CIJ da década de 50 já evidenciavam como regra geral de interpretação que as cláusulas dos acordos internacionais deviam ser construídas sob a presunção de que produziriam efeitos em conformidade com o Direito Internacional existente e não a afrontá-lo. ${ }^{361}$. Nesse cenário, o intérprete deve partir da premissa que a construção de sentido de termos não definidos em acordos de dupla tributação adota o esquema interpretativo requerido pela norma geral da CVDT (em conformidade, portanto, com o Direito Internacional). Para se desviar dessas normas gerais, seria necessário que claramente os Estados acordassem norma especial de interpretação, desenhando novos métodos. No caso, é necessário verificar se o Direito tributário internacional, por meio do art. 3 (2) dos acordos de dupla tributação, estabelece exceções àquelas regras gerais da CVDT.

Confessadamente intrigado com a questão da delimitação do "contexto" referido no art. 3 (2) da CM-OCDE, EDWIN VAN DER BRUGGEN ${ }^{362}$ suscita que uma das poucas certezas que se pode ter é de que o art. 3 (2) da CM-OCDE não removeu a teoria do contexto internacional amplo ("large contextual approach"), de forma que o operador dos acordos internacionais permanece obrigado a percorrer diferentes fontes de informação para a composição de um sentido contextualizado.

Nessa linha, concorda MichAEL LANG ${ }^{363}$ que a determinação para a interpretação de quaisquer termos dos acordos de bitributação a partir do "contexto" decorre diretamente da norma geral da CVDT. Assim, como o art. 3 (2) da CM-OCDE não estabelece um

${ }^{360}$ GARBARINO, Carlo. Manuale di tassazione Internazionale. Milão : Kluwer, 2005, p. 173-177

${ }^{361}$ Vide, por exemplo: Right of Passage over Indian Territory (Portugal $v$. India). Acesso na Internet, no endereço:

cij.org/docket/index.php?sum $=278 \& \operatorname{code}=$ poi $\& p 1=3 \& \mathrm{p} 2=3 \&$ case $=32 \& \mathrm{k}=\operatorname{ce} \& \mathrm{p} 3=5$. Último acesso em 10.04.2014.

${ }^{362}$ BRUGGEN, Edwin van der. Unless the Vienna Convention Otherwise Requires: notes on the relationship between Art. 3 (2) of the OECD Model Tax Convention and art. 31 and 32 of the Vienna Convention on the Law of Treaties, in European Taxation of May 2003. IBFD : Amsterdam, 2003, p. 147.

${ }^{363}$ LANG, Michael. Introduction to the law of double taxation conventions. Vienna : Linde, 2013, p. 56-57. 
repertório de evidências para a construção de um sentido contextualizado diverso da CVDT, o professor de Viena sustenta a sua completa irrelevância, bem como que os tribunais interpretariam o acordo de bitributação da mesma forma, havendo ou não o dispositivo em questão. ${ }^{364} \mathrm{~A}$ corroborar com tal perspectiva, há algumas decisões de Cortes nacionais que, mesmo sem a presença desse dispositivo no específico acordo de dupla tributação, recorreram ao reenvio ao Direito doméstico, o que pode representar a aceitação dos Estados quanto à presença implícita desse recurso, tal como também compreendem as autoridades fiscais de algumas jurisdições. ${ }^{365}$

Resta claro, assim, que a única e combinada operação de interpretação prevista pela CVDT não é restringida pelo art. 3 (2) CM-OCDE, de forma que seria aplicada independentemente deste. Não é tão claro, contudo, se a exclusão do art. 3 (2) CM-OCDE não traria nenhuma consequência ao processo interpretativo, o que tornaria o dispositivo totalmente dispensável, como sustenta LANG.

Embora KLAUS VogEL ${ }^{366}$ também tenha suscitado que o art. 3 (2) da CM-OCDE tal como expresso atualmente seria prescindível, apontou que a ausência do dispositivo abriria espaço para uma interpretação mais livre a partir do Direito interno dos Estados contratantes: os limites impostos por tal cláusula, que só permitem o recurso ao Direito doméstico quando o "contexto" assim requerer, não mais estariam presentes.

Conforme o entendimento adotado na presente tese, contudo, o art. 3 (2) da CMOCDE possui um elemento que não consta da norma geral de interpretação dos arts. 31 a 33 da CVDT: a cláusula de reenvio ao Direito doméstico. Há, sem dúvida, uma norma especial de reenvio ao Direito doméstico veiculada pelo art. 3 (2) da CM-OCDE que justifica a inclusão desse dispositivo na generalidade dos acordos de dupla tributação firmados. Trata-se de norma excepcionalíssima, já que não se tem notícia de outros segmentos do Direito Internacional que contenham cláusula de reenvio semelhante à contida no art. 3 (2) da CM-OCDE.

\footnotetext{
${ }^{364}$ Nesse sentido, vide também: EDWARDES-KER, Michael. Tax Treaty Interpretation - The International Tax Treaties Service. In-Depth Publishing : Athlone, 1994, p. 6-7, Capítulo 7.

${ }^{365}$ Vide, em relação às autoridades fiscais norte-americanas: KATZ, Stanley I. United States National Report. Cahiers de Droit Fiscal International by the International Fiscal Association (studies on international tax law), volume LXXVIIIa - Subject I. Interpretation of double taxation conventions. Kluwer Law and Taxation Publishers / IFA : Rotterdam, 1993, p. 641.

${ }^{366}$ Vide, em especial: VOGEL, Klaus. Klaus Vogel on Double Taxation Conventions. Kluwer : London, 1999, p. 210.
} 
O objetivo e propósito do art. 3 (2) da CM-OCDE é precisamente regular o reenvio ao Direito doméstico e tratar da necessária interpretação harmônica entre os Estados contratantes, a fim de concretizar a vocação do acordo (evitar a dupla tributação) pela aplicação de uma mesma norma por ambos os Estados contratantes, promovendo, assim, o seu efeito útil. Diante desses fatores, é possível apresentar uma formulação funcional: o papel do "contexto" é prover uma ou mais evidências quanto ao sentido dos termos dos acordos de bitributação, de modo a promover o efeito útil e a interpretação harmônica de tais normas de Direito Internacional.

Também é possível elaborar uma formulação constitutiva do "contexto" enquanto repertório, acervo, coleção de elementos capazes de evidenciar o sentido contextualizado dos termos do acordo de dupla tributação. Dito de outro modo, o contexto referido no art. 3 (2) da CM-OCDE seria um repertório de evidências legitimadas pelo Direito tributário internacional a prover sentido aos termos não definidos no acordo de dupla tributação, ainda que tais sentidos sejam diversos daqueles existentes no sistema jurídico doméstico dos Estados contratantes, pois representam fontes alternativas.

A noção de "evidência", nesta tese, coincide com a formulação de DouglaS WALTON $^{367}$, em epígrafe, aproximando-a da ideia de argumento para a construção de sentido de normas jurídicas. Observa o autor que, quando se diz "eu tenho evidências sobre esta proposição", isso significa "eu tenho um argumento para tal proposição, o argumento possui uma estrutura coerente e as premissas adotadas possuem peso probatório".

A partir de tal concepção de "evidência", o "contexto" referido no art. 3 da CMOCDE representaria um conjunto de todos os argumentos (ou evidências) legitimados a contribuir para a construção dos sentidos consentidos dos termos dos acordos de dupla tributação. A questão da legitimação de tais evidências será analisada em tópico a seguir.

A partir da aproximação do "contexto" referido no art. 3 (2) da CM-OCDE com o sentido contextualizado requerido pela CVDT, também é possível construir uma formulação diferencial, distinguindo-o: (i) do "contexto" inserto no art. 31 (2) da CVDT,

${ }^{367}$ WALTON, Douglas. Legal argumentation and evidence. Pennsylvania Satate Press : Pennsylvania, 2002, p. 202-206. 
que o compõe, mas não o exaure; (ii) do Direito doméstico dos Estados contratantes, cujo acesso depende exatamente do fracasso do contexto para prover um sentido contextualizado razoável e (iii) de posturas liberais ou extensivas.

Em síntese, o "contexto" referido no art. 3 (2) da CM-OCDE, adotado ao longo desta tese, será considerado como repertório, acervo, conjunto, coleção de evidências (formulação constitutiva) capazes de servir de argumento quanto ao sentido contextualizado dos termos dos acordos de dupla tributação, de modo a promover o efeito útil e a interpretação harmônica deste, com a observância das normas de fundamental importância de ambos os Estados contratantes (formulação funcional), que não se confunde com os elementos indicados pela formulação diferencial aduzida no parágrafo anterior.

A questão, contudo, não é solucionada apenas com a apresentação de tais formulações quanto ao sentido do "contexto" referido no art. 3 (2) da CM-OCDE. As peculiaridades inerentes ao Direito tributário internacional nem sempre permitem que das normas gerais veiculadas pela CVDT imediatamente se colham evidências empiricamente disponíveis no trato dos acordos de dupla tributação.

Como se expôs, as críticas à teoria do contexto internacional amplo muitas vezes se referem à sua ineficiência prática ou mesmo abertura a liberalidades. Parece necessário que sejam investigados critérios mínimos sobre os quais os operadores do Direito tributário internacional - juízes, em última análise - tenham que argumentar para fundamentar a admissibilidade ou a recusa de evidências quanto ao sentido contextualizado dos termos não definidos em acordos de dupla tributação. Nesse seguir, neste Capítulo também se analisará critérios formais e funcionais para a identificação das evidências sob o escopo do “contexto" referido no art. 3 (2) da CM-OCDE. 


\title{
3.2. A relação de precedência entre o "contexto" e o Direito doméstico na norma do art. 3 (2) da CM-OCDE.
}

\begin{abstract}
"In the latter case, the choice is either to use the relevant terms of the treaty as the text of the domestic law or to pass bespoke laws to reflect each of the treaty obligations. This choice is not usually the concern of international law. The state must simply comply with its international obligations in full and in good faith. Constitutional arrangements within the state will dictate what are the necessary and appropriate processes"”.
RICHARD K. GARDINER $(2003)^{368}$
\end{abstract}

Evidências intrínsecas e extrínsecas conduzem à conclusão de que a teoria da precedência do "contexto" em relação ao reenvio é a que melhor explica o funcionamento do art. 3 (2) da CM-OCDE.

O acordo de dupla tributação Brasil-Portugal de $2001^{369}$, que segue o art. 3 (2) da CM-OCDE de 1995, apresenta a seguinte redação: “(...) qualquer termo ou expressão que nela não se encontre definido terá, a não ser que o contexto exija interpretação diferente, o significado que lhe for atribuído nesse momento pela legislação desse Estado que regula os impostos a que a Convenção se aplica (...)". De início, é preciso investigar quais evidencias intrínsecas são fornecidas por esse texto para a solução da questão.

Sob a perspectiva da análise sintática, a cláusula "a não ser que o contexto exija interpretação diferente" representa uma condição para a realização ou não do acontecimento da oração principal, qual seja, o reenvio ao Direito doméstico. Ao analisarse todo o período do art. 3 (2) da CM-OCDE, pode-se verificar que a oração - "a não ser que o contexto exija interpretação diferente" - é subordinada adverbial condicional.

Tratando-se de período composto por subordinação, a oração principal, subordinante, corresponde a "qualquer termo ou expressão que nela não se encontre definido terá (...) o significado que lhe for atribuído nesse momento pela legislação desse Estado". A oração "a não ser que o contexto exija interpretação diferente" está subordinada àquela oração principal e funciona como adjunto adverbial desta, evidenciando-se, ainda, a locução conjuntiva condicional "a não ser que".

${ }^{368}$ GARDINER, Richard K. International Law. Pearson : Harlaw, 2003, p. 139.

${ }^{369}$ BRASIL. Decreto $n^{\circ} 4.012$, de 13 de novembro de 2001. Acordo de dupla tributação Brasil-Portugal. 
Há, assim, uma fórmula condicional: se o "contexto" não prover um sentido plausível ao termo do acordo, o "Direito doméstico" deverá provê-lo. O "contexto" impõe a condição, que pode ou não ocorrer: caberia ao "contexto" e não ao "Direito doméstico", então, primeiro requerer qual interpretação será aplicada. Se o "contexto" exigir o sentido "X", mas o Direito doméstico o sentido "Y", a condição se concretiza e o sentido a ser adotado seria "X". Se tanto o "contexto" quanto o Direito doméstico exigirem o sentido "X", então a condição não se concretizaria; contudo, nesse caso o sentido adotado também teria sido o mesmo fornecido pelo "contexto" ("X") . Apenas se o Direito doméstico exigir o sentido "Y", mas o "contexto" não fornecer qualquer sentido legítimo ou mesmo evidenciar que o sentido provido pelo Direito doméstico deveria ser adotado, é que a cláusula de reenvio realmente controlaria a interpretação e aplicação da convenção físcal.

Ainda sob o escopo das evidências intrínsecas, é necessário analisar se os objetivos e propósitos da CM-OCDE, ou específicos ao seu art. 3 (2), colaboram para essa análise.

O quase consenso doutrinário de que interpretações autônomas são hábeis a promover a interpretação harmônica e o efeito útil dos acordos internacionais, enquanto que o reenvio ao Direito doméstico traz consigo problemas como os conflitos de qualificação e grandes chances de dupla tributário da renda, parece confirmar as conclusões construídas a partir do contexto intrínseco: sentidos construídos a partir do "contexto" teriam precedência em relação àqueles providos pelo Direito doméstico dos Estados contratantes, pois conduziriam de forma mais eficaz à concretização dos objetivos e propósitos do acordo.

Evidências extrínsecas ao texto dos acordos de dupla tributação também conduzem à essa conclusão. Os acordos de dupla tributação, como se viu, não emergem de um vácuo jurídico; a cláusula especial de interpretação do art. 3 (2) da CM-OCDE não está à deriva, mas relacionada com uma série de normas gerais do Direito Internacional ${ }^{370}$. Em especial, parece ser determinante o princípio da integração sistêmica estabelecido pelo art. 31 (3) “c” da CVDT, pelo qual o contexto extrínseco primário comporta como evidência quanto

\footnotetext{
${ }^{370}$ Nesse sentido, vide: BROEKHUIJSEN, Dirk M. A Modern Understanding of Article 31(3)(c) of the Vienna Convention (1969): A New Haunt for the Commentaries to the OECD Model?, in Bulletin for International Taxation, volume 67, n. 9. Amsterdã : IBFD, 2013.
} 
ao sentido dos termos dos acordos internacionais "quaisquer regras pertinentes de Direito Internacional aplicáveis às relações entre as partes".

É necessário considerar que, enquanto a interpretação conforme o "contexto" é a regra no Direito Internacional, a adoção do reenvio ao Direito doméstico constitui uma rara exceção. Tratando-se de regra de exceção, a cláusula de reenvio do art. 3 (2) da CMOCDE deve ser interpretada de forma restritiva, já que, como observa EDWIN VAN DER BRUGGEN $^{371}$, um recurso tão inusual como esse exigiria que os Estados tornassem clara a sua adoção com precedência aos demais meios, o que não vem sendo feito.

Assumindo-se que o sentido contextualizado tem precedência sobre aqueles colhidos do Direito doméstico dos Estados contratantes, o recurso a este somente se daria em situações excepcionais, quando sucessivamente falhassem as evidências intrínsecas e as evidências extrínsecas, ou ainda, o que pode ser mais comum, quando tais evidências conduzirem aos sentidos do Direito doméstico.

Não se ignora, contudo, que os negociadores dos acordos de dupla tributação, bem como os legisladores que os ratificam, não estão hermeticamente fechados aos sistemas jurídicos domésticos em que residem. Pelo contrário, não é difícil imaginar que determinado dispositivo de um acordo de bitributação tenha os seus termos selecionados para melhor contemplar situações peculiares aos sistemas jurídicos domésticos dos Estados contratantes. Nada impede que o intérprete compreenda que um termo não definido na convenção fiscal tenha o sentido de seu Direito doméstico. Essa conclusão, no entanto, deve ser obtida a partir de evidências do contexto intrínseco, extrínseco primário ou extrínseco secundário, o que apenas confirma a precedência do "contexto".

Os termos não definidos nos acordos de dupla tributação apenas seriam interpretados conforme o Direito doméstico dos Estados contratantes, então, quando o "contexto" conduzir para tal conclusão ou, ainda, em face do fracasso do contexto em fornecer uma solução interpretativa adequada à questão. O gatilho para o reenvio ao Direito doméstico dos Estados contratantes é, assim, a precedente análise do "contexto".

${ }^{371}$ BRUGGEN, Edwin van der. Unless the Vienna Convention Otherwise Requires: notes on the relationship between Art. 3 (2) of the OECD Model Tax Convention and art. 31 and 32 of the Vienna Convention on the Law of Treaties, in European Taxation of May 2003. IBFD : Amsterdam, 2003, p. 150-151. 


\section{A IDENTIFICAÇÃO DAS EVIDÊNCIAS SOB O ESCOPO DO “CONTEXTO" REFERIDO NO ART. 3 (2) DA CM-OCDE: CRITÉRIOS FORMAIS, FUNCIONAIS E MATERIAIS DE RECONHECIMENTO.}

Nos tópicos anteriores, após a revisão doutrinária quanto ao sentido do "contexto" e de sua relação de precedência com a cláusula de reenvio ao Direito doméstico, foram justificadas as posições adotadas nesta tese. No entanto, não é suficiente reconhecer a precedência do "contexto", bem como atribuir-lhe uma dimensão ampla. É preciso investigar os critérios que devem ser adotados para o reconhecimento de evidências que estejam sob o escopo do referido "contexto".

Neste tópico, serão investigados critérios formais de reconhecimento, capazes de identificar (i) elementos provenientes de fontes legitimadas pelo Direito tributário internacional e (ii) em consonância com as normas do Direito interno de importância fundamental e manifesta, bem como critérios funcionais de reconhecimento, relacionados à promoção (iii) do efeito útil e da (iv) interpretação harmônica dos acordos de dupla tributação. Será analisado, ainda, (v) até que ponto a plausividade da interpretação construída (critério material) interfere na seleção de evidências sob o escopo do “contexto" referido no art. 3 (2) da CM-OCDE.

Embora se compreenda que os sentidos providos pelo "contexto" tenham precedência em relação àqueles construídos a partir do Direito doméstico, a investigação desenvolvida nesta tese procura ser útil também àqueles que compreendem ser mais adequada a teoria oposta. Ocorre que, ao adotar-se essa segunda perspectiva, a parte que pretender afastar determinado sentido colhido do Direito interno de um dos Estados contratantes teria o ônus de provar a pertinência de tal procedimento. ${ }^{372}$

\footnotetext{
${ }^{372}$ Nesse sentido, vide: BROE, Luc De. International tax planning and prevention of abuse (doctoral series $\mathrm{n}$. 14). Amsterdã : IBFD, 2007, 277.
} 


\subsection{Critérios formais de reconhecimento: a validade das evidências conforme os critérios do Direito Internacional.}

Diante da fórmula condicional veiculada pelo art. 3 (2) da CM-OCDE, as evidências para a construção de sentido dos termos não definidos nos acordos de bitributação devem ser levantadas a partir do "contexto" ou do Direito doméstico.

Alguns critérios para a identificação de evidências quanto ao sentido de tais termos na hipótese de reenvio são tratados no referido art. 3 (2) da CM-OCDE, que remete o intérprete aos sistemas jurídicos nacionais, em que há um poder constituído, um órgão legislativo centralizado e instituições vocacionadas a fazer valer "a lei"373. Ao se referir à "lei" tributária - e, se consideradas as versões posteriores a 1995, também as não tributárias - a CM-OCDE prevê um requisito formal de reconhecimento de evidências admissíveis no processo de reenvio.

A cláusula do "contexto", contudo, enseja as dificuldades inerentes ao Direito Internacional do qual emergem os acordos de bitributação, em que não há um poder central para a produção e aplicação normativa. As dificuldades em questão, surgidas diante do Direito Internacional, devem ser solucionadas também a partir deste. Ocorre que, contrapondo-se à cláusula de reenvio, em que os elementos utilizados pelo intérprete buscam validade no Direito doméstico dos Estados contratantes, as evidências sob o escopo do "contexto" são legitimadas pelas regras do Direito internacional, especialmente da CVDT.

Assumindo-se que a função exercida pelo contexto na fórmula veiculada pelo texto do art. 3 (2) da CM-OCDE é de um repertório de evidências quanto ao sentido consentido dos termos do acordo de dupla tributação, parece necessário analisar: (i) de quais fontes reconhecidas pelo Direito tributário internacional irradiam os elementos que compõem o referido acervo (CVDT, arts. 31 a 33) e (ii) como as normas de fundamental importância de ambos os Estados contratantes (CVDT, arts. 27 e 46) influenciam em sua validade. O propósito dos subtópicos seguintes é o estudo de tais critérios.

\footnotetext{
${ }^{373}$ Nesse sentido, vide: ROTHMANN, Gerd W. Interpretação e aplicação dos acordos internacionais contra a bitributação. Tese de doutorado. São Paulo : Faculdade de Direito da Universidade de São Paulo (USP), 1978, p. 135.
} 


\subsubsection{Fontes formais e fontes materiais dos acordos de dupla tributação (ou: onde procurar por evidências?).}

"Certain materials bearing on the interpretation of an income tax treaty are properly regarded as controlling the meaning to be accorded to a treaty provision. At the other extreme, there are certain materials whith seem to be of such little probative value that they should generally be considered irrelevant.

Between these two poles lie a number of potentially available sources of interpretative guidance, each of which may be accorded a different weight, and a weight which may vary according to the circunstances"

American Law Institute $(1992)^{374}$

A emancipação e o desenvolvimento do Direito tributário internacional não requer uma nova teoria quanto ao tema das "fontes", mas o enfrentamento de questões há tempos analisadas pelo Direito Internacional, bem como outras tantas atinentes a peculiaridades técnicas inerentes aos acordos de bitributação. A tradicional classificação adotada pela doutrina internacionalista segrega as fontes em formais e materiais.

A função das fontes do Direito Internacional é produzir normas para a composição desse sistema e legitimar evidências para o seu reconhecimento: se determinada norma não puder ser relacionada a uma fonte do Direito Internacional, então ela não o compõe. ${ }^{375} \mathrm{O}$ termo fonte, que deriva do latim fons, fontis, fundere com o sentido de "dar à luz", "produzir", "derramar" 376 vem sendo adotado há décadas pela doutrina do Direito, em especial da seara internacional. ${ }^{377}$

Por fontes formais compreendem-se os procedimentos legais de criação e de identificação de regras cogentes aos seus destinatários. Trata-se dos fundamentos jurídicos para que determinado elemento seja considerado integrante do conjunto de normas que compõem o Direito, no caso, o Direito tributário internacional. ${ }^{378}$

\footnotetext{
${ }^{374}$ EUA. American Law Institute. Federal Income Tax Project, International Aspects of United States Income Taxation II. Proposal on United States Income Tax Treaties. 1992, p. 44-45.

${ }^{375}$ Cf. THIRLWAY, Hugh. The Sources of International Law. Oxford : Oxford, 2014, p. 13.

${ }^{376}$ Cf. GRUPENMACHER, Betina Treiger. Tratados internacionais em matéria tributária e ordem interna. São Paulo : Dialética, p. 54.

${ }^{377}$ Cf. OPPENHEIM, Lassa. International Law. A treatise. Volume I (of 2) - Peace. Longmans : Londres, 1912 (Kindle), Introduction Foundation and Development os the Law of Nations, $\S 15$.

${ }^{378}$ Cf. GRUPENMACHER, Betina Treiger. Tratados internacionais em matéria tributária e ordem interna. São Paulo : Dialética, 1999, p. 55-56.
} 
Baseando-se geralmente no positivismo legal ("positivist or voluntarist approach") ${ }^{379}$, a teoria das fontes formais assume como premissa que os Estados apenas se vinculam por normas a que tenham consentido (pacta sunt servanda). O próprio princípio pacta sunt servanda, contudo, não é absoluto, admitindo exceções impostas por normas peremptórias do Direito Internacional (jus cogens), bem como por normas de fundamental importância de cada Estado contratante, já que tratados firmados pelos Estados em afronta a tal conjunto de normas não seriam reconhecidos juridicamente. ${ }^{380}$

Apoiado na ideia de soberania, ${ }^{381}$, o consentimento seria um dos fatores mais importantes - senão o único necessário - para vincular dois Estados por meio de um acordo internacional, como se observa do art. 11 da CVDT. Enquanto em um sistema jurídico doméstico a Constituição assume o papel de fonte formal, o seu substitutivo no Direito Internacional seria o consentimento dos Estados. SAMANTHA BESSON ${ }^{382}-\mathrm{em}^{2}$ meio às suas críticas ao positivismo legal - indica que o consensualismo emite três mensagens sobre o Direito Internacional: (i) os seus limites são acordados pelos próprios Estados; (ii) suas normas são cogentes apenas em relação aos Estados que assim tenham consentido; e (iii) há apenas um único grau de consentimento para todos os Estados que sejam parte de uma convenção.

Embora diversas críticas ${ }^{383}$ possam ser opostas ao positivismo legal associado às tradicionais fontes do Direito Internacional, que invoca o consensualismo como a base fundamental para o estabelecimento das normas em questão, não é possível refutar que o consenso de Estados soberanos é o alicerce da cogência (pacta sunt servanda) dos $\operatorname{tratados}^{384}$. Para o Direito tributário internacional, em que a consideração dos costumes (não enquanto hábitos, mas como um corpo de normas jurídicas ${ }^{385}$ ) parece ser

\footnotetext{
${ }^{379}$ CF. BESSON, Samantha. Theorizing the Sources of International Law, in The Philosophy of International Law. Oxford : Oxford, 2010, p. 164-166.

${ }^{380}$ Cf. THIRLWAY, Hugh. The Sources of International Law. Oxford : Oxford, 2014, p. 1-8.

${ }^{381}$ Cf. HOFFMEISTER, Frank. "Article 11 - Means of expressing consent to be bound by a treaty", in "Vienna Convention on the Law of Treaties: a Commentary", DÖRR, Oliver; SCHMALENBACH, Kirsten (Editors). Springer, 2012, p. 153.

${ }^{382}$ Criticando tal posição tradicional: BESSON, Samantha. Theorizing the Sources of International Law, in The Philosophy of International Law. Oxford : Oxford, 2010, p. 164-166.

${ }^{383}$ Vide, por exemplo: BESSON, Samantha. Theorizing the Sources of International Law, in The Philosophy of International Law. Oxford : Oxford, 2010, p. 164-166.

${ }^{384}$ Nesse sentido, vide: THIRLWAY, Hugh. The Sources of International Law. Oxford : Oxford, 2014, p. 31.

${ }^{385}$ Cf. GARDINER, Richard K. International Law. Pearson : Harlaw, 2003, p. 8.
} 
incipiente $^{386}$, tal questão é de fundamental importância: por configurar Direito Internacional "particular" e não "universal", umbilicalmente baseado em acordos internacionais, o consentimento ocupa a posição de fonte formal por excelência.

Por sua vez, as fontes materiais seriam os elementos legitimados pelas fontes formais para veicular uma norma de Direito Internacional. As fontes materiais seriam as evidências da existência de regras jurídicas que, quando reconhecidas, teriam o status de normas legalmente cogentes. ${ }^{387}$ Trata-se de processos morais e sociais pelos quais o conteúdo do Direito Internacional se desenvolve, mas que nem sempre resultam em documentos. ${ }^{388}$

Tais questões parecem ter desdobramentos importantes para o presente estudo: evidências que reflitam o consentimento dos Estados contratantes quanto ao sentido dos termos dos acordos de dupla tributação se mostram, a priori, válidas perante o Direito tributário internacional (teoria das fontes formais). Por sua vez, a CVDT elencou, em seus arts. 31 e 32, uma série de fontes materiais pelas quais se pode evidenciar o sentido dos termos dos acordos de dupla tributação. Pode-se dizer que tais fontes materiais, tal como as evidências que delas decorram, tiveram a sua validade perante o Direito tributário internacional expressamente declarada pela CVDT, afastando dúvidas que podem surgir em meio aos seus intérpretes.

Contudo, conforme será detalhadamente investigado nos Capítulos II, III e IV, é fundamental notar que constam dos arts. 31 a 33 da CVDT referências a fontes materiais de Direito Internacional propriamente ditas, bem como elementos que apenas provam a existência destas, mas que com elas não se confundem. Todos eles são importantes para a interpretação das convenções fiscais. Ocorre que, para a construção de sentido do termo de um acordo de dupla tributação, não se entende ser sempre necessária a identificação de fontes materiais em si, mas as evidências destas.

\footnotetext{
${ }^{386}$ No sentido de que os costumes internacionais não proíbem a bitributação da renda, , vide: VOGEL, Klaus. Klaus Vogel on Double Taxation Conventions. Kluwer : London, 1999, p. 12-16. Colocando em questão tal ponto, vide: SCHOUERI, Luís Eduardo. O princípio do não retrocesso como nova perspectiva à denúncia de acordos de bitributação, in Revista de Direito Tributário Atual n. 29. São Paulo : IBDT/Dialética, 2013, p. 237-245; SCHOUERI, Luís Eduardo. Tratados e Convenções Internacionais sobre Tributação, in Revista de Direito Tributário Atual n. 17. São Paulo : IBDT/Dialética, 2003, p. 22.

${ }^{387}$ BROWNLIE, Ian. Principles of public internacional law. Oxford : Oxford, 1998, p. 1.

${ }^{388}$ BESSON, Samantha. Theorizing the Sources of International Law, in The Philosophy of International Law. Oxford : Oxford, 2010, p. 170.
} 


\subsubsection{Normas domésticas de fundamental relevância a cada um dos Estados contratantes.}

A CVDT reconhece, em seu art. 27, que "uma parte não pode invocar as disposições de seu direito interno para justificar o inadimplemento de um tratado", salvo se o consentimento em obrigar-se por tal tratado houver sido expresso em violação a disposições do Direito interno dos Estados contratantes que se mostrem manifestas e de importância fundamental (CVDT, art. 46). Decorre daí que as evidências sob o escopo do “contexto" referido no art. 3 (2) da CM-OCDE não podem afrontar normas domésticas de importância fundamental e manifesta de qualquer dos Estados contratantes.

O Direito tributário internacional, mantém contato e se submete às normas domésticas de importância fundamental e manifesta de dois ou mais Estados em particular, o que reclama, portanto, a análise caso a caso. Como esta tese é desenvolvida diante do sistema jurídico brasileiro, é pertinente considerar três aspectos da Constituição Federal de 1988: (i) as normas de competência para a criação de tributos e para a representação do Estado perante o Direito Internacional; (ii) procedimentos de ratificação e adoção do Direito Internacional em âmbito doméstico e; (iii) posição dos acordos de dupla tributação no sistema jurídico brasileiro.

Há ao menos três correntes quanto à posição dos acordos de dupla tributação no sistema jurídico brasileiro: (i) normas de caráter infraconstitucional, equivalentes às leis ordinárias; (ii) normas de caráter infraconstitucional, mas que se sobrepõem às leis ordinárias $^{389}$; (iii) normas de caráter constitucional ${ }^{390}$. Adotando-se quaisquer umas dessas posturas, pode-se entender que normas domésticas de importância fundamental e manifesta (CVDT, art. 46) estariam contidas na Constituição Federal.

\footnotetext{
${ }^{389}$ Nesse sentido, vide: GRUPENMACHER, Betina Treiger. Tratados internacionais em matéria tributária e ordem interna. São Paulo : Dialética, 1999, p. 115-117.

${ }^{390}$ Nesse sentido, vide: SCHOUERI, Luís Eduardo. Preços de transferência no direito tributário brasileiro. São Paulo: Dialética, 2013, p. 421-422; SILVEIRA, Rodrigo Maitto da. Aplicação de Tratados Internacionais Contra a Bitributação - Qualificação de Partnership Joint Ventures. IBDT/Quartier Latin : São Paulo, 2006, p. 88-91; 229/
} 
Não há duvidas de que normas constitucionais devem ser observadas para que normas infraconstitucionais sejam validamente produzidas e aplicadas no ordenamento jurídico brasileiro. Caso a convenção fisscal tenha status de lei, então haveria natural sujeição às normas constitucionais. Por sua vez, ainda que se considerem os acordos de bitributação como normas de caráter constitucional, também estas deveriam ser interpretadas em conjunto com as demais normas constitucionais existentes. Assim, como observou LUís EDUARDO SCHOUERI ${ }^{391}$, as normas constitucionais devem ser respeitadas pelo aplicador do Direito, ainda que este se valha do Direito internacional.

A Constituição brasileira é particularmente detalhista quanto à distribuição de competências tributárias entre os entes federados (art. 153 e 154, no caso da União), bem como em relação às garantias do contribuinte (art. 150, em especial).

Também não se pode dizer que a Constituição seja omissa em relação aos procedimentos para a celebração e ratificação de acordos internacionais, ou seja, para a adoção do Direito Internacional.

Enquanto a competência para celebrar tratados, convenções e atos internacionais, tenha sido atribuída ao Poder Executivo, tais instrumentos devem ser necessariamente referendados pelo Congresso Nacional (CF, art. 84, VIII). É da competência exclusiva do Poder Legislativo "resolver definitivamente sobre tratados, acordos ou atos internacionais que acarretem encargos ou compromissos gravosos ao patrimônio nacional" (CF, Art. 49, I).

\subsection{Critérios funcionais de reconhecimento: a promoção do efeito útil e da interpretação harmônica dos acordos de dupla tributação.}

Nos subtópicos anteriores, foram analisados critérios formais de reconhecimento de evidências sob o escopo do "contexto" referido no art. 3 (2) da CM-OCDE, assumindose que essas: (i) devem decorrer de fontes formais do Direito tributário internacional, consubstanciando fontes materiais ou, ainda, evidenciar a existência dessas, bem como; (ii)

\footnotetext{
${ }^{391}$ SCHOUERI, Luís Eduardo. Planejamento Fiscal Através de Acordos de Bitributação (Treaty Shopping). São Paulo: Ed. Revista dos Tribunais, 1995, p. 37.
} 
não devem colidir com o Direito interno de importância fundamental e manifesta dos Estados contratantes. Em tais circunstâncias, diz-se que a evidência possui a validade perante o Direito internacional para compor o "contexto" referido no art. 3 (2) da CMOCDE.

No entanto, embora uma série de elementos possa ser válida perante o Direito internacional, não se pode imaginar que todos eles sejam capazes de servir como evidência para a formulação do sentido de determinado termo presente em um acordo de bitributação. Propõe-se, então, que a tais critérios formais sejam adicionados outros, atinentes a fatores funcionais, de tal forma que as referidas evidências devem ser aptas a promover certos fins, quais sejam: (i) o efeito útil do acordo de dupla tributaçao e (ii) a interpretação harmônica dessa convenção.

Apenas a título ilustrativo, note-se que postura semelhante é assumida em Technical Explanations emitidas pelo Departamento do Tesouro dos EUA ${ }^{392}$, com referência ao objetivo do procedimento amigável para a contrução de sentidos de termos não definidos nos acordos de dupla tributação. Sugere-se, no caso, que as autoridades competentes instaurem procedimentos amigáveis para solucionar a questão por meio de uma interpretação harmônica ("common meaning"), a fim de atribuir efeito útil ao acordo de dupla tributação celebrado ("in order to prevent double taxation or to further any other purpose of the Convention"). Tais documentos ainda expressam que a interpretação harmônica alcançada pelos Estados contratantes não precisaria se conformar com os sentidos contidos no Direito doméstico de nenhum deles.

Os fundamentos para a adoção de tais critérios funcionais, bem como o perfil de cada um destes, é o objeto dos subtópicos seguintes.

\footnotetext{
${ }^{392}$ Vide, por exemplo: Department Of The Treasury Technical Explanation Of The Convention Between The Government Of The United States Of America And The Government Of The Kingdom Of Belgium For The Avoidance Of Double Taxation And The Prevention Of Fiscal Evasion With Respect To Taxes On Income Signed At Brussels On November 27, 2006. Acesso no endereço na Internet http://www.irs.gov/pub/irstrty/belgiumte07.pdf, em 20.06.2014.
} 


\subsubsection{A promoção do efeito útil dos acordos de dupla tributação.}

"É de se considerar, também, que os países signatários devem conferir aos termos pactuados a máxima efetividade possível, desde que adequados, no caso do Brasil, aos nossos ditames constitucionais". Parecer PGFN/CAT n. 2363/2013 393

A máxima 'ut res magis valeat quam pereat" 394 , que veicula o que a doutrina chama de "princípio do efeito útil",395, há muito é reconhecida no Direito, especialmente no Direito Internacional. Em geral, ao menos duas consequências decorrem dessa máxima: (i) a todos os termos de um acordo internacional devem ser atribuídos algum significado; (ii) o acordo internacional como um todo deve ser interpretado de modo a desencadear os efeitos próprios dos objetivos e propósitos que motivaram a sua celebração ${ }^{396}$.

Quando um acordo internacional suportar duas interpretações, mas apenas uma se mostrar capaz de lhe atribuir efeitos apropriados, conforme a boa-fé, e os propósitos e objetivos do acordo, então apenas esta poderá ser adotada pelas partes. Além disso, tal como decidiu a CIJ no caso Nicaragua v. United States of America, também se requer que os Estados não atuem de forma a enfraquecer o objeto e o propósito de um acordo internacional, ainda que de modo não expressamente vedada em suas cláusulas.

Como já houvera sido aduzido pela $\mathrm{PICJ}^{397}$, a máxima ut res magis valeat quam pereat não autoriza ao juiz atribuir às previsões de um acordo internacional sentido que afronta o seu texto e espírito, não cabendo ao intérprete rever aquilo que foi acordado. Também a CIJ manteve vivo o mesmo entendimento, como se observa do Caso South West $\boldsymbol{A f r i c a}^{398}$, em que consignou-se que àquela Corte não caberia remediar as deficiências

${ }^{393}$ BRASIL. Parecer PGFN/CAT n. 2363/2013, p. 21. Último acesso em 9/12/2014, no endereço eletrônico http://dados.pgfn.fazenda.gov.br/dataset/pareceres/resource/23632013.

${ }^{394}$ Para PAUlo CALIENDO, o brocardo latino "ut res magis valeat quam pereat", que determina que quando uma norma não é suficientemente clara deve ser buscado o sentido que preserve a sua utilidade, de tal modo que é melhor a sua utilização (valeat) do que simplesmente ignorá-la (pereat). Trata-se de uma norma com sentido valorativo neutro, que não explicita exatamente qual o valor ou finalidades a serem buscadas, devendo ser apreciadas caso a caso na interpretação útil da norma" (CALIENDO, Paulo, RIDB, Ano 2 (2013), no 11, p. 12178. Último acesso em http://mdf.secrel.com.br/dmdocuments/PAULOCALIENDO.pdf, em 17.08.2014).

${ }^{395}$ ROTHMANN, Gerd W. Interpretação e aplicação dos acordos internacionais contra a bitributação. Tese de doutorado. São Paulo : Faculdade de Direito da Universidade de São Paulo (USP), 1978, p. 135.

${ }^{396}$ Nesse sentido, vide: STARKE, J.G.; SHEARER, I.A. Starke's international law. Butterworths : Canada, 1994, p. 437.

${ }^{397}$ PICJ. Interpretation of Peace Treaties Advisory Opinion.

398 ICJ. South West Africa (Ethiopia v. South Africa). Disponível na Internet em http://www.icjcij.org/docket/index.php?p1=3\&p2=3\&code=esa\&case=46\&k=c1 . Último acesso em 03.04.2014. 
do texto do tratado internacional se, para tanto, fosse necessário exceder a natural função do julgador. Não caberia à Corte, em especial, estabelecer quais seriam os desejos e intenções de todos os negociadores de um tratado em relação a situações que sequer poderiam ter sido previstas por estes.

A doutrina clássica do Direito Internacional também se preocupou em distinguir o princípio da efetividade do método teleológico de interpretação. Conforme IAN SINCLAIR ${ }^{399}$, o primeiro se refere à questão de tornar o acordo internacional efetivo e não inócuo, enquanto o método teleológico diz respeito à apreciação sobre o que teria sido pretendido pelas partes, cuja investigação restou confinada ao texto pela CVDT.

Note-se que o texto da CVDT não traz referências explícitas à promoção do efeito útil, o que não significa que sua importância tenha sido refugada nesse tratado multilateral, pelo contrário. Os embaixadores com assento na ILC-ONU ${ }^{400}$, na reunião que culminou na aprovação do texto final da CVDT, consignaram que a máxima 'ut res magis valeat quam pereat' sem dúvida representaria um dos princípios gerais de interpretação do Direito Internacional, pois é uma consequência direta do princípio pacta sunt servanda e da boa$f e ́$, que constituem as normas mais fundamentais do Direito dos tratados ${ }^{401}$.

Os princípios pacta sunt servanda e da boa-fé foram afirmados no preâmbulo e no art. 31 (1) da CVDT, sendo que aquele primeiro também está explícito em seu art. 26. OLIVER DÖRR ${ }^{402}$ pondera que tais princípios seriam como um guarda-chuva que cobre todo o processo de interpretação dos acordos internacionais, ainda que possuam significado abstrato. Também sob essa premissa, LUís EDUARDO SCHOUERI ${ }^{403}$ observa que o princípio da boa-fé consistiria na própria base do direito internacional público, bem como a CVDT

\footnotetext{
${ }^{399}$ SINCLAIR, Ian M. The Vienna Convention on the Law of Treaties. Manchester University Press : Manchester, 1973, p. 75.

${ }^{400}$ ONU. Yearbook of the International Law Commission. 1966. Records on the 866th meeting. ONU, 1966, vol. II, par. 9.

${ }^{401}$ Nesse sentido, vide, ainda: SINCLAIR, Ian M. The Vienna Convention on the Law of Treaties. Manchester University Press : Manchester, 1973, p. 74-75, 119; EDWARDES-KER, Michael. Tax Treaty Interpretation - The International Tax Treaties Service. In-Depth Publishing : Athlone, 1995, Cap. 5, p. 1; ROCHA, Sergio André. Interpretação dos tratados para evitar a dupla tributação. São Paulo : Quartier Latin, 2013, p. 158-160.

${ }^{402}$ DÖRR, Oliver. "Article 31 - General rule of interpretation", in "Vienna Convention on the Law of Treaties: a Commentary”, DÖRR, Oliver; SCHMALENBACH, Kirsten (Editors). Springer, 2012, p. 523.

${ }^{403}$ SCHOUERI, Luís Eduardo. Planejamento Fiscal Através de Acordos de Bitributação (Treaty Shopping). São Paulo: Ed. Revista dos Tribunais, 1995, p. 124-125.
} 
corroborou o entendimento doutrinário existente de que o princípio da boa-fé se estende às relações contratuais do Estado enquanto uma limitação geral ao exercício de seus direitos.

No âmbito do Direito tributário internacional, portanto, cada termo utilizado pelos Estados deve ser interpretado de forma a ter um efeito útil à satisfação dos objetivos e propósitos do acordo de dupla tributação.

Há, contudo, objeções na doutrina brasileira ao critério da promoção do efeito útil no processo de interpretação de leis tributárias. Com olhos no Direito doméstico brasileiro, PAUlo CALIENDO ${ }^{404}$ afirma que o princípio da efetividade, contido na máxima 'ut res magis valeat quam pereat', teria como "efeito prático" autorizar que a interpretação seja conduzida conforme as preferências e ideologias do intérprete. Tal máxima, conclui CALIENDO, teria sido rejeitada pelo sistema jurídico brasileiro, como decorrência do princípio da legalidade. Não se pode, no entanto, concordar por completo com referidas objeções, já que não é absoluto que tal máxima conduza a resultados aleatórios ou, ainda, que conceda um cheque em branco ao intérprete.

A interpretação liberal, extensiva, não representa o princípio da promoção do efeito útil dos acordos internacionais, mas justamente o menoscabo deste, a sua patologia. A concretização da máxima 'ut res magis valeat quam pereat' requer que se evitem tais situações patológicas. A promoção do efeito útil não pode se converter em um cheque em branco ao intérprete por força dos princípios pacta sunt servanda e da boa-fé, que condicionam a decisão do intérprete aos objetivos e propósitos construídos em especial a partir do texto do acordo de dupla tributação. Desse modo, mostra-se mais adequado suscitar objeções à interpretação extensiva ou mesmo a atividades integrativas desempenhadas pelo intérprete, mas não à fórmula contida na máxima 'ut res magis valeat quam pereat'.

Não se pode afirmar que a atividade do intérprete esteja plenamente livre e descompromissada. Ao adotarem-se critérios aceitos no Direito Internacional e normas de Direito interno de importância fundamental e manifesta para a seleção de evidências quanto ao sentido contextualizado dos termos dos acordos de dupla tributação.

\footnotetext{
${ }^{404}$ CALIENDO, Paulo, RIDB, Ano 2, n. 11. IDB : Lisboa, 2013, p. 12178. Último acesso em http://mdf.secrel.com.br/dmdocuments/PAULOCALIENDO.pdf, em 17.08.2014.
} 
Além disso, dizer que as evidências quanto ao sentido dos termos dos acordos de dupla tributação devem preencher o critério da promoção do efeito útil é assumir que a resposta à questão “útil para quê?” é “útil para a concretização dos objetivos e propósitos do acordo". É necessário, assim, enfrentar questões como: (i) quais são os objetivos e propósitos dos acordos de dupla tributação e; (ii) qual é, de fato, a influência de tais objetivos e propósitos no ato interpretativo do intérprete. Os subtópicos a seguir possuem a missão de analisar tais questões. Tais questões serão abordadas a seguir, após a exposição de alguns exemplos de aplicação do princípio pacta sunt servanda e da promoção dos efeitos úteis dos acordos.

\subsubsection{Exemplo: Os tribunais canadenses e o princípio pacta sunt servanda.}

No caso Melford Case (Canadá, 1981), o tribunal canadense foi provocado a decidir se os termos "interest" ou "industrial or commercial profits", insertos mas não definidos no acordo Canadá-Alemanha, teriam amplitude suficiente para abranger "guarantee fees". Para a construção do sentido desses termos, o tribunal canadense não admitiu como evidência elementos do Direito doméstico dos Estados contratantes existentes no momento da aplicação do acordo, apoiado no dever de preservar o princípio pacta sunt servanda.

Esse princípio, tão caro aos juízes canadenses, não foi valorado da mesma forma pelos legisladores daquele país. Em razão dessa decisão, foi introduzido no Direito canadense (Canada's Income Tax Conventions Interpretation Act) norma que expressamente determina a adoção dinâmicada de normas domésticas para a interpretação dos acordos de dupla tributação.

\subsubsection{Exemplo: O CAF-OCDE e o princípio pacta sunt servanda.}

Note-se que o CAF-OCDE, em seu estudo sobre o tema do treaty shopping 1987, observou que a ausência de cláusulas de salvaguarda contra o uso abusivo de seus benefícios obrigaria cada um dos Estados contratantes, por força do princípio pacta sunt 
servanda, a tolerar estruturas como de treaty shopping. Nessa linha, os Comentários à CMOCDE da época já suscitavam que os Estados poderiam concordar em incluir o acordo de dupla tributação com a previsão, por exemplo em seu art. 10, cláusula restritiva de benefícios. $^{405}$

Os Comentários à CM-OCDE caminharam, contudo, para a direção de que os Estados “devem acatar escrupulosamente as obrigações específicas que decorrem das convenções fiscais para eliminar as duplas tributações desde que não exista prova evidente de uso abusivo destas convenções" ${ }^{\text {406 }}$.

\subsubsection{Exemplo: o caso brasileiro da construção de sentido de "business profit" do art. 7 da CM-OCDE conforme o Direito doméstico.}

No Caso Copesul (Brasil, 2012), o STJ decidiu que os termos "lucro da empresa estrangeira" devem ser interpretados com acepção mais ampla do que "lucro real", como pretendia o fisco, mas equivalente a "lucro operacional".

Como fundamento para tanto, julgou o Ministro CASTRO MEIRA que a interpretação sustentada pelo fisco seria contrária ao efeito útil que se deve atribuir às convenções fiscais, tornando o art. 7 dos acordos celebrados com Canadá e Alemanha sem valia, letra morta e, ainda, conduzindo à bitributação da renda que se propõe evitar com a celebração destes. Dessa forma, decidiu o tribunal que "para tornar o dispositivo minimamente aplicável é preciso equiparar 'lucro da empresa' a 'lucro operacional'.

\footnotetext{
${ }^{405}$ Sobre o tema, vide: SCHOUERI, Luís Eduardo. Planejamento Fiscal Através de Acordos de Bitributação (Treaty Shopping). São Paulo: Ed. Revista dos Tribunais, 1995, p. 159 e seg.; MACHADO DE MELLO, Nivaldo Edson. O uso impróprio das convenções bilaterais de dupla tributação, in Revista de Direito Tributário Internacional - ano 1 - n. 2. São Paulo : Quartier Latin, 2006, p. 89 e seg.

${ }^{406}$ OCDE. Modelo de Convenção Fiscal sobre o Rendimento e o Patrimônio - Comitê dos Assuntos Fiscais da OCDE. Lisboa : Centro de Estudos Fiscais, 2008, p. 91, Comentário n. 22 ao art. $1^{\text {o }}$.
} 


\subsubsection{Exemplo: Os tribunais ingleses e a promoção do efeito útil das convenções} fiscais.

No Caso Exxon (Reino Unido, 1960), o juiz GoUldING declarou que sua decisão estaria aberta à duas possíveis soluções: tornar inútil a segunda sentença do art. 15 do acordo de bitributação Reino Unido-EUA ou, a fim de evitar tal fenômeno, se desprender da literalidade do texto e adotar uma interpretação mais liberal.

Decidiu o tribunal inglês adotar a segunda opção, que seria a única capaz de promover o efeito útil do acordo de bitributação. Para tanto, foi necessário reconhecer que os termos "resident of a Contracting State", presente na segunda sentença do art. 15 da convenção Reino Unido-EUA, não obedeceria à definição estabelecida pelo art. 2, (1) "g" e "h". O juiz Goulding declarou-se convencido de que, por mais estranho que isso lhe parecesse, palavras semelhantes adotadas na mesma convenção fiscal poderiam ter sentidos diversos.

No Caso Banco do Brasil/Commerzbank (Reino Unido, 1990), o tribunal inglês também aceitou a proposição de que as convenções fiscais devem ser interpretadas de forma que sejam atribuídos efeitos a cada uma de suas palavras, sendo necessária muita cautela para não se esvaziar o sentido de dispositivos celebrados entre dois Estados. $\mathrm{O}$ aplicador do acordo de bitributação deveria, por exemplo, considerar o documento como um todo e verificar se os termos interpretados seriam adotados em outras passagens, em caso positivo, se o mesmo sentido teria sido utilizado indistintamente. 


\subsubsection{Os objetivos e propósitos de acordos de dupla tributação.}

"At the other end of the spectrum will be found those who, far from wishing the would-be interpreter to traverse the arid desert without signposts, seek to plunge him into the impenetrable jungle of interpretation by reference to 'overriding community goals' while instructing him not to ignore any pathway (however meandering) which might be thought to lead in the direction of the 'genuine shared expectations, of the parties". IAN SINCLAIR $(1973)^{407}$

A assunção de que evidências quanto ao sentido dos termos de acordos de bitributação devem satisfazer ao critério da promoção do efeito útil, conduzindo à concretização dos objetivos e propósitos do acordo, deixa em aberto a questão sobre quais seriam esses objetivos e os propósitos ${ }^{408}$. A questão não é simples e tem sido respondida de forma variada pela doutrina. ${ }^{409}$

Os subtópicos seguintes se dedicam à investigação dos objetivos e propósitos dos acordos de dupla tributação a partir dos métodos prescritos pela CVDT, bem como à análise de como tais elementos são aptos a abastecer o critério da promoção do efeito útil na seleção de evidências do sentido contextualizado. Para a organização dessa análise, os objetivos e propósitos dos acordos de dupla tributação serão organizados em: (i) pressupostos; (ii) específicos e; (iii) técnicos.

${ }^{407}$ SINCLAIR, Ian M. The Vienna Convention on the Law of Treaties. Manchester University Press : Manchester, 1973, p. 70.

${ }^{408}$ KLAUS VOGEL observa que geralmente as palavras "objeto" e "propósito" sejam utilizadas como uma expressão, uma unidade, sem sentidos distintos. VOGEL, Klaus. Klaus Vogel on Double Taxation Conventions. Kluwer : London, 1999, p. 37.

${ }^{409}$ Vide, por exemplo: ROTHMANN, Gerd W. Interpretação e aplicação dos acordos internacionais contra a bitributação. Tese de doutorado. São Paulo : Faculdade de Direito da Universidade de São Paulo (USP), 1978, p. 149-150; KATZ, Stanley I. United States National Report. Cahiers de Droit Fiscal International by the International Fiscal Association (studies on international tax law), volume LXXVIIIa - Subject I. Interpretation of double taxation conventions. Kluwer Law and Taxation Publishers / IFA : Rotterdam, 1993, p. 634-635. 


\title{
4.2.2.1. Objetivos e propósitos pressupostos dos acordos de dupla tributação: coordenação, cooperação e reciprocidade internacionais.
}

\begin{abstract}
“A segunda função do direito internacional é estabelecer as regras de coexistência e de cooperação entre os atores internacionais. As regras de coexistência compreendem três grandes modalidades: as regras que dizem respeito à restrição da violência entre os Estados e outros atores internacionais; as regras que disciplinam os acordos internacionais; e as normas relativas à soberania e à independência. Essas regras realizam os valores da paz, do cumprimento das promessas e da estabilidade das relações de domínio. Já as regras de cooperação recobrem temas tão amplos, que vão das questões estratégicas e de segurança aos assuntos econômicos e ambientais”. ALBERTO DO AMARAL JÚNIOR ${ }^{410}$
\end{abstract}

A ideia comum em todos os acordos internacionais é que esses ensejam reciprocidade, o que DUNCAN B. HOLLIS ${ }^{411}$ bem identifica como uma comunicação entre os Estados contratantes que gera um compromisso de legítima expectativa entre as partes. Se há um acordo internacional a ser interpretado, é porque há cooperação, coordenação e reciprocidade entre os Estados; trata-se de fator implícito e pressuposto em qualquer espécie de tratado.

Tais concepções são basilares no direito internacional público, pois a comunidade internacional não se estabeleceu com base em uma relação de dominação, mas num desejo comum de cooperação, como bem observa LUís EDUARDO SCHOUERI ${ }^{412}$.

A aproximação de dois Estados para a negociação e a celebração de um acordo internacional pressupõe que já exista uma relação entre estes a que se quer incrementar (a exemplo de acordos para a criação de mercados comuns, como o Mercosul) ou, ainda, pode representar o marco para o início de um relacionamento amistoso (a exemplo do acordo de paz que faz cessar a guerra). Embora nestes últimos o cooperação, coordenação e reciprocidade internacionais possam figurar como seus objetivos e propósitos mais imediatos e urgentes, naqueles primeiros, mais comuns, podem ser considerados como objetivos e propósitos pressupostos, reafirmados pela celebração de tratados. Assim, quando dois Estados discutem os seus interesses econômicos, comerciais e físcais e decidem quais receitas serão tributadas por um, por outro ou por ambos, é possível afirmar

${ }^{410}$ AMARAL JÚNIOR, Alberto do. Curso de Direito Internacional Público. Atlas : São Paulo, 2013, p. 21.

${ }^{411}$ HOLLIS, Duncan B. Defining treaties, in The Oxford Guide to Treaties (Ed. HOLLIS, Duncan B.). Oxford University Press : Oxford, 2012, p. 20-21.

${ }^{412}$ SCHOUERI, Luís Eduardo. Planejamento Fiscal Através de Acordos de Bitributação (Treaty Shopping). São Paulo: Ed. Revista dos Tribunais, 1995, p. 124-125. 
que os interesses imediatos envolvidos são de ordem tributária e comercial, mas trazem consigo também o objetivo e propósito de aperfeiçoar a cooperação, coordenação e reciprocidade internacionais, tal como ocorre nas mais variadas espécies de acordos internacionais.

Embora "cooperação, coordenação e reciprocidade" nem sempre sejam sejam consignados expressamente no texto das convenções fiscais, o seu reconhecimento como objetivos e propósitos pressupostos não contraria a CVDT, pela qual os objetivos e propósitos dos tratados devem ser construídos a partir de seu texto ${ }^{413}$.

Na verdade, tal assunção considera a norma preambular da CVDT, que reconhece "a importância cada vez maior dos tratados como fonte do Direito Internacional e como meio de desenvolver a cooperação pacífica entre as nações, quaisquer que sejam seus sistemas constitucionais e sociais". A reciprocidade na aplicação dos tratados também pode ser justificada por seu caráter contratual. ${ }^{414}$

O reconhecimento da cooperação, coordenação e reciprocidade internacionais como propósitos e objetivos pressupostos dos acordos de dupla tributação também tem uma justificativa histórica contundente: em 1923, a espinha dorsal das medidas para evitar a dupla tributação identificada pela Liga das Nações seria justamente a cooperação internacional, a qual seria dependente da celebração de acordos internacionais.

As Cortes nacionais também reconhecem que cooperação, coordenação $e$ reciprocidade internacionais sejam propósitos e objetivos fundamentais dos acordos de dupla tributação. No Caso Maximov (EUA, 1963), a Suprema Corte dos EUA enfatizou que o objetivo da interpretação de um acordo internacional não seria localizar o propósito vislumbrado por aquele país, mas as genuínas expectativas compartilhadas por ambos os Estados contratantes, o que envolve coordenação e reciprocidade.

${ }^{413}$ ONU. Yearbook of the International Law Commission. 1966. Records on the 866th meeting. vol. II. ONU, 1966, par. 9.

${ }^{414}$ Cf. ARNOLD, J. Brian. The interpretation of tax treaties: myth or reality, in Bulletin for international Taxation (tax treaty monitor) - january of 2010. IBFD : Amsterdã, 2010, p. 10. 
Uma série de Comentários à CM-OCDE assume a reciprocidade como princípio no qual quaisquer acordos de dupla tributação se baseiam ${ }^{415}$. Conforme o CAF-OCDE, as reservas realizadas por um Estado (“A”) a determinada previsão da CM-OCDE não afastariam a expectativa de reciprocidade de outros Estados (“B”) na negociação de acordos de dupla tributação com aquele Estado (“A-B”) "16. Também indicam os Comentários à CM-OCDE que a obrigação de reciprocidade estaria igualmente presente no dever dos Estados buscarem soluções para eliminar casos de dupla tributação por meio de procedimentos amigáveis ${ }^{417}$. Há, ainda, uma série de Comentários que evidenciam obrigações recíprocas nos dispositivos que preveem ajustes na base de cálculo tributável ${ }^{418}$ ou que cuidam do método do crédito ${ }^{419}$. Há, por sua vez, também Comentários que sugerem a inexistência de expectativa de reciprocidade em relação a outros dispositivos específicos da CM-OCDE ${ }^{420}$.

A igualdade entre as nações é justificativa suficiente para que a reciprocidade seja uma premissa na aplicação dos acordos internacionais, ainda que nem todas as obrigações devam ser necessariamente recíprocas. ${ }^{421}$

Note-se que a existência de obrigações não recíprocas entre os Estados contratantes não ofende ou afasta o princípio da cooperação, coordenação e reciprocidade internacionais. Embora geralmente sejam acordadas normas com direitos e deveres iguais aos dois Estados contratantes, nada impede que obrigações e deveres desiguais sejam acordados; assim ocorrendo, ambos os Estados mutuamente deverão aplicar o acordo da forma como celebrado, salvo ofensas às normas de jus cogens. A reciprocidade tampouco significa que o descumprimento das obrigações contratadas por um dos Estados contratantes deve ensejar igual descumprimento pelo outro Estado contratante.

\footnotetext{
${ }^{415}$ Vide, por exemplo: OECD, Model Tax Convention on Income and on Capital 2014 (Full Version), OECD Publishing, 2014. Comentários aos art. 3, parágrafo 12, e ao art. 10, adicionados em 1992.

${ }^{416}$ Cf. OECD, Model Tax Convention on Income and on Capital 2014 (Full Version), OECD Publishing, 2014. Introdução. "Reservations of certain member countries on some provisions of the Convention", parágrafo 31 .

${ }^{417}$ Vide, por exemplo: OECD, Model Tax Convention on Income and on Capital 2014 (Full Version), OECD Publishing, 2014. Comentário ao art. 3, parágrafo 69, desde 2010.

${ }^{418}$ Vide, por exemplo: OECD, Model Tax Convention on Income and on Capital 2014 (Full Version), OECD Publishing, 2014. Comentário ao art. 7, parágrafos 53 e 58, desde 2010.

${ }^{419}$ Vide, por exemplo: OECD, Model Tax Convention on Income and on Capital 2014 (Full Version), OECD Publishing, 2014. Comentário ao art. 23.

${ }^{420}$ Vide, por exemplo: OECD, Model Tax Convention on Income and on Capital 2014 (Full Version), OECD Publishing, 2014. Comentário ao art. 7, 24, 26.

${ }^{421}$ Cf. EDWARDES-KER, Michael. Tax Treaty Interpretation - The International Tax Treaties Service. InDepth Publishing : Athlone, 1995, p. 2, Capítulo 5.
} 


\subsection{Exemplo: A reciprocidade na troca de informações.}

No Caso Stuart (EUA, 1989), em homenagem ao principio da reciprocidade, o juíz BRENNAN a Suprema Corte norte-americana consignou que, sob o sistema jurídico doméstico do Canadá, as informações em questão poderiam ser concedidas pelas autoridades fiscais canadenses aos EUA.

\subsubsection{Os objetivos e propósitos específicos do acordo de dupla tributação.}

Enquanto a cooperação, coordenação e reciprocidade internacionais são propósitos e objetivos pressupostos em quaisquer tratados, com a fragmentação do Direito Internacional, cada um de seus segmentos apresentará em seus respectivos tratados objetivos e propósitos próprios às suas peculiaridades, chamados aqui de "especificos". No Direito tributário internacional, a literatura especializada ${ }^{422}$ vem identificando que os acordos de dupla tributação celebrados pelos Estados teriam, em especial, os seguintes propósitos e objetivos específicos: (i) repartir competências tributárias; (ii) aliviar ou mesmo evitar a dupla tributação da renda; (iii) combater a evasão fiscal; (iv) viabilizar a troca de informações sobre os contribuintes de ambos os Estados contratantes; (v) viabilizar a assistência na arrecadação tributária; (vi) garantir a não discriminação; (vii) garantir os resultados de incentivos concedidos por países em desenvolvimento para a atração de investimentos; (viii) incrementar as relações entre os Estados contratantes; e (ix) atribuir maior segurança aos investimentos financeiros.

O propósito de evitar a dupla tributação da renda geralmente consta no preâmbulo de todos os acordos tributários e pode ser identificado a partir de diversos de seus dispositivos, pelos quais os Estados contratantes se comprometem a não tributar (ou a tributar de forma mais amena) certos rendimentos e capitais em determinadas

\footnotetext{
${ }^{422}$ Vide: BROE, Luc De. International tax planning and prevention of abuse (doctoral series n. 14). Amsterdã : IBFD, 2007, p. 227 e seg; ROCHA, Sergio André. Interpretação dos tratados para evitar a dupla tributação. São Paulo : Quartier Latin, 2013, p. 74-89; ROTHMANN, Gerd W. Interpretação e aplicação dos acordos internacionais contra a bitributação. Tese de doutorado. São Paulo : Faculdade de Direito da Universidade de São Paulo (USP), 1978, p. 149-150.
} 
circunstâncias. $^{423}$ Trata-se, como observa Jõ̃o FrANCISCO BIANCO ${ }^{424}$, do principal objetivo e propósito de uma convenção fiscal. Contudo, não se pode afirmar que a interpretação de dispositivos de acordos de bitributação apenas estará conforme os seus objetivos e propósitos caso afaste a dupla tributação. É necessário ter em mente que tais acordos internacionais não pretendem afastar todas as hipóteses de dupla tributação, mas apenas os casos sob o seu escopo. ${ }^{425}$

Por sua vez, parte da doutrina e da jurisprudência das Cortes nacionais, acompanhada pelo CAF-OCDE ${ }^{426}$, vem identificando como objetivo e propósito de tais acordos internacionais evitar a dupla não tributação da renda. Assim, para REUVEN AVI$\mathrm{YONAH}^{427}$, o Direito tributário internacional conteria o princípio da tributação única (single tax principle), pelo qual todas as rendas devem ser tributadas uma única vez, nem mais e nem menos.

Essa questão, contudo, não está isenta de discussões. Autores como AlBERTO XAVIER $^{428}$, Michael LANG ${ }^{429}$ e SERGIO ANDRÉ RochA ${ }^{430}$ rejeitam a ideia que evitar a dupla isenção seja um propósito de tais acordos internacionais. Se um Estado (“A”) estiver impedido de exercer a sua competência tributária sobre determinado rendimento em razão de um acordo de dupla tributação (“A-B”), mas o outro Estado ("B”), a quem competiria tal tributação, também não a exerce em seu Direito doméstico, nada impediria a dupla não tributação da renda. No caso de acordos de bitributação sem as chamadas cláusulas de sujeição ao imposto ("subject-to-tax-clauses”), os Estados não poderiam se voltar contra a dupla não tributação da renda. Nesse sentido, MiCHAEL LANG ${ }^{431}$ observa que, se um acordo de dupla tributação ("A-B") atribuir a determinado Estado ("A") a competência para a

${ }^{423}$ Sobre o tema, vide: UCKMAR, Victor. Double Taxation Conventions, in International Tax Law (Ed. Andrea Amatucci). Klumer : Netherlands, 2006, p. 152 e seg.

${ }^{424}$ BIANCO, João Francisco. A CIDE sobre royalties e os tratados internacionais contra a dupla tributação, in Grandes Questões Atuais do Direito Tributário vol. 8 (Coord. Valdir de Oliveira Rocha). São Paulo : Dialética, 2004.

${ }^{425}$ Cf. LANG, Michael. The application of the OECD Model Tax Convention to Partnerships - A critical Analysis of the Report Prepared by the OECD Committee on Fiscal Affairs. Viena : Linde, 2000, p. 28-29.

${ }^{426}$ Vide, por exemplo: OECD. The application of the OECD Model Tax Convention to partnerships, in OECD, Model Tax Convention on Income and on Capital 2010 (Full Version), OECD Publishing, p. 34-36.

${ }^{427}$ AVI-YONAH, Reuven. International Tax as International Law - an analysis of the international tax regime. New York, Cambridge University Press, 2007, p. 1-12.

${ }^{428}$ XAVIER, Alberto. Direito tributário internacional do Brasil. Forense : Rio de Janeiro, 2010, p. 30 e seg.

${ }^{429}$ LANG, Michael. The application of the OECD Model Tax Convention to Partnerships - A critical Analysis of the Report Prepared by the OECD Committee on Fiscal Affairs. Viena : Linde, 2000, p. 28-29.

${ }^{430}$ ROCHA, Sergio André. Interpretação dos tratados para evitar a dupla tributação. São Paulo : Quartier Latin, 2013, p. 78.

${ }^{431}$ LANG, Michael. Introduction to the law of double taxation conventions. Vienna : Linde, 2013, p. 44-45. 
tributação de um certo rendimento, mas este ("A") não exercer tal potestade em sua legislação doméstica, não seria legítimo argumentar que, como o objetivo e propósito do acordo é evitar a dupla tributação, o outro Estado contratante ("B”), cuja competência foi renunciada, estaria autorizado a tributar o aludido rendimento, já que esta seria a única incidência tributária efetiva ${ }^{432}$.

Também o propósito de prevenir o planejamento tributário abusivo e a evasão fiscal pode constar no preâmbulo dos acordos de dupla tributação ${ }^{433}$. Em 1923, os relatórios entregues pelos especialistas em finanças públicas à Liga das Nações consistiam em dois textos, um deles relativo à questão da dupla tributação da renda, e outro sobre o tema da evasão fiscal ${ }^{434}$. Apenas em 2003, por sua vez, os Comentários à CM-OCDE foram revistos, a fim de expressar a posição do CAF-OCDE de que a prevenção do planejamento tributário abusivo e da evasão fiscal corresponderiam a um de seus principais objetivos e propósitos ${ }^{435}$. Para, FRANK VAN BRUNSCHOT ${ }^{436}$, esta seria uma nova linha de pensamento do CAF-OCDE, já que as versões mais antigas claramente deixavam para os Estados a escolha entre incluir ou não em seus acordos medidas contra o abuso e a evasão fiscal, a exemplo das LOB típicas da CM-EUA. Desde então, os Comentários à CM-OCDE pretenderiam proibir treaty shoppings e estruturas consideradas artificiais, bem como autorizar normas domésticas de reação ao planejamento tributário abusivo livre para superar o acordo (treaty override).

O objetivo e propósito de viabilizar a troca de informações sobre os contribuintes dos Estados contratantes decorre do art. 26 da CVDT e estão intimamente relacionados com a prevenção da evasão fiscal e, em alguns casos, com o planejamento tributário abusivo. O objetivo e propósito de viabilizar a assistência na arrecadação tributária entre os Estados contratantes decorrem do art. 27 da CVDT.

\footnotetext{
${ }^{432}$ Em sentido oposto: AVI-YONAH, Reuven. International Tax as International Law - an analysis of the international tax regime. New York, Cambridge University Press, 2007, p. 1-12.

${ }^{433}$ Sobre o tema, vide: UCKMAR, Victor. Double Taxation Conventions, in International Tax Law (Ed. Andrea Amatucci). Klumer : Netherlands, 2006, p. 153-154; BROE, Luc De. International tax planning and prevention of abuse (doctoral series n. 14). Amsterdã : IBFD, 2007, p. 229 e seg.

${ }^{434}$ Cf. RAAD, Kees van. The term 'Enterprise' in the Model Double Taxation Conventions - Seventy Years of Confusion, in Intertax 1994/11, Intertax, 1994, p. 494 e seg.; VOGEL, Klaus. Double Taxation Convention, Kluwer : London, 1997, p. 17.

${ }^{435}$ Vide Vide, por exemplo: OECD, Model Tax Convention on Income and on Capital 2014 (Full Version), OECD Publishing, 2014. Comentário ao art. 1, parágrafo 7 e seguintes.

${ }^{436}$ BRUNSCHOT, Frank van. The Judiciary and the OECD Model Tax Convention and its Commentaries, in Bulletin - Tax Treaty Monitor of January 2005. IBFD, 2005, p. 7-8.
} 


\subsection{Exemplo: um caso brasileiro de interpretação contrária ao objetivo $e$ propósito de evitar a dupla tributação.}

A interpretação mantida pelo fisco brasileiro por mais de uma década, quanto ao sentido dos termos "lucros das empresas", é um exemplo de como não promover o efeito útil das convenções fiscais e criar obstáculos ao objetivo e propósito específico de evitar a dupla tributação.

Como se viu, o Ato Declaratório COSIT n. 1/2000 vinculou a interpretação dos agentes fiscais brasileiros, no sentido de que remessas decorrentes de contratos de prestação de assistência técnica e de serviços técnicos sem transferência de tecnologia não estariam compreendidos no sentido do termo "lucros das empresas" geralmente referido no art. 7 dos acordos de dupla tributação celebrados pelo Brasil, mas sim no art. 21 (“Rendimentos não Expressamente Mencionados"), sujeitando-se à tributação na fonte.

O absurdo de tal interpretação, que certamente não seria compartilhado pelos demais Estados contratantes, conduzia à dupla tributação da renda, chegou a ser acatado por alguns tribunais brasileiros.

No entanto, após a decisão do STJ no Caso Copesul, a PGFN não apenas deixou de recorrer e desistiu de discutir o tema perante o STF, mas também emitiu o Parecer PGFN/CAT n. 2363/2013, em que consigna expressamente que a interpretação até então sustentada pela RFB seria contrária ao objetivo e propósito das convenções fiscais de evitar a bitributação da renda, com o esvaziamento do efeito útil do art. $7^{\circ}$ de tais acordos. Tal interpretação deveria ser banida, sob pena de ensejar a denúncia justificada de convenções fiscais pelos outros Estados contratantes, como oficialmente anunciou a Finlândia. 


\subsection{Exemplo: Os tribunais australianos e os objetivos e propósitos técnicos do art. $7^{0}$ da CM-OCDE.}

O propósito e objetivo técnico do art. 7 da CM-OCDE é isentar lucros empresariais no Estado da fonte, de tal forma que sejam tributados apenas no Estado da residência do contribuinte, evitando-se, de forma coordenada, a dupla tributação e conduzindo à consentida alocação da tributação sobre a capacidade contributiva gerada pela atividade empresarial.

No Caso Lamesa (Austrália, 1997), para aplicar o acordo de bitributação AustráliaPaíses Baixos, o tribunal australiano precisou interpretar o sentido de termos não definidos em seu texto, entre os quais "business profits", referidos no art. 7 daquele acordo.

Entre os argumentos do fisco, suscitou-se que os rendimentos em questão não estariam sujeitos a tributação na legislação holandesa, de forma que a aplicação do art. 7 da convenção fiscal conduziria à não tributação da renda, posto que o dispositivo reserva apenas aos Países Baixos o exercício da competência tributária.

Para a solução do caso, o tribunal delineou uma série de dispositivos da convenção fiscal que não seriam diretamente aplicáveis ao caso, mas que demonstrariam os seus específicos objetivos e propósitos como um todo. Concluiu-se, então, que o acordo Austrália-Países Baixos se propunha mais substancialmente a alocar o poder de tributar entre os Estados ("the Agreement substantially concerns allocation of taxing power"), mas em nenhum momento exigiria que tal prerrogativa fosse exercida por quaisquer das partes ("there is nothing in the Agreement which compels a jurisdiction to exercise that right").

Desse modo, decidiu-se que o objetivo e propósito de alocar a prerrogativa do exercício da competência tributária deveria ser concretizado. Embora o tratado também se propusesse a evitar a dupla tributação da renda, o não exercício do poder de tributar pelo Estado de residência não alteraria a regra estabelecida no art. 7 do acordo Austrália-Países Baixos. 


\subsubsection{Objetivos e propósitos técnicos.}

"Furthermore, in DTC law, it is not enough to refer to general principles. The object and purpose of every single provision need to be understood" MiCHAEL LANG (2013) ${ }^{437}$

Os propósitos e objetivos específicos respondem à questão de como haverá cooperação, coordenação e reciprocidade entre os estados (propósitos e objetivos pressupostos) no Direito tributário internacional. Por sua vez, os acordos de dupla tributação também veiculam cláusulas que se destinam justamente a implementar os propósitos e objetivos específicos anteriormente analisados: normas que dispõem tecnicamente em que hipóteses e de que maneira a dupla tributação será evitada, quais hipóteses de planejamentos tributários não serão tolerados, como e quais informações serão trocadas etc.

Tais critérios técnicos são, muitas vezes, acolhidos como "princípios" de acordos de dupla tributação, a exemplo do princípio da tributação dos rendimentos de trabalho dependente no local de seu desempenho etc.

Note-se que as convenções fiscais não estabelecem a cooperação e a reciprocidade entre os Estados (objetivos e propósitos pressupostos) em quaisquer situações. Tais acordos internacionais também não impõem que a dupla tributação da renda seja afastada (objetivo e propósito específico) em quaisquer situações, mas nas hipóteses delineadas pelo tratado (objetivos e propósitos técnicos).

Para StAnlEY I. KATZ ${ }^{438}$, não estaria realmente claro se a consideração dos objetivos e propósitos técnicos seria mais ou menos importante que os pressupostos ou especificos. Suscita o autor que, embora existam alguns exemplos, os tribunais costumariam evitar solucionar os casos com base em objetivos e propósitos amplos da convenção como um todo ou, ainda, em vista de objetivos e propósitos do acordo como um todo.

\footnotetext{
${ }^{437}$ LANG, Michael. Introduction to the law of double taxation conventions. Vienna : Linde, 2013, p. 44-45.

${ }^{438}$ KATZ, Stanley I. United States National Report. Cahiers de Droit Fiscal International by the International Fiscal Association (studies on international tax law), volume LXXVIIIa - Subject I. Interpretation of double taxation conventions. Kluwer Law and Taxation Publishers / IFA : Rotterdam, 1993, p. 633-634.
} 
Os subtópicos seguintes apresentam alguns exemplos sobre a consideração dos objetivos e propósitos técnicos de dispositivos dos acordos de dupla tributação.

\subsection{Exemplo: os objetivos e propósitos técnicos do art. 15 da CM-OCDE.}

$\mathrm{O}$ artigo 15 da CM-OCDE (rendimentos de atividades dependentes) pode ser tomado como exemplo, por ser vocacionado a concretizar, por meio de critérios técnicos, os objetivos e propósitos específicos da promoção do trânsito internacional de pessoas e de operação entre empresas engajadas no comércio internacional. O art. 15 (2) "b" e "c" teria objetivos e propósitos técnicos de assegurar que o Estado onde o trabalho é executado possua a prerrogativa de tributar os rendimentos em questão, caso tal remuneção seja dedutível naquele Estado. Como forma de compensação pela dedutibilidade, o Estado onde o trabalho é executado teria assegurada a tributação sobre os rendimentos do empregado.

Além disso, KASPER DZIURdź \& FranK PöTGENS ${ }^{439}$ ponderam que o art. 15 (2) “b” e "c" da CM-OCDE também teria o objetivo e propósito técnico de reduzir o ônus operacional entre os Estados contratantes, a fim de implementar o objetivo e propósito especifico de facilitar o trânsito internacional de pessoas e de operações entre empresas engajadas no comércio internacional. Haveria um ônus administrativo excessivo caso o Estado em que as atividades de curta duração são desempenhadas exigisse a retenção de impostos, e nem o empregador nem o empregado estivessem substancialmente presentes em tal Estado para cumprir com tal obrigação, ou, ainda, possuíssem um estabelecimento permanente nesse território para suportar tal ônus operaracional.

Nas discussões do Congresso da IFA de 2013, em Copenhagen, alguns de seus participantes compreenderam preponderar no art. 15 (2) "b" e "c" da CM-OCDE o propósito de reduzir ônus operacionais excessivos, tendo menos peso assegurar a tributação ao Estado onde a dedução foi autorizada. Apenas se o empregador ou o empregado apresentassem nível de presença suficiente no Estado onde as atividades são

\footnotetext{
${ }^{439}$ DZIURDŹ, Kasper; PÖTGENS, Frank. Cross-Border Short-Term Employment, Bulletin for International Taxation Vol. 68, n. 8 (agosto). Amsterdã : IBFD, 2014, p. 404-406.
} 
exercidas é que seria adequada a tributação nesse Estado. ${ }^{440}$

O Caso Johansson (EUA, 1964), embora antigo, ilustra a questão. Nele, um tribunal norte-americano acolheu a mensagem do Caso Maximov para que não se examinasse apenas a linguagem dos acordos de dupla tributação, mas todo o seu contexto, especialmente com vistas aos objetivos e propósitos específicos da convenção.

Compreendeu o Juiz RIVES, acompanhado de seus pares, que para interpretar o termo "residente" (não definido no acordo) seria necessário considerar o objetivo e propósito do acordo de eliminar os impedimentos ao comércio internacional criados pela dupla tributação da renda, estabelecendo-se, para tanto, padrões técnicos para a mais apropriada alocação da tributação em cada transação envolvendo os dois países contratantes. Entre tais padrões, deveria ser observado que os serviços seriam tributados no Estado em que são prestados, admitindo-se exceções como às do art. 10 (equivalente ao art. 15 da CM-OCDE). O referido art. 10 seria uma "commercial traveler provision", vocacionada a assegurar que empresas de ambos os Estados contratantes pudessem enviar seus empregados e agentes ao outro Estado sem, contudo, sujeitá-los à tributação neste. Quando as condições para a aplicação dessa exceção não estivessem presentes, deveria ser aplicada a regra geral, tributando-se da renda no Estado da prestação dos serviços.

O tribunal norte-americano decidiu, então, que o famoso boxeador Johansson não poderia ser compreendido como residente suíço para os propósitos do art. 10 em questão.

\subsection{Exemplo: os objetivos e propósitos técnicos de oposição a planejamentos tributários considerados abusivos.}

A CM-OCDE possui uma série de dispositivos contendo regras de intolerância a planejamentos tributários específicos, a exemplo da cláusula de "special relationship" contida nos arts. $11(6)^{441}$ e $12(4)^{442}$, da cláusula de venda de ações ou quotas de empresas

${ }^{440}$ Cf. DZIURDŹ, Kasper; PÖTGENS, Frank. Cross-Border Short-Term Employment, Bulletin for International Taxation Vol. 68, n. 8 (agosto). Amsterdã : IBFD, 2014, p. 404-406.

${ }^{441}$ A título de exemplo, vide: BRASIL, Decreto $\mathrm{n}^{\circ} 72.542$, de 30 de Julho de 1973. Acordo Brasil-Bélgica, art. 10 (8). 
com ativos imobiliários do art. 13 (4), do tratamento estabelecido no art. $17(2)^{443}$ para as empresas constituídas por artistas e esportistas para o desempenho de suas atividades ("star companies" ou "rent-a-star") ou, ainda, da cláusula do beneficiário efetivo (“beneficial owner") dos rendimentos, prevista nos arts. 10, 11 e $12^{444}$.

A consideração de propósitos e objetivos de técnicos de oposição a planejamentos tributários abusivos, contudo, exige muita cautela. O Caso U2 (Espanha, 2012), para ANDRÉS BÁEZ MORENO ${ }^{445}$, seria um exemplo a não ser seguido.

O Tribunal Supremo espanhol decidiu que o pagamento a todas as empresas envolvidas com a banda U2, responsáveis, de forma segregada, pela performance dos artista em si, pelo fornecimento dos equipamentos utilizados nos espetáculos, como som, iluminação, decoração, pelo gerenciamento, pela produção etc., estariam sob o escopo do art. 17 (1) e (2) do acordo Espanha-Irlanda. Assim, seria autorizada a tributação pela Espanha, enquanto Estado da fonte.

Para chegar a essa conclusão, o tribunal considerou que o propósito e objetivo do art. 17 (2) da CM-OCDE seria combater o planejamento tributário abusivo realizado por meio de star-companies.

No entanto, ANDrÉS BÁEz MoRENO ${ }^{446}$ opõe à decisão do tribunal espanhol que ambos os parágrafos do art. 17 da CM-OCDE apenas se aplicam às atividades pessoalmente exercidas pelos artistas. Assim, o art. 17 (2) seria aplicável à abusiva atribuição dos rendimentos de artistas a terceiros com o propósito de se aproveitar de vantagens fiscais, mas não impediria a segregação dos contratos e pagamentos realizados a

${ }^{442}$ A título de exemplo, vide: BRASIL, Decreto $\mathrm{n}^{\mathrm{o}}$ 72.542, de 30 de Julho de 1973. Acordo Brasil-Bélgica, art. $12(6)$.

${ }^{443}$ A título de exemplo, vide: BRASIL, Decreto ${ }^{\circ} 4.852$, de 2 de outubro de 2003. Acordo Brasil-Chile, art. $17(2)$

${ }^{444}$ A título de exemplo, vide: BRASIL, Decreto ${ }^{\circ} 4.852$, de 2 de outubro de 2003. Acordo Brasil-Chile, art. 11 (1) e (2).

${ }^{445}$ MORENO, Andrés Báez. Contract Splitting and Article 17 of the OECD Model: Is Source Taxation of Artistes and Sportsmen a New Dummensteuer?, in Bulletin for International Taxation vol. 68, n. 3. Amsterdã : 2014 .

${ }^{446}$ MORENO, Andrés Báez. Contract Splitting and Article 17 of the OECD Model: Is Source Taxation of Artistes and Sportsmen a New Dummensteuer?, in Bulletin for International Taxation vol. 68, n. 3. Amsterdã : 2014, p. 1 . 
outros profissionais que trabalham no espetáculo e que não se confundem com os artistas de (“contract splitting”).

\subsubsection{A influência dos objetivos e propósitos dos acordos de dupla tributação em seu processo de interpretação.}

Não está em debate apenas quais seriam os objetivos e propósitos dos acordos de dupla tributação, mas também qual seria a sua utilidade no processo de interpretação. ${ }^{447}$ Ao menos três posturas podem ser identificadas nas decisões jurisprudenciais e trabalhos acadêmicos analisados nesta tese: (i) a negação da influência dos objetivos e propósitos dos acordos de dupla tributação para a interpretação de seus termos; (ii) a aceitação aparente da influência dos objetivos e propósitos dos acordos de dupla tributação, sem atribuição de efeitos práticos na interpretação de seus termos e; (iii) a efetiva influência dos objetivos e propósitos dos acordos de bitributação na interpretação de seus termos.

Os subtópicos seguintes se dedicam à análise de cada uma dessas correntes.

\subsection{A negação da influência dos objetivos e propósitos dos acordos de dupla tributação para a interpretação de seus termos.}

Muitos trabalhos acadêmicos ${ }^{448}$ e decisões de Cortes nacionais consideram que os objetivos e propósitos dos acordos de dupla tributação seriam irrelevantes ou, ainda, um fator temerário na interpretação de tais convenções. Mais do que estéreis, alguns doutrinadores consideram que os objetivos e propósitos dos acordos de dupla tributação não deveriam influenciar para a construção de sentido dos termos desses acordos. Em especial, preocupa a doutrina a possibilidade de se utilizar objetivos e propósitos de acordos de dupla tributação como argumento para o reconhecimento de competências tributárias que não constam no texto negociado pelos Estados ("subject to tax clause").

\footnotetext{
${ }^{447}$ Vide, por exemplo: ROTHMANN, Gerd W. Interpretação e aplicação dos acordos internacionais contra a bitributação. Tese de doutorado. São Paulo : Faculdade de Direito da Universidade de São Paulo (USP), 1978, p. 149 e seg.

${ }^{448}$ Vide: LANG, Michael. Introduction to the law of double taxation conventions. Vienna : Linde, 2013, p. 40 e seg.
} 
Sobre o tema, Vogel \& PROKISCH consideraram que objetivos e propósitos poderiam ser utilizados apenas para a análise de casos extraordinários de planejamento tributário abusivo, mas não poderiam ser utilizados ordinariamente na interpretação dos acordos de dupla tributação.

\subsection{Exemplo: Cautelas para a consideração dos objetivos e propósitos das convenções fiscais.}

No Caso Vas (Reino Unido, 1989), o Tribunal inglês (High Court of London, Chancery Division), para a aplicação do acordo de dupla tributação Reino Unido-Hungria, consignou ser necessária bastante cautela na consideração dos objetivos e propósitos de um acordo de dupla tributação. Como tais acordos internacionais seriam negociados entre especialistas que representam Estados, haveria questões econômicas e outros fatores que os motivariam e que não seriam perceptíveis e discerníveis por meio de seu texto ou, ainda, de outros materiais acessados no caso. Para os juízes daquela Corte londrina, os objetivos e propósitos dos acordos de dupla tributação não influenciariam em sua interpretação, pois não haveria evidências disponíveis no caso para que pudessem ser verdadeiramente descortinadas.

\subsection{Exemplo: a irrelevância dos objetivos e propósitos na interpretação do art. 13 da CM-OCDE}

No Caso Gladden (Canadá, 1985), a fim de aplicar o acordo Canadá-EUA, o tribunal canadense compreendeu evidente que a efetiva dupla tributação não seria condição ou pré-requisito para invocar-se a proteção do acordo. A partir do art. 8 daquele acordo (equivalente ao art. 13 da CM-OCDE, por cuidar da tributação dos ganhos de capital), então, o não-residente poderia beneficiar-se da isenção ali prevista independentemente da tributação exercida por seu país de residência: se os EUA, no caso, abolissem por completo a tributação dos ganhos de capital, ainda assim os seus residentes contariam com a isenção a ser concedida pelo Canadá, quanto tais rendimentos provierem de fontes canadenses. 


\subsubsection{A aparente aceitação da influência dos objetivos e propósitos dos acordos de dupla tributação, sem atribuição de efeitos práticos na interpretação de seus termos.}

A CVDT foi ratificada pela generalidade dos Estados modernos e, em muitos desses, como é o caso do Brasil ${ }^{449}$, incorporada aos seus respectivos sistemas jurídicos domésticos por instrumentos próprios. Trata-se de norma cogente que deve ser observada pelas Cortes nacionais, salvo quando houver fundamentos capazes de afastar a sua aplicação, a exemplo de incongruências com o regime constitucional vigente ou de cláusulas específicas de acordos internacionais. Ausentes tais justificativas, estaria o julgador compelido a observar o art. 31 (1) da CVDT e a considerar, na interpretação das convenções fiscais, seus objetivos e propósitos.

No entanto, quando um julgador adota a postura de expressamente declarar sujeição à CVDT e à sua cláusula de relevância dos objetivos e propósitos para a interpretação dos acordos, mas não atribui a isso efeitos interpretativos práticos, torna apenas aparente a aceitação dessa norma como critério de seleção de evidências quanto ao sentido de seus termos.

\subsection{A efetiva influência dos objetivos e propósitos dos acordos de dupla tributação na interpretação de seus termos.}

Há, ainda, diversas decisões de Cortes nacionais que recorrem a objetivos $e$ propósitos da convenção como evidências para a construção de sentido de termos presentes nos acordos de dupla tributação que lhes são submetidos à análise.

Como se pode observar dos exemplos a seguir, alguns tribunais nacionais adotam a criticada postura de extrair do objetivo e propósito de evitar a dupla tributação cláusulas de sujeição ao tributo ("subject to tax clauses").

${ }^{449}$ BRASIL. Decreto n. 7.030/2009. 


\subsection{Exemplo: Os objetivos e propósitos das convenções fiscais nos tribunais canadenses.}

No Caso Crown Forest (Canadá, 1995), a Suprema Corte do Canadá considerou que a isenção concedida pelos EUA afastaria a possibilidade de dupla tributação dos rendimentos em questão e, como o propósito e objetivo do acordo seria evitar a bitributação, a aplicação deste deixaria de ser justificável.

Compreendeu o julgador que o objetivo daquele acordo internacional não seria permitir que empresas incorporadas em terceiros países - como no caso, Bahamas usufruíssem de seus benefícios tributários com o simples estabelecimento de um escritório nos EUA para a os negócios realizados com o Canadá.

\subsection{Exemplo: o sentido do termo "payable" diante dos objetivos e propósitos técnicos do acordo de dupla tributação Reino Unido-França.}

No Caso Sportsman (Reino Unido, 1998), o tribunal inglês recusou a aplicação do acordo de dupla tributação Reino Unido-França, considerando a ausência de evidências quanto à efetiva tributação dos rendimentos pelo Estado francês. Consignou o julgador que a convenção fiscal teria sido celebrada com o propósito de evitar que mais do que um Estado efetivamente tributasse a mesma renda, de forma que a tutela jurídica de suas normas não afastariam a sujeição ao tributo, mas sim a concretização de tal responsabilidade pelo pagamento. Além disso, como o objetivo e propósito do acordo Reino Unido-França também seria prevenir a evasão fiscal, a interpretação sustentada pelo contribuinte em questão deveria ser rejeitada, pois conduziria à facilitação de atos evasivos.

Assim, o termo "payable", adotado no art. 24 (a) do acordo Reino Unido-França, foi interpretado pelo tribunal inglês com o sentido de pago e não de pagável. 


\subsubsection{A promoção da interpretação harmônica dos acordos de bitributação.}

"Tendo em conta a finalidade do acordo de bitributação, entre vários sentidos que um termo inserido numa norma de repartição possa apresentar, deve-se escolher aquele que possibilite afastar a bitributação. Daí caber ao intérprete buscar a interpretação que seja o entendimento comum entre as partes, já que interpretações diferentes em cada um dos Estados contratantes podem levar à bitributação ou à não tributação. A harmonia decisória, pois, que decorre da finalidade dos acordos de bitributação, implica a busca de um sentido comum para os termos do acordo de bitributação." LUÍS EDUARDO SCHOUERI $(2013)^{450}$

Neste tópico, propõe-se mais um critério para o reconhecimento de evidências sob o escopo do "contexto" referido no art. 3 (2) da CM-OCDE: evidências quanto ao sentido contextualizado de termos dos acordos de dupla tributação, válidas perante o Direito Internacional e que, a priori, promovam o efeito útil, devem também ser aptas à promoção da interpretação harmônica entre as partes. Para que os objetivos e propósitos dos acordos de dupla tributação se concretizem - isto é, o seu efeito útil - é requisito indispensável a interpretação harmônica de seus termos por ambos os Estados contratantes. ${ }^{451}$

Tradicionalmente, a interpretação harmônica parte da ideia básica de que o propósito de evitar a dupla tributação, com a distribuição da competência tributária entre os Estados contratantes, apenas poderá ser obtida se ambos aplicarem de forma semelhante e consistente as normas do acordo internacional, o que somente se poderia garantir por meio da interpretação autônoma ${ }^{452}$.

A interpretação harmônica decorre dos objetivos e propósitos pressupostos do acordo de dupla tributação ${ }^{453}$ : se os Estados não forem capazes de alcançar uma interpretação harmônica, pode-se afirmar que não houve coordenação, reciprocidade emuito provavelmente - cooperação. No entanto, diante de duas interpretações possíveis, a escolha da que não se harmonize com o outro Estado contratante pode ferir a boa-fé, a cooperação, coordenação e a reciprocidade que regem o Direito Internacional, requerendo justificação por parte do julgador.

${ }^{450}$ SCHOUERI, Luís Eduardo. Preços de transferência no direito tributário brasileiro. São Paulo: Dialética, 2013, p. 410-411.

${ }^{451}$ Em especial, vide: VOGEL, Klaus. Klaus Vogel on Double Taxation Conventions. Kluwer : London, 1999 , p. 39-59.

${ }^{452}$ Nesse sentido, vide: VOGEL, Klaus. Klaus Vogel on Double Taxation Conventions. Kluwer : London, 1999, p. 55-60; ROHATGI, Roy. Basic International taxation. Volume 1: principles. Nova Deli : Taxmann, 2005 , p. 47.

${ }^{453}$ Nesse sentido, vide: ROTHMANN, Gerd W. Interpretação e aplicação dos acordos internacionais contra a bitributação. Tese de doutorado. São Paulo : Faculdade de Direito da Universidade de São Paulo (USP), 1978, p. 149-150 
As contribuições de KLAUS VOGEL ${ }^{454}$ sobre a interpretação harmônica têm nutrido o debate doutrinário para a compreensão desse fenômeno, bem como inspirado a procura por meios para a sua concretização. É o que se observa em trabalhos publicados por autores como KEES VAN RAAD ${ }^{455}$, EKKEHART REIMER ${ }^{456}$ e outros $^{457}$.

Nesse seguir, discutem-se quais seriam os meios mais efetivos para tal desiderato, considerando, por exemplo, a importância da identidade dos métodos de interpretação empregados por ambos os Estados contratantes. Partindo da premissa de que a eficácia e a reciprocidade dos acordos de dupla tributação demandam que esses sejam aplicados uniformemente pelos Estados contratantes, MiCHAEL EDWARDES-KER ${ }^{458}$ relaciona a uniformidade de decisões de diferentes jurisdição à adoção de métodos coincidentes de interpretação, baseados na CVDT, enquanto que conclusões divergentes teriam sido construídas por Cortes nacionais que ignoraram os referidos métodos. A tese do autor inglês se choca com a posição de BRIAN J. ARNOLD ${ }^{459}$, para quem a interpretação harmônica não está relacionada com os métodos utilizados na interpretação, mas com a identidade dos resultados em si, já que iguais métodos podem gerar resultados diversos e métodos diferentes podem chegar a um mesmo resultado.

Embora significativa, não é essa a única controvérsia quanto ao critério de seleção de evidência quanto ao sentido contextualizado. Muitos autores não procuram por meios de concretizar a interpretação harmônica, pois consideram tal fator irrelevante. Não houve, vale destacar, ponto mais questionado que a interpretação harmônica em painéis de discussão sobre a elaboração da presente tese, especialmente em seminários na

\footnotetext{
${ }^{454}$ Em especial, vide: VOGEL, Klaus. Klaus Vogel on Double Taxation Conventions. Kluwer : London, 1999; VOGEL, Klaus. Double tax treaties and their interpretation, in Berkeley Journal of International Law v. 4.1986.

${ }^{455}$ RAAD, Kees van. International coordination of tax treaty interpretation and application, in International and comparative taxation - essays in honour of Klaus Vogel. KIRCHHOF, Paul et. al. eds London : Kluwer, 2002, p. 223-224.

456 REIMER, Ekkehart. Interpretation of tax treaties - Germany. European Taxation. IBFD, 1999 (December), p. 466-469.

${ }^{457}$ Vide, por exemplo: SILVEIRA, Rodrigo Maitto da. Aplicação de Tratados Internacionais Contra a Bitributação - Qualificação de Partnership Joint Ventures. IBDT/Quartier Latin : São Paulo, 2006, p. 121 e seg.

${ }^{458}$ EDWARDES-KER, Michael. Tax Treaty Interpretation - The International Tax Treaties Service. InDepth Publishing : Athlone, 1995, p. 3-4, Capítulo 1.

${ }^{459}$ ARNOLD, J. Brian. The interpretation of tax treaties: myth or reality, in Bulletin for International Taxation (tax treaty monitor) - january of 2010. IBFD : Amsterdã, 2010, p. 10-11.
} 
Universidade de Valência (Espanha) ${ }^{460}$ e na Universidade de Uppsala (Suécia) ${ }^{461}$. Em tais oportunidades, dois pontos em especial foram levantados: (i) se as consequências de uma interpretação devem influenciar no trabalho de intérprete ${ }^{462}$ e (ii) se a interpretação harmônica é realmente exigida pelo Direito tributário internacional. ${ }^{463}$

Os subtópicos seguintes se dedicam à análise de tais controvérsias, essenciais para que a interpretação harmônica seja aceita como critério para a seleção de evidências quanto ao sentido contextualizado de termos dos acordos de dupla tributação. Serão investigadas, ainda, as dificuldades e objeções empíricas na aplicação da interpretação harmônica, bem como as interpretações divergentes suportadas pelo Direito tributário internacional.

\subsubsection{As consequências de uma interpretação devem influenciar no trabalho de intérprete?}

"A existência do Direito assenta numa série de fenômenos que se concretizam com regularidade. Sem essa regularidade, o Direito não teria qualquer consistência ideal ou real: ininteligivel, imperceptivel e ineficaz, ele deveria ser afastado das categorias existentes". ANTÓNIO MANUEL DA Rocha E MENEZES CORDEIRO $(2008)^{464}$

Ao assumir-se o Direito tributário internacional como um sistema de preceitos que governam relações entre sujeitos que podem escolher entre cumprir ou não os seus deveres, mas que não têm o controle sobre a consequência de tais atos devido à cogência das normas jurídicas ${ }^{465}$, é preciso saber se aos acordos de bitributação celebrados estão sendo atribuídas as consequências que correspondam às legítimas expectativas dos Estados.

\footnotetext{
${ }^{460}$ Universitat de València (Espanha). Seminar on International and EU Tax Law. 2014. Debatedores: Ekkehart Reimer, Francisco Alfredo García Prats e Gianluigi Bizioli.

${ }^{461}$ Uppsala Univesitet (Suécia). "Doctorate Seminar on Comparative Tax Law". 2014. Professores debatedores: Bertil Wiman e John Avery Jones.

${ }^{462}$ Em especial, ao comentar minha exposição sobre o ponto, o Prof. JOHN AVERY JONES suscitou que a interpretação dos acordos de dupla tributação não poderia levar em consideração as suas consequências (não se altera a interpretação por conta de suas consequencias, de tal forma que se o recurso ao Direito doméstico conduziria ou não à dupla tributação não seria poderia ser levado em consideração.

${ }^{463}$ Em especial, ao comentar minha esposição sobre o ponto, o Prof. ALFREDO GARCIA PRATZ suscitou que a questão deve ser enfrentada.

${ }^{464}$ MENEZES CORDEIRO, António Manuel da Rocha e. "Introdução à edição portuguesa", in Pensamento sistemático e conceito de sistema na ciência do Direito (Claus-Wilhelm Canaris). Lisboa : Fundação Calouste Gulbenkian, 2008, p. LXIII.

${ }^{465}$ Cf. THIRLWAY, Hugh. The Sources of International Law. Oxford : Oxford, 2014, p. 1-2.
} 
Como se expôs anteriormente, quando um acordo internacional suportar duas interpretações, aquela que se mostrar capaz de promover o efeito útil do acordo deveria ser a adotada. Sob tal premissa, as consequências da interpretação são relevantes.

Os princípios pacta sunt servanda e boa-fé, ao atribuírem cogência ao Direito Internacional ${ }^{466}$, também exigem a consideração de como o acordo internacional é interpretado e as consequências de sua aplicação. Tais princípios se voltam precisamente para o momento posterior à celebração do acordo, de tal modo que devem os Estados se atentar a aplicá-lo de forma que os seus atos vivifiquem seus objetivos e propósitos: a aplicação do acordo internacional não pode gerar consequências discrepantes de seus objetivos e propósitos.

De outro modo - com olhos à passagem em epígrafe - o Direito tributário internacional se tornaria ininteligível, imperceptível e ineficaz, deixando de ser "Direito".

\subsubsection{A interpretação harmônica é realmente exigida pelo Direito tributário internacional?}

Como qualquer teoria, a interpretação harmônica encontra oposição. Embora desejável, WIM WIJNEN ${ }^{467}$ considera a tese idealista, pois não teria embasamento em ordenamentos jurídicos nacionais ou internacionais, bem como não representaria a solução para todos os problemas interpretativos, mas faria com que outros surgissem. Como oposição, o autor sugere o seguinte exercício: suponha-se que um Estado ("A") possua acordos de dupla tributação com dois Estados (acordos " $A-B$ " e " $A$-C"), bem como que tais Estados (" $B$ " $e$ " $C$ ") apresentam interpretações divergentes em relação a um mesmo termo de suas respectivas convenções. Qual interpretação deveria ser privilegiada pelo juiz do primeiro Estado ("A")? Deveria ser adotado pelo juiz de tal Estado ("A") determinado sentido quando se deparasse com um daqueles Estados contratantes ("B") e, então, outro sentido para o mesmo termo quando se deparasse com o outro Estado ("C")? Mais ainda,

\footnotetext{
${ }^{466}$ Sobre o tema, vide: SCHMALENBACH, Kirsten. "Article 26 - Pacta sunt servanda", in "Vienna Convention on the Law of Treaties: a Commentary", DÖRR, Oliver; SCHMALENBACH, Kirsten (Editors). Springer, 2012, p. 427-428.

${ }^{467}$ WIJNEN, Wim. Some Thoughts on Convergence and Tax Treaty Interpretation, in Tax Treaty Monitor Bulletin for International Taxation (November 2013). IBFD: Amsterdã, 2013, p. 577.
} 
BRIAN J. ARNOLD ${ }^{468}$ opõe que não haveria qualquer exigência que sejam dados os mesmos efeitos ao tratado por ambos os Estados contratantes.

No entanto, é necessário reconhecer que abundantes argumentos suportam a teoria da interpretação harmônica, que não se embasa apenas na autoridade acadêmica dos autores que a defendem ${ }^{469}$, mas em seu valor jurídico e argumentativo. ${ }^{470}$

Inicialmente, é necessário reconhecer que a adoção dos mesmos métodos de interpretação não traz consigo garantias mais firmes de que um mesmo resultado seja alcançado por operadores de ambos os Estados contratantes (neutralizando, assim, os efeitos das diferenças do contexto nacional em que cada um deles está inserido). Entretanto, disso não decorre necessariamente a refutação da tese da interpretação harmônica, bem como não tem como consequência imediata a aceitação dos Comentários à CM-OCDE como fonte material absoluta de sentidos, como sugere BRIAN J. ARNOLD ${ }^{471}$.

Se a adoção dos mesmos métodos de interpretação por dois Estados contratantes não é suficiente para assegurar a concretização do postulado da interpretação harmônica, permanece aberto o desafio de investigação sobre os meios mais eficazes para tanto. A presente tese busca contribuir para tais esforços.

Como segundo argumento, pode-se observar que a determinação do art. 31 (1) da CVDT, para que os acordos internacionais sejam interpretados "à luz de seu objetivo e finalidade", prescreve que um Estado conduza a interpretação de tal forma que possa ser aceita pelo outro Estado contratante como correspondente às suas legítimas expectativas, ou seja, com vistas à interpretação harmônica.

Em terceiro lugar, questões basilares como o propósito e objetivo de promover a cooperação, coordenação e reciprocidade internacionais, bem como os princípios pacta

\footnotetext{
${ }^{468}$ ARNOLD, J. Brian. The interpretation of tax treaties: myth or reality, in Bulletin for International Taxation (tax treaty monitor) - january of 2010. IBFD : Amsterdã, 2010, p. 10-11.

${ }^{469}$ Por todos, vide: VOGEL, Klaus. Klaus Vogel on Double Taxation Conventions. Kluwer : London, 1999, p. 43 e seg.

${ }^{470}$ Para diversos argumentos levantados pela doutrina alemã, vide: ROTHMANN, Gerd W. Interpretação e aplicação dos acordos internacionais contra a bitributação. Tese de doutorado. São Paulo : Faculdade de Direito da Universidade de São Paulo (USP), 1978, p. 149-157 e seg.

${ }^{471}$ ARNOLD, J. Brian. The interpretation of tax treaties: myth or reality, in Bulletin for International Taxation (tax treaty monitor) - january of 2010. IBFD : Amsterdã, 2010, p. 10-11.
} 
sunt servanda" e boa-fé, fazem com que, se o termo de um acordo de dupla tributação puder ser interpretado de diversas maneiras prima facie válidas, mas apenas uma de acordo com os objetivos e propósitos do tratado (ou, ainda, que de alguma maneira melhor os cumpra), então esse sentido deve ser o adotado. Assumindo tal postura, EDWIN VAN DER BRUGGEN $^{472}$ conclui que o imediato reenvio ao Direito doméstico dos Estados contratantes pode conduzir a resultados que não se conformam com os objetivos e propósitos do acordo de dupla tributação, especialmente porque isso transfere a cada um dos Estados a possibilidade de, unilateralmente, minimizar suas obrigações em face do acordo internacional.

Como quarto argumento, a interpretação harmônica também pode ser justificada com vistas ao art. 33 (4) da CVDT. Requer esse dispositivo que, quando o acordo internacional houver sido autenticado em duas línguas, deverá ser adotado o sentido que melhor reconcilie os textos, tendo em vista o seu objetivo e propósito. ${ }^{473}$ A reconciliação dos textos, para que um sentido harmonioso seja construído, é o mandamento que deflui desse dispositivo.

Como quinto argumento ${ }^{474}$, é possível ainda sustentar que a previsão do procedimento amigável pelo art. 25 (3) da CM-OCDE representa a intenção dos Estados contratantes de manterem a cooperação, coordenação e reciprocidade necessárias para que seja construída uma interpretação harmônica dos termos do acordo de dupla tributação. A questão se tal dispositivo da CM-OCDE possui eficácia técnica para alcançar tal desiderato será analisada mais adiante. No entanto, independentemente de tal questão, é necessário reconhecer que o art. 25 (3) da CM-OCDE escancara aos Estados o dever de empenhar os seus máximos esforços para que obtenham consenso na aplicação do acordo internacional, ainda que não estejam obrigados a ter sucesso.

Por último, mas não menos importante, o art. 3 (2) da CM-OCDE também conduz, em si, à exigência da interpretação autônoma e harmônica. O sentido contextualizado requerido por essa cláusula tem como pressuposto que ambos os Estados participem em

\footnotetext{
${ }^{472}$ BRUGGEN, Edwin van der. Unless the Vienna Convention Otherwise Requires: notes on the relationship between Art. 3 (2) of the OECD Model Tax Convention and art. 31 and 32 of the Vienna Convention on the Law of Treaties, in European Taxation of May 2003. IBFD : Amsterdam, 2003, p. 148-149.

${ }^{473}$ Cf. VOGEL, Klaus. Klaus Vogel on Double Taxation Conventions. Kluwer : London, 1999, p. 41.

${ }^{474}$ Vide: AVERY JONES, John et al., The interpretation of tax treaties with particular reference to article 3(2) of the OECD Model - II. 1984, British Tax Review, p. 95-96.
} 
conjunto na composição do "contexto", de forma que, em tese, interpretariam o acordo de forma harmônica. O art. 3 (2) da CM-EUA, por sua vez, deixa ainda mais expresso que as autoridades competentes devem alcançar uma interpretação harmônica, fazendo menção ao procedimento amigável. ${ }^{475}$

\title{
4.2.3.2.1. Exemplo: a promoção da interpretação harmônica nos tribunais australianos.
}

\author{
"Yet the Agreement must operate uniformly, \\ whether the realty is in the Netherlands or in Australia".
} Caso Lamesa, Austrália (1997)

No Caso Lamesa, (Austrália, 1997), o tribunal australiano julgou que o acordo de dupla tributação Austrália-Países Baixos deveria ser interpretado de forma uniforme por ambos os Estados contratantes.

Para que isso fosse possível, os juízes consignaram que seria necessário afastar fatores que pudessem interferir e desviar os Estados de uma interpretação uníssona. Naquele caso, o tribunal decidiu abstrair se os Países Baixos tributariam ou não os rendimentos do contribuinte, concentrando-se na construção da norma consentida pelos Estados ao celebrarem a convenção fiscal. Se esse fator fosse considerado, consignou o julgador, a Austrália aplicaria o tratado de uma forma e os Países Baixos de outra.

\subsubsection{Dificuldades e objeções empíricas na aplicação da interpretação harmônica.}

Alguns autores refutam a tese da interpretação harmônica pelo argumento de que tal fenômeno dificilmente ocorreria na prática. Nos idos da década de 60, RAOUL LENZ ${ }^{476}$ observou que os objetivos e propósitos de acordos de dupla tributação nem sempre seriam alcançados, pois as autoridades fiscais de ambos os Estados contratantes poderiam se valer de seu poder discricionário de forma divergente, sem que com isso violasse o texto ou o

${ }^{475}$ EDWARDES-KER, Michael. Tax Treaty Interpretation - The International Tax Treaties Service. InDepth Publishing : Athlone, 1995, p. 2-3, Capítulo 5.

${ }^{476}$ LENZ, Raoul. General Report. Cahiers de Droit Fiscal International by the International Fiscal Association (studies on international tax law), volume XLII - Subject II: The interpretation of the Double Taxation Convention. / IFA : Roterdã, 1960, p. 301-302. 
espírito do tratado, contra o que não haveria remédio. Quase 50 anos depois, WiM WIJNEN $^{477}$ coloca em dúvida se o critério da interpretação harmônica seria relevante, pois não há sequer uma Corte Internacional competente para harmonizar as interpretações finais dos acordos de dupla tributação celebrados, bem como lhe parece discutível se a arbitragem internacional possa colaborar para isso.

Note-se que KLAUS VogEL ${ }^{478}$ reconhecia que alguns Estados podem ser resistentes às interpretações autônomas. Ao se submeter à harmonização decisória e deixar de escolher sozinho a "melhor" interpretação, o Estado restringe o seu poder de decisão na aplicação do acordo internacional. Ensina aquele professor que, quanto mais os Estados contratantes apresentarem sistemas jurídicos com tradições diversas, mais a interpretação autônoma se mostraria importante, embora mais difícil se mostraria tal harmonização de fato. Vogel citou como exemplo acordos assinados pela Suíça, segundo os quais, em certas circunstâncias, o domicílio físcal do contribuinte estaria situado no país onde este mantém suas relações mais próximas, os seus laços mais estreitos. Para o autor, seria evidente que a determinação do local onde o indivíduo possui o seu centro de interesses vitais pode dar ensejo a compreensões diversas por parte dos dois Estados contraentes, sem que nenhuma delas seja conduzida de forma arbitrária, dando ensejo a casos de dupla tributação.

Contudo, tais dificuldades não justificam o abandono da idealização da interpretação harmônica entre os Estados. Metaforicamente, se automóveis congestionam as ruas, não se pode simplesmente proibir o seu uso, mas encontrar maneiras de viabilizálo.

As dificuldades para a concretização da interpretação harmônica não devem redundar na desconsideração de tal postulado, mas na concentração de esforços acadêmicos e políticos - para a sua viabilização.

\footnotetext{
${ }^{477}$ WIJNEN, Wim. Some Thoughts on Convergence and Tax Treaty Interpretation, in Tax Treaty Monitor Bulletin for International Taxation (November 2013). IBFD: Amsterdã, 2013, p. 577.

${ }^{478}$ VOGEL, Klaus. Klaus Vogel on Double Taxation Conventions. Kluwer : London, 1999, p. 39-59.
} 


\subsubsection{Interpretações divergentes suportadas pelo Direito tributário internacional.}

Suscita SERGio ANDRÉ RoCHA ${ }^{479}$ que interpretações divergentes entre os Estados contratantes de acordos internacionais podem conduzir ao mútuo entendimento de "ilícito internacional", tendo em vista que tal dissonância pode levar ao inadimplemento das obrigações assumidas. O chamado "interpretative treaty override" fragilizaria ou mesmo afastaria a interpretação harmônica, o que poderia decorrer da atribuição de sentidos a um acordo de dupla tributação que não encontre suporte em seu contexto intrínseco ou extrínseco. Tais divergências interpretativas também poderiam decorrer do recurso ao Direito doméstico, sem a observância adequada das regras estabelecidas pelo art. 3 (2) da CM-OCDE. Tal assertiva, no entanto, não é absoluta, como demonstra o autor.

Assim, é necessário ponderar que nem todos os casos de interpretações divergentes configuram hipóteses de ilícito internacional, especialmente diante da premissa de que não há uma única interpretação correta. Como observou RAOUL LENZ ${ }^{480}$, não haveria nada a se opor diante de duas decisões dos Estados contratantes divergentes entre si, mas igualmente justificáveis. A pedra de toque sobre o tema, então, reside na identificação de critérios jurídicos de justificação das decisões, a fim de que essas cumpram com as expectativas compartilhadas por ambos os Estados contratantes ${ }^{481}$.

Não parece razoável sustentar que a interpretação harmônica, a partir de conceitos autônomos do Direito tributário internacional, seja infalível e tenha conteúdo suficiente para afastar, em todos e quaisquer casos, o recurso dos Estados contratantes aos seus respectivos sistemas internos, ainda que tal ação conduza à frustração dos objetivos e propósitos do acordo ${ }^{482}$. KLAUS VOGEL ${ }^{483}$ recusava-se a aceitar a tese da presunção de reenvio ao Direito interno em relação a todos os termos não definidos no texto do acordo,

\footnotetext{
${ }^{479}$ ROCHA, Sergio André. Interpretação dos tratados para evitar a dupla tributação. São Paulo : Quartier Latin, 2013, p. 160-161.

${ }^{480}$ LENZ, Raoul. General Report. Cahiers de Droit Fiscal International by the International Fiscal Association (studies on international tax law), volume XLII - Subject II: The interpretation of the Double Taxation Convention. / IFA : Roterdã, 1960, p. 301-302.

${ }^{481}$ Nesse sentido: ROCHA, Sergio André. Interpretação dos tratados para evitar a dupla tributação. São Paulo : Quartier Latin, 2013, p. 187 e seg.

${ }^{482}$ ARNOLD, J. Brian. The interpretation of tax treaties: myth or reality, in Bulletin for International Taxation (tax treaty monitor) - january of 2010. IBFD : Amsterdã, 2010, p. 10-11.

${ }^{483}$ VOGEL, Klaus. Klaus Vogel on Double Taxation Conventions. Kluwer : London, 1999, p. 42; 208-209.
} 
mas reconhecia que a interpretação autônoma nem sempre seria possível diante da ausência de elementos suficientes para a sua construção: como consequência inevitável, então, ambos os Estados contratantes poderiam recorrer às suas respectivas legislações domésticas, com a obtenção de sentidos potencialmente diversos aos termos do mesmo acordo e, assim, possivelmente descumprindo o objetivo de evitar a dupla tributação a que se destinava (ou, ainda, redundando em dupla não tributação). O professor alemão ponderou, ainda, que a interpretação harmônica não seria aplicável quando o acordo de dupla tributação remetesse expressamente cada um dos Estados contratantes ao seu próprio Direito doméstico, de tal modo que o sentido atribuído pelo outro Estado contratante passaria a ser irrelevante.

A eficácia jurídica da cláusula do sentido contextualizado também encontra limites nas diferenças culturais e tradições que influenciam, na perspectiva, os juízes e demais operadores das diferentes jurisdições. Se os mesmos dispositivos legais e evidências são interpretados de forma diversa por juízes de uma mesma jurisdição, o que se dirá entre indivíduos com tradições bastante diversas? No entanto, a consideração de evidências comuns certamente aumenta em muito as chances de um mesmo resultado.

A questão, então, é saber se a existência dessas exceções infirma ou confirma a regra. Parece correto compreender que a interpretação harmônica está contida na cláusula geral de interpretação do art. 3 (2) da CM-OCDE, que não se aplica em situações especiais. Em casos excepcionais, a interpretação harmônica não será privilegiada pela inexistência de evidências providas pelo "contexto" referido no art. 3 (2) da CM-OCDE. Em tais casos, com o reenvio ao Direito doméstico e os possíveis conflitos de qualificação daí decorrente, a aplicação uniforme do acordo passa a ser uma questão de sorte.

Em outras situações, nas quais expressa ou implicitamente os Estados reservarem aos seus respectivos Direitos internos o papel de provedor de sentido ao termo do acordo, há consenso dos Estados para que lhes seja reservada a prerrogativa de guiar certos fatores: contudo, a existência de tais casos não afasta a regra de que a interpretação harmônica deve necessariamente estar presente na generalidade dos termos presentes nos acordos de dupla tributação. O inverso é que é a exceção. 


\subsection{Critério material de reconhecimento: a plausividade da interpretação.}

"When we say that something is evidence for something else, on the new theory this assertion needs to be understood as expressing and depending on a triple sequence, a three-place relation bridging the basis stage, the inference stage and de pragmatic stage, that is appealed to. One component is the body of basis evidence itself, some collection of facts or objects or reports. The next component is the conclusion (or conclusions) drawn or proven by inference from this body of evidence - what the evidence shows. The third component is the use of the evidence collected and interpreted in the first two parts. In this regard, the notion of something's being evidence for something else seems comparable to the notion of argument".

DOUGLAS WALTON ${ }^{484}$

Além dos critérios formal e funcional de reconhecimento, para que determinados elementos sejam evidências quanto ao sentido de termos dos acordos de bitributação, devem ser plausíveis. Douglas WALTON ${ }^{485}$ suscita que evidências, inclusive quanto ao sentido de normas jurídicas, seriam mais do que simples argumentos, mas argumentos que se prestam a cumprir funções probatórias em um discurso. A coerência da estrutura adotada por tais argumentos, bem como as premissas adotadas, atribuiriam peso probatório a este.

Como se poderá observar nos Capítulos II, III e IV desta tese, diversas espécies de evidências sob o escopo do "contexto" referido no art. 3 (2) da CM-OCDE têm questionada a sua plausividade como fator de decisão por parte de tribunais nacionais.

\subsubsection{Exemplo: o caso brasileiro da construção de sentido de "business profit" do art. 7 da CM-OCDE conforme o Direito doméstico.}

No Caso Copesul (Brasil, 2012), ao julgar o sentido dos termos "lucro da empresa estrangeira" presentes nos acordos Brasil-Canadá e Brasil-Alemanha, o STJ compreendeu que a interpretação sugerida pelas autoridades fiscais brasileiras não seria plausível e conduziria ao absurdo, devendo ser afastada.

${ }^{484}$ WALTON, Douglas. Legal argumentation and evidence. Pennsylvania Satate Press : Pennsylvania, 2002, p. 202.

${ }^{485}$ WALTON, Douglas. Legal argumentation and evidence. Pennsylvania Satate Press : Pennsylvania, 2002, p. 214 e seg. 


\subsection{Linguagem tributária internacional: requisito fundamental para a seleção de evidências do sentido contextualizado?}

“(...) a language that can be spoken and understood across borders in the interpretation and application of tax treaties; a language of which the growth will largely be determined by the highest national courts." KEES VAN RAAD (1996) ${ }^{486}$

Já em 1935, MitChell B. CARROLL ${ }^{487}$ chamava a atenção para o desenvolvimento de uma "international tax language" (linguagem tributária internacional, "terminologia tributária internacional" "488). A “lingua franca", como prefere KEES VAN RAAD ${ }^{489}$, seria um idioma que poderia ser falado e compreendido por todas as nações na interpretação de acordos de dupla tributação. Atualmente, não

No entanto, nem mesmo o maior dos defensores da linguagem tributária internacional, KLAUS VOGEL ${ }^{490}$, a considerou madura o suficiente para fornecer sentidos autônomos aos termos não definidos no texto dos acordos de dupla tributação. Tratar-se-ia de um processo em andamento, de um projeto em construção ${ }^{491}$.

Mais do que isso, embora encantadora, a tese da linguagem tributária internacional encontra oposições convincentes ao menos para a sua aceitação como critério de seleção de evidências sob o escopo do "contexto" referido no art. 3 (2) da CM-OCDE. Assim como o autor da passagem em epígrafe, reconhece-se, seguindo em especial a posição de KLAUS VOGEL ${ }^{492}$, que as Cortes nacionais seriam os agentes competentes para a construção da linguagem tributária internacional. O problema é que tais Cortes nacionais, a quem caberia o papel fundamental de edificá-la, são heterogêneas por natureza. Há dúvidas se cada um dos juízes dos mais variados Estados seria invidualmente capaz de sustentar uma

\footnotetext{
${ }^{486}$ RAAD, Kees van. Interpretation and Application of Tax Treaties by Tax Courts, in European Taxation January 1996. IBFD : Amsterdã, 1996, p. 7.

${ }^{487}$ EDWARDES-KER, Michael. Tax Treaty Interpretation - The International Tax Treaties Service. InDepth Publishing : Athlone, 1995, cap. 7, p. 1.

${ }^{488}$ Adotando essa nomenclatura: TÔRRES, Heleno Taveira. Pluritributação internacional sobre as rendas das empresas. São Paulo : Revista dos Tribunais, 2001, p. 660.

${ }^{489}$ RAAD, Kees van. Interpretation and Application of Tax Treaties by Tax Courts, in European Taxation January 1996. IBFD : Amsterdã, 1996, p. 7.

${ }^{490}$ VOGEL, Klaus. Klaus Vogel on Double Taxation Conventions. Kluwer : London, 1999, p. 60. Na posição do autor, até que esse processo não se desenvolvesse a contento, seria necessário recorrer à interpretação conforme a lex fori.

${ }^{491}$ Nesse sentido, vide: ROCHA, Sergio André. Interpretação dos tratados para evitar a dupla tributação. São Paulo : Quatier Latin, 2013, p. 193.

${ }^{492}$ VOGEL, Klaus. Klaus Vogel on Double Taxation Conventions. Kluwer : London, 1999, p. 39 e seg.
} 
linguagem tributária internacional, ou, ainda, se os Estados possuiriam interesse na composição dessa língua franca potencialmente restritiva de manobras unilaterais. ${ }^{493}$

Há, ainda, outro fator fundamental que deve ser enfrentado pela tese da linguagem tributária internacional: os acordos de dupla tributação não estariam inseridos em meio a um Direito Internacional tributário "universal”, mas a um Direito tributário internacional “particular”, nos moldes da classificação de LASSA OPPENHEIM ${ }^{494}$.

É certo que a interpretação harmônica se molda perfeitamente ao Direito tributário internacional "particular", em que o acordo de dupla tributação celebrado entre os dois Estados contraentes se encontra inserido. A interpretação harmônica, assim, se mostra um fator de grande relevância para a seleção das evidências que se prestam a determinar o sentido dos termos de acordo de dupla tributação, pois se volta à relação mantida entre os dois Estados contratantes. Já a linguagem tributária internacional tem um escopo muito mais ambicioso: que todos os Estados construam um mesmo sentido a partir de termos semelhantes, adotados em seus diferentes acordos de dupla tributação ${ }^{495}$. Tal concepção se adequaria bem em um Direito Internacional tributário “universal”, o que não é o caso.

Não se pode ignorar que alguns termos têm se tornado linguagem corrente entre os operadores do Direito tributário internacional das mais variadas nações. MiCHAEL EDWARDES-KER ${ }^{496}$ suscita termos da CM-OCDE (1977) que demandariam interpretação autônoma, por comporem uma linguagem tributária internacional, como: "enterprise", "permanent establishment", "fixed base", "business profit" (art. $7^{\circ}$ ), "profits from the operation of ships and aircraft" (art. $8^{\circ}$ ), "associated enterprises" (art. 9"), "special relationship" (art. 11(6) e 12(4)), "interest" (art. 11), "employer" (art. 15), "entertainers" and "sportsmen"497 (art. 17), "student or business apprentice" (art. 20). Em especial, a expressão "beneficial owner" (art. 10, 11 e 12) que sequer possuiria correspondente em

\footnotetext{
${ }^{493}$ Colocando em dúvida a aptidão das Cortes nacionais para a construção da linguagem internacional, vide: WIJNEN, Wim. Some Thoughts on Convergence and Tax Treaty Interpretation, in Tax Treaty Monitor Bulletin for International Taxation (November 2013). IBFD: Amsterdã, 2013, p. 576-577; ROCHA, Sergio André. Interpretação dos tratados para evitar a dupla tributação. São Paulo : Quartier Latin, 2013, p. 147.

${ }^{494}$ OPPENHEIM, Lassa. International Law: A treatise. Volume I (of 2) - Peace. Longmans : Londres, 1912 (Kindle), Introdução, §1.

${ }^{495}$ Em sentido contrário, vide: ROHATGI, Roy. Basic International taxation. Volume 1: principles. Nova Deli : Taxmann, 2005, p. 39.

${ }^{496}$ EDWARDES-KER, Michael. Tax Treaty Interpretation - The International Tax Treaties Service. InDepth Publishing: Athlone, 1994, p. 2-3, Capítulo 7.

${ }^{497}$ A versão de 2014 da CM-OCDE substituiu o termo por Entertainers and "sportspersons".
} 
muitos dos Estados membros da OCDE com tradição no civil law, sendo comum a sua identificação como um caso evidente de linguagem tributária internacional ${ }^{498}$.

A jurisprudência das Cortes nacionais ocasionalmente também faz referência à linguagem tributária internacional. No Caso Ostime (1959), o juiz RADCLIFFE, da House of Lords inglesa, compreendeu que o acordo Reino Unido-Austrália (1946) teria como base a convenção modelo da Liga das Nações. Na posição sustentada pelo juiz RADCLIFFE, a linguagem utilizada no acordo internacional em questão seguiria uma "international tax language", tal como termos como "enterprise", "industrial or comercial profits" e "permanente establishment", que não possuiriam sequer similares no Direito tributário inglês.

No entanto, embora seja correto que o reconhecimento por dois Estados contratantes de tal linguagem internacional tributária resulte na interpretação harmônica do acordo internacional por eles celebrado, o inverso não parece ser igualmente defensável: a interpretação harmônica de determinado termo por dois Estados contratantes não tem como necessária consequência a formação da linguagem internacional tributária. Basta imaginar a situação hipotética em que as Cortes nacionais de dois Estados contratantes ("A" e "B") interpretam determinado termo do acordo de dupla tributação celebrado entre estes ("A-B") de forma integralmente harmônica, divergindo da forma como as Cortes nacionais de uma série de outros Estados ("C", "D", "E") interpretam termos semelhantes nos seus respectivos acordos de dupla tributação ("C-D", "C-E”).

Diante de tais elementos, a presente tese não considera a linguagem tributária internacional requisito fundamental para a seleção de evidências do sentido contextualizado. Não se pode exigir que tais evidências colaborem à composição dessa língua, ou que deem origem a sentidos pertencentes a essa linguagem. Se tais conclusões estiverem corretas, evidências como decisões de Cortes nacionais e Comentários à CMOCDE, cujo apelo geralmente reside em sua suposta função de construção da linguagem tributária internacional, teriam que buscar fundamento em outros critérios, no caso, nos critérios formais e funcionais analisados anteriormente.

\footnotetext{
${ }^{498}$ Nesse sentido, vide: TOIT, Charl du. The Evolution of the Term "Beneficial Ownership" in Relation to International Taxation over the Past 45 Year, in Bulletin for International Taxation Vol. 64, n. 10. Amsterdã : IBFD, 2010, p. 501.
} 


\section{CAPÍTULO II \\ O CONTEXTO INTRÍNSECO DOS ACORDOS DE DUPLA TRIBUTAÇÃO}

\section{NOTAS INTRODUTÓRIAS.}

Após a investigação, no "Capítulo I", de critérios para a identificação de evidências sob o escopo do "contexto" referido no art. 3 (2) da CM-OCDE, a exposição do presente estudo prossegue, neste Capítulo e nos dois subsequentes, com uma pergunta inserida na hipótese analisada nesta tese: quais evidências seriam admissíveis com vistas ao contexto intrínseco, ao contexto extrínseco primário e ao contexto extrínseco secundários dos acordos de dupla tributação?

Neste Capítulo, será examinado o repertório de evidências do contexto intrínseco, a que CARlo GARBARINO ${ }^{499}$ chama de "co-testo", conforme delineado no tópico "2" a seguir. No tópico “4”, por sua vez, serão analisados os materiais que se revestem com tais características no caso dos acordos de bitributação.

O contexto intrínseco, amplamente aceito ${ }^{500}$ como provedor de evidências quanto ao sentido comum contextualizado dos termos dos acordos de dupla tributação, é descrito no art. 31 (1) e (2) da CVDT e compreende o próprio signo linguístico sob interpretação ou outros presentes no texto do tratado, no preâmbulo, nos anexos, bem como em qualquer acordo ou instrumento celebrado pelas partes relativos tratado e em conexão com a sua conclusão.

O texto de um acordo de dupla tributação é o protagonista, pois é especialmente sobre ele e ao seu redor que se desenvolve todo o processo de interpretação e aplicação do

${ }^{499}$ GARBARINO, Carlo. Manuale di tassazione Internazionale. Milão : Kluwer, 2005, p. 175-185.

${ }^{500}$ A rejeição a tais elementos apenas é apresentada por posturas bastante radicais, que consideram o contexto insignificante e, ainda, necessário o reenvio imediato dos termos não definidos no acordo de dupla tributação ao Direito interno dos Estados contratantes, o que padece pela desconsideração de normas fundamentais do Direito tributário internacional. 
Direito tributário internacional. O referido texto deve ser compreendido como autêntica manifestação da intenção dos Estados ${ }^{501}$, não devendo o intérprete lançar-se a uma investigação $a b$ initio para o acesso da íntima intenção das partes. ${ }^{502} \mathrm{O}$ intérprete jamais pode afastar-se dos termos do acordo, já que são justamente esses que estão sob interpretação.

As regras gerais de interpretação veiculadas pela CVDT indicam os elementos textuais como o ponto de partida para a construção de sentido dos termos dos acordos internacionais. Como se viu, contudo, permanecem em discussão questões importantes. Em especial, não é claro a muitos acadêmicos e julgadores se o intérprete poderia cessar o seu trabalho interpretativo caso encontrasse algum sentido razoável a partir de evidências intrínsecas ao texto. Surge daí o questionamento se as evidências intrínsecas teriam prevalência sobre as evidências extrínsecas, de modo a representar o ponto de partida e, quando razoáveis, o ponto final da investigação, como sugere CARLO GARBARINO ${ }^{503}$. Este será o objeto do tópico “3” deste Capítulo.

Dos três "contextos" analisados nesta tese, certamente o contexto intrínseco é o mais reconhecido pela doutrina e jurisprudência de Cortes nacionais, pois nenhuma das correntes geralmente propagadas quanto ao art. 3 (2) da CM-OCDE o repele. No entanto, a elevada aceitação do contexto intrínseco não se traduz necessariamente em seu êxito na construção de sentidos dos termos não definidos nos acordos de dupla tributação.

Diversas decisões de Cortes nacionais, a seguir examinadas, expressamente declaram que elementos do contexto intrínseco seriam importantes no processo interpretativo, mas acabam por não lhes imprimir efeitos práticos. Quando tais tribunais adotam como postura a corrente do contexto exclusivamente intrínseco, a alternativa imediata ao fracasso das evidências intrínsecas é o reenvio ao Direito doméstico. Desse modo, a teoria com contexto intrínseco exclusivo, tal como defendida por FRANK

\footnotetext{
${ }^{501}$ Vide: GARDINER, Richard K. International Law. Pearson : Harlaw, 2003, p. 85 e seg.

${ }^{502}$ Cf. UN. International Law Commission, Yearbook of the International Law Commission, 1966, vol. II. aft Articles on the Law of Treaties with commentarie, p. 220.

${ }^{503}$ GARBARINO, Carlo. Manuale di tassazione Internazionale. Milão : Kluwer, 2005, p. 175-185.
} 
ENGELEN $^{504}$, muitas vezes, torna o art. 3 (2) da CM-OCDE basicamente uma cláusula de reenvio ao Direito doméstico.

No entanto, uma série de outras decisões de Cortes nacionais demonstra que diversas evidências sob o escopo do contexto intrínseco são capazes de fornecer um sentido plausível aos termos não definidos nos acordos de dupla tributação. A utilidade que se pode obter de evidências intrínsecas geralmente depende do dominío de técnicas para manejá-las. Em termos pragmáticos, o advogado do fisco ou do contribuinte, como operador no Direito tributário internacional, terá maior poder de convencimento quanto ao sentido de determinado termo, se fortalecer seus argumentos valendo-se de evidências intrínsecas ao texto do acordo. Para tanto, contudo, é preciso conhecê-las.

A partir dos critérios formais, funcionais e materiais de identificação de evidências sob o escopo do "contexto" referido no art. 3 (2) da CM-OCDE, este Capítulo se dedica à identificação de elementos que possam ser admitidos como evidências e, ainda, técnicas úteis à exploração de tais evidências para a construção do sentido contextualizado de termos dos acordos de dupla tributação. Entre as técnicas que o operador pode recorrer para construir sentidos a partir do contexto intrínseco, serão especialmente examinados: (i) métodos sintáticos e semânticos de interpretação do texto do acordo; (ii) testes comparativos, com vistas à função e ao sentido dos termos no acordo de dupla tributação como um todo e; (iii) a identificação do propósito do acordo a partir de detalhes de cada uma de suas partes: análise do texto do acordo como um todo.

${ }^{504}$ ENGELEN, Frank. Interpretation of Tax Treaties under International Law. Doctoral series n. 7. IBFD : Amsterdam, 2004, p. 149-150. 


\title{
2. HIERARQUiA DE FONTES: A RELAÇÃO DE PREVALÊNCIA ENTRE EVIDÊNCIAS INTRÍNSECAS E EXTRÍNSECAS.
}

\begin{abstract}
"The most rigid adherent of the textual approach would scarcely argue that a tribunal should deliberately seek to establish a meaning which was not within the contemplation, or intention, of any of the parties to the dispute; and the most rigid adherent of the intentions approach would not seek to deny that the text of the treaty will constitute evidence of what was the intent of the parties". IAN SINCLAIR (1973) $)^{505}$
\end{abstract}

É bastante comum encontrar em textos acadêmicos ${ }^{506}$ e em decisões de Cortes nacionais a afirmação de que os elementos do contexto intrínseco corresponderiam ao ponto de partida para a construção de sentido dos acordos de dupla tributação, independentemente da teoria adotada quanto à amplitude do referido "contexto". A ILC$\mathrm{ONU}^{507}$ deixou consignado que o art. 31 (1) da CVDT teria sido inspirado na ideia de que o texto seria a autêntica expressão da vontade das partes e, por consequência, o ponto de partida do intérprete seria a elucidação do sentido de seus termos e não uma investigação $a b$ initio quanto à intenção dos negociadores.

Cortes nacionais de países como Austrália (Caso Lamesa) e Canadá (Caso Saunders) se referem à ideia de "four corners of the actual text" como referência à doutrina de que o ponto de partida para a interpretação dos acordos de dupla tributação está confinado ao texto do acordo. No Caso Gladden (Canadá, 1985), a fim de aplicar o acordo Canadá-EUA, o Tribunal canadense enfatizou que o texto do acordo controlaria o resultado da interpretação.

Sob a teoria do contexto intrínseco exclusivo, é natural que tais elementos textuais sejam o ponto de partida do processo de interpretação, já que também seriam o ponto final, que antecederia o reenvio ao Direito doméstico. No entanto, as demais correntes, que adotam como premissa a consideração de evidências colhidas tanto do contexto intrínseco quanto do contexto extrínseco, devem justificar por que necessariamente tal ordem deve

${ }^{505}$ SINCLAIR, Ian M. The Viena Convention on the Law of Treaties. Manchester University Press : Manchester, 1973, p. 70.

${ }_{506}$ Nesse sentido, vide: ROTHMANN, Gerd W. Interpretação e aplicação dos acordos internacionais contra a bitributação. Tese de doutorado. São Paulo : Faculdade de Direito da Universidade de São Paulo (USP), 1978, p. 108.

${ }^{507}$ ONU. International Law Commission. Reports of the Commission to the General Assembly. Draft Articles on the Law of Treaties with commentaries, pag. 220, n. 11. 
ser observada. Se elementos extrínsecos ao texto podem prover sentidos tanto quanto elementos intrínsecos, por que alguma ordem deve ser adotada pelo intérprete?

A investigação dessa questão pode ensejar ao menos três diferentes posições, examinadas nos subtópicos seguintes, quais sejam: (i) a tese da suficiência do sentido literal "claro"; (ii) a tese da suficiência do sentido "claro" provido por elementos do contexto intrínseco e (iii) a tese de que o contexto intrínseco representa apenas um dos estágios da investigação.

\subsection{A corrente da consideração lexical e da suficiência do sentido literal "claro".}

"Interpretar o tratado internacional significa determinar o exato sentido da norma expressa num texto obscuro, impreciso, contraditório, incompleto ou ambíguo. Não por acaso, o primeiro princípio a nortear esta análise, e que tem raízes na antiguidade romana, é o de que não há por que interpretar o que já está claro e unívoco" JOSÉ FRANCISCO REZEK $(2000)^{508}$

Como já se pôde observar, a corrente da interpretação literal sustenta que o sentido lexical dos termos deve ser considerado suficiente pelo intérprete, caso forneça uma solução razoável ao caso. Dessa forma, o próprio termo, sem a colaboração do contexto intrínseco ou extrínseco, poderia prover, por si próprio, um sentido literal que bastaria ao intérprete. Tal corrente parece valer-se não apenas da análise sintática ${ }^{509}$ do termo, mas também de considerações semânticas, ainda que limitadas à pesquisa em dicionários, bem como pragmáticas, ao valer-se do uso comum das palavras no meio social.

Não é raro encontrar citações doutrinárias e de Cortes nacionais a respeito de qual o sentido dos termos dos acordos de dupla tributação nos dicionários, sejam eles especializados ou gerais. Assim, RAOUL LENZ ${ }^{510}$, no início dos anos 60, observou que o sentido cotidiano de um termo, colhido em dicionários, poderia ser uma evidência interpretativa melhor do que o Direito doméstico dos Estados contratantes, por possibilitar que ambos os Estados aplicassem o acordo de dupla tributação uniformemente. Observou

\footnotetext{
${ }^{508}$ REZEK, José Francisco. Direito internacional público. São Paulo : Saraiva, 2000, p. 90.

${ }^{509}$ De modo até certo ponto diverso, vide: CARVALHO, Paulo de Barros. Curso de Direito Tributário. São Paulo : Saraiva, 2000, p. 105.

${ }^{510}$ LENZ, Raoul. General Report. Cahiers de Droit Fiscal International by the International Fiscal Association (studies on international tax law), volume XLII - Subject II: The interpretation of the Double Taxation Convention. / IFA : Rotterdam, 1960, p. 299-300. No original autor se refere ao "normal significance of a term used in everyday language”.
} 
aquele autor que tal método somente seria recomendável quando o sentido cotidiano do termo provisse uma acurada e generalizada definição. Mais de trinta anos depois, nos anos 90, MichAEL EDWARDES-KER ${ }^{511}$ sustentou que a edificação da linguagem tributária internacional estaria evidenciada pelo surgimento de dicionários especializados, bem como que esses (assim como os dicionários em geral) comporiam o "contexto" dos acordos de dupla tributação. Mais recentemente, é possível identificar tal postura em trabalhos de RoY ROHATGI ${ }^{512}$, ao considerar que o recurso a dicionários pode ser capaz de refletir o sentido contextualizado dos termos das convenções fiscais de forma mais efetiva que o Direito doméstico dos Estados contratantes.

Trata-se, portanto, da assunção de dicionários, comuns ou especializados, como evidência suficiente do sentido contextualizado dos acordos de dupla tributação, baseado essencialmente no sentimento de que a facilidade de acesso a tais materiais por todos os operadores do Direito Internacional possa conduzir à segurança jurídica. ${ }^{513}$

Nos subtópicos a seguir serão analisados exemplos em que tal recurso foi efetivamente adotado por tribunais (“2.1.1” a "2.1.4”), seguindo-se de críticas opostas a tal recurso pela doutrina ("2.1.5"), bem como do reconhecimento de sua utilidade dentro de determinados limites (“2.1.6”). Também serão analisados exemplos de rejeição por tribunais nacionais à adoção de tal recurso de forma exclusiva (“2.1.7”).

\subsubsection{Exemplo: O Caso Falcão.}

No Caso Falcão (Brasil, 2009), o STJ precisou examinar se o sentido dos termos "participantes em diversões públicas” comportaria técnicos de futebol.

É possível observar que alguns julgadores não mencionaram qualquer recurso ao “contexto" referido no art. 2 (2) do acordo Brasil-Japão (equivalente ao art. 3 (2) da CMOCDE), bem como nenhum deles sugeriu o reenvio à legislação brasileira ou mesmo à

\footnotetext{
${ }^{511}$ EDWARDES-KER, Michael. Tax Treaty Interpretation - The International Tax Treaties Service. InDepth Publishing : Athlone, 1994, Capítulo 7, p. 3 e seguintes.

512 ROHATGI, Roy. Basic International taxation. Volume 1: principles. Nova Deli : Taxmann, 2005, p. 49.

${ }^{513} \mathrm{Em}$ oposição a esta ideia: ARNOLD, J. Brian. The interpretation of tax treaties: myth or reality, in Bulletin for International Taxation (tax treaty monitor) - january of 2010. IBFD : Amsterdã, 2010, p. 6.
} 
CVDT. Os ministros parecem ter baseado seus votos em concepções próprias quanto ao sentido corriqueiro, lexical dos termos "participantes em diversões públicas".

Assim, para o Ministro CASTRo MeIRA, no caso do art. 15 do acordo Brasil-Japão, "a hipótese é de atletas e outras atividades incondizentes com a contratação do autor na qualidade de técnico". Acompanhou-o o Ministro Humberto MARTins.

Por sua vez, para a Ministra ElIANA CALMON, "naturalmente que o artista, o atleta, o músico etc. não podem funcionar sozinhos. Precisam de uma equipe de apoio, mesmo quando se apresentam sozinhos para o público". Decorreria daí a "abrangência da norma ao técnico, aquele que faz acontecer o espetáculo público, o partícipe inconteste da diversão, para usar exatamente da expressão da norma".

Não se pode dizer com precisão a quais evidências do contexto intrínseco e extrínseco os julgadores teriam à sua disposição para esse caso específico. No entanto, não se pode deixar de observar a notória existência de evidências extrínsecas a respeito do sentido dos termos em questão. Estudos do CAF-OCDE, estudos doutrinários e decisões de outros outros Estados podem ser citados como exemplos.

\subsubsection{Exemplo: A consulta de dicionários nos tribunais britânicos.}

No Caso Squirrell (Reino Unido, 2005), na qualidade de julgador, JoHN AVERY JONES precisou atribuir sentido aos termos "salaries, wages and other similar remuneration", utilizados no art. 15 do acordo Reino Unido-EUA. Tais termos não se encontravam definidos no texto da convenção, bem como a legislação inglesa não adotava tais palavras.

Nesse seguir, AVERY JONES recorreu ao Shorter Oxford English Dictionary e verificou que "term", referido no art. 3 (2) do acordo Reino Unido-EUA, poderia ser compreendido como "any word or group of words expressing a notion or conception, or denoting an object of thought; an expression (for something)." Ou seja, o reenvio ao Direito doméstico britânico poderia considerar palavras ou expressões contidas neste que, 
embora não fossem idênticas àquelas adotadas na convenção fisscal, expressariam noções ou concepções semelhantes.

Há, no entanto, uma série de outros julgados ingleses em que o recurso a dicionários e à consideração do sentido puramente lexical de termos presentes em convenções fiscais foi rejeitado, como se poderá observar a adiante no Caso Sportsman (Reino Unido, 1998).

\subsubsection{Exemplo: $O$ uso comercial dos termos dos acordos de bitributação.}

No Caso Melford (Canadá, 1981), a fim de aplicar o acordo de bitributação Canadá-Alemanha, o tribunal canadense precisou julgar se o termo juros ("interest") nele adotado compreenderia pagamentos anuais pela contratação de fianças bancárias ("garantee fee").

A Suprema Corte canadense julgou que seria necessário considerar qual sentido o termo "interest" assumiria em seu uso comercial ordinário ("ordinary commercial usage") à época em que o acordo foi celebrado. Consignou-se, então, que tal sentido seria equivalente a pagamento pelo efetivo empréstimo de uma quantia em dinheiro, realizado pelo contratante em razão da utilização do montante principal.

Nesse seguir, ao menos para a aplicação do acordo de bitributação CanadáAlemanha, tal sentido comercial ordinário não poderia ser alterado unilateralmente pelo Canadá, mediante a alteração de sua legislação interna. Essa não foi a única evidência considerada pelos juízes canadenses, mas corroborou com a construção de sentido necessária à solução do caso. 


\subsubsection{Exemplo: A jurisprudência francesa.}

O sistema jurídico francês tornou-se exemplo conhecido na literatura do Direito tributário internacional ${ }^{514}$ de adesão à concepção de que haveria duas categorias de palavras: termos suficientemente claros por si próprios e outros.

Durante muito tempo os tribunais administrativos franceses se recusavam a interpretar termos de acordos de dupla tributação que não fossem claros em si. Tal tarefa, compreendiam os juízes, competeria ao Ministro de Relações Exteriores. No início da década de 90, no entanto, o Conseil d'Etat decidiu que os tribunais poderiam interpretar e aplicar acordos de dupla tributação ainda que os seus termos não fossem, a priori, claros, bem como a interpreção emitida pelo Ministro de Relações Exteriores sequer vincularia o Judiciário $^{515}$.

A transição da jurisprudência francesa pode ser compreendida por diferentes perspectivas. Por um lado, representa o abandono da ideia de que haveria termos suficientemente claros, cujo sentido não dependeria de seu "contexto". Por outro lado, os juízes passaram a assumir mais propriamente o encargo de guardiões do quanto contratato pela França com os seus parceiros internacionais, deixando de aceitar como autêntica a interpretação indicada pelo Ministro de Relações Exteriores.

\subsubsection{Críticas à corrente da consideração lexical e da suficiência do sentido literal "claro". \\ "Muitas vezes se disse que a interpretação termina quando o texto é claro: 'interpretatio cessat in claris'. Mas que um texto é claro, somente se pode dizer quando todas as interpretações razoáveis conduzam a uma mesma solução”. GERD W. ROTHMANN $(1978)^{516}$}

À corrente da interpretação literal pode ser oposta uma série de críticas contundentes, como a lição em epígrafe, de GERD W. RothMANN. Na mesma ordem de ideias, de que o sentido de um termo não pré-existe à sua interpretação, SERGIO ANDRÉ

\footnotetext{
${ }^{514}$ XAVIER, Alberto. Direito tributário internacional do Brasil. Forense : Rio de Janeiro, 2010, p. 134-135.

${ }^{515}$ Sobre o tema, vide: GUTMANN, Daniel. Tax treaty interpretation in France, in Tax treaty interpretation (Org.: Michael Lang). Viena : Linde, 2001, p. 108 e seg.; BAKER, Philip. Double taxation conventions and international tax law. Londres : Sweet \& Maxwell, 1994, par. C-07.

${ }^{516}$ ROTHMANN, Gerd W. Interpretação e aplicação dos acordos internacionais contra a bitributação. Tese de doutorado. São Paulo : Faculdade de Direito da Universidade de São Paulo (USP), 1978.
} 
RocHA $^{517}$ sustenta que, no atual estágio da hermenêutica jurídica, não há espaço para a adoção de posturas como essa, "que desconsidera o contexto dentro do qual se realiza a interpretação, assim como os fins buscados pela norma e sua carga axiológica, uma reminiscência de um formalismo jurídico de matiz napoleônico inalcançável em termos práticos".

Mesmo com olhos ao direito doméstico, a doutrina brasileira rejeita de forma quase unânime a suficiência de interpretações lexicais ${ }^{518}$. RUY BARBOSA NOGUEIRA ${ }^{519}$ associou concepções restritivas aliadas às interpretações puramente lexicais à "arqueologia fiscal": o texto escrito seria naturalmente o ponto de partida, mas cabe ao intérprete "desconfiar se essa clareza verbal não é apenas aparente e contrastá-la por meio de outros métodos, só a aceitando se realmente dela se convencer".

Por sua vez, LUC DE BROE ${ }^{520}$ expressou a sua convicção de que análises puramente gramaticais do texto de um acordo de dupla tributação seriam inapropriadas, advertindo que o recurso às definições providas por dicionários frequentemente geraria confusões. A única e combinada operação de interpretação prevista pela CVDT exigiria uma interpretação menos literal e legalista, apresentando-se, nesse sentido, mais liberal.

Dois outros argumentos são apresentados por esse professor da Universidade de Leuven $^{521}$. Primeiro, ao exigir-se que os acordos internacionais sejam interpretados com boa-fé, requer-se que sejam atribuídas aos seus termos acepções suportadas pelas expectativas compartilhadas por ambos os Estados contratantes, de forma que a interpretação puramente lexical e isolada de seus termos apenas seria pertinente se essa fosse a mútua intenção destes. Conclusão semelhante foi adotada, por exemplo, pela Suprema Corte canadense, no caso Crown Forest (Canadá, 1995).

\footnotetext{
${ }^{517}$ ROCHA, Sergio André. Interpretação dos tratados para evitar a dupla tributação. São Paulo : Quartier Latin, 2013, p.135; 146-147.

${ }^{518}$ Nesse sentido, vide: CARVALHO, Paulo de Barros. Curso de Direito Tributário. São Paulo : Saraiva, 2000, p. 121. Discordando:

${ }^{519}$ NOGUEIRA, Ruy Barbosa. Curso de Direito Tributário. São Paulo, Saraiva, 1995, p. 88-89.

${ }^{520}$ BROE, Luc De. International tax planning and prevention of abuse (doctoral series n. 14). Amsterdã : IBFD, 2007, 244-245.

${ }^{521}$ BROE, Luc De. International tax planning and prevention of abuse (doctoral series n. 14). Amsterdã : IBFD, 2007, 245-247.
} 
Em segundo lugar, acordos de dupla tributação não trariam consigo o mesmo grau de precisão e detalhadamento geralmente observado na legislação doméstica. Ao contrário, os modelos de acordos de dupla tributação exigem a adoção de terminologias e estilos mais generalistas, aptos a se moldar aos mais diferentes Estados e - como a emenda de tratados é algo problemático - que suportem por um longo período as alterações que possam ocorrer nesses sistemas jurídicos internos. Tais fatores justificam a utilização de termos nos acordos de dupla tributação que, muitas vezes, sequer são conhecidos no sistema jurídico interno dos Estados contratantes.

$\mathrm{O}$ argumento de que o princípio da segurança jurídica exigiria essa interpretação restritiva também não foge às críticas. BRIAN J. ARNOLD ${ }^{522}$ opõe que, embora a segurança jurídica deva ser considerada, questões como consistência, justiça, razoabilidade $e$ praticabilidade podem apresentar ainda mais relevância. Para o professor, a consideração lexical estrita poderia conduzir a resultados absurdos, como ocorre em alguns Comentários à CM-OCDE. DANIEL GUTMANN ${ }^{523}$ também opõe severas críticas a esta tese, ao constatar que a jurisprudência do Conseil $d^{\prime}$ Etat francês, ao procurar seguí-la, alternou a problemática para a identificação de situações em que o termo seria ou não suficientemente claro: o problema não teria sido solucionado e outros teriam sido criados. Também sob essa perspectiva, EKKEHART REIMER ${ }^{524}$ aduz que a tese apenas transportaria a discussão a um nível mais linguístico, sem necessariamente trazer soluções, bem como reclamaria por um teste tão estrito que apenas evitaria o recurso a outras evidências quando não restasse qualquer dúvida ou ambiguidade quanto ao termo em questão.

Além disso, tal postura pode ser inconsistente com o fato de que toda linguagem, por definição, apresenta certa indeterminação: palavras não possuem um sentido único, absoluto ou objetivo, requerendo interpretação para que se determine o seu sentido em cada situação em que é utilizada. Parece irrefutável que o intérprete não deve procurar pelo sentido literal e isolado dos termos presentes no acordo de dupla tributação. O símbolo sob interpretação necessariamente estará relacionado com a sentença em que está inserido, com o dispositivo por completo, com todo o restante do texto do acordo, bem como em

\footnotetext{
${ }^{522}$ ARNOLD, J. Brian. The interpretation of tax treaties: myth or reality, in Bulletin for International Taxation (tax treaty monitor) - january of 2010. IBFD : Amsterdã, 2010, p. 3, 6-7.

${ }^{523}$ GUTMANN, Daniel. Tax treaty interpretation in France, in Tax treaty interpretation (Org.: Michael Lang). Viena : Linde, 2001.

${ }^{524}$ REIMER, Ekkehart. Interpretation of tax treaties - Germany. European Taxation. IBFD, 1999 (December).
} 
uma série de evidencias extrínsecas ao texto. Deve ser recusada uma interpretação lexical, enciclopédica, que não traga consigo o espírito que motivou a celebração do acordo de dupla tributação (objetivos e propósitos). ${ }^{525}$

Considerando que quaisquer das evidências sob o escopo do "contexto" referido no art. 3 (2) da CM-OCDE devem ser válidas perante o Direito tributário internacional, bem como a necessidade de promover o efeito útil e a interpretação harmônica, realmente parece não haver fundamento para o recurso exclusivo a dicionários, sejam eles genéricos ou especializados. De início, a ausência de consentimento de quaisquer dos Estados contratantes - fonte formal por excelência do Direito Internacional - torna possível que os sentidos indicados por dicionários não coincidam ou mesmo que sejam estranhos ao Direito tributário internacional; faltam-lhes, portanto, o critério formal adotado nesta tese. EKKEHART REIMER ${ }^{526}$ observa que as Cortes alemãs algumas vezes se referem a grandes dicionários para fazer referência ao sentido ordinário de certos termos; contudo, quanto mais complicado e artificial o termo se apresente, menor será a possibilidade de se encontrar um sentido ordinário, razão pela qual esse recurso seria insatisfatório.

$\mathrm{Na}$ composição da norma do acordo de dupla tributação, a afirmação de que determinado termo possui um claro sentido literal somente surge ao final do processo de interpretação, mas não é pressuposto. Qualquer termo presente no texto de acordo internacional, ainda que pareça claro, deve ser analisado em seu contexto, considerando o objetivo e propósito que vocaciona cumprir. A conclusão obtida após essa análise pode até ser a mesma que se compreenderia como clara a partir de sua literalidade, mas isso não afasta o processo de interpretação envolvido. ${ }^{527}$

Ainda que as normas de interpretação de tratados veiculadas pela CVDT não sejam vocacionadas a codificar o ato cognitivo do intérprete, possuem cogência suficiente para afastar o operador do Direito tributário internacional do sentido puramente lexical, comum ao dia a dia dos interloculores de algum dos Estados contratantes, quando houver

${ }^{525}$ BRUGGEN, Edwin van der. Unless the Vienna Convention Otherwise Requires: notes on the relationship between Art. 3 (2) of the OECD Model Tax Convention and art. 31 and 32 of the Vienna Convention on the Law of Treaties, in European Taxation of May 2003. IBFD : Amsterdam, 2003, p. 147-148.

${ }_{526}$ REIMER, Ekkehart. Interpretation of tax treaties - Germany. European Taxation. IBFD, 1999 (December), p. 459.

${ }^{527}$ Vide: SINCLAIR, Ian M. The Viena Convention on the Law of Treaties. Manchester University Press : Manchester, 1973, p. 116; EDWARDES-KER, Michael. Tax Treaty Interpretation - The International Tax Treaties Service. In-Depth Publishing: Athlone, 1995, p. 3, cap. 4. 
evidências intrínsecas ou extrínsecas de que os termos em questão assumem sentidos diversos em função do contexto em que estão inseridas. Na verdade, busca-se construir sentidos contextualizados dos termos dos acordos de dupla tributação, o que reclama a análise de todo o seu pano de fundo (contexto intrínseco e extrínseco).

Desse modo, como a construção de sentido contextualizado dos termos dos acordos de dupla tributação deve considerar a única e combinada operação de interpretação prevista pela CVDT, o sentido literal de determinado termo apenas poderia ser acolhido pelo intérprete caso as demais evidências do contexto corroborassem com tal conclusão.

O sentido contextualizado parece o único adequado para a promoção do efeito útil dos acordos de dupla tributação por questões muito objetivas, relacionadas à sofisticação, tecnicidade e singularidade dos temas sob o seu escopo. Soma-se a isso que a investigação da origem semântica de determinados termos presentes em um específico acordo de dupla tributação - o que poderia ser provido por dicionários especializados e enciclopédias - não é conclusivo quanto ao consentimento transmitido por parte dos dois Estados contratantes em questão. Assim, por exemplo, como não se pode assumir - pois de fato assim não o é que cada um e todos os interlocutores, negociadores e, em especial, legisladores, possuem total domínio quanto às informações técnicas e históricas relacionadas aos primórdios de um determinado termo, tais materiais apenas se mostrariam determinantes para a solução de um caso concreto na presença de evidências quanto ao consentimento dos Estados em adotá-los.

Os dicionários, especializados ou não, não são capazes de garantir a promoção do efeito útil do acordo de dupla tributação, por não estarem conectados aos seus objetivos e propósitos. Ocorre que a sofisticação, tecnicidade e singularidade dos temas envolvidos em convenções fiscais tornam os seus termos extremamente artificiais, de tal forma que tais dicionários não são capazes de exprimir suficientemente o seu sentido. Mesmo que se recorra a dicionários especializados ${ }^{528}$ - como o "IBFD Tax Glossary" 529 - e se localize o verbete correspondente, não se teria uma solução conclusiva. Tal simplificação, infelizmente, não funcionaria satisfatoriamente.

\footnotetext{
${ }^{528}$ Cf. EDWARDES-KER, Michael. Tax Treaty Interpretation - The International Tax Treaties Service. InDepth Publishing : Athlone, 1994, p. 3, Capítulo 7.

${ }^{529}$ IBFD. International Tax Glossary. (B. Larking, Ed.) Amsterdã: IBFD, 2005.
} 
Diversos julgados de Cortes norte-americanas ${ }^{530}$ evidenciam a necessidade de se investigar elementos intrínsecos e extrínsecos do contexto dos acordos de dupla tributação, ainda que o sentido literal de determinado termo aparente ser claro e não conter ambiguidades. Decisões como essas levaram autores como STANLEY I. KATZ ${ }^{531}$ a sustentar que a interpretação literal costuma ser o ponto de partida para a aplicação dos acordos de dupla tributação, mas geralmente as Cortes norte-americanas procurariam também analisar o "contexto" (intrínseco e extrínseco), incluindo os objetivos e propósitos dos dispositivos interpretados e do tratado como um todo, a fim de determinar o sentido adequado ao acordo firmado entre as partes.

\subsubsection{A utilidade de dicionários na interpretação de acordos de dupla tributação.}

Embora não sejam conclusivos, os dicionários possuem alguma utilidade. Não se pode afastar a possibilidade de outras evidências do contexto extrínseco conduzirem à necessidade da consideração de dicionários como evidência do sentido contextualizado do acordo de dupla tributação. É o que se daria, por hipótese, se trabalhos preparatórios portanto, uma evidência do contexto extrínseco secundário - demonstrassem que os negociadores recorreram à edição de um determinado dicionário para conduzirem as suas negociações, diante de um impasse quanto ao termo em questão.

$\mathrm{O}$ art. 33 da CVDT estabelece que, quando um tratado for autenticado em duas ou mais línguas, seu texto fará igualmente fé em cada uma delas, a não ser que as partes concordem que, em caso de divergência, um deles deve prevalecer. A linguagem natural, que constitui a base para os idiomas em que os acordos de dupla tributação são celebrados, certamente é importante: é preciso compreender os códigos de linguagem do idioma do tratado para interpretá-lo.

Note-se que, embora o art. 33 (3) da CVDT estabeleça a presunção de que os termos do tratado têm o mesmo sentido nos textos autênticos elaborados em diferentes

${ }^{530}$ Nesse sentido, vide: Casos The Great West, Maximov.

${ }^{531}$ KATZ, Stanley I. United States National Report. Cahiers de Droit Fiscal International by the International Fiscal Association (studies on international tax law), volume LXXVIIIa - Subject I. Interpretation of double taxation conventions. Kluwer Law and Taxation Publishers / IFA : Rotterdam, 1993, p. 629 e seg. 
idiomas, o parágrafo seguinte desse dispositivo afasta o caráter determinante de qualquer um desses textos, salvo previsão expressa em sentido contrário. O art. 33 (4) da CVDT prevê que, "quando a comparação dos textos autênticos revela uma diferença de sentido que a aplicação dos artigos 31 e 32 não elimina, adotar-se-á o sentido que, tendo em conta o objeto e a finalidade do tratado, melhor conciliar os textos."

Assim, não se discute a utilidade de dicionários para esclarecer dúvidas quanto a essa linguagem natural, mas isso não significa dizer que tais evidências sejam determinantes ou conclusivas, especialmente diante das peculiaridades técnicas que os termos utilizados em convenções fiscais trazem consigo em cada caso.

Outra exceção à recusa da consideração exclusivamente lexical dos termos dos acordos de dupla tributação poderia ser verificada com tal remissão expressa, incluída no texto do acordo de dupla tributação, em seu preâmbulo, anexos ou demais elementos do contexto intrínseco. Contudo, trata-se apenas de divagação teórica, pois não se tem notícia da adoção de tal claúsula em nenhum acordo de dupla tributação.

Desse modo, não se afasta de forma absoluta a possibilidade do recurso a dicionários, genéricos ou especializados. Não se pode recusar a possibilidade de que tais materiais passem a compor o contexto de um acordo de dupla tributação, em determinadas circunstâncias. As críticas apresentadas à tese da consideração lexical e da suficiência do sentido literal "claro" se voltam à descontextualização do produto da interpretação assim conduzida.

\subsubsection{A recusa da aplicação da teoria da consideração lexical dos termos dos acordos de bitributação pelos tribunais}

Alguns exemplos, colhidos de decisões de tribunais nacionais, demonstram a recusa da interpretação lexical como meio suficiente para a interpreção dos acordos de bitributação. Embora tal expediente naturalmente faça parte do processo interpretativo, é corrente no tribunal de diversas jurisdições tratar-se de apenas um estágio deste. 


\subsubsection{Exemplo: A experiência brasileira e os riscos da consideração lexical dos termos das convenções fiscais.}

Em dicionários da língua portuguesa, a exemplo do Michaelis ${ }^{532}$, o termo "lucro" é definido como "ganho que se obtém de qualquer especulação, depois de descontadas as despesas; ganho líquido", tendo como antônimo o termo "prejuízo”.

No Caso Copesul (Brasil, 2012), o fisco sustentou que os "business profit" ("lucro da empresa"), contidos no art. $7^{\circ}$ dos acordos de dupla tributação, deviam ser compreendidos em seu sentido literal, o qual supostamente corresponderia a "lucro líquido" ou "lucro real" na legislação brasileira do imposto de renda.

Ao julgar a questão, consignou o Min. CAStro MeIRA, do STJ, que "na prática, quando os rendimentos são disponibilizados e devem ser submetidos à tributação, o Fisco quase sempre adota uma interpretação literal e restritiva das normas convencionais, o que culmina com a não aplicação do acordo". No caso, tal literalidade foi rejeitada, a fim de que "lucros da empresa" tenha a acepção de receita bruta da venda de bens e da prestação de serviços ("lucro operacional").

A decisão do STJ no Caso Copesul possui efeitos apenas entre as partes e não vincularia a administração fiscal. Contudo, esse julgamento forneceu fundamentos para a publicação do Parecer PGFN/CAT n. 2363/2013, em que se reconhece a necessidade dos agentes fiscais abandonarem a interpretação lexical até então empreendida, de modo a interpretar "lucros das empresas" conforme o seu contexto.

532 Último acesso em $9 / 12 / 2014, \quad$ no endereço etrônico:




\subsubsection{Exemplo: Os tribunais canadenses e a rejeição da consideração lexical dos termos das convenções fiscais.}

No Caso Cruikshank (Canadá, 1977), o tribunal canadense foi provocado a determinar o sentido do termo "pension", utilizado no art. 11 do acordo de bitributação Canadá-França (equivalente ao art. 18 da CM-OCDE), mas não definido em seu texto. A questão seria saber se um único pagamento (“lump sum payment”), realizado por uma companhia canadense a um residente da França, estaria compreendido no conceito de pensão ("pension"). Se assim fosse, apenas o fisco francês poderia tributá-lo.

Sob o argumento do fisco canadense, contudo, o sentido lexical provido por dicionários ("the ordinary dictionary or lexicon meaning") ao termo "pension" não incluiria tais modalidades de pagamentos (“lump sum payment”).

$\mathrm{Na}$ visão do juiz GIBSON, acompanhado por seus pares, o termo "pension", tal como adotado no art. 11 do acordo Canadá-França, deveria ser interpretado de forma mais ampla que rendimentos periódicos (“...should be given a wider meaning than its lexicon meaning"), ainda que a legislação canadense adotasse qualificação mais estrita.

\subsubsection{Exemplo: a rejeição do sentido lexical do termo "payable" do acordo de dupla tributação Reino Unido-França.}

No Caso Sportsman (Reino Unido, 1998), como evidência quanto ao sentido do termo "payable" inserto no acordo de dupla tributação Reino Unido-França, o contribuinte recorreu aos dicionários "The Oxford English Dictionary" e "Chambers", os quais remeteriam à concepção de valores que poderiam vir a ser pagos ("that is to be paid, due or owing" e "that may or should be paid").

O tribunal inglês, contudo, não admitiu que dicionários fossem utilizados como evidências quanto ao sentido do referido termo, distinguindo o sentido contextualizado do mero sentido lexical. A decisão declara que o sentido contextualizado, requerido pela CVDT, não equivale a definições de dicionários, já que o sentido de cada termo seria 
dependente de sua posição na frase em que está inserido e da função que tal frase exerce sobre o texto como um todo.

Não apenas a CVDT afastaria a consideração lexical dos termos dos tratados internacionais, mas os precedentes dos tribunais ingleses conduziriam aos mesmos resultados. O Caso Fothergill (Reino Unido, 1981), analisado no início do Capítulo II, também foi indicado no Caso Sportsman como fundamento para a rejeição de dicionários ou de outros meios que se limitariam a fornecer interpretação demasiadamente literais.

\subsubsection{Exemplo: o sentido do termo "exchange" referido no 26 (3) do acordo de bitributação Canadá-França.}

No Caso Pacific Network (Canadá, 2002), o contribuinte alegou que o termo "exchange" presente no artigo 26 do acordo Canadá-França, atinente à troca de informações entre os Estados contratantes, deveria ser interpretado em seu sentido literal, de tal modo que as autoridades fiscais canadenses apenas poderiam fornecer aos franceses informações que já possuíssem; para que as autoridade fiscais canadenses pudessem ou tivessem que empreender esforços especialmente para a coleta de tais informações, tal fator deveria estar expresso no texto do acordo internacional.

Para atribuir peso a tal argumento, seus advogados levaram à análise do tribunal canadense evidências do contexto extrínseco, a exemplo de parallel treaties: em outras convenções fiscais, em que o Canadá teria se comprometido a obter informações de interesse do outro Estado contratante, a exemplo do acordo Canadá-EUA, teria sido adotada a fórmula literal "endeavour to obtain the information"; já nas convenções fiscais em que apenas o termo "exchange" tenha sido utilizado, como no acordo Canadá-França, apenas informações já detidas pelas autoridades fiscais francesas poderiam ser fornecidas. Sob a perspectiva do contribuinte, restaria demonstrado por meio de parallel treaties, então, que o sentido literal teria sido o consentido pelos Estados contratantes, de forma que o fisco canadense apenas poderia fornecer aos EUA informações que já possuísse.

No entanto, o tribunal canadense julgou que acordos de dupla tributação demandariam interpretação liberal e não literal, concluindo que o acordo Canadá-EUA 
obrigaria as autoridades fiscais a empenhar esforços para obter informações solicitadas pelo outro Estado contratante e que ainda não estivessem em seu poder.

Julgou-se que o contexto intrínseco não seria suficiente para prover um sentido plausível, conduzindo à conclusões contraditórias, enquanto que outras evidências, fornecidas pelo contexto extrínseco, conduziriam a resultados mais plausíveis, como se examinará adiante.

\subsection{A corrente da suficiência do sentido "claro" provido por elementos do contexto intrínseco.}

"Nell'attuare l'interpretazione, quindi, il riferimento va fatto prima al testo (significato ordinário ex art. 31, comma 1), e poi gradualmente secondo le necessità al 'co-testo' (art. 31, comma 2, lett. a) e b)), al 'contesto in senso stretto' (art. 31, comma 3), ed infine al 'contesto in senso lato' (art. 31, comma 3)". CARLO GARBARINO $(2005)^{533}$

Em uma segunda perspectiva, não o sentido literal do termo em si, mas as evidências do contexto intrínseco seriam consideradas suficientes caso se mostrassem razoáveis a priori. Ou seja, a existência do sentido "claro" de um termo, provido por elementos de seu contexto intrínseco, colocaria fim à atividade do intérprete. Sob tal postura, não se toma o termo em completa abstração, como o faz a corrente anterior, mas se considera o texto como todo, com todos os elementos textuais em seu entorno. Tal teoria foi acolhida pela jurisprudência de uma série de jurisdições nas últimas décadas, além de também ter sido objeto de análise por organismos internacionais de julgamento.

Autores como STARKE \& SHEARER ${ }^{534}$ parecem desconsiderar a única e combinada operação de interpretação estabelecida pela CVDT. Os autores identificam nesse tratado multilateral o mandamento para que tanto as evidências extrínsecas primárias quanto as secundárias sejam acessadas pelo intérprete tão somente na hipótese de as evidências intrínsecas não se mostrarem aptas a fornecer sentidos isentos de ambiguidades ou obscuridades.

\footnotetext{
${ }^{533}$ GARBARINO, Carlo. Manuale di tassazione Internazionale. Milão : Kluwer, 2005, p. 172. Grifamos.

${ }^{534}$ STARKE, JOSEPH GABRIEL.; SHEARER, I.A. Starke's international law. Butterworths : Canada, 1994, p. 437-438.
} 
Para CARLO GARBARINO ${ }^{535}$, como se pode observar na passagem em epígrafe, haveria uma relação de progressividade para o acesso aos três contextos analisados nesta tese. O intérprete procuraria por evidências quanto ao sentido contextualizado de um determinado termo em seu contexto intrínseco ("co-testo") e, caso não as encontrasse, poderia recorrer ao contexto extrínseco primário ("contesto in senso stretto"). Progressivamente, caso esse segundo passo não fosse suficiente para prover um sentido contextualizado, o intérprete poderia finalmente recorrer ao contexto extrínseco secundário ("contesto in senso lato"). O professor italiano suscita que tal forma de aplicar a CVDT traz consigo traços de uma teoria formalística.

$\mathrm{Na}$ doutrina brasileira, HELENO TôRRES ${ }^{536}$ acompanha o entendimento de GARBARINO, indicando que o contexto extrínseco dos acordos de bitributação apenas seria acessado quando necessário, ou seja, quando o contexto intrínseco ("interpretação intratextual") não fornecer por sí só um sentido aos termos das convenções fiscais.

\subsubsection{Exemplo: O Caso Falcão.}

"O técnico de futebol - função exercida pelo ora recorrente - está inserido na definição de 'participante em diversão pública'., Min. HeRman BENJAMIN (2009)

Os votos apresentados no Caso Falcão (Brasil, 2009) não fornecem apenas exemplos da consideração do sentido dos termos si dos acordos de bitributação, como se viu acima. O contexto intrínseco dos termos "participantes em diversões públicas" também foi utilizado como evidência para a interpretação sustentada nesse julgamento.

De acordo com o Min. Herman Benjamin, a compreensão da expressão "participantes em diversões públicas" exigiria o exame da estrutura do art. 15 (correspondente ao art. 17 da CM-OCDE). Tal análise conduziria à conclusão que o sentido daquela expressão comportaria técnicos de futebol, pois embora o dispositivo faça referência a artistas de teatro, cinema, rádio ou televisão, e músicos, bem como por

\footnotetext{
${ }^{535}$ GARBARINO, Carlo. Manuale di tassazione Internazionale. Milão : Kluwer, 2005, p. 176.

${ }^{536}$ TÔRRES, Heleno Taveira. Pluritributação internacional sobre as rendas das empresas. São Paulo : Revista dos Tribunais, 2001, p. 639-641.
} 
atletas, tal relação é antecedida das palavras "tais como", o que demonstraria o caráter exemplificativo desse rol.

\subsubsection{Exemplo: Os tribunais ingleses e a rejeição da corrente da suficiência do sentido "claro" provido por elementos do contexto intrínseco.}

Os tribunais ingleses naturalmente não recusam a importância do contexto intrínseco no processo de interpretação dos termos das convenções fiscais. No entanto, os casos analisados a seguir demonstram que os julgadores ingleses também não se contentam com o sentido construído a partir de tais evidências, inquirindo pelo contexto extrínseco para conclusão desse processo interpretativo.

No Caso Exxon (Reino Unido, 1960), embora o juiz tenha demonstrado aderência à corrente da suficiência do sentido provido pelo contexto intrínseco, recorreu ao contexto extrínseco para a solução da questão.

Por um lado, os elementos textuais indicariam que aos termos "resident of the other Contracting Party”, adotados na segunda sentença do art. 15 do acordo Reino UnidoEUA, deveriam ser atribuídos ao sentido fornecido pela cláusula de definição de "residente" daquela convenção fiscal. Por outro lado, tal interpretação tornaria parte do dispositivo sem utilidade, de forma a reclamar por evidências colhidas do contexto extrínseco capazes de lhe atribuir efeitos úteis.

Também no Caso Banco do Brasil/Commerzbank (Reino Unido, 1990), o tribunal inglês julgou que, embora o primeiro passo a ser adotado diante do texto de uma convenção fiscal seja considerar o sentido claro de seus termos ("It is necessary to look first for a clear meaning of the words used in the relevant article of the convention"), interpretações puramente literais poderiam se mostrar obviamente inconsistentes com os propósitos de dispositivos específicos ou do acordo como um todo. 


\subsubsection{Exemplo: o sentido do termo "person" referido no art. 26 (3) do acordo de bitributação EUA-Reino Unido.}

No Caso Stuart (EUA, 1999), a tese de que o sentido claro provido pelo contexto intrínseco ao termo deveria ser considerado suficiente foi tratada de forma explícita.

A Suprema Corte norte-americana foi unânime na compreensão de que as evidências do contexto intrínseco do acordo de dupla tributação EUA-Canadá indicavam que as autoridades fiscais deveriam obter informações bancárias em sua jurisdição e transmití-las às autoridades canadenses, independentemente da existência de procedimento criminal em andamento no Canadá. Aquele Tribunal, no entanto, se dividiu quanto à necessidade - ou mesmo admissibilidade - da consideração do contexto extrínseco quando evidências intrínsecas se mostraram suficientemente esclarecedoras ao julgador.

Enquanto o juiz BRENNAN, acompanhado da maioria de seus pares, consignou a necessidade de aprofundamento da investigação e a consideração de elementos extrínsecos de forma ampla, os juízes KENNEDy e O'CONNOR e, em especial, SCALIA, opuseram que, como os elementos intrínsecos seriam suficientes para a solução da questão em análise, não haveria fundamento para empreender novos esforços para a investigação da intenção dos Estados contratantes; para aqueles juízes, haveria razões para evitar tal empreitada.

Coube ao juiz SCALIA a fundamentação mais extensa de que apenas quando os dispositivos de um tratado se mostrassem ambíguos seria apropriado dar atenção aos elementos extrínsecos ao texto. A questão não seria quanto à relevância da intenção dos Estados contratantes; esse fator, sem dúvida, seria relevante para os julgadores. A questão crucial seria se, quando o texto do acordo - cuidadosamente celebrado e solenemente ratificado - se mostrasse claro, seria mais adequado reconstruir tais intenções a partir do próprio texto em questão ou poderia o intérprete abandonar tal clareza textual, para procurar pela "genuína intenção" contida no acordo. Para o juiz SCALIA, não seria apropriado desviar-se da clareza do texto de um acordo de dupla tributação, ainda que existissem evidências quanto à intenção diversa dos Estados contratantes. Também não seria aconselhável prosseguir com a análise de elementos extrínsecos com o propósito de confirmar o sentido construído a partir do texto, quando este já se mostrasse suficientemente claro. 


\subsection{O contexto intrínseco como apenas um dos estágios da investigação.}

"Every text, however clear on its face, requires to be scrutinised in its context and in the light of the object and purpose which it is designed to serve. The conclusion which may be reached after such a scrutiny

in most instances, that the clear meaning which originally presented itself is the correct one, but this should not be used to disguise the fact that what is involved is a process of interpretation" IAN SINCLAIR (1973) $)^{537}$

As duas correntes analisadas nos subtópicos anteriores enfrentam críticas por divergirem da forma aberta com que o conhecimento humano se desenvolve, de modo que muitas vezes são consideradas não realísticas. Outra objeção, ainda, é que as teorias antecedentes divergem da própria forma como o Direito Internacional normatiza a matéria: as regras de interpretação da CVDT estabelecem o que foi chamado pela ILC-ONU de única e combinada operação de interpretação ("a closely integrated single rule of interpretation"), que requer a construção de sentidos contextualizados a partir de evidências do contexto intrínseco e extrínseco dos termos interpretados.

Há também o outro lado da moeda: embora também seja necessário examinar o contexto extrínseco, não se pode ignorar o contexto intrínseco. CHARL DU TOIT ${ }^{538}$ critica decisões de Cortes nacionais que abandonam por completo a análise de evidências intrínsecas dos acordos de dupla tributação e recorrem diretamente aos sentidos providos pelos Comentários à CM-OCDE para a interpretação de expressões como beneficiário efetivo ("beneficial ownership").

O operador do Direito tributário internacional não deve cessar a sua atividade interpretativa diante do sentido literal ou lexical de determinado termo ou, ainda, com a análise de seu contexto intrínseco, mesmo que tenha obtido um sentido a priori claro e razoável. A CVDT exige que o intérprete considere tanto evidências do contexto intrínseco quanto do contexto extrínseco. Ao final, nada impede que aquele sentido provido por evidências intrínsecas seja acolhido, mas tal conclusão apenas estará conforme o Direito

${ }^{537}$ SINCLAIR, Ian M. The Viena Convention on the Law of Treaties. Manchester University Press : Manchester, 1973, p. 72-73.

538 TOIT, Charl du. The Evolution of the Term "Beneficial Ownership" in Relation to International Taxation over the Past 45 Year, in Bulletin for International Taxation Vol. 64, n. 10. Amsterdã : IBFD, 2010, p. 505. 
tributário internacional caso também seja suportada pelas evidências extrínsecas disponíveis no caso concreto. ${ }^{539}$

Como se pôde analisar, a afirmação de que o contexto intrínseco é o ponto de partida para a interpretação dos acordos de dupla tributação, bem como a sua inserção no topo da relação de evidências prescrita pela CVDT, se justifica apenas por uma questão pragmática: os elementos textuais são os primeiros a que o intérprete se depara. No entanto, da adoção dessa sequência natural não decorre qualquer consequência hierárquica a priori entre as evidências colhidas em quaisquer desses estágios, bem como não está o intérprete autorizado a encerrar a sua investigação com as evidências intrínsecas ou, o que seria pior, imediatamente com o sentido lexical de determinado termo.

Sob tal perspectiva, o contexto intrínseco deve ser considerado como apenas um dos estágios da investigação: embora possa ser o ponto de partida, está longe de ser o ponto final.

É necessário concordar que essa terceira postura teórica é a mais adequada ao Direito tributário internacional. Sob a cláusula do "contexto" do art. 3 (2) da CM-OCDE, os elementos do contexto intrínseco correspondem ao ponto de partida para o levantamento de evidências quanto ao sentido comum contextualizado dos acordos de dupla tributação. O ponto final de tal labor, no entanto, exige ainda que se percorra uma série de outros elementos do contexto intrínseco primário e secundário, analisados nos Capítulos III e IV desta tese.

Os tópicos seguintes deste Capítulo se dedicam à investigação de evidências sob o escopo do art. 31 (2) da CVDT - com validade, portanto, perante Direito tributário internacional - e que se mostrem apta à promoção do efeito útil e da interpretação harmônica entre os Estados contrantantes. Dois fatores em especial serão investigados: (i) a identificação de elementos que possam ser admitidos como tais evidências e; (ii) a exploração dessas evidências para a construção do sentido contextualizado de termos do acordo de bitributação.

\footnotetext{
${ }^{539}$ Nesse sentido, vide: BECERRA, Andrés González. The interpretational approaches to the Vienna Convention - application to (tax) treaty analysis, in Bulletin for International taxation - setembro 2011. IBFD : Amsterdam, 2011, p. 4-5.
} 


\subsubsection{Exemplo: A interpretação holística nos tribunais australianos}

Os tribunais australianos fornecem exemplo interessante da interpretação holística, em que o contexto intrínseco aparece como o estágio inicial da investigação, mas não representa o seu ponto final.

O Caso Lamesa (Austrália, 1997) expõe a adesão dos tribunais canadenses à interpretação holística dos acordos de bitributação, a qual o tribunal considerou ser coerente com a única e combinada operação de interpretação prevista no art. 31 da CVDT.

No Caso McDermott (Austrália, 2005), para a interpretação do acordo AustráliaSingapura, o tribunal canadense consignou que seria necessário considerar os "four corners of the actual text", de forma a atribuir primazia ao seu texto, que representaria a autêntica intenção das partes contratantes.

Nesse seguir, os juízes australianos observaram que o texto do art. 10 da convenção (equivalente ao art. 12 da CM-OCDE) transparecia a intenção das partes em não considerar como royalties situações sob o escopo do art. $5^{\circ}$ (equivalente ao art. 7 da CM-OCDE) quando o bem do qual se originar os rendimentos que geralmente seriam tributados como royalties estiver efetivamente conectado à atividade exercida por um estabelecimento permanente.

No entanto, novamente o tribunal australiano não encerrou a sua investigação nesse contexto intrínseco do acordo Austrália-Singapura, recorrendo ainda a outras evidências do contexto extrínseco da convenção. 


\section{A IDENTIFICAÇÃO DE EVIDÊNCIAS DO CONTEXTO INTRÍNSECO: O PONTO DE PARTIDA PARA A CONSTRUÇÃO DO SENTIDO CONTEXTUALIZADO DOS TERMOS DE ACORDOS DE DUPLA TRIBUTAÇÃO.}

Ao se adentrar na interpretação textual dos acordos de bitributação, não se perquire necessariamente de início os métodos interpretativos que devem ser adotados. Primeiro, é necessário identificar quais seriam os elementos objetos da interpretação ${ }^{540}$.

Sob o escopo do art. 31 (2) da CVLT, o contexto intrínseco inclui o texto do acordo, seu preâmbulo e anexos, qualquer acordo ou instrumento relativo ao tratado e feito entre todas as partes em conexão com a conclusão do tratado. Todos os elementos em questão apresentam ao menos três características em comum: (i) consenso dos Estados contratantes; (ii) formalização por escrito ou em meio que possa ser assim vertido; e (iii) contemporaneidade. ${ }^{541}$

Como se poderá observar nos subtópicos seguintes, não há maior dificuldade em reconhecer o texto do acordo, seu preâmbulo e anexos, bem como o seu status de contexto intrínseco sob o escopo do art. 31 (2) da CVDT.

A questão se complica, contudo, na identificação dos acordos e instrumentos relativos ao tratado principal e concluidos em conexão com a conclusão deste, bem como para distinguí-los de outros elementos, como trabalhos preparatórios. RICHARD GARDINER ${ }^{542}$ observa que relatórios explicativos ("explanatory reports") teriam um importante papel interpretativo e seriam elaborados e adotados ao mesmo tempo em que o texto do tratado é negociado e concluído; contudo, não restaria totalmente claro se tais evidências estariam sob o escopo do contexto intrínseco (CVDT, art. 31 (2), "b”) ou, ainda, se deveriam ser considerados como trabalhos preparatórios, sob o escopo, portanto, do contexto extrínseco secundário (CVDT, art. 32). O problema da identificação de tais

\footnotetext{
${ }^{540}$ TÔRRES, Heleno Taveira. Pluritributação internacional sobre as rendas das empresas. São Paulo : Revista dos Tribunais, 2001, p. 646-647.

${ }^{541}$ Vide: GARDINER, Richard K. International Law. Pearson : Harlaw, 2003, p. 86SILVEIRA, Rodrigo Maitto da. Aplicação de Tratados Internacionais Contra a Bitributação - Qualificaçãoo de Partnership Joint Ventures. IBDT/Quartier Latin : São Paulo, 2006, p.119-120.

${ }^{542}$ GARDINER, Richard K. International Law. Pearson : Harlaw, 2003, p. 86-87.
} 
evidências adquire cores especiais diante das peculiaridades do Direito tributário internacional.

Note-se que, como a maior parte das correntes analisadas consideram o contexto intrínseco como ponto de partida, diferindo apenas quanto ao seu papel como ponto final ou não, atribuir a determinado elemento o timbre de contexto intrínseco (critério formal) o tornará relevante para quaisquer das correntes em questão. Assim, ao ser identificado como uma evidência intrínseca, o elemento em questão se torna admissível inclusive ao julgador que adote a tese da suficiencia do sentido "claro" provido por elementos do contexto intrínseco.

\subsection{O texto do acordo de dupla tributação, seu preâmbulo e anexos.}

Como se viu, a CVDT prescreve como regra geral uma única e combinada operação de interpretação, em que o texto do acordo constitui a principal base para a construção da norma acordada entre os Estados contraentes, embora não seja a única.

Os textos dos acordos de dupla tributação, tal como prevê o art. 33 (1) da CMOCDE, são autenticados em duas ou mais línguas e fazem igualmente fé. Em geral, os acordos de dupla tributação seguem tal regra e são elaborados em dois idiomas, a fim de contemplar as línguas oficiais de cada um dos Estados, como é o caso, por exemplo, do acordo Brasil-Áustria, redigido na língua portuguesa e alemã. O acordo Brasil-Canadá ${ }^{543}$, por sua vez, foi elaborado em três idiomas oficiais, expressamente considerados igualmente autênticos, nas línguas portuguesa, inglesa e francesa.

A CVDT ressalta a relevância do preâmbulo e dos anexos do tratado internacional, como parte de seu texto. Como se viu, os propósitos do acordo de dupla tributação geralmente constam de seus preâmbulos, o que enseja uma série de questionamentos.

Embora não seja raro o reconhecimento dessas características dos preâmbulos em decisões de Cortes nacionais, também não é raro que nenhum efeito prático seja atribuído a tal declaração, tornando as evidências do contexto intrínseco sem grande poder de

${ }^{543}$ BRASIL. Decreto n 92.318 , de 23 de Janeiro de 1986 (Acordo Brasil-Canadá). 
persuasão e, logo, insignificantes na tomada de decisão. Como exemplo, no Caso Thiel (Austrália, 1990), o Tribunal australiano ("High Court of Australia") mencionou expressamente que o preâmbulo e os anexos do acordo de dupla tributação Austrália-Suíça fariam parte de seu contexto intrínseco, sob o escopo do art. 31 (2) da CVDT, mas nenhuma consequência prática foi atribuída a tal constatação.

Contudo, como se pode observar nos exemplos a seguir, Cortes nacionais também têm atribuído consequências aos propósitos e objetivos construídos a partir de evidências textuais.

\subsubsection{Exemplo: Evidências levantadas a partir do preâmbulo do acordo de dupla tributação EUA-Reino Unido.}

No Caso Maximov (EUA, 1963), a Suprema Corte norte-americana considerou que o preâmbulo do acordo de dupla tributação EUA-Reino Unido teria consignado o seu propósito e objetivo de evitar a dupla tributação e prevenir a evasão fiscal. Com base em tal evidência, a Corte concluiu que na ausência de tributação pelo Reino Unido do ganho de capital obtido por um trust, caberia aos EUA tributar os seus detentores, a fim de não ensejar a dupla tributação prevenida pelo acordo internacional.

\subsubsection{Exemplo: Evidências levantadas a partir do preâmbulo do acordo de dupla tributação Reino Unido-França.}

No Caso Sportsman Case (Reino Unido, 1998), o tribunal considerou que o acordo de bitributação Reino Unido-França possuiria como propósito e objetivo também o combate à evasão fiscal, tal como disposto em seu preâmbulo. Sob tal premissa, a Corte inglesa concluiu que haveria mandamento advindo da convenção para que fosse ela própria interpretada de forma a evitar a dupla tributação e a evasão fiscal, de modo que não se poderia adotar interpretação pela qual nenhum imposto fosse recolhido pelo contribuinte em razão da alteração de sua residência de um Estado ("A") para outro ("B"), o que ainda seria contrário à boa fé. 


\subsubsection{Exemplo: Evidências levantadas a partir do preâmbulo do acordo de dupla tributação Reino Unido-Croácia.}

No Caso Tomislav (Reino Unido, 2011), o contribuinte não havia recolhido impostos ao seu Estado de residência (Croácia) e requereu a restituição dos impostos recolhidos ao Reino Unido (fonte), por compreender que os rendimentos de suas atividades dependentes, desempenhadas na qualidade de empregado, somente poderiam ser tributados em sua residência em função do benefício da isenção concedido por aquele acordo internacional.

O tribunal inglês, contudo, consignou que o preâmbulo do acordo de dupla tributação Reino Unido-Croácia expressaria que o objetivo e propósito da convenção seria evitar a dupla tributação da renda e não conduzir a situações em que o contribuinte não recolha tributos em quaisquer desses Estados.

\subsection{Documentos elaborados em conexão com o acordo de dupla tributação.}

$\mathrm{O}$ art. 31 (2) "a" e "b" da CVDT requer que o intérprete considere evidências levantadas a partir de "qualquer acordo relativo ao tratado e feito entre todas as partes em conexão com a conclusão do tratado", bem como de "qualquer instrumento estabelecido por uma ou várias partes em conexão com a conclusão do tratado e aceito pelas outras partes como instrumento relativo ao tratado".

A norma da CVDT reforça o óbvio: acordos subsequentes sobre a interpretação de um determinado acordo internacional naturalmente devem ser considerados como evidência para a construção do sentido contextualizado de seus termos. Embora tenham nascido separados pela diferença de pouco tempo, os acordos e instrumentos em questão se fundiriam ao acordo como um todo.

A questão da integração de tais materiais ao texto do acordo de dupla tributação possui relevância não apenas teórica. Ocorre que o art. 25 (3) da CM-OCDE prevê que as autoridades competentes dos Estados Contratantes esforçar-se-ão, mediante procedimento 
amigável, para resolver as dificuldades ou dirimir as dúvidas que possam surgir na interpretação ou aplicação da Convenção. Ocorre que, conforme observam autores como FRANK ENGELEN ${ }^{544}$ e LUC DE BROE ${ }^{545}$, tal procedimento amigável apenas poderia ter como objeto o texto do acordo de dupla tributação e materiais que passassem a integrá-lo.

Outra questão que surge é como identificar os referidos acordos e instrumentos internacionais que se fundem ao texto como um todo do acordo de dupla tributação, possivelmente vocacionados à sua interpretação autêntica.

Em relação aos aspectos formais de reconhecimento, exige-se que os mesmos procedimentos para a aprovação da convenção fiscal sejam observados em relação aos acordos e instrumentos conectados a estes. Apenas será considerada interpretação autêntica aquela veiculada por instrumento de igual ou superior hierarquia que o instrumento interpretado: caso acordos ou instrumentos conectados aos tratados de bitributação possuam tal vocação, devem se submeter aos mesmos procedimentos do acordo de dupla tributação interpretado.

Para KlAUS VoGEL ${ }^{546}$, os instrumentos estabelecidos entre as partes poderiam incluir notas e cartas trocadas ao tempo da celebração do acordo de dupla tributação, bastando que fossem capazes de exprimir o consentimento de ambos os Estados quanto à determinada questão. Transportando os exemplos fornecidos por esse professor aos dias atuais, tais documentos poderiam consistir na troca de e-mails ou mesmo de mensagens em redes sociais de comunicação via Internet.

Para que seja concluído um acordo ou instrumento válido no âmbito do Direito tributário internacional, embora o art. 2 (1) "a" da CVDT não exija maiores formalidades, o art. 46 (1) dessa convenção multilateral exige obediência a qualquer regra geral de Direito interno de importância fundamental e manifesta.

\footnotetext{
${ }^{544}$ ENGELEN, Frank. Interpretation of Tax Treaties under International Law. Doctoral series n. 7. IBFD : Amsterdam, 2004, p. 429-430.

${ }^{545}$ BROE, Luc De. International tax planning and prevention of abuse (doctoral series n. 14). Amsterdã : IBFD, 2007, 252-253.

${ }^{546}$ VOGEL, Klaus. Klaus Vogel on Double Taxation Conventions. Kluwer : London, 1999, p. 37.
} 
Assim, embora o Direito Internacional não requeira formalidades específicas para a celebração de um acordo internacional, deve ser averiguada a existência de normas do Direito interno de importância fundamental e manifesta (CVDT, art. 27 e 46) nesse sentido.

No sistema jurídico brasileiro, embora o Poder Executivo possua competência para celebrar quaisquer tratados, convenções e atos internacionais, é condição essencial que eles sejam referendados pelo Congresso Nacional (CF, art. 84, VIII), exigindo-se, portanto, participação desses dois Poderes, não sendo suficiente a simples troca de comunicação entre agentes públicos.

Nos subtópicos seguintes, serão analisados exemplos de documentos elaborados em conexão com o acordo de dupla tributação, como os protocolos e memorandos, bem como avaliada a legitimidade de tais materiais para fornecer evidências quanto ao sentido dos acordos de bitributação.

\subsubsection{Protocolos anexados aos acordos de dupla tributação.}

Os "protocolos" correspondem a notas que acompanham o texto dos acordos de dupla tributação, tornando-se parte integrante deste. Trata-se de documentos elaborados em conexão com o acordo de dupla tributação que, em geral, são submetidos à apreciação do Poder Legislativo juntamente com este ${ }^{547}$ e que geralmente possuem igual valor jurídico ${ }^{548}$. Os protocolos podem ser compreendidos como "anexo" do texto do acordo de dupla tributação, sob o escopo do caput do art. 31 (2) da CVDT ou, ainda, como "acordos relativos ao tratado e feitos entre todas as partes em conexão com a conclusão do tratado", sob o escopo, portanto, da alínea "a" do art. 31 (2).

A título ilustrativo, o preâmbulo do protoloco que acompanha o acordo BrasilEspanha, ${ }^{549}$ o qual não difere em grande medida do preâmbulo de outros protocolos

\footnotetext{
${ }^{547}$ A titulo de exemplo, vide Decreto Legislativo 13/1990, pelo qual o Congresso Nacional ratificou o acordo Brasil-Hungria e, no mesmo ato, o seu protocolo.

${ }^{548}$ XAVIER, Alberto. Direito tributário internacional do Brasil. Forense : Rio de Janeiro, 2010, p. 74.

${ }^{549}$ BRASIL. Decreto n ${ }^{\circ} 76.975$, de 2 de Janeiro de 1976 (acordo Brasil-Espanha).
} 
relacionados aos acordos de dupla tributação celebrados pelo Brasil, possui a seguinte redação:

\footnotetext{
"No momento da assinatura da Convenção para Evitar a Dupla Tributação em Matéria de Impostos sobre a Renda entre a República Federativa do Brasil e o Estado Espanhol, os abaixo-assinados, para isso devidamente autorizados, convieram nas seguintes disposições que constituem parte integrante da presente Convenção".
}

Para FrAnK ENGELEN ${ }^{550}$, depende da comum intenção das partes que tais materiais, contemporâneos ao acordo de dupla tributação, sejam considerados parte integrante deste. Como se pode observar do protoloco que acompanha o acordo Brasil-Espanha, a referida intenção foi consignada expressamente.

O protocolo pode estar vocacionado a veicular interpretações autônomas de termos utilizados no acordo de dupla tributação, esclarecer as disposições da convenção, dirimir dúvidas que possam surgir em relação à legislação doméstica dos Estados contratantes ${ }^{551}$ ou, afastando-se dessa função interpretativa, introduzir alterações em suas disposições ${ }^{552}$. Como observa CARlo GARBARINO ${ }^{553}$, caso o Poder Legislativo de um dos Estados contratantes aprove o texto do acordo de dupla tributação com alguma reserva, tornando necessário que os Estados retomem negociações a fim de contemplá-las, tais mudanças provavelmente serão inseridas no "protocolo" do respectivo acordo. Tanto em uma quanto em outra situação, o protocolo deverá ser submetido ao mesmo procedimento que o acordo de dupla tributação original.

\subsubsection{Exemplo: O sentido de "pessoa" no acordo Brasil-Canadá, conforme o seu protoloco.}

O protocolo ao acordo Brasil-Canadá ${ }^{554}$, por exemplo, estabeleceu que o termo “pessoa", referido no art. 3 (1) “d” daquele acordo de dupla tributação também inclui uma sociedade de pessoas ("partnership"), um espólio (“estate”) e um "trust", bem como que,

${ }^{550}$ ENGELEN, Frank. Interpretation of Tax Treaties under International Law. Doctoral series n. 7. IBFD : Amsterdam, 2004, p. 429-430.

${ }^{551}$ Cf. XAVIER, Alberto. Direito tributário internacional do Brasil. Forense : Rio de Janeiro, 2010, p. 74.

${ }^{552}$ Cf. GARBARINO, Carlo. Manuale di tassazione Internazionale. Milão : Kluwer, 2005, p. 183.

${ }^{553}$ GARBARINO, Carlo. Manuale di tassazione Internazionale. Milão : Kluwer, 2005, p. 183-184.

${ }^{554}$ BRASIL. Decreto n ${ }^{\circ}$ 92.318, de 23 de Janeiro de 1986 (Acordo Brasil-Canadá). 
na língua francesa, o termo "société" inclui uma "corporation" com a significação atribuída pela lei canadense, entre outras definições.

\subsubsection{Exemplo: O sentido de "residente de um Estado contratante" referido no art.} 14 dos acordos celebrados pelo Brasil.

Embora o art. 14 ("independent personal services") tenha sido excluído da CMOCDE, o dispositivo está presente em todos os acordos de bitributação celebrados pelo Brasil. Conforme o seu texto, os rendimentos em de profissão liberal ou de outras atividades independentes de caráter análogo serão tributados no Estado de residência deste.

Por sua vez, o protoloco das convenções celebradas pelo Brasil com Alemanha, Coreia, Dinamarca, Equador, Espanha, Filipinas, Hungria, Itália, Luxemburo, República Checa e Eslováquia preveem que o art. 14 será aplicável mesmo quando tais serviços forem providos por intermédio de uma pessoa jurídica. Assim, por exemplo, prevê o item 5 do protocolo anexo ao acordo Brasil-Luxemburgo que "as disposições do artigo 14 aplicarse-ão mesmo se as atividades mencionadas nesse artigo forem exercidas por uma sociedade civil", enquanto o item 6 do protocolo ao acordo Brasil-Itália prevê que "as disposições do Artigo 14 aplicam-se mesmo se as atividades forem exercidas por uma sociedade de pessoas ou uma sociedade civil (civil company)".

\subsubsection{Exemplo: O sentido de "royalties" no acordo Brasil-Hungria, conforme o seu protoloco.}

Outro exemplo que pode ser colhido dos protocolos dos acordos de dupla tributação celebrados pelo Brasil se refere à interpretação do termo "royalties" (CMOCDE, art. 12). Tal como se dá no item 6 do protocolo ao acordo Brasil-Hungria, os alguns acordos de bitributação brasileiros possuem nesse anexo a mensagem de que " $O$ disposto no parágrafo 3 do Artigo XII aplica-se aos pagamentos de qualquer natureza 
recebidos como remuneração pela prestação de assistência técnica e de serviços técnicos".

Diante de tal protocolo, a "prestação de assistência técnica e de serviços técnicos" seriam considerados não como "lucro das empresas", mas sim como "royalties". Como consequência, os rendimentos em questão estariam sob o escopo do art. 12 dos acordos celebrados pelo Brasil, que permite ao Estado da fonte exercer a sua competência tributária, e não do art. $7^{\circ}$, pelo qual apenas o Estado de residência poderia tributá-los.

Tal cláusula do protoloco de tais convenções fiscais, contudo, não está isenta de discussões. AlBerto XAVIER ${ }^{555}$ sustenta que, em algumas hipóteses, a transmissão da informação objeto do contrato de know how comporta um ato único de mera cessão de direitos para uso de plantas, manuais, desenhos ou fórmulas. Em outros casos, contudo, faz-se necessária atividade continuada de prestação de serviços, de forma permanente ou periódica, a fim de que a informação necessária para o uso da tecnologia seja disponibilizada ao cessionário. Para esse autor, as referências presentes em protocolos de convenções fiscais celebradas pelo Brasil a prestação de assistência técnica e de serviços técnicos dizem respeito a segunda hipótese, exigindo-se "nexo de complementariedade ou instrumentalidade em relação a uma outra operação que aquela visa a 'assistir' e que consista numa transmissão de know how em si mesmo considerada”.

A solução da questão, contudo, parece exigir a análise mais detalhada de todo o contexto em que cada um desses protocolos foi celebrado.

\subsubsection{Exemplo: A adoção de protocolos para a alteração da convenção fiscal.}

A flexibilidade dos meios utilizados para a expressão do consentimento de autolimitação da soberania dos Estados permite que os protocolos também sejam utilizados para posteriores alterações de acordos de dupla tributação. No Caso Pacific Network (Canadá, 2002), o Tribunal canadense considerou o texto do acordo Canadá-França conforme a redação que lhe foi atruída por dois protocolos firmados entre aqueles Estados.

\footnotetext{
${ }^{555}$ XAVIER, Alberto. Direito Tributário Internacional do Brasil. Rio de Janeiro: Forense, 2010, p. 625-627.
} 


\subsection{Acordos posteriores celebrados pelos Estados contratantes sob o escopo do contexto intrínseco.}

O fator temporal, para a distinção entre acordos celebrados em conjunto ou posteriormente ao tratado de bitributação, não foi e nem poderia ter sido adotado pela ILCONU para a hierarquização de tais materiais. Assim, não apenas instrumentos celebrados em conjunto com o acordo de dupla tributação compõem o contexto intrínseco deste.

Acordos posteriores, celebrados por dois Estados contratantes (“A” e "B”), para a alteração de dispositivos de um acordo de dupla tributação (“A-B”) formalizado entre estes no passado, naturalmente também devem ser considerados sob o escopo do contexto intrínseco. Esse é o caso do acordo celebrado entre Brasil e Bélgica, em 2002, para inserir alterações na "Convenção Adicional Alterando a Convenção para Evitar a Dupla Tributação e Regular Outras Questões em Matéria de Impostos sobre a Renda e o Protocolo Final, assinados em Brasília em 23 de junho de 1972”.

Algumas dificuldades podem surgir, contudo, para a identificação de tais acordos posteriores celebrados pelos Estados contratantes sob o escopo do contexto intrínseco.

Como se viu, para que seja concluído um tratado no âmbito do Direito tributário internacional, não são exigidas maiores formalidades. No entanto, os sistemas jurídicos domésticos podem possuir requisitos especiais, o que deve ser verificado caso a caso.

O acordo de dupla tributação Brasil-Suécia pode ser utilizado como exemplo do modo como a flexibilidade do Direito Internacional passa pelo filtro de normas do Direito interno de importância fundamental e manifesta de cada um dos Estados contratantes. Tal convenção foi celebrada entre esses Estados em 25.04.1975, com a previsão para a duração de alguns de seus dispositivos por um período determinado. Em 19.03.1996, tais Estados simplesmente trocaram entre si notas verbais com o propósito de prorrogar tais cláusulas por um período adicional de dois anos, nos artigos 10 (2) e (5), 11 (2), "b", 12 (2), "b" e, ainda, 23 (3) daquele acordo de dupla tributação. O legislador brasileiro, por sua vez, 
resguardou sua prerrogativa e formalmente aprovou tais notas verbais, vertendo-as no Decreto Legislativo ${ }^{\circ}$ 57, de 1997.

\subsubsection{Memorandos de entendimentos quanto ao acordo de dupla tributação.}

Memorandos de entendimentos mútuos ("Memorandum of Understanding", “MoU") ${ }^{556}$ são documentos elaborados pelos Estados contratantes para estabelecer o entendimento destes em relação à interpretação de termos de uma convenção fiscal. É possível compreender que tais materiais sob o escopo do art. 31 (2) da CVDT.

\subsubsection{Exemplo: o "Joint Explanatory Memorandum” ao acordo de bitributaçãoo Bélgica-Países Baixos.}

O “Joint Explanatory Memorandum”, elaborado em conexão com o acordo de dupla tributação Bélgica-Países Baixos, é um exemplo interessante a ser observado. Tal material foi elaborado por ambos os Estados, com a apresentação de entendimentos comuns quanto à interpretação desse tratado, bem como ratificado por seus respectivos poderes legislativos, embora não tenha sido publicado pelo Diário Oficial belga. Não obstante Luc De Broe ${ }^{557}$ (Leuven, Bélgica) e FrANK ENGElen ${ }^{558}$ (Leiden, Holanda) concordem em enquadrá-lo sob o escopo do art. 31 (2) "a" da CVDT, os professores discordam quanto ao seu efeito vinculante na interpretação daquele acordo de dupla tributação.

Sob a perspectiva de ENGELEN, embora a integração de tal material ao texto do acordo Bélgica-Países Baixos não tenha restado tão clara quanto em relação aos dois protocolos firmados entre aqueles Estados para a aplicação do acordo, o seu caráter interpretativo conduziria a tal resultado, vinculando a ambos. LUC DE BROE concorda com

\footnotetext{
${ }^{556}$ Cf. IBFD. Glossary. Acesso possível no endereço eletrônico na Internet (website) www.ibfd.org (ultimo acesso em 25/10/2014).

${ }^{557}$ BROE, Luc De. International tax planning and prevention of abuse (doctoral series n. 14). Amsterdã : IBFD, 2007, 252-253.

${ }^{558}$ ENGELEN, Frank. Interpretation of Tax Treaties under International Law. Doctoral series n. 7. IBFD : Amsterdam, 2004, p. 429-430.
} 
tais conclusões, mas compreende que a ausência de publicação no Diário Oficial belga enfraquece a vinculação dos contribuintes.

\section{A EXPLORAÇÃO DAS EVIDÊNCIAS DO CONTEXTO INTRÍNSECO.}

Identificados os elementos do contexto intrínseco, surge a questão de como manejá-los. A utilidade que se pode obter de evidências intrínsecas - e logo o poder de convencimento dos advogados - é fortemente influenciada pela maneira com que se manejam os referidos elementos textuais.

Entre as estratégias que podem ser adotadas, a doutrina ${ }^{559}$ do Direito Internacional tem identificado, por exemplo, a consideração dos idiomas utilizados e o vocabulário adotado (com atenção aos termos, aos seus sentidos comuns, técnicos ou especiais, bem como a possíveis variações históricas ou geográficas), à interpretação gramatical e à interpretação lógica (o que envolveria a distinção de cláusulas gerais e cláusulas especiais, analogia, efeito-útil, argumento “a contrário" e "ab absurdo" etc.).

No Direito tributário internacional, entre outros, parece ser especialmente útil: (i) a adoção de métodos sintáticos, semânticos, lógicos e de coesão na interpretação do texto do acordo como um todo; (ii) a realização de testes comparativos entre os termos utilizados no acordo de dupla tributação como um todo e; (iii) a identificação dos objetivos e propósitos do acordo a partir de detalhes de cada uma de suas partes. Os subtópicos seguintes se dedicam à análise de tais estratégias para se manejar as evidências intrínsecas dos acordos de dupla tributação.

\footnotetext{
${ }^{559}$ Vide, nesse sentido: ROTHMANN, Gerd W. Interpretação e aplicação dos acordos internacionais contra a bitributação. Tese de doutorado. São Paulo : Faculdade de Direito da Universidade de São Paulo (USP), 1978, p. 141-142.
} 


\subsection{Adoção de métodos sintáticos e semânticos na interpretação do texto do acordo como um todo.}

Não há dúvidas de que o texto do acordo com um todo, tal como referido no art. 31 (2) da CVDT, deve ser considerado pelo operador do Direito tributário internacional. A busca por evidências sob o escopo do contexto intrínseco, para a construção de sentido dos termos dos acordos de dupla tributação, tem início em instrumentais básicos da língua escrita, relacionados especialmente aos seus planos sintáticos e semânticos. ${ }^{560}$ Para que o intérprete construa o sentido contextualizado de um termo, a partir de evidências intrínsecas ao texto do acordo de dupla tributação, deverá estar inserido em seu contexto idiomático e gramatical desse.

Esse exercício vem sendo desenvolvido por Cortes nacionais, como se pode observar pelos exemplos a seguir.

\subsubsection{Exemplo: o termo "income" e os métodos sintáticos e semânticos de interpretação textual do acordo de dupla tributação Canadá-Alemanha.}

Os tribunais do Canadá há tempos explicitam de forma fundamentada o modo como exploram as evidências intrínsecas no processo decisório. O Caso Melford (Canadá, 1981) pode ser tomado como exemplo, em que dois exercícios nesse sentido foram realizados para a interpretação do art. 3 (1) e (5) do antigo acordo Canadá-Alemanha (1956), com a seguinte redação:

${ }^{560}$ Cf. CARVALHO, Paulo de Barros. Curso de Direito Tributário. São Paulo : Saraiva, 2000, p. 97-99. 
Art. 3. 1. The industrial or commercial profits of an enterprise of one of the territories shall not be subject to tax in the other territory unless the enterprise carries on a trade or business in the other territory through a permanent establishment situated therein. If it carries on a trade or business in that other territory through a permanent establishment situated therein, tax may be imposed on those profits in the other territory but only on so much of them as is attributable to that permanent establishment.

(...)

5. Paragraphs (1) and (2) shall not be construed as preventing one of the contracting States from imposing pursuant to this Convention a tax on income (e.g. dividends interest, rents or royalties) derived from sources within its territory by a resident of the other territory if such income is not attributable to a permanent establishment in the first-mentioned territory.

Conforme o julgador, a primeira questão a ser considerada seria se adoção dos termos entre parênteses (“dividends, interest, rents or royalties"), logo após ao termo "income". Seria necessário investigar se essa redação limitaria a aplicação do dispositivos apenas àquelas espécies de rendimentos entre parênteses. Caso tais termos tivessem o condão de limitar o sentido do termo "income" para hipóteses abrangidas por alguma das quatro palavras descritas entre parênteses (“dividends, interest, rents or royalties"), os rendimentos em questão ("guarantee fee") não estariam sob o escopo do art. 3 (5), mas sim do art. 3 (1), o que autorizaria a tributação apenas pela Alemanha, Estado de residência do banco beneficiário dos rendimentos.

Seria, ainda, necessário analisar se as letras "e.g." limitariam ou expandiriam o sentido do termo "income", possibilitando que a outras espécies fossem atribuídas a mesma consequência. De fato, compreendeu a Corte que se trataria de uma relação apenas ilustrativa, capaz de comportar outras categorias.

A questão, contudo, não foi solucionada exclusivamente a partir de tais evidências intrínsecas. A investigação de evidências do contexto extrínseco conduziram a Suprema Corte canadense à conclusão de que os rendimentos em questão ("guarantee fee") não estariam suportados pelo sentido de "income" tal como exemplificado no art. 3 (5) do acordo Canadá-Alemanha. Tais rendimentos estariam sob o escopo dos termos "industrial or commercial profits", referidos no art. 3 (5) daquela convenção. 


\subsubsection{Exemplo: os tribunais canadenses e o métodos de dedução indireta.}

No Caso Gladden (Canadá, 1985), o tribunal canadense, valendo-se também de outras, recorreu ao contexto intrínseco para a solução do caso.

Como no método da dedução indireta, os julgadores partiram da afirmação do fisco canadense de que a tributação do ganho de capital pelo Canadá não seria obstaculizada pelo acordo Canadá-EUA e procuraram evidências que a confirmassem ou a infirmasse. Os julgadores encararam o texto do art. 8 da convenção fiscal, bem como o acordo como um todo, concluindo que não haveria qualquer cláusula de exclusão ou limitação relacionada ao termo "gains" inserto naquele tratado internacional, de tal forma que não se poderia excluir a sua proteção a contra a tributação de rendimentos qualificados como "ganhos de capital".

\subsection{Testes comparativos: a função e o sentido dos termos no acordo de dupla tributação como um todo.}

"In considering the question before the Court upon the language of the Treaty, it is obvious that the Treaty must be read as a whole, and that its meaning is not to be determined merely upon particular phrases which, if detached from the context, may be interpreted in more than one sense. PCIJ. Competence of the ILO in regard to International Regulation of the Conditions of the Labour of Persons Employed in Agriculture", $(1922)^{561}$,

O trecho em epígrafe, de uma antiga decisão da PCIJ, reconhece como natural que o termo de um tratado deve ser interpretado como sendo parte do texto como um todo. No Direito tributário internacional, a questão é igualmente relevante.

Considerando-se o texto como um todo, um determinado termo, inserto em um acordo de bitributação, pode influenciar na construção de sentido de um outro termo, inserto no mesmo acordo internacional. Além disso, ao considerar-se o texto como um todo, é possível verificar se um mesmo signo a que se procura atribuir sentido tenha sido utilizado em outros enunciados do acordo de dupla tributação: sob o escopo do contexto intrínseco, um certo termo ("x"), por ter a grafia idêntica à de outro termo ("x") também utilizado no texto da convenção fiscal poderia ser adotado como um par de comparação

\footnotetext{
${ }^{561}$ PCIJ. Competence of the ILO in regard to International Regulation of the Conditions of the Labour of Persons Employed in Agriculture", p. 23.
} 
deste. Do mesmo modo, um determinado termo ("x") poderia servir de par de comparação para um outro termo utilizado no mesmo acordo e que, embora apresente grafia diversa (“y”), desempenhe função semelhante.

\subsubsection{Exemplo: A experiência brasileira da interpretação de termos das convenções fiscais comparando a sua utilização em diferentes dispositivos.}

O Caso Alubar (Brasil, 2004) envolveu a prestação de serviços de consultoria tecnológica (sem transferência de tecnologia) por uma empresa portuguesa a uma empresa brasileira. Entre outras coisas, alegou o contribuinte que o art. 14 do acordo BrasilPortugal seria aplicável ao caso para afastar a tributação brasileira, de modo que os rendimentos apenas seriam tributáveis em Portugal, ainda que os serviços em questão sejam prestados por uma sociedade mercantil ou civil.

Conforme o argumento do contribuinte, o art. 14 do acordo Brasil-Portugal deveria ser interpretado em conjunto com os arts. 4 e 3 (1) "d" e "e" daquela convenção fiscal. No caso, o art. 4 define a expressão "residente de um Estado Contratante" como "qualquer pessoa que por virtude da legislação desse Estado está aí sujeita a imposto devido ao seu domicílio, à sua residência, ao local de direção ou a qualquer outro critério de natureza similar. Já o art. 3 (1) "d" do acordo define o termo "pessoa" como "uma pessoa singular ou física, uma sociedade, ou qualquer outro agrupamento de pessoas", bem como esclarece o inciso "e" que "o termo 'sociedade' significa qualquer pessoa coletiva ou jurídica ou qualquer entidade que é tratada como pessoa coletiva ou jurídica para fins tributários".

Nesse seguir, ao dispor o art. 14 que os rendimentos que "um residente de um Estado Contratante" obtiver pelo exercício de uma profissão liberal ou de outras atividades independentes de caráter análogo só são tributáveis no Estado de residência, sua norma deveria ser aplicada a pessoas físicas, jurídicas, bem como quaisquer outros tipos societários, dotados ou não de personalidade jurídica pela lei civil ou comercial, a exemplo de sociedades em conta de participação e empresas individuais. 
A questão foi julgada no âmbito do CARF, que refutou tais argumentos ao considerar que o art. 14 do acordo Brasil-Portugal apenas seria aplicável às pessoas físicas que desenvolvem atividades independentes tuteladas no dispositivo.

\subsubsection{Exemplo: a comparação do "tax", nos art. 2, 23, 24, 26 e 27 da CM-OCDE.}

O termo "tax" é utilizado nos arts. 2 (escopo do acordo), 23 (métodos de evitar a dupla tributação), 24 (cláusula de não discriminação), 26 (troca de informações) e 27 (assistência na arrecadação tributária) da CM-OCDE. AdOLFO J. MARTín JiMÉNEZ ${ }^{562}$ propõe a interpretação desse signo a partir do problema da inclusão ou não de contribuições sociais sob o escopo do termo "tax" presente no art. 2 da CM-OCDE. As questões que o problema suscita são, então, testadas pelo autor com a investigação de evidencias intrínsecas e extrínsecas. É possível observar que o referido termo pode apresentar sentidos variados, naqueles diversos dispositivos em que é utilizado.

$\mathrm{O}$ art. 24 da CM-OCDE veicula cláusula de não discriminação, à qual, conforme o art. 24 (6), não obstante a previsão do art. 2, aplica-se a qualquer espécie de impostos ("apply to taxes of every kind and description"). A consideração do termo "tax" nos dois dispositivos, com o recurso ao "contexto" e ao reenvio ao Direito doméstico, pode conduzir a resultados diversos. KEES VAN RAAD ${ }^{563}$, por adotar a teoria da precedência do Direito doméstico em relação ao "contexto" referido no art. 3 (2) da CM-OCDE, sustentou a posição de que, ao não se limitar aos impostos sob o escopo da convenção, a cláusula de não discriminação do art. 24 seria aplicável a quaisquer "tributos" tal como definidos pela legislação doméstica dos Estados contratantes.

Por sua vez, partindo de uma concepção ampla de "contexto" e, ainda, considerando-o precedente ao Direito doméstico, ADOLFO J. MARTín JiMÉNEZ ${ }^{564}$ identifica evidências do contexto intrínseco, extrínseco primário ou mesmo secundário que

\footnotetext{
562 JIMÉNEZ, Adolfo J. Martín. Defining the objective scope of income tax treaties: the impact of the other treaties and EC Law on the Concept of Tax in the OCED Model, in Bulletin - Tax Treaty Monitor - October 2005. Amsterdã : IBFD, 2005, p. 432 e seg.

${ }^{563}$ Raad, Kees van. Nondiscrimination in international tax law. Deventer : Kluwer, 1986.

564 JIMÉNEZ, Adolfo J. Martín. Defining the objective scope of income tax treaties: the impact of the other treaties and EC Law on the Concept of Tax in the OCED Model, in Bulletin - Tax Treaty Monitor - October 2005. Amsterdã : IBFD, 2005, p. 432 e seg.
} 
conduzem à construção de um sentido muito mais limitado ao termo "taxes" referido no art. 24 (6) da CM-OCDE. Valendo-se de parallel treaties, o autor espanhol observa que o GATT regularia de forma mais específica encargos aduaneiros e tributos sobre bens. No âmbito da UE, há ainda regulação própria para tais encargos, com liberdade bastante limitada para que cada um dos Estados membros se desvie das diretrizes gerais, bem como das contribuições relacionadas à seguridade social. Tais normas aplicáveis às partes seriam evidências de que o sentido do termo "taxes" referido no art. 24 (6) da CM-OCDE não seria tão amplo a ponto de ser aplicável a quaisquer tributos previstos no sistema jurídico doméstico de cada um dos Estados contratantes, não abrangendo, por exemplo, encargos aduaneiros e tributos sobre bens e algumas contribuições sociais.

Por sua vez, o art. 26 (1) da CM-OCDE dispõe que a troca de informações entre os Estados contratantes se dará em relação a tributos de qualquer tipo ("concerning taxes of every kind and description"). Embora a interpretação literal do dispositivo possa conduzir à ideia de uma cláusula tão ampla quanto sejam as espécies tributárias presentes nos sistemas jurídicos domésticos dos Estados contratantes, evidências extrínsecas conduzem à construção de um sentido mais restrito da cláusula em questão. AdOLFO J. MARTíN JiMÉNEZ ${ }^{565}$ concluiu que o sentido contextualizado do termo "taxes" presente na cláusula de troca de informações das convenções fiscais deve considerar como evidências outros acordos internacionais, especialmente aqueles atinentes a encargos aduaneiros e tributos sobre bens. No caso de Estados membros da UE, os regulamentos de seu Direito comunitário deveriam ser observados, o que manteria sob o escopo dos acordos de dupla tributação informações relacionadas ao imposto sobre a renda e contribuições sociais, mas restringiria o sentido do termo "taxes" para excluir encargos aduaneiros, IVA, prêmios de seguros, tendo em vista a sua regulamentação específica. Analisou-se, ainda, a regulamentação da troca de informações relacionada a encargos aduaneiros promovidos pela WTO.

Como se pode notar, se é verdade que o contexto intrínseco requer que se comparem os sentidos de um mesmo termo em diferentes posições do acordo de dupla tributação sob interpretação, também é verdade que, para que tal comparação seja possível,

\footnotetext{
${ }^{565}$ JIMÉNEZ, Adolfo J. Martín. Defining the objective scope of income tax treaties: the impact of the other treaties and EC Law on the Concept of Tax in the OCED Model, in Bulletin - Tax Treaty Monitor - October 2005. Amsterdã : IBFD, 2005, p. 439-442.
} 
para cada uma dessas aparições deverá ser construído o respectivo sentido contextualizado, o que requer a consideração do contexto intrínseco e extrínseco. Para que o mais básico exercício de comparação de um termo seja concretizado, é necessário admitir que o intérprete acesse evidências intrínsecas e extrínsecas para construir o sentido do termo que servirá de par de comparação, em uma única e combinada operação de interpretação ("a closely integrated single rule of interpretation").

\subsubsection{Exemplo: a comparação dos termos "enterprise", "person" e "business" para a interpretação da CM-OCDE.}

Esse exercício foi desenvolvido por KEES VAN RAAD ${ }^{566}$ em relação ao termo "enterprise", ainda em face da CM-OCDE de 1977 e 1992: o termo "enterprise" possuiria algumas vezes o sentido correspondente à "person", ora o sentido de "business" e, em outros dispositivos, o sentido tanto de "person" como de "business".

Com o sentido de "person", o professor de Leiden observou que o termo "enterprise" seria utilizado no texto da CM-OCDE: (i) com referência a entidades sob determinada situação jurídica, nos arts. 2(2), 5(5), 9 (1) e (2), bem como pelo art. 24(5) e (6); (ii) com referência a entidades, em um sentido não necessariamente jurídico, nos arts. 3(1) “d”, 7(1) e (2) e 9; e (iii) com sentido ambivalente, no art. 5(1), (4) e (5), art. 6 (4), art. 7 (1), art. 9 (2) e 24 (5).

Com o sentido de "business", o termo "enterprise" seria utilizado no texto da CMOCDE, entre outros, em seu art. 7(1), art. 8(1) e (3), art. 15(3) e art. 22(3). Por fim, Kees van Raad observou que em alguns dispositivos o termo "enterprise" assumiria tanto o sentido de "person" quanto de "business", como no art. 5(4) “e”, (5), (6), art. 7(2), art. 9(1) art. 13 (2), art. 22(2) e art. 24(4) da CM-OCDE.

\footnotetext{
${ }^{566}$ RAAD, Kees van. The term 'Enterprise' in the Model Double Taxation Conventions - Seventy Years of Confusion, in Intertax 1994/11, Intertax, 1994, p. 492-493.
} 


\subsubsection{Exemplo: A experiência australiana da interpretação de termos das convenções} fiscais comparando a sua utilização em diferentes dispositivos.

No caso Caso Thiel (Austrália, 1990), o tribunal australiano precisou construir o sentido dos termos "enterprise" e "carring on business" presente no art. 7 (1) do acordo de dupla tributação Austrália-Suíça. Para concluir que tal termo teria o sentido de uma entidade ou estrutura pela qual uma atividade seria desempenhada, bem como a própria atividade em si, o juiz DAWSON fundamentou a sua decisão em uma análise comparativados arts. 5, 7, 9 e 13 do mesmo acordo internacional, os quais apresentariam atributos relevantes à tais definições.

A partir de tal análise, acompanhada também de outras evidências intrínsecas e extrínsecas à convenção fiscal Austrália-Suíça, concluiu o tribunal que o art. 7 (1) seria aplicável tanto às empresas (entidades) quanto às atividades empresariais, bem como não seria necessária qualquer frequência no exercício desta para a sua caracterização.

\subsubsection{Exemplo: a comparação do termo "income" em dispositivos do acordo de bitributação Canadá-Alemanha.}

No Caso Melford (Canadá, 1981), a Suprema Corte canadense também se valeu de tal recurso. Os específicos regimes adotados em relação aos dividendos (artigo VI), certos juros (artigo 7), royalties (8) e alugueres (artigo 13) corroborariam a ideia de que o termo "income", referido no art. 7 do acordo de dupla tributação Canadá-Alemanha, não possuiria amplitude maior que a ilustrada pelos termos entre parênteses que os sucediam.

\subsubsection{Exemplo: a comparação da função dos enunciados para a interpretação do acordo de dupla tributação EUA-Reino Unido.}

No Caso McDermott (Austrália, 2005), foi necessário interpretar termos não definidos no acordo de bitributação Austrália-Singapura, como "used", utilizado em seu art. 4 (3) "b". Ocorre que, embora tal cláusula seja equivalente ao art. $5^{\circ}$ da CM-OCDE 
(estabelecimento permanente), veicula dispositivo ausente neste, segundo o qual se considera presente um estabelecimento permanente de uma empresa de um Estado contratante, bem como que seus negócios são conduzidos por meio deste, se "substantial equipment is being used in that other State by, for or under contract with the enterprise".

Em seu art. 10 (equivalente ao art. 12 da CM-OCDE), o acordo AustráliaSingapura previa que os impostos australianos sobre royalties pagos a residentes de Singapura não excederiam 10\%. O item (3) "a" "ii" do dispositivo especificou que seriam considerados royalties quaisquer pagamentos realizados pelo uso ("use") ou direito de uso ("right to use") de equipamentos industriais, comerciais ou científicos. Por sua vez, o item (4) do dispositivo afastou a aplicação das regras especificadas em seus itens (1) e (2) se o residente de um dos Estados contratantes beneficiário dos royalties possuisse, no outro Estado contratante, um estabelecimento permanente e as informações, direitos ou propriedade que dessem origem a tais royalties se mostrassem efetivamente conectados com as atividades desenvolvidas pelo referido estabelecimento pemanente.

O tribunal australiano consignou que, para se atribuir efeitos adequados ao texto de um acordo de bitributação, seria essencial considerar o seu "contexto". A decisão, então, empreendeu uma investigação sobre o acordo como um todo, segregando os dispositivos em duas grandes categorias: rendimentos ativos e rendimentos passivos. O lucro das empresas, tutelado pelo art. 5 do acordo (equivalente ao art. 7 da CM-OCDE) estaria compreendido naquela primeira categoria, enquanto que os royalties referidos no art. 10 (equivalente ao art. 12 da CM-OCDE) seriam rendimentos passivos.Tal análise, para o tribunal, seria útil para evidenciar se o termo "used", utilizado na fórmula de caracterização de estabelecimentos permanentes, teria acepções diversas em relação aos rendimentos ativos ou passivos. 


\subsubsection{Exemplo: a comparação do termos "beneficial owner", "beneficiário efetivo" no art. 10, 11 e 12 da CM-OCDE.}

Outro exemplo pode ser observado no exercício desenvolvido por LEONARDO Freitas de Moraes e CASTRO ${ }^{567}$. Os arts. 10 (Dividendos), 11 (Juros) e 12 (Royalties) da CM-OCDE estabelecem como requisito para a sua aplicação à determinada pessoa que: (i) esteja compreendida entre as "pessoas visadas" referidas no art. 1 da CM-OCDE; (ii) seja considerada residente em um dos Estados Contratantes, conforme o artigo 4 da CMOCDE; (iii) os dividendos, juros e royalties sejam considerados pagos a essa pessoa; e (iv) essa pessoa seja considerada beneficiária efetiva dos rendimentos. Conclui o autor, então, que os termos benefíciário efetivo veiculam condição para que determinadas pessoas possam se valer dos benefícios do acordo de bitributação.

\subsection{A identificação dos objetivos e propósitos do acordo a partir de detalhes de cada uma de suas partes: análise do texto do acordo como um todo.}

"A finalidade objetivada no texto e no contexto se revela nas peculiaridades das intenções contidas nos preceitos e conceitos jurídicos". RUY BARBOSA NOGUEIRA (1995) ${ }^{568}$

Como é sabido, os objetivos e os propósitos dos acordos internacionais devem ser construídos especialmente a partir de evidências do contexto intrínseco ${ }^{569}$. O preâmbulo dos acordos internacionais frequentemente é citado como evidência quanto aos referidos objetivos e propósitos, por geralmente trazer algumas disposições expressas a esse respeito.

No entanto, a identificação dos objetivos e propósitos do acordo a partir de detalhes de cada uma de suas partes também é uma técnica correntemente adotada por Cortes nacionais para a interpretação dos acordos de dupla tributação.

\footnotetext{
${ }^{567}$ MORAES E CASTRO, Leonardo Freitas de. Conceito de beneficiário efetivo nos acordos internacionais contra a bitributação (dissertação de mestrado). São Paulo : Faculdade de Direito da Universidade de São Paulo, 2012, p. 207.

${ }^{568}$ NOGUEIRA, Ruy Barbosa. Curso de Direito Tributário. São Paulo, Saraiva, 1995, p. 93.

${ }^{569}$ ONU. Yearbook of the International Law Commission. 1966. Records on the 866th meeting. vol. II. ONU, 1966.
} 


\subsubsection{Exemplo: A experiência norte-americana de identificação dos objetivos e propósitos do acordo a partir de detalhes de cada uma de suas partes.}

No Caso Maximov (EUA, 1963), a Suprema Corte dos EUA analisou a tese de que o acordo de dupla tributação EUA-Reino Unido teria o propósito de atribuir reciprocidade e igualdade entre aqueles Estados, de tal modo que a ausência de previsão no sistema jurídico inglês para a tributação dos ganhos de capital realizados por trusts constituídos no Reino Unido por residentes dos EUA justificaria o mesmo tratamento nos EUA ${ }^{570}$.

O juiz GoldBerg, acompanhado por todo o Tribunal, rejeitou a tese sob a evidência de que a análise de cada um dos dispositivos da convenção não conduzia necessariamente à igualdade ou reciprocidade entre os Estados contratantes; casos de benefícios atribuídos apenas a pessoas residentes de um dos Estados contrantes contrastariam de outras hipóteses, em que a reciprocidade era expressamente acordada. Decidir de outra forma contrariaria o texto da convenção fiscal, o que a Corte consignou que procuraria evitar.

\subsubsection{Exemplo: A identificação do treaty entitlement pela análise de diferentes dispositivos da convenção fiscal.}

No Caso Banco do Brasil/Commerzbank (Reino Unido, 1990), o tribunal consignou que não haveria indicações claras no acordo de bitributação Reino Unido-EUA de que os seus benefícios seriam aplicáveis exclusivamente a pessoas residentes em um dos dois Estados contratantes. Para o tribunal, alguns dispositivos não excluiriam residentes de terceiros Estados, enquanto outros expressamente identificariam aqueles que poderiam se valer dos benefícios da convenção, confinando-os a cidadãos e residentes de um dos Estados contratantes.

No caso, não haveria, no dispositivo cujos termos estariam sendo interpretados (art. 15), disposição expressa quanto aos indivíduos visados, mas apenas referências quanto à caracterização da fonte dos pagamentos. Decidiu o tribunal, ao final, que as filiais dos

${ }^{570}$ À época, o Reino Unido não tributava o ganho de capital de forma geral. 
bancos brasileiro e alemão, estabelecidas no Reino Unido, fariam jus aos benefícios do acordo Reino Unido-EUA em relação aos juros pagos por empresas residentes nos EUA em função de empréstimos realizados.

\subsubsection{Exemplo: a interpretação do termo "tax" com base nos objetivos e propósitos do acordo desvendados a partir de detalhes de cada uma de suas partes}

Na investigação proposta por ADOLFO J. MARTín JIMÉNEZ ${ }^{571}$ para a interpretação do termo "tax" referido no art. 2 da CM-OCDE, o autor também recorre à análise sistemática, procurando integrar as diversas partes do próprio art. 2 com tal finalidade. Sustenta, então, que a lista do art. 2 (3) dos acordos de dupla tributação geralmente inclui contribuições sociais. Nesse caso, por uma interpretação baseada unicamente no contexto intrínseco de tais convenções, para que contribuições sociais pudessem ser incluídas em seu escopo, o intérprete deveria partir do pressuposto de que a definição geral veiculada pelo art. 2 (2) expandiria a listagem enunciada pelo (3) desse dispositivo.

O professor da Universidade de Cádiz ${ }^{572}$ também observa como o art. 26 colabora para a interpretação do termo "taxes" referido no art. 27 desde a versão da CM-OCDE de 2003, o que também seria reconhecido pelos Comentários do CAF-OCDE ${ }^{573}$. Tal como o art. 26, o art. 27 não tem o seu escopo limitado aos tributos referidos no art. 2 da CMOCDE, aplicando-se sobre tributos de quaisquer espécies. Sob tal perspectiva, seria possível concluir que o termo "taxes", disposto no art. 27 da CM-OCDE, teria o mesmo alcance que o mesmo termo referido no art. 26, mas não se limitando ao escopo do termo "tax" referido no art. 2.

\footnotetext{
${ }^{571}$ JIMÉNEZ, Adolfo J. Martín. Defining the objective scope of income tax treaties: the impact of the other treaties and EC Law on the Concept of Tax in the OCED Model, in Bulletin - Tax Treaty Monitor - October 2005. Amsterdã : IBFD, 2005, p. 432 e seg.

572 JIMÉNEZ, Adolfo J. Martín. Defining the objective scope of income tax treaties: the impact of the other treaties and EC Law on the Concept of Tax in the OCED Model, in Bulletin - Tax Treaty Monitor - October 2005. Amsterdã : IBFD, 2005, p. 443.

${ }^{573} \mathrm{O}$ autor, no caso, se refere ao Comentário n. 13 ao art. 27, em sua versão de 2003.
} 
No entanto, Adolfo J. MARTín JiMÉnez ${ }^{574}$ também observa que as limitações ao termo "taxes" do art. 26 da CM-OCDE, justificadas por parallel treaties que veiculam cláusulas específicas de troca de informações, podem não ser aplicáveis na mesma extensão em relação ao artigo 27. Ocorre que, em geral, os acordos internacionais, como aqueles específicos à tributação aduaneira, cuidam da troca de informações, mas não exatamente da questão tratada pelo art. 27 da CM-OCDE (assistência para a coleta de tributos).

\subsubsection{Exemplo: a interpretação da expressão "borne by a permanent establishment" com base nos objetivos e propósitos do acordo desvendados a partir de detalhes de cada uma de suas partes}

Outro exemplo que pode ser observado se refere ao sentido da expressão "borne by a permanent establishment", referida no art. 15 (2) “c” da CM-OCDE e geralmente traduzida aos acordos brasileiros como "imputadas a um estabelecimento permanente",575 ou "couber a um estabelecimento",576. O dispositivo, como se viu, veicula regra aplicável aos empregos de curta duração, estabelecendo exceção à regra da tributação desses rendimentos exclusivamente no local onde tais atividades são desenvolvidas.

Para a interpretação dessa expressão, os Comentários à CM-OCDE sugerem o recurso ao contexto intrínseco, com a análise sistemática do art. 15 (2) “c" e do art. 7 (2) da $\mathrm{CM}^{-O C D E}{ }^{577}$. Caso seja autorizada ao estabelecimento permanente situado no Estado em que as atividades são desempenhadas a dedução da aludida remuneção paga ao empregado, então esses valores deveriam ser imputados a esse estabelecimento permanente, ou seja, os rendimentos do referido empregado seriam tributados também em tal Estado, cabendo ao seu Estado de residência aliviar a dupla tributação pelo método do crédito. ${ }^{578}$

\footnotetext{
${ }^{574}$ JIMÉNEZ, Adolfo J. Martín. Defining the objective scope of income tax treaties: the impact of the other treaties and EC Law on the Concept of Tax in the OCED Model, in Bulletin - Tax Treaty Monitor - October 2005. Amsterdã : IBFD, 2005, p. 432 e seg.

${ }^{575}$ Vide, por exemplo: BRASIL, Decreto n $\mathrm{n}^{\mathrm{o}} 7.020$, de 27/11/2009 (TRATADO BRASIL-PERU), art. 15 (2).

${ }^{576}$ Vide, por exemplo: BRASIL, Decreto $\mathrm{n}^{\mathrm{o}} 4.852$, de 02/10/2003 (TRATADO BRASIL-CHILE): art. 15 (2).

${ }^{577}$ Vide, por exemplo: OECD, Model Tax Convention on Income and on Capital 2014 (Full Version), OECD Publishing, 2014. Comentário ao art. 15 da CM-OCDE, parágrafo 7.

${ }^{578}$ Nesse sentido, vide: DZIURDŹ, Kasper; PÖTGENS, Frank. Cross-Border Short-Term Employment, Bulletin for International Taxation Vol. 68, n. 8 (agosto). Amsterdã : IBFD, 2014, p. 404-406.
} 


\section{CAPÍTULO III O CONTEXTO EXTRÍNSECO PRIMÁRIO DOS ACORDOS DE DUPLA TRIBUTAÇÃO}

\section{NOTAS INTRODUTÓRIAS.}

Teorias como do contexto exclusivamente intrínseco sustentam que as evidências que advogados poderiam colher do "contexto" referido no art. 3 (2) da CM-OCDE estariam confinadas ao texto da específica convenção fiscal, ao seu preâmbulo, aos anexos e a qualquer acordo ou instrumento a elas relativas e firmado entre as partes em conexão com o tratado. Estaria o juiz hermeticamente fechado em relação a outras evidências. Já teorias como da suficiência do sentido "claro" provido pela literalidade do termo ou, ainda, por elementos do contexto intrínseco, não necessariamente recusariam a possibilidade do recurso a elementos do contexto extrínseco, mas o considerariam geralmente desnecessário ou mesmo desaconselhável quando evidências textuais fornecessem sentidos razoáveis ao termo de uma convenção fiscal sob interpretação.

No entanto, a norma do art. 3 (2) da CM-OCDE, a partir dos critérios estabelecidos pela CVDT, exige dos operadores do Direito tributário internacional uma ampla investigação para a construção do sentido contextualizado dos termos de acordo de dupla tributação. O sentido comum, contextualizado, consentido, sob o escopo do "contexto" referido no art. 3 (2) da CM-OCDE, requer a aplicação da única e combinada operação de interpretação vigente no Direito Internacional público, pela qual são admissíveis tanto evidências intrínsecas quanto extrínsecas. Ainda que se admitam os elementos intrínsecos analisados no Capítulo II deste estudo como ponto de partida, o processo de interpretação dos acordos de dupla tributação apenas se conclui após o levantamento e consideração de todas as evidências intrínsecas e extrínsecas disponíveis em cada caso.

O presente Capítulo se dedica à investigação de evidências quanto ao sentido de termos dos acordos de dupla tributação apuradas no contexto extrínseco primário, sob o 
escopo do art. 3 (2) da CM-OCDE e do art. 31 (3) da CVDT. O contexto extrínseco secundário será analisado no "Capítulo IV", que antecede as "Conclusões" deste estudo.

Tal como proposto nesta tese, a admissibilidade das evidências extrínsecas primárias será examinada sob a perspectiva de critérios formais de validade perante o Direito tributário internacional e critérios funcionais, especialmente a promoção do efeito útil e da interpretação harmônica da convenção fiscal. A tese procura investigar, ainda, até que ponto a plausividade da interpretação construída (critério material) pode interferir na seleção de evidências sob o escopo do "contexto" referido no art. 3 (2) da CM-OCDE, o que dá ensejo a uma série de considerações colhidas de decisões de Cortes nacionais, expostas a título de exemplo.

A investigação do contexto extrínseco primário que se propõe tem o objetivo de suscitar elementos que sirvam como argumento quanto ao sentido dos acordos de bitributação em ambos os Estados contratantes, sem que, para isso, se recorra ao Direito doméstico destes. Essa análise demanda, em especial, o exame: (i) se os procedimentos amigáveis, conduzidos nos moldes do art. 25 da CM-OCDE, podem ser considerados como um "acordo posterior entre as partes relativo à interpretação do tratado ou à aplicação de suas disposições" ${ }^{\text {,579; }}$ ( ii) se decisões e normas enunciadas por autoridades fiscais, juízes ou mesmo pelo Poder Legislativo, advindas de um ou de ambos os Estados contratantes, podem ser reconhecidas como "prática seguida posteriormente na aplicação do tratado, pela qual se estabeleça acordo entre as partes relativo à sua interpretação" ${ }^{, 500} \mathrm{e}$, ainda; (iii) se outros acordos de dupla tributação ou outros tratados (não tributários) de que façam parte os Estados contratantes poderiam ser adotados como pares de comparação (parallel treaties), bem como se seriam evidências sob o escopo do princípio da integração sistêmica ${ }^{581}$.

\footnotetext{
${ }^{579}$ CVDT, art. 31 (3), “a”.

${ }^{580}$ CVDT, art. $31(3)$, "b".

${ }^{581}$ CVDT, art. 31 (3), "c".
} 


\section{PROCEDIMENTO AMIGÁVEL: EVIDÊNCIAS EXTRÍNSECAS NO DIREITO TRIBUTÁRIO INTERNACIONAL?}

Com vistas aos elementos do Direito tributário internacional sob o escopo do art. 31 (3) "a" da CVDT, a doutrina ${ }^{582}$ com frequência faz referência aos "procedimentos amigáveis" ("mutual agreements") do art. 25 da CM-OCDE. Tratar-se-ia de acordos posteriores entre as partes relativos à interpretação do tratado ou à aplicação de suas disposições, de modo a pertencerem ao contexto extrínseco primário dos acordos de dupla tributação. Tal postura é, contudo, criticada por outros acadêmicos, bem como não observada por tribunais que recusam a sua relevância ou mesmo validade.

Os próximos subtópicos se dedicam à análise do procedimento amigável, especialmente quanto: (i) ao seu delineamento na CM-OCDE, CM-ONU e CM-EUA; (ii) à revisão doutrinária quanto à sua validade e eficácia e; (iii) à sua aptidão para fornecer evidências quanto ao sentido contextualizado de termos dos acordos de bitributação, sob o escopo do contexto extrínseco primário. Em relação a esta última temática, os procedimentos amigáveis serão analisados com vistas aos três critérios formais, funcionais e materiais propostos nesta tese.

Dois pontos preliminares devem ser sublinhados. Primeiro, é preciso enfatizar que os procedimentos amigáveis serão analisados neste estudo com vistas à utilidade que possam apresentar aos contribuintes que os instaurarem, à generalidade dos residentes dos Estados que os promoverem e, ainda, aos residentes de outros Estados, terceiros em um procedimento amigável.

Além disso, é preciso considerar que não há, ao menos em relação ao Brasil, divulgação automática de procedimentos amigáveis celebrados com os seus parceiros, bem como não há notícia de decisões administrativas ou judiciais que os tenham considerado. A

\footnotetext{
${ }^{582}$ Vide, por exemplo: AVERY JONES, John et al., The interpretation of tax treaties with particular reference to article 3(2) of the OECD Model - II. 1984, British Tax Review, p. 95-96; VOGEL, Klaus; PROKISCH, Rainer G. Cahiers de Droit Fiscal International by the International Fiscal Association (studies on international tax law), volume LXXVIIIa - Subject I. Interpretation of double taxation conventions. Kluwer Law and Taxation Publishers / IFA : Rotterdam, 1993, p. 71; ROHATGI, Roy. Basic International taxation. Volume 1: principles. Nova Deli : Taxmann, 2005, p. 47; TÔRRES, Heleno Taveira. Pluritributação internacional sobre as rendas das empresas. São Paulo : Revista dos Tribunais, 2001, p. 652.
} 
questão vai além do sigilo: as autoridades administrativas brasileiras parecem não ter tradição em promover tais acordos com os seus parceiros internacionais. A recusa das autoridades administrativas brasileiras para a condução de procedimentos amigáveis sobre a interpretação e aplicação do acordo Brasil-Alemanha foi inclusive indicada por GERD W. ROTHMANN $^{583}$ como uma das justificativas para a denúncia alemã daquela convenção.

\subsection{Os procedimentos amigáveis previstos na CM-OCDE.}

Os acordos de dupla tributação em geral contêm cláusulas que regulam como as autoridades fiscais dos Estados contratantes devem promover procedimentos amigáveis ("mutual agreements") para dirimir conflitos de interpretação e outras causas que possam conduzir à dupla tributação. $\mathrm{O}$ art. 25 da CM-OCDE é geralmente adotado como padão nas convenções fiscais celebradas pelos Estados, ainda que não integralmente, como se poderá observar nos acordos celebrados pelo Brasil examinados adiante.

$\mathrm{O}$ art. 25 da CM-OCDE cuida basicamente de quatro questões inerentes aos procedimentos amigáveis: (i) sujeitos competentes para a sua instauração e condução (questão subjetiva); (ii) as causas para a sua instauração (questão substantiva); (iii) o modo de sua condução (questão adjetiva) e; (iv) os seus propósitos (questão finalística).

Em relação aos seus sujeitos (questão subjetiva), os procedimentos amigáveis podem ser instaurados pelo contribuinte ou por um dos Estados contratantes (procedimentos amigáveis individuais). O parágrafo $1^{\circ}$, do art. 25, da CM-OCDE, presente em todos os acordos de bitributação assinados pelo Brasil ${ }^{584}$, assegura ao contribuinte dirigir-se ao seu Estado de residência e reclamar da exigência de tributos em desacordo com a convenção fiscal celebrada com o Estado da fonte de seus rendimentos. O parágrafo 3, do art. 25, da CM-OCDE, por sua vez, atribui às "autoridades competentes" dos Estados contratantes a prerrogativa (ou dever) de dar início ao procedimento amigável.

${ }^{583}$ ROTHMANN, Gerd W. A denúncia do acordo de bitributação Brasil-Alemanha e suas consequências, in Grandes Questões Atuais do Direito Tributário vol. 9 (Coord. Valdir de Oliveira Rocha). Dialética : São Paulo, 2005, p. 147-148.

${ }^{584}$ Vide, por exemplo, BRASIL, Decreto n ${ }^{\text {o }} 7.020$, de 27/11/2009 (TRATADO BRASIL-PERU), art. 24. 
Não é demais observar que, embora o contribuinte possua legitimidade para instaurar o procedimento amigável, não tem efetiva participação em sua condução. $\mathrm{O}$ contribuinte é mero expectador ou sequer isso. Nem sempre lhe é possibilitado ter acesso a esse processo administrativo desenvolvido em uma ou em ambas as jurisdições. Ainda no Congresso da IFA de $1960^{585}$, ERNST FrITSCH e PAUL SiBILLE, respectivamente relatores da Áustria e Bélgica, sugeriram que o contribuinte afetado pelo procedimento amigável conduzido pelas autoridades fiscais dos Estados contratantes deveria ser chamado a colaborar, como ocorria em algumas jurisdições. Também GERD W. ROTHMANN ${ }^{586}$, já em 1978, concluiu que deficiências do procedimento amigável reclamavam pelo seu aperfeiçoamento, para que se permitisse que o contribuinte alcançado pelas pretensões fiscais concorrentes tivesse garantida a possibilidade de participar e, logo, colaborar para a solução das questões.

Quanto à sua questão substantiva (ou, o que justifica a sua instauração), os procedimentos amigáveis previstos pela CM-OCDE podem ser segregados em: (a) individuais; (b) interpretativos e; (c) integrativos ${ }^{587}$.

Os procedimentos amigáveis individuais ("specific case provision"), conforme o art. 25 (1) e (2) da CM-OCDE, seriam instaurados pelo contribuinte em seu Estado de residência (ou, em certos casos, nacionalidade) para prevenir ou reprimir ${ }^{588}$ a cobrança de tributos sem a observância de normas da convenção fiscal por um ou por ambos os Estados contratantes, ainda que não haja efetiva dupla tributação. Os Comentários à CM-OCDE sugerem que, para dar início ao procedimento amigável, o contribuinte deverá demonstrar que: (i) atos ou decisões adotados por um ou por ambos os Estados contratantes, de natureza legislativa ou regulatória, de aplicação geral ou individual; (ii) figuram como "um

\footnotetext{
${ }^{585}$ LENZ, Raoul. General Report. Cahiers de Droit Fiscal International by the International Fiscal Association (studies on international tax law), volume XLII - Subject II: The interpretation of the Double Taxation Convention. / IFA : Roterdã, 1960, p. 305.

${ }^{586}$ ROTHMANN, Gerd W. Interpretação e aplicação dos acordos internacionais contra a bitributação. Tese de doutorado. São Paulo : Faculdade de Direito da Universidade de São Paulo (USP), 1978, p. 187.

${ }^{587}$ ROY ROHATGI os segrega apenas em "interpretative to avoid doubts or difficulties"e "legislative to avoid double taxation". (ROHATGI, Roy. Basic International taxation. Volume 1: principles. Nova Deli : Taxmann, 2005, p. 47).

${ }^{588}$ OECD, Model Tax Convention on Income and on Capital 2014 (Full Version), OECD Publishing, 2014. Comentário N. 14 e 39 do art. 25.
} 
risco não meramente possível, mas provável”, da cobrança de tributos contra o reclamante sem a observância das normas da convenção fiscal. ${ }^{589}$

A primeira parte do art. 25 (3) da CM-OCDE tutela os chamados procedimentos amigáveis interpretativos, os quais são instaurados por um dos Estados contratantes a fim de solucionar dúvidas e dificuldades na melhor interpretação e aplicação da convenção internacional celebrada. É o que se observa no acordo Brasil-Peru ${ }^{590}$, que em seu art. 24 (3) dispõe que "as autoridades competentes dos Estados Contratantes farão o possível para resolver as dificuldades ou para dirimir as dúvidas que possam dar lugar a interpretação ou a aplicação da Convenção mediante acordo amigável”.

Por sua vez, a segunda parte do art. 25 (3) da CM-OCDE dispõe que as autoridades competentes dos Estados contratantes poderiam consultar-se para eliminar hipóteses de bitributação não previstas na convenção fiscal celebrada. Como exemplo de dispositivo com a previsão desse procedimento amigável integrativo, pode-se observar que, no acordo Brasil-Espanha $^{591}$, a segunda oração do art. 25 (3) dispõe que as autoridades administrativas de ambos os Estados "poderão, também, consultar-se mutuamente com vistas a eliminar a dupla tributação nos casos não previstos na presente Convenção". ALBERTO XAVIER ${ }^{592}$ noticia que essa espécie de procedimento sequer consta em quaisquer das convenções fiscais celebradas pelo Reino Unido, como reflexo de vedações no sistema jurídico doméstico daquele Estado para que as autoridades administrativas celebrem acordos que alargem o âmbito de um tratado sem que haja nova participação do Parlamento.

O modo pelo qual os procedimentos amigáveis devem ser conduzidos (questão adjetiva) é distinto em relação aos procedimentos amigáveis individuais e àqueles instaurados apenas entre os Estados contratantes (interpretativo e integrativo). O parágrafo $2^{\circ}$ do art. 25 da CM-OCDE, também presente em todos os acordos de dupla tributação

\footnotetext{
589 OCDE. Modelo de Convenção Tributária sobre o Rendimento e o Capital. Versão Condensada, de 22 de julho de 2010. Tradução: Demarest \& Almeida Advogados, p. 369-372, parágrafo 13 e 14 dos comentários ao art. 25.

${ }^{590}$ BRASIL. Decreto n 7.020 , de 27/11/2009 (TRATADO BRASIL-PERU).

${ }^{591}$ BRASIL. Decreto no 76.975 , de 2/01/1976 (TRATADO BRASIL-ESPANHA).

${ }^{592}$ XAVIER, Alberto. Direito Tributário Internacional do Brasil. Rio de Janeiro: Forense, 2010, p. 168-169.
} 
celebrados pelo Brasil ${ }^{593}$, estabelece os dois passos que devem ser manejados nos procedimentos amigáveis individuais pelo Estado de residência diante da reclamação do contribuinte quanto à exigência de tributo sem a observância das disposições da Convenção: (i) diante da reclamação proposta por seu residente (ou nacional), o Estado deve tentar solucioná-la por si só; (ii) caso não haja êxito na solução da questão domesticamente, deverá o Estado de residência se comunicar com o outro Estado contratante, a fim de que se empenhem na solução da questão.

Em relação aos procedimentos amigáveis instaurados diretamente por um dos Estados contratantes (interpretativo ou integrativo), prevalece o caráter informal ${ }^{594}$, podendo as autoridades competentes ajustarem a forma de sua condução, inclusive com vistas a exigências de sua legislação doméstica.

Note-se, ainda, que o art. 25 (5) da CM-OCDE disciplina o recurso à arbitragem, caso o procedimento amigável não se mostre hábil para a solução da questão. Tal cláusula, vale notar, não foi adotada em nenhum dos acordos de dupla tributação celebrados pelo Brasil.

\subsection{O procedimento amigável previsto na CM-ONU.}

A CM-ONU acompanha o padrão da cláusula do procedimento amigável do art. 25 da CM-OCDE, incluindo como alternativa, inclusive, o dispositivo sobre a adoção da arbitragem.

\subsection{O procedimento amigável previsto na CM-EUA.}

A CM-EUA também prevê a adoção de procedimentos amigáveis em seu art. 25, com algumas peculiaridades em relação à CM-OCDE, embora em geral sejam semelhantes.

\footnotetext{
${ }^{593}$ Vide, por exemplo: BRASIL. Decreto ${ }^{\circ}{ }^{7}$ 7.020, de 27/11/2009 (TRATADO BRASIL-PERU), artigo 24 (2).

${ }^{594}$ XAVIER, Alberto. Direito Tributário Internacional do Brasil. Rio de Janeiro: Forense, 2010, p. 164-166.
} 
É importante notar, contudo, que a CM-EUA também faz referência à utilização do procedimento amigável no enunciado de seu art. 3 (2), o que foi adotado em boa medida nos acordos de bitributação celebrados pelo Brasil com a Argentina ${ }^{595}$ e com o Equador ${ }^{596}$.

Como exemplo, a “technical explanation” emitida pelo Departamento do Tesouro dos EUA, com referência ao acordo de dupla tributação EUA-Bélgica ${ }^{597}$, observa que os termos não definidos no texto do acordo deveriam ter o seu sentido construído com o reenvio ao Direito doméstico dos Estados contratantes quando o contexto não prover sentido diverso ou, ainda, quando as autoridades competentes não acordarem um sentido diverso por meio de procedimentos amigáveis. Se o sentido do termo em questão não puder ser construído com base no "contexto" ou mesmo com o reenvio ao Direito doméstico dos Estados contratantes, a technical explanation conclui que as autoridades competentes devem instaurar o procedimento amigável para solucionar a questão por meio de uma interpretação harmônica, a fim de atribuir efeito útil ao acordo de dupla tributação celebrado. O documento ainda expressa que a interpretação harmônica alcançada pelos Estados contratantes não precisaria se conformar com os sentidos contidos no Direito doméstico de nenhum destes.

\subsection{Critérios formais de reconhecimento: a validade e a eficácia dos procedimentos amigáveis perante o Direito tributário internacional.}

A doutrina ${ }^{598}$ e a jurisprudência de Cortes nacionais geralmente atribuem aos procedimentos amigáveis o status do art. 31 (3) "a" da CVDT (contexto extrínseco

${ }^{595}$ BRASIL. Decreto n ${ }^{\circ}$ Decreto $n^{\circ}$ 87.976, de 22 de Dezembro de 1982 (Acordo Brasil-Argentina). Art. 3 (2).

${ }^{596}$ BRASIL. Decreto $n^{\circ}$ 95.717, de 11 de fevereiro de 1988 (Acordo Brasil-Equador). Art. 3 (2).

${ }^{597}$ EUA. Department of the Treasury of USA. Technical Explanation of the Convention between the Government of the United States of America and the Government of the Kingdom of Belgium for the Avoidance of Double Taxation and the Prevention of Fiscal Evasion with Respect To Taxes On Income Signed At Brussels On November 27, 2006.

${ }^{598}$ Vide: AVERY JONES, John. et al., The interpretation of tax treaties with particular reference to article 3(2) of the OECD Model - II. 1984, British Tax Review, p. 95-96; VOGEL, Klaus; PROKISCH, Rainer G. Cahiers de Droit Fiscal International by the International Fiscal Association (studies on international tax law), volume LXXVIIIa - Subject I. Interpretation of double taxation conventions. Kluwer Law and Taxation Publishers / IFA : Rotterdam, 1993, p. 71. 
primário), equiparando-os, portanto, a acordos posteriores entre as partes relativos à interpretação do tratado ou à aplicação de suas disposições.

Note-se que acordos aludidos nesse dispositivo da CVDT são muito semelhantes àqueles relacionados em seu 31 (2) " $a$ " "599, pertencentes ao contexto intrínseco analisado no Capítulo II. O critério distintivo adotado pela ILC-ONU para segregar os primeiros dos segundos teria sido apenas temporal, já que estes últimos seriam contemporâneos ao tratado principal e, aqueles primeiros, posteriores a ele. Tal frágil segregação, contudo, deve ser compreendida a partir da única e combinada operação de interpretação (" $a$ closely integrated single rule of interpretation") vislumbrada pela ILC-ONU, pela qual não há precedência entre quaisquer dos elementos do contexto intrínseco e do contexto extrínseco primário.

Há uma questão que deve ser analisada quando se considera a possibilidade de se obter evidências a partir de procedimentos amigáveis. É necessário distinguir situações: (i) em que um Tribunal recorre a um procedimento amigável anteriormente instaurado com vistas ao mesmo caso sob análise, ou seja, envolvendo os mesmos Estados contratantes e, tratando-se de procedimento amigável individual, o mesmo contribuinte que o instaurou; (ii) de casos em que se recorre a procedimentos amigáveis celebrados por terceiros.

Isso porque, há uma primeira limitação que decorre da assunção do procedimento amigável entre os elementos do art. 31 (3) "a" da CVDT: apenas procedimentos amigáveis firmados entre as partes seriam relevantes, de tal modo que um Estado (“C”) não poderia reclamar interpretação igual àquela adotada em procedimento amigável concluído entre dois outros Estados ("A" e "B"). ${ }^{600}$ Além de tal limitação normativa, é preciso reconhecer que a solução obtida em procedimentos amigáveis relacionados a dois Estados (“A” e "B”) provavelmente levaria em consideração fatores que não estão presentes em outros acordos internacionais (“A-C”, “B-D”).

\footnotetext{
${ }^{599}$ DÖRR, Oliver. "Article 31 - General rule of interpretation", in "Vienna Convention on the Law of Treaties: a Commentary”, DÖRR, Oliver; SCHMALENBACH, Kirsten (Editors). Springer, 2012, p. 553554.

${ }^{600}$ Nesse sentido, vide: WIJNEN, Wim. Some Thoughts on Convergence and Tax Treaty Interpretation, in Tax Treaty Monitor - Bulletin for International Taxation (November 2013). IBFD: Amsterdã, 2013, p. 576.
} 
Tradicionalmente, o tema dos procedimentos amigáveis traz consigo a discussão quanto à vinculação dos contribuintes, agentes físcais e juízes em relação às suas conclusões. Para IGOR MAUler SAnTIAGO ${ }^{601}$, por exemplo, tais elementos seriam classificados como meios diplomáticos de solução de conflitos internacionais, mais especificamente negociações diretas, marcados pela não-vinculatividade das conclusões obtidas.

Em especial, tais elementos suscitam a discussão quanto à sua validade tanto perante o Direito Internacional quanto diante do sistema jurídico dos Estados contratantes. Assim, ainda que os procedimentos amigáveis sejam considerados acordos internacionais plenamente válidos em face daquele primeiro, deveriam ainda ser submetidos ao crivo Constitucional, a fim de que pudessem vincular os respectivos tribunais nacionais.

Nesse seguir, com referência a variadas jurisdições, tem sido largamente questionado na literatura jurídica se haveria exigências constitucionais da participação do Congresso (ou Senado) que afastariam a vinculação de procedimentos amigáveis em relação aos contribuintes e tribunais ${ }^{602}$. O problema é que o procedimento amigável, tal como previsto no art. 25 (3) da CM-OCDE, deveria ser concluído por suas "autoridades competentes", as quais, conforme o art. 3 (1) " $\mathrm{f}$ " dos acordos das convenções físcais em geral, compreenderiam apenas as autoridades fiscais dos Estados contratantes, isto é, agentes administrativos. Com referência ao procedimento amigável integrativo, IGOR MAUler SANTIAGO ${ }^{603}$ suscita "dificuldades que o Direito Constitucional da quase totalidade dos países impõe para a celebração desses acordos, que se equiparam a novos tratados, exigindo referendo parlamentar".

${ }^{601}$ SANTIAGO, Igor Mauler. Método de Solução dos Conflitos fundados em Convenções contra a Dupla Tributação Internacional, in Direito Tributário Internacional Aplicado, vol. III. Tôrres, Heleno Taveira (coord.). São Paulo : Quartier Latin, 2005, p. 672-673.

${ }^{602}$ Nesse sentido, vide: VOGEL, Klaus. Klaus Vogel on Double Taxation Conventions. Kluwer : London, 1999, p. 48; VOGEL, Klaus; PROKISCH, Rainer G. Cahiers de Droit Fiscal International by the International Fiscal Association (studies on international tax law), volume LXXVIIIa - Subject I. Interpretation of double taxation conventions. Kluwer Law and Taxation Publishers / IFA : Rotterdam, 1993, p. 71-76; REIMER, Ekkehart. Interpretation of tax treaties - Germany. European Taxation. IBFD, 1999 (December).

${ }^{603}$ SANTIAGO, Igor Mauler. Método de Solução dos Conflitos fundados em Convenções contra a Dupla Tributação Internacional, in Direito Tributário Internacional Aplicado, vol. III. Tôrres, Heleno Taveira (coord.). São Paulo : Quartier Latin, 2005, p. 676. 
Os argumentos geralmente adotados para impugnar a validade dos procedimentos amigáveis perante o ordenamento constitucional são baseados, assim, na questão da "legalidade”, em especial: (i) a exigência de lei para a validade de norma decorrente de tratados internacionais em geral e; (ii) o princípio da estrita legalidade em matéria tributária.

Ao menos no Brasil, o argumento da legalidade tributária não parece ser o mais adequado para solucionar a questão da validade dos procedimentos amigáveis perante o sistema jurídico pátrio. Ocorre que, conforme o art. 150. I, da CF, o princípio da legalidade em matéria tributária veda a exigência ou o aumento de tributo sem lei que o estabeleça. Exige-se, portanto, que uma lei estabeleça a cobrança de impostos, o que não é o objeto de acordos de dupla tributação.

Embora o princípio da legalidade em matéria tributária pareça não criar óbice para que autoridades administrativas celebrem procedimentos amigáveis, a legalidade da decisão de vinculação do Brasil por meio de acordos internacionais parece levantar dúvidas quanto à necessidade de participação legislativa nos procedimentos amigáveis.

Uma série de competências relacionadas aos tratados foi delimitada na Constituição, de um modo que, para PEDRO DE ABREU DALLARI ${ }^{604}$, “a vinculação do Brasil a tratado internacional é decisão que depende, portanto, do concurso de dois Poderes: o Executivo e o Legislativo". Outros autores ${ }^{605}$ se posiciona de forma semelhante quanto à "necessária parceria entre o Poder Executivo e o Poder Judiciário" nesse processo.

No caso, como já se suscitou nos capítulos anteriores, compete privativamente ao Presidente da República "celebrar tratados, convenções e atos internacionais, sujeitos a referendo do Congresso Nacional" (CF, art. 84, VIII). É da competência exclusiva do Congresso Nacional "resolver definitivamente sobre tratados, acordos ou atos internacionais que acarretem encargos ou compromissos gravosos ao patrimônio nacional" (CF, Art. 49, I).

${ }^{604}$ DALLARI, Pedro Bohomoletz de Abreu. Constituição e tratados internacionais. São Paulo : Saraiva, 2003, p. 89.

${ }^{605}$ Nesse sentido: GRUPENMACHER, Betina Treiger. Tratados internacionais em matéria tributária e ordem interna. São Paulo : Dialética, 1999, p. 102; 134-135; 146. 
$\mathrm{Na}$ esfera judiciária, aos juízes federais compete processar e julgar "as causas fundadas em tratado ou contrato da União com Estado estrangeiro ou organismo internacional" (CF, art. 109, III), competindo ao Superior Tribunal de Justiça julgar, em recurso especial, decisão que contrariar tratado ou lei federal, ou negar-lhes vigência $(\mathrm{CF}$, art. 105, III, “a"), bem como ao Supremo Tribunal Federal, enquanto guardião da Constituição, julgar, mediante recurso extraordinário, decisão que "declarar a inconstitucionalidade de tratado ou lei federal" (CF, art. 102, III, “b”).

É preciso, então, analisar como tais normas constitucionais influenciam na validade dos procedimentos amigáveis no Direito tributário internacional do Brasil.

A revisão da literatura suscita três posturas que se poderiam assumir diante de procedimentos amigáveis, mas nem todas parecem consentâneas com a Constituição brasileira. Seriam elas: (i) invalidade, com vistas à Constituição; (ii) validade, à revelia da Constituição; e (iii) validade, com vistas à Constituição.

Para a análise de tais correntes, propõe-se que se suponha o seguinte cenário: dois Estados ("A" e "B"), que possuem dispositivos constitucionais exigindo a participação do Poder Legislativo em decisões que os onerem ou os vinculem no Direito Internacional, celebram um acordo de bitributação (“A-B”), sob os padrões da CM-OCDE. Tal convenção (“A-B”) foi devidamente ratificada por seus respectivos parlamentos, contendo cláusula semelhante ao art. 25 da CM-OCDE. Posteriormente, suas respectivas administrações fiscais estabeleceram contato e instauraram três procedimentos amigáveis. Quanto ao primeiro, trata-se de um procedimento amigável individual, decorrente de reclamação de um contribuinte ("X") residente em um dos Estados ("A"), que se queixa da tributação neste de rendimentos recebidos de fonte (" $y$ ") localizada no outro Estado contratante (“B”). Quanto ao segundo, trata-se de procedimento amigável interpretativo, instaurado por iniciativa das autoridades fiscais dos dois Estados (“A-B”) para solucionar questões interpretativas que poderiam conduzir à dupla tributação de rendimentos sob o escopo da convenção. O terceiro, por fim, consubstancia um procedimento amigável integrativo, também promovido pelas autoridades fiscais dos dois Estado (“A-B”), não por conta de dúvidas em sua interpretação, mas diante da concordância de ambos quanto à ausência de previsão na convenção de mecanismos para eliminar uma determinada situação de dupla tributação econômica. 


\subsubsection{A corrente da invalidade dos procedimentos amigáveis, com vistas à Constituição.}

Para uma primeira corrente, faltaria a esse "acordo posterior entre as partes relativo à interpretação do tratado ou à aplicação de suas disposições” eficácia no sistema jurídico doméstico para vincular contribuintes e juízes quanto ao sentido dos termos de um acordo de bitributação. Para que o procedimento amigável se tornasse vinculante, seria necessária a sua ratificação pelo Poder Legislativo ${ }^{606}$. Sob tal perspectiva, todos os procedimentos amigáveis suscitados no cenário anteriormente proposto (individual, interpretativo e integrativo) sequer necessitariam ser considerados por juízes de quaisquer das jurisdições (“A” ou "B”).

Em especial, MiCHAEL LANG ${ }^{607}$ suscita que não há autorização na CVDT para que agentes administrativos modifiquem tratados por meio de procedimentos amigáveis, ainda que esses sejam considerados sob o escopo do art. 31 (3) "a" da CVDT. Ocorre que aquele acordo multilateral distingue modificação (arts. 39-41) de interpretação (art. 31-33).

Sob tal perspectiva, poder-se-ia argumentar que, no caso brasileiro, a ausência de participação do Congresso Nacional na ratificação do acordo por meio de decretolegislativo, bem como a ausência de publicação do decreto do Presidente da República dando ciência do quanto acordado, excluiria sua própria feição de acordo internacional, inclusive de "acordo posterior entre as partes relativo à interpretação do tratado", de tal forma que não se reconheceria os procedimentos amigáveis entre os elementos do art. 31 (3) "a" da CVDT.

Como se verá adiante, a legitimidade dos procedimentos amigáveis perante a Constituição brasileira é sustentada por alguns autores sob o fundamento de que

\footnotetext{
${ }^{606}$ Nesse sentido, vide: LANG, Michael. Introduction to the law of double taxation conventions. Vienna : Linde, 2013, p. 55.

${ }^{607}$ LANG, Michael. Introduction to the law of double taxation conventions. Vienna : Linde, 2013, p. 42
} 
prescindiriam da participação do Legislativo. ALBERTO XAVIER ${ }^{608}$, por sua vez, suscita que os "meros acordos de forma simplificada" ( "agreements in simplified form", "accords en forme simplifiée") realmente não demandariam atos legislativos no Direito brasileiro: "Mas por isso mesmo não podem atuar na zona submetida constitucionalmente ao princípio da legalidade ou reserva de lei”.

Se tais assunções estiverem corretas, nenhum Estado que, por meio de seus agentes administrativos, formalizasse procedimento amigável com as autoridades fiscais brasileiras, poderia alegar expectativa de cumprimento por parte do Brasil que não existisse antes deste, por se tratar de uma limitação constitucional notória e presente na generalidade dos Estados. Para os fins desta tese, então, os procedimentos amigáveis não poderiam ser considerados evidências sob o escopo do contexto referido no art. 3 (2) da CM-OCDE, independentemente de se tratar de procedimento amigável individual, interpretativo ou integrativo.

\subsubsection{A corrente da validade dos procedimentos amigáveis, à revelia da Constituição.}

É possível examinar uma segunda postura, presente no debate internacional sobre o tema, pela qual seria preciso desconsider as normas constitucionais dos Estados contratantes na análise dos procedimentos amigáveis. O acordo internacional celebrado por dois Estados ("A" e "B") deveria ser respeitado por eles, independentemente de disposições em seus sistemas jurídicos domésticos, ainda que de ordem constitucional. No cenário anteriormente proposto para exame, contribuintes, fisco e juízes dos dois Estados contratantes ("A" e "B") deveriam considerar e seguir as soluções obtidas pelas aquelas autoridades administrativas em quaisquer dos procedimentos amigáveis em questão (individual, interpretativo ou integrativo).

É o que sugerem os Comentários à CM-OCDE.

Os Comentários à CM-OCDE, desde o seu capítulo de introdução ${ }^{609}$, assumem que o procedimento amigável é o meio adequado para que questões quanto à interpretação dos

${ }^{608}$ XAVIER, Alberto. Direito Tributário Internacional do Brasil. Rio de Janeiro: Forense, 2010, p. 168-169.

${ }^{609}$ OECD. MODEL TAX CONVENTION (FULL VERSION), 2012, Introduction, par. 33, p. I.10. 
acordos sejam solucionadas diretamente pelas "autoridades competentes" dos Estados contratantes.

O Comentário n. 27 ao art. 25 da CM- OCDE (2014), aponta que “o princípio geral reconhecido em relação aos tratados tributários e de outros tipos é que a legislação interna, mesmo de direito constitucional interno, não justifica, contudo, o descumprimento de objeções do tratado." Caso os referidos impedimentos fossem pré-existentes, deveriam constar do texto do tratado; se tais impedimentos surgissem após a assinatura do acordo, o outro Estado contratante deveria ser notificado quanto às razões que conduzissem a tal conclusão.

\subsubsection{A corrente da validade dos procedimentos amigáveis, com vistas à Constituição.}

A revisão doutrinária do tema conduz a uma terceira corrente, para a qual os procedimentos amigáveis podem se mostrar válidos tanto perante Direito Internacional quanto diante das ordens jurídicas internas com tradição no princípio da legalidade. As normas Constitucionais dos Estados contratantes seriam relevantes, mas em geral não apresentariam obstáculos aos procedimentos amigáveis.

$\mathrm{O}$ argumento de que a Constituição de cada um dos Estados contratantes é relevante para a aplicação de um acordo de bitributação é considerado inderrogável para boa parte da doutrina ${ }^{610}$. Sem oposição a esse critério, então, alguns autores consideram que, com a aprovação do art. 25 (3) de um acordo de dupla tributação pelo Poder Legislativo dos Estados contratantes, o princípio da legalidade restaria plenamente cumprido e os procedimentos amigáveis firmados seriam, então, vinculantes ${ }^{611}$. Não seriam exigidas, então, novas manifestações do Poder Legislativo para expressar a sua concordância quanto às posições assumidas em futuros procedimentos amigáveis celebrados pelas autoridades administrativas.

${ }^{610}$ REIMER, Ekkehart. Interpretation of tax treaties - Germany. European Taxation. IBFD, 1999 (December).

${ }^{611}$ Vide: SCHOUERI, Luís Eduardo. Arbitragem no Direito Tributário Internacional, in Revista de Direito Tributário Atual n. 23. São Paulo : IBDT/Dialética, 2009, p. 315-317; ROCHA, Sergio André. Interpretação dos tratados para evitar a dupla tributação. São Paulo : Quartier Latin, 2013, p. 166-169; ENGELEN, Frank. Interpretation of Tax Treaties under International Law. Doctoral series n. 7. IBFD : Amsterdam, 2004, p. 150. 
É necessário, então, analisar tal corrente tendo em vista os procedimentos amigáveis individual, interpretativo e integrativo, como apresentado no cenário proposto para exame.

Nesse seguir, SERGIO ANDRÉ ROCHA ${ }^{612}$ sustenta que tratados interpretativos estariam sob a "competência técnica do Poder Executivo", prescindindo de aprovação do Poder Legislativo. Para esse autor, no Direito tributário internacional brasileiro, a competência para a solução de controvérsias interpretativas, que corresponderia à tarefa de concretização da convenção fiscal, pertenceria exclusivamente ao Poder Executivo, "de forma que a interpretação autêntica acordada entre o Estado brasileiro e a outra parte se impõe aos tribunais judiciais do país, não podendo estes discordarem das conclusões a que chegaram as partes". Traços de tal posicionamento podem ser também identificados em trabalhos de autores do Direito Internacional público como FRANCISCO REZEK ${ }^{613}$.

Nessa ordem de ideias e com vistas ao Brasil, Luís EDUARDO SCHOUERI ${ }^{614}$ conclui que, diante de variadas soluções igualmente "corretas", não haveria ofensas à legalidade quando autoridades fiscais de dois Estados contratantes, previamente autorizadas pelo Poder Legislativo mediante a ratificação do art. 25 do acordo de dupla tributação, escolhessem uma delas como a mais adequada ao caso concreto. A autoridade fiscal brasileira, acrescenta o professor, atuaria na qualidade de "agente internacional, por delegação do próprio tratado internacional", representando o Estado na solução de controvérsias.

Nos anos 60, RAOUL LENZ ${ }^{615}$ suscitou que o valor jurídico das conclusões obtidas por meio de procedimentos amigáveis poderia variar. Se estivesse em jogo a coordenação das administrações fiscais do exercício do poder discricionário que lhes coubesse em vista de uma situação concreta, as conclusões obtidas por meio do procedimento não vinculariam os tribunais. No entanto, caso as autoridades fiscais conduzissem o

${ }^{612}$ ROCHA, Sergio André. Interpretação dos tratados para evitar a dupla tributação. São Paulo : Quartier Latin, 2013, p. 166-169.

${ }^{613}$ REZEK, José Francisco. Direito internacional público. São Paulo : Saraiva, 2000, p. 90.

${ }^{614}$ SCHOUERI, Luís Eduardo. Arbitragem no Direito Tributário Internacional, in Revista de Direito Tributário Atual n. 23. São Paulo : IBDT/Dialética, 2009, p. 315-319.

${ }^{615}$ LENZ, Raoul. General Report. Cahiers de Droit Fiscal International by the International Fiscal Association (studies on international tax law), volume XLII - Subject II: The interpretation of the Double Taxation Convention. / IFA : Rotterdam, 1960, p. 294. 
procedimento amigável com o propósito de suplementar o acordo (procedimentos amigáveis integrativos), por agirem com delegação de poderes do Poder Legislativo, tal ato vincularia inclusive os juízes de ambos os Estados. A referida delegação de poderes decorreria da própria cláusula do acordo internacional que autorizaria as autoridades competentes a se consultarem nos casos em que a dupla tributação não houvesse sido evitada ou, ainda, a fim de suplementar o acordo ou atribuir-lhe uma interpretação autêntica. Para LENZ, apenas quando a autoridade administrativa excedesse os poderes que lhes foram delegados poderia um Tribunal recusar a eficácia do procedimento amigável em questão.

\subsubsection{O status dos procedimentos amigáveis entre as evidências do "contexto" referido no art. 3 (2) da CM-OCDE.}

A revisão doutrinária analisada nos subtópicos anteriores enseja algumas conclusões quanto ao status dos procedimentos amigáveis entre as evidências do “contexto" referido no art. 3 (2) da CM-OCDE.

Diante do cenário anteriormente proposto para exame, suponha-se que a administração fiscal de um dos Estados ("A") acolha a tese do outro Estado contratante (“B”) quanto à melhor interpretação a ser adotada diante da convenção fiscal (“A-B”), ainda que esta conduza à adoção do método da isenção apenas no primeiro (“A”), restando ao segundo ("B") tributar ilimitadamente, conforme a sua legislação doméstica.

Algumas questões podem ser suscitadas a partir daí e as respostas sobre se os procedimentos amigáveis seriam válidos ou não perante o sistema jurídico brasileiro parecem não ser absolutas.

De plano, não se poderia considerar ilegal um procedimento amigável em que ambas as autoridades administrativas obtiveram êxito em eliminar a dupla tributação por estabelecerem interpretação harmônica, desde que essa seja razoável e não extravase os limites típicos da interpretação da lei para a prática de atos administrativos. Tratando-se de procedimentos amigáveis interpretativos, parece assistir razão à terceira corrente examinada: não haveria ofensa à legalidade quando as autoridades administrativas 
acordam que, entre diversas interpretações igualmente possíveis e plausíveis, uma delas será adotada de forma harmônica, a fim de garantir que a dupla tributação da renda seja evitada.

Mas é necessário questionar se os tribunais brasileiros estariam vinculados à solução adotada no procedimento amigável, caso julguem que a interpretação veiculada neste: (i) não seria "correta" ou; (ii) não seria "a mais correta" (isto é, embora possível, outras seriam preferíveis).

Parece correto concluir que nada afastaria do Poder Judiciário brasileiro a função de decidir se a interpretação conduzida pelas autoridades administrativas seria ou não “correta" ${ }^{\prime 616}$. Caso assim se compreenda, não seria afastada a aplicação conduzida pela administração fiscal, solucionando-se a questão (i) do parágrafo anterior. Já quando o juiz verificar que as administrações fiscais de fato alcançaram uma interpretação plausível para a convenção fiscal, mas ainda assim outras seriam igualmente possíveis, como sugerido na questão (ii) do parágrafo acima, parece ser papel da jurisprudência privilegiar a versão da norma formulada bilateralmente pelas "autoridades competentes", para a promoção da interpretação harmônica e efeito útil da convenção fisscal.

Em relação ao procedimento amigável individual, parece que as mesmas conclusões seriam aplicáveis. Supondo-se que o contribuinte ("x") que tenha instaurado o procedimento amigável obtenha a solução favorável que procurava, a concordância da administração fiscal de seu Estado de residência (“A”), obtida com o deslinde de um procedimento amigável com o outro Estado contratante ("B”), pode ser equiparada a um procedimento de consulta ou mesmo de um processo administrativo. A depender do sistema jurídico adjetivo de cada Estado, a administração fiscal (“A”) pode estar vinculada a observá-la, tornando remota a possibilidade de provocação do Poder Judiciário. No entanto, também parece necessário reconhecer que a fonte dos rendimentos ("y") poderia questionar, perante o Poder Judiciário de sua jurisdição ("B”) a correção da interpretação alcançada pelo procedimento amigável em questão, especialmente se esta, no caso, lhe atribuir o dever de retenção dos tributos sobre os rendimentos pagos (à “x”).

${ }^{616}$ Constituição Federal, art. 5. 
Também é importante observar que os procedimentos amigáveis individuais teriam efeitos apenas sobre o contribuinte reclamante. Embora peculiaridades de sistemas jurídicos domésticos pudessem estender os seus efeitos internamente, em geral os referidos procedimentos amigáveis não são sequer publicados.

Por sua vez, ao menos no sistema jurídico brasileiro, os procedimentos amigáveis integrativos parecem sujeitos a maiores questionamentos, pois exigem a aceitação da tese da delegação de competência atribuída ao Poder Legislativo às autoridades administrativas.

Para Vogel \& PROKISCH ${ }^{617}$, perante o Direito Internacional as autoridades administrativas teriam competência para explícita ou implicitamente (por meio de práticas subsequentes, por exemplo), alterar o texto do acordo de dupla tributação, a fim de lhe atribuir interpretação compatível com aquilo que originalmente foi acordado entre os Estados. No entanto, os professores não deixaram de reconhecer as limitações constitucionais que poderiam ser encontradas para essa delegação de competência. ${ }^{618}$

Nas lições de KLAUS VoGEL ${ }^{619}$, aceitar que as autoridades fiscais possuem competência para delimitar a interpretação dos acordos ou, ainda, suplementá-los, é aceitar como válida a delegação de poderes, ato que não seria suportado pela Constituição de diversos Estados. Note-se que, embora o professor tradicionalmente ${ }^{620}$ tenha considerado os procedimentos amigáveis apenas como "opinion by administrative experts", em meados de 2000 passou a considerá-los como elementos aptos a obrigar as respectivas administrações, ainda que não vinculassem os contribuintes.

Diante da situação hipotética proposta - procedimento amigável integrativo para eliminar situações de bitributação econômica não previstas na convenção fiscal -, parece

${ }^{617}$ VOGEL, Klaus; PROKISCH, Rainer G. Cahiers de Droit Fiscal International by the International Fiscal Association (studies on international tax law), volume LXXVIIIa - Subject I. Interpretation of double taxation conventions. Kluwer Law and Taxation Publishers / IFA : Rotterdam, 1993, p. 47.

${ }^{618}$ Ainda nesse sentido, vide: BRUNSCHOT, Frank van. The Judiciary and the OECD Model Tax Convention and its Commentaries, in Bulletin - Tax Treaty Monitor of January 2005. IBFD, 2005, p. 7; KATZ, Stanley I. United States National Report. Cahiers de Droit Fiscal International by the International Fiscal Association (studies on international tax law), volume LXXVIIIa - Subject I. Interpretation of double taxation conventions. Kluwer Law and Taxation Publishers / IFA : Rotterdam, 1993, p. 639-640.

${ }^{619}$ VOGEL, Klaus. Klaus Vogel on Double Taxation Conventions. Kluwer : London, 1999, p. 48.

${ }^{620}$ VOGEL, Klaus. The influence of the OECD Commentaries on Treaty Interpretation, in Bulletin - Tax Treaty Monitor - December 2000. IBFD : Amsterdã, 2000, p. 613 e seg. Como exceção à exigência de aprovação do Congresso ou do Senado que o mutual agreement vincule inclusive o Tribunal, Prof. Klaus Vogel cita decisão da Suprema Corte da Noruega (Høyesterett). 
necessário reconhecer que as autoridades administrativas extravasariam o seu âmbito de atuação. Ocorre que a celebração de um acordo de bitributação, contendo cláusula equivalente à segunda parte do art. 25 (3) da CM-OCDE, não atribui às autoridades administrativas um cheque em branco para comprometerem o País em situações muito diversas àquelas que contaram com a aprovação do Congresso Nacional (dupla tributação jurídica).

Entende-se, assim, que a administração possui competência para aplicar o acordo, o que pressupõe a sua interpretação; mas não possuem os agentes administrativos a competência para modificar e ou para expressar, como última manifestação do Estado, o sentido dos termos contratados. Os limites de que disporiam agentes administrativos na celebração do procedimento amigável, sob tal perspectiva, seriam da promoção do efeito útil, da interpretação harmônica e da plausividade. A aferição da razoabilidade, no entanto, depende da revisão por um órgão imparcial, em geral tribunais nacionais.

\subsection{Critérios funcionais e materiais de reconhecimento dos procedimentos amigáveis como "contexto".}

O procedimento amigável parece estar vocacionado à promoção do efeito útil dos acordos de dupla tributação, especialmente no que se refere ao seu objetivo e propósito de incrementar a cooperação, coordenação e reciprocidade internacionais, entre as autoridades fiscais dos Estados contratantes. Decorre daí, também, a sua vocação para a promoção da interpretação harmônica entre os Estados contratantes: vivificando a cooperação, coordenação e reciprocidade que animam as relações internacionais, os Estados devem procurar chegar a um consenso sobre o sentido dos termos do acordo celebrado e do seu sucesso decorrerá a satisfação de propósitos e objetivos do acordo, como evitar a dupla tributação da renda.

Tratando-se de procedimentos amigáveis individuais, instaurados pelo contribuinte, é necessário distinguir: (i) o próprio caso concreto que ensejou o procedimento amigável firmado entre os Estados; (ii) outros casos subsequentes entre os mesmos Estados e; (iii) casos entre terceiros Estados. Ocorre que, nos procedimentos amigáveis individuais, a harmonia decisória apenas seria almejada naquela primeira situação, isto é, em relação ao 
próprio contribuinte. Coerentemente, WIM WIJNEN ${ }^{621}$ suscita que a ausência do dever de publicação dos procedimentos amigáveis torna frágil a sua contribuição em relação a outros casos subsequentes entre os mesmos Estados. Por fim, o procedimento amigável é considerado débil para influenciar terceiros Estados, seja por sua inaptidão jurídica para tanto, seja porque, como observa KEES VAN RAAD ${ }^{622}$, tais mecanismos não necessariamente buscam construir o melhor sentido contextualizado para determinado termo, mas encontrar uma solução prática para um específico caso em disputa.

Nesse cenário, é possível concluir que o cumprimento dos critérios da promoção do efeito útil e da interpretação harmônica, da forma como o procedimento amigável vem sendo regulado pelo art. 25 da CM-OCDE, somente seria obtido quando se mantiverem em seus limites interpretativos.

Da mesma forma, a plausividade inerente aos procedimentos amigáveis será determinante para que possam ser considerados como evidências do sentido dos termos de um acordo de bitributação, a serem observadas pelos tribunais. Quanto mais se distanciar de tais fatores, mais precária será a solução alcançada por meio do procedimento amigável.

\section{PRÁticas SEguidas PELOS ESTAdos PARA A APLiCAÇÃo DE ACORDOS DE DUPLA TRIBUTAÇÃO.}

"Surge a necessidade, pois, de se desenvolver um princípio, observado pelos Estados contratantes, favorável à harmonia decisória, de modo que um Estado, ao aplicar um acordo de bitributação, se veja obrigado a observar como o outro Estado contratante o aplicou”. LUÍS EDUARDO SCHOUERI (2003) ${ }^{623}$

As práticas seguidas posteriormente na aplicação do tratado são evidências relevantes quanto ao sentido dos termos contidos em tratados internacionais. Embora parcela da doutrina as classifique sob o escopo do art. 32 da CVDT (contexto extrínseco

\footnotetext{
${ }^{621}$ WIJNEN, Wim. Some Thoughts on Convergence and Tax Treaty Interpretation, in Tax Treaty Monitor Bulletin for International Taxation (November 2013). IBFD: Amsterdã, 2013, p. 576.

${ }^{622}$ RAAD, Kees van. International coordination of tax treaty interpretation and application, in International and comparative taxation - essays in honour of Klaus Vogel. KIRCHHOF, Paul et. al. eds London : Kluwer, 2002.

${ }^{623}$ Sobre a questão, vide: SCHOUERI, Luís Eduardo. Tratados e Convenções Internacionais sobre Tributação, in Revista de Direito Tributário Atual n. 17. São Paulo : IBDT/Dialética, 2003, p. 49.
} 
secundário $)^{624}$, as práticas subsequentes dos Estados podem ser mais bem compreendidas sob o escopo do contexto intrínseco primário, conforme se expõe neste tópico.

Para o exame das práticas subsequentes, devem ser compreendidas: (i) as suas funções; (ii) os seus requisitos no Direito tributário internacional; e (iii) as formas peculiares que podem assumir no Direito tributário internacional, como: (a) decisões e normas enunciadas por autoridades fiscais; (b) decisões judiciais do outro Estado contratante e (c) alterações no Direito doméstico dos Estados contratantes como práticas subsequentes à conclusão do acordo. Os subtópicos seguintes se ocupam de tais questões.

\subsection{Funções, perfil e posição das práticas subsequentes no Direito Internacional público.}

"Here the actual acts of States, rather than their words, are taken as the evidence of agreement." RICHARD K. GARDINER (2003) ${ }^{625}$

O projeto levado à reunião final da ILC-ONU ${ }^{626}$ e que culminou na CVDT previa, em seu art. 68 que os tratados poderiam ser modificados pela prática seguida pelos Estados na aplicação destes. Na versão final celebrada, entretanto, o dispositivo foi renumerado, passando a constar na posição do "art. 38", bem como substancialmente alterado. A hipótese de modificação dos tratados por meio de práticas subsequentes foi rejeitada pela CVDT, sob o argumento de que poderia gerar instabilidade.

Essa alteração no texto da CVDT nos mostra o clima de debate sobre a questão instaurado na ILC-ONU. Na doutrina, IAN BROWNLIE ${ }^{627}$ considera a solução encontrada pela ILC-ONU insatisfatória, ao menos por três razões: (i) embora tenha sido rejeitada a referência expressa às práticas subsequentes como meio para a modificação dos tratados, o art. 39 da CVDT prevê que um tratado pode ser alterado por meio de acordo entre os Estados, sem que, para isso, requeira qualquer formalidade específica para a sua conclusão; (ii) práticas subsequentes podem representar evidências quanto ao consenso dos Estados

\footnotetext{
${ }^{624}$ Nesse sentido, vide: ROHATGI, Roy. Basic International taxation. Volume 1: principles. Nova Deli : Taxmann, 2005, p. 42.

${ }^{625}$ GARDINER, Richard K. International Law. Pearson : Harlaw, 2003, p. 50.

${ }^{626}$ ONU. Yearbook of the International Law Commission. 1966. Records on the 866th meeting. ONU, 1966, vol. II. Article 68. Modification of a treaty by a subsequent treaty, by subsequent practice or by customary law.

${ }^{627}$ BROWNLIE, Ian. Principles of public international law. Clarendon : Oxford, 1998, p. 630-631.
} 
para alterações no acordo; e (iii) modificações em acordos internacionais por meio de práticas subsequentes ocorrem de fato, o que não deveria ter sido ignorado pela ILC-ONU.

De fato, embora o art. 2 da CVDT requeira a forma escrita para a celebração dos tratados, não estabeleceu qualquer formalidade específica, como assinaturas, denominações ou mesmo a publicação. Conforme aquela convenção multilateral, a "ratificação", "aceitação", "aprovação", "adesão" a um acordo internacional se dá com o consentimento em obrigar-se por um tratado, o que se torna, no mais das vezes, o requisito a ser demonstrado. Observou-se na ILC-ONU de $1966^{628}$ que um tratado poderia existir por qualquer meio de digitação e impressão, ou qualquer outro método permanente de gravação. Atualmente, podem-se cogitar formas muito mais modernas para a veiculação de tal consentimento, incluindo telegrama, fax, e-mail e quaisquer novas formas de comunicação eletrônica, tais como mensagens de texto ou utilização das mídias sociais ${ }^{629}$.

Embora não tenha sido reconhecida pela CVDT a função modificadora das práticas subsequentes, lhes foi atribuída a função interpretativa, ou seja, de provedora de evidências para a construção de sentido do quanto acordado entre os Estados. É possível compreender que, sob o escopo do art. 31 (3) "b" da CVDT, "qualquer prática seguida posteriormente na aplicação do tratado, pela qual se estabeleça o acordo das partes relativo à sua interpretação" compõe o contexto extrínseco primário dos acordos internacionais, o qual deve ser considerado em conjunto com os elementos do contexto intrínseco. $^{630}$

O recurso a tais materiais pode ser fundamentado, ainda, a partir do art. 31 (3) "c" da CVDT, o qual torna mandatória a consideração do art. 38 (1) "b” do ECIJ, segundo o qual a prática aceita como sendo o Direito (costumes) deve conduzir a interpretação do Direito Internacional. RICHARD K. GARDINER ${ }^{631}$ leciona que tais práticas podem prover a

\footnotetext{
${ }^{628}$ ONU. Yearbook of the International Law Commission. 1966. Records on the 866th meeting. vol. II. ONU, 1966, p. 179 e seg.

${ }^{629}$ Sobre essa evolução, vide HOLLIS, Duncan B. Defining treaties, in The Oxford Guide to Treaties (Ed. HOLLIS, Duncan B.). Oxford University Press : Oxford, 2012, p. 23.

${ }^{630}$ A referida prática como critério de interpretação é adotada por diversas decisões de Cortes Internacionais, por exemplo: PCIJ, Competence of the ILO in regard to International Regulation of the Conditions of the Labour of Persons Employed in Agriculture, para. 39; PCIJ, Case Concerning the Payment in Gold of Brazilian Federal Loans Contracted In France, par. 93, 119; CIJ, Corfu Channel Case, par. 25; CIJ, Kasikili/Sedudu Island, par. 50.

${ }^{631}$ GARDINER, Richard K. International Law. Pearson : Harlaw, 2003, p. 49-50.
} 
mais clara das evidências ("clearest guidance") a respeito do que os Estados assumem ter acordado e, ainda, de como têm construído e desenvolvido (ou mesmo alterado) o sentido do acordo internacional.

Tais fatores das práticas subsequentes no Direito Internacional podem ser desdobrados em outros mais, especialmente relacionados a (i) formalidades; (ii) frequência; (iii) exigência de consenso; (iv) agentes competentes e (v) eficácia em relação a terceiros. Referidas questões serão consideradas em face ao Direito tributário internacional, no subtópico seguinte.

\subsection{As práticas subsequentes no Direito tributário internacional.}

"I cannot find, on the evidence before me, that this appellant ever had a permanent establishment in Canada for the purpose of carrying on his business. His attendances were sporadic, his explanation as to the apartment is acceptable, and I find him in no different position than that of any foreigners, if I may use the term, who transact business in this country without anyone suggesting that they are taxable". JuIZ FLANigAN. Caso Ezra" (1975).

O antigo Caso Ezra (Canadá, 1975), do qual se colhe a passagem em epígrafe, nos mostra que, no Direito tributário internacional, as práticas subsequentes devem ser levadas em consideração na interpretação das convenções fiscais, sob a premissa de que podem representar evidências úteis para a promoção do efeito útil e da interpretação harmônica. $^{632}$

Na linha da CVDT, não se requer das práticas subsequentes mais do que se exige para a formalização das próprias convenções internacionais, para as quais não são necessárias maiores formalidades. Embora a forma escrita, típica dos tratados, não seja necessariamente exigida em relação às práticas, esta parece ser predominante em matéria tributária, que requer publicidade formal. Quanto à frequência em que a prática é exercitada, não há no Direito Internacional exigência de qualquer lapso temporal ou continuidade, do mesmo modo que a formação de costumes internacionais prescindem de tal requisito; também não há no self-contained regime tributário norma especial requerendo

632 Nesse sentido, vide: LANG, Michael. Introduction to the law of double taxation conventions. Vienna : Linde, 2013, p. Cf. 43; VOGEL, Klaus; PROKISCH, Rainer G. Cahiers de Droit Fiscal International by the International Fiscal Association (studies on international tax law), volume LXXVIIIa - Subject I. Interpretation of double taxation conventions. Kluwer Law and Taxation Publishers / IFA : Rotterdam, 1993, p. $70-71$ 
critério diverso. São as questões relacionadas à exigência de consenso, aos agentes competentes e à eficácia em relação a terceiros que apresentam maiores questionamentos.

Quanto ao fator "exigência de consenso", para RICHARD K. GARDINER ${ }^{633}$, como a prática deve estabelecer um acordo entre as partes, apenas teriam relevância atos com os quais os Estados envolvidos tenham concordado: a existência de consenso seria um fator essencial para que as referidas práticas adquirissem validade no Direito Internacional. Na doutrina do Direito tributário internacional, pareceu claro a AVERY JONES ${ }^{634}$ que, quando um Estado ("A") modifica suas práticas em atenção a um outro Estado ("B”), com o recíproco consentimento deste outro Estado (“B”), seria estabelecido um acordo entre estes (“A-B").

Tal posição, contudo, está sujeita a severos questionamentos. Ao menos para a questão das evidências quanto ao sentido dos termos de uma convenção fiscal, afastar a admissibilidade de práticas unilaterais corresponde a impedir que o próprio processo de formação do consenso entre os Estados se desenvolva. Se determinado acordo for aplicado de uma maneira por um Estado (“A”), o outro Estado (“B”) poderá disso tomar conhecimento e - ainda que inspirado no anseio pela reciprocidade - aplicá-lo do mesmo modo, constituindo, assim, o consenso no Direito Internacional, que não exige forma especial.

Não se recusa a constatação de RICHARD K. GARDINER ${ }^{635}$, de que práticas uniformes e abundantes com as quais os Estados tenham reciprocamente consentido se mostram excelente meio para determinar o sentido dos tratados. No entanto, embora relevante, o consenso não parece ser tão determinante para que práticas sejam adotadas como evidências; mais determinante é o consentimento de ao menos um dos Estados contratantes quanto à atribuição de um certo sentido ao acordo internacional.

Nos subtópicos a seguir, tal questão poderá ser analisada com maiores detalhes, com a investigação de práticas conduzidas pelos três Poderes na aplicação de acordos de dupla tributação, ou seja, por agentes do Poder Executivo (decisões e normas enunciadas

${ }^{633}$ GARDINER, Richard K. International Law. Pearson : Harlaw, 2003, p. 49-51; 88-89.

${ }^{634}$ AVERY JONES, John et al., The interpretation of tax treaties with particular reference to article 3(2) of the OECD Model - II. British Tax Review, 1984, p. 95-96. 
por autoridades fiscais do outro Estado contratante), Judiciário (decisões judiciais do outro Estado contratante) e Legislativo (alterações no Direito doméstico do outro Estado contratante).

\subsection{Decisões e normas enunciadas por autoridades fiscais sobre a aplicação de acordos de dupla tributação.}

Diversos agentes atuam no processo de aplicação do Direito tributário internacional: o contribuinte, com seus advogados e consultores, o fisco, que também conta com seus advogados, e o juiz. Tais atores podem atuar separadamente ou em conjunto e as suas práticas podem apresentar diferentes consequências em um dado sistema jurídico doméstico. Em geral, contudo, antes de ser levado à apreciação de um juiz, os acordos de dupla tributação são analisados e aplicados inicialmente por autoridades físcais e, antes dessas, por contribuintes e seus consultores. ${ }^{636}$

A relevância da investigação de práticas da administração fiscal pode ser observada em trabalhos como de SERGIO ANDRÉ RoCHA ${ }^{637}$ e FRANCISCO REZEK ${ }^{638}$, os quais sustentam a competência técnica do Poder Executivo para decidir quanto ao sentido de termos adotados no acordo internacional celebrado com outro Estado.

Conforme a tese da "competência técnica do Poder Executivo", defendida por RoCHA, o monopólio da última palavra quanto ao sentido dos termos dos acordos de dupla tributação pertenceria àquele e não ao Poder Judiciário. Em tal ordem de ideias, afirmar-se que as práticas da administração pública - e não de Cortes nacionais - expressariam de forma definitiva e legítima o entendimento do Estado brasileiro quanto aos compromissos que reconhece ter assumido, já que tais interpretações seriam mandatórias aos tribunais judiciais do país.

A questão, contudo, pode ser analisada sob uma perspectiva diversa.

\footnotetext{
${ }^{636}$ Cf. VOGEL, Klaus. The influence of the OECD Commentaries on Treaty Interpretation, in Bulletin Tax Treaty Monitor - December 2000. IBFD : Amsterdã, 2000, p. 614.

${ }^{637}$ ROCHA, Sergio André. Interpretação dos tratados para evitar a dupla tributação. São Paulo : Quartier Latin, 2013, p. 166-169.

${ }^{638}$ REZEK, José Francisco. Direito internacional público. São Paulo : Saraiva, 2000, p. 90.
} 
Aceitando-se que o consenso, embora importante, não seja tão determinante quanto o consentimento (individual) de cada Estado, parece relevante examinar duas práticas conduzidas pelas autoridades fiscais brasileiras, a fim de averiguar sua aptidão para compor o contexto extrínseco primário de acordos de dupla tributação: (i) decisões em processos administrativos, normas individuais e concretas relacionadas à discordância entre contribuinte e fisco, em casos específicos de aplicação de acordos de dupla tributação; e (ii) pronunciamentos e diretrizes internas, normas gerais e abstratas enunciadas para orientação das autoridades fiscais - e, colateralmente, dos contribuintes sobre o entendimento do Governo quanto aos compromissos assumidos nos acordos de dupla tributação.

A questão pode ser colocada da seguinte forma: qual a relevância de um advogado apresentar ao juiz decisões administrativas advindas do outro Estado contratante que tratem justamente da interpretação do termo adotado no mesmo tratado sob a sua análise? Decisões proferidas por autoridades fisscais do outro Estado contratante, em relação à mesma operação, seriam mais relevantes?

A resposta parece não ser absoluta, mas dependente de características dos Estados envolvidos. Na construção de sentido de termos de um acordo de bitributação (“A-B”), a admissibilidade por um Estado ("A") de práticas de autoridades administrativas do outro Estado contratante (“B”) pode depender de quão precárias elas sejam no outro Estado ("B").

Em sistemas jurídicos nos quais as autoridades administrativas correntemente têm seus atos de aplicação da lei tributária revistos por suas Cortes nacionais (“A”), caso os seus parceiros de convenções fiscais ("B") considerem as práticas administrativas como evidência na interpretação de um acordo de bitributação (“A-B”), não se teria segurança de que trilhar o mesmo sentido representaria a interpretação harmônica em relação àquela outra jurisdição, que ainda poderia alterar tal sentido por decisão do Poder Judiciário.

Por sua vez, em sistemas jurídicos com baixo índice de litigiosidade, nos quais o entendimento das autoridades administrativas tradicionalmente se alinham - por variadas razões - ou mesmo se sobrepõe ao dos tribunais judiciais, suas práticas parecem contar 
com mais legitimidade, ou melhor, potencial argumentativo perante os seus parceiros de convenções fiscais quanto ao sentido de termos contidos nessas.

Nesse cenário, a precariedade das práticas subsequentes seguidas por agentes fiscais parece ser um fator determinante, inclusive por enfraquecer drasticamente o potencial desse elemento para cumprir com a interpretação harmônica.

No Brasil, salvo uma exceção, não parece haver outras hipóteses em que o Poder Judiciário deva considerar irreversível a decisão da administração fiscal. Pelo contrário, como "a lei não excluirá da apreciação do Poder Judiciário lesão ou ameaça a direito",639, o STF tem reiteradamente afastado óbices à revisão jurisdicional de decisões administrativas.

A exceção acima se refere às situações em que os órgãos administrativos de julgamento (no caso, o CARF) se alinham à interpretação sustentada pelo contribuinte, o qual, então, se torna vencedor em um procedimento administrativo para o qual não caiba mais recurso. Nesse caso, como a autoridade fiscal não poderá recorrer ao Poder Judiciário para anular sua própria decisão, esta se torna definitiva no sistema jurídico brasileiro.

Além disso, é necessário reconhecer a elevada litigiosidade entre o fisco brasileiro e o contribuinte, não faltando exemplos de reforma de interpretações administrativas pelo Poder Judiciário. Em matéria de acordos de bitributação, embora recente, é crescente a provocação do Poder Judiciário por parte do contribuinte.

Muitas das questões suscitadas em relação aos procedimentos amigáveis podem ser levantadas em relação às decisões e normas enunciadas por autoridades fiscais sobre a aplicação de acordos de dupla tributação. No entanto, o tema ora tratado apresenta um agravante: enquanto nos procedimentos amigáveis é possível argumentar-se que a aprovação pelo Congresso Nacional de um acordo de bitributação contendo o art. 25 sugerido pela CM-OCDE operaria delegação de poderes à administração fiscal ("autoridades competentes" das convenções fiscais), o mesmo argumento não a socorre na prática de atos unilaterais em âmbito exclusivamente doméstico. Ao menos no sistema

${ }^{639}$ BRASIL. CF, art. 5, XXXV. 
jurídico brasileiro, as autoridades fiscais não possuem competência para expressar unilateralmente a forma como o País interpreta em definitivo um acordo de bitributação, o que exigiria o poder de vincular inclusive o Poder Judiciário.

No entanto, não se pode considerar, em absoluto, que a análise de tais elementos seja irrelevante ao julgador, ou mesmo que a sua investigação - e por ventura apresentação - pelos advogados seja despicienda. Ainda que a consideração de tais evidências não venha a ser considerada mandatória, remanesceria em tais elementos certa relevância didática, exemplificativa, semelhante à que se encontra presente nos textos doutrinários .

\subsubsection{Exemplo: o caso brasileiro da construção de sentido de "lucro da empresa" (“business profit”) do art. 7 da CM-OCDE pelas autoridades fiscais.}

Por mais de 10 anos, a administração fiscal brasileira publicou uma série de manifestações quanto à interpretação dos termos "lucro da empresa" ("business profit"), presentes no art. 7 dos acordos de bitributação celebrados pelo Brasil ${ }^{640}$. No Ato Declaratório COSIT $n^{\circ} 1 / 2000$, a RFB adotou a posição de que remessas decorrentes de contratos de prestação de assistência técnica e de serviços técnicos sem transferência de tecnologia estariam sob o escopo do art. 21 das convenções fiscais, refutando a aplicação do art. 7 dos acordos. Essa posição foi ainda sustentada pelo Parecer PGFN/CAT n. $776 / 2011$.

Tal prática conduzida pelas autoridades administrativas brasileiras, contudo, não se harmonizava com a interpretação dos demais Estados. Esse fato poderia arranhar a reputação e a credibilidade do Brasil quanto à aplicação de suas convenções fiscais, como observou a Assessoria de Assuntos Internacionais (“Asain”), atualmente denominada Coordenação-Geral de Relações Internacionais ("CORIN”). Na Nota Gab/Asain n. 14/2006, esse órgão da RFB solicitou o reexame da matéria, uma vez que o entendimento adotado "desgastava a imagem da RFB, por se tratar de interpretação isolada nos fóruns internacionais".

\footnotetext{
${ }^{640}$ Vide, por exemplo: Parecer Cosit $\mathrm{n}^{\mathrm{o}} 58$, de 01 de outubro de 1999; Ato Declaratório COSIT n ${ }^{\circ}$ 1/2000; Parecer Cosit n ${ }^{\circ} 33$, de 25 de novembro de 2002.
} 
Na Nota COSIT n. 23/2013, a administração fiscal brasileira suscitou que tal posição "traduz interpretação equivocada das disposições dos acordos para evitar a dupla tributação e está em desacordo com o entendimento da doutrina internacional, o que gera violação dos tratados e motivos para sua denúncia”.

A mudança de entendimento da administração fiscal sobre a questão, consagrada pelo Parecer PGFN/CAT n. 2363/2013, foi impulsionada pelo julgamento do Caso Copesul (Brasil, 2012), em que o STJ consignou "que devem ser rechaçadas as interpretações que levem ao absurdo".

É possível observar que as manifestações formais da administração fiscal, por mais de 10 anos, sinalizavam aos contribuintes e aos demais Estados que uma interpretação absurda seria adotada pelo Brasil. A relevância dessa evidência pode ter assumido diferentes graus diante de investidores e contribuintes que, nesse período, precisaram equacionar as consequências fiscais da contratação e da prestação de serviços no Brasil.

A nova posição assumida no Parecer PGFN/CAT n. 2363/2013, por sua vez, pode ser considerada uma evidência mais forte quanto à forma como o Brasil interpreta os termos "lucros da empresa", geralmente presentes no art. 7 de seus acordos de bitributação. Ocorre que a interpretação nele veiculada também é suportada por outras evidências intrínsecas e extrínsecas, bem como ostenta plausividade, como será discutido em tópicos seguintes.

\subsubsection{Exemplo: A consideração de decisões de autoridades fiscais sobre a aplicação de acordos de dupla tributação no Canadá.}

No caso Caso Saunders (Canadá, 1954), o tribunal canadense consignou que, quando os termos de uma convenção fiscal permitirem acompanhar a interpretação atribuída pela administração tributária por um longo período, os tribunais deveriam hesitar adotar outros sentidos que conduzissem ao abandono da prática em questão. 
Curiosamente, tal postura foi adotada para refutar a alteração da prática conduzida pela administração fiscal canadense: a forma como até então o fisco vinha aplicando a convenção fisscal seria satisfatória e não deveria ser alterada.

\subsubsection{Exemplo: A consideração de decisões de autoridades fiscais sobre a aplicação de acordos de dupla tributação nos EUA.}

As conclusões suscitadas no tópico anterior não estão isentas de questionamento.

No Caso Stuart (EUA, 1989), a maioria da Suprema Corte norte-americana acompanhou o juiz BRENNAN no entendimento de que as práticas subsequentes a um acordo de dupla tributação, em especial a sua aplicação por parte das autoridades fiscais, forneceriam evidências aos Tribunais quanto à correta interpretação deste, já que tal conduta geralmente refletiria o entendimento dos seus próprios negociadores.

No caso, as autoridades fiscais norte-americanas vinham atendendo a pedidos de troca de informações elaborados pelo Canadá, sem impor questões prévias quanto ao destino de tais dados. A questão em debate, então, seria se o tribunal deveria interpretar o acordo como se refletisse forma de compreendê-lo ou não. Tomando como precedente o caso Sumitomo, a Suprema Corte norte-americana compreendeu que, embora não fosse conclusiva, a posição da administração quanto ao sentido do acordo celebrado seria de grande relevância ("great weight").

\subsection{Decisões judiciais do outro Estado contratante.}

"The decisions of the Courts of every country show how the law of nations, in the given case, is understood in that country, and will be considered in adopting the rule which is to prevail in this." JUIZ Marshall. Suprema Corte dos EUA. $(1815)^{641}$

A tão antiga afirmação em epígrafe, de que decisões dos tribunais domésticos mostram como o Direito Internacional é compreendido em sua jurisdição e será observado na decisão de um determinado caso concreto desse Estado, enseja que se

${ }^{641}$ EUA. Suprema Corte. THIRTY HOGSHEADS OF SUGAR, (Adrian B. Bentzon, Claimant,) v. BOYLE AND OTHERS, Being the officers and crew of the privateer Comet. 
analisem tais possíveis evidências sob o escopo do contexto extrínseco primário. Como observa IAN BROWNLIE ${ }^{642}$, tais decisões podem prover evidências indiretas ("indirect evidence") quanto à prática de um Estado a respeito de determinado tema, bem como possibilitar a investigação quanto à determinada questão jurídica ou quanto às fontes do Direito utilizadas.

Diversos argumentos sugerem que o operador do Direito tributário internacional considere decisões de Cortes estrangeiras a respeito da aplicação de acordos de bitributação, mas dois em especial devem ser sublinhados. O primeiro, de caráter eminentemente teórico, se refere à identificação das Cortes nacionais como agentes propulsores da linguagem tributária internacional ${ }^{643}$. O segundo, de caráter pragmático, pedagógico e, nesse ponto, assemelhando-se às decisões administrativas analisadas no subtópico anterior, consiste no reconhecimento de que o juiz de um determinado Estado (“A”) poderá aprender muito com a análise de questões complexas, que já tenham tomado o tempo de seus colegas estrangeiros, ao decidir questões semelhantes dentro de suas jurisdições (“B”), especialmente para a aplicação da mesma convenção fiscal (“A-B”).

O recurso à tais evidências foi sustentado por PHILIP BAKER ${ }^{644}$, que se declarou convicto de que as autoridades de um Estado ("A") devem examinar as decisões do outro Estado contratante ("B"), apenas deixando de seguí-las, caso verifique estarem incorretas. Para BAKER, como as autoridades fiscais de um Estado contrantante ("A") seguiriam as decisões de suas Cortes (“A”) quanto à interpretação de um acordo de dupla tributação ("A-B"), também as autoridades fiscais do outro Estado contratante ("B") deveriam observar as decisões daquele Tribunal (“A”), sob pena de um mesmo acordo (“A-B") possuir sentidos diversos nos dois Estados contratantes. A posição de BAKER, como será analisado a seguir, merece alguns temperos.

De todo modo, a doutrina do Direito tributário internacional, que começou e ganhou corpo com a intensificação da celebração de acordos internacionais a partir da década de 40, sempre reclamou pela investigação de decisões de Cortes nacionais, embora

${ }^{642}$ BROWNLIE, Ian. Principles of public international law. Clarendon : Oxford, 1998, 23.

${ }^{643}$ RAAD, Kees van. Interpretation and Application of Tax Treaties by Tax Courts, in European Taxation January 1996. IBFD : Amsterdã, 1996, p. 7.

${ }^{644}$ BAKER, Philip. Double taxation conventions and international tax law. Londres : Sweet \& Maxwell, 1994, par. C28 e C-29. 
dificuldades técnicas a tenham impossibilitado em grande medida até recentemente. Mas se nos anos 90 o material doutrinário a respeito do tema ou mesmo o acesso às decisões das Cortes nacionais era escasso ${ }^{645}$, o cenário atual é bastante diferente e merece novas reflexões. Este é o objeto do presente subtópico, em que se consideram os critérios formais, funcionais e materiais adotados nesta tese.

\subsubsection{Critérios formais de reconhecimento de evidências: decisões judiciais do outro Estado contratante.}

Quanto ao critério formal de reconhecimento, parece necessário observar que decisões judiciais do outro Estado contratante devem ser reconhecidas pelo Direito Internacional como práticas subsequentes para fins de interpretação, com o status do art. 31 (3) "b" da CVDT. Além disso, sob o escopo do art. 31 (3) "c" da CVDT, decisões de Cortes nacionais também encontrariam fundamento no art. 38 (1) "d" do ECIJ, o qual não se restringe a decisões de Cortes Internacionais ou, ainda, a decisões da própria CIJ.

O monopólio da última palavra, geralmente atribuído constitucionalmente ao Poder Judiciário, contribui para a confirmação de que tais práticas do Estado na aplicação de um acordo de dupla tributação observam as suas normas de fundamental relevância (art. $27 \mathrm{e}$ 46 da CVDT).

Note-se que, embora IAN BROWNLIE ${ }^{646}$ assuma como evidente o valor de decisões das Cortes nacionais e que um coerente corpo jurisprudencial gere consequências importantes na interpretação do Direito Internacional, suscita que estas não seriam propriamente fontes de Direito Internacional. Para o professor, embora apliquem o Direito Internacional, as decisões de Tribunais não o criam. STARKE \& SHEARER ${ }^{647}$, por sua vez, apontam que apenas em algumas situações as decisões de Cortes nacionais poderiam ser consideradas fontes do Direito Internacional, em especial se consideradas como

\footnotetext{
${ }^{645}$ Vide: RAAD, Kees van. Interpretation and Application of Tax Treaties by Tax Courts, in European Taxation - January 1996. IBFD : Amsterdã, 1996, p. 3-4.

${ }^{646}$ BROWNLIE, Ian. Principles of public international law. Clarendon : Oxford, 1998, p. 19-24.

${ }^{647}$ STARKE, Joseph Gabriel; SHEARER, I.A. Starke's international law. Butterworths : Canada, 1994, p. 42-43.
} 
precedentes ou mesmo se assumirem autoridade vinculante, bem como se puderem ser consideradas como práticas de costumes internacionais.

Importa notar que as questões opostas às decisões de Cortes nacionais no parágrafo anterior - de que estas não seriam em si fontes do Direito internacional - apresentam relevância apenas indireta à presente tese. Ocorre que este estudo não tem como objeto principal fontes do Direito tributário internacional, mas sim suas evidências. É importante compreender que fontes do Direito tributário internacional podem ser evidências quanto aos sentidos de um determinado acordo de dupla tributação, mas, por sua essência, muitos elementos que não possuem rigorosamente o perfil de "fontes" são aptos a prover evidências e a revelar qual o Direito tributário internacional foi produzido por determinadas fontes. O papel das evidências é justamente demonstrar a existência e as normas emanadas por fontes do Direito tributário internacional.

\subsubsection{Critérios funcionais de reconhecimento de evidências: decisões judiciais do outro Estado contratante}

Assumindo-se que há relevantes argumentos para que se considerem decisões judiciais do outro Estado contratante como evidência para a construção de sentido dos termos de um acordo internacional, especialmente em matéria tributária, é preciso investigar se tais evidências também satisfariam os critérios funcionais sugeridos nesta tese. É necessário reconhecer que as decisões judiciais do outro Estado contratante também parecem aptas a promover o efeito útil e a interpretação harmônica dos acordos de dupla tributação.

Com a publicação de decisão judicial definitiva, em que um dos Estados contratantes ("A") define a forma como efetivamente interpreta um acordo de dupla tributação ("A-B"), tanto os operadores deste Estado ("A”) quanto do outro Estado contratante ("B") passam a contar com uma evidência quanto ao sentido dos termos dessa convenção internacional.

Se os tribunais do outro Estado contratante ("B") se alinharão ou não à mesma interpretação é uma outra questão. O ponto que se quer sublinhar é que, caso a decisão 
judicial daquele primeiro Estado contratante (“A”) não seja considerada como evidência quanto ao sentido contextualizado, restaria minorada, de plano, a possibilidade de concordância entre os dois Estados (“A” e "B"), a qual representaria a interpretação harmônica estabelecida pela prática de agentes detentores do monopólio da última palavra em ambos os Estados contratantes. Assim, diversos autores ${ }^{648}$ têm reconhecido que decisões de outros Estados quanto à aplicação de acordos internacionais podem conduzir à interpretação harmônica destes.

A relevância do caráter da definitividade com que o acordo é aplicado torna necessária a consideração da hierarquia do tribunal que emanou determinada decisão quanto ao sentido de um termo do acordo de dupla tributação. Em geral, as decisões se tornam mais relevantes quanto mais elevada for a hierarquia do tribunal judicial que a proferiu; assim, decisões da Suprema Corte seriam mais relevantes que quaisquer outras ${ }^{649}$.

Em sistemas constitucionais como o do Brasil, em que o Supremo Tribunal Federal possuem a competência para enunciar decisões com efeitos erga omnes, evidências com tais características devem ser consideradas ainda mais relevantes, pois representam a fórmula como determinada norma do acordo de dupla tributação deve ser construída em todos os casos, por contribuintes, autoridades fiscais e juízes.

No entanto, também é importante considerar que a interpretação de acordos de bitributação nem sempre está sob a competência da Suprema Corte dos Estados. Assim, em sistemas em que a competência para julgar em última instância tais casos pertença a um tribunal inferior à Suprema Corte, as decisões de tal órgão julgador é que seriam de máxima relevância.

O risco de dupla tributação é majorado quando a Corte nacional de um dos Estados contratantes ("A") constrói o sentido de determinado termo de um acordo de dupla tributação ("A-B"), sem tomar conhecimento do sentido atribuído a esse mesmo termo nas Cortes do outro Estado contratante ("B" $)^{650}$. Aliando-se tal constatação à necessidade de

${ }^{648}$ ROHATGI, Roy. Basic International taxation. Volume 1: principles. Nova Deli : Taxmann, 2005, p. 47.

${ }^{649} \mathrm{Cf}$. LANG, Michael. Introduction to the law of double taxation conventions. Vienna : Linde, 2013, p. 56.

${ }^{650}$ Nesse sentido, vide: RAAD, Kees van. International coordination of tax treaty interpretation and application, in International and comparative taxation - essays in honour of Klaus Vogel. KIRCHHOF, Paul et. al. eds London : Kluwer, 2002, p. 218-219. 
cumprir com o princípio pacta sunt servanda, a fim de promover a interpretação harmônica e o efeito útil de um acordo de dupla tributação, os Estados devem promover os seus máximos esforços para superar as dificuldades com a troca de informações quanto às decisões de suas Cortes domésticas relevantes para evidenciar qual sentido é atribuído aos termos de seus acordos de dupla tributação, isto é, como tal acordo é, em última análise, aplicado na prática.

Duas questões devem ainda ser suscitadas: (i) a promoção da interpretação harmônica compete também ao primeiro juiz (“A”) que aplicar o acordo e; (ii) não está o juiz do segundo Estado a aplicar a convenção fiscal ("B”) obrigado a seguir o argumento do primeiro (“A”).

Desse modo, embora haja elevada conexão das decisões judiciais do outro Estado contratante com a interpretação harmônica, a concretização desta não se resume à consideração de decisões do outro Estado contratante, de modo que também incumbe ao primeiro dos Estados (“A”) a aplicar o acordo de dupla tributação (“A-B”) e promover a interpretação harmônica, a partir das demais evidências intrínsecas e extrínsecas investigadas nesta tese.

Por sua vez, ao segundo Estado contratante (“B”), surge a questão de se alinhar ou não à interpretação construída no leading case já julgado por seu parceiro internacional (“A”). Não há dúvida de que a forma mais objetiva de concretizar a intepretação harmônica seja o alinhamento das tribunais nacionais dos dois Estados contratantes ao emitirem a forma alinhada, em suas respectivas jurisdições, a última palavra quanto à forma de aplicar o acordo de dupla tributação celebrado.

Contudo, a admissibilidade de decisões judiciais de um Estado contratante ("A") como evidências do sentido de um determinado termo de um acordo de dupla tributação (“A-B") não significa que o juiz de um Estado contratante (“B”) esteja obrigado a alcançar as mesmas conclusões obtidas pelo juiz do outro Estado (“A”). Tal elemento deve ser considerado dentro de todo o conjunto de evidências intrínsecas e extrínsecas disponíveis para a construção de sentido do termo sob interpretação. Mesmo em segmentos do Direito Internacional que contam com uma Corte Internacional, não se tem notícia de que decisões anteriores sejam consideradas precedentes vinculantes para a solução dos casos futuros. A 
CIJ, por exemplo, não considera suas próprias decisões precedentes a serem seguidos, mas procura manter a coerência entre as decisões proferidas ${ }^{651}$.

Assim, sob a perspectiva da promoção do efeito útil, decisões judiciais do outro Estado contratante parecem cumprir bem o propósito de promover a cooperação, coordenação e reciprocidade internacionais entre os Estados contratantes. Ao considerar admissível tal evidência, o juiz terá segurança que, caso a considere plausível e acompanhe as suas conclusões, a mesma norma referente ao acordo de dupla tributação será construída em ambos os Estados contratantes. Se os Poderes Judiciários de ambos os Estados concordam quanto aos sentidos dos enunciados contidos no acordo celebrado entre este, não há como contestar que os objetivos e propósitos destes - nos moldes reconhecidos pelos órgãos julgadores dos Estados - seriam cumpridos. Se, por sua vez, levarem em consideração as decisões uns dos outros, mas delas divergirem, haverá transparência na relação mantida entre os Estados, bem como oportunidade para que negociem alterações no texto da convenção.

\subsubsection{Critérios materiais de reconhecimento de evidências: decisões judiciais do outro Estado contratante}

"Subsequent commentaries on a convention or treaty have persuasive value only, depending on the cogency of their reasoning. Similarly, decisions of foreign courts on the interpretation of a convention or treaty text depend for their authority on the reputation and status of the Court in question (...)." Reino Unido (High Court, London). Caso Banco do Brasil (1990)

Ao tratar da teoria geral das evidências no Direito, Douglas WALtoN ${ }^{652}$ observa que a base da argumentação a partir dos "precedentes", qualquer que seja a tradição jurídica, é a justiça da decisão. A justiça, sob a temática ora em análise, pode coincidir com a plausibilidade do sentido e da norma de Direito tributário internacional construídos na decisão judicial adotada como evidência, bem como maior será a vocação de uma decisão judicial para a promoção da interpretação harmônica quanto mais plausíveis forem os seus fundamentos.

${ }^{651}$ BROWNLIE, Ian. Principles of public international law. Clarendon : Oxford, 1998, p. 20-21.

${ }^{652}$ WALTON, Douglas. Legal argumentation and evidence. Pennsylvania Satate Press : Pennsylvania, 2002, p. 29. 
Na doutrina do Direito tributário internacional, MiCHAEL LANG ${ }^{653}$ conclui que a relevância de decisões de Cortes estrangeiras depende de quão convincentes essas sejam. Decisões judiciais perdem relevância por conta de deficiências quanto ao conhecimento por parte dos juízes do Direito tributário internacional, quando não apresentam coerência com suas premissas ou quando são desarrazoadas. KEES VAN RAAD ${ }^{654}$ observa que, em muitos países, as Cortes competentes para aplicar os acordos de dupla tributação são especializadas em questões tributárias ou possuem divisões especiais para tratar desse tema; contudo, em muitos outros Estados, haveria apenas tribunais generalistas, o que pode prejudicar a qualidade técnica de suas decisões, que naturalmente dependem da familiaridade do julgador com questões tributárias e, ainda, das peculiares e sofisticadas problemáticas do Direito tributário internacional.

De todo modo, em sua essência, há em geral consenso quanto às conclusões de VOGEL \& PROKISCH ${ }^{655}$, no sentido de que, se a interpretação adotada pelo Tribunal de um Estado contratante ("A") se mostrar plausível, o juiz do outro Estado contratante ("B") teria de fundamentar a sua interpretação divergente com argumentos contundentes.

O que se afirma - é bom deixar claro - não é a competência das Cortes nacionais para chegar a um acordo com o outro Estado quanto ao ao melhor acordor que poderia ter sido celebrado para ambos: tais dimensões já foram estabelecidas nas negociações e pelos instrumentos trocados pelos respectivos Governos dos Estados contratantes e ratificados por seus Poderes Legislativos. A competência dos tribunais consiste na construção de sentido do acordo já celebrado diante de demandas concretas ou, a depender das peculiaridades dos sistemas jurídicos, de forma abstrata; juízes não possuem competência para construir sentidos que não sejam suportados por quaisquer de suas evidências intrínsecas ou extrínsecas, o que consistiria em estabelecer um novo "acordo".

Nesse cenário, conclui-se que os Estados são obrigados a considerar decisões do outro Estado contratante como evidência do sentido de termos dos acordos de dupla

\footnotetext{
${ }^{653}$ LANG, Michael. Introduction to the law of double taxation conventions. Vienna : Linde, 2013, p. 56.

${ }^{654}$ RAAD, Kees van. International coordination of tax treaty interpretation and application, in International and comparative taxation - essays in honour of Klaus Vogel. KIRCHHOF, Paul et. al. eds London : Kluwer, 2002, p. 218-219.

${ }^{655}$ VOGEL, Klaus; PROKISCH, Rainer G. Cahiers de Droit Fiscal International by the International Fiscal Association (studies on international tax law), volume LXXVIIIa - Subject I. Interpretation of double taxation conventions. Kluwer Law and Taxation Publishers / IFA : Rotterdam, 1993, p. 63-64.
} 
tributação, especialmente quando tais decisões cuidarem de situações similares e atinentes ao mesmo acordo internacional. Isso não significa, contudo, que os juízes de um Estado (“A”) esteja vinculado, isto é, seja obrigado a concordar e seguir a interpretação conduzida pelos Tribunais do outro Estado contratante ("B”). De outro modo, o primeiro Estado a publicar decisão de suas Cortes domésticas tutelaria a questão interpretativa e o monopólio da última palavra sobre o que foi bilateralmente contratado (“A-B”) em relação à jurisdição que lhe cabe e à que cabe ao outro Estado contratante.

\subsubsection{O efetivo processo de comunicação entre as Cortes nacionais.}

Tribunais de diversos Estados consideram decisões judiciais de outras jurisdições como aptas a prover o sentido contextualizado de acordos de dupla tributação. Os exemplos a seguir relacionam alguns desses casos.

\subsubsection{Exemplo: A consideração de decisões judiciais do outro Estado contratante por tribunais da Austrália.}

No Caso Lamesa, (Austrália, 1997), ao analisar o acordo de dupla tributação Austrália-Países Baixos, o tribunal australiano considerou decisões da Corte holandesa (“Hoge Raad”).

Consignou-se que evidências quanto à forma com que o outro Estado contratante interpreta o acordo compõem o repertório de elementos do contexto para a construção dos sentidos de acordo internacional e, no caso, decisões daquela Corte holandesa deveriam ser admitidas como relevantes. 


\subsubsection{Exemplo: A consideração de decisões judiciais do outro Estado contratante por tribunais do Reino Unido.}

No Caso Banco do Brasil/Commerzbank (Reino Unido, 1990), o tribunal inglês, a fim de aplicar o acordo de dupla tributação Reino Unido-EUA, considerou que a decisão proferida pela Suprema Corte norte-americana no Caso The Great-West (EUA, 1982) seria útil para demonstrar como aquele outro Estado contratante atuaria em casos semelhantes.

No entanto, o tribunal inglês considerou inaplicáveis as conclusões obtidas pela decisão da Suprema Corte dos EUA, sob a justificativa de que em tal sistema jurídico seriam admissíveis métodos de interpretação e evidência inadmissíveis no sistema britânico.

\subsubsection{Exemplo: A consideração de decisões judiciais do outro Estado contratante por tribunais do Canadá.}

No Caso Gladden (Canadá, 1985), para a aplicação do acordo Canadá-EUA, o tribunal canadense consignou que os juízes norte-americanos observariam os mesmos métodos de interpretação dos acordos internacionais, o que poderia ser constatado a partir do do Caso The Great West (EUA, 1982).

Também no Caso Crown Forest (Canadá, 1995), os juízes canadenses investigaram a jurisprudência dos EUA quanto à aplicação do acordo Canadá-EUA, a fim de fundamentar que algumas de suas posições também seriam compartilhadas por este, em especial que a interpretação da convenção deveria ser mais liberal que da legislação puramente doméstica, que o sentido atribuído aos termos de tal acordo internacional não poderia ser estranho ao que foi pretendido pelos Estados contratantes, bem como que a interpretação adotada pela administração fiscal, embora não fosse determinante, seria relevante ao Poder Judiciário. 


\subsubsection{Dificuldade de acesso às decisões de Cortes nacionais de outros Estados.}

"I imagine that the fact that tax courts rarely consult foreign sources is not due to their belief that such sources are unimportant in interpreting treaty provisions based on the OECD Model. Often this shortcoming will be the result of not having the sources readily available in the libraries of these institutions, the limitations of their retrieval systems and the degree to which these systems are up-to-date, and possibly also the foreign language of the source in question"”.

KEES VAN RAAD $(1996)^{656}$

Além da relevância das decisões de tribunais estrangeiros, é necessário analisar a questão pragmática do acesso a tais materiais. Trata-se de questão que importuna a doutrina do Direito tributário internacional há décadas ${ }^{657}$.

Nos idos de 1960, dificuldades geográficas, culturais e linguísticas eram suscitadas como dificuldades para a comunicação dos Estados a respeito de suas decisões domésticas quanto à aplicação de convenções fiscais. ${ }^{658}$ Semelhante obstáculo empírico foi apresentado por WIM WIJNEN ${ }^{659}$ em 2013, quando apontou que um dos problemas fundamentais na interpretação dos acordos de bitributação seria que os juízes não tomam conhecimento da jurisprudência de outros países, seja pelo não conhecimento do idioma estrangeiro, seja pela ausência de tradição na realização de pesquisa sobre tais decisões, com a consulta exclusiva a julgados pátrios. Observa o autor que tal isolacionismo nacional seria menos evidente no mundo anglo-saxão. Por partilhar a mesma língua, os tribunais nos países anglo-saxões em geral considerariam decisões proferidas por seus colegas no Commonwealth, citando exemplos da Austrália, Canadá e, ainda que com menos frequência, de tribunais do Reino Unido. Do mesmo modo, tribunais da Alemanha e da Áustria por vezes fariam referências a decisões estrangeiras. No entanto, em outros casos, como na França, referências à jurisprudência estrangeira seriam bastante limitadas, bem como não existiriam na jurisprudência italiana.

\footnotetext{
${ }^{656}$ RAAD, Kees van. Interpretation and Application of Tax Treaties by Tax Courts, in European Taxation January 1996. IBFD : Amsterdã, 1996, p. 6.

${ }^{657}$ VOGEL, Klaus; PROKISCH, Rainer G. Cahiers de Droit Fiscal International by the International Fiscal Association (studies on international tax law), volume LXXVIIIa - Subject I. Interpretation of double taxation conventions. Kluwer Law and Taxation Publishers / IFA : Rotterdam, 1993, p. 63-64; BAKER, Philip. Double taxation conventions and international tax law. Londres : Sweet \& Maxwell, 1994, par. C-35.

${ }^{658}$ Cf. LENZ, Raoul. General Report. Cahiers de Droit Fiscal International by the International Fiscal Association (studies on international tax law), volume XLII - Subject II: The interpretation of the Double Taxation Convention/IFA : Rotterdam, 1960, p. 296; UCKMAR, Victor; CORASANITI, Giuseppe; VIMERCATE, Paolo de'Capitani; OLIVA, Caterina Corrado (aspectos gerais); GRECO, Marco Aurélio; ROCHA, Sérgio André (sistema brasileiro). Manual de Direito Tributário Internacional. Dialética : São Paulo, 2012, p. 45.

${ }^{659}$ WIJNEN, Wim. Some Thoughts on Convergence and Tax Treaty Interpretation, in Tax Treaty Monitor Bulletin for International Taxation (November 2013). IBFD: Amsterdã, 2013, p. 577.
} 
Nesse cenário, na opinião de WiM WiJNEN, ainda hoje, na era da informação, muitos juízes seriam incapazes de se beneficiar das soluções encontradas por Cortes estrangeiras para questões específicas que também precisam enfrentar.

Ao assumir-se que tais materiais podem ser evidências quanto ao sentido que se quer construir a partir de termos de um acordo de bitributação, os advogados assumem papel fundamental nesse processo, investigando e apresentado decisões judiciais do outro Estado contratante aos julgadores da jurisdição em que atuam. KLAUS VOGEL ${ }^{660}$ observou que depende do sistema processual de cada Estado se o juiz tem o dever, de ofício, de pesquisar relevantes casos estrangeiros, se tal esforço é discricionário ou, ainda, se ele deve ser provocado pelas partes a analisar tais casos que lhe sejam apresentados. No entanto, o professor alemão sustentava que o juiz seria obrigado a considerar decisões de Cortes nacionais, aos menos aquelas relacionadas ao mesmo acordo de dupla tributação sob análise, que lhe fossem apresentados pelas partes. Se o juiz não fosse capaz de ler a decisão, deveria determinar a sua tradução, mas não desconsiderá-la.

Não se pode, no entanto, dizer que tais dificuldades tenham privado por completo as Cortes nacionais de tal recurso. O Caso Gladden (Canadá, 1985) pode ser considerado um exemplo já antigo da consideração de decisões judiciais do outro Estado contratante para a interpretação de convenções fiscais por tribunais canadenses.

Embora nas últimas décadas algumas Cortes nacionais possam ter se valido esporadicamente de decisões proferidas por Cortes estrangeiras, como evidência para a construção de sentido dos acordos de dupla tributação, o desafio que o Direito tributário internacional enfrenta é disponibilizar tal acesso de forma massificada, a todo e qualquer operador do Direito tributário internacional, especialmente aos juízes, às autoridades administrativas, aos advogados e aos consultores.

Nos idos de 1996, KEES VAN RAAD ${ }^{661}$ reclamava pela criação de um revolucionário “CD-Rom database”, que fosse constantemente atualizado com as mais relevantes

\footnotetext{
${ }^{660}$ VOGEL, Klaus. Klaus Vogel on Double Taxation Conventions. Kluwer : London, 1999, p. 42.

${ }^{661}$ RAAD, Kees van. Interpretation and Application of Tax Treaties by Tax Courts, in European Taxation January 1996. IBFD : Amsterdã, 1996, p. 6.
} 
decisões judiciais e regras do Direito doméstico, em uma linguagem conhecida universalmente, no caso, a língua inglesa. Os custos proibitivos de tal empreitada justificariam ao professor holandês que se iniciasse o catálogo de tais materiais por meio de sumários e palavras-chave em inglês.

O reclamo pelo desenvolvimento de bancos de dados com decisões de Cortes nacionais sobre a aplicação de acordos internacionais não é exclusividade do Direito tributário internacional. Assim os como as convenções fiscais, diversas outras espécies de tratados são aplicadas em última instância pelo Poder Judiciário dos Estados contratantes. Como observa JEAN D’ASPREMONT ${ }^{662}$, a expansão do acesso a tais informações surge da demanda pela aplicação harmoniosa entre os Estados contratantes. O "Oxford Reports on Internacional Law”, ${ }^{\prime 63}$, por exemplo, cobre uma série de áreas do Direito Internacional e possui um módulo dedicado ao catálogo de decisões de tribunais domésticos (Oxford Reports on International Law in Domestic Courts ${ }^{\text {"664 }}$ ).

No entanto, os quase 20 anos que se passaram desde o projeto de KEES VAN RAAD para um revolucionário CD-Rom certamente serão lembrados como o período em que o mundo presenciou a mais ágil, constante, massificada e surpreendente revolução tecnológica da história, especialmente no que se refere aos mecanismos de troca de informações pela Internet e ao acesso pela população mundial a equipamentos baratos capazes de implementar tal processo. No novo cenário mundial, universidades, institutos, órgãos públicos e o setor privado dos mais variados Estados passaram a identificar decisões de suas Cortes domésticas quanto à aplicação de acordos de dupla tributação, bem como a comunicar-se amplamente para a troca de informações do mesmo teor de outras jurisdições.

Nos dias de hoje, ainda não se encontra disponível um sistema totalmente alimentado com informações completas sobre as decisões de quaisquer países quanto a aplicação de seus acordos de bitributação, traduzidas em um idioma disponível a todos.

${ }^{662}$ D'ASPREMONT, Jean. The Systemic Integration of International Law by Domestic Courts: Domestic Judges as Architects of the Consistency of the International Legal Order, in The Practice of International and National Courts and the (De-) Fragmentation of International Law (Nollkaemper, A.; Fauchald, O. K., eds). Hart Publishing : Oxford, 2012, p. 142 e seg.

${ }^{663}$ Acesso possível no endereço eletrônico na internet (website): http://opil.ouplaw.com/home/oril (acesso em 25/07/2014).

${ }^{664}$ Acesso possível no endereço eletrônico na internet (website): http://opil.ouplaw.com/page/ILDC/oxfordreports-on-international-law-in-domestic-courts\#. 
Este é um trabalho em andamento, que tem sido assumido por importantes institucionais, mas em especial pelo IBFD, que apresenta um exemplo extraordinário de esforços para o ideal de um banco de dados central. No Brasil, o IBDT mantém vivo há alguns anos o projeto de identificação de todas as decisões administrativas e judiciais relacionadas à aplicação de acordos de dupla tributação, em cooperação com o IBFD para a exposição internacional de tais materiais.

O banco de decisões do IBFD - até o momento em que esta tese foi escrita - possui cerca de 5500 decisões, distribuídas por Cortes de aproximadamente 200 países. Tal fonte é, contudo, alimentada frequentemente, com saltos constantes no número de casos, que geralmente possibilitam o acesso aos textos completos das decisões em seus idiomas originais, acompanhados de textos sumarizados conforme um mesmo padrão e na língua inglesa.

Diz-se que esse é um trabalho em andamento não apenas porque novas decisões são proferidas diariamente e o catálogo dessas estará sempre fadado a estar também diariamente desatualizado. Mais do que isso, há ao menos duas razões pelas quais ainda não se pode dizer que o banco do IBFD seja uma ferramenta sempre eficiente para fornecer evidências quanto ao sentido dos termos dos acordos de dupla tributação.

A primeira delas diz respeito a questões pontuais, como decisões antigas que não foram ainda catalogadas, outras que apresentam apenas o sumário em inglês, com a omissão do texto original, ou ainda o inverso, em que o sumário foi omitido e apenas o texto original e dados básicos são apresentados.

Um segundo fator está relacionado à ausência de vocação de sumários para a captação de detalhes. O levantamento eficaz de evidências quanto ao sentido de um determinado termo exige que o intérprete leia diretamente o texto da decisão adotada pelo Poder Judiciário do outro Estado contratante (ou mesmo de terceiros Estados). Sumários são por natureza vocacionados a transmitir aspectos gerais e, portanto, não podem ser criticados por omitir detalhes que seriam importantes para a solução de um determinado caso em particular. Com as ressalvas que quaisquer traduções possam conter ("traduttore, traditore”), o banco de decisões ideal precisaria contar também com o texto integral da decisão traduzida para um idioma acessível ao número de operadores do Direito tributário 
internacional da maior quantidade de Estados possíveis: a língua inglesa. Os custos e o tempo envolvido na construção desse banco de decisões ideal podem perfeitamente justificar a atual estratégia adotada pelo IBFD, como um estágio salutar para a sua evolução. Por isso, então, diz-se tratar-se de um trabalho em andamento.

\title{
3.4.6. Lege ferenda: medidas para a facilitação do acesso às informações quanto à interpretação do acordo de dupla tributação por parte do outro Estado contratante.
}

\begin{abstract}
"Following Article 2(2)(2) of the US Model, Double Taxation Conventions should stipulate that Contracting States shall not only notify each other of changes in their tax law, but also 'of any official published material concerning the application of the Convention, including explanations, regulations, rulings or judicial decisions'. The other Contracting State should be obliged to make such material available to its courts and the interested public, which, if necessary, should include translations. To facilitate this procedure, OECD or another international body should undertake to publish case law regarding Double Taxation Conventions on a worldwide basis, both in the original version and in one or more language(s) internationally understood". VOGEL \& PROKISCH (1993) ${ }^{665}$
\end{abstract}

O trabalho em andamento para a implementação de mecanismos de acesso às decisões de Cortes estrangeiras quanto à aplicação de acordos de dupla tributação, acima referido, exige união de esforços. Quem sabe por essa razão, tem se tornado tradição que a academia procure impulsionar novos projetos para o avanço da questão. O presente subtópico tem o objetivo de colaborar com medidas para a facilitação do acesso às informações quanto à interpretação do acordo de dupla tributação por parte do outro Estado contratante.

Em especial, o problema da difusão das decisões de Cortes domésticas aos operadores e julgadores de outros Estados poderia ser solucionado com a ampliação das hipóteses do artigo 2 (4) da CM-OCDE/ONU, de forma que os Estados contratantes se comprometeriam a informar as decisões judiciais que tratam da interpretação do acordo de dupla tributação em questão. Autores como PhILIP BAKER ${ }^{666}$, VOGEL \& PROKISCH $^{667}$ (estes

${ }^{665}$ VOGEL, Klaus; PROKISCH, Rainer G. Cahiers de Droit Fiscal International by the International Fiscal Association (studies on international tax law), volume LXXVIIIa - Subject I. Interpretation of double taxation conventions. Kluwer Law and Taxation Publishers / IFA : Rotterdam, 1993, p. 84-85.

${ }^{666}$ BAKER, Philip. Double taxation conventions and international tax law. Londres : Sweet \& Maxwell, 1994, par. C-35.

${ }^{667}$ VOGEL, Klaus; PROKISCH, Rainer G. Cahiers de Droit Fiscal International by the International Fiscal Association (studies on international tax law), volume LXXVIIIa - Subject I. Interpretation of double taxation conventions. Kluwer Law and Taxation Publishers / IFA : Rotterdam, 1993, p. 84-85. 
na qualidade de relatores do Congresso IFA de 1993) apresentaram apoio à insersão de tal cláusula.

É curioso notar que disposição semelhante a essa foi incluída na CM-EUA de 1981, com a ampliação das hipóteses de seu artigo 2 (2), de forma que, além de mudanças significativas nas respectivas legislações fiscais, os Estados contratantes deveriam notificar-se mutuamente quanto a qualquer publicação oficial relacionada à aplicação do acordo, incluindo atos declaratórios, regulamentos e decisões judiciais ("any officially published material concerning the application of the Convention, including explanations, regulations, rulings or judicial decisions”). No entanto, desde a versão de 2006, tal disposição foi excluída da CM-EUA, sem que quaisquer justificativas tenham sido apresentadas pelo Governo dos EUA.

Bastante pessimista em relação à eficácia de uma cláusula de mútua troca de informações quanto às decisões das Cortes nacionais (ou mesmo de atos administrativos) relacionadas à aplicação do acordo de dupla tributação, WIM WIJNEN ${ }^{668}$ sustenta que, dadas as extensas redes de acordos de dupla tributação existentes, a notificação das decisões judiciais não seria realista e condenada a permanecer letra morta.

Mais do que apenas um banco de dados com decisões de variados Estados, WiM WIJNEN $^{669}$ suscita que seria fundamental a existência de uma organização internacional em que os juízes pudessem se reunir regularmente para a discussão de assuntos que compreendam relevantes questões que se deparem em seu cotidiano, o que também seria um trabalho em andamento.

Sob essa diretriz, foi idealizada no Congresso da IFA de 2009 (Vancouver) a criação da International Association of Tax Judges ("IATJ"), com sede no IBFD, em Amsterdã. Essa associação, bastante abrangente, congrega julgadores judiciais e administrativos, de quaisquer países, que trabalhem com a questão tributária. Até meados de 2013, a associação possuía 150 membros de cerca de 30 países e já havia realizado assembleias em 2010 (Roma), 2011 (Paris), 2012 (Munique) e 2013 (Amsterdã). Como

${ }^{668}$ WIJNEN, Wim. Some Thoughts on Convergence and Tax Treaty Interpretation, in Tax Treaty Monitor Bulletin for International Taxation (November 2013). IBFD: Amsterdã, 2013, p. 578.

${ }^{669}$ WIJNEN, Wim. Some Thoughts on Convergence and Tax Treaty Interpretation, in Tax Treaty Monitor Bulletin for International Taxation (November 2013). IBFD: Amsterdã, 2013, p. 579. 
representante brasileiro na referida associação, cite-se JoÃo FrANCISCO BIANCO, um de seus diretores.

Outras iniciativas também parecem ser possíveis e necessárias, como o estabelecimento de convênios entre os tribunais dos Estados contratantes de convenções fiscais para que se comuniquem diretamente. No Brasil, convênios de colaboração mútua são firmados com certa frequência por tribunais como o STF. Seria auspicioso se a adequada interpretação e aplicação de convenções fiscais também entrasse em pauta.

\subsection{Alterações no Direito doméstico dos Estados contratantes como práticas} subsequentes à conclusão do acordo: seu status de evidência do sentido de termos dos acordos de dupla tributação.

Neste último subtópico da série que se prestou à investigação de candidatos a evidências extrínsecas sob o escopo de práticas conduzidas pelos três Poderes, serão analisadas as alterações no Direito doméstico dos Estados contratantes, ou seja, as práticas subsequentes do Poder Legislativo. Por essa perspectiva, os atos legislativos que se seguissem à celebração de um acordo de bitributação poderiam ser considerados como evidências quanto ao sentido do referido acordo internacional.

A influência do Direito Internacional na edificação do Direito doméstico dos Estados contratantes é evidenciada na doutrina. No Direito tributário internacional, RICHARD VANN ${ }^{670}$ pondera que, ao adotar as normas geralmente presentes nos acordos de dupla tributação em seu Direito doméstico, o Estado transmite transparência ao capital estrangeiro quanto à sua intenção de alinhar-se aos padrões internacionais.

A questão, contudo, é saber se alterações introduzidas no Direito doméstico dos Estados contratantes poderiam influenciar na interpretação de seus acordos de dupla tributação, representando a intenção do aludido Estado quanto à política internacional que pretende adotar.

\footnotetext{
${ }^{670}$ VANN, Richard J. International Aspects od Income Tax, in Tax Law Design and Drafting (Ed. THURONYI, Victor). Londres : Kluwer, 1998, p. 727-728.
} 
Há uma diferença sutil na adoção de medidas legislativas tendentes a alterar o conteúdo de uma convenção fiscal celebrada (treaty override) de outras, que apenas aclarariam o quanto foi acordado internacionalmente. Enquanto as primeiras não seriam toleradas, as segundas, embora raras e em geral desnecessárias perante o Direito Internacional, poderiam ser úteis em algumas situações.

Como exemplo hipotético, é possível imaginar um ambiente em que a administração fiscal de um Estado (“A”) não aplique os acordos de bitributação com o conteúdo que o Poder Legislativo pátrio tenha ratificado, levando-o a enunciar lei pedagógica que com mais claridade expresse a expectativa de cumprimento do acordo que se tem diante de outros Estados contratantes ("B", "C" etc.) e que, naturalmente, devem ser seguidas por seus executores nacionais (“A”). Nesse caso, os operadores do Direito tributário internacional do outro Estado contratante ("B") poderiam considerar tal norma pedagógica daquele Estado (“A”) como evidência do sentido do acordo de bitributação firmado entre eles (“A-B”). A sua observância poderia potencialmente promover a interpretação harmônica e os efeitos úteis do acordo internacional.

Um outro exemplo pode ser observado na jurisprudência norte-americana, analisado no subtópico seguinte.

\subsubsection{Exemplo: A consideração de alterações legislativas subsequentes como evidências para a interpretação de convenção fiscal celebrada pelos EUA.}

No caso Great-West (EUA, 1982), um tribunal norte-americano considerou que atos legislativos subsequentes à celebração do acordo de dupla tributação EUA-Canadá seriam evidências quanto ao propósito da celebração deste.

O tribunal evidenciou que poucos meses após a celebração desse acordo, em 1942, foi aprovado o "Revenue Act of 1942”, que alterou substancialmente a tributação dos juros atribuídos às empresas estrangeiras que conduzissem negócios nos EUA relacionados a seguros de vida. Antes, tais empresas seriam tributadas em uma certa porcentagem de sua renda mundial; após, passaram a ser tributadas apenas sobre a renda mundial reconhecida conforme determinados regulamentos contábeis. Analisado o histórico legislativo, seria 
ainda possível verificar que tal ato foi impulsionado por insistentes reclamos de seguradoras canadenses, insatisfeitas com a sistemática anterior.

Nesse cenário, aquele tribunal concluiu que, caso o Congresso considerasse que o art. XII do acordo de dupla tributação USA-Canadá concedesse isenção tão ampla quanto a reclamada por Great-West, as alterações introduzidas pelo "Revenue Act of 1942" seriam completamente desnecessárias.

Como se pode observar, o recurso adotado pelo tribunal norte-americano não consistiu no mero reenvio ao Direito doméstico daquele país. Considerou-se que a alteração neste foi conduzida por um ato do poder legislativo tão próximo à aprovação da convenção fiscal que deveriam harmonizar-se.

\section{PARALlEL treaties: O PRINCÍPIO DA INTEGRAÇÃO SISTÊMICA DOS ACORDOS INTERNACIONAIS E AS EVIDÊNCIAS EXTRÍNSECAS PRIMÁRIAS.}

"Determining the scope of the OECD Model by reference to other international instruments is nothing more than checking whether this is one of the cases where "context" (in the broad sense the word is used in Art. 3(2) of the OECD Model) excludes reference to the domestic law of the state applying the treaty."

AdOLFO J. MARTÍN JiMÉNEZ (2005) $)^{671}$

O princípio da integração sistêmica adota a ficção de que, embora os emissores das normas de Direito Internacional sejam fragmentados e descentralizados, qualquer norma produzida deve levar em consideração e estar em conformidade com as demais de seu sistema, o que inclui todas as fontes de Direito Internacional. Tal como consignou a ILC$\mathrm{ONU}^{672}$, o principio da integração sistêmica, estabelecido pelo art. 31 (3) "c" da CVDT, requer que se considere que, qualquer que seja o tema envolvido, tratados são criações do Direito Internacional e devem operar considerando tal fato. Os acordos internacionais não

\footnotetext{
${ }^{671}$ JIMÉNEZ, Adolfo J. Martín. Defining the objective scope of income tax treaties: the impact of the other treaties and EC Law on the Concept of Tax in the OCED Model, in Bulletin - Tax Treaty Monitor - October 2005. Amsterdã : IBFD, 2005, p. 432.

${ }^{672}$ UN. International Law Commission Fifty-Eighth Session. Geneva, 2006. Fragmentation Of International Law: Difficulties Arising From The Diversification and Expansion of International Law - Report of the Study Group of the International Law Commission, p. 13-14.
} 
estão à deriva ou em um vácuo, mas imersos no Direito Internacional público ${ }^{673}$. Os princípios da boa-fé e da pacta sunt servanda podem ser considerados fundamentos para que a CVDT tenha prescrito tal norma, assumindo-se como legítima a expectativa de que todas as partes de um tratado irão cumprir com suas obrigações assumidas, em conformidade com todas as normas de Direito Internacional. ${ }^{674}$

A partir de tal premissa, JEAN D'ASPREMONT ${ }^{675}$ compreende que referida norma exige dos juízes de Cortes domésticas predisposição para a construção do Direito Internacional como um consistente sistema normativo. Tratar-se-ia, como observa o autor, de norma com o caráter de Direito consuetudinário, de forma que mesmo os Estados que não sejam signatários da CVDT estariam compelidos a observá-lo. O Brasil, de todo modo, é signatário dessa convenção internacional, o que torna mandatória a consideração do princípio da integração sistêmica.

Note-se que o art. 31 (3) "c" da CVDT atribui relevância a priori a "quaisquer regras pertinentes de Direito Internacional aplicáveis às relações entre as partes”. O termo "quaisquer" é uma forte indicação de que o intérprete deve adotar perspectiva bastante ampla, embora o art. 31 (3) "c" da CVDT preveja certos critérios de seleção das evidências em questão. O termo "pertinente", que qualifica as referidas regras do Direito Internacional, estabelece um filtro para a seleção de tais evidências. Outro filtro é estabelecido, ainda, na parte final do dispositivo, de tal modo que tais regras de Direito Internacional devem ser "aplicáveis às relações entre as partes”. Nesse cenário, a literatura ${ }^{676}$ do Direito Internacional geralmente reconhece que o art. 31 (3) "c" da CVDT, com os requisitos que estabelece, veicula uma referência implícita ao art. 38 (1) do ECIJ.

\footnotetext{
${ }^{673}$ Nesse sentido, vide, ainda: BROEKHUIJSEN, Dirk M. A Modern Understanding of Article 31(3)(c) of the Vienna Convention (1969): A New Haunt for the Commentaries to the OECD Model?, in Bulletin for International Taxation, volume 67, n. 9. Amsterdã : IBFD, 2013.

${ }^{674}$ Nesse sentido, vide: DÖRR, Oliver. "Article 31 - General rule of interpretation", in "Vienna Convention on the Law of Treaties: a Commentary”, DÖRR, Oliver; SCHMALENBACH, Kirsten (Editors). Springer, 2012, p. 560-561.

${ }^{675}$ D'ASPREMONT, Jean. The Systemic Integration of International Law by Domestic Courts: Domestic Judges as Architects of the Consistency of the International Legal Order, in The Practice of International and National Courts and the (De-) Fragmentation of International Law (Nollkaemper, A.; Fauchald, O. K., eds). Hart Publishing : Oxford, 2012, p. 146- 152.

${ }^{676}$ Nesse sentido, vide: DÖRR, Oliver. "Article 31 - General rule of interpretation", in "Vienna Convention on the Law of Treaties: a Commentary", DÖRR, Oliver; SCHMALENBACH, Kirsten (Editors). Springer, 2012, p. 561-562.
} 
Com suporte nos elementos elencados no art. 38 (1) "a" do ECIJ, outras convenções internacionais, que estabeleçam regras reconhecidas pelas partes, devem ser investigadas como evidências para a construção de sentido de termos dos acordos de dupla tributação, que geralmente são conhecidos como "parallel treaties". Por tal expediente, a fim de interpretar um acordo internacional, os tribunais devem recorrer a outros acordos internacionais tomados como pares de comparação ${ }^{677}$.

Entre as questões envolvidas nessa análise, é importante saber se tal recurso assume um caráter primário ou sendário no processo interpretativo. Ocorre que parcela da doutrina $^{678}$ classifica o recurso aos parallel treaties sob o escopo do art. 32 da CVDT, ou seja, no contexto extrínseco secundário. A alocação de tal evidência no presente Capítulo, dedicado às evidências extrínsecas primárias, antecipa a conclusão obtida na investigação empreendida a esse respeito. Note-se, ainda, que outras evidências referidas no art. 38 (1) "a" do ECIJ, como os trabalhos dos mais qualificados publicistas e decisões judiciais de terceiros Estados, serão analisadas no Capítulo seguinte, conjuntamente com outros elementos que têm como característica a subsidiariedade.

\subsection{O recurso a parallel treaties nos Tribunais internacionais.}

A experiência das Cortes internacionais, ainda que relacionada à aplicação de acordos não tributários, é útil para suscitar questões como: (i) se o princípio "res inter alios acta nec nocet nec prodest" ${ }^{\text {,679 }}$, codificado no art. 34 da CVDT, impede tal recurso e; (ii) se tal recurso assume um caráter primário ou subsidiário no processo interpretativo.

Para, Hugh ThIRLWAY ${ }^{680}$, a máxima res inter alios acta nec nocet nec prodest, codificado no art. 34 da CVDT, afastaria qualquer importância de um determinado acordo perante terceiros.

\footnotetext{
${ }^{677}$ Contrário à utilidade de tais instrumentos devido às particularidades de cada caso, vide: THIRLWAY, Hugh. The Sources of International Law. Oxford : Oxford, 2014, p. 36.

${ }^{678}$ Nesse sentido, vide: ROHATGI, Roy. Basic International taxation. Volume 1: principles. Nova Deli : Taxmann, 2005, p. 42.

${ }^{679}$ Tradução livre: Nenhum benefício será conferido e nenhuma obrigação será imposta a terceiros de uma transação.

${ }^{680}$ THIRLWAY, Hugh. The Sources of International Law. Oxford : Oxford, 2014, p. 35-36.
} 
No entanto, o recurso aos parallel treaties é amplamente utilizado por tribunais internacionais para a interpretação de acordos não tributários ${ }^{681}$. No Caso Land, Island And Maritime Frontier Dispute, por exemplo, a CIJ precisou construir o sentido dos termos "to delimit the boundary line" e, assim, solucionar a disputa entre os Estados quanto à delimitação do espaço marítimo. Para tanto, aquele Tribunal internacional consignou que sua interpretação seria confirmada pelo contexto amplo ("wider contexto"), por meio do qual seria relevante considerar também outros tratados relacionados às partes, especialmente o art. 18 do Acordo Geral de Paz.

A questão da subsidiariedade do recurso a parallel treaties também vem sendo enfrentada na jurisprudência de Cortes Internacionais. No Caso Oil plataforms, a CIJ recorreu a um parallel treaty, não porque se deparou com um caso de ambiguidade ou obscuridade, mas por considerar que os acordos internacionais, tomados como pares de comparação, seriam parte integrante do contexto primário que atribui sentido aos termos do tratado.

\subsection{Parallel treaties no Direito tributário internacional.}

“Essa comparação não pode, entretanto, ser efetuada sem a cautela de considerar que cada acordo de bitributação é único, resultado de uma negociação em que dois Estados soberanos resolveram abrir mão de parte de seu legítimo poder de tributar".

LUÍS EDUARDO SCHOEURI ${ }^{682}$

No âmbito do Direito tributário internacional, discute-se se seria possível o recurso a parallel treaties. Para EDUARDO BAISTROCCHI ${ }^{683}$, nem sempre tal recurso seria admissível, tendo em vista que o art. 31 da CVDT afastaria a utilização de materiais unilaterais no processo interpretativo: um acordo de dupla tributação celebrado entre " $\mathrm{A}$ " $\mathrm{e}$ "B" seria um material unilateral de "C" quando utilizado para a interpretação do acordo de dupla tributação celebrado entre "A" e "C". Por sua vez, LUC DE BROE ${ }^{684}$ compreende que

\footnotetext{
${ }^{681}$ Vide, por exemplo: Venezuelan bond; Decision regarding interest on owards; Oil Platforms; Territorial Dispute between El Salvador and Honduras.

${ }^{682}$ SCHOUERI, Luís Eduardo. Tratados e Convenções Internacionais sobre Tributação, in Revista de Direito Tributário Atual n. 17. São Paulo : IBDT/Dialética, 2003, p. 36.

${ }^{683}$ BAISTROCCHI, Eduardo A., The Use and Interpretation of Tax Treaties in the Emerging World: Theory and Implications. British Tax Review n. 4. Londres : Thomson, 2008, p. 389.

${ }^{684}$ BROE, Luc De. International tax planning and prevention of abuse (doctoral series n. 14). Amsterdã : IBFD, 2007, 252-257-258.
} 
tal recurso estaria fundado no art. 32 da CVDT, mais especificamente entre as circunstâncias relacionadas à conclusão do acordo de dupla tributação.

No entanto, o princípio da integração sistêmica (CVDT, art. 31 (3) “c") parece legitimar perfeitamente o recurso a parallel treaties. Primeiro, é possível cogitar o recurso a outros acordos internacionais celebrados entre ambos os Estados contratantes (" $A$ " e "B") de um acordo de bitributação (“A-B”). Entre esses, podem haver acordos mantidos por ambos os Estados relacionados a outras questões tributárias, a exemplo de tratados sobre a tributação de doações e heranças, bem como outros acordos internacionais celebrados entre as partes, mas relacionados a matérias não tributárias. Também podem haver antigos tratados de bitributação celebrados entre os mesmos Estados.

Segundo, diante de um específico acordo de bitributação (“A-B”), também poderia ser cogitada a comparação com outros acordos internacionais ("A-C") celebrados por apenas um dos Estados ("A") contratantes com terceiros ("C"). Novamente, entre esses poderiam haver outros acordos internacionais em matéria tributária ou em matérias não tributárias, conforme anteriormente referidos.

Nos subtópicos seguintes, propõe-se a análise sobre se tais materiais compõem o “contexto" referido no art. 3 (2) da CM-OCDE, com exceção de antigos acordos de dupla tributação celebrados entre ambos os Estados. Parece mais apropriado que estes sejam analisados no Capítulo IV desta tese, em meio às circunstâncias em que a convenção sob interpretação foi celebrada (contexto extrínseco secundário). Ocorre que tais antigos acordos, por terem sido sucedidos pela convenção sob interpretação, não são mais "aplicáveis às relações entre as partes", como requer o art. 31 (3) "c" da CVDT como condição para a composição do contexto extrínseco primário.

Cumpre observar, ainda, que acordos celebrados entre terceiros Estados ("C-D”) também não cumpririam o requisito do art. 31 (3) "c" da CVDT, pois não seriam pertinentes a nenhum dos Estados contratantes do acordo de dupla tributação (“A-B”), de forma a não serem "aplicáveis às relações entre as partes".

Além do recurso aos outros acordos internacionais celebrados pelos Estados contratantes como pares de comparação (parallel treaties próprios), é bastante comum 
identificar em textos acadêmicos e em decisões de Cortes nacionais a adoção da CMOCDE, da CM-ONU e/ou da CM-EUA como par de comparação. Por não se tratarem de "acordos" propriamente ditos, mas apenas de modelos de acordos, não se tratam de regras efetivamente "aplicáveis às relações entre as partes", de forma que não se encontram sob o escopo do 31 (3) "c" da CVDT.

Conforme será exposto no Capítulo IV desta tese, o recurso à CM-OCDE, à CMONU e/ou à CM-EUA, como pares de comparação para a contrução de sentido de termos de um específico acordo de dupla tributação (parallel treaty impróprio), pode estar sob o escopo do art. 32 da CVDT (contexto extrínseco secundário). ${ }^{65}$

\subsubsection{Parallel treaties: outros acordos de dupla tributação como pares de comparação.}

"Parallel treaties are treaties on a similar subject matter concluded between third States or between one of the parties and a third State. Such treaties can provide interpretative guidance through their working, explanatory notes and judicial decisions. For exemple, a similar provision may be contained, or left out, or be absent from another treaty." ROY ROHATGI (2005) $)^{686}$

A questão suscitada pelo parallel treaty próprio é se a relação jurídica de um Estado ("A") com um outro Estado ("B”), estabelecida por meio de uma específica convenção fiscal (“A-B”) celebrada nos moldes da CM-OCDE, poderia ser influenciada, com algum grau de cogência, por outro acordo internacional ("A-C" ou "B-C") firmado com um terceiro Estado ("C") também nos moldes da CM-OCDE. Como se viu, tais evidências possuem validade no Direito tributário internacional com fundamento no art. 31 (3) "c" da CVDT, bem como no art. 38 (1) "a" do ECIJ (critério formal).

Assim, por exemplo, quando um Estado (“A”) parte de um mesmo padrão para negociar acordos de dupla tributação com variados Estados ("B" e "C"), mas utiliza cláusulas com peculiaridades diversas no acordo celebrado com cada um desses (“A-B" e “A-C”), uma exceção constante em um desses acordos (“A-B”) pode ser compreendida como intenção daquele Estado ("A”) para a contratação de coisas diversas com aqueles outros Estados ("B" e "C").

${ }^{685}$ Sobre a consideração da CM-OCDE como elemento do contexto e controvérsias na doutrina, vide: SILVEIRA, Rodrigo Maitto da. Aplicação de Tratados Internacionais Contra a Bitributação - Qualificação de Partnership Joint Ventures. IBDT/Quartier Latin : São Paulo, 2006, p. 140.

${ }^{686}$ ROHATGI, Roy. Basic International taxation. Volume 1: principles. Nova Deli : Taxmann, 2005, p. 47. 
A ideia predominante na doutrina é de aceitação dos parallel treaties como evidências sob o escopo do "contexto" referido no art. 3 (2) da CM-OCDE, com ressalvas de que cuidados são necessários. PHILIP BAKER ${ }^{687}$, por exemplo, vê tantas ressalvas que, embora não reconheça razões para rejeitar tais evidências, considera os parallel treaties de pouca valia no processo interpretativo.

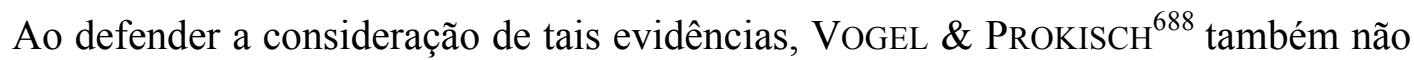
deixaram de ressaltar o extremo cuidado que tal recurso exige. Diferenças na redação de um acordo não necessariamente significam que substantivas alterações em seu sentido foram pretendidas por seus negociadores, bem como é razoável que os Estados contratantes de um acordo tenham desejado esclarecimentos que não foram reclamados pelas partes de outro tratado. A advertência parece ser procedente.

É necessário investigar, contudo, se parallel treaties seriam aptos a promover a interpretação harmônica e o efeito útil dos acordos de dupla tributação (critério funcional).

O mesmo parece aplicar-se em relação à promoção do efeito útil. A adoção de pares de comparação maximiza a percepção do intérprete quanto ao sentido contextualizado que se pode atribuir a cada um de seus termos.

Para que tal recurso se mostre apto à promoção da interpretação harmônica de uma convenção fiscal (“A-B”), o acordo de dupla tributação adotado como par de comparação (“A-C”) deve ser investigado com o mesmo zelo que o próprio tratado sob interpretação (“A-B”). Afinal, apenas com a análise das evidências intrínsecas e extrínsecas do acordo adotado como par de comparação (“A-C") seria possível compreender as semelhanças e diferenças sintáticas, semânticas, as circunstâncias em seu entorno etc., capazes de justificar a construção de sentido convergente ou divergente para o termo inserto na convenção fiscal interpretada (“A-B”).

${ }^{687}$ BAKER, Philip. Double taxation conventions and international tax law. Londres : Sweet \& Maxwell, 1994, par. C-33.

${ }^{688}$ VOGEL, Klaus; PROKISCH, Rainer G. Cahiers de Droit Fiscal International by the International Fiscal Association (studies on international tax law), volume LXXVIIIa - Subject I. Interpretation of double taxation conventions. Kluwer Law and Taxation Publishers / IFA : Rotterdam, 1993, p. 70. 
Os parallel treaties, assim, podem ser considerados como evidências admissíveis à construção do sentido contextualizado dos termos insertos nas convenções fiscais. ${ }^{689}$ Além de admissíveis, Cortes nacionais têm reconhecido amplamente a plausibilidade de tais evidências (critério material).

\subsubsection{Exemplo: O recurso aos parallel treaties em julgados do CARF.}

No Caso Alubar (Brasil, 2004), serviços de consultoria tecnológica (sem transferência de tecnologia) foram providos por uma empresa portuguesa ("Hodler") a uma empresa brasileira (“Alubar”). Não foi realizada a retenção de imposto de renda no pagamento de tais serviços, o que gerou a autuação fiscal. O contribuinte se opôs à exigência do fisco brasileiro, alegando, entre outras coisas, que o art. 14 do acordo BrasilPortugal seria aplicável ao caso.

Conforme o argumento do contribuinte o art. 14 do acordo Brasil-Portugal não seria aplicável apenas às pessoas físicas, mas também às pessoas jurídicas que se dediquem às atividades independentes tuteladas naquele dispositivo. Tal entendimento seria confirmado por protocolos anexos a uma série de acordos de bitributação de que o Brasil faz parte, a exemplos daqueles celebrados com Alemanha (sem efeito), Coréia, Dinamarca, Equador, Espanha, Filipinas, Hungria, Itália, Luxemburo, República Checa e Eslováquia.

O contribuinte, então, valeu-se de tais protocolos anexos aos referidos acordos de bitributação como parallel treaties.

No entanto, tal recurso a parallel treaties serviu justamente como fundamento para que o CARF afastasse tal argumento: embora a interpretação sugerida pelo contribuinte pudesse ser válida perante aquelas convenções fiscais adotadas como pares de comparação, restaria evidenciado que Brasil e Portugal não pretenderam que o art. 14 do acordo celebrado fosse aplicado também às pessoas jurídicas, precisamente por não terem incluído tal previsão semelhante em seu protocolo.

${ }^{689}$ BECERRA, Andrés González. The interpretational approaches to the Vienna Convention - application to (tax) treaty analysis, in Bulletin for International taxation - setembro 2011. IBFD : Amsterdam, 2011, p. 5. 


\subsubsection{Exemplo: O recurso aos parallel treaties nos tribunais dos EUA.}

Embora STANLEY I. KATZ ${ }^{690}$ aponte que raramente os Tribunais dos EUA recorram a parallel treaties como instrumento para a interpretação de acordos de dupla tributação, tal recurso pode ser observado com certa frequência na jurisprudência norte-americana, como se pode observar nos casos Great-West e Stuart.

No Caso Great-West (EUA, 1982), o tribunal considerou parallel traties como evidência de que o art. 12 do acordo EUA-Canadá não veicularia uma isenção ilimitada. Embora não tenha realizado uma investigação e comparação detalhada a respeito de cada um, indicou como dispositivos comparáveis o art. 7 do acordo EUA-Honduras (1957), o art. 12 do acordo EUA-Países Baixos (1948), o art. 10 do acordo EUA-Luxemburgo (1964) e o art. 15 do acordo EUA-Reino Unido (1946).

No Caso Stuart (EUA, 1989), estava em disputa se os termos "entitled to obtain under the revenue laws of the United States of America", presentes no art. 21 da convenção fiscal EUA-Canadá, restringiriam a possibilidade de troca informações às circunstâncias em que as próprias autoridades fiscais norte-americanas estivessem legitimadas a obtê-las. Para a interpretação desse dispositivo, o juíz BRENNAN observou que, nos acordos de bitributação celebrados com mais de 30 países, não haveria maiores impedimentos ao acesso de tais informações, o que corroboraria para o mesmo entendimento fosse adotado.

\subsubsection{Exemplo: O recurso aos parallel treaties nos tribunais do Reino Unido.}

No Caso Vas (Reino Unido, 1989), o tribunal inglês, a fim de aplicar o acordo de dupla tributação Reino Unido-Hungria, comparou as suas cláusulas com dispositivos do acordo de dupla tributação Canadá-EUA.

${ }^{690}$ KATZ, Stanley I. United States National Report. Cahiers de Droit Fiscal International by the International Fiscal Association (studies on international tax law), volume LXXVIIIa - Subject I. Interpretation of double taxation conventions. Kluwer Law and Taxation Publishers / IFA : Rotterdam, 1993, p. 638. 
No caso, o acordo Canadá-EUA possuía dispositivo similar ao acordo Reino Unido-Hungria, dedicado aos rendimentos de professores e pesquisadores; no entanto, o primeiro possuía cláusula omitida no segundo. O art. 20 (2) do acordo Canadá-EUA previa que a isenção concedida a tais rendimentos deveria ser aplicada pelo Estado contratante em que as aulas ou pesquisas fossem desenvolvidas como contrapartida aos pagamentos realizados aos professores ou pesquisadores. Assim, o art. 21 do acordo Reino UnidoHungria seria idêntico ao art. 20 do acordo Canadá-EUA, exceto pelo referido (2).

O caso apresenta uma peculiaridade que não pode ser ignorada. O acordo de bitributação adotado como par de comparação não envolvia nenhuma das partes: embora o tratado Reino Unido-Hungria estivesse sob interpretação, um acordo celebrado entre Canadá e EUA foi considerado. O problema é que tal material não seria legitimado pelo art. 31 (3) "c" da CVDT, pois não veicularia normas "aplicáveis às relações entre as partes”, como se viu no início deste tópico.

\subsubsection{Exemplo: O recurso aos parallel treaties nos tribunais do Canadá.}

O acordo Canadá-EUA também foi adotado como par de comparação no Caso Pacific Network (Canadá, 2002), no qual o Tribunal canadense analisou o sentido do termo "exchange", presente no artigo 26 do acordo Canadá-França.

Conforme o argumento sustentado pelo contribuinte, o art. 26 do acordo CanadáFrança não possuiria cláusula semelhante à veiculada pelo art. 26 (2) do acordo CanadáEUA, que previa expressamente o dever dos Estados de empenhar esforços para a obtenção de informações ("endeavour to obtain the information") sob a sua jurisdição, na mesma intensidade, caso o interesse arrecadatório do próprio Estado estivesse em jogo. Diante da ausência de tal cláusula no acordo Canadá-França, que simplesmente previa a troca ("exchange") de informações e não o empenho de esforços ("endeavour"), os Estados apenas deveriam fornecer informações que já detivessem.

O Caso Pacific Network também é interessante por nos mostrar a única e combinada operação de interpretação em funcionamento, com a consideração de todas as evidências disponíveis ao julgador e, ainda, com a adoção de evidências extrínsecas 
secundárias. Naquela oportunidade, o tribunal canadense considerou que parallel treaties como o acordo Canadá-EUA não seriam evidências tão persuasivas aquelas providas pela CM-OCDE ou por seus Comentários. Para aquela Corte, a presença de cláusula semelhante à do art. 26 (2) do acordo Canadá-EUA no texto do acordo Canadá-França não seria decisiva para que ambos fossem aplicados da mesma forma no que concerne à troca de informações.

\subsubsection{Parallel treaties: outros acordos internacionais que afetam a matéria tributária como pares de comparação.}

O princípio da integração sistêmica requer que o intérprete analise os acordos de bitributação a partir de uma perspectiva ampla, atentando-se para "quaisquer regras pertinentes de Direito Internacional aplicáveis às relações entre as partes”. A partir daí, é possível cogitar que outros acordos internacionais em matéria tributária celebrados pelos Estados contratantes $^{691}$, que não tenham como objeto necessariamente a dupla tributação da renda e do capital, poderiam servir de evidências quanto à interpretação de um determinado termo de um acordo de dupla tributação elaborado sob a CM-OCDE.

Trata-se de operação semelhante ao parallel trieaty analisado anteriormente, embora o acordo internacional adotado como par de comparação não tenha como objeto a dupla tributação jurídica da renda ou do capital.

Podem ser relevantes nesse exercício materiais como o Acordo Geral de Tarifas e Comércio (GATT), acordos multilaterais celebrados entre os membros da Comunidade Europeia ${ }^{692}$ ou do Mercosul, por se tratarem, sem dúvida, de "regras pertinentes de Direito Internacional aplicáveis às relações entre as partes”.

\footnotetext{
${ }^{691}$ ROY ROHATGI noticia a existência de mais de 20 tipos de acordos internacionais em matéria tributária e que não têm o mesmo escopo da CM-OCDE, entre os quais convenções sobre heranças, doações e troca de informações. (ROHATGI, Roy. Basic International taxation. Volume 1: principles. Nova Deli : Taxmann, 2005, p. 3).

${ }^{692}$ Cf. TÔRRES, Heleno Taveira. Pluritributação internacional sobre as rendas das empresas. São Paulo : Revista dos Tribunais, 2001, p. 661.
} 


\subsubsection{Exemplo: $O$ recurso a outras espécies de tratados internacionais em matéria tributária para a interpretação do termo "tax" utilizado na CM-OCDE.}

Um exemplo interessante do recurso a outros tratados (não tributários) como par de comparação é fornecido por ADOLFO J. MARTín JIMÉNEZ ${ }^{693}$, para a construção de sentido do termo "tax" e "taxes". O autor parte de um problema: a inclusão ou não de contribuições sociais sob o escopo do termo "tax" presente nos art. 2, 23, 25, 26 e 27 da CM-OCDE. As questões suscitadas por tal problema o conduz à investigação de evidências para a construção de sentido de tal termo, em especial se outros instrumentos internacionais relacionados às contribuições sociais teriam valor para a composição do contexto interpretativo. Em sua investigação, o professor da Universidade de Cádiz recorre à legislação da União Europeia atinente às contribuições para a seguridade social.

Conclui AdOLFO J. MARTín JIMÉNEZ ${ }^{694}$, então, que as contribuições relacionadas ao financiamento da seguridade social dos Estados da UE, estejam elas conectadas ou não com os benefícios que o contribuinte possa vir a fluir, estariam fora do escopo dos acordos de dupla tributação celebrados entre Estados membros da UE que adotem cláusula semelhante ao art. 2 da CM-OCDE. Tais contribuições, em especial, estariam sob o escopo do Regulamento 1.408/71 da UE. Observa o autor, então, que o Regulamento 1.408/71 autoriza dois ou mais Estados membros a concluir tratados entre si, desde que mantenham os princípios e espírito da referida regulamentação, o que não se dá com a CM-OCDE.

Outros acordos bilaterais e multilaterais, de fato, são comuns entre os membros da UE, em geral, baseados nos princípios da territorialidade e da não cumulação de contribuições à seguridade social, embora peculiaridades marquem cada um destes. $\mathrm{O}$ principal tratado nesse sentido seria a Convenção Europeia sobre a Seguridade Social, de 1972. Para Adolfo J. MARTín JiMÉnez ${ }^{695}$, sob a máxima da lex specialis, as obrigações compreendidas por tais convenções estariam excluídas do escopo dos acordos de dupla

${ }^{693}$ JIMÉNEZ, Adolfo J. Martín. Defining the objective scope of income tax treaties: the impact of the other treaties and EC Law on the Concept of Tax in the OCED Model, in Bulletin - Tax Treaty Monitor - October 2005. Amsterdã : IBFD, 2005, p. 433 e seg.

${ }^{694}$ JIMÉNEZ, Adolfo J. Martín. Defining the objective scope of income tax treaties: the impact of the other treaties and EC Law on the Concept of Tax in the OCED Model, in Bulletin - Tax Treaty Monitor - October 2005. Amsterdã : IBFD, 2005, p. 433-435.

${ }^{695}$ JIMÉNEZ, Adolfo J. Martín. Defining the objective scope of income tax treaties: the impact of the other treaties and EC Law on the Concept of Tax in the OCED Model, in Bulletin - Tax Treaty Monitor - October 2005. Amsterdã : IBFD, 2005, p. 435-436. 
tributação celebrados entre os seus membros, por conta da integração sistêmica de seu art. 2.

Em relação ao art. 26 da CM-OCDE (cláusula de troca de informações), AdOLFO J. MARTín JiMÉNEZ ${ }^{696}$ observa que o sentido contextualizado do termo "taxes" deveria considerar como evidências outros acordos internacionais, especialmente aqueles atinentes a encargos aduaneiros. Entre eles, o autor destaca a Convenção Internacional de Mútua Assistência Administrativa para a Prevenção, Investigação e Repressão de Infrações Alfandegárias, celebrada em Nairobi, em 1977 (“Convenção de Nairobi”) e a Convenção Internacional de Mútua Assistência para Questões Alfandegárias, celebrada em 2003, em Joanesburgo (“Convenção de Joanesburgo"), embora esta ainda não tenha vigência. A Convenção de Nairobi se aplica aos tributos de importação e exportação, definidos em seu art. 1 "e" como quaisquer encargos ("customs and all other duties, taxes, fees or other charges") incidentes sobre a importação e exportação de bens. Os Comentários à Convenção de Nairobi, por sua vez, excluem de seu escopo os casos de dumping, que estariam sob a égide das normas anti-dumping ou de compensação do GATT/WTO. De forma semelhante, a Convenção de Joanesburgo se aplicaria também a tributos alfandegários, definidos em seu art. 1, "g" como todos os encargos ("all duties, taxes, fees or any other charges") cobrados no território dos Estados contratantes pela aplicação do Direito aduaneiro.

No âmbito da UE, uma série de normas comunitárias, bem como acordos multilaterais em que figuram apenas alguns Estados membros, também contribui para delimitar o sentido do termo "taxes" contido no art. 26 de acordos de dupla tributação celebrados entre dois desses Estados membros. Como observa AdOLFO J. MARTín JIMÉNEZ ${ }^{697}$, as normas comunitárias atinentes à troca de informações não previne que os Estados acordem convenções que ampliem tais procedimentos; no entanto, caso os Estados membros acordem cláusulas mais restritas, as normas comunitárias devem ser aplicadas.

\footnotetext{
${ }^{696}$ JIMÉNEZ, Adolfo J. Martín. Defining the objective scope of income tax treaties: the impact of the other treaties and EC Law on the Concept of Tax in the OCED Model, in Bulletin - Tax Treaty Monitor - October 2005. Amsterdã : IBFD, 2005, p. 432 e seg.

${ }^{697}$ JIMÉNEZ, Adolfo J. Martín. Defining the objective scope of income tax treaties: the impact of the other treaties and EC Law on the Concept of Tax in the OCED Model, in Bulletin - Tax Treaty Monitor - October 2005. Amsterdã : IBFD, 2005, p. 434.
} 
O princípio da integração sistêmica tornaria cogente, portanto, que os Estados signatários de Convenções como de Nairobi e Johannesburg, apliquem a cláusula de troca de informações de seus acordos de bitributação de forma limitada, tendo em vista a influência desses na construção de sentido do termo "taxes" adotado no art. 26 da CMOCDE.

4.2.3. Parallel treaties: acordos internacionais em matéria não tributária como pares de comparação.

Teoricamente, um tratado internacional em matéria não tributária também poderia servir de evidência para a construção de sentido dos termos de um acordo de bitributação. 


\title{
CAPÍTULO IV \\ O CONTEXTO EXTRÍNSECO SECUNDÁRIO DOS \\ ACORDOS DE DUPLA TRIBUTAÇÃO
}

\section{NOTAS INTRODUTÓRIAS.}

\author{
"In any event, it is clear that no would-be interpreter of a treaty, \\ whatever his doctrinal point of departure, will deliberately ignore any material \\ which can usefully serve as a guide towards establishing the meaning of the text with he is \\ confronted." \\ IAN SINCLAIR (1973)
}

Sob o escopo do "contexto" referido no art. 3 (2) da CM-OCDE, o operador do Direito tributário internacional pode encontrar um longo caminho a percorrer. O trabalho de um advogado - representante do contribuinte ou do fisco -, imbuído na missão de fornecer evidências hábeis para convencer um juiz quanto ao sentido de um termo utilizado em um acordo de dupla tributação, pode ter como ponto de partida a análise de elementos intrínsecos ao seu texto, seguido da investigação de elementos levantados do contexto extrínseco primário, examinados, respectivamente, nos Capítulos "II" e "III" desta tese.

Ainda assim, a procura por tais evidências para a construção do sentido contextualizado de termos utilizados no texto de um acordo de bitributação pode se mostrar infrutífera. Vale lembrar que, diante de um contexto estéril seria justificável o reenvio ao Direito doméstico dos Estados contratantes.

Sem embargo, tal investigação ainda pode estar longe de ser considerada frustrada em face do "contexto" referido no art. 3 (2) da CM-OCDE

Nesse ponto, passa a ser necessário discutir a admissibilidade de evidências extrínsecas secundárias, o que pode conduzir ao menos a quatro diferentes linhas, analisadas no tópico " 2 ” deste Capítulo: (i) admissibilidade irrestrita, fundada na ineficácia técnica da CVDT; (ii) não admissibilidade de evidências do contexto extrínseco secundário; (iii) admissibilidade condicionada a situações específicas e com propósitos

\footnotetext{
${ }^{698}$ SINCLAIR, Ian M. The Viena Convention on the Law of Treaties. Manchester University Press : Manchester, 1973, p. 72-73.
} 
limitados, fundada na norma da CVDT; (iv) admissibilidade condicionada a situações específicas e com propósitos amplos, fundada na norma da CVDT.

O objeto deste último Capítulo, que antecede as conclusões do presente trabalho, consiste no reconhecimento e análise de evidências admissíveis ao processo de construção de sentido dos termos dos acordo de bitributação, sob o escopo de normas do Direito Internacional, formalmente recepcionadas pelo Direito brasileiro.

Nesse seguir, os tópicos “3” a "8" deste Capítulo se dedicam à análise de evidências com status do escopo do contexto extrínseco secundário, quais sejam: (i) as decisões de Cortes nacionais de terceiros Estados; (ii) a doutrina dos publicistas mais qualificados das diferentes Nações; (iii) a Convenção Modelo da OCDE e os seus respectivos Comentários; (iv) os trabalhos preparatórios; (v) os atos unilaterais quanto à intenção dos Estados contratantes; (vi) as circunstâncias relacionadas à conclusão da convenção fiscal.

O tópico “2” deste Capítulo analisa uma questão preliminar de grande importância. Ocorre que o operador do Direito tributário internacional pode encontrar evidências intrínsecas ou extrínsecas primárias que, em uma primeira leitura e de forma plausível, contribuam para a construção de sentido de termos não definidos no acordo de bitributação. A questão é saber se o intérprete deve se dar por satisfeito diante de evidências do contexto intrínseco e extrínseco primário ou se deve prosseguir com a sua investigação e questionar a existência de evidências sob o escopo do contexto extrínseco secundário. Ainda, as evidências colhidas no contexto extrínseco secundário, mais do que admitidas, poderiam prevalecer sobre evidências do contexto intrínseco ou extrínseco primário? Se o contribuinte prover o juiz de evidências fundadas no art. 31 da CVDT e a priori plausíveis, poderia o fisco infirmá-las com evidências sob o escopo do art. 32 da CVDT, ou vice-versa? As evidências extrínsecas secundárias teriam a sua admissibilidade condicionada à obscuridade ou contradição ou mesmo inexistência das evidências com fundamentadas no art. 31 da CVDT? Ou, ainda, a admissibilidade de tais evidências do contexto extrínseco secundário teria a admissibilidade condicionada à sua própria plausividade? 
Note-se que a indagação ora proposta é diversa da analisada no Capítulo II, em que a disputa por admissibilidade ou mesmo prevalência é reclusa pela doutrina entre as evidências intrínsecas e extrínsecas primárias. Aqui, entram em cena algumas evidências geralmente marginalizadas no debate da doutrina especializada, para questionar a sua função no processo de construção de sentido dos termos das convenções fiscais.

\section{A ADMISSIBILIDADE DE EVIDÊNCIAS EXTRÍNSECAS SECUNDÁRIAS NO PROCESSO DE CONSTRUÇÃO DE SENTIDO DE TERMOS DOS ACORDOS DE DUPLA TRIBUTAÇÃO.}

Há ao menos cinco correntes quanto à admissibilidade de evidências extrínsecas secundárias no processo de construção de sentido de termos dos acordos de dupla tributação, expostas nos subtópicos seguintes a partir de revisão doutrinária e da análise de decisões de Cortes nacionais.

Trata-se de questão anterior a muitas outras, como a identificação de quais seriam tais evidências diante das peculiaridades do Direito tributário internacional e a relação hierárquica com as evidências intrínsecas e extrínsecas primárias. Ocorre que, caso não se admitam evidências extrínsecas secundárias no processo de construção de sentido de termos contidos em acordos de bitributação, seria desnecessária a investigação de quais seriam estas.

Sob uma perspectiva pragmática, a questão é saber se o advogado deve investigar e explorar tais evidências extrínsecas secundárias ao empreender os seus esforços investigativos ou argumentativos. A perquirição influencia também o labor do juiz, seja em uma posição passiva de decisão quanto à admissibilidade de tais evidências apresentadas por advogados, seja quando assume postura proativa de investigação, impulsionada por peculiaridades processuais de seu sistema jurídico doméstico ou, ainda, por assumir as vestes de guardião do Direito Internacional, obediente aos princípios da boa-fé e pacta sunt servanda. 


\subsection{A corrente da admissibilidade irrestrita, fundada na ineficácia técnica da CVDT.}

"Fazendo a ressalva da posição dominante na doutrina internacional, deve-se reconhecer que, na prática, qualquer tentativa de hierarquização entre os elementos de interpretação é vã, já que a formação de sentido pelo intérprete pode levar todos em consideração e tal hierarquização, quando muito, gerará uma distorção da exteriorização das razões de sua conclusão."

SERGIO ANDRÉ ROCHA (2013) ${ }^{699}$

Como se viu, não apenas o alcance, mas a própria eficácia técnica da CVDT é objeto de debate na doutrina do Direito Internacional. Nesse cenário, alguns autores sustentam que a segregação das evidências do contexto extrínseco secundário não teria quaisquer efeitos práticos, permanecendo o intérprete livre para acessá-las sem as possíveis limitações impostas pela CVDT. A passagem em epígrafe, de SERGIO ANDRÉ RoCHA, pode simbolizar essa corrente, que não nega que os acordos de bitributação estejam sujeitos às normas da CVDT, mas não lhe credita eficácia técnica para limitar a atividade do intérprete $^{700}$.

Duas premissas parecem ser adotadas por autores que seguem tal teoria da admissibilidade irrestrita fundada na ineficácia técnica da CVDT, ainda que adotadas isoladamente: (i) refuta-se a própria função da CVDT, que não teria eficácia normativa para dirigir o ato interpretativo, de tal forma que os referidos meios suplementares de interpretação poderiam inclusive prover evidências mais úteis que quaisquer dos elementos referidos no art. 31 da CVDT e; (ii) a CVDT não veicula costumes do Direito Internacional, mas inova ao limitar o recurso ao que chama de "meios suplementares de interpretação", de forma que não haveria limitação ao acesso de evidências extrínsecas secundárias aos países não signatários daquela convenção multilateral.

Na “Klaus Vogel Lecture" de 2009, BRIAN J. ARNOLD ${ }^{701}$ refutou que a CVDT poderia ter eficácia normativa para dirigir o ato interpretativo dos operadores do Direito tributário internacional. $\mathrm{O}$ autor sustentou que o estudo da linguagem em geral seria o único caminho adequado para a solução das questões relacionadas à interpretação de

\footnotetext{
${ }^{699}$ ROCHA, Sergio André. Interpretação dos tratados para evitar a dupla tributação. São Paulo : Quartier Latin, 2013, p. 78.

${ }^{700}$ Vide, ainda: ROCHA, Sergio André. Interpretação dos tratados para evitar a dupla tributação. São Paulo : Quartier Latin, 2013, p. 187 e seg.

${ }^{701}$ ARNOLD, J. Brian. The interpretation of tax treaties: myth or reality, in Bulletin for international Taxation (tax treaty monitor) - january of 2010. IBFD : Amsterdã, 2010, p. 7-8.
} 
quaisquer textos, o que não incluiriam os acordos de bitributação ${ }^{702}$. A positivação das regras de interpretação da CVDT representaria o mito da possibilidade de regramento da interpretação de acordos internacionais e, por isso, seria criticável. A tentativa da CVDT de limitar a utilização pelo intérprete de elementos ao qual tenha tido acesso representaria a limitação do ilimitável e desconectaria o art. 32 da forma como a interpretação ocorre na realidade.

Note-se que tal teoria não influencia apenas o acesso às evidências extrínsecas secundárias, mas todo o processo de interpretação. Não seria possível estabelecer a priori distinção de peso entre quaisquer dos elementos do contexto intrínseco ou extrínseco: a tutela da relevância dos meios suplementares de interpretação seria fútil e arbitrária, pois o peso de qualquer informação não pode ser estabelecido em abstrato, mas apenas diante das particulares circunstâncias de cada caso. Assim, a depender da situação concreta, seria possível atribuir mais relevância aos elementos do art. 32 do que àqueles indicados no art. 31, ambos da CVDT. Nessa ordem de ideias, BRIAN J. ARNOLD ${ }^{703}$ argumenta que seria difícil distinguir os ditos materiais suplementares daqueles cujo intérprete poderia ter acesso imediato. Sustenta, ainda, que os fatores ambiguidade, obscuridade, manifesto absurdo ou ausência de razoabilidade, requeridos pelo art. 32 da CVDT, seriam tão vagos que se tornariam incapazes de regrar a atividade dos juízes na decisão de casos concretos.

De forma semelhante, MiCHAEL EDWARDES-KER ${ }^{704}$ sustenta que a subordinação dos elementos referidos no art. 32 em relação àqueles apontados no art. 31, ambos da CVDT, seria mais aparente do que real. A imposição de limites à utilização de tais evidências seria artificial e não possuiria embasamento prático e nem refletiria a jurisprudência internacional. $\mathrm{O}$ autor apoiou tal pensamento no argumento de que certamente fisco e contribuinte procurariam, na prática, confirmar a clareza de sua interpretação em trabalhos preparatórios que se mostrassem disponíveis. Não seria, ademais, possível determinar se a aparente clareza de um texto seria real antes de consultar tais meios suplementares de interpretação.

\footnotetext{
${ }^{702}$ Nesse sentido, vide também: ROCHA, Sergio André. Interpretação dos tratados para evitar a dupla tributação. São Paulo : Quartier Latin, 2013, p. 191.

${ }^{703}$ ARNOLD, J. Brian. The interpretation of tax treaties: myth or reality, in Bulletin for international Taxation (tax treaty monitor) - january of 2010. IBFD : Amsterdã, 2010, p. 7-8.

${ }^{704}$ EDWARDES-KER, Michael. Tax Treaty Interpretation - The International Tax Treaties Service. InDepth Publishing : Athlone, 1994 p. 5-6, Capítulo 4.
} 
O segundo argumento dessa teoria, anteriormente suscitado, pode ser observado na posição de STANLEY I. KATZ ${ }^{705}$, para quem, ao limitar o acesso às evidências quanto à intenção dos Estados contratantes, a CVDT teria estabelecido norma que não decorre do Direito internacional consuetudinário. Assim, como tal convenção multilateral não foi ratificada pelos EUA, ainda que a interpretação dos acordos de dupla tributação naquele país em muito se alinhe com as regras da CVDT, poderá também apresentar importantes distinções, como o recurso a trabalhos preparatórios.

\subsection{A corrente da não admissibilidade de evidências do contexto extrínseco secundário.}

"They do not constitute context and may only be used to confirm, but not to contradict, or as independent support for an Article 31 interpretation" ROY ROHATGI (2005)

Parte da doutrina ${ }^{707}$ considera os elementos no art. 32 da CVDT algo à parte do contexto ("noncontextual materials") ${ }^{708}$. Como consequência da não admissibilidade de evidências extrínsecas secundárias, o fracasso das evidências colhidas pelo contexto intrínseco e contexto extrínseco secundário autorizaria o recurso ao Direito doméstico dos Estados contratantes.

\subsection{A corrente da admissibilidade condicionada a situações restritas e com propósitos limitados, fundada na norma da CVDT.}

\footnotetext{
“Look, but don't touch... Touch, but don't taste... Taste, but don't swallow..." "Devil's Advocate" (1997)
}

A CVDT pode ser interpretada de forma a não excluir o acesso às evidências extrínsecas secundárias, mas a limitar o seu recurso a situações restritas e lhes atribuir

\footnotetext{
${ }^{705}$ KATZ, Stanley I. United States National Report. Cahiers de Droit Fiscal International by the International Fiscal Association (studies on international tax law), volume LXXVIIIa - Subject I. Interpretation of double taxation conventions. Kluwer Law and Taxation Publishers / IFA : Rotterdam, 1993, p. 624.

${ }^{706}$ ROHATGI, Roy. Basic International taxation. Volume 1: principles. Nova Deli : Taxmann, 2005, p. 3.

${ }^{707}$ Nesse sentido, vide: AULT, Hugh. The role of the OECD Commentaries in the Interpretation of Tax Treaties, in Intertax v. 22. Kluwer Law International : 1994, p. 145.

${ }^{708}$ AULT, Hugh. The role of the OECD Commentaries in the Interpretation of Tax Treaties, in Intertax v. 22. Kluwer Law International : 1994, p. 145.
} 
propósitos muito específicos.

$\mathrm{O}$ recurso aos meios suplementares de interpretação teria ensejo em situações específicas, sempre que as evidências do contexto intrínseco e extrínseco primário não fossem suficientes para a construção de um sentido razoável dos termos utilizados no acordo internacional. Assim, caso nenhum sentido razoável possa ser contruído a partir daquelas outras evidências ou, ainda, os sentidos construídos a partir destas se mostrarem obscuros ou contraditórios, poderia o intérprete recorrer às evidências do contexto extrínseco secundário. $^{709}$

Por sua vez, tais evidências também teriam propósitos específicos: como a intenção das partes deve ser averiguada a partir do texto do acordo, os trabalhos preparatórios não se prestariam a desvendar por si a intenção das partes de forma independente, mas a evidenciar a intenção das partes a partir de tal texto ${ }^{710}$. Os materiais referidos no art. 32 da CVDT teriam a função de apoiar ("supporting role") outras interpretações, mas não seriam capazes de prover interpretações alternativas ou isoladas daquelas providas pelo contexto intrínseco ou extrínseco primário. ${ }^{711}$

Na doutrina do Direito tributário internacional, é aceito por uma série de autores que o recurso a evidências como trabalhos preparatórios seria possível somente em casos de evidente ambiguidade ou obscuridade do texto do acordo e, ainda, se outros meios se mostrassem ineficazes. Caso não estejam presentes tais condições, o recurso seria obsoleto, pois as evidências extrínsecas secundárias não possuiriam força suficiente para prover qualquer sentido alternativo ${ }^{712} \mathrm{ou}$, ainda, contraditar ou infirmar sentidos providos por evidências intrínsecas ou extrínsecas primárias ${ }^{713}$.

${ }^{709}$ AULT, Hugh. The role of the OECD Commentaries in the Interpretation of Tax Treaties, in Intertax v. 22. Kluwer Law International : 1994, p. 144-145.

${ }^{710}$ Cf. SINCLAIR, Ian M. The Viena Convention on the Law of Treaties. Manchester University Press : Manchester, 1973, p. 72.

${ }^{711}$ Cf. DÖRR, Oliver. "Article 31 - General rule of interretation", in "Vienna Convention on the Law of Treaties: a Commentary”, DÖRR, Oliver; SCHMALENBACH, Kirsten (Editors). Springer, 2012, p. 571572.

${ }^{712}$ Cf. VOGEL, Klaus; PROKISCH, Rainer G. Cahiers de Droit Fiscal International by the International Fiscal Association (studies on international tax law), volume LXXVIIIa - Subject I. Interpretation of double taxation conventions. Kluwer Law and Taxation Publishers / IFA : Rotterdam, 1993, p. 73-74.

${ }^{713} \mathrm{Cf}$. AVERY JONES, John et al., The interpretation of tax treaties with particular reference to article 3(2) of the OECD Model - II. 1984, British Tax Review, p. 95-96. 


\subsection{A corrente da admissibilidade condicionada a situações restritas e com propósitos amplos, fundada na norma da CVDT.}

O entendimento de STARKE \& SHEARER ${ }^{714}$ pode ser agrupado sob essa teoria, pois apresenta uma peculiaridade importante em relação à analisada no subtópico anterior. Os professores canadenses, como já se viu, sustentam a teoria de que o juiz estaria limitado às evidências intrínsecas de um acordo internacional, podendo, caso essas não provejam sentidos claros e sem contradição, acessar evidências extrínsecas (primárias e secundárias).

Um primeiro fator que diferencia essa teoria das anteriores é que não se segrega o contexto extrínseco primário do secundário, de tal forma que, caso as evidências intrínsecas fracassem o acesso ao contexto extrínseco primário - qual seja, o fracasso da evidências intrínsecas - também restaria o intérprete livre para acessar o contexto extrínseco secundário. Para aqueles autores, o contexto extrínseco seria uma opção em bloco ao contexto intrínseco, composto pelas seguintes evidências: (a) fatores históricos relevantes ao acordo; (b) trabalhos preparatórios, compreendendo-se, em especial, minutas preliminares, emendas à minuta do acordo, gravações de conferências; (c) protocolos interpretativos, resoluções e relatórios em que os Estados concordem com determinada interpretação, os quais seriam considerados como trabalhos preparatórios salvo se passassem a compor o próprio tratado interpretado (quando, então, poderiam ser considerados em conjunto com as evidências intrínsecas); (d) acordos subsequentes entre os Estados a respeito da interpretação do acordo, ao teor do art. 31 (3) da CVDT; (e) práticas subsequentes dos Estados contratantes, como evidência da intenção e concepção destes quanto ao acordo celebrado, vinculantes apenas se puderem ser considerados como acordos suplementares e $(f)$ outros acordos, relacionados ao mesmo objeto, para a solução de dúvidas.

O segundo fator da referida teoria é que, acessado o contexto extrínseco, seja ele o primário ou o secundário, suas evidências seriam aptas a fornecer, ainda que isoladamente,

\footnotetext{
${ }^{714}$ STARKE, JOSEPH GABRIEL.; SHEARER, I.A. Starke's international law. Butterworths : Canada, 1994, p.
} 437-438. 
sentido aos termos dos acordos internacionais.

\subsection{Corrente da admissibilidade e propósitos amplos, com atenção à CVDT.}

Para a corrente ora em revista, as evidências extrínsecas secundárias sempre deveriam ser acessadas e, quando colaborassem para a construção de sentidos plausíveis, admitidas para tanto. Há uma diferença fundamental entre esta e as correntes anteriores. Naquelas, o acesso às evidências extrínsecas secundárias dependeria da ausência de plausividade das evidências intrínsecas e extrínsecas primárias, que gerasse obscuridades ou contradições. Ou seja, o acesso às evidências extrínsecas secundárias seria admissível apenas em caso de fracasso do contexto intrínseco e do contexto extrínseco secundário em prover um sentido razoável a determinado termo de um acordo de dupla tributação. Para a corrente analisada neste subtópico, por sua vez, a admissibilidade das evidências extrínsecas secundárias dependeria apenas da plausividade delas próprias.

Sob essa perspectiva, o requisito da plausibilidade das evidências extrínsecas secundárias passa a compor o seu próprio teste de admissibilidade. Caso evidências sob o escopo do art. 31 (3) "c" da CVDT cumulado com o art. 38 (1) “c” do ECIJ ou, ainda, do art. 32 da CVDT apresentassem mensagens plausíveis e úteis, poderiam ser utilizadas para confirmar ou mesmo infirmar o sentido construído a partir de evidências intrínsecas ou de evidencias extrínsecas primárias. Considerado em conjunto com o contexto intrínseco, extrínseco primário e extrínseco secundário, a questão se resolveria em favor da evidência dotada de argumento mais plausível.

Há casos, contudo, que evidências do contexto intrínseco ou do contexto extrínseco primário poderiam se mostrar tão plausíveis quanto aquelas fornecidas pelo contexto extrínseco secundário. Em tais casos, então, deveriam ser adotados os critérios de desempate de evidências disciplinados pela CVDT.

Assim, supondo-se que os contextos intrínseco e extrínseco primário forneçam um sentido plausível aos termos dos acordos de dupla tributação, bem como que os trabalhos 
preparatórios conduzam a outro sentido, igualmente plausível sob a perspectiva argumentativa, a CVDT estabeleceria como critério de desempate que o primeiro vença.

Deixando-se de lado por um segundo as regras da CVDT, parece duvidoso que se evidências do contexto extrínseco secundário pudessem apresentar-se, sob uma perspectiva argumentativa, mais persuasivos que evidências do contexto intrínseco ou extrínseco primário. Adotando-se como exemplo os trabalhos preparatórios, é possível observar que são geralmente lacunosos ou mesmo caóticos e confidenciais ${ }^{715}$, o que prejudicaria o potencial argumentativo de tais evidências, justificando que não tenha precedência.

Para LUC DE BROE ${ }^{716}$, o intérprete poderia sempre recorrer às evidências do art. 32 da CVDT, seja para confirmar o sentido provido por outros meios ou, quando esses conduzissem à ambiguidade, obscuridade, manifesto absurdo ou ausência de razoabilidade, para lhe determinar tal sentido. Observa o professor belga que tais situações não seriam excepcionais, mas corriqueiras, já que as questões encaminhadas aos tribunais têm como causa justamente a existência de obscuridades ou ambiguidades no texto do acordo. Pondera o autor, contudo, que sentidos providos por evidências do art. 32 da CVDT apenas prevaleceriam em casos de ambiguidade, obscuridade, manifesto absurdo ou ausência de razoabilidade.

\subsection{Positivo: é pertinente a investigação de evidências extrínsecas secundárias.}

Entende-se que as evidências extrínsecas secundárias possuem a função de confirmar ou infirmar determinado sentido construído a partir de evidências intrínsecas ou evidências extrínsecas secundárias. Sob certa ótica, o que está em jogo é a questão da contraprova que pode ser lançada por advogados do fisco ou do contribuinte. Assim, por exemplo, se o contribuinte prover ao juiz evidências admissíveis, com status do art. 31 da CVDT, os quais sejam a priori plausíveis, poderia o Fisco infirmá-las com evidências sob o escopo do art. 32.

\footnotetext{
${ }^{715}$ Cf. DINH, Nguyen Quoc; DAILLER, Patrick; PELLET, Alain. Direito Internacional Público. Lisboa : Fundação Calouste Gulbenkian, 2003, p. 267.

${ }^{716}$ BROE, Luc De. International tax planning and prevention of abuse (doctoral series n. 14). Amsterdã : IBFD, 2007, 252-259.
} 
A última teoria analisada parece ser a que melhor responde tais questões. A única e combinada operação de interpretação ("a closely integrated single rule of interpretation") requerida pela CVDT não exclui o acesso a evidências do contexto extrínseco, mas regulamenta a sua admissibilidade, bem como estabelece a precedência do sentido provido por evidências do contexto intrínseco e do contexto extrínseco primário.

Nos tópicos seguintes, será examinada uma série de elementos, a fim de averiguar se configurariam evidências sob o escopo do art. 31 (3) "c" da CVDT cumulado com o art. 38 (1) "c" do ECIJ ou, ainda, do art. 32 da CVDT.

\section{DECISÕES DE CORTES NACIONAIS DE TERCEIROS ESTADOS COMO EVIDÊNCIAS DO CONTEXTO EXTRÍNSECO SECUNDÁRIO.}

"Opinion may differ how much weight should be given to decisions of foreign courts on such treaty provisions when interpreting treaties, but the proposition that these decisions should be given some weight would seem to be subject to rather general agreement"

KEES VAN RAAD ${ }^{717}$ (1996)

O primeiro elemento ora investigado entre as evidências do contexto extrínseco secundário são decisões de Cortes nacionais de terceiros Estados. Assim como juízes de um Estado ("A") podem recorrer às decisões advindas de tribunais do outro Estado contratante ("B"), também consideram, com alguma frequência, decisões de terceiros Estados ("C") para a construção de sentido dos termos de um acordo de bitributação ("AB").

Conforme a proposta desta tese, a admissibilidade de tais elementos para a construção de sentido dos termos não definidos em acordos de bitributação demanda a análise de critérios formais, funcionais e materiais.

\footnotetext{
${ }^{717}$ RAAD, Kees van. Interpretation and Application of Tax Treaties by Tax Courts, in European Taxation January 1996. IBFD : Amsterdã, 1996, p. 4-5.
} 


\subsection{Critérios formais de reconhecimento.}

Para RICHARD K. GARDINER ${ }^{718}$, não seria tão claro se práticas de um Estado (“A”) concretizadas com referência a um tratado (“A-B”) celebrado com outro Estado ("B”) seria relevante a um terceiro Estado ("C"), na interpretação de um tratado ("A-C") celebrado entre este último (“C”) e o primeiro (“A”).

Assim, em relação ao critério formal, questionamentos podem surgir diante da ausência de consentimento dos Estados contratantes quanto ao conteúdo das decisões preferidas por Cortes de outros Estados.

No entanto, aceitando-se o princípio da integração sistêmica prescrito pelo art. 31 (3) "c" da CVDT, tal obstáculo deve ser superado. Assume-se que os acordos internacionais devem ser cumpridos com vistas a todas as normas do Direito Internacional $^{719}$. Embora apenas vinculem aqueles que são partes do respectivo processo judicial, decisões de Cortes nacionais de Estados que não integram a convenção fisscal sob interpretação (terceiros Estados) podem ser reconhecidas como evidências interpretativas pelo art. 31 (3) "c" da CVDT, cumulado com o art. 38 (1) "c" do ECIJ, com relevante potencial persuasivo ${ }^{720}$.

Ainda que se possa compreender que os arts. 31, 32 e 33 da CVDT apenas declaram Direito já existente com base nos costumes internacionais então existentes, é relevante considerar que a ampla maioria dos Estados modernos ratificaram tal acordo multilateral, bem como a Carta da ONU, que contempla em seu anexo o referido ECIJ. Tais Estados, a exemplo do Brasil, manifestam expressante o seu consentimento à regra do art. 31 (3) 'c', legitimando o recurso às evidências em questão. Conforme o art. 19 da CVDT, ao assinar, ratificar, aceitar, aprovar ou aderir a um tratado - que inclui a própria CVDT - um Estado pode formular reservas. Se nenhuma reserva houver sido formulada

\footnotetext{
${ }^{718}$ GARDINER, Richard K. International Law. Pearson : Harlaw, 2003, p. 49-50.

${ }^{719}$ Vide: DÖRR, Oliver. "Article 31 - General rule of interpretation", in "Vienna Convention on the Law of Treaties: a Commentary”, DÖRR, Oliver; SCHMALENBACH, Kirsten (Editors). Springer, 2012, p. 560561.

${ }^{720}$ Sobre a poder de persuasão de tais decisões, vide: STARKE, Joseph Gabriel; SHEARER, I.A. Starke's international law. Butterworths : Canada, 1994, p. 434.
} 
quanto ao princípio da integração sistêmica veiculada pela CVDT, então as Cortes do Estado devem considerar os materiais em questão.

\subsection{Critérios funcionais de reconhecimento.}

É intrigante saber se a consideração de decisões de terceiros Estados quanto à interpretação de determinada cláusula de convenções fiscais realmente se coadunaria com o critério funcional, em especial se promoveria a interpretação harmônica. KLAUS VOGEL $^{721}$ sustentou que a medida mais importante para que a interpretação harmônica possa ser alcançada é que autoridades fiscais e tribunais levem em consideração e avaliem o mérito de decisões relevantes adotadas por instituições semelhantes do outro Estado contratante ou até mesmo de terceiros Estados.

Nesse seguir, no Caso Unisys (Austrália, 2002), a Suprema Corte australiana, a fim de aplicar o acordo de dupla tributação Austrália-EUA, consignou que os tribunais devem considerar decisões de outras jurisdições a fim de alçar uma uniformidade internacional. $\mathrm{O}$ objetivo mais imediato da consideração de tais evidências, para os julgadores australianos, seria a construção de uma linguagem tributária internacional, a qual, quando suficientemente amadurecida, teria como consequência a interpretação harmônica.

No entanto, é possível compreender que o juiz não deve decidir determinado caso apenas sob a justificativa de colaborar com a construção de uma suposta linguagem internacional, ainda que esse efeito, de fato, possa decorrer da jurisprudência. O dever do juiz é decidir o caso concreto com a atribuição a determinado termo do sentido que melhor se adeque ao acordo celebrado entre os dois Estados envolvidos. Não parece ser legítimo simplesmente acolher o entendimento da Corte nacional de um terceiro Estado sob o argumento de que, com isso, contribui-se para a uniformização da linguagem tributária internacional, ainda que tal interpretação contrarie outras evidências atinentes ao específico acordo de dupla tributação firmado entre os Estados.

\footnotetext{
${ }^{721}$ VOGEL, Klaus. Klaus Vogel on Double Taxation Conventions. Kluwer : London, 1999, p. 39-40.
} 
Primeiro, é importante compreender quão distintas são as evidências atinentes às decisões proferidas por Cortes nacionais do outro Estado contratante dessas outras, ora analisadas, emanadas por terceiros Estados. Em relação às primeiras, caso um Estado (“A”) resolva seguir a decisão adotada pelo tribunal do outro Estado contratante ("B”) na aplicação do acordo de bitributação (“A-B”), o efeito será necessariamente a interpretação harmônica nos Estados (“A" e "B"). Em um extremo, os julgadores do primeiro Estado (“A”) poderiam se convencer a seguir a decisão do outro Estado ("B”) ainda que não concordassem com esta, em nome da interpretação harmônica. Por sua vez, caso aquele primeiro Estado (“A”) siga a decisão adotada pelo Tribunal de um terceiro Estado ("C") em relação à interpretação de cláusula semelhante à que consta no referido acordo de dupla tributação (“A-B”), a interpretação harmônica apenas seria obtida se o outro Estado contratante ("B") também se convencesse da plausividade ou das vantagens de seguir aludida decisão advinda daquele terceiro Estado (“C”).

Grande entuasiasta da capacidade e do compromisso das Cortes nacionais para a construção de uma interpretação harmônica dos termos dos acordos de bitributação, PHILIP BAKER ${ }^{722}$ sustenta que se um Estado (“A”) possui convênios fiscais com uma série de Estados ("B", “C”, "D" etc.), todos eles celebrados em moldes semelhantes, seria correto afirmar que decisões emanadas por aquele primeiro Estado ("A”) para a aplicação de um desses acordos (“A-B") deveriam influenciar a interpretação e a aplicação de toda a sua rede de acordos ("A-C", "A-D" etc.). Como o autor inglês compreende que também os outros Estados contratantes ("B", "C", "D" etc.) deveriam observar a mesma interpretação do tribunal daquele primeiro Estado (“A”), haveria uma espécie de efeito dominó, em que todos os acordos celebrados com base na CM-OCDE ("B-C", "C-D" etc.) seriam interpretados de modo uniforme.

Esse efeito dominó, contudo, parece encontrar obstáculos que se observam de forma pragmática. A inexistência de dever de quaisquer Estados em seguir as decisões de tribunais de outros Estados, ou mesmo a discordância quanto às premissas e as conclusões adotadas em decisões estrangeiras, conduz ao fato de que não há, de fato, comunicação tão eficaz e potente quanto aquela idealizada por BAKER.

${ }^{722}$ BAKER, Philip. Double taxation conventions and international tax law. Londres : Sweet \& Maxwell, 1994, par. C-29. 
Tais considerações, contudo, não conduzem à inaptidão das decisões de Cortes nacionais para servirem de evidências quanto ao sentido contextualizado de termos dos acordos de dupla tributação. Ocorre que é necessário ter em conta duas questões: (i) $a$ função das evidências extrínsecas secundárias e (ii) a plausividade da decisão.

Evidências extrínsecas secundárias possuem a função de servir de par de comparação, a fim de confirmar ou infirmar determinado sentido, construído a partir de evidências intrínsecas ou evidências extrínsecas secundárias. Parece razoável considerar que, no caso de coincidência de resultados obtidos por tribunais de terceiros Estados, o sentido construído a partir de evidências intrínsecas ou evidências extrínsecas secundárias pode ganhar força argumentativa e mais aparência de credibilidade.

\subsection{Critérios materiais de reconhecimento.}

É necessário considerar que o potencial de tal evidência depende também do critério material adotado neste estudo. Tudo leva a crer que a plausividade da decisão proferida por um terceiro Estado seria um fator fundamental à sua aptidão para colaborar com a interpretação harmônica dos Estados contratantes. Autores como KLAUS VoGEL ${ }^{723}$, MiCHAEL LANG ${ }^{724}$ e KEES VAN RAAD ${ }^{725}$ enfatizaram que a relevância de decisões de Cortes estrangeiras depende de quão convincentes elas sejam. Se tal proposição estiver correta, não seria impróprio afirmar que uma decisão judicial advinda de um terceiro Estado ("C") possa se mostrar mais relevante que decisões de Cortes de um dos Estados ("A" ou "B") que são partes do acordo de dupla tributação em análise (“A-B”), caso apresente argumentos contundentes a respeito do tema em questão.

A abstrata questão da plausibilidade das decisões de Cortes domésticas de um determinado Estado (“A”) sob a perspectiva de outro Estado (“B”) pode envolver diversos aspectos, a exemplo do acesso aos idiomas em que as decisões são redigidas, laços

\footnotetext{
${ }^{723}$ VOGEL, Klaus. Klaus Vogel on Double Taxation Conventions. Kluwer : London, 1999, p. 39 e seg.

${ }^{724}$ LANG, Michael. Introduction to the law of double taxation conventions. Vienna : Linde, 2013, p. 56.

${ }^{725}$ RAAD, Kees van. International coordination of tax treaty interpretation and application, in International and comparative taxation - essays in honour of Klaus Vogel. KIRCHHOF, Paul et. al. eds London : Kluwer, 2002.
} 
culturais entre os Estados ${ }^{726}$, métodos interpretativos e qualificação técnica dos julgadores. INES HOFBAUER $^{727}$ observa que decisões de Cortes alemãs seriam frequentemente citadas por Cortes austríacas, não apenas por conta do idioma alemão ser adotado por ambos os países. Com a ocupação da Áustria em 1938, normas tributárias alemãs passaram a viger e ter eficácia naquele país e, com o fim da Segunda Guerra Mundial e o fim da ocupação, decidiu-se republicar os dispositivos alemães para a edificação da "nova" legislação austríaca. Embora os dois sistemas sejam independentes e tenham sido alterados diversas vezes desde então, ambos ainda permaneceriam a priori comparáveis, possibilitando que os juízes de um consulte como o juiz do outro enfrentou certa questão em contextos bastante similares.

A plausividade da decisão de um terceiro Estado pode abrir os olhos do intérprete para interpretações que já lhe seriam possíveis ainda que não as tivesse acessado. Nessa linha, KEES VAN RAAD ${ }^{728}$ busca atribuir valor ao acesso de informações proferidas por tribunais estrangeiros na aplicação de acordos de dupla tributação. Para o professor de Leiden, o conhecimento dos fundamentos adotados em tais decisões se mostraria útil especialmente em relaçãos aos dispositivos que veiculam temas mais complexos, como a questão do "permanent establishment" e "agency", do art. 5 (5) e (6) da CM-OCDE.

Conduzida em tais termos, a consideração de decisões de terceiros Estados pode também colaborar com a promoção do efeito útil dos acordos de dupla tributação. Tal análise pode evidenciar que certa interpretação, adotada por um terceiro Estado, teve como consequência a frustração dos objetivos e propósitos do acordo em questão, o que pode ser considerado razão suficiente para que o juiz que analisa tal evidência evite igual interpretação. Ou seja, decisões de terceiros Estados não perdem a utilidade ainda quando são criticáveis e, assim, evitadas.

\footnotetext{
${ }^{726}$ Nos idos de 1960, GOTHENBURG observou que os países com proximidades geográticas e ideológicas vinham encontrando soluções para divergências de interpretação de forma mais efetiva que os países que não contavam com essa proximidade. (GOTHENBURG, K. Ahlm. National Report of Sweden. Cahiers de Droit Fiscal International by the International Fiscal Association (studies on international tax law), volume XLII Subject II: The interpretation of the Double Taxation Convention. / IFA : Roterdã, 1960, p. 262.

${ }^{727}$ HOFBAUER, Ines. Tax treaty interpretation in Austria, in Tax treaty interpretation. LANG, Michael (ed). LINDE : Vienna, 2001, p. 38.

${ }^{728}$ RAAD, Kees van. Interpretation and Application of Tax Treaties by Tax Courts, in European Taxation January 1996. IBFD : Amsterdã, 1996, p. 3-4.
} 
Por sua vez, quando a decisão de um terceiro Estado ("C") se mostrar plausivel, poderá servir de fundamento para que juízes de Estados contraentes ("A" e "B") as utilize inclusive para infirmar interpretações construídas a partir de outras evidências ou, ainda, suprir a ausência de quaisquer outras evidências no contexto internacional, evitando, assim, o reenvio ao Direito doméstico.

\subsubsection{Exemplo: A consideração de decisões de terceiros Estados por tribunais do Canadá.}

No Caso Melford (Canadá, 1981), a fim de aplicar o acordo de bitributação Canadá-Alemanha, a Suprema Corte canadense consignou ter consultado uma série de julgados de tribunais do Reino Unido atinentes ao relacionamento de convenções fiscais com a legislação tributária doméstica.

É ilustrativo notar que, embora considerados, os fundamentos adotados pelos julgadores ingleses não fizeram com que a Suprema Corte canadense se convencesse que, diante das peculiaridades do Caso Melford, deveriam aceitar que alterações na legislação do Canadá pudessem alterar unilateralmente o conteúdo da norma acordada na convenção fiscal Canadá-Alemanha.

\subsubsection{Exemplo: A consideração de decisões de terceiros Estados por tribunais da Austrália.}

No Caso McDermott (Austrália, 2005), para aplicar o acordo Austrália-Singapura, o tribunal australiano observou que a primeira utilização de dispositivo semelhante àquele do art. 4(3) "b" se deu na convenção fiscal Australia-EUA (1953). Observou-se que, nos tribunais dos EUA o conceito de royalties excluiria rendimentos de arrendamento de equipamentos para uso industrial, comercial ou científico, incluindo neste apenas pagamentos relacionados a direitos de autor (copyright) ou pela exploração de minas, pedreiras ou outros recursos naturais. 


\title{
4. A DOUTRINA DOS PUBLICISTAS MAIS QUALIFICADOS DAS DIFERENTES NAÇÕES COMO EVIDÊNCIA INDIRETA DO SENTIDO DE TERMOS DE CONVENÇÕES FISCAIS.
}

\begin{abstract}
"International law is part of our law, and must be ascertained and administered by the courts of justice of appropriate jurisdiction as often as questions of right depending upon it are duly presented for their determination. For this purpose, where there is no treaty and no controlling executive or legislative act or judicial decision, resort must be had to the customs and usages of civilized nations, and, as evidence of these, to the works of jurists and commentators who by years of labor, research, and experience have made themselves peculiarly well acquainted with the subjects of which they treat. Such works are resorted to by judicial tribunals, not for the speculations of their authors concerning what the law ought to be, but for trustworthy evidence of what the law really is." Suprema Corte dos EUA. The Paquete Habana Case (1900) ${ }^{729}$
\end{abstract}

Na célebre passagem em epígrafe, a Suprema Corte norte-americana admitiu o recurso à doutrina como evidência quanto ao Direito Internacional aplicável. Embora essa decisão tenha mais de cem anos, ainda hoje exige uma série de considerações.

No presente tópico, tal evidência será analisada a partir dos critérios formais, funcionais e materiais propostos nesta tese. No que se refere aos critérios formais de reconhecimento, a doutrina dos publicistas mais qualificados das diferentes Nações está albergada pelo art. 31 (3) "c" da CVDT (princípio da integração sistêmica), cumulado com o art. 38 (1) “c” do ECIJ. IAN BROWNLIE ${ }^{730}$, nesse bojo, suscita uma série de autores que teria efetivamente influenciado a formação e o desenvolvimento do Direito Internacional moderno, entre os quais se detacam Grotios, VATTEL, CALVo e HALL.

Contudo, embora tenha sido prestigiada pelo art. 38 do ECIJ - dispositivo amplamente reconhecido como uma relação das fontes do Direito Internacional - em geral a própria doutrina ${ }^{731}$ (incluindo BROWNLIE) concorda que o seu papel seria apenas o de evidenciar o Direito e não o de criá-lo, como as fontes o fazem. A doutrina fala sobre o que é ou, ainda, como deveria ser o Direito, mas não é ou cria ela própria o Direito.

Não é de se estranhar que juízes e advogados (do fisco ou do contribuinte) mantenham sempre acessíveis em seus escritórios livros e trabalhos publicados por doutrinadores que fizeram (ou fazem) parte de sua formação. É possível conhecer o Direito

\footnotetext{
${ }^{729}$ EUA. Supreme Court. The Paquete Habana, 175 U.S. 677 (1900).

${ }^{730}$ BROWNLIE, Ian. Principles of public international law. Clarendon : Oxford, 1998, 24.

${ }^{731}$ Nesse sentido, vide: BROWNLIE, Ian. Principles of public international law. Clarendon : Oxford, 1998, p. 24-25; StARKE, J.G.; SHEARER, I.A. Starke's international law. Butterworths : Canada, 1994, p. 44-45
} 
a partir da doutrina, que pode e deve torná-lo mais compreensível, o que não muda o fato de tratar-se de fonte indireta para se chegar até ele. Hugh THIRLWAY ${ }^{732}$ assume que o caráter subsidiário da doutrina decorre também do fato de ser uma fonte intermediária: um doutrinador não tem competência para dizer "é assim porque quero", mas assume a função de evidenciar como outras fontes se manifestam (por exemplo, "é assim devido a um costume internacional").

Na mesma linha, STARKE \& SHEARER ${ }^{733}$ observam que a doutrina não é fonte autônoma do Direito, mas que atua para iluminar as regras existentes no Direito Internacional, tornando-as de mais simples compreensão. A função da doutrina seria fornecer evidências confiáveis sobre o Direito tributário internacional.

Para a investigação conduzida nesta tese, contudo, basta que se reconheça a doutrina como evidência do Direito Internacional (ainda que indireta), o que justifica o seu estudo.

Tal como as demais evidências extrínsecas primárias e secundárias, a admissibilidade de pareceres doutrinários demanda que esses também satisfaçam os requisitos funcionais propostos, com a promoção da interpretação harmônica e do efeito útil do acordo de dupla tributação.

Embora a subjetividade imanente ao Direito proporcione uma variedade de proposições doutrinárias a respeito de um mesmo tema, o recurso à doutrina é apto a amparar determinada interpretação que, por ser plausível, poderia ser adotada de forma harmônica por ambos os Estados contratantes. Ocorre que, se a interpretação dos acordos de bitributação não é uma tarefa para leigos, é principalmente na academia que são forjados os especialistas. Quanto mais houver a discussão entre a doutrina especializada, mais se avançará na compreensão do sentido dos termos das convenções fiscais ou, ainda, do aprimoramento de seus textos. Não se pode esperar, contudo, por consensos acadêmicos, posto que inalcançáveis em quaisquer dilemas jurídicos.

\footnotetext{
${ }^{732}$ THIRLWAY, Hugh. The Sources of International Law. Oxford : Oxford, 2014, p. 8.

${ }^{733}$ STARKE, J.G.; SHEARER, I.A. Starke's international law. Butterworths : Canada, 1994, p. 44-45.
} 
A doutrina também pode promover o efeito útil dos acordos de dupla tributação. Aliás, é essa uma de suas missões mais fundamentais: transmitir da forma mais amplificada possível os sentidos que instrumentos legais possam veicular, o que vai ao encontro da concretização da máxima 'ut res magis valeat quam pereat'.

Contudo, é necessário observar que a doutrina pode direcionar os seus esforços para cumprir diferentes objetivos, em especial: (i) descrever o Direito tributário internacional existente e; (ii) propor mudanças neste. Ocorre que muitos dos trabalhos atualmente desenvolvidos nas universidades e institutos dedicados ao Direito tributário internacional são vocacionados não apenas a determinar com mais clareza quais as regras de Direito existentes; a academia participa de importantes projetos para o desenho de novos sistemas tributários, para a reforma de sistemas existentes e, ainda, para a criação de novas políticas tributárias pontuais.

Não pairam quaisquer dúvidas quanto ao mérito dessa colaboração da doutrina para a produção normativa. No entanto, não se pode colher evidências sobre qual o atual estado do Direito tributário internacional a partir de trabalhos doutrinários que tenham como objeto a questão de como deveria vir a ser o Direito tributário internacional (lege ferenda).

Por fim, a doutrina também deve satisfazer ao critério material para ser reconhecida como evidência do contexto extrínseco secundário. Tal assertiva repele a adoção de definições baseadas meramente em argumentos de autoridade (é assim, pois o autor " $y$ ” assim afirma ser). Naturalmente a reputação de um profissional é relevante, inclusive por alça-lo entre os publicistas mais qualificados das diferentes Nações. No entanto, é a plausividade de suas posições e a coerência de suas premissas que devem ser determinantes para que os operadores do Direito tributário internacional reconheçam e apliquem os sentidos que lhe são sugeridos. 


\subsection{Quem produz os elementos referidos no art. 38 (1) "c" do ECIJ: "a doutrina dos publicistas mais qualificados das diferentes Nações"?}

Admitindo-se que "a doutrina dos publicistas mais qualificados das diferentes Nações" possa ser adotada como evidência quanto ao sentido de termos dos acordos de dupla tributação, passa a ser necessário identificar tal material. Quem seriam os tais publicistas mais qualificados? Tratar-se-iam apenas de pessoas físicas ou instituições também estariam sob o seu bojo?

\subsubsection{Quem são os publicistas mais qualificados das diferentes nações?}

Como estratégia retórica, o advogado, imbuído na missão de convencer o juiz sobre uma determinada interpretação, pode levar em consideração quais doutrinadores mais têm influenciado os tribunais de sua jurisdição, o que redunda em certo argumento de autoridade. A consideração do argumento apresentado por um parecer ou um texto colhido da literatura jurídica depende não apenas da qualificação técnica de seu autor, mas de uma série de outros fatores, como reputação e experiência prática.

Seria útil às Cortes nacionais tanto a consideração de doutrina nacional quanto estrangeira na análise de questões relacionadas a acordos de dupla tributação. Por mais diferentes que sejam os idiomas e a nacionalidades dos autores, grande parte de suas produções tem o mesmo objeto: o Direito tributário internacional, especialmente baseados na CM-OCDE e na CVDT. Naturalmente, o Direito tributário internacional é recepcionado pelo sistema jurídico de cada Estado em observância aos seus peculiares mandamentos Constitucionais, de tal forma que as observações da doutrina estrangeira devem ser consideradas com ressalva a tais peculiaridades. ${ }^{734}$

No entanto, tal como ocorre em relação às decisões de tribunais estrangeiros, é necessário ponderar que juízes de diversas jurisdições podem não estar familiarizados com

${ }^{734}$ Vide Introdução, tópico X, sobre o Direito tributário internacional do Brasil. 
trabalhos produzidos por importantes publicistas de diferentes nações especializados em Direito tributário internacional, o que não é um problema isolado dos tributaristas. IAN BROWNLIE $^{735}$, tratando do Direito Internacional de uma forma geral, suscita ser comum que Cortes nacionais não possuam familiaridade com a doutrina internacional, acessando-a por meio de fontes secundárias, como as petições que lhes são apresentadas, de tal modo que poucas referências doutrinárias geralmente seriam identificadas em suas decisões.

É necessário investigar, ainda, se apenas indivíduos poderiam produzir "a doutrina dos publicistas mais qualificados das diferentes Nações" ou, ainda, se "instituições" poderiam assumir tal papel.

\subsubsection{Exemplo: A influência da doutrina na interpretação de acordos de bitributação pelo CARF.}

No Caso BBA (Brasil, 2006), o CARF precisou analisar se determinados rendimentos estariam compreendidos no conceito de "lucro da empresa", sob o escopo do art. 7 do acordo Brasil-Portugal, ou no conceito de "dividendos" referidos pelo art. 10 da convenção. Em seu voto, a julgadora SANDRA MARIA FARONI recorreu aos trabalhos de Alberto Xavier e Heleno Torres, enquanto o julgador Mário Junqueira Franco JúNIOR suscitou publicações de Alberto XAVIER, Luís EdUARdo SchOUeri e Miguel Hilu NeTO.

${ }^{735}$ BROWNLIE, Ian. Principles of public international law. Clarendon : Oxford, 1998, p. 24-25. 


\subsubsection{Instituições podem produzir "a doutrina dos publicistas mais qualificados das diferentes Nações"?}

"However, the international scene has seen such a proliferation of organizations, suborganizations, organs, subordinate organs, commissions, etc., and such a welter of resolutions, decisions, directives, regulations, principles, guidelines, and similar lawmaking or apparently lawmaking instruments, that individual governments may be unable to discern at just what point consent to law creation was given, and to any observer the pattern may look much more like legislative activity than the product of meeting of minds and an informed consent embodied in a treaty". Hugh THIRLWAY (2014) $)^{736}$

Como a passagem em epígrafe antecipa, o presente subtópico se ocupa do ponto de encontro da evidência ora em análise com o tema que será objeto de investigação no próximo tópico (Comentários à CM-OCDE).

Observa IAN BROWNLIE ${ }^{737}$ que minutas publicadas pela ONU ("International Law Comission"), universidades ("Harvard Research drafts") e outras instituições seriam análogas à doutrina dos publicistas mais qualificados das diferentes Nações. Parece realmente assistir razão ao autor.

No entanto, é importante segmentar algumas situações, que podem emanar consequências diversas: $i$ ) decisões enunciadas por entidades internacionais com as quais o Estado se declara vinculado e que envolvem a própria parte; ii) decisões enunciadas por entidades internacionais com as quais o Estado se declara vinculado mediante acordo internacional, mas que não envolvem o referido Estado; iii) decisões enunciadas por entidades internacionais com as quais o Estado não se declara vinculado mediante acordo internacional.

No Caso Application of the Genocide Convention, a CIJ acolheu a norma veiculada pelo art. 16 do ILC Draft Articles on State Responsability, um trabalho elaborado no âmbito da ONU.

Para reconhecer tal elemento como fonte material do Direito Internacional, aquela Corte reconheceu como fonte formal certos costumes internacionais, que estariam refletidos naquele dispositivo.

${ }^{736}$ THIRLWAY, Hugh. The Sources of International Law. Oxford : Oxford, 2014, p. 34.

${ }^{737}$ BROWNLIE, Ian. Principles of public international law. Clarendon : Oxford, 1998, p. 25. 
Hugh ThIRLWAy ${ }^{738}$ observa que as decisões enunciadas por entidades internacionais com as quais o Estado se declara vinculado teriam cogência por conta do consenso emanado do Estado. O autor critica o fundamento expresso na decisão do Caso Application of the Genocide Convention, pois seria mais apropriado qualificar tal evidência como doutrina dos publicistas mais qualificados das diferentes Nações.

Em resumo, a doutrina dos publicistas mais qualificados das diferentes nações apresenta características bastante claras, quais sejam: (i) não cria o Direito tributário internacional, mas apenas o descreve; (ii) é atemporal; (iii) requer o recurso à analogia (iv) quanto ao seu aspecto subjetivo, admite pessoas físicas ou instituições; (v) promove o critério funcional como meio auxiliar para a determinação de sentido; e (vi) requer critérios materiais de reconhecimento, como perícia, reputação e plausibilidade.

\section{A CM-OCDE, OS COMENTÁRIOS À CM-OCDE E OUTROS MATERIAIS COMO EVIDÊNCIAS DO SENTIDO CONTEXTUALIZADO DE TERMOS DE CONVENÇÕES FISCAIS.}

"The Tribunal accepts that the Commentaries are of relevance in this case." Juíza AnNE ScotT, Caso Tomislav (Reino Unido, 2011)

Como já se observou, sob o ponto de vista empírico, a CM-OCDE e os seus respectivos Comentários estão entre as evidências prediletas dos operadores do Direito tributário internacional quanto ao sentido dos termos de convenções fiscais, especialmente pelo argumento da praticidade. Também os reports e guidelines, estudos que podem corresponder alterações dos Comentários à CM-OCDE, são francamente suscitados em discussões acadêmicas. Da mesma forma, outros modelos e seus comentários, especialmente publicados pela ONU e EUA, são amplamente conhecidos entre os profissionais que lidam com a tributação internacional. Contudo, também são essas as evidências que geram as maiores controvérsias.

${ }^{738}$ THIRLWAY, Hugh. The Sources of International Law. Oxford : Oxford, 2014, p. 19-23. 
A norma construída pelo intérprete a partir do art. 3 (2) da CM-OCDE será decisiva para a relevância da CM-OCDE e de seus Comentários. Assim, caso se considere que os sentidos colhidos a partir do Direito doméstico dos Estados contratantes (cláusula de reenvio) assumem precedência em relação ao contexto, então tais materiais realmente não teriam maior importância. Afinal, ainda que se assumisse por hipótese que a CM-OCDE e os seus Comentários estejam sob o escopo do "contexto", esse recurso seria subsidiário ao reenvio. ${ }^{739}$ Por sua vez, tal como se assume nesta tese, é possível adotar a premissa de que o contexto internacional possui precedência em relação ao Direito doméstico dos Estados contratantes. De uma maneira ou de outra, no entanto, não há como escapar à questão formal se os materiais publicados especialmente pela OCDE são ou não suportados pelo contexto referido no art. 3 (2) da CM-OCDE, o que exige que se analise a natureza jurídica desses.

Nesse cenário, os subtópicos seguintes apresentam uma breve exposição quanto aos Comentários à CM-OCDE, reports e guidelines publicados pelo CAF-OCDE, seguida da análise da natureza jurídica desses, determinante para os seu exame como componente do contexto extrínseco secundário (critério formal). $\mathrm{Na}$ sequência, tais evidências serão analisadas a partir dos critérios funcionais e materiais propostos no presente estudo.

\subsection{Modelos de tratado como pares de comparação: parallel treaty impróprio.}

Como se viu, é preciso distinguir o recurso a outros acordos de bitributação (“AC", “A-D”) celebrados por um Estado (“A”) como evidências para a interpretação de uma específica convenção fiscal (“A-B”), do recurso ora em análise (parallel treaties impróprios), em que os pares de comparação são modelos (CM-OCDE, CM-ONU etc.) e não acordos internacionais efetivamente celebrados (parallel treaties próprios).

O parallel treaty impróprio exige a análise: (i) do recurso à CM-OCDE e a outros modelos de acordos de bitributação; bem como (ii) do recurso a modelos de outras espécies de acordos internacionais em matéria tributária, como por exemplo a "Estate and

\footnotetext{
${ }^{739}$ MAARTEN J. Ellis. The influence of the OECD Commentaries on Treaty Interpretation - Response to Prof. Dr. Klaus Vogel, in Bulletin - Tax Treaty Monitor - December 2000. IBFD : Amsterdã, 2000, p. 617618.
} 
Inheritance Draft Model Convention" e a "Estate, Inheritance and Gift Model Convention".

Por sua vez, também é necessário considerar variações que podem surgir se: (a) ambos os Estados contratantes são membros da instituição que mantém a convenção modelo (como a OCDE); (b) se ao menos um dos Estados contratantes não é membro, mas observador convidado (como se dá com o Brasil em relação à OCDE) ou; (c) se ao menos um dos Estados contratantes não é membro e nem observador convidado. Também é necessário investigar se parallel treaty impróprios preencheriam os requisitos funcionais e materiais adotados nesta tese.

\subsubsection{A CM-OCDE como par de comparação.}

"Daí concluir-se que se dois Estados contratantes celebraram um acordo de bitributação contendo dispositivo extraído da convenção-modelo da OCDE, deve-se dar àquele acordo, no que tange ao dispositivo em exame, a interpretação proposta no comentário da OCDE, já que esta interpretaçãoo será a que melhor propiciará a harmonia necessária à finalidade do acordo de bitributação.

Mas a importância da comparação entre o modelo e o acordo concreto não para ai. Também no caso de divergências, a análise é relevante, já que ela pode permitir o emprego do raciocínio a contrário, como modo de melhor compreender a intenção das partes".

LUís EDUARDO SCHOEURI (2003) $)^{740}$

O CAF-OCDE sustenta que, desde a sua primeira versão (1963), a CM-OCDE repercutiria amplamente na negociação, interpretação e aplicação de acordos de bitributação. ${ }^{741}$ Para aquele grupo de trabalho, a efetiva adoção da CM-OCDE na celebração e revisão de tratados de bitributação por Estados membros facilitaria as negociações bilaterais e conduziria à harmonização da rede de convenções internacionais, em benefício de contribuintes e autoridades fiscais ${ }^{742}$. Da mesma forma, haveria ainda grande influência da CM-OCDE sobre Estados não-membros, ou mesmo sobre outros modelos, a exemplo da CM-ONU, que reproduz boa parte de seus dispositivos ${ }^{743}$.

Os exemplos a seguir demonstram que Cortes nacionais, de fato, consideram relevante o recurso à $\mathrm{CM}-\mathrm{OCDE}$ ou à $\mathrm{CM}-\mathrm{ONU}$.

\footnotetext{
${ }^{740}$ SCHOUERI, Luís Eduardo. Tratados e Convenções Internacionais sobre Tributação, in Revista de Direito Tributário Atual n. 17. São Paulo : IBDT/Dialética, 2003, p. 39.

${ }^{741}$ OECD. MODEL TAX CONVENTION (FULL VERSION), 2012, Introduction, par. 12, p. I.3.

${ }^{742}$ OECD. MODEL TAX CONVENTION (FULL VERSION), 2012, Introduction, par. 13, p. I.4.

${ }^{743}$ OECD. MODEL TAX CONVENTION (FULL VERSION), 2012, Introduction, par. 14, p. I.4.
} 


\subsubsection{Exemplo: Os tribunais ingleses e a adoção da CM-OCDE como par de comparação.}

No Caso Banco do Brasil/Commerzbank (Reino Unido, 1990), o tribunal inglês precisou analisar se o acordo Reino Unido-EUA seria aplicável a filiais de um banco brasileiro e um banco alemão efetivamente estabelecidos naquele país.

Entre os exercícios realizados, o tribunal inglês adotou a CM-OCDE (1977) como par de comparação, evidenciando que essa possuía em seu art. $1^{\circ}$ a seguinte disposição, ausente no acordo Reino Unido-EUA: "This Convention shall apply to persons who are residents of one or both of the Contracting States". Como conclusão, o tribunal concluiu que as filiais daqueles bancos fariam jus aos benefícios da convenção fiscal.

No Caso Sportsman (Reino Unido, 1998), a fim de aplicar o acordo de bitributação Reino Unido-França, o tribunal inglês, precisou construir o sentido do termo "payable" inserto em seu art. 24, o qual seria comparável, mas não idêntico ao art. 23-B da CMOCDE.

O tribunal reconheceu que o acordo Reino Unido-França não seguiu a CM-OCDE de 1963 ou a CM-ONU de 1946, nas quais os termos "paid" e "collected" foram adotados, preferindo o termo "payable”. No entanto, afirmou que isso não teria maior relevância: "payable" não deveria ser compreendido como algo que poderia vir a ser pago, mas como algo efetivamente pago, ao teor daquele modelos de convenções, pois este - supostamente - seria o sentido presente no contexto internacional ("the international context is that relief is given for tax actually paid").

\subsubsection{Exemplo: Os tribunais canadenses e a adoção da CM-OCDE como par de comparação.}

No Caso Crown Forest (Canadá, 1995), a Suprema Corte canadense também considerou relevante o parallel treaty impróprio, com o recurso à CM-OCDE e à CM- 
ONU, consignando, contudo, que este não seria o único elemento do contexto extrínseco disponível para a construção de sentido dos termos em questão.

Estava em questão o sentido de "residente" no acordo de bitributação Canadá-EUA (1980). Em seu art. 4 (1) a convenção fiscal definiu o aludido termo tal como a primeira sentença do art. 4 da CM-OCDE, mas não adotou a segunda sentença presente nesse modelo desde 1977: "This term, however, does not include any person who is liable to tax in that State in respect only of income from sources in that State or capital situated therein".

A comparação da CM-OCDE (1977) e o acordo de bitributação Canadá-EUA (1980) suscitou a dúvida de que se, para a aplicação desse, o termo "residente" deveria ser interpretado de forma a compreender pessoas sujeitas apenas à tributação na fonte nos EUA ou no Canadá, não se exigindo sujeição ampla à jurisdição tributária desses (full tax liability).

Para a Suprema Corte canadense, contudo, a omissão daquela segunda sentença sugerida no art. 4 da CM-OCDE (1977) não seria relevante: para fins do acordo CanadáEUA, não seriam considerados "residentes" os contribuintes sujeitos exclusivamente à tributação na fonte em um dos Estados contratantes. Para chegar a essa conclusão, o tribunal considerou que a introdução dessa sentença em 1977, que não constava na CMOCDE de 1963, não teve como finalidade estabelecer um novo conceito de "residente", mas apenas aclarar situações como as dos diplomatas que residiriam em determinado Estado por seu ofício e não estariam sujeitos à tributação neste em bases universais.

\subsubsection{Reservas à CM-OCDE e as suas consequências para a interpretação dos acordos de bitributação.}

O tema das reservas é geralmente estudado em relação aos acordos multilaterais. Hugh THIRLWAY ${ }^{74}$ considera que a questão perderia o sentido em relação aos tratados bilaterais, pois todo o conteúdo veiculado por esses já seria aquele integralmente

${ }^{744}$ THIRLWAY, Hugh. The Sources of International Law. Oxford : Oxford, 2014, p. 39. 
consentido pelas partes, sem a necessidade de ressalvas. No Direito tributário internacional, composto basicamente por convenções bilaterais para evitar a dupla tributação, não se discute necessariamente a existência de reservas a esses. O que está em voga é a possibilidade de oposição de reservas à $C M-O C D E$, assim como observações aos seus respectivos Comentários.

O CAF-OCDE ${ }^{745}$ sugere que os Estados membros da OCDE oponham reservas a determinados dispositivos da CM-OCDE com os quais não concordem. Não haveria necessidade, contudo, que os Estados consignassem, por meio de reservas, a intenção de adotar dispositivos alternativos ou adicionais já previstos na CM-OCDE ou, ainda, a fim de expressar a incorporação de algum Comentário ao texto de seus tratados. Além disso, o CAF-OCDE ainda aponta que a existência de ressalvas de um determinado Estado ("A") não impede que negocie cláusulas diversas da sua ressalva com outros Estados (“B”).

Assim, a relevância de reservas opostas à CM-OCDE como evidências para a interpretação de convenções fiscais efetivamente celebradas entre os Estados é controversa e muitas variáveis são possíveis.

Por um primeiro exercício hipotético, é possível que um Estado-membro (“A”) oponha reserva a um certo dispositivo explicitando as suas razões, bem como celebre acordos de bitributação ("A-B", “A-C") com outros Estados-membros da OCDE ("B”, “C”) precisamente com o desvio ressalvado em sua reserva. Poder-se-ia argumentar, então, que ambos os Estados contratantes estavam conscientes do sentido da cláusula em questão, compondo o seu conceito a reserva apresentada pelo Estado em questão (“A”). A própria CM-OCDE também poderia ser utilizada como par de comparação, a fim de evidenciar um sentido ao qual não se quis atruibuir à convenção.

Por um segundo exercício hipotético, também é possível cogitar que um Estadomembro ("A") apresente reserva a um dispositivo, mas celebre um acordo de bitributação (“A-B”) com outro Estado membro ("B”) nos precisos moldes da CM-OCDE. Poder-se-ia argumentar, nesse caso, que o Estado que opôs tais reservas se dobrou, mediante negociações com o outro Estado contratante (“B”), à norma proposta pela CM-OCDE.

${ }^{745}$ OECD. MODEL TAX CONVENTION (FULL VERSION), 2012, Introduction. “Reservations of certain member countries on some provisions of the Convention”, parágrafos 31 e 32 . 
Suas reservas poderiam, então, ser adotadas com evidências de um sentido que não se quis atruibuir ao acordo internacional.

Naturalmente, uma série de outras conclusões são possíveis em casos concretos, bem como outras evidências devem estar presentes no contexto intrínseco e extrínseco, as quais devem ser consideradas pelo intérprete.

\subsubsection{Outros modelos de outras espécies de acordos internacionais em matéria tributária como pares de comparação.}

De forma semelhante como se dá em relação ao parallel treaty impróprio exposto anteriormente, em que se recorre por exemplo à CM-OCDE como par de comparação, também se pode considerar a possibilidade de outros modelos de acordos internacionais, que não tenham como objeto a dupla tributação jurídica da renda, servirem de pares de comparação para a construção de sentido de termos utilizados em uma específica convenção fiscal.

Há outros modelos de acordos internacionais promovidos pela OCDE, como "Estate and Inheritance Draft Model Convention" e "Estate, Inheritance and Gift Model Convention".

Uma série de variáveis também deve ser considerada para que tais materiais sejam admitidos como evidências como a participação dos Estados contratantes na organização promotora do modelo em questão ou mesmo se algum desses, mesmo que membro, efetivamente celebrou algum acordo conforme tais modelos sugeridos, por exemplo. 


\subsubsection{Exemplo: Outros modelos de outras espécies de acordos internacionais para a interpretação do termo "tax" da CM-OCDE.}

Tal recurso é adotado por MARTín JIMÉNEZ ${ }^{746}$ para a construção de sentido do termo "tax", referido no art. $2^{\circ}$ da CM-OCDE. Como já se expôs, o professor espanhol adota como ponto de partida (problema) a inclusão ou não de contribuições sociais sob o escopo desse termo e investiga evidências quanto ao seu sentido. No caso, questionou-se o valor de outros modelos de outras espécies de acordos internacionais em matéria tributária para a composição do contexto interpretativo, como "Estate and Inheritance Draft Model Convention" e "Estate, Inheritance and Gift Model Convention”.

\subsection{Comentários à CM-OCDE e Reports publicados pelo CAF-OCDE: breve retrospecto.}

Cada artigo da CM-OCDE é objeto de comentários elaborados pelo CAF-OCDE, vocacionados a "explicar" os seus dispositivos, como já se analisou no Capítulo I. ${ }^{747}$ Notese que os Comentários à CM-OCDE, contam com a participação e aprovação - ainda que com eventuais ressalvas - não apenas de autoridades fiscais, mas também de embaixadores de seus Estados membros e de outros Estados não membros convidados como observadores.

Em seu capítulo de introdução, os próprios Comentários à CM-OCDE ${ }^{748}$ assumem que não seriam instrumentos legais internacionalmente vinculantes, embora não deixem de lhes autoatribuir o status de fonte provedora de interpretação. Ao destacar a influência da CM-OCDE na negociação, interpretação e aplicação de acordos de dupla tributação, o CAF-OCDE aponta que a sua adoção ampla faria com que os seus Comentários se

\footnotetext{
${ }^{746}$ JIMÉNEZ, Adolfo J. Martín. Defining the objective scope of income tax treaties: the impact of the other treaties and EC Law on the Concept of Tax in the OCED Model, in Bulletin - Tax Treaty Monitor - October 2005. Amsterdã : IBFD, 2005.

${ }^{747}$ Sobre um histórico o tema, vide: MAARTEN J. Ellis. The influence of the OECD Commentaries on Treaty Interpretation - Response to Prof. Dr. Klaus Vogel, in Bulletin - Tax Treaty Monitor - December 2000. IBFD : Amsterdã, 2000, p. 618; SILVEIRA, Rodrigo Maitto da. Aplicação de Tratados Internacionais Contra a Bitributação - Qualificação de Partnership Joint Ventures. IBDT/Quartier Latin : São Paulo, 2006, p. 142.

${ }_{748}$ OECD. MODEL TAX CONVENTION (FULL VERSION), 2012, Introduction, parágrafo 29.2.
} 
tornassem amplamente aceitos como uma guia ("guide") para interpretação e aplicação das convenções fiscais de forma harmônica ("common lines") 749 . Os Comentários à CMOCDE - afirmam eles próprios - seriam de grande relevância para o desenvolvimento do Direito tributário internacional, também por serem elaborados por especialistas indicados pelos Governos dos Estados membros ${ }^{750}$. $^{751}$

Note-se que não apenas Estados-membros podem participar das atividades promovidas pela OCDE, conforme previsto no art. 12 de sua convenção de constituição ${ }^{752}$. Como é sabido, desde 1997, Estados não da OCDE são convidados a também apresentarem as suas reservas e observações aos Comentários à da CM-OCDE, o que possibilita ao Brasil, que não é um Estado membro daquela organização, fazê-lo na qualidade de observador. ${ }^{753}$

Não se pode deixar de reafirmar, contudo, que nem os negociadores dos acordos de dupla tributação, nem os seus aplicadores estão vinculados a seguir cegamente os Comentários à CM-OCDE ou outros estudos elaborados pelo $\mathrm{CAF}-O C D E^{754}$. Como observou KLAUS VOGEL ${ }^{755}$ sequer os Estados-membros da OCDE estão compelidos a seguir às cegas os Comentários; os Estados membros da OCDE se obrigam, conforme o art. 18 do regulamento ${ }^{756}$ daquela organização, a analisar tais comentários quando tiverem

\footnotetext{
${ }^{749}$ OECD. MODEL TAX CONVENTION (FULL VERSION), 2012, Introduction, par. 15, p. I.4.

${ }^{750}$ OECD. MODEL TAX CONVENTION (FULL VERSION), 2012, Introduction, parágrafo 29, p. I.9.

${ }^{751}$ Sobre o tema, vide, ainda: AULT, Hugh. The role of the OECD Commentaries in the Interpretation of Tax Treaties, in Intertax v. 22. Kluwer Law International : 1994, p. 145.

752 OCDE. Convention on the Organisation for Economic Co-operation and Development. "Article 12. Upon such terms and conditions as the Council may determine, the Organisation may: (a) address communications to non-member States or organisations; (b) establish and maintain relations with non-member States or organisations; and (c) invite non-member Governments or organisations to participate in activities of the Organisation." (Último acesso em 20/10/2014, no endereço eletrônico http://www.oecd.org/general/conventionontheorganisationforeconomicco-operationanddevelopment.htm.)

${ }^{753}$ Sobre o tema, vide: BROE, Luc De. International tax planning and prevention of abuse (doctoral series n. 14). Amsterdã : IBFD, 2007, p. 253, nota de rodapé 75; ENGELEN, Frank; DOUME, Sjoerd. Conference position paper: the quest for the holy grail in international tax law - the legal status of the Commentaries on the OECD Model Tax Convention on Income and on Capital, in The legal status of the OECD Commentaries. Amsterdã : IBFD, 2008, p. 255 e seg.

${ }^{754}$ BRUNSCHOT, Frank van. The Judiciary and the OECD Model Tax Convention and its Commentaries, in Bulletin - Tax Treaty Monitor of January 2005. IBFD, 2005, p. 6.

${ }^{755}$ VOGEL, Klaus. The influence of the OECD Commentaries on Treaty Interpretation, in Bulletin - Tax Treaty Monitor - December 2000. IBFD : Amsterdã, 2000, p. 614.

${ }^{756}$ OCDE. RULES OF PROCEDURE OF THE ORGANISATION. "VI. ACTS OF THE ORGANISATION. Rule 18. Último acesso em 20/10/2014, no endereço eletrônico http://www.oecd.org/legal/Rules\%20of\%20Procedure\%20OECD\%20Oct\%202013.pdf.)
} 
de aplicar acordos de dupla tributação e, se oportuno, segui-los ${ }^{757}$. Daí, conclui VoGEL, caso a interpretação de um acordo de dupla tributação conduzir a resultado diverso ao dos Comentários à CM-OCDE, mesmo a administração fiscal de um Estado-membros não teria o compromisso jurídico de observar esses Comentários. Caso a administração fiscal considere determinado Comentário à CM-OCDE oportuno, estaria compelida a seguí-lo. Contudo, enfatizou o professor alemão que tal obrigação poderia não ser aplicável ao Poder Judiciário por limitações constitucionais, posto que não há participação do Poder Legislativo na produção dos Comentários.

A CAF-OCDE também desenvolve e publica uma série de estudos ("reports", "guidelines") relacionados a assuntos específicos e que podem conduzir a posteriores alterações na CM-OCDE ou, ainda que de forma resumida, em seus Comentários. Apenas como exemplo, examinado a seguir, é possível citar o estudo da aplicação da CM-OCDE em casos envolvendo partnerships, publicado em $1999^{758}$.

No Brasil, apenas recentemente se intensificou a demanda pela produção de decisões de tribunais administrativos ou judiciais quanto à aplicação de acordos de bitributação. É possível que haja a tendência para que os julgadores brasileiros - tal como muitos de seus colegas estrangeiros - olhem para os Comentários à CM-OCDE, que conta, inclusive, com versões traduzidas à língua portuguesa ${ }^{759}$. Tal tendência justifica ainda mais a análise exposta no subtópico seguinte a seguir, quanto à natureza jurídica dos Comentários à OCDE.

\footnotetext{
${ }^{757}$ Sobre a questão, vide: ROHATGI, Roy. Basic International taxation. Volume 1: principles. Nova Deli : Taxmann, 2005, p. 44-45.

${ }^{758}$ OECD. The Application of the OECD Model Tax Convention to Partnerships, in Issues in International Taxation n. 6. Paris: OECD Publishing, 1999.

${ }^{759}$ OCDE. Modelo de Convenção Tributária sobre o Rendimento e o Capital. Versão Condensada, de 22 de julho de 2010. Tradução: Demarest \& Almeida Advogados; OCDE. Modelo de Convenção Fiscal sobre o Rendimento e o Patrimônio - Comitê dos Assuntos Fiscais da OCDE. Lisboa : Centro de Estudos Fiscais, 2008.
} 


\subsubsection{Exemplo: $O$ recurso aos Comentários à CM-OCDE pela PGFN.}

"Os comentários da OCDE à Convenção Modelo esclarecem de forma bastante incisiva que o conceito de lucro tratado no art. $7^{\circ}$ apresenta significado amplo". Parecer PGFN/CAT n. 2363/2013 $3^{760}$

No parecer PGFN/CAT referido em epígrafe, a administração fiscal brasileira reverteu o seu entendimento quanto ao sentido dos termos "lucro da empresa" ("business profit"), presentes no art. $7^{\circ}$ dos acordos de bitributação celebrados. Como se pode observar, ainda que de forma subsidiária, foram mencionados Comentários à CM-OCDE para respaldar essa mudança de postura.

Como justificativa ao recurso a tais materiais, a $\mathrm{PGFN}^{761}$ suscitou que "o recurso aos Comentários da OCDE à Convenção Modelo costuma ser utilizado pelo CARF na solução das controvérsias de interpretação do tratado, o que possibilita a aplicação do TDT em sintonia ao costume internacional". Ocorre que os Comentários ao art. $7^{\circ}$ da CMOCDE sugeririam, em seu parágrafo 71, que o termo "lucro" teria "significado amplo, incluindo todo o rendimento auferido na condução de uma empresa".

\subsubsection{Exemplo: $O$ recurso aos Comentários à CM-OCDE nos tribunais australianos.}

O Caso Thiel (Austrália, 1990) foi citado por KlAus Vogel como um exemplo do recurso aos Comentários à $\mathrm{CM}-\mathrm{OCDE}$ como evidência do sentido dos termos dos acordos de bitributação.

No Caso McDermott (Austrália, 2005), o tribunal australiano considerou importante investigar o histórico de alguns artigos do acordo de bitributação AustráliaSingapura (1989), como forma de descortinar o que as partes pretendiam. Para tanto, os Comentários à CM-OCDE seriam um ponto de partida útil.

Para o julgador, embora os Comentários à CM-OCDE possam ser utilizados no auxílio da interpretação de convenções fiscais baseadas em tal modelo, há dificuldades

${ }^{760}$ BRASIL. Parecer PGFN/CAT n. 2363/2013, p. 21. Último acesso em 9/12/2014, no endereço eletrônico http://dados.pgfn.fazenda.gov.br/dataset/pareceres/resource/23632013.

${ }^{761}$ Vide: BRASIL. Nota PGFN/COCAT n. 1291/2013. 
teóricas em aceitar a sua consideração dinâmica. Ainda assim, a evolução dos Comentários e, em especial a sua revisão em 1997, demonstraria um claro desacordo entre os Estados quanto à inclusão de rendimentos provenientes do arrendamento de equipamentos de uso industrial, comercial ou científico no conceito de royalties (CM-OCDE, art. 12) ou lucros das empresas (CM-OCDE, art. 7, “business profits”).

Naquele ano, o CAF-OCDE decidiu excluir tais rendimentos da definição de royalties, considerando-os sob o escopo de "lucros das empresas", de forma que não estariam sujeitos à tributação na fonte, mas apenas no país de residência de seus beneficiários. A Austrália, por sua vez, apresentou sua posição de tratar tais rendimentos como royalties em relação às fontes conectadas à sua jurisdição, enquanto outros países teriam seguido em direção diversa, como se poderia observar do "report on the taxation of income derived from the leasing of industrial, commercial or scientific equipment" (1997).

Consignou o julgador, ainda, que a revisão da definição royalties empreendida pelo CAF-OCDE não seria capaz de solucionar todos os problemas relacionados ao tema. Acompanhando a posição doutrinária de EvAns, professor da Dalhousie University, a ausência de disposição especial nos acordos de bitributação deixaria em aberto a questão se a presença dos equipamentos arrendados em determinado Estado configurariam um estabelecimento permanente nesse, o que autorizaria a tributação nessa jurisdição sob o escopo do art. 7.

\subsubsection{Exemplo: $O$ recurso aos Comentários à CM-OCDE nos tribunais canadenses.}

No Caso Crown Forest (Canadá, 1995), a Suprema Corte canadense considerou que os Comentários à CM-OCDE (e a própria CM-OCDE) seriam internacionalmente reconhecidos como documento base para a negociação, aplicação e interpretação acordos de dupla tributação.

Ainda que um acordo de dupla tributação específico não possuísse determinada cláusula presente na CM-OCDE, ainda assim esses deveriam ser considerados, pois tal supressão não seria considerada indicativa da intenção dos negociadores em se desviar daquele padrão básico. 
Sucedendo tal jurisprudência, no Caso Pacific Network (Canadá, 2002), o tribunal canadense considerou que os Comentários à CM-OCDE seriam evidências mais persuasivas que intrínsecas e extrínsecas secundárias apresentadas pelo contribuinte.

\subsubsection{Exemplo: $O$ recurso aos Comentários à $\mathrm{CM}-\mathrm{OCDE}$ pelo próprio $\mathrm{CAF}-\mathrm{OCDE}$ (circularidade).}

"The OECD Report develops a scheme to resolve which are created by its own assumptions: if the Committe paid more attention to the 'context' of certain tax treaty when interpreting its provisions, conflicts of qualification could be avoided from the start.

It is disappointing that the Committe does not focus on the examination how to avoid conflicts of qualification, but accepts premises which provoque conflicts of qualification the Committe attempts to resolve later on through questionable means, as will be discussed later". Michael LANG $(2000)^{762}$

No seu estudo sobre as partnerships de 1999, o CAF-OCDE se baseou francamente nos próprios CM-OCDE para a construção de suas conclusões diante de uma série de casos hipotéticos nos quais a existência de partnerships poderiam causar dúvidas quanto à aplicação dos benefícios de acordos de dupla tributação, bem como sinalizou que alterações em alguns Comentários à CM-OCDE seriam necessárias a fim de aclarar tais dificuldades, o que se concretizou nas revisões seguintes. ${ }^{763}$

O referido report a respeito das partnerships, ora tomado como exemplo, demonstra a forma como o CAF-OCDE autolegitima os entendimentos e decisões veiculados pelos materiais que produz, em um movimento autopoiético sem precedente no Direito Internacional. Ocorre que o documento utiliza como fundamento para as posições assumidas os Comentários à CM-OCDE, que também foram elaborados por tal pela CAFOCDE, sem que quaisquer outros fundamentos sejam apresentados.

\footnotetext{
${ }^{762}$ LANG, Michael. The application of the OECD Model Tax Convention to Partnerships - A critical Analysis of the Report Prepared by the OECD Committee on Fiscal Affairs. Viena : Linde, 2000, p. 20-28.

${ }^{763}$ Sobre o tema, vide ainda: LANG, Michael. The application of the OECD Model Tax Convention to Partnerships - A critical Analysis of the Report Prepared by the OECD Committee on Fiscal Affairs. Viena : Linde, 2000, p. 15 e seg.
} 


\title{
5.3. A natureza jurídica dos Comentários à CM-OCDE entre as evidências admitidas
} para a construção do sentido ordinário contextualizado dos termos da CM-OCDE.

\begin{abstract}
"It is submitted that, although the exact role of the Commentaries in the process of interpretation can be debated, what cannot be debated is that a court cannot refer to the Commentaries as the first or only source of the meaning of beneficial ownership". CHARL DU TOIT (2010) $)^{764}$
\end{abstract}

Assim como outras possíveis evidências do Direito tributário internacional investigadas nesta tese, os Comentários à CM-OCDE passam por questionamentos formais, funcionais e materiais. Neste subtópico serão analisados os critérios formais em questão, a fim de se averiguar se os Comentários à CM-OCDE estão sob o escopo do Direito Internacional.

A natureza jurídica de tais evidências tem suscitado variadas teorias na doutrina, mas muito pouco consenso ${ }^{765}$. Como se pode observar nos subtópicos a seguir, ao menos onze correntes podem ser identificadas na doutrina especializada.

\subsubsection{Os Comentários à CM-OCDE como acordo multilateral (CVDT, art. 31).}

Sob a perspectiva de que os Comentários à CM-OCDE seriam elaborados pela reunião de representantes de diversos Estados, seria possível equipará-los a um tratado multilateral relacionado ao acordo de dupla tributação sob a interpretação, sob o escopo, portanto, do art. 31 da CVDT (contexto intrínseco ou extrínseco primário). Tal teoria pode basear-se no argumento de que a CVDT não estabelece formalidades para a celebração de acordos internacionais, de tal forma que o consenso - ou ausência de oposição - das nações, por meio de seus representantes com assento no CAF-OCDE, daria origem a um acordo multilateral plenamente válido perante o Direito tributário internacional. ${ }^{766}$ Essa

\footnotetext{
${ }^{764}$ TOIT, Charl du. The Evolution of the Term "Beneficial Ownership" in Relation to International Taxation over the Past 45 Year, in Bulletin for International Taxation Vol. 64, n. 10. Amsterdã : IBFD, 2010, p. 504505.

${ }^{765}$ Cf. BAKER, Philip. Double taxation conventions and international tax law. Londres : Sweet \& Maxwell, 1994, par. C-12.

${ }^{766}$ Tratando da tese, mas refutando-a, vide: BRUNSCHOT, Frank van. The Judiciary and the OECD Model Tax Convention and its Commentaries, in Bulletin - Tax Treaty Monitor of January 2005. IBFD, 2005, p. 6 e seg.; GOTHENBURG, K. Ahlm. National Report of Sweden. Cahiers de Droit Fiscal International by the International Fiscal Association (studies on international tax law), volume XLII - Subject II: The interpretation of the Double Taxation Convention. / IFA : Roterdã, 1960, p. 257.
} 
teoria se divide entre aqueles que atribuem a tal "acordo multilateral" o efeito de vincular o Poder Judiciário e os que não lhe reconhecem tal efeito.

Provavelmente em seu último trabalho sobre o tema, KLAUS VoGEL ${ }^{767}$ sustentou que os Comentários à CM-OCDE poderiam ser considerados como acordos internacionais multilaterais, plenamente válidos perante o Direito Internacional e aptos a obrigar as respectivas administrações fiscais, mas que não vinculariam os contribuintes e nem os Tribunais. O professor considerou semelhante o que se daria em relação aos procedimentos amigáveis.

Ao debater a posição de Vogel, MAARTEN J. ElLis ${ }^{768}$ lhe opôs que tal teoria seria atraente aos contribuintes, pois lhes possibilitaria recorrer aos Comentários à CM-OCDE apenas quando estes lhes fossem benéficos, mas não solucionaria a ausência de consentimento dos Estados por meio de seus agentes competentes para a celebração de um acordo multilateral. Ocorre que, para este professor, os indivíduos que discutem e elaboram a CM-OCDE e os seus Comentários, a exemplo de embaixadores e autoridades fiscais, não possuiriam delegação de poderes dos Estados para elaborar um acordo multilateral propriamente dito.

No Brasil, embaixadores ${ }^{769}$ e autoridades fiscais pertencem à estrutura do Governo (Poder Executivo) e não são dotados de competência para a celebração de acordos multilaterais em matéria tributária à revelia da participação do Poder Legislativo. Diante de tal questão, a classificação dos Comentários à CM-OCDE como acordo multilateral se torna questionável, bem como a vinculação de agentes fiscais, contribuintes ou juízes.

\footnotetext{
${ }^{767}$ VOGEL, Klaus. The influence of the OECD Commentaries on Treaty Interpretation, in Bulletin - Tax Treaty Monitor - December 2000. IBFD : Amsterdã, 2000, p. 613 e seg.

${ }^{768}$ MAARTEN J. Ellis. The influence of the OECD Commentaries on Treaty Interpretation - Response to Prof. Dr. Klaus Vogel, in Bulletin - Tax Treaty Monitor - December 2000. IBFD : Amsterdã, 2000, p. 617618.

${ }^{769}$ BRASIL. Decreto n ${ }^{\circ} 4.118$, de 7 de fevereiro de 2002. Seção IV. Do Ministério das Relações Exteriores, arts. 33 e 34 .
} 


\subsubsection{Os Comentários à CM-OCDE como declarações interpretativas unilaterais.}

Sustenta Guglielmo Maisto ${ }^{770}$ que os Comentários à CM-OCDE podem ser considerados como declarações interpretativas unilaterais. $\mathrm{O}$ fato de serem elaborados simultaneamente por diversos Estados não alteraria tal perfil.

Para o professor italiano, deveriam ser somadas aos Comentários à CM-OCDE as observações opostas por Estados-membros, que também assumiriam a natureza jurídica de declarações unilaterais, conforme se analisará adiante.

\subsubsection{Os Comentários à CM-OCDE como instrumentos estabelecidos em conexão com cada acordo de dupla tributação (CVDT, art. 31 (2)).}

Sob uma terceira teoria, sustentada por autores como KEES VAN RAAD ${ }^{771}$ e PHILIP BAKER $^{772}$, os Comentários à CM-OCDE seriam considerados instrumentos estabelecidos em conexão com cada acordo de dupla tributação, sob o escopo do art. 31 (2) "b" da CVDT (contexto intrínseco). Para o professor de Leiden, os Comentários à CM-OCDE seriam o resultado de discussões travadas entre os Estados membros daquela organização, que estariam livres para opor reservas, de tal forma que os Estados que não o fizessem deveriam observá-los. Por sua vez, PHILIP BAKER sustenta que, ao se reconhecer os Comentários à CM-OCDE sob o escopo do art. 31 (2) da CVDT, inclusive os Estados não membros da OCDE, ao aceitá-los, restariam vinculados à sua observação.

Tal teoria recebeu críticas de autores como KLAUS VOGEL ${ }^{773}$, Hugh AulT ${ }^{774}$ e ALBERTO XAVIER ${ }^{775}$ por desconsiderar que os Comentários não são formalmente

\footnotetext{
${ }^{770}$ MAISTO, Guglielmo. The Observations on the OECD Commentaries in the Interpretation of Tax Treaties, in Bulletin for International Taxation - Agosto, vol. 59, n. 1. Amsterdã : IBFD, 2005, p. 16-17.

${ }^{771}$ RAAD, Kees van. International coordination of tax treaty interpretation and application, in International and comparative taxation - essays in honour of Klaus Vogel. KIRCHHOF, Paul et. al. eds London : Kluwer, 2002, p. 220-223.

772 BAKER, Philip. Double taxation conventions and international tax law. Londres : Sweet \& Maxwell, 1994, par. C-13 e C-14.

${ }^{773}$ VOGEL, Klaus. Klaus Vogel on Double Taxation Conventions. Kluwer : London, 1999, p. 44.
} 
elaborados em conexão com cada um dos específicos acordos de dupla tributação celebrados. Como se viu, o fator temporal da simultaneidade foi considerado essencial pela CVDT para que instrumentos sejam considerados relacionados a uma convenção físcal.

\subsubsection{Exemplo: Exemplo: Os Comentários á CM-OCDE sob o art. 31 (2) da CM- OCDE.}

"For my part, I do not see why the OECD Model Convention and Commentaries should not be regarded as having been made in connection with and accepted by the parties to a bilateral treaty subsequently concluded in accordance with the framework of the Model".

Caso Thiel, juiz DAwson (1990)

No caso Caso Thiel (Austrália, 1990), foi abertamente reconhecida a importância dos Comentários à CM-OCDE para a interpretação de termos do acordo Austrália-Suíça. Como se pode observar na passagem em epígrafe, tais materiais foram inclusive considerados legitimados pelo CVDT, art. 31 (2).

Contudo, não deixou de ser consignado pelo juiz DAWSON que seu entendimento encontrava grande divergência doutrinária, referindo-se, inclusive, aos trabalhos de AVERY JONES e do "International Tax Group" 776.

\subsubsection{Os Comentários à CM-OCDE como sentidos especiais atribuídos pelas partes (CVDT, art. 31 (4)).}

Uma quarta teoria considera que os Comentários à CM-OCDE assumiriam a condição de sentidos especiais atribuidos pelas partes, sob o escopo dos arts. 31 (4) e 32 da CVDT (contexto intrínseco e contexto extrínseco secundário). Para HugH AULT ${ }^{777}$, o art. 31 (4) funcionaria como uma ponte de interligação entre o contexto intrínseco sob o escopo desse dispositivo e o contexto extrínseco secundário, sob o escopo do art. 32 da CVDT. Para aquele professor, tal norma autorizaria que sejam consideradas evidencias

${ }^{774}$ AULT, Hugh. The role of the OECD Commentaries in the Interpretation of Tax Treaties, in Intertax v. 22. Kluwer Law International : 1994, p. 145.

${ }^{775}$ XAVIER, Alberto. Direito Tributário Internacional do Brasil. Rio de Janeiro: Forense, 2010, p. 137.

${ }^{776}$ Vide: The Interpretation of Tax Treaties with Particular Reference to Article 3(2) of the OECD Model II, in British Tax Review, 1984.

${ }^{777}$ AULT, Hugh. The role of the OECD Commentaries in the Interpretation of Tax Treaties, in Intertax v. 22. Kluwer Law International : 1994, p. 146-147. 
suplementares quanto à intenção das partes em atribuir um sentido especial a determinado termo, ainda que as evidências sob o escopo do art. 31 conduzissem a sentidos opostos e isentos de ambiguidade. Adotando-se tal postura, seria preservado o objetivo primordial de tais acordos internacionais, evitando-se a dupla tributação gerada por interpretações discrepantes.

De forma semelhante, BRIAN J. ARNOLD ${ }^{778}$ sustenta que quaisquer métodos de interpretação suportariam o recurso aos Comentários à CM-OCDE, inclusive o método literal. Neste, os Comentários à CM-OCDE seriam relevantes por veicularem sentidos especiais, com status do art. 31 (4) da CVDT. Conforme esse autor, a questão em aberto para quaisquer métodos de interpretação seria apenas o peso que deveria ser atribuído aos referidos Comentários.

Também é importante considerar que tal teoria ganha força nos casos em que há referência expressa no texto do acordo de dupla tributação aos Comentários à CM-OCDE. Tal medida pode ser observada em acordos como Portugal-EUA ${ }^{779}$, EUA-Reino Unido (2001), EUA-Japão (2001), Bélgica-Estônia, entre outros ${ }^{780}$. Como exemplo, o protocolo do acordo de dupla tributação Bélgica-Estônia prevê que a expressão "information concerning industrial, commercial or scientific experience", presente no art. 12 (3), deve ser interpretada em conformidade com os Comentários ao art. 12 (2) da CM-OCDE ${ }^{781}$.

Essa estratégia, elogiada por alguns ${ }^{782}$, é criticada por LUC DE BROE ${ }^{783}$. Ocorre que tal referência expressa poderia conduzir a outras dúvidas, como: também poderiam ser considerados tais materiais em relação a termos do acordo de bitributação, para os quais

\footnotetext{
${ }^{778}$ ARNOLD, J. Brian. The interpretation of tax treaties: myth or reality, in Bulletin for international Taxation (tax treaty monitor) - january of 2010. IBFD : Amsterdã, 2010, p. 13.

${ }^{779}$ Cf. XAVIER, Alberto. Direito Tributário Internacional do Brasil. Rio de Janeiro: Forense, 2010, p. 137.

${ }^{780}$ A Bélgica teria adotado tal medida nos acordos celebrados com Estônia, Latvia e Lituania. Nesse sentido, vide: BROE, Luc De. International tax planning and prevention of abuse (doctoral series n. 14). Amsterdã : IBFD, 2007, p. 296.

${ }^{781} \mathrm{Na}$ versão traduzida à lingua inglesa: "12, paragraph 3. It is understood that the term 'information concerning industrial, commercial or scientific experience' is to be interpreted according to the Commentary on paragraph 2 of Article 12 of the OECD Model Tax Convention on Income and on Capital". (IBFD, http://online.ibfd.org/kbase/\#topic=doc\&url=/data/treaty/docs/html/tt beee 01 eng_1999 tt td1.html\&WT.z_nav=Navigation\&colid=4932)

${ }^{782}$ TÔRRES, Heleno Taveira. Pluritributação internacional sobre as rendas das empresas. São Paulo : Revista dos Tribunais, 2001, p. 654.

${ }^{783}$ BROE, Luc De. International tax planning and prevention of abuse (doctoral series n. 14). Amsterdã : IBFD, 2007, p. 293.
} 
não foi realizada remissão aos Comentários à CM-OCDE? Vale notar, contudo, que nenhuma convenção fiscal celebrada pelo Brasil possui cláusula semelhante.

\subsubsection{Os Comentários à CM-OCDE como trabalhos preparatórios (CVDT, art. 32).}

Para uma quinta corrente, bem como para uma sexta analisada a seguir, os Comentários à CM-OCDE estariam sob o escopo do art. 32 da CVDT, assumindo a natureza jurídica, então, de meios suplementares de interpretação, relevantes apenas em situações de ambiguidade, obscuridade, absurdo ou ausência de razoabilidade. ${ }^{784}$ Sob tal insígnia, os defensores dessa corrente consideram que os Comentários à CM-OCDE não seriam vinculantes ${ }^{785}$.

Como se viu anteriormente, PHILIP BAKER ${ }^{786}$ sustenta que os Comentários à CMOCDE seriam instrumentos estabelecidos em conexão com cada acordo de dupla tributação, sob o escopo do art. 31 (2) "b" da CVDT e, portanto, capazes de vincular inclusive Estados não membros da OCDE. Além disso, o professor inglês também compreende os Comentários à CM-OCDE já existentes, quando da celebração de uma convenção fiscal como trabalhos preparatórios deste, sob o escopo, portanto, do art. 32 da CVDT.

Também essa corrente está sujeita a críticas. Autores como AlBerto XAVIER ${ }^{787}$ opõem que os Comentários não possuem a conexão necessária aos específicos acordos para que sejam considerados como trabalhos preparatórios à sua celebração.

\footnotetext{
${ }^{784}$ Cf. VOGEL, Klaus. The influence of the OECD Commentaries on Treaty Interpretation, in Bulletin Tax Treaty Monitor - December 2000. IBFD : Amsterdã, 2000, p. 614.

${ }^{785}$ Nesse sentido, vide: GUTMANN, Daniel. Tax treaty interpretation in France, in Tax treaty interpretation. LANG, Michael (ed). LINDE : Vienna, 2001,

${ }^{786}$ BAKER, Philip. Double taxation conventions and international tax law. Londres : Sweet \& Maxwell, 1994, par. C-13 e C-14.

${ }^{787}$ XAVIER, Alberto. Direito Tributário Internacional do Brasil. Rio de Janeiro: Forense, 2010, p. 137.
} 


\subsubsection{Os Comentários à CM-OCDE como circunstâncias em que os acordos de dupla tributação são celebrados (CVDT, art. 32).}

Por essa corrente ${ }^{788}$, os Comentários também estariam sob o escopo do art. 32 da CVDT, não como trabalhos preparatórios, mas como circunstâncias relacionadas à celebração da convenção fiscal. LUC DE BROE ${ }^{789}$ sugere ser uma tarefa difícil ou mesmo de pouca utilidade classificar os Comentários à CM-OCDE entre os elementos referidos nos arts. 31 e 32 da CVDT. No entanto, o autor compreende que os Comentários à CM-OCDE se assemelhariam às circunstâncias relacionadas à celebração do acordo de dupla tributação, sob o escopo, portanto, do art. 32 da CVDT.

Como oposição a tal tese, pode ser suscitado que os Comentários à OCDE não seriam suportados pelo escopo do art. 32 da CVDT, pois tal dispositivo se dirige aos documentos utilizados ou produzidos na elaboração e celebração de um acordo internacional em específico, o que não inclui a CM-OCDE e os seus Comentários, de modo que não se pode atribuir a esses o status de meio suplementar de interpretação. ${ }^{790}$

\subsubsection{Exemplo: Os tribunais do Canadá e a consideração dos Comentários à CM- OCDE como circunstâncias em que as convenções fiscais são celebradas.}

No Caso Pacific Network (Canadá, 2002), o tribunal canadense compreendeu que a CM-OCDE e os seus Comentários seriam evidências mais relevantes para a interpretação do acordo de dupla tributação Canadá-França, consignando o fato de que o Canadá seria um Estado membro da OCDE desde 1961, bem como teria participado ativamente no CAF-OCDE para a elaboração dos materiais em questão.

\footnotetext{
${ }^{788}$ Vide, por exemplo: AVERY JONES, John et al., The interpretation of tax treaties with particular reference to article 3(2) of the OECD Model - II. 1984, British Tax Review, p. 100; LANG, Michael. Introduction to the law of double taxation conventions. Vienna : Linde, 2013, p. 48 e seg.; GUTMANN, Daniel. Tax treaty interpretation in France, in Tax treaty interpretation. LANG, Michael (ed). LINDE : Vienna, 2001, p. 113-115.

${ }^{789}$ BROE, Luc De. International tax planning and prevention of abuse (doctoral series n. 14). Amsterdã : IBFD, 2007, p. 293.

${ }^{790}$ REIMER, Ekkehart. Interpretation of tax treaties - Germany. European Taxation. IBFD, 1999 (December), p. 467-469.
} 
Para os juízes canadenses, os Comentários à CM-OCDE formariam o contexto da convenção fiscal Canadá-França, em meio às circunstâncias de sua celebração.

\subsubsection{Os Comentários à CM-OCDE como práticas ou acordos subsequentes (CVDT, art. $31(3))$.}

Em uma sétima teoria, as versões "atualizadas" e "revisadas" dos Comentários à CM-OCDE poderiam ser consideradas como práticas ou acordos subsequentes, sob o escopo do art. 31 (3) da CVDT (contexto extrínseco primário). ${ }^{791}$

Além das duas outras categorias analisadas nos subtópicos anteriores instrumentos estabelecidos em conexão com a convenção, sob o escopo do art. 31 (2) "b" da CVDT, e trabalhos preparatórios, sob o escopo do art. 32 da CVDT -, PHILIP BAKER ${ }^{792}$ sustenta que também a teoria ora examinada estaria correta: novas versões dos Comentários, publicadas pelo CAF-OCDE, após a celebração de um acordo de dupla tributação, seriam práticas ou acordos subsequentes, sob o escopo do art. 31 (3) da CVDT.

$\mathrm{O}$ argumento de que as alterações nos Comentários da OCDE poderiam ser compreendidas como acordos subsequentes ao tratado, sob o escopo do art. 31 (3) "a" da CM-OCDE, foi rechaçado por KLAUS VOGEL ${ }^{793}$, por não visualizar a conexão necessária de tais materiais com as convenções anteriormente celebradas pelos Estados.

\subsubsection{Os Comentários à CM-OCDE como "soft law".}

Por uma sexta perspectiva, os Comentários à CM-OCDE seriam considerados "soft law”, com grau de normatividade menor que normas tradicionais, já que o seu

\footnotetext{
${ }^{791}$ Nesse sentido, vide: MAARTEN J. Ellis. The influence of the OECD Commentaries on Treaty Interpretation - Response to Prof. Dr. Klaus Vogel, in Bulletin - Tax Treaty Monitor - December 2000. IBFD : Amsterdã, 2000, p. 617-618.

${ }^{792}$ BAKER, Philip. Double taxation conventions and international tax law. Londres : Sweet \& Maxwell, 1994, par. C-13 e C-14.

${ }^{793}$ VOGEL, Klaus. Klaus Vogel on Double Taxation Conventions. Kluwer : London, 1999, p. 46.
} 
cumprimento seria apenas recomendável, sem qualquer sanção jurídica em caso de descumprimento. ${ }^{794}$

Tal teoria também chegou a receber a aprovação de KLAUS VOGEL ${ }^{795}$, ao menos em relação aos Estados-membros da OCDE, que em princípio estariam juridicamente obrigados a seguir a CM-OCDE e os seus Comentários. Para VoGEL, haveria certo grau de vinculação dos Estados membros (“at least some form of a 'soft' obligation”), já que os Estados deveriam seguí-las salvo no caso de reservas oportunamente opostas ou, ainda, de questões materiais por ventura existentes, como peculiaridades do Direito doméstico que impedissem o Estado de observá-las.

\subsubsection{Os Comentários à CM-OCDE como elemento da integração sistêmica (CVDT,} art. 31 (3) "c").

"Considering the unique position of the OECD Commentary - it is clearly part of the heuristic process of courts of OECD jurisdictions when interpreting tax treaties - reliance on article 31(3)(c) of the

Vienna Convention (1969) may prove to be an acceptable and legitimate way to justify recourse to the OECD Commentary. This might particularly hold true when the OECD Commentary is used to interpret a tax treaty that follows the OECD Model and where the tax treaty is concluded between two OECD member countries. In any case, article 31(3)(c) of the Vienna Convention (1969) provides an opportunity to proceed in a reasoned way if an interpretative argument on (one of the other) elements of article 31 proves to be unsuccessful",
DIRK BROEKHUIJSEN (2013)

Como se expôs no Capítulo III, o art. 31 (3) "c" da CVDT atribui relevância $a$ priori a "quaisquer regras pertinentes de Direito Internacional aplicáveis às relações entre as partes”, veiculando o princípio da integração sistêmica. Esse é o fundamento adotado por DIRK BROEKHUIJSEN ${ }^{797}$ para justificar o recurso aos Comentários à CM-OCDE como evidência extrínseca do sentido dos termos dos acordos de dupla tributação.

\footnotetext{
${ }^{794}$ Sobre o tema, apoiando a classificação de soft law, vide: BROEKHUIJSEN, Dirk M. A Modern Understanding of Article 31(3)(c) of the Vienna Convention (1969): A New Haunt for the Commentaries to the OECD Model?, in Bulletin for International Taxation, volume 67, n. 9. Amsterdã : IBFD, 2013, p. 4. Discordando da classificação enquanto soft law, vide: Silveira, Rodrigo Maitto da. Aplicação de Tratados Internacionais Contra a Bitributação - Qualificação de Partnership Joint Ventures. IBDT/Quartier Latin : São Paulo, 2006, p. 191-192.

${ }^{795}$ VOGEL, Klaus. Klaus Vogel on Double Taxation Conventions. Kluwer : London, 1999, p. 44. ("they are legally obligated to follow the Model and the Commentaries in principle”).

${ }^{796}$ BROEKHUIJSEN, Dirk M. A Modern Understanding of Article 31(3)(c) of the Vienna Convention (1969): A New Haunt for the Commentaries to the OECD Model?, in Bulletin for International Taxation, volume 67, n. 9. Amsterdã : IBFD, 2013, p. 8.

${ }^{797}$ BROEKHUIJSEN, Dirk M. A Modern Understanding of Article 31(3)(c) of the Vienna Convention (1969): A New Haunt for the Commentaries to the OECD Model?, in Bulletin for International Taxation, volume 67, n. 9. Amsterdã : IBFD, 2013.
} 
Entre os filtros estabelecidos pelo art. 31 (3) "c" da CVDT, para que outras regras de Direito internacional sejam evidências admissíveis, requer-se que sejam "aplicáveis às partes”. Daí, questiona o autor se apenas normas cogentes às partes estariam sob o escopo do aludido dispositivo: caso apenas normas cogentes sejam suportadas pelo princípio da integração sistêmica, os Comentários à CM-OCDE, por não serem cogentes, estariam de fora. Embora não ignore a oposição doutrinária, conclui que também normas não cogentes, como é o caso dos Comentários à CM-OCDE, estariam sob o escopo do art. 31 (3) "c" da CVDT.

As conclusões de DIRK BROEKHUIJSEN ${ }^{798}$ partem especialmente da jurisprudência da ECtHR, a exemplo dos casos Demir and Baykara v. Turkey e Saadi v. United Kingdom. No caso Demir and Baykara v. Turkey, foram consideradas evidências não cogentes, materiais produzidos pela "International Labour Organization" (ILO), recomendações da União Europeia, a "European Social Charter" (não ratificada pela Turquia) e a interpretação adotada pelo "Charter's Committee of Independent Experts”. No caso Saadi v. United Kingdom (2008), o art. 31(3) "c" da CVDT foi invocado para justificar o recurso às diretrizes das Nações Unidas quanto aos Direitos dos refugiados em relação à detenção arbitrária, bem como recomendações do Conselho europeu, as quais também não possuiriam cogência a priori.

\subsubsection{Os Comentários à CM-OCDE como doutrina dos publicistas mais qualificados das diferentes nações (CVDT, art. 31 (3) "c", c/c ECIJ, art. 38 (1) “c”). \\ "O peso interpretativo dos Comentários não pode, pois, ir além do que se reconhece à melhor doutrina" ALBERTO XAVIER (2010) $)^{799}$}

Conforme analisado anteriormente, não só indivíduos, mas também instituições podem assumir a feição de "doutrina dos publicistas mais qualificados das diferentes nações" para fins do contexto extrínseco secundário dos acordos de dupla tributação, com o status do art. 31 (3) "c" da CVDT, cumulado com o art. 38 (1) "c" do ECIJ. Assim, ainda

${ }^{798}$ BROEKHUIJSEN, Dirk M. A Modern Understanding of Article 31(3)(c) of the Vienna Convention (1969): A New Haunt for the Commentaries to the OECD Model?, in Bulletin for International Taxation, volume 67, n. 9. Amsterdã : IBFD, 2013.

${ }^{799}$ XAVIER, Alberto. Direito Tributário Internacional do Brasil. Rio de Janeiro: Forense, 2010, p. 136. 
que os Comentários à CM-OCDE e os reports publicados pelo CAF-OCDE possam ser motivados por questões não apenas acadêmicas, seria necessário considerar que tais materiais são elaborados por especialistas em Direito tributário internacional. Entre os autores que assim classificam os Comentários à CM-OCDE, podem ser citados FRANK VAN BRUNSCHOT ${ }^{800}$ e LUÍS EDUARDO SCHOEURI ${ }^{801}$. Para esse último professor, no entanto, apenas os Comentários produzidos após a celebração de um específico acordo de bitributação assumiriam tal natureza.

\subsubsection{Os Comentários à CM-OCDE como um contexto extrínseco sem paralelo na CVDT.}

Como se pôde observar, as teorias analisadas nos subtópicos anteriores procuram identificar os Comentários à CM-OCDE entre os elementos referidos na CVDT. Para LUC DE $\mathrm{BROE}^{802}$, tais materiais produzidos pelo CAF-OCDE não precisariam estar sob o escopo dos arts. 31, 32 e 33 para compor o "contexto" referido no art. 3 (2) da CM-OCDE. Ocorre que a CVDT não representaria uma codificação exaustiva quanto a todos os elementos úteis à interpretação de quaisquer acordos internacionais.

Sob tal perspectiva ${ }^{803}$, os Comentários à CM-OCDE existentes no momento em que a convenção fiscal foi celebrada comporiam o contexto extrínseco ("external context") e veiculariam sentidos especiais ("special meanings") que, por representarem o consenso dos Estados membros da OCDE (ou, ainda, dos Estados não membros convidados a participar como observadores), prevaleceriam sobre o Direito doméstico dos Estados contratantes quando fornecessem sentidos claros e livres de ambiguidades.

${ }^{800}$ BRUNSCHOT, Frank van. The Judiciary and the OECD Model Tax Convention and its Commentaries, in Bulletin - Tax Treaty Monitor of January 2005. IBFD, 2005, p. 6.

${ }^{801}$ SCHOUERI, Luís Eduardo. Tratados e Convenções Internacionais sobre Tributação, in Revista de Direito Tributário Atual n. 17. São Paulo : IBDT/Dialética, 2003, p. 40.

${ }^{802}$ BROE, Luc De. International tax planning and prevention of abuse (doctoral series n. 14). Amsterdã : IBFD, 2007, p. 293-296.

${ }^{803}$ BROE, Luc De. International tax planning and prevention of abuse (doctoral series n. 14). Amsterdã : IBFD, 2007, p. 295-299. 
No entanto, LUC DE BROE ${ }^{804}$ frisa que não utiliza a expressão “special meaning” com referência ao art. 31 (4) da CVDT, para o qual se exigiria a adoção de autênticos instrumentos de interpretação, o que não seria o caso dos Comentários à CM-OCDE.

\subsubsection{Conclusões e uma questão a mais: a mutação do status dos Comentários à CM- OCDE entre as evidências admitidas para a interpretação dos termos das convenções fiscais.}

A teoria que reconhece a natureza jurídica dos Comentários à CM-OCDE, equiparando-os à doutrina dos publicistas mais qualificados das diferentes nações, parece ser coerente com a única função que pode ser assumida por tais materiais, que não cria o Direito tributário internacional, mas apenas o descreve. Em especial, ao atribuir-se o status de doutrina aos Comentários, soluciona-se o obstáculo da ausência de participação do legislativo em sua produção.

É papel da doutrina analisar como um conjunto " $\mathrm{X}$ " de evidências poderiam conduzir à construção de determinados sentidos a partir dos termos da CM-OCDE, especialmente diante de situação que emerge da experiência empírica dos operadores do Direito tributário internacional. Seu papel é de tradução e auxílio, tal como realmente parece ser a função dos Comentários à CM-OCDE.

Os Comentários à CM-OCDE, tal como a doutrina: (i) não criam o sentido dos termos dos acordos de dupla tributação, mas apenas descrevem interpretações que o CAFOCDE compreende possíveis; (ii) são atemporais, pois as interpretações descritas em tais materiais poderiam ser consideradas plausíveis ou refutadas por Cortes nacionais, independentemente do momento de sua produção; (iii) requerem o recurso à analogia (iv) trata-se de uma instituição que congrega especialistas; $(v)$ promovem o critério funcional como meio auxiliar para a determinação de sentido; e (vi) requerem critérios materiais de reconhecimento, como perícia, reputação e plausibilidade.

\footnotetext{
${ }^{804}$ BROE, Luc De. International tax planning and prevention of abuse (doctoral series n. 14). Amsterdã : IBFD, 2007, p. 293-296.
} 
Os Comentários à CM-OCDE, tal como a doutrina, têm a vocação pedagógica, ilustrando aos operadores do Direito tributário internacional situações com as quais irão se deparar: ao ler os Comentários à CM-OCDE, pode-se aprender muito, implementar discussões e simular cenários sobre questões complexas ali retratadas. Tal como a doutrina, o CAF-OCDE deve aspirar à constante e proativa investigação por situações econômicas que demandam a reflexão quanto às normas da CM-OCDE e, dialeticamente, sugerir evidências que poderiam conduzir à construção de determinados sentidos.

Em relação aos Estados membros da OCDE, por força do 18 do regulamento daquela organização ${ }^{805}$, os Comentários funcionam como doutrina de consideração obrigatória e de observação dependente de sua plausividade.

O que de pior pode acontecer com os Comentários à CM-OCDE? Tornar-se literatura ruim, à qual se deve refugar sob pena de conclusões equivocadas.

Naturalmente, é possível que outras evidências demonstrem que os Estados contratantes atribuem aos termos não definidos em no texto de um acordo de bitributação os sentidos fornecidos pelos Comentários à CM-OCDE. Tal constatação, contudo, não altera o seu status original: se evidências demonstrassem que a doutrina de um determinado publicista teria sido decisivo para a delimitação dos termos adotados em uma certa convenção fiscal, sua relevância seria igual à dos Comentários também considerado pelos negociadores.

Além disso, um outro elemento deve ser adicionado ao debate: o fenômeno da mutação da natureza jurídica dos Comentários à CM-OCDE. Ocorre que, independente da discussão de quão vinculante são tais materiais ou mesmo quanto à natureza jurídica destes, a sua adoção expressa por uma Corte nacional - o que tem se tornado cada vez mais comum - lhe atribui um status extra, qual seja, de decisão de outros Estados contratantes (contexto extrínseco primário) ou, ainda, de decisão de terceiros Estados (contexto extrínseco secundário). Do mesmo modo, a sua adoção por autoridades

\footnotetext{
${ }^{805}$ OCDE. RULES OF PROCEDURE OF THE ORGANISATION. "VI. ACTS OF THE ORGANISATION. Rule 18. Último acesso em 20/10/2014, no endereço eletrônico http://www.oecd.org/legal/Rules\%20of\%20Procedure\%20OECD\%20Oct\%202013.pdf.)
} 
administrativas ou pelo Poder Judiciário poderá atribuir-lhe o status de práticas subsequentes conduzidas por estes, conforme analisados no Capítulo III.

Tal mutação não soluciona por si a questão da admissibilidade das evidências para a solução de um caso concreto. Se, por um lado, esse fenômeno atribui aos Comentários à CM-OCDE status de outros elementos, passa a ser necessário o enfrentamento de todas as questões suscitadas em relação ao seu novo enquadramento.

\subsubsection{Exemplo: O caso mexicano de mutação do status dos Comentários à CM- OCDE.}

O México apresenta situação peculiar. Em 1996, foi publicada uma resolução administrativa, vinculante para os agentes fiscais, segundo a qual a interpretação dos acordos de dupla tributação celebrados pelo México deveria ser realizada conforme os Comentários à CM-OCDE, na medida em que esses fossem congruentes com as disposições dos respectivos acordos internacionais e com as explicações técnicas emitidas pela Secretária da Fazenda mexicana. O dispositivo foi redigido da seguinte forma:

\footnotetext{
"15. Para la interpretación de los tratados celebrados por México para evitar la doble tributación, serán aplicables los Comentarios del Modelo de Convenio para Evitar la Doble Imposición e Impedir la Evasión Fiscal, a que hace referencia la recomendación adoptada por el Consejo de la Organización para la Cooperación y el Desarrollo Económico, el día 21 de septiembre de 1995 o aquella que la sustituya, en la medida en que los mismos sean congruentes con las disposiciones de los tratados celebrados por México y de acuerdo con las explicaciones técnicas emitidas por la Secretaría de Hacienda y Crédito Público."
}

No Caso Intercontinental (México, 1998), o tribunal mexicano reconheceu a vinculação das autoridades fiscais mexicanas aos Comentários à CM-OCDE, por força da referida norma doméstica. No caso, o tribunal recorreu aos Comentários para a interpretação dos termos "beneficiário efetivo" contidos no art. 11 do acordo MéxicoReino Unido. 


\subsection{Oposição de observações aos Comentários à OCDE: consequências sobre o seu status de evidência do sentido de termos dos acordos de dupla tributação.}

Os Comentários à $\mathrm{CM}^{-O C D E}{ }^{806}$ consignam que observações the podem ser opostas a pedido de Estados membros que não concordem com a interpretacação adotada pelo CAF-OCDE. Tais observações, no caso, não expressariam desacordo quanto ao texto da CM-OCDE em si, mas quanto sua à interpretação. Em sua versão inaugural, de 1963, nenhuma observação foi apresentada pelos Estados membros aos Comentários à CMOCDE, o que passou a ocorrer a partir da versão de 1977, quando foram opostas 36 observações $^{807}$, em número crescente.

As observações aos Comentários à CM-OCDE, argumenta GuGLIELMO MAISTO ${ }^{808}$, não possuiriam o perfil de declarações interpretativas assim que apresentadas ao CAFOCDE, nem seriam vinculantes nesse momento. No entanto, passariam a ser consideradas declarações interpretativas unilaterais em face de cada acordo de dupla tributação efetivamente celebrado entre os Estados, nos quais tais observações seriam implicitamente reiteradas. Embora não vinculem terceiros diante de seu caráter unilateral, tais observações poderiam se tornar vinculantes, especialmente quando o outro Estado contratante formalmente aceitasse a referida interpretação.

O professor italiano ainda pondera que, caso se considerem os Comentários veiculadores de sentidos especiais dos termos utilizados na CM-OCDE, então as observações opostas pelos Estados membros possuiriam a mesma natureza.

O silêncio dos Estados-membros diante de revisões dos Comentários à CM-OCDE, muitas delas bastante substanciais, pode ser visto como concordância às interpretações sugeridas pelo CAF-OCDE. Para HuGH AulT ${ }^{809}$, os Comentários à CM-OCDE assumiriam o papel de prover um sentido padrão (“default”) aos termos utilizados nos acordos de

\footnotetext{
${ }^{806}$ OECD. MODEL TAX CONVENTION (FULL VERSION), 2014, Introduction, par. 30.

${ }^{807}$ Cf. MAISTO, Guglielmo. The Observations on the OECD Commentaries in the Interpretation of Tax Treaties, in Bulletin for International Taxation - Agosto, vol. 59, n. 1. Amsterdã : IBFD, 2005, p. 14.

${ }^{808}$ MAISTO, Guglielmo. The Observations on the OECD Commentaries in the Interpretation of Tax Treaties, in Bulletin for International Taxation - Agosto, vol. 59, n. 1. Amsterdã : IBFD, 2005, p. 16-17.

${ }^{809}$ AULT, Hugh. The role of the OECD Commentaries in the Interpretation of Tax Treaties, in Intertax v. 22. Kluwer Law International : 1994, p. 146-147.
} 
dupla tributação que tiveram como base a CM-OCDE. Tal padrão poderia ser alterado pelos Estados por meio de observações aos Comentários, mas na ausência dessas operaria uma presunção a favor de tal sentido padrão.

Cite-se como exemplo a revisão dos Comentários ao art. 15 da CM-OCDE, alterando a perspectiva em relação ao termo "employer": apenas foram apresentadas observações em relação ao critério da "integral part of the business". 810

Estados não membros também podem apresentar reservas e observações à CMOCDE e aos seus Comentários, desde que convidados por aquela organização. Assim, por exemplo, o Brasil assumiu oficialmente a posição de não aderência à interpretação adotada nos Comentários à $\mathrm{CM}-\mathrm{OCDE}$ em relação à expressão sede de direção ("place of effective management"), a qual, para o CAF-OCDE, teria o sentido de local onde as principais decisões gerenciais e comerciais necessárias para a condução da entidade empresarial como um todo são substancialmente formuladas ${ }^{811}$. No caso, as autoridades fiscais brasileiras compreenderam que caberia à legislação doméstica e às Cortes nacionais definir o sentido de tal expressão ${ }^{812}$.

Por sua vez, pareceu óbvio a autores como KlaUs VoGEL ${ }^{813}$ e LUC De BROE ${ }^{814}$ que os Comentários à CM-OCDE não poderiam ser aplicados em toda a sua extensão aos Estados que lhe opuseram reservas ou observações.

Note-se que, diferente da CM-OCDE, a CM-ONU e os seus Comentários não estão abertos a reservas ou observações, de tal forma que não há espaço para que os Estados registrem suas posições e interpretações divergentes. Tal omissão, para WIM WIJNEN ${ }^{815}$, enfraqueceria a aptidão dos Comentários à CM-ONU à promoção da interpretação harmônica dos acordos de dupla tributação sob a CM-ONU.

\footnotetext{
${ }^{810}$ Nesse sentido, vide: DZIURDŹ, Kasper; PÖTGENS, Frank. Cross-Border Short-Term Employment, Bulletin for International Taxation Vol. 68, n. 8 (agosto). Amsterdã : IBFD, 2014, p. 409.

${ }^{811}$ OCDE, Model Tax Convention on Income and on Capital 2014 (Full Version), OECD Publishing, 2014. Introduction, p. 90-91, parágrafo n. 24 dos Comentários aos art. 4.

${ }^{812}$ OCDE, Model Tax Convention on Income and on Capital 2014 (Full Version), OECD Publishing, 2014. Introduction, p. 456, Posição de Estados não-membros em relação aos Comentários ao art. 4, parágrafo 12.

${ }^{813}$ VOGEL, Klaus. Klaus Vogel on Double Taxation Conventions. Kluwer : London, 1999, p. 44.

${ }^{814}$ BROE, Luc De. International tax planning and prevention of abuse (doctoral series n. 14). Amsterdã : IBFD, 2007, p. 293.

${ }^{815}$ WIJNEN, Wim. Some Thoughts on Convergence and Tax Treaty Interpretation, in Tax Treaty Monitor Bulletin for International Taxation (November 2013). IBFD: Amsterdã, 2013, p. 576.
} 


\subsubsection{Exemplo: A relevância de observações aos Comentários à CM-OCDE para os tribunais da Espanha.}

Nos casos Halcon (Espanha, 2011) e Televisió de Catalunya (Espanha, 2011), a fim de aplicar o acordo de dupla tributação Espanha-Países Baixos, o Tribunal Supremo espanhol deu destaque ao fato de que ambos os Estados contratantes seriam membros da OCDE e não opuseram quaisquer reservas à consideração dinâmica dos Comentários à $C M-O C D E$ e nem à revisão dos referidos Comentários em 1992, que alteraram substancialmente a interpretação do art. 17 (rendimentos de artistas e esportistas).

Para os julgadores espanhóis, tais fatores justificariam a adoção dinâmica dos Comentários à CM-OCDE para considerar - embora inexistente em seu texto - a cláusula do art. 17 (2) que passou a constar na CM-OCDE desde 1992, atinente à desconsideração de star companies.

\subsection{A natureza jurídica dos Comentários à CM-OCDE perante um Estado não membro e que não o adota integralmente em seus acordos de dupla tributação: Brasil.}

"Obviamente, no caso de acordos de bitributação assinados pelo Brasil, aquela Recomendação não tem força vinculante, já que o País não é membro da OCDE. Entretanto, se o País se dispõe a assinar um acordo segundo o modelo da OCDE, parece válido - a não ser que as circunstâncias indiquem o contrárioo argumento de que ambas as partes conhecem aquele modelo e, portanto, seus comentários", LUís EDUARDO SCHOUERI (2013) ${ }^{816}$

Para Vogel \& Prokisch ${ }^{817}$, a influência dos Comentários à CM-OCDE como parte do contexto também estaria presente quando os Estados adotam a CM-ONU como base para as suas negociações.

\footnotetext{
${ }^{816}$ SCHOUERI, Luís Eduardo. Preços de transferência no direito tributário brasileiro. São Paulo: Dialética, 2013, p. 410.

${ }^{817}$ VOGEL, Klaus; PROKISCH, Rainer G. Cahiers de Droit Fiscal International by the International Fiscal Association (studies on international tax law), volume LXXVIIIa - Subject I. Interpretation of double taxation conventions. Kluwer Law and Taxation Publishers / IFA : Rotterdam, 1993, p. 65.
} 
Por sua vez, é geralmente aceito ${ }^{818}$ que os Comentários à CM-OCDE se tornam menos importantes no caso de convenções fiscais envolvendo um Estado não membro da OCDE. Para KLAUS VOGEL ${ }^{819}$, a intenção de tais Estados em adotar os sentidos contidos nos Comentários não poderia ser afirmada de forma genérica e apenas poderia ser presumida se o texto do dispositivo coincidir com o adotado na CM-OCDE e não houver outra interpretação fornecida pelo "contexto".

Como se viu, a questão é especialmente relevante ao Brasil, que não é um Estadomembro da OCDE mas que, desde 1997, assume a posição de observador convidado. Luís EduARdo Schoueri \& Natalie Matos $\operatorname{Silva}^{820}$ se posicionam no sentido de que a adoção de dispositivos da CM-OCDE nos acordos de dupla tributação celebrados pelo Brasil pode representar um indicativo de que os Estados contratantes estavam conscientes quanto ao conteúdo de tal modelo e dos respectivos Comentários elaborados pelo CAFOCDE, salvo quando as circunstâncias conduzam à entendimentos diversos.

Com referência à jurisprudência de tribunais alemães, EKKEHART REIMER ${ }^{821}$ observa que os Comentários à CM-OCDE podem influenciar a interpretação de acordos de dupla tributação que sequer tenham seguido a mesma redação da CM-OCDE, desde que o contexto em que o referido acordo está inserido autorizasse tal recurso. Assim, apenas quando o texto de um acordo específico e o seu contexto indicassem a intenção de desalinhamento com os Comentários à CM-OCDE é que o recurso a eles seria totalmente dispensável. ${ }^{822}$

\footnotetext{
${ }^{818}$ Nesse sentido, vide: BROE, Luc De. International tax planning and prevention of abuse (doctoral series $\mathrm{n}$. 14). Amsterdã : IBFD, 2007, p. 294; HOFBAUER, Ines. Tax treaty interpretation in Austria, in Tax treaty interpretation. LANG, Michael (ed). LINDE : Vienna, 2001, p. 25.

${ }^{819}$ VOGEL, Klaus. Klaus Vogel on Double Taxation Conventions. Kluwer : London, 1999, p. 44.

${ }^{820}$ SCHOUERI, Luís Eduardo; SILVA, Natalie Matos. Brazil, in The Impact of the OECD and UN Model Conventions on Bilateral Tax Treaties. (Editores: LANG, Michael; PISTONE, Pasquale; SCHUCH, Josef; STARINGER, Claus). Cambridge : Cambridge University Press, 2012, p. 172-173.

${ }^{821}$ REIMER, Ekkehart. Interpretation of tax treaties - Germany. European Taxation. IBFD, 1999 (December), p. 467-469.

${ }^{822}$ Cf. VOGEL, Klaus. Klaus Vogel on Double Taxation Conventions. Kluwer : London, 1999, p. 44.
} 


\title{
5.6. Critérios funcionais: a promoção do efeito útil e da interpretação harmônica pelos Comentários à CM-OCDE.
}

\begin{abstract}
"Daí concluir-se que se dois Estados Contratantes celebram um acordo de bitributação contendo dispositivo extraído da Convenção-Modelo da OCDE, é razoável dar àquele acordo, no que tange ao dispositivo em exame, a interpretação proposta no comentário da OCDE, se divulgada no momento da celebração do acordo, já que esta interpretação será a que melhor propiciará a harmonia decisória, necessária à finalidade do acordo de dupla tributação". LUÍS EDUARDO SCHOUERI (2013) $)^{823}$
\end{abstract}

Assumindo-se que os Comentários à CM-OCDE estejam sob o escopo do art. 31 (3) “c" da CVDT c/c art. 38 (1) “c”" do ECIJ, passa a ser relevante adentrar-se na análise de critérios funcionais, isto é, relacionados à sua aptidão para a promoção do efeito útil e à interpretação harmônica de acordos de dupla tributação.

Como se viu, parte da doutrina sustenta que a interpretação harmônica não dependeria da adoção dos mesmos métodos de interpretação por ambos os Estados contratantes, mas que esses obtivessem um mesmo resultado em seu processo. Sob tal premissa, então, a interpretação harmônica poderia ser eficazmente concretizada caso ambos os Estados contratantes recorressem aos Comentários à CM-OCDE, que não sugerem formas para se construir o sentido dos termos dos acordos, mas apresentam cruamente tal sentido. Além disso, em geral, as teorias desenvolvidas por variados autores concordam que seria meritório, caso os Comentários à CM-OCDE tornassem fluente uma linguagem tributária internacional ${ }^{824}$, da qual decorreria a interpretação harmônica de todos os acordos de dupla tributação.

Os Comentários à CM-OCDE, assim, poderiam ser eficazes para a promoção do efeito útil dos acordos de dupla tributação. Em primeiro lugar, os objetivos e propósitos de coordenação, cooperação e reciprocidade seriam, em tese, vivificados nos Comentários à CM-OCDE, que supostamente ensejariam a discussão entre os mais variados Estados com participação naquela organização, possibilitando inclusive a oposição de reservas que, em última análise, evitariam que compreensões divergentes se tornariam conflitos.

\footnotetext{
${ }^{823}$ SCHOUERI, Luís Eduardo. Preços de transferência no direito tributário brasileiro. São Paulo: Dialética, 2013, p. 409-410.

${ }^{824}$ Nesse sentido, vide: RAAD, Kees van. International coordination of tax treaty interpretation and application, in International and comparative taxation - essays in honour of Klaus Vogel. KIRCHHOF, Paul et. al. eds London : Kluwer, 2002.
} 
Nesse seguir, o CAF-OCDE considera que diversas dificuldades que surgem na aplicação das convenções fiscais poderiam ser superadas com uma melhor coordenação entre os Estados na interpretação e aplicação de tais tratados, o que tornaria relevante a ampla observância de suas recomendações. ${ }^{825}$

A promoção do objetivo e propósito de evitar a dupla tributação (ou, ainda, a dupla não tributação) também poderia ser - em tese - alcançada se os dois Estados contratantes seguissem as recomendações do CAF-OCDE como evidência quanto ao sentido dos termos insertos em seu acordo de dupla tributação. Se ambos os Estados contratantes aceitassem como plausível uma mesma interpretação apresentada pelos Comentários à CM-OCDE, a interpretação harmônica redundaria em coordenação e reciprocidade.

No entanto, algumas objeções podem ser opostas a tais conclusões, também relacionadas à promoção do efeito útil pelos Comentários à CM-OCDE.

Em primeiro lugar, a aceitação às cegas dos Comentários à CM-OCDE pode conduzir ao enfraquecimento ou mesmo engessamento da cooperação entre os Estados: restaria ausente a necessidade de diálogo, já que bastaria a ambas as partes contratantes seguir os Comentários à CM-OCDE. Além disso, não é tão claro se há efetiva discussão entre os Estados na elaboração dos Comentários.

Em segundo lugar, é importante observar que também os Comentários à CMOCDE estão sujeitos à interpretação e, por conseguinte, há divergências interpretativas entre os Estados contratantes. Como observa WiM WiJNEN ${ }^{826}$, ainda que se aceite que os Comentários à OCDE sejam hábeis para dirimir dúvidas quanto ao sentido dos termos de convenções fiscais, a interpretação harmônica entre os Estados contratantes poderia ser obstada por divergências na interpretação dos próprios Comentários: tais materiais, que se destinam à interpretação dos acordos em matéria tributária são, eles próprios, interpretados de variadas formas por diferentes tribunais nacionais e, ao invés de colaborar, às vezes criam eles próprios outros problemas interpretativos.

${ }^{825}$ OECD. The application of the OECD Model Tax Convention to partnerships", in OECD, Model Tax Convention on Income and on Capital 2010 (Full Version), OECD Publishing, p. 7.

${ }^{826}$ WIJNEN, Wim. Some Thoughts on Convergence and Tax Treaty Interpretation, in Tax Treaty Monitor Bulletin for International Taxation (November 2013). IBFD: Amsterdã, 2013, p. 576. 
Por fim, ainda que soe auspicioso o argumento da praticidade de um guia central de interpretação aplicável a todos os acordos de dupla tributação celebrados sob os moldes da CM-OCDE, é necessário refletir por qual razão os Comentários à CM-OCDE ainda não receberiam, após tantas décadas de existência, o aval e prestígio geral da doutrina e da jurisprudência de Cortes nacionais como um meio eficaz para a promoção da interpretação harmônica e do efeito útil. Entre as possíveis respostas, pode-se considerar que o CAF-OCDE peca pela falta de justificação de suas conclusões, pela manutenção de contradições e pela flutuação de suas posições presentes em alguns comentários que, muitas vezes parecem estar vocacionados por fatores econômicos e não jurídicos. $O$ subtópico a seguir tem como especial objeto tal questão, ao abordar o aspecto material da plausibilidade dos Comentários à CM-OCDE.

\subsubsection{Exemplo: A consideração dos Comentários à CM-OCDE pelos tribunais ingleses como forma de promover o efeito útil e a interpretação harmônica das convenções fiscais.}

No Caso Tomislav (Reino Unido, 2011), o tribunal abertamente recorreu aos Comentários à CM-OCDE relativos ao seu art. 15 (2) “b” para a aplicação do acordo de dupla tributação Reino Unido-Croácia. Embora o Reino Unido fosse um membro fundador da OCDE, a Croácia não possui participação naquela organização: não se trata de um Estado membro ou mesmo observador da OCDE.

O risco de apenas o Reino Unido observar os Comentários à CM-OCDE na interpretação do acordo de dupla tributação com a Croácia poderia ser o prelúdio de interpretações divergentes, o qual a juíza ANNE SCOTT cuidou de afastar. Para justificar que a interpretação harmônica do acordo internacional em questão seria provida se o Reino Unido observasse os Comentários à CM-OCDE, a decisão atribui fé à afirmação do fisco inglês de que, conforme a sua experiência, a Croácia também aplicaria os seus acordos de dupla tributação em conformidade com tais materiais. 


\subsection{O critério material: a plausibilidade dos Comentários à CM-OCDE.}

"As you know, when everybody puts in a colour, the result is grey. With the OECD Model Commentary, it is about the same. The Commentary is full of contradictions. I have a running bet with a friend that whenever he can support a statement by referencing the OECD Commentary, I can support the opposite statement by quoting the Commentary".

MAARTEN J. ELLIS (2000) $)^{827}$

A questão da plausividade dos Comentários à CM-OCDE é relevante. A não ser que se assuma que devem ser considerados pelo intérprete simplesmente por se tratar dos Comentários à CM-OCDE (isto é, relevantes por natureza), a sua influência depende da qualidade de seu conteúdo. Além disso, ao assumir-se a análise dos Comentários à CMOCDE sob o contexto intrínseco dos acordos de dupla tributação, com o status da doutrina dos publicistas mais qualificados das diferentes nações, tais materiais assumem feição pedagógica, para a qual a plausividade é fundamental. Os Comentários à CMOCDE assumem o perfil de doutrina dos publicistas mais qualificados das diferentes nações, assumindo, então, fatores em comum, demandando aqueles critérios materiais de reconhecimento, como perícia, reputação e plausibilidade.

No entanto, como se colhe da crítica em epígrafe, as objeções mais graves opostas aos Comentários à CM-OCDE estão justamente relacionadas à sua plausividade e coerência. Dificilmente se encontrará alguém que recuse todas as posições assumidas pelos Comentários à CM-OCDE. No entanto, também não há como deixar de reconhecer contradições e posições de fraca sustentação em tais trabalhos.

Muitas vezes, os Comentários não apresentam uma clara interpretação sobre o dispositivo analisado, limitando-se a apresentar um background sobre o dispositivo, com supostas intenções dos responsáveis pela elaboração da minuta do modelo de convenção. Como observa MiCHAEL $\mathrm{LANG}^{828}$, não é raro que os Comentários simplesmente apresentem as conclusões e posições apregoadas pelo CAF-OCDE, sem referências quanto aos seus fundamentos. Por tal razão, o professor de Viena lamenta que os Comentários frequentemente não possuam persuasão suficiente para influenciar na solução de questões concretas.

\footnotetext{
${ }^{827}$ MAARTEN J. Ellis. The influence of the OECD Commentaries on Treaty Interpretation - Response to Prof. Dr. Klaus Vogel, in Bulletin - Tax Treaty Monitor - December 2000. IBFD : Amsterdã, 2000, p. 618. ${ }^{828}$ LANG, Michael. Introduction to the law of double taxation conventions. Viena : Linde, 2013, p. 48 e seg.
} 
Nessa mesma linha, embora considere que os Comentários à CM-OCDE não vinculem o juiz, FRANK VAN BRUNSCHOT ${ }^{829}$ reconhece que esses o auxiliam na interpretação dos acordos de dupla tributação ("Would the judiciary be better off without the OECD Model and Commentaries? Definitely not!"'). O autor, no entanto, destaca falhas que os tornam imprestáveis em relação a diversos assuntos. Além do insuficiente e raso tratamento do "contexto" referido no art. 3 (2) da CM-OCDE, outros estudos elaborados pelo CAF-OCDE seriam também inconclusivos em diversos assuntos, como no Transfer Pricing Guidelines, que o autor classifica como monumento de contradições, por tentar acriticamente conciliar uma série de sistemas internos de Estados membros com perspectivas, muitas vezes, inconciliáveis.

O report do CAF-OCDE quanto às partnerships também é criticável. Por ausência de justificação e por autolegitimação de suas premissas, em processo movimento autopoiético. Crítico severo desse material, MiCHAEL LANG ${ }^{830}$ suscita, por exemplo, que o CAF-OCDE adota a premissa de que suas conclusões seriam relevantes aos acordos já celebrados e aos acordos que viessem a ser assinados, sem que qualquer fundamentação tenha sido exposta para tanto. A isso opõe esse professor que, por não se tratar de um órgão competente para produzir normas no Direito Internacional, não cumpre ao CAFOCDE decidir qual a relevância de suas conclusões; se as conclusões obtidas no report são relevantes ou não, depende de quão convincentes essas se apresentam. Ocorre que, quando tais reports deixam de fundamentar as posições assumidas, o que ocorre em diversas passagens importantes, enfraquecem a sua relevância para a interpretação de casos concretos e o seu potencial para servir de evidência convincente.

$\mathrm{O}$ report do CAF-OCDE atinente às partnerships fornece ainda outros exemplos. Como se analisou no Capítulo I desta tese, os acordos de dupla tributação possuem hipóteses expressas de reenvio ao Direito doméstico dos Estados contratantes. Em especial, para se identificar sujeito intitulado a requerer os benefícios desses acordos de dupla tributação, é necessário recorrer à definição de contribuinte no Direito doméstico. O report assume tal premissa, mas aponta que o caso das partnerships seria uma exceção, sem

\footnotetext{
${ }^{829}$ BRUNSCHOT, Frank van. The Judiciary and the OECD Model Tax Convention and its Commentaries, in Bulletin - Tax Treaty Monitor of January 2005. IBFD, 2005, p. 6.

${ }^{830}$ LANG, Michael. The application of the OECD Model Tax Convention to Partnerships - A critical Analysis of the Report Prepared by the OECD Committee on Fiscal Affairs. Viena : Linde, 2000, p. 15-20.
} 
apresentar, contudo, justificativas para tanto. A tal postura MICHAEL LANG ${ }^{831}$ opõe críticas bastante severas, considerando deplorável a sua ausência de razoabilidade ("The lack of reasoning in this paragraph is very deplorable").

\subsection{Revisões nos Comentários à CM-OCDE e a sua influência na construção de sentido dos termos dos acordos de dupla tributação.}

"At the same time, however, as you rightly point out, the fact that the Commentary is now changed so frequently and that it is impossible to track those changes, if I may put it a little bit more extremely than you have, makes it less valuable and certainly less authoritative. So, on the one hand, the courts want to use the Commentary more and more; on the other hand, the OECD makes that more and more difficult for them.

I do not know where that should lead us". MAARTEN J. ELLIS ${ }^{832}$

\subsubsection{A política de revisões frequentes dos Comentários à CM-OCDE.}

O contínuo trabalho do CAF-OCDE exige que os interlocutores previamente especifiquem qual a versão da CM-OCDE ou de seus Comentários será objeto de discussão: caso versões diferentes sejam adotadas, o dialógo pode restar prejudicado por se discutir materiais diferentes. Assim, a consideração de que os Comentários à CM-OCDE fariam parte do "contexto" ou, ainda, a adoção da teoria da correlação do "contexto" com os Comentários à CM-OCDE, conduz a doutrina especializada, Cortes nacionais e o próprio CAF-OCDE a discutir qual de suas várias versões deveria ser utilizada pelo intérprete na construção de sentido de cada convenção fiscal: a consideração estática ou a consideração dinâmica? Caso os advogados do contribuinte recorram aos Comentários à CM-OCDE contemporâneos à celebração do acordo de dupla tributação, por se mostrarem favoráveis, mas os advogados do fisco recorram aos Comentários à CM-OCDE revisados e publicados ao tempo da aplicação do acordo, por lhes serem favoráveis, qual deles deveria ser considerado pelo juiz? No caso, aqueles primeiros estariam se apoiando na consideração estática (“static approach”) dos Comentários à CM-OCDE, enquanto esses outros na sua consideração dinâmica (“ambulatory approach”).

${ }^{831}$ LANG, Michael. The application of the OECD Model Tax Convention to Partnerships - A critical Analysis of the Report Prepared by the OECD Committee on Fiscal Affairs. Viena : Linde, 2000, p. 29.

${ }^{832}$ MAARTEN J. Ellis. The influence of the OECD Commentaries on Treaty Interpretation - Response to Prof. Dr. Klaus Vogel, in Bulletin - Tax Treaty Monitor - December 2000. IBFD : Amsterdã, 2000, p. 617618. 
Essa essa não fosse a posição sustentada até 1997, os Comentários à CM-OCDE, a partir da revisão publicada naquele ano, passou a auto considerar-se aplicável de forma dinâmica $^{833}$. No entanto, os Comentários ressalvam que apenas seria cabível a consideração dinâmica de alterações na CM-OCDE e em seus Comentários que simplesmente aclarassem interpretações que já seriam possíveis na versão revisada.

É preciso ser claro: aceitar a consideração dinâmica dos Comentários à CM-OCDE é atribuir Poder Legislativo ao CAF-OCDE.

A consideração estática dos Comentários à CM-OCDE, como observou KLAUS VOGEL $^{834}$, tem fundamento no princípio da legalidade em matéria tributária. Tendo em vista que o CAF-OCDE é composto apenas por representantes do Poder Executivo dos Estados membros, sem competência para delimitar ou alterar o acordo de dupla tributação, apenas os Comentários à CM-OCDE contemporâneos à celebração do acordo ratificado pelo Poder Legislativo dos Estados contratantes teriam alguma relevância. Adotada a postura estática, contudo, surgem problemas práticos para a colheita de evidências ${ }^{835}$, tendo em vista o modo pelo qual a OCDE tem publicado as alterações nos comentários.

A fim de ultrapassar tais questões, alguns Estados vêm inserindo no texto de seus acordos de dupla tributação cláusulas expressas, em que os Comentários à CM-OCDE devem ser considerados de forma dinâmica, a exemplo do protocolo do acordo ÁustriaUcrânia $^{836}$. Parece remanescer, contudo, que limitações Constitucionais aplicáveis sejam suscitadas em face da própria norma do tratado, o que não afasta o debate, mas acrescenta um fator a mais à discussão.

\footnotetext{
${ }^{833}$ OECD, Model Tax Convention on Income and on Capital 2014 (Full Version), OECD Publishing, 2014. Introduction, par. 3, p. I.1.

${ }_{834}^{834}$ VOGEL, Klaus. Klaus Vogel on Double Taxation Conventions. Kluwer : London, 1999, p. 46-47.

${ }^{835}$ AULT, Hugh. The role of the OECD Commentaries in the Interpretation of Tax Treaties, in Intertax v. 22. Kluwer Law International : 1994, p. 148.

${ }^{836}$ Cf. HOFBAUER, Ines. Tax treaty interpretation in Austria, in Tax treaty interpretation. LANG, Michael (ed). LINDE : Vienna, 2001, p. 26-29.
} 


\subsubsection{Exemplo: nem todos os Comentários à CM-OCDE são constantemente revisados.}

A cautela que se exige na consideração de Comentários à CM-OCDE é que cada vez mais as posições sugeridas por tais materiais no momento em que o acordo foi celebrado flutuam até o momento em que um dos Estados contratantes de um acordo celebrado em seus moldes o aplica. É o que se pode observar nos subtópicos seguintes.

Certamente, contudo, há muitos casos em que tal situação não ocorre.

No Caso Pacific Network (Canadá, 2002), o tribunal canadense recorreu à CMOCDE e aos seus Comentários para a aplicação do art. 26 do acordo de dupla tributação Canadá-França de 1975, com a redação que lhe foi dada em 1995 pelo protocolo celebrado entre as partes. A decisão investigou as versões de 1977, 1992, 1996 e 2000 da CM-OCDE e consignou que o art. 26 teria permanecido sem alterações, bem como as alterações introduzidas pelo protocolo de 1995, celebrado entre Canadá e França, teriam alinhado o acordo de dupla tributação mantido entre esses Estados ao modelo da OCDE. Além disso, a decisão também observou que, em relação aos tópicos relevantes ao caso, os Comentários à CM-OCDE não teriam sofrido alteração em suas versões de 1977 (existentes à época em que o protocolo foi celebrado), 1996 e 2000.

\subsubsection{A perda de credibilidade dos Comentários em função de suas constantes revisões.}

Apenas dois anos após o início da política do CAF-OCDE de publicar revisões pontuais aos Comentários à CM-OCDE sob a sistemática de folhas soltas, o Editorial do conhecido periódico Intertax, de novembro de 1994, recebeu o título "Changes to OECD Commentary may affect its credibility" ${ }^{837}$. As frequentes revisões realizadas pelo CAF$\operatorname{OCDE}(1992,1994,1995,1997,2000,2003,2005,2008,2010$ e 2014) tornaram a doutrina ainda mais cautelosa - ou mesmo receosa - para o recurso aos Comentários à CM-OCDE.

\footnotetext{
${ }^{837}$ ROMYN, Marcel. Editorial - Changes to OECD Commentary may affect its credibility, in Intertax 1994/11, Intertax, 1994, p. 470-472.
} 
Embora KLAUS VogeL ${ }^{838}$ tenha reconhecido que, em tese, os Comentários poderiam assumir tanto a posição do sentido ordinário quanto do sentido especial referidos na CVDT, bem como poderiam ser considerados em algumas situações de forma dinâmica, o professor lamentou que todas essas convicções teriam sido destruídas pelas incessantes alterações na CM-OCDE e em seus Comentários em espaços exíguos de tempo, bem como pela forma como tais revisões vinham sendo publicadas. Diante disso, inclusive Estados membros da OCDE deveriam estar alertas para adotar severas reservas ao recorrer aos Comentários para a interpretação de seus acordos de dupla tributação. Na literatura brasileira, Luís EDUARDO SCHOUERI ${ }^{839}$ adverte que a frequente mudança de posição do CAF-OCDE manifestada na revisão dos Comentários seria um argumento forte para a adoção de muitas cautelas ao se considerar os Comentários à CM-OCDE: as sugestões da CAF-OCDE de hoje podem não refletir os Comentários existentes à época da negociação e celebração da convenção fiscal em questão.

No entanto, nem todas as revisões dos Comentários à CM-OCDE são absolutamente repugnadas pela doutrina. Como suscita LUC DE BROE ${ }^{840}$, seria necessário distinguir quatro espécies de alterações em tais materiais: (i) novos Comentários que amplificam interpretações que desde sempre seriam possíveis a partir do texto da CMOCDE; (ii) preenchimento de lacunas por meio dos Comentários; (iii) novos Comentários revertendo posições anteriores do CAF-OCDE e; (iv) alinhamento dos Comentários às novas práticas dos Estados.

Tal segmentação do tema parece apropriada e será adotada nos subtópicos seguintes.

\footnotetext{
${ }^{838}$ VOGEL, Klaus. The influence of the OECD Commentaries on Treaty Interpretation, in Bulletin - Tax Treaty Monitor - December 2000. IBFD : Amsterdã, 2000, p. 616.

${ }^{839}$ SCHOUERI, Luís Eduardo. Preços de transferência no direito tributário brasileiro. São Paulo: Dialética, 2013, p. 412.

${ }_{840}$ BROE, Luc De. International tax planning and prevention of abuse (doctoral series n. 14). Amsterdã : IBFD, 2007, p. 297-299.
} 


\subsubsection{Revisão dos Comentários à CM-OCDE para amplificar interpretações que desde sempre seriam possíveis a partir do texto dos acordos de dupla tributação.}

As chamadas revisões amplificadoras seriam alterações nos Comentários à CMOCDE que apenas tornariam mais claras interpretações que desde sempre seriam possíveis em face da CM-OCDE. Para LuC De Broe, tais materiais poderiam compor o contexto extrínseco dos acordos de dupla tributação. Após uma cuidadosa análise quanto ao que realmente foi revisado pelo CAF-OCDE, seria legítima, então, a consideração dinâmica.

Tal como um texto doutrinário moderno pode explicar com clareza ímpar norma jurídica de séculos, os Comentários à CM-OCDE também poderiam ser considerados atemporais, pois as interpretações descritas em tais materiais poderiam ser consideradas plausíveis ou refutadas por Cortes nacionais, independentemente do momento de sua produção.

É possível observar que, em geral, a consideração dinâmica de revisões meramente amplificadoras não encontra maiores oposições na doutrina ${ }^{841}$. O ponto nevrálgico consiste em saber quando uma revisão seria puramente esclarecedora, amplificadora.

Nesse seguir, MAARTEN J. ELLIS ${ }^{842}$ adverte que uma alteração no texto dos Comentários nunca seria realmente neutra: qualquer alteração, ainda que na ordem das palavras ou nas vírgulas utilizadas, teria consequências, mais cedo ou mais tarde. Seria artificial a distinção de alterações estilísticas, explicativas do que já existiria e materiais.

Embora tenha revisto a sua posição em meados de $2000^{843}$, KLAUS VOGEL ${ }^{844}$ também observou que a tese defendida pela OCDE não se sustentaria, inclusive em conta do dilema de se saber se a nova versão dos comentários realmente comporta interpretações já suportadas pelo acordo assinado. Para esse professor, apenas os Comentários já existentes no momento da celebração do acordo de dupla tributação seriam relevantes.

\footnotetext{
${ }^{841}$ Nesse sentido, vide: VOGEL, Klaus. Klaus Vogel on Double Taxation Conventions. Kluwer : London, 1999, p. 43-47.

${ }^{842}$ MAARTEN J. Ellis. The influence of the OECD Commentaries on Treaty Interpretation - Response to Prof. Dr. Klaus Vogel, in Bulletin - Tax Treaty Monitor - December 2000. IBFD : Amsterdã, 2000, p. 617618.

${ }^{843}$ VOGEL, Klaus. The influence of the OECD Commentaries on Treaty Interpretation, in Bulletin - Tax Treaty Monitor - December 2000. IBFD : Amsterdã, 2000.

${ }^{844}$ VOGEL, Klaus. Klaus Vogel on Double Taxation Conventions. Kluwer : London, 1999, p. 46-47.
} 


\subsection{Exemplo: revisões amplificadoras de interpretações desde sempre possíveis.}

Com a revisão de 2005, o parágrafo 5.2 dos Comentários ao art. 26 da CM-OCDE passou a consignar que a cláusula de troca de informações seria aplicável a "taxes of every kind and description”. Tais Comentários, adotados a partir de 2005, transcrevem passagens do art. 27 (1) da Convenção da OCDE do Conselho da Europa, de 1988.

Sob tal perspectiva, AdOLFO J. MARTín JiMÉNEZ ${ }^{845}$ suscita que alterações introduzidas em 2005, no parágrafo 5.2 dos Comentários ao art. 26 da CM-OCDE, apenas reconheceriam a influência de outras normas pré-existentes no Direito internacional (princípio da integração sistêmica), amplificando que evidências colhidas de parallel treaties confirmam que contribuições sociais estariam sob o escopo do termo "taxes" para fins da cláusula de troca de informações do art. 26 da CM-OCDE.

Tal caráter pedagógico permitiria aos Comentários aclarar ainda mais a relação dos acordos de dupla tributação com outros acordos internacionais. Ocorre que os Comentários à referida Convenção da OCDE do Conselho da Europa, datados de 1989, destacam que a troca de informações regulada por aquela convenção abrangeria também contribuições sociais $^{846}$.

\subsubsection{Revisão dos Comentários à CM-OCDE para o preenchimento de lacunas dos acordos de dupla tributação.}

O preenchimento de lacunas, para LuC DE BROE, estaria entre as situações mais problemáticas, não sendo possível sustentar que tais materiais sejam vocacionados a refletir a intenção dos Estados contratantes de acordos já celebrados. É importante notar que aquele professor de Leuven sustenta que, em quaisquer dessas quatro situações, novos

\footnotetext{
${ }^{845}$ JIMÉNEZ, Adolfo J. Martín. Defining the objective scope of income tax treaties: the impact of the other treaties and EC Law on the Concept of Tax in the OCED Model, in Bulletin - Tax Treaty Monitor - October 2005. Amsterdã : IBFD, 2005, p. 432 e seg.

${ }^{846}$ Cf. JIMÉNEZ, Adolfo J. Martín. Defining the objective scope of income tax treaties: the impact of the other treaties and EC Law on the Concept of Tax in the OCED Model, in Bulletin - Tax Treaty Monitor October 2005. Amsterdã : IBFD, 2005, p. 432 e seg.
} 
Comentários à CM-OCDE não poderiam afetar rendimentos já auferidos ou operações já realizadas, de forma a tornar mais severa a tributação sobre o contribuinte.

Por sua vez, alguns doutrinadores chegam a considerar preferível que alterações sejam feitas nos Comentários à CM-OCDE do que na própria CM-OCDE: adotando-se como premissas o efeito vinculante e a interpretação dinâmica dos Comentários, as alterações realizadas nestes teriam eficácia imediata sobre todas as relações internacionais realizadas sob acordos de dupla tributação já celebrados com base na convenção modelo, enquanto que, para que alterações na CM-OCDE em si tivessem eficácia, seria necessário renegociar e alterar a rede de acordos celebrados até ali.

Tal questão foi analisada por KLAUS VOGEL ${ }^{847}$, que adotou como mote o segundo dos dez enunciados do "Dr. Loukota's 10 Guiding Principles", apresentados por HeLMUT Loukota, no Congresso da IFA de 1999: $2^{\circ}$ - "Changing the OECD Commentary is preferable to changing the Model Convention". VoGEL, contudo, concluiu que apenas quando as alterações nos Comentários não os afetassem materialmente, isto é, quanto apenas clarificassem interpretações que já estariam implícitas no texto da CM-OCDE, é que a consideração dinâmica seria admissível. Por sua vez, apenas os Comentários existentes no momento em que o acordo de dupla tributação foi celebrado vinculariam os Estados, com fulcro no "sentido ordinário" referido no art. 31 (1) ou o "sentido especial" referido no art. 31 (4), ambos da CVDT.

Nesse mesmo seguir, Hugh AULT ${ }^{848}$ observa que, tal como o Direito doméstico não pode ser modificado para impor alterações no que foi contratado pelos Estados, a mesma regra deve ser observada em relação aos Comentários da OCDE. O autor concorda que, embora revisões no texto para tornar a sua formulação mais clara sejam possíveis, a adoção dinâmica dos Comentários apenas seria admissível em tais casos.

${ }^{847}$ VOGEL, Klaus. The influence of the OECD Commentaries on Treaty Interpretation, in Bulletin - Tax Treaty Monitor - December 2000. IBFD : Amsterdã, 2000, p. 612 e seg.

${ }^{848}$ AULT, Hugh. The role of the OECD Commentaries in the Interpretation of Tax Treaties, in Intertax v. 22. Kluwer Law International : 1994, p. 148. 


\subsection{Exemplo: revisões dos Comentários à CM-OCDE para o preenchimento de lacunas no art. 17 dos acordos de bitributação.}

Nos casos Halcon (Espanha, 2011) e Televisió de Catalunya (Espanha, 2011), o Poder Judiciário espanhol não poderia deixar expresso de forma mais clara que segue os Comentários à CM-OCDE de forma dinâmica, ainda que tal perspectiva conduzisse à revisão do acordo de dupla tributação pela via jurisprudencial e, portanto, unilateral.

Nesses casos, para a aplicação do acordo Espanha-Países Baixos de 1971, o tribunal considerou presente - embora inexistente em seu texto - a cláusula do art. 17 (2) que passou a constar da CM-OCDE desde 1992. Os julgadores espanhóis consignaram expressamente que reconheciam o salto qualitativo importante e a modificação quase da totalidade dos Comentários ao art. 17 da CM-OCDE desde a versão de 1992, para decidir que tais evoluções deveriam ser incorporadas ao acordo internacional.

Em passagem transcrita no Caso Televisió de Catalunya, consignou o Juiz JUAN Gonzalo Martinez Mico, no Caso Halcon, saber das críticas doutrinárias a que tal decisão estaria sujeita, por incorporar unilateralmente ao acordo bilateral celebrado com outro Estado soberano. A justificativa para tal agir, para os julgadores espanhóis, residia na necessidade de se recorrer aos mais modernos Comentários à CM-OCDE quanto aos métodos para se prevenir planejamentos tributários abusivos e, assim, preservar a soberania reservada à Espanha pelo acordo Espanha-Países Baixos para a tributação dos rendimentos de artistas e esportistas em questão.

\subsubsection{Revisão dos Comentários à CM-OCDE para a reversão de posições anteriores do CAF-OCDE.}

A inversão de posições anteriores do CAF-OCDE por novos Comentários, fazendo com que a interpretação sugerida por essa organização flutue, tem se tornado cada vez mais comum. 
Suponha-se, por exemplo ${ }^{849}$, que dois Estados ("A" e "B") tenham celebrado um acordo de dupla tributação (“A-B”) em 1979, baseados na CM-OCDE de 1977, bem como o contribuinte, uma orquestra organizada sob a forma de uma organização musical com fins lucrativos residente de um Estado (“A"), tenha realizado em 1980 uma turnê pelo exterior, inclusive por aquele outro Estado contratante (“B”), no qual não possui qualquer estabelecimento permanente e no qual estava localizada a fonte de seus pagamentos. Por um lado, seria possível compreender que o art. 17 (2) do acordo de dupla tributação (“AB”) justificaria que esse Estado da fonte (“B”) exercesse a tributação. No entanto, conforme os Comentários da OCDE da época, tal dispositivo teria o objetivo de combater estruturas abusivas, geralmente cunhadas de star companies, o que impossibilitaria o Estado da fonte ("B") de tributar tais rendimentos quando não houvesse abuso. Caso as autoridades fiscais do Estado da fonte ("B”) reclamassem a retenção do imposto de renda sobre tais rendimentos, o advogado do contribuinte poderia reclamar a consideração dos Comentários à CM-OCDE como evidência de que as normas do acordo de dupla tributação (“A-B”) reservariam ao Estado de residência (“A”) a competência para tal tributação.

Suponha-se, então, que tal orquestra realize uma nova turnê em 1993, nas mesmas condições daquela realizada em 1980, logo após as substanciais revisões realizadas nos Comentários à CM-OCDE. De acordo com os Comentários revisados, o Estado da fonte (“B”) poderia exercer a sua competência tributária sobre a referida orquestra, ainda que ausente no território deste qualquer estabelecimento permanente ou, ainda, traços de abuso. Nesse cenário, caso as autoridades fiscais do Estado da fonte ("B”) reclamassem a retenção do imposto sobre os pagamentos realizados à orquestra, o advogado do contribuinte poderia basear-se na consideração estática dos Comentários à CM-OCDE, alegando como evidência os materiais contemporâneos à celebração do acordo de dupla tributação (“AB”), ao que os advogados do fisco poderiam valer-se da consideração dinâmica para a apresentação de evidências que lhe são favoráveis. Quais evidências deveriam ser admitidas pelo juiz?

Tal inversão de posições anteriores do CAF-OCDE por novos Comentários seriam, para LUC DE BROE, situações muito problemáticas. Não seria possível sustentar que tais materiais seriam vocacionados a refletir a intenção dos Estados contratantes de acordos já

\footnotetext{
${ }^{849} \mathrm{O}$ exemplo foi adotado por Hugh Ault. Vide: AULT, Hugh. The role of the OECD Commentaries in the Interpretation of Tax Treaties, in Intertax v. 22. Kluwer Law International : 1994, p. 147-148.
} 
celebrados. É importante notar que, para esse professor de Leuven, em quaisquer das quatro situações, novos Comentários à CM-OCDE não poderiam afetar rendimentos já auferidos ou operações já realizadas, de forma a tornar mais severa a tributação sobre o contribuinte.

\subsection{Exemplo: revisões dos Comentários à CM-OCDE para a reversão de posições sobre o art. 15 dos acordos de bitributação.}

O art. 15 da CM-OCDE também é um exemplo interessante: embora o texto desse dispositivo não tenha sofrido alterações desde a sua versão de 1977, os Comentários do CAF-OCDE a seu respeito passaram por substanciais revisões.

Até 1992, os Comentários ao art. 15 da CM-OCDE não continham explicações quanto ao sentido do termo “empregador" (“employer”). Com a revisão de 1992, os Comentários (especialmente o parágrafo 8) passaram a definir o termo "empregador" de forma autônoma e a partir de uma perspectiva econômica, com a finalidade de prevenir casos de planejamento tributário abusivo. Diante de uma situação de international hiringout of labour, então, a exceção prevista pelo art. 15 (2) não seria aplicável.

Em 2010, os Comentários foram novamente revisados, passando a conter explicações detalhadas quanto ao sentido dos termos "employment" e "employer", sob uma perspectiva diversa daquela de 1992. Como observam KASPER DzIURDź \& FrANK PÖTGENS ${ }^{850}$, a versão de 2010 não apenas esclarece o sentido de "empregador" para a questão da international hiring-out of labour, mas altera a perspectiva anteriormente adotada, distinguindo-a de casos de abuso. Desde estão, o CAF-OCDE sugere a posição de que a consideração estritamente jurídica ou econômica do termo "empregador" dependerá do Direito doméstico dos Estados contratantes. ${ }^{851}$

\footnotetext{
${ }^{850}$ DZIURDŹ, Kasper; PÖTGENS, Frank. Cross-Border Short-Term Employment, Bulletin for International Taxation Vol. 68, n. 8 (agosto). Amsterdã : IBFD, 2014, p. 409-410.

${ }^{851}$ Comentários ao art. 15 da CM-OCDE (2014), parágrafo 8.2.
} 


\subsection{Exemplo: outras revisões dos Comentários à CM-OCDE para a reversão de posições nos acordos de bitributação.}

Diversos outros exemplos de revisões substanciais nos Comentários à CM-OCDE poderiam ser suscitados. Entre eles, no entanto, os Comentários atinentes à interpretação da expressão beneficiário efetivo ("beneficial ownership") estão entre os mais $\operatorname{polêmicos}^{852}$.

Tal expressão foi utilizada na CM-OCDE pela primeira vez em 1977, dispondo os Comentários de então que não estariam sob o seu escopo intermediários como agentes ou “nominee”. Quase 10 anos após, em 1986, foi publicado estudo da OCDE sobre a questão das conduit companies utilizadas em planejamentos tributários por "treaty shopping”, sugerindo que também fosse excluída do conceito de beneficiário efetivo a pessoa que, embora figurasse como proprietária formal dos ativos geradores dos rendimentos, possuísse poderes muito limitados sobre eles ("narrow powers"), tornando-a um administrador do interesse de terceiros. Em 2003, no entanto, os Comentários foram revisados de maneira bastante substancial, não apenas por incorporar as conclusões daquele de 1986.

Como observa CHARL DU TOIT ${ }^{853}$, desde 2003, o CAF-OCDE parece ter abandonado a concepção de beneficiário efetivo ("beneficial owner") como uma questão de direito, passando a interpretá-la como uma questão de fato ("a practical matter"), de modo que não deveria ser compreendida de maneira estritamente técnica, mas a partir do contexto e à luz dos objetivos e propósitos do acordo de dupla tributação. Ao sugerir que o sentido de beneficiário efetivo seria uma questão de fato e não de direito, a OCDE teria dado um salto, desprendendo-se da origem da expressão.

\footnotetext{
${ }^{852}$ Cf. TOIT, Charl du. The Evolution of the Term "Beneficial Ownership" in Relation to International Taxation over the Past 45 Year, in Bulletin for International Taxation Vol. 64, n. 10. Amsterdã : IBFD, 2010, p. 504 e seg.

${ }^{853}$ TOIT, Charl du. The Evolution of the Term "Beneficial Ownership" in Relation to International Taxation over the Past 45 Year, in Bulletin for International Taxation Vol. 64, n. 10. Amsterdã : IBFD, 2010, p. 504505 .
} 


\subsubsection{Revisão dos Comentários à CM-OCDE para alinhamento às novas práticas dos Estados.}

As alterações realizadas para o alinhamento dos Comentários às novas práticas dos Estados, para LUC DE BROE, seriam problemáticas, pois indicariam que os entes não seguiriam os Comentários anteriores, bem como as práticas conduzidas por alguns poderiam não refletir o entendimento de uma série de outros Estados.

Por sua vez, ainda que se alinhem à prática de alguns Estados, é preciso admitir que tais revisões poderiam igualmente incorrer em modificações ou reversões de posições anteriores do CAF-OCDE, de forma que não poderiam ser consideradas como meramente amplificadoras.

\section{TRABALHOS PREPARATÓRIOS COMO EVIDÊNCIAS SOB O ESCOPO DO CONTEXTO EXTRÍNSECO DOS ACORDOS DE DUPLA TRIBUTAÇÃO.}

Conforme já analisado ${ }^{854}$, a ILC-ONU não enunciou uma lista taxativa de evidências do contexto extrínseco secundário no art. 32 da CVDT, mas alguns exemplos. No caso, os trabalhos preparatórios constam expressamente entre tais exemplos, sendo considerados diversas vezes pela doutrina como o principal deles. Não há dúvidas, assim, que os trabalhos preparatórios ("travaux préparatoires", "preparatory work") são evidências do contexto extrínseco secundário, sob o escopo do art. 32 da CVDT.

No Direito tributário internacional, entre as questões peculiares que rondam essa evidência, destacam-se: (i) a identificação de tais materiais neste segmento; (ii) a eficácia jurídica de tais materiais, considerando (a) o seu relacionamento com as demais evidências dos contextos intrínseco e extrínseco primário, (b) a sua capacidade para construir sentidos autônomos e (c) o caráter sigiloso que possam revestir; (iii) a sua vocação para a promoção 
do efeito útil e da interpretação harmônica (critério funcional) e, por fim; (iv) questões de ordem material, relacionadas à sua plausibilidade diante de casos concretos.

Para a análise ora proposta, serão adotados como mote trabalhos preparatórios para a celebração do acordo de dupla tributação Brasil-Áustria, de 1975, cujo processo de obtenção perante o Governo brasileiro, com novos paradigmas no Direito Internacional, será descrito adiante.

\subsection{A identificação de trabalhos preparatórios dos acordos de dupla tributação.}

Embora a CVDT tenha consignado que "trabalhos preparatórios" compõem o repertório de evidências do contexto extrínseco secundário, não definiu expressamente o que seriam "trabalhos preparatórios", dando origem a um antigo debate quanto ao seu perfil.

De maneira geral, trata-se de materiais que teriam auxiliado a dar forma ao acordo internacional e, por isso, poderiam ser úteis para clarificar a intenção das partes. Entre as características geralmente aceitas na literatura do Direito Internacional, inclusive naquela especializada na matéria tributária, destacam-se: (i) contemporaneidade; (ii) forma livre; (iii) bilateralidade; (iv) produzidos pelas autoridades competentes. ${ }^{855}$

Por se tratar de materiais que registram como os negociadores prepararam o solo para a celebração do acordo de bitributação, tais evidências devem ser contemporâneas a este. Como já se viu, a CVDT não exigiu formalidades especiais sequer para a celebração de tratados, não havendo razão para exigí-las de trabalhos preparatórios. Tais materiais podem assumir formas variadas, como registros por escrito ou mesmo gravações de áudio e vídeo, com o consentimento e sob a propriedade de ambos os Estados.

Anos atrás não se poderia deixar de cogitar que trabalhos preparatórios fossem conduzidos por meio de telegrama ou fax. Hoje, não se pode excluir que e-mail, redes sociais em módulo privativo ou quaisquer novas formas de comunicação eletrônica sejam

\footnotetext{
${ }^{855}$ BROE, Luc De. International tax planning and prevention of abuse (doctoral series n. 14). Amsterdã :
} IBFD, 2007, 257. 
utilizadas pelos negociadores de acordos de dupla tributação. A constante evolução dos meios de comunicação certamente permite - e cada vez permitirá - que negociações de convenções fiscais com o registro de todos os seus detalhes sejam realizadas de forma eficaz a distância. O desafio será saber se seria adotada como práticados negociadores acionar, por exemplo, um "modulo sigiloso" durante negociações via-satélite.

Independentemente do formato adotado, o que parece ser realmente importante é que ambos os Estados expressem o seu consentimento a determinado sentido que se possa atribuir aos termos utilizados no acordo de bitributação.

A doutrina também costuma requerer a bilateralidade dos "trabalhos preparatórios", a fim de que o seu conteúdo pudesse vincular ambos os Estados.

As autoridades competentes para a produção dos trabalhos preparatórios seriam as mesmas competentes para a negociação e celebração da convenção fiscal, em geral, do Poder Executivo. No entanto, não se espera ou se exige que os trabalhos preparatórios sejam ratificados pelo Poder Legislativo.

\subsection{A eficácia jurídica de trabalhos preparatórios dos acordos de dupla tributação.}

Aplicam-se aos trabalhos preparatórios as conclusões anteriormente expostas, quanto ao relacionamento das evidências extrínsecas secundárias com as demais evidências dos contextos intrínseco e extrínseco primário. Assim, a pergunta quanto à autonomia dos trabalhos preparatórios para estabelecer o sentido de termos dos acordos de dupla tributação, tal como as demais evidências extrínsecas secundárias, deve ser compreendida diante da função auxiliar que esses desempenham no quadro de evidências a que o operador do Direito tributário internacional deve recorrer.

Os trabalhos preparatórios demonstram bem como evidências do contexto extrínseco secundário se dobram às evidências dos contextos intrínseco ou extrínseco primário. Tais elementos representam o registro de negociações, atos e diálogos entre os interlocutores de dois Estados contratantes, que partem da CM-OCDE como padrão para a celebração de um acordo de dupla tributação específico. Naturalmente, o aprofundamento 
dos diálogos quanto a temas e desdobramentos do acordo internacional, que restarão registrados nos trabalhos preparatórios, é dependente da qualificação técnica, experiência, estratégia ou mesmo disposição dos negociadores.

No entanto, não se pode esperar que convenções fiscais sejam aplicáveis às restritas hipóteses que possam ter vindo à mente de um negociador mal preparado. Isso demonstra que não se pode atribuir a essa evidência peso absoluto, assumindo no mais das vezes papel auxiliar.

Ao exercer tal função auxiliar, os trabalhos preparatórios sempre poderão ser acessados pelo operador, não apenas quando as evidências intrínsecas ou extrínsecas primárias conduzirem à ambiguidade, obscuridade, manifesto absurdo ou ausência de razoabilidade. Pelo contrário, no processo argumentativo em que as partes - fisco e contribuinte - apresentam ao juiz suas evidências quanto aos sentidos dos termos de um acordo de dupla tributação, trabalhos preparatórios podem dar ensejo a argumentos plausíveis, capazes de iluminar, inclusive, a compreensão de outras evidências componentes do contexto. Por se tratar de meio suplementar, contudo, não prevaleceria no embate com outros argumentos também plausíveis.

Note-se, ainda, a situação hipotética em que um Estado (“A”) possua uma série de acordos de dupla tributação, em que um determinado dispositivo se repita. Suponha-se que, diante de dificuldades na aplicação desse dispositivo a um caso concreto, o intérprete tenha recorrido à evidência extrínseca primária dos paralell treaties, adotando como par de comparação, para a interpretação de um acordo (“A-B”) um outro acordo de dupla tributação (“A-C") firmado com um terceiro Estado (“C”). Supondo que esse acordo internacional (“A-C") adotado como par de comparação contenha uma cláusula diversa do enunciado sob interpretação e, ainda, de toda uma série de outros acordos celebrados por aquele Estado (“A”), não parece haver dúvida de que se deve averiguar se os trabalhos preparatórios do acordo adotado como par de comparação ("A-C") contêm dados relevantes e esclarecedores ao caso concreto. Com sorte, tal investigação pode demonstrar que os dois Estados ("A" e "C") procuraram evitar determinados sentidos que julgam presentes naquela série de acordos de dupla tributação firmados pelo Estado em questão (“A”). 
Boa parte da doutrina ${ }^{856}$ do Direito tributário internacional, por sua vez, geralmente considera os trabalhos preparatórios como de pouca valia para a interpretação de termos dos acordos de bitributação. O argumento normalmente utilizado é de que os trabalhos preparatórios dos acordos de dupla tributação, muitas vezes, não seriam levados a termo, não seriam registrados por escrito, sua gravação poderia não ser fidedigna, ainda, seriam oficialmente secretos, de tal modo que as Cortes nacionais poderiam ter a tendência a recusar a sua admissibilidade. LUC DE BROE $^{857}$ observa que o valor interpretativo de tais evidências depende de fatores como autenticidade, disponibilidade e completude, de forma que os trabalhos preparatórios seriam de pouca utilidade na seara tributária diante da ausência de costume na gravação ou documentação destes.

A ausência de publicidade dos trabalhos preparatórios, em termos pragmáticos, inutilizaria tais elementos: os operadores do Direito tributário internacional naturalmente precisariam ter acesso a tais evidências para que essas possam ser úteis à construção de sentido de termos dos acordos de dupla tributação.

No Brasil, contudo, desde 2011, a Lei de Acesso à Informação ${ }^{858}$ pode trazer novas luzes a essa discussão. Como demonstrado em projeto desenvolvido pelo IBDT ("História das políticas e das negociações das convenções internacionais em matéria tributária celebradas pelo Brasil." ${ }^{, 859}$ ), tal legislação tornou possível requisitar ao Governo brasileiro, em especial à Coordenação de Relações Internacionais da Receita Federal do Brasil (CORIN), a disponibilização dos trabalhos preparatórios dos acordos de dupla tributação celebrados pelo Brasil. Nesse projeto que contou com JEFERSON TEODOROVICZ como pesquisador, foram obtidos pelo IBDT uma série de documentos oficiais do Governo Brasileiro relativos às negociações que resultaram na celebração do acordo Brasil-Áustria, de 1975. Nesses materiais, é possível observar, por exemplo, correspondências trocadas entre as autoridades brasileiras e austríacas, bem como trabalhos de tradução do acordo nos

\footnotetext{
${ }^{856}$ Nesse sentido, vide: JONES, J. Avery; et al. The interpretation of tax treaties with particular reference to article 3(2) of the OECD Model - II. 1984, British Tax Review, p. 99; VOGEL, Klaus; PROKISCH, Rainer G. Cahiers de Droit Fiscal International by the International Fiscal Association (studies on international tax law), volume LXXVIIIa - Subject I. Interpretation of double taxation conventions. Kluwer Law and Taxation Publishers / IFA : Rotterdam, 1993, p. 68-69.

${ }^{857}$ BROE, Luc De. International tax planning and prevention of abuse (doctoral series n. 14). Amsterdã : IBFD, 2007, 257.

${ }^{858}$ BRASIL. Lei n. 12.527, de 2011.

${ }^{859}$ Todos as cópias dos documentos oficiais coletados neste projeto podem ser acessados por meio do website do IBDT (http://www.ibdt.com.br/p117, ultimo acesso em 7/10/2014).
} 
respectivos idiomas, com a rejeição de traduções equivocadas e a validação de sentidos considerados corretos.

Chama a atenção, contudo, o péssimo estado de conservação em que tais documentos oficiais foram mantidos, sendo nítida a ausência de diversas partes. A precária conservação de tais documentos não deve ser atribuída à má-fé da administração pública; fosse assim, tais documentos históricos teriam desaparecido por completo com o passar de tantas décadas.

A canhestra percepção de que trabalhos preparatórios não seriam realmente úteis aos operadores do Direito tributário internacional que, afinal, se estabelece com a celebração do acordo em questão, bem como posturas de sigilo absoluto, em relação aos nacionais e a outros Estados, sobre documentos cujos guardiões provavelmente sequer tinham conhecimento de seu conteúdo, pode ter conduzido à sua má conservação. Tal cenário, contudo, tende a ser drasticamente alterado e, ao menos no Brasil, tal movimento é impulsionado pela Lei de Acesso à Informação e também pelo crescente avanço das tecnologias para a organização e troca de informações.

Antigos obstáculos devem, assim, ser superados, oportunizando aos advogados do contribuinte e do fisco, bem como aos julgadores ou a qualquer interessado, o acesso aos trabalhos preparatórios de quaisquer acordos de dupla tributação celebrados pelo Brasil, a fim de levantar evidências quanto ao sentido contextualizado de seus termos.

\subsection{Critérios funcionais de reconhecimento de trabalhos preparatórios dos acordos de dupla tributação.}

Os trabalhos preparatórios acessados devem, ainda, ser analisados sob os aspectos

funcionais propostos nesta tese. É possível compreender que a bilateralidade que marca a produção de tais documentos os tornam aptos à promoção da interpretação harmônica, de tal modo que, em tese, ambos os Estados contratantes teriam acesso às mesmas evidências.

No entanto, também é necessário considerar que, caso um dos Estados contratantes disponibilize os trabalhos preparatórios de seus acordos de dupla tributação (como no 
Brasil), enquanto o outro Estado contratante os mantém em sigilo, a capacidade dessa evidência para a promoção da interpretação harmônica pode ser comprometida.

A aptidão dos trabalhos preparatórios para a promoção do efeito útil dos acordos de dupla tributação deve ser analisada com cautela. Devido ao seu caráter fragmentário, tais materiais podem não refletir integralmente as mútuas expectativas dos Estados contratantes, como requerido pela máxima ut res magis valeat quam pereat. No entato, tal assertiva apenas confirma que o seu recurso deve ser acompanhado de outras evidências, que fortaleçam o argumento da parte quanto ao sentido de determinado termo do acordo de bitributação.

\subsection{Critérios materiais de reconhecimento de trabalhos preparatórios dos acordos de dupla tributação.}

Como se disse anteriormente, o aprofundamento dos diálogos que possam se tornar trabalhos preparatórios úteis à interpretação da convenção fiscal celebrada é dependente da qualificação técnica, experiência, estratégia ou mesmo disposição dos negociadores.

Assim, mais uma vez, a plausividade se mostra como fator determinante para o fortalecimento do argumento quanto ao sentido de um determinado termo utilizado nos acordos de bitributação. 


\title{
7. ATOS UNILATERAIS QUANTO À INTENÇÃO DOS ESTADOS CONTRATANTES.
}

\begin{abstract}
"The concept of common interpretation suggests that, where a treaty is held to have a particular meaning in one state, it is desirable if it has the same meaning in the other state. However, this does not mean that unilateral statements, prepared by the negotiating authority of one state and not agreed with the other authority, should be regarded as binding. There is no reason why appropriate consideration should not be given to universal material, but as an aid with no binding force".

PHILIP BAKER (1994) $)^{860}$
\end{abstract}

Na doutrina do Direito tributário internacional ${ }^{861}$, é bastante controverso se atos unilaterais dos Estados poderiam servir de evidências para a construção do sentido contextualizado dos termos de acordos de bitributação. Por sua vez, há jurisprudência de Cortes Internacionais, naturalmente relacionada a temas não tributários, e de Cortes nacionais, essas para a aplicação de convenções fiscais, que enfrentam a questão da eficácia jurídica de tais atos unilaterais.

Nos subtópicos seguintes, será investigada a posição das Cortes Internacionais e nacionais, bem como os debates da doutrina especializada sobre o tema. Logo após, alguns subtópicos colocarão em questão, cada qual, se uma série de atos unilaterais seria admissível como evidência para a reconstrução do sentido de termos dos acordos de dupla tributação, quais sejam: (i) exposições de motivos, memorandos e "technical explanations" utilizados pelo Poder Legislativo no processo de ratificação do acordo de dupla tributação e; (ii) testemunho pessoal dos negociadores.

\subsection{Os efeitos jurídicos dos atos unilaterais dos Estados perante as Cortes Internacionais}

Os Tribunais Internacionais fornecem exemplos interessantes, que auxiliam na compreensão do tema dos atos unilaterais dos Estados como expressão de seu consentimento quanto ao contratado no Direito Internacional, a exemplo do Caso Nuclear

\footnotetext{
${ }^{860}$ BAKER, Philip. Double taxation conventions and international tax law. Londres : Sweet \& Maxwell, 1994, par. C-32.

${ }^{861}$ Sobre o tema, vide: BROE, Luc De. International tax planning and prevention of abuse (doctoral series $\mathrm{n}$. 14). Amsterdã : IBFD, 2007, p. 258-259; ROHATGI, Roy. Basic International taxation. Volume 1: principles. Nova Deli : Taxmann, 2005, p. 47.
} 
Test. Nesse julgamento, a CIJ admitiu como evidência um ato unilateral emanado do Governo francês para a construção de uma norma de Direito Internacional que impediria aquele país de desenvolver testes nucleares na atmosfera. Em sua decisão, o julgador observou que atos unilaterais emanados pelos Estados, como específicas manifestações públicas, teriam eficácia suficiente para criar obrigações legais, inclusive por respeito aos princípios da boa-fé e da cooperação internacional. Diante da ação do Estado de enunciar uma declaração que lhe possa vincular, então tal Estado se torna juridicamente obrigado a conduzir os seus atos de forma consistente com suas assertivas. Tais declarações tornadas públicas, ainda que não tenham sido propagadas em meio a uma negociação internacional ou mesmo sido endereçadas a algum Estado específico, vinculariam o referido Estado, não sendo necessária qualquer resposta ou manifestação do outro Estado contratante para tanto. A única exigência para que tal ato unilateral vincule o Estado é a demonstração de seu consentimento em torná-lo vinculante quanto à sua enunciação. No mais, nenhuma outra formalidade seria exigida ou viria a ser determinante: não haveria exigência no Direito Internacional de que tais atos unilaterais sejam emanados de forma oral ou escrita. Seria necessário, apenas, demonstrar o consentimento do Estado em vincular-se.

Assumindo tais pressupostos, a CIJ considerou que, ao se comprometer no ano de 1974 a encerrar testes nucleares daquela natureza, o Governo francês teria se vinculado em tal sentido. A validade e as consequências de tal pronunciamento deveriam ser consideradas com vistas à segurança internacional e à confiança entre os Estados. Assim, embora não houvesse norma no Direito Internacional que proibisse a França de realizar tais testes, o pronunciamento francês lhe vincularia a seguir esse caminho.

É oportuno mencionar que, como Hugh ThIRLWAY ${ }^{862}$, um pacto seria necessariamente servandum, mas nem todos os atos devem ser qualificados como pactos para que se qualifiquem como servandum no Direito Internacional.

${ }^{862}$ THIRLWAY, Hugh. The Sources of International Law. Oxford : Oxford, 2014, p. 51. (“a pactum - an agreement - is necessarily servandum - something that has to be complied (...), but something does not have to qualify as a pactum in order to have the quality of being servandum"). 


\subsection{Os atos unilaterais dos Estados contratantes como expressão do Direito tributário internacional.}

No Direito tributário internacional, há debate quanto à utilidade dos atos unilaterais para fins interpretativos, embora não haja quem sustente o seu vinculante em relação a terceiros.

Por um lado, LUC DE BROE ${ }^{863}$ sustenta que, como apenas elementos que reflitam uma interpretação compartilhada por ambos os Estados contratantes poderiam ser qualificados como meios suplementares de interpretação, o recurso a documentos produzidos por apenas um desses, sem a aprovação pelo outro, teria valor interpretativo bastante limitado, muitas vezes, se prestando apenas para aclarar o entendimento do agente que os emitiu.

Por sua vez, GUGLIELMO MAISTO ${ }^{864}$ assume postura menos restritiva, reconhecendo que declarações interpretativas unilaterais não deixariam de ter utilidade, podendo, inclusive, tornarem-se vinculantes perante terceiros Estados que formalmente com ela concordem. Observa o professor italiano, ainda, que a ausência de formalidade ou de exigência de conexão temporal com o acordo de dupla tributação possibilita que tais atos sejam informais e que possam ser emitidos a qualquer tempo.

Também suscita RoY RoHATGI ${ }^{865}$ que materiais unilaterais, embora não vinculantes, seriam úteis como guia para a interpretação harmônica entre os Estados, devendo ser aceitos por ambos os Estados contratantes para alcançar tal fim.

Por sua vez, a experiência do Direito Internacional, a exemplo da manifestada no Caso Nuclear Test, suscita questões que também devem ser consideradas na seara tributária. A decisão da CIJ reflete a teoria das fontes, que fundamenta a existência do Direito Internacional na soberania de cada Estado para vincular-se a outros Estados, aceitando obrigações recíprocas ou não: tal como o outro lado da mesma moeda, a teoria

\footnotetext{
${ }^{863}$ BROE, Luc De. International tax planning and prevention of abuse (doctoral series n. 14). Amsterdã : IBFD, 2007, 258-259.

${ }^{864}$ MAISTO, Guglielmo. The Observations on the OECD Commentaries in the Interpretation of Tax Treaties, in Bulletin for International Taxation - Agosto, vol. 59, n. 1. Amsterdã : IBFD, 2005, p. 16-17.

${ }^{865}$ ROHATGI, Roy. Basic International taxation. Volume 1: principles. Nova Deli : Taxmann, 2005, p. 47.
} 
consensualista também conduz à norma do Direito Internacional de que nenhum Estado assume deveres e obrigações para os quais não tenha consentido.

Dialeticamente, a transposição da teoria consensualista das fontes ao Direito tributário internacional legitimaria que um Estado, por ato unilateral, se comprometesse a determinada interpretação de seus acordos de dupla tributação cuja consequência seja a redução do exercício de sua competência tributária, com o incremento (ou não) do âmbito de tributação de seus parceiros internacionais. No entanto, atos unilaterais não teriam eficácia para vincular parceiros internacionais, de tal forma que não teriam o condão de suprimir ou reduzir a porção assegurada a outros Estados por meio de tratado internacional.

Sob essa perspectiva, embora seja correto distinguir atos unilaterais dos trabalhos preparatórios, que pressupõem bilateralidade, não se pode recusar a priori que aqueles também possam configurar evidências quanto ao sentido dos termos dos acordos de dupla tributação, sob o escopo do contexto extrínseco secundário, e com a eficácia limitada para vincular apenas o Estado do qual tais atos unilaterais tenham sido emanados.

Por hipótese, suponha-se que um Estado ("A") soberanamente decida emitir pronunciamentos quanto a determinado termo de seus acordos de dupla tributação, expressando justamente um sentido que reduza o âmbito de exercício de sua competência tributária. Se um de seus Estado parceiros (“B”) não considerar tal evidência quanto ao sentido a ser observado na interpretação do acordo de dupla tributação (“A-B”), duas consequências seriam possíveis: (i) a interpretação desse outro Estado contratante ("B”) conduziria aos mesmos resultados que do Estado (“A”) que emitiu o ato unilateral, de forma que aquele Estado ("B") exerceria sua competência tributária da forma consentida por este ("A"); e (ii) a interpretação desse outro Estado contratante ("B”) conduziria a resultados diversos àquele consentida pelo Estado (“A”), pois reconheceria a este ("A") parcela maior da fatia tributária, à qual, então, não seria tributada por nenhum destes.

Objeções a esse cenário seriam possíveis se compreender-se que os acordos de dupla tributação também o propósito e objetivo de evitar a dupla não tributação da renda. Nesse caso, a consideração do ato unilateral emanado por um Estado ("A") poderia ter evitado tal efeito, influenciando na interpretação do outro Estado contratante (“B”). 
Nesse seguir, parece necessário descortinar objeções apriorísticas à possibilidade de atos unilaterais se prestarem a evidenciar o sentido de termos dos acordos de dupla tributação, o que faz surgir questões como: (i) quem seria o agente competente para emitir tais atos; (ii) quais atos estariam sob tal escopo; (iii) quando tais atos deveriam ser emitidos; e (iv) para que se prestariam tais evidências no âmbito do Direito tributário internacional.

A questão sobre quem seria o agente competente para emitir tais atos unilaterais conduz a temas já abordados nesta tese e será examinada nos subtópicos seguintes, conjuntamente com a questão quanto a quais atos poderiam ser considerados evidências sob o escopo do contexto extrínseco secundário para a construção de sentido de convenções fiscais.

A investigação empírica na série de julgados de Cortes nacionais analisadas nesta tese requer que se considerem atos como: (i) exposições de motivos, memorandos $e$ “technical explanations" utilizados pelo Poder Legislativo no processo de ratificação do acordo de dupla tributação; (ii) testemunho pessoal dos negociadores e; (iii) pareceres administrativos.

Por sua vez, a questão de quando tais atos deveriam ser emitidos pode suscitar, tal como ocorreu na jurisprudência norte-americana ${ }^{866}$, a distinção entre atos unilaterais emitidos ao tempo da ratificação do acordo, de outros, enunciados posteriormente, o que também será analisado nos subtópicos seguintes.

\footnotetext{
${ }^{866}$ KATZ, Stanley I. United States National Report. Cahiers de Droit Fiscal International by the International Fiscal Association (studies on international tax law), volume LXXVIIIa - Subject I. Interpretation of double taxation conventions. Kluwer Law and Taxation Publishers / IFA : Rotterdam, 1993, p. 636 e seg.
} 


\subsection{Exposições de motivos, memorandos e "technical explanations" utilizados pelo}

\section{Poder Legislativo no processo de ratificação do acordo de dupla tributação.}

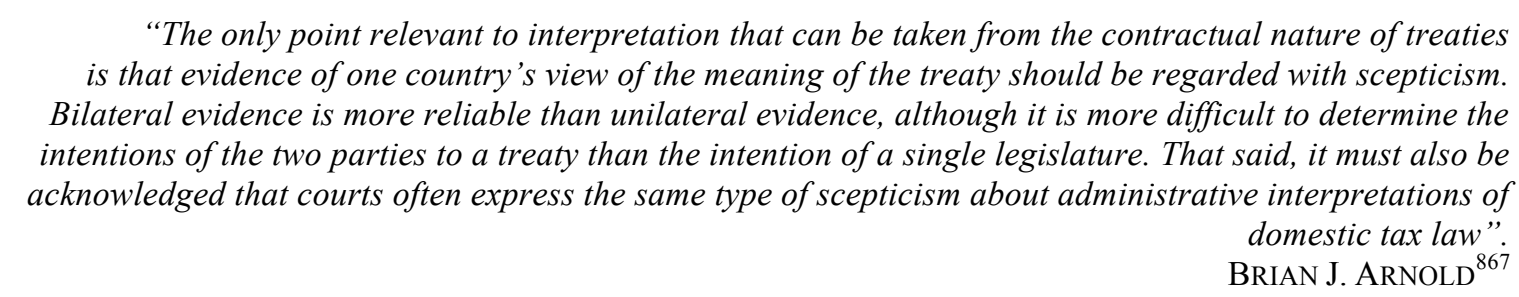

Alguns países têm como tradição a elaboração de explicações técnicas, geralmente para a apresentação ao Poder Legislativo como forma de corroborar com a análise e aprovação de convenções fiscais celebradas pelo Executivo.

Os EUA, por exemplo, adotam como procedimento a elaboração e posterior publicação de resumos do processo legislativo (“legislative history”) para a aprovação dos acordos de dupla tributação, bem como explicações técnicas ("technical explanation"), geralmente nos moldes já previstos na minuta anexa à CM-EUA. ${ }^{868} \mathrm{Na}$ Alemanha, também um memorando é apresentado ao Parlamento juntamente com a minuta do acordo celebrado. $^{869}$

Há, ainda, outros atos administrativos e unilaterais que expressam entendimentos quanto à norma contratada pelo acordo de dupla tributação, tal como memorandos, mas não se dirigem ao Poder Legislativo do respectivo Estado. Trata-se de atos administrativos internos, emitidos durante as negociações para a assinatura do acordo de dupla tributação.

A admissibilidade dessas evidências, no entanto, está sujeita a uma série de considerações. KLAUS VOGEL ${ }^{870}$ chegou a suscitar, inclusive, que não fariam parte do contexto dos acordos de dupla tributação. Para o professor, não seria possível identificá-los entre os materiais referidos nos art. 31 (1) ou (2) da CVDT, bem como não preencheriam os requisitos do seu art. 32, já que, para tanto, deveriam apenas reproduzir o conteúdo de

\footnotetext{
${ }^{867}$ ARNOLD, J. Brian. The interpretation of tax treaties: myth or reality, in Bulletin for international Taxation (tax treaty monitor) - january of 2010. IBFD : Amsterdã, 2010, p. 10.

${ }^{868}$ AVERY JONES, J. et al., The interpretation of tax treaties with particular reference to article $3(2)$ of the OECD Model - II. 1984, British Tax Review, p. 95-96.

${ }^{869}$ VOGEL, Klaus. Klaus Vogel on Double Taxation Conventions. Kluwer : London, 1999, p. 38.

${ }^{870}$ VOGEL, Klaus. Klaus Vogel on Double Taxation Conventions. Kluwer : London, 1999, p. 38.
} 
notas ou cartas trocadas entre os Estados contratantes durante o período de negociação e conclusão do acordo internacional.

Aceitando-se como correta a posição do professor alemão, faltaria às exposições de motivos, memorandos e "technical explanations" a natureza jurídica necessária à composição do repertório de evidências para a construção do sentido contextualizado. Ao juiz, então, caberia rejeitar tal evidência apresentada tanto pelo advogado do fisco quanto do contribuinte. Em um caso concreto, caso o advogado de uma das partes apresentasse como evidência exposições de motivos, memorandos e "technical explanations", o advogado da outra poderia impugná-los, alegando, inclusive, que tais materiais não seriam contemporâneos à negociação do acordo de dupla tributação em questão, pois teriam sido elaborados após a sua conclusão. A unilateralidade de tal evidência fragilizaria a vocação à interpretação harmônica, o que não seria remediado sequer pela publicação de tais atos em jornais oficiais, pois não se pode exigir que o outro Estado contratante tenha conhecimento destes.

Note-se que, embora Klaus Vogel tenha tecido as críticas citadas anteriormente, não deixou de mencionar que seriam evidências úteis ao outro Estado contratante para a aplicação uniforme da convenção. Nesse mesmo sentido, AVERY JONES ${ }^{871}$ e RAINER PROKISCH $^{872}$.

É possível ponderar, contudo, que não necessariamente a unilateralidade de tais materiais prejudica a sua utilidade, como se viu anteriormente. Parece necessário verificar qual o status de tais materiais perante o sistema doméstico do Estado que o emanou, especialmente no que se refere à competência do agente que os emanou.

\footnotetext{
${ }^{871}$ AVERY JONES, John. et al., The interpretation of tax treaties with particular reference to article 3(2) of the OECD Model - II. 1984, British Tax Review, p. 98, nota de rodapé n. 34.

${ }^{872}$ VOGEL, Klaus; PROKISCH, Rainer G. Cahiers de Droit Fiscal International by the International Fiscal Association (studies on international tax law), volume LXXVIIIa - Subject I. Interpretation of double taxation conventions. Kluwer Law and Taxation Publishers / IFA : Rotterdam, 1993, p. 69.
} 


\subsubsection{Exemplo: o recurso a materiais unilaterais por tribunais norte-americanos.}

O Caso Great-West (EUA, 1982) demonstra um franco recurso a evidências unilaterais por tribunais norte-americanos.

No caso, os advogados do contribuinte alegaram que os termos "exempt from all income taxes", presentes no art. 12 do acordo de dupla tributação a partir de sua nova redação acordada em 1951, seriam evidências intrínsecas de que o propósito daquele dispositivo seria bastante amplo, com isenção completa dos juros de empresas canadenses pagas para sujeitos não discriminados naquele dispositivo. O propósito da emenda de 1951 ao acordo de dupla tributação não teria sido apenas conferir reciprocidade de tratamento entre os Estados contratantes (na versão de 1942, a isenção seria concedida apenas em relação aos EUA), já que o Canadá sequer exercia tal tributação em sua legislação doméstica.

Por sua vez, o tribunal norte-americano considerou determinante para a solução do caso evidências extrínsecas e unilaterais, rejeitando os argumentos do contribuinte. $\mathrm{O}$ Acting Secretary of State Sumner Welles indicaria um propósito mais reduzido, de forma que os benefícios do tratado deveriam ter eficácia apenas em relação a algumas espécies de juros. Conforme essa mensagem, os arts. XII e XIII do acordo de dupla tributação em questão teriam a função de "alleviation, with respect to Canada, of certain allegedly extraterritorial taxation by the United States of nonresident aliens and foreign corporations", bem como que isenções mais amplas apenas seriam concedidas entre os dispositivos 1 a 10 daquele acordo.

Além disso, para concluir que o propósito da emenda ao acordo de dupla tributação realizada em 1951 não seria conceder uma isenção ilimitada (ou seja, para rejeitar os argumentos Great West), o Tribunal ainda considerou outros documentos produzidos unilateralmente, como registros do processo legislativo (“legislative history"), em especial a mensagem transmitida ao Senado pelo Secretário de Estado norte-americano Dean Acheson quanto à emenda de 1951 desse acordo, segundo a qual o propósito da emenda seria tornar a previsão do acordo de dupla tributação recíproca e não mais unilateral. Já o testemunho de Eldon P. KING, Special Deputy Commissioner of Internal Revenue, foi 
considerado como evidência para confirmar que a reciprocidade teria sido o maior objetivo dos acordos de dupla tributação negociados pelos EUA que presenciou, ainda quando não se mostrar necessário e não forem estabelecidas cláusulas recíprocas.

No Caso Stuart (EUA, 1989), a Suprema Corte dos EUA analisou novamente o acordo de dupla tributação EUA-Canadá. Unanimamente, o Tribunal autorizou a obtenção e transmissão ao Canadá de informações bancárias solicitadas. A Suprema Corte norteamericana, contudo, divergiu quanto à admissibilidade de evidências extrínsecas secundárias quanto ao sentido do acordo, especialmente atos unilaterais emanados do Governo dos EUA.

Embora o juiz BRENNAN tenha considerado o texto do acordo claro o suficiente para a solução da questão a partir de evidências intrínsecas, avançou a sua investigação na busca de evidências extrínsecas, consultando, especialmente o histórico da ratificação do acordo e sua subsequente aplicação, com suposto fundamento no caso Sumitomo. Tais evidências, sob a perspectiva dos juízes que acompanharam o voto do juiz BRENNAN, não seriam impróprias na interpretação de acordos de dupla tributação; ao contrário, sua relevância seria reconhecida inclusive pelo ALI.

A essa posição adotada pela maioria da Suprema Corte norte-americana, opuseramse os juízes KENNEDy e O'CONNOR e SCALIA, no sentido de que não seria adequado levantar a questão, naquele caso, se documentos relacionados aos debates ou ratificação do Senado seriam autorizativos ou mesmo úteis para determinar a intenção dos Estados contratantes; tal discussão deveria ser reservada a situações em que não houvesse evidências intrínsecas disponíveis para a determinação do sentido do acordo de dupla tributação.

Conforme a posição do juiz SCALIA, acompanhada pelos juízes KenNEDY e O'CONNOR, ainda que se pudesse cogitar o recurso às evidências extrínsecas diante de textos ambíguos, como trabalhos preparatórios, haveria especiais razões para recusá-las naquele caso, em que evidências intrínsecas estavam disponíveis. De todo modo, considerou ainda o juiz SCALIA que atos unilaterais, em especial registros de debates ou ratificação do Senado norte-americano, não estariam sob o escopo do contexto extrínseco, pois teriam o condão de evidenciar apenas as intenções e propósitos dos EUA, e não de 
ambos os Estados contratantes, o que seria a finalidade da interpretação a que aquela Suprema Corte deveria se ater.

\subsubsection{Exemplo: o recurso a materiais unilaterais por tribunais canadenses.}

Por sua vez, também a Suprema Corte do Canadá analisou a pertinência de atos unilaterais como evidência para a construção de sentido de termos do acordo de dupla tributação Canadá-EUA. No Caso Crown Forest (Canadá, 1995), aquele tribunal considerou como evidência o "U.S. Senate (Foreign Relations Committee), Tax Convention and Proposed Protocols with Canada", segundo o qual os principais objetivos e propósitos daquele acordo de dupla tributação seria reduzir ou eliminar a dupla tributação da renda de cidadãos e residentes de um dos Estados contratantes provenientes de fontes localizadas no outro Estado contratante, bem como prevenir planejamentos tributários abusivos e a evasão fiscal e, ainda, reduzir complexidades administrativas a que o contribuinte estaria sujeito ao ter de obter restituições em ambos os Estados.

\subsubsection{Exemplo: o recurso a materiais unilaterais por tribunais australianos.}

No Caso McDermott (Austrália, 2005), para aplicar o acordo Austrália-Singapura, foi necessário ao tribunal australiano determinar se rendimentos advindos do arrendamento de equipamentos de uso industrial, comercial ou científico estariam compreendidos no conceito de royalties (CM-OCDE, art. 12) ou lucros das empresas (CM-OCDE, art. 7, "business profits”), bem como se a presença de tais equipamentos seria suficiente para a caracterização de um estabelecimento permanente.

Entre os elementos apresentados pelas partes para a interpretação do termo estabelecimento permanente ("permanent establishment"), destaca-se o memorando elaborado pelo tesouro australiano para auxiliar o parlamento daquele país na aprovação do acordo de bitributação Austrália-EUA (1953).

Conforme a posição do Tesouro australiano descrita no memorando, o conceito de estabelecimento permanente deveria ser interpretado de forma ampla, incluindo o uso ou a 
instalação de substanciais equipamentos ou maquinários no outro Estado contratante. $\mathrm{O}$ mesmo resultado deveria ser obtido, ainda, no caso de substanciais equipamentos ou maquinários instalados ou utilizados em um Estado para a utilização por uma empresa do outro Estado contratante.

Duas questões, contudo, deveriam ser superadas pelo tribunal para a consideração de tais evidências: (i) tratavam-se de materiais unilaterais para a interpretação de uma convenção bilateral, bem como e; (ii) se poderia ser adotada para a interpretação do acordo EUA-Singapura uma convenção fiscal celebrada entre a Austrália e um terceiro Estado (EUA).

Nesse seguir, o tribunal australiano consignou que tais materiais teriam pouca utilidade. Mesmo que se considerassem materiais produzidos unilateralmente pelo Tesouro para a interpretação de uma convenção internacional celebrada por dois Estados, o acordo Austrália-EUA possuía definição de estabelecimento permanente diversa da contida no acordo Austrália-Singapura no que tange à linguagem e estrutura utilizada.

\subsection{Testemunho pessoal dos negociadores.}

Questões semelhantes àquelas opostas às exposições de motivos, memorandos $e$ "technical explanations" podem ser suscitadas em relação ao testemunho pessoal dos negociadores. De início, lhe faltaria a natureza jurídica necessária à admissão como evidência. Como observa RICHARD K. GARDINER ${ }^{873}$, as normas dos arts. 31 e 32 da CVDT não autorizam a investigação da intenção dos Estados contratantes por meio de depoimentos pessoais, autobiografias ou outras evidências baseadas no entendimento de indivíduos quanto ao sentido que se pretendeu atribuir com a adoção de determinado termo no acordo celebrado.

${ }^{873}$ GARDINER, Richard K. International Law. Pearson : Harlaw, 2003, p. 81. 
A ausência de publicidade e, portanto, a inconsistência com o papel dos acordos de dupla tributação, que é governar os atos de atores individuais, bem como o fato de se tratar de um ato unilateral, abriria franco espaço para que tal evidência fosse impugnada. ${ }^{874}$

\subsubsection{Exemplo: a importância do testemunho dos negociadores para os tribunais norte-americanos.}

Também no caso Caso Great-West (EUA, 1982), um tribunal norte-americano (“Court of Claims”) considerou o testemunho de ELDON P. KING, então Special Deputy Commissioner of Internal Revenue, como evidência quanto aos propósitos da emenda de 1951 ao acordo de dupla tributação EUA-Canadá.

Vale obsersar que, embora seja possível citar exemplos, parecem tratar-se de casos raros, já que YARIV BRAUNER ${ }^{875}$ se queixa justamente da ausência de tais materiais para a melhor compreensão da política de acordos internacionais dos EUA.

\subsection{Atos normativos das autoridades administrativas.}

Os atos normativos das autoridades administrativas trazem consigo as discussões analisadas anteriormente, relativos à legalidade.

No Direito brasileiro, PAUlo Borba CASELlA ${ }^{876}$ sustenta que tais materiais seriam desprovidos de efeitos jurídicos sempre que introduzirem exigências ou proibições não contempladas na própria convenção fiscal.

No Caso Maximov (1963), a Suprema Corte dos EUA se referiu à longa tradição de pronunciamentos da administração fiscal americana a respeito da interpretação de outros

${ }^{874}$ Nesse sentido, vide: KATZ, Stanley I. United States National Report. Cahiers de Droit Fiscal International by the International Fiscal Association (studies on international tax law), volume LXXVIIIa - Subject I. Interpretation of double taxation conventions. Kluwer Law and Taxation Publishers / IFA : Rotterdam, 1993, p. 633 .

${ }^{875}$ BRAUNER, Yariv. Por que os Estados Unidos firmam Tratados Tributários? E por que não têm Tratado Tributário com o Brasil?, in Revista Direito Tributário Atual n. 26. São Paulo : IBDT/Dialética, 2011, p. 110 e seg.

${ }^{876}$ CASELLA, Paulo Borba. Direito internacional tributário brasileiro. São Paulo : LTR, 1995, p. 40-41. 
acordos de dupla tributação celebrados por aquele país, a respeito de cláusulas semelhantes à analisada.

\title{
8. CIRCUNSTÂNCIAS RELACIONADAS À CONCLUSÃO DO ACORDO DE DUPLA TRIBUTAÇÃO COMO EVIDÊNCIAS DO SENTIDO DE SEUS TERMOS.
}

\begin{abstract}
"Este destaque contrastante serve para ressaltar que sendo o Direito disciplina lógico-normativa da convivência social é influenciado na sua própria elaboração, como na sua interpretação e aplicação, pela experiência social concreta. Não é apenas construção teórica, mas teorização diretiva da conduta social. Não é fruto arbitrário de construções legislativas, porque elas nem sempre se apartam dos vínculos históricos, tradicionais. São elaboradas em momentos circunstanciais e segundo necessidades sociais a que visa dar soluções histórico-jurídicas".

RUY BARBOSA NOGUEIRA (1995) ${ }^{877}$

$\mathrm{O}$ ensinamento do professor, que segue à passagem em epígrafe, adverte que o elemento histórico pode não se mostrar decisivo por si na interpretação dos textos legais. Algumas leis são produzidas para alterar o status quo, outras para consolidar costumes. A relevância dessa evidência dependeria, então, do suporte de outras mais, que "se conjugam na pesquisa da verdade jurídica”, "a vontade objetivada na lei”.
\end{abstract}

No Direito tributário internacional ocorre o mesmo. O art. 32 da CVDT, vocacionado a regular o recurso ao contexto extrínseco secundário, também relaciona "circunstâncias de sua conclusão" como exemplo de evidências gravadas com o seu status. Em outros segmentos (não tributários), não é novidade a admissibilidade de circunstâncias relacionadas à conclusão do tratado como evidências quanto ao sentido que se deve atribuir aos seus termos ${ }^{878}$.

No Direito tributário internacional, tal recurso também já vinha sendo reconhecido por alguns Estados antes mesmo da celebração da CVDT. No caso Maximov (EUA, 1963), a Suprema Corte dos EUA indicou como parte do contexto as circunstâncias em que o acordo EUA-Reino Unido foi celebrado. Não está claro na decisão, contudo, a que espécie de eventos, relações econômicas ou regras jurídicas pré-existentes à celebração do acordo se referia o julgador.

\footnotetext{
${ }^{877}$ NOGUEIRA, Ruy Barbosa. Curso de Direito Tributário. São Paulo, Saraiva, 1995, p. 94-95.

${ }^{878}$ Vide CIJ, "Case Concerning The Land, Island And Maritime Frontier Dispute” (1992).
} 
Os subtópicos que seguem se dedicam à exposição de possíveis evidências admissíveis no âmbito do Direito tributário internacional para que o seu operador construa o sentido de termos dos acordos de dupla tributação.

\subsection{Circunstâncias fáticas ocorridas no período das negociações e da celebração do acordo de dupla tributação.}

"One need only to listen on those rare occasions, usually at a very late hour, when former tax treaty negotiators relate their war stories: stories of delaying negotiations on importante issues until the airplane for the return trip is ready to take off, so that the other party is pressed to make additional concessions if the negotiatons are to be concluded in the current round; stories of the famous night negotiations, in which the physically robust have the advantage; stories of the host delegation that promissed to serve an evening buffet after conclusion of the negotiations, and even arranged the food in an adjacente room in view of the delegations, only to prolong the negotiations mercilissly into the night (according to rumour, the host were able to sneak out individually for snacks). Even if ninety per cent of these stories may

be comparable to stories told by sailors, hunters or fishermen, enough remains to demonstrate that treaties very often result from stubborn and wily battles in which the negotiating parties are ready willing and able to make use of every possible advantage. This fact cannot be neglected when interpreting tax treaties.", KLAUS VOGEL (1999) $)^{879}$

Circunstâncias fáticas ocorridas no período das negociações e da celebração do acordo de dupla tributação estão sob o escopo do art. 32 da CVDT. ${ }^{880}$ A conhecida passagem em epígrafe sinaliza que é inimaginável a quantidade de circunstâncias que rondam a negociação de convenções fiscais.

Tais questões são admitidas com certa frequência por Cortes nacionais na aplicação de acordos de dupla tributação, como se pode observar nos exemplos a seguir.

\subsubsection{Exemplo: Os tribunais ingleses e a consideração de circunstâncias fáticas ocorridas no período das negociações da convenção fiscal.}

Recentemente, no Caso Tomislav (Reino Unido, 2011), um tribunal inglês precisou interpretar o termo "person", presente no art. 15 (3) do acordo de dupla tributação Reino Unido-Croácia ("paid by, or on behalf of a person"), compreendendo que o seu sentido

${ }^{879}$ VOGEL, Klaus. Klaus Vogel on Double Taxation Conventions. Kluwer : London, 1999, p. 50.

${ }^{880}$ Sobre o tema, vide: DÖRR, Oliver. "Article 31 - General rule of interpretation", in "Vienna Convention on the Law of Treaties: a Commentary", DÖRR, Oliver; SCHMALENBACH, Kirsten (Editors). Springer, 2012, p. 548. 
poderia ser assimilado ao de "employer", tal como presente no equivalente dispositivo da CM-OCDE ("paid by, or on behalf of, an employer"). Mais precisamente, o voto da juíza ANNE SCOTT expõe que aquele primeiro seria mais amplo que esse último, o que não alteraria, contudo, o teste a ser desenvolvido para a aplicação do art. 15 (3) do acordo Reino Unido-Croácia que seria o mesmo previsto em seu equivalente da CM-OCDE, qual seja, o art. 15 (2) da CM-OCDE.

A questão poderia ser explicada, contudo, pelas circunstâncias em que a convenção fiscal foi celebrada.

Como observa BRIAN CleAve ${ }^{881}$, o acordo analisado no Caso Tomislav, aplicável às relações mantidas entre Reino Unido e Croácia, foi firmado sob o regime Federal Socialista da República da Iugoslávia. Trata-se do único acordo de dupla tributação firmado pelo Reino Unido com a referida fórmula, embora essa tenha sido adotada pela Ioguslávia, nos anos 80 e 90, em acordos firmados com Bélgica, China e Alemanha. Ocorre que o termo "empregador" não se adequou à doutrina socialista ("self-managing socialism"), obrigando os negociadores à adoção de alguma palavra que não lhe fosse ofensiva.

\subsubsection{Exemplo: Os tribunais canadenses e a consideração de circunstâncias fáticas ocorridas no período das negociações da convenção fiscal.}

No Caso Crown Forest (Canadá, 1995), a Suprema Corte do Canadá suscitou que o acordo Canadá-EUA, especialmente o dispositivo sob análise, teria sido celebrado com o objetivo de beneficiar os trabalhadores e empresas canadenses e norte-americanas que trabalhavam, e operavam respectivamente nos EUA e no Canadá. Seria mútuo o interesse de evitar a bitributação, a evasão fiscal e o excesso de ônus administrativos sobre tais indivíduos e empresas, de modo a incentivar o comércio internacional entre os dois países.

${ }^{881}$ Cleave, Brian. Editor's notes, in United Kingdom - Tomislav Kljun v. Commissioners for Her Majesty's Revenue and Customs, 3 June 2011 (Summary). Último acesso em 10.11.2014, no endereço eletrônico

http://online.ibfd.org/kbase/\#topic=doc\&url=/highlight/collections/ttcls/html/cl_uk_2011-06-03_1-

summary.html\&q=tomislav\&WT.z_nav $=$ Search\&colid $=4938$ 
No entanto, o tribunal compreendeu que a situação existente no Caso Crown Forest não seria a mesma, bem como que não haveria expectativa dos Estados em aplicar os benefícios do acordo a empresas que apenas possuíssem um escritório em seus territórios.

\subsubsection{Exemplo: Os tribunais australianos e a consideração de circunstâncias fáticas ocorridas no período das negociações da convenção fiscal.}

No Caso Lamesa (Austrália, 1997), para aplicar o acordo de bitributação AustráliaPaíses Baixos, o tribunal australiano precisou interpretar o sentido de termos não definidos em seu texto, como "real property", presente em seu art. 13 (equivalente, mas diverso do art. 13 da CM-OCDE).

Os juízes consideraram que a Austrália, repleta de recursos naturais e interessada na exploração desses, claramente desejaria assegurar que aquele dispositivo alcançaria também lucros da alienação de tais propriedades ou, ainda, de participações nessas. Daí a preocupação do art. 13 do acordo Austrália-Países Baixos em ampliar o sentido ordinário de "real property".

\subsection{Acordos de dupla tributação anteriormente celebrados entre os mesmos Estados.}

O recurso a parallel treaties pode se basear em antigos acordos de dupla tributação celebrados entre ambos os Estados. Nesse caso, não se teria como par de comparação "regras pertinentes de Direito Internacional aplicáveis às relações entre as partes" (CVDT, art. 31 (3) “c”), mas justamente uma regra que não lhe é mais aplicável, por ter sido denunciada ou, ainda, modificada por acordo posterior entre as partes.

Por essa razão, parece mais adequado analisar tais materiais como parte do contexto extrínseco secundário (CVDT, art. 32), enquanto circunstância em que a convenção fiscal foi celebrada, e não como parte do contexto extrínseco primário (CVDT, art. 31 (3) “c”).

Tal como se observou no Capítulo III, predomina na doutrina a aceitação aos parallel treaties como evidências sob o escopo do "contexto" referido no art. 3 (2) da CM- 
OCDE, mas com advertências. PHILIP BAKER ${ }^{882}$ suscita que o fato de um dispositivo de um novo acordo de dupla tributação entre dois Estados contratantes adotar enunciado diverso do existente no acordo anteriormente celebrado entre esses mesmos Estados, ou ainda omitir tal dispositivo, não necessariamente seria útil para a compreensão destes.

Tal advertência vai ao encontro da concepção de que evidencias do contexto extrínseco secundário geralmente precisam ser suportadas por outras evidências, que fortaleçam a sua aptidão para delinear o sentido consentido pelos Estados contratantes.

\subsubsection{Exemplo: A análise do texto original para a compreensão do texto do acordo modificado por protocolo.}

No Caso Lord Strathalmond (Reino Unido, 1972), o tribunal inglês precisou analisar o sentido de termos do art. 15 do antigo acordo Reino Unido-EUA de 1945, mas com a redação que lhe havia sido dada pelo protocolo celebrado em 1966.

O exercício desenvolvido pelas autoridades fiscais, pelo contribuinte e pelo juiz, consistiu em analisar a norma do dispositivo original, os propósitos dos Estados contratantes com a revisão de seu texto e, finalmente, decidir qual a norma teria sido estabelecida com a celebração do protocolo.

\subsection{O Direito doméstico dos Estados contratantes no momento da celebração da convenção fiscal.}

Entre as circunstâncias do contexto extrínseco secundário, é possível investigar o Direito doméstico dos Estados contratantes no momento da celebração da convenção fiscal $^{883}$.

${ }^{882}$ BAKER, Philip. Double taxation conventions and international tax law. Londres : Sweet \& Maxwell, 1994, par. C-33.

${ }^{883}$ Nesse sentido, vide: ROHATGI, Roy. Basic International taxation. Volume 1: principles. Nova Deli : Taxmann, 2005, p. 49-50. 
Como se viu, há na doutrina do Direito tributário internacional ${ }^{884}$ a concepção de que tais acordos não são celebrados em um vácuo jurídico, mas com vistas ao sistema jurídico doméstico de cada um dos Estados contratantes, de tal modo que os seus negociadores seriam influenciados pelos sentidos providos por eles ao selecionarem os termos utilizados no texto do tratado. Sob tal perspectiva, essas evidências estariam sob o escopo do art. 32 da CVDT.

Note-se que tal teoria se mostra mais coerente para aqueles que, a partir do art. 3 (2) da CM-OCDE, compreendem necessário o reenvio dinâmico ao Direito doméstico isto é, vigente no momento em que o acordo é aplicado e não quando de sua celebração na hipótese em que as evidências do "contexto" não fornecer um sentido contextualizado ao termo em questão. Ocorre que seria contraditório considerar que a cláusula de reenvio do art. 3 (2) da CM-OCDE requer que se considere o Direito interno dos Estados contratantes vigente no momento em que o acordo foi celebrado (consideração estática) e, ainda, que tal reenvio seria requerido diante da inexistência de solução razoável a partir do “contexto" composto pelo mesmo conjunto de normas domésticas de ambos os Estados.

Dado o seu status no Direito tributário internacional, o Direito doméstico dos Estados contratantes existente no momento em que o acordo foi celebrado e mantém-se entre as evidências do contexto extrínseco secundário e, como tal, nem sempre será determinante no processo de interpretação. Para MiCHAEL LANG ${ }^{885}$, por exemplo, quando os Estados contratantes adotam sem alterações o texto da CM-OCDE, seria necessário considerar o sentido indicado pelos Comentários à CM-OCDE do momento em que o acordo tenha sido celebrado, de modo a ser um erro suscitar o sentido do Direito doméstico de tais Estados.

Se a cláusula já estiver na CM-OCDE, provavelmente os Estados irão seguí-la ainda que não exerçam a tributação internamente. Mas se uma cláusula especial for inserida nos moldes adotados no Direito doméstico, seria possível perquirir os sentidos colhidos do sistema interno é que deveriam influenciar a interpretação do acordo.

\footnotetext{
${ }^{884}$ Nesse sentido, vide: BROE, Luc De. International tax planning and prevention of abuse (doctoral series $\mathrm{n}$. 14). Amsterdã : IBFD, 2007, 257; ENGELEN, Frank. Interpretation of Tax Treaties under International Law. Doctoral series n. 7. IBFD : Amsterdam, 2004, p. 149-150.

${ }^{885}$ LANG, Michael. Introduction to the law of double taxation conventions. Vienna : Linde, 2013, p. 49.
} 
O teste proposto nesta tese parece ser útil para o exame da admissibilidade do Direito doméstico dos Estados contratantes, existente no momento em que o acordo de dupla tributação foi celebrado. Identificado o status da evidência (art. 32 da CVDT), passase então ao exame dos critérios funcionais e materiais.

Sob a perspectiva dos aspectos funcionais, a evidência em análise apenas seria admissível nas hipóteses em que cortejar a interpretação harmônica e promover o efeito útil do acordo. Por sua vez, seria inadmissível quando promover interpretações notadamente divergentes entre os Estados contratantes ou que enfraquecessem o seu efeito útil.

Para aceitar-se tal evidência para a construção de sentido dos termos dos acordos de dupla tributação, parece razoável reconhecer que ambos os Estados contratantes devem estar cientes, por seus representantes, quanto às normas domésticas que deverão ser consideradas como existentes no momento da celebração do acordo de dupla tributação. Nem a CVDT, nem a CM-OCDE tratam da prova a ser produzida quanto ao conhecimento de tal questão pelos Estados contratantes, permitindo às Cortes nacionais adotar presunções ou, ainda, exigir a comprovação de tal estado de coisas.

Alguns exemplos colhidos da jurisprudência das Cortes nacionais, expostos a seguir, podem ilustrar a questão.

\subsubsection{Exemplo: Os tribunais canadenses e a consideração do Direito doméstico dos Estados contratantes no momento da celebração da convenção fiscal.}

\footnotetext{
"Another aspect of the application of the terms of the Convention, and particularly Article VIII thereof, was raised by the appellant on the basis that this Convention dates back to 1942 at which time the now well-worn phrase 'adventure in the nature of trade' became part of our income tax law, and therefore any gain that was made was treated as a 'capital gain' in the United States, and this country should not, and cannot, unilaterally change the connotation of whatever was known by that term in 1942 when the Convention was signed". Juiz Flanigan. Caso Ezra" (1975).
}

O antigo Caso Ezra (Canadá, 1975), do qual se colhe a passagem em epígrafe, fornece um bom exemplo da consideração do Direito doméstico dos Estados contratantes como evidência de qual o sentido teria sido consentido pelas partes do acordo internacional, o qual não poderia vir a ser alterado por legislações supervenientes. 
No Caso Melford (Canadá, 1982), a Suprema Corte do canadense parece ter aceito que o ambiente jurídico do Canadá, existente no momento em que o acordo CanadáAlemanha foi celebrado, seria conhecido não apenas pelos negociadores canadenses, mas também pelos alemães. Note-se, contudo, que nenhuma demonstração a esse respeito - a exemplo da troca de memorando entre os negociadores - foi requerida ou mesmo citada pela decisão da Corte canadense.

O Caso Gladden (Canadá, 1985) também pode ser adotado como exemplo. Com o falecimento do Sr. Gladden e a transmissão de seus bens à sua viúva, o Direito canadense exigiria a apuração do ganho de capital auferido por essa. O seu patrimônio, no entanto, consistia em participações em duas empresas residentes dos EUA, o que reclamaria a aplicação do acordo de bitributação firmado entre esses Estados, com a tributação de tais ganhos apenas pelo fisco norte-americano.

As autoridades fiscais canadenses, no entanto, exerceram tal tributação, refutando a aplicação do acordo Canadá-EUA. Conforme os seus argumentos, como o Canadá não tributava o ganho de capital à época da celebração dessa convenção internacional, não teria sido a sua intenção incluí-lo no acordo. Como forma de demonstrar que os Estados apenas teriam se comprometido em relação à tributação exercida à época em que o acordo de bitributação foi celebrado, o fisco canadense suscitou que o seu texto tutelaria os ganhos de capital decorrentes de "sale or exchange", precisamente os termos adotados pela legislação norte-americana à época.

O tribunal canadense, contudo, rejeitou tais evidências para a interpretação da convenção Canadá-EUA. Ao assumir um compromisso perante outro Estado de não exercer a tributação sobre determinados rendimentos, o Canadá deveria se manter firme em tal compromisso, tornando irrelevante se tal tributação já não se dava mesmo antes da celebração do acordo. Para o tribunal, seria uma noção trivial do Direito que as partes pudessem celebrar contratos antecipando-se a eventos futuros.

Além disso, o tribunal canadense julgou aplicável o art. 32 da CVDT, que impede a adoção de interpretações manifestamente absurdas e não razoáveis. Caso fosse adotado o sentido sugerido pelo fisco, a ficção jurídica criada pela legislação canadense 
superveniente ao acordo, que considera a sucessão hipótese de "sale or exchange", estaria sujeita à tributação no Canadá quando o patrimônio do de cujus estivesse localizado nos EUA; contudo, no caso de "sale or exchange" reais, em que bens estivessem localizados nos EUA, não seriam tributados no Canadá. Tal consequência pareceu absurda e não razoável aos juízes canadenses.

\subsubsection{Exemplo: Os tribunais norte-americanos e a consideração do Direito doméstico dos Estados contratantes no momento da celebração da convenção fiscal.}

No Caso Great-West (EUA, 1982), a fim de aplicar o acordo de dupla tributação EUA-Canadá, o tribunal considerou que os arts. 12 e 13 do aludido tratado buscou solucionar problemas que teriam surgido diante da legislação norte-americana de tributação de juros e dividendos pagos a canadenses por empresas canadenses, conforme a qual seriam tributados juros ou dividendos pagos por empresa estrangeira a não residentes, cuja fonte estivesse localizada nos EUA. O Direito canadense, observou o Tribunal, não possuía previsão similar. A coleta de tais tributos pelos EUA na prática teria se mostrado problemática e motivado a sua isenção no art. 12 do acordo Canadá-EUA, removendo a tributação sobre tais fontes, mas também garantindo aos EUA informações quanto aos contribuintes residentes nos EUA e que recebem rendimentos de fontes canadenses, a exemplo de dividendos e juros.

\subsection{A origem histórica do termo utilizado no acordo de dupla tributação.}

A linguagem técnica do Direito, especialmente do Direito tributário internacional, faz com que os seus operadores, muitas vezes, adotem termos estranhos à comunicação cotidiana. Tal fator pode tornar relevante que se investigue o fenômeno da criação de tais termos, bem como a sua evolução.

Na doutrina do Direito tributário internacional, parece ser AVERY JONES quem mais tem se dedicado a essa estratégia investigativa. Especialmente nos últimos anos, muitas vezes, em conjunto com outros autores, o professor inglês tem publicado trabalhos com a investigação da origem histórica de diversos termos importantes utilizados na CM- 
$\mathrm{OCDE}^{886}$.

É digno de nota, ainda, uma importante fonte de pesquisa sobre a história dos acordos de bitributação mantida pelo Institute for Austrian and International Tax Law $W U$, que pode ser acessada pela Internet ${ }^{887}$.

A questão, contudo, é saber qual a relevância de algumas pesquisas históricas. Ocorre que a origem histórica de alguns termos pode ser tão remota a ponto de se desprender do sentido a que os Estados contratantes consentiram em lhe atribuir para a celebração de uma específica convenção fiscal. Assim, se negociadores e os membros do Poder Legislativo de dois Estados contratantes não estavam a par da forma como determinados termos era utilizados em seus primórdios, descobertas arqueológicas a esse respeito em trabalhos acadêmicos em nada devem influenciar a interpretação e a aplicação de tal acordo de bitributação.

Por sua vez, é justamente por meio de investigações históricas que o intérprete pode averiguar a evolução do sentido atribuído a determinado termo, desde a sua origem até os dias atuais, com o propósito de identificar qual sentido seria capaz de satisfazer as expectativas mútuas dos Estados contratantes.

\subsubsection{Exemplo: A origem dos termos beneficiário efetivo ("beneficial owner").}

A expressão beneficiário efetivo ("beneficial ownership") pode ser adotada como exemplo. Originária do commow law, a expressão foi adotada pela primeira vez em 1966, em um protocolo firmado Reino Unido-EUA para a revisão do acordo de dupla tributação celebrado em 1945. Em 1977, a expressão passou a ser adotada pela CM-OCDE em seus arts. 10, 11 e 12, gerando discussões quanto ao seu sentido que ainda hoje estão longe de seu fim. Como a expressão sequer é adotada pelo sistema jurídico de uma série de

${ }^{886}$ Vide: AVERY JONES, John F; LÜDICKE, Jürgen. The Origins of Article 5(5) and 5(6) of the OECD Model, in World Tax Journal v. 6, n. 3. Amsterdam: IBFD, 2014; AVERY JONES, John F. Avoiding Double Taxation: Credit versus Exemption - The Origins, in Bulletin for International Taxation v.66, n. 2. Amsterdam: IBFD, 2012; AVERY JONES John F.; LÜDICKE, Jürgen. The Definitions of Dividends and Interest in the OECD Model: Something Lost in Translation?, in World Tax Journal v.1, n. 1. Amsterdam: IBFD, 2009; AVERY JONES John F. 2008 OECD Model: place of effective management - what one can learn from the history, in Bulletin for International Taxation v. 63, n. 5. Amsterdam: IBFD, 2009.

${ }^{887}$ Vide: http://www.taxtreatieshistory.org. Último acesso em 08/07/2014. 
ordenamentos legais, especialmente naqueles de tradição no civil law, o reenvio, muitas vezes, sequer é uma opção à interpretação a partir do "contexto".

Para a construção de sentido da expressão beneficiário efetivo ("beneficial ownership"), CHARL DU TOIT ${ }^{888}$ sugere como ponto de partida a investigação da fonte de onde se originou, bem como das evoluções que experimentou nesses quase 50 anos. $\mathrm{O}$ fato de a expressão ter surgido pela primeira vez em um acordo de dupla tributação celebrado por dois Estados de tradição no commow law (EUA e Reino Unido) faz despertar o interesse quanto ao seu sentido em tais sistemas jurídicos, com especial atenção à jurisprudência. Ocorre que tanto no caso Montana Catholic Missions v. Missoula County, julgado pela Suprema Corte norte-americana em 1906, quanto no caso Ayerst (Inspector of Taxes) v. $C \& K$ (Construction) Ltd, julgado pela House of Lords em 1975, a expressão estaria relacionada a incidentes ou atributos da propriedade e envolveria questões de direito e não de fato.

\subsubsection{Exemplo: a distinção entre sistemas jurídicos de tradição no common law e no civil law.}

Reunindo a experiência dos sistemas jurídicos com que têm afinidade, JOHN F. Avery Jones (Reino Unido), Luc De Broe (Bélgica), Maarten J. Ellis (Países Baixos), Kees van RaAd (Países Baixos), Jean-Pierre Le Gall (França), Henri Torrione (Suíça), Toshio Miyatake (Japão), Sidney I. Roberts (EUA), SAnford H. GoldberG (EUA), Jürgen Killius (Alemanha), Guglielmo Maisto (Itália), Federico GiUliani (Itália), Richard J. VANN (Austrália), DAVID A. WARD (Canadá) e BERTIL WimaN ${ }^{889}$ (Suécia) demonstram como uma variedade de termos presentes no acordos de bitributação podem ter sentidos diversos em sistemas de tradição no common law ou no civil law.

\footnotetext{
${ }^{888}$ TOIT, Charl du. The Evolution of the Term "Beneficial Ownership" in Relation to International Taxation over the Past 45 Year, in Bulletin for International Taxation Vol. 64, n. 10. Amsterdã : IBFD, 2010, p. 501 e

${ }^{889}$ AVERY JONES, John F; BROE, Luc De, ELLIS, Maarten J.; RAAD, and Kees van; GALL, Jean-Pierre Le; TORRIONE, Henri, MIYATAKE, Toshio; ROBERTS, Sidney I.; GOLDBERG, Sanford H.; KILLIUS, Jürgen; MAISTO, Guglielmo; GIULIANI, Federico; VANN, Richard J., WARD, David A.; WIMAN, Bertil. Treaty Conflicts in Categorizing Income as Business Profits Caused by Differences in Approach between Common Law and Civil Law, in Bulletin for International Taxation vol. 57, n. 6. Amsterdã : IBFD, 2013, p. 237-238.
} 
Uma diferença fundamental consiste que os países com tradição no civil law tratam todos os rendimentos de uma empresa comercial como "business profits", de forma a distinção de tratamento se dá em razão da pessoa que os aufere. Já a distinção para fins tributários nos países com tradição no common law geralmente se daria em razão da espécie de rendimento obtido.

O termo "capital gain" ilustra bem a questão, pois países do civil law podem não distinguir ganhos de capital de lucros das empresas ("business profits"), enquanto que países do common law os tratam como rendimentos distintos na tributação de pessoas jurídicas. Nesse seguir, RICHARD VANN ${ }^{890}$ observa que países com tradição no common law em geral consideram como ganho de capital quaisquer ganhos obtidos com ativos, exceto sobre invenções ou bens de uso pessoais; entre esses, alguns países não tributariam tais ganhos, enquanto outros concedem tratamento mais benéfico a esses. Por sua vez, países com tradição no civil law possuem concepções muito mais estreitas quanto aos "ganhos de capital" ou, ainda, não possuem tal previsão, com a tributação indistinta de tais rendimentos em relação aos demais.

\subsubsection{Exemplo: O termo "enterprise" na CM-OCDE.}

Ao investigar o termo "enterprise" da CM-OCDE, KEES VAN RAAD" ${ }^{891}$, recorreu a evidências do contexto intrínseco (comparação de diferentes dispositivos da CM-OCDE), bem como à origem histórica desse termo nos trabalhos desenvolvidos pela Liga das Nações. O relatório apresentado em 1925 teria utilizado os termos "undertaking”, "enterprises" e "company" de forma indiscriminada, com referência a "business organization".

Tal constatação poderia trazer obscuridade ao termo "enterprises", já que KEES VAN RAAD iniciou tal investigação histórica portando dois outros sentidos, construídos do contexto intrínseco do referido termo: "business" ou "person". O mesmo teria ocorrido com os projetos de convenções apresentados pela Liga das Nações em 1927, 1933 e 1943.

\footnotetext{
${ }^{890}$ VANN, Richard J. International Aspects od Income Tax, in Tax Law Design and Drafting (Ed. THURONYI, Victor). Londres : Kluwer, 1998, p. 743-744.

${ }^{891}$ RAAD, Kees van. The term 'Enterprise' in the Model Double Taxation Conventions - Seventy Years of Confusion, in Intertax 1994/11, Intertax, 1994, p. 494-498.
} 
A CM-OCDE de 1977 e 1992 - embora ainda devessem ser revistas na posição do professor de Leiden - teriam o mérito de ter aperfeiçoado os termos da fórmula irregular e errática adotada pela Liga das Nações.

\subsection{A participação de um ou de ambos os Estados contratantes em grupos econômicos}

A participação de um de ambos os Estados contratantes em comunidades, grupos econômicos, mercados comuns etc. envolve a consideração de diversos fatores anteriormente analisados neste estudo, o princípio da integração sistêmica, parallel treaties e circunstâncias para a celebração do outro acordo, de modo que as evidências geradas nesse contexto podem assumir diferentes status perante o Direito tributário internacional.

Assim, no caso de Estados membros da UE, os regulamentos de seu Direito comunitário deveriam ser observados ${ }^{892}$, da mesma forma que não se poderia cogitar a consideração de normas do MERCOSUL.

\subsection{A celebração de acordos entre países industrializados e países em desenvolvimento.}

GERD W. ROTHMANN ${ }^{893}$ observou que haveria ao menos quatro grandes gêneros de acordos de dupla tributação: “a) tipo europeu, em que, em princípio, prevalece o método da isenção, com algumas exceções a favor do método do crédito fiscal; b) tipo anglosaxônico, em que o respectivo Estado aplica o método do crédito fiscal, mesmo quando o outro Estado Contratante utilizar o método de isenção; c) tipo sul-americano, que, via de regra, tem caráter especial, devido à aplicação do princípio da territorialidade, que prepondera nos países sul-americanos; d) acordos entre países industrializados e países em desenvolvimento, que, de um lado, levam em consideração as necessidades do respectivo

\footnotetext{
892 JIMÉNEZ, Adolfo J. Martín. Defining the objective scope of income tax treaties: the impact of the other treaties and EC Law on the Concept of Tax in the OCED Model, in Bulletin - Tax Treaty Monitor - October 2005. Amsterdã : IBFD, 2005, p. 434.

${ }^{893}$ ROTHMANN, Gerd W. Interpretação e aplicação dos acordos internacionais contra a bitributação. Tese de doutorado. São Paulo : Faculdade de Direito da Universidade de São Paulo (USP), 1978, p. 148-149.
} 
país em desenvolvimento, e, por outro lado, contêm normas para não desestimular os investimentos naqueles países."

Também seriam distintas as motivações que conduzem países em desenvolvimento à celebração de acordos de dupla tributação. ROY ROHATGI ${ }^{894}$ considera que, enquanto dois países desenvolvidos e com semelhantes sistemas jurídicos celebram tais acordos simplesmente para implementar um melhor balanceamento da divisão das receitas tributárias, países em desenvolvimento também seriam conduzidos por fatores econômicos e sociais, como a promoção do fluxo de capitais, de trabalho e de tecnologia.

Nesse seguir, Luís EdUARDo SCHOUERI ${ }^{895}$ suscita que, além dos objetivos e propósitos geralmente presentes nas convenções fiscais, essas também podem servir de instrumento para o desenvolvimento de países menos desenvolvidos. Em tais acordos, a reciprocidade entre os Estados contratantes daria lugar a fluxos financeiros unidirecionais, com a renúncia mais evidente de receitas pelo Estado desenvolvido em favor de seu parceiro internacional menos desenvolvido. Cláusulas de tax sparing ou matching credit seriam mecanismos utilizados para tanto.

A questão que surge, contudo, é se tais características poderiam direcionar o intérprete na interpretação de seus termos, de tal modo que o sentido desses sempre deveriam favorecer os Estados em desenvolvimento.

Acordos celebrados entre Estados em desenvolvimento podem ainda enfraquecer a valia de evidências consideradas úteis por países desenvolvidos para a interpretação dos termos insertos em seus acordos de bitributação. Os Comentários à CM-OCDE representam um excelente exemplo. Como o CAF-OCDE é composto basicamente por Estados desenvolvidos, que naturalmente possuem muitos interesses diversos dos países em desenvolvimento, suas conclusões podem não ser tão úteis para esses últimos ${ }^{896}$.

\footnotetext{
${ }^{894}$ ROHATGI, Roy. Basic International taxation. Volume 1: principles. Nova Deli : Taxmann, 2005, p. 3.

${ }^{895}$ Sobre a questão, vide: SCHOUERI, Luís Eduardo. Tratados e Convenções Internacionais sobre Tributação, in Revista de Direito Tributário Atual n. 17. São Paulo : IBDT/Dialética, 2003, p. 37.

${ }^{896}$ Sobre a questão, vide: SCHOUERI, Luís Eduardo. Tratados e Convenções Internacionais sobre Tributação, in Revista de Direito Tributário Atual n. 17. São Paulo : IBDT/Dialética, 2003, p. 37.
} 


\subsection{A política adotada por parte dos Estados contratantes em relação aos acordos de dupla tributação.}

Ao adotar-se um conceito amplo de "contexto", RoY RoHATGI ${ }^{897}$ pondera que deveria ser considerada a política adotada por parte dos Estados contratantes em relação aos acordos de dupla tributação.

No entanto, não é tão claro como tal elemento poderia efetivamente auxiliar no processo de interpretação de termos específicos utilizados em convenções fiscais. Em geral, sequer é possível identificar se há ou não uma política clara estabelecida pelos Estados para a formação de sua rede de acordos internacionais em matéria tributária. Como exemplo, YARIV BRAUNER ${ }^{898}$ relata que o processo de negociação e as políticas adotadas nos EUA para a celebração de acordos de bitributação mostram-se extremamente sigilosas e obscuras: "a razão com frequência mencionada para essa falta de transparência é o desejo de manter o poder no processo de negociação".

\subsection{O idioma no qual as negociações foram conduzidas.}

Um último elemento pode ser considerado: o idioma em que o acordo de bitributação é negociado e celebrado pode influenciar na seleção dos termos adotados em seu texto. Na opinião de KLAUS VOGEL ${ }^{899}$, no entanto, pouco proveito se poderia obter com esse fator.

A questão, objeto do art. 33 da CVDT, foi abordada no Capítulo II desta tese, ao qual ora se faz remissão.

\footnotetext{
${ }^{897}$ ROHATGI, Roy. Basic International taxation. Volume 1: principles. Nova Deli : Taxmann, 2005, p. 4950.

${ }^{898}$ BRAUNER, Yariv. Por que os Estados Unidos firmam Tratados Tributários? E por que não têm Tratado Tributário com o Brasil?, in Revista Direito Tributário Atual n. 26. São Paulo : IBDT/Dialética, 2011, p. 110 e seg.

${ }^{899}$ VOGEL, Klaus. Klaus Vogel on Double Taxation Conventions. Kluwer : London, 1999, p. 39.
} 


\section{CONCLUSÕES}

O presente estudo se ocupou do "contexto" referido no art. 3 da CM-OCDE, especialmente em seu $2^{\circ}$ parágrafo, com o objetivo de compreender essa norma de interpretação e aplicação de termos não definidos nas convenções fiscais.

A pesquisa demonstrou a existência de uma quantidade considerável de materiais produzidos pela doutrina e por tribunais de diferentes nações a respeito do tema, embora frequentemente esparsos, contraditórios e omissos. Não obstante, há elementos suficientes para confirmar a hipótese assumida na introdução da presente tese: o "contexto" referido no art. 3 (2) da CM-OCDE corresponde a um repertório, acervo, conjunto, coleção de evidências (formulação constitutiva) capazes de servir de argumento quanto ao sentido contextualizado dos termos dos acordos de dupla tributação, de modo a promover o efeito útil e a interpretação harmônica deste, com a observância das normas de fundamental importância de ambos os Estados contratantes (formulação funcional).

Por uma formulação diferencial, também é possível distinguir o "contexto" referido no art. 3 (2) da CM-OCDE: (i) do "contexto" inserto no art. 31 (2) da CVDT, o que afasta a teoria do contexto exclusivamente intrínseco; (ii) do Direito doméstico dos Estados contratantes, cujo acesso depende exatamente do fracasso do contexto para prover um sentido contextualizado razoável e (iii) de posturas liberais ou extensivas.

No Capítulo I, foi possível concluir que a corrente do contexto amplo parece ser a que melhor explica o sentido e a extensão do "contexto" referido no art. 3 (2) da CMOCDE, bem como a sua precedência em relação à cláusula de reenvio ao Direito doméstico presente no mesmo dispositivo. O art. 3 (2) da CM-OCDE adota uma fórmula condicional: se o "contexto" não prover um sentido plausível ao termo do acordo, o "Direito doméstico" deverá provê-lo. O "contexto" impõe a condição, que pode ou não ocorrer: cabe ao "contexto" e não ao "Direito doméstico" a preferência para requerer qual interpretação será aplicada.

Os termos não definidos nos acordos de dupla tributação apenas devem ser interpretados conforme o Direito doméstico dos Estados contratantes quando o "contexto" 
conduzir para tal conclusão ou, ainda, em face do fracasso do "contexto" em fornecer uma solução interpretativa adequada à questão. Por isso, concluiu-se que o gatilho para o reenvio ao Direito doméstico dos Estados contratantes é, portanto, a precedente análise do "contexto".

Verificou-se no Capítulo I, ainda, critérios para o reconhecimento de evidências componentes do "contexto": (i) critérios formais, capazes de identificar elementos provenientes de fontes legitimadas pelo Direito Internacional e em consonância com as normas do Direito interno de importância fundamental e manifesta; (ii) critérios funcionais, relacionados à promoção do efeito útil e da interpretação harmônica das convenções fiscais, bem como; (iii) critérios materiais, relacionados à plausividade das evidências.

Os Capítulos II, III e IV se dedicaram à análise de evidências em espécies, organizadas, respectivamente, no "contexto intrínseco", "contexto extrínseco primário" e "contexto extrínseco secundário".

No Capítulo II, verificou-se que o contexto intrínseco é apenas um dos estágios da investigação do operador do Direito tributário internacional: embora possa ser o ponto de partida, está longe de ser o ponto final. A única e combinada operação de interpretação ("a closely integrated single rule of interpretation") requerida pela CVDT exige que se considere tanto o contexto intrínseco quanto o extrínseco, não havendo necessária relação de hierarquia entre eles. Por isso, o intérprete não deve se dar por satisfeito diante de evidências do contexto intrínseco que se mostrem à primeira vista convincentes quanto ao sentido dos termos dos acordos de bitributação, mas prosseguir com a sua investigação e questionar a existência de outras evidências no contexto extrínseco primário e secundário. Tais evidências extrínsecas podem conduzir a outros sentidos mais adequados para os propósitos e objetivos da convenção fiscal, bem como servir de contraprova àquele sentido inicialmente construído a partir do contexto intrínseco.

Entre as evidências intrínsecas analisadas no Capítulo II, destacam-se o texto do acordo de bitributação, seu preâmbulo e anexos, documentos elaborados em conexão com o tratado, protocolos e acordos posteriores celebrados pelos Estados contratantes. 
Tão importante quanto identificar as evidências intrínsecas é saber como manejálas. Assim, também foram analisadas técnicas úteis à exploração do contexto intrínseco, como métodos sintáticos e semânticos de interpretação do texto, testes comparativos da função e do sentido dos termos no acordo de dupla tributação como um todo, a identificação dos objetivos e propósitos do acordo a partir de detalhes de cada uma de suas partes.

Concluiu-se, ainda, que o art. 3 (1) pode ser diferenciado do art. 3 (2) da CMOCDE devido às evidências intrínsecas disponíveis ao intérprete. Em relação ao art. 3 (1) da CM-OCDE, o texto do acordo indica sentido de uma série de termos, enquanto que os termos sob o escopo do art. 3 (2) da CM-OCDE são identificados justamente por não possuir evidências intrínseca tão claras. Tanto para um quanto para o outro, no entanto, o “contexto" é relevante.

A análise do contexto extrínseco primário, no Capítulo III, teve início com os procedimentos amigáveis. Após o delineamento de seu perfil na CM-OCDE, CM-ONU, CM-EUA e nos acordos de bitributação em geral celebrados pelo Brasil, foram verificados argumentos especialmente baseados na questão da "legalidade”, que vêm sendo suscitados pela doutrina para a sua impugnação perante diversos ordenamentos constitucionais.

No Brasil, o argumento da legalidade tributária não parece ser o mais adequado para solucionar a questão da validade dos procedimentos amigáveis perante o sistema jurídico pátrio. Ocorre que, conforme o art. 150. I, da CF, o princípio da legalidade em matéria tributária veda a exigência ou o aumento de tributo sem lei que o estabeleça. Exige-se, portanto, que uma lei estabeleça a cobrança de impostos, o que não é o objeto de acordos de dupla tributação.

Há, por sua vez, exigência de legalidade da decisão de vinculação do Brasil por meio de acordos internacionais, com a necessária parceria entre o Poder Executivo e o Poder Judiciário. O art. 84, VIII da Constituição atribui ao Presidente da República competência privativa para "celebrar tratados, convenções e atos internacionais, sujeitos a referendo do Congresso Nacional". Ocorre que é de competência exclusiva do Congresso Nacional "resolver definitivamente sobre tratados, acordos ou atos internacionais que 
acarretem encargos ou compromissos gravosos ao patrimônio nacional", conforme o art. 49, I da Constituição.

O princípio da legalidade para a decisão de vinculação do Brasil por meio de acordos internacionais não conduz, contudo, à necessária invalidade dos procedimentos amigáveis, conduzidos, como se viu, por autoridades administrativas de dois Estados contratantes. É necessário distinguir algumas situações.

Tratando-se de procedimentos amigáveis interpretativos ou individuais, parece não haver ofensa à legalidade quando as autoridades administrativas acordam que, entre diversas interpretações igualmente possíveis e plausíveis, uma delas será adotada de forma harmônica, a fim de evitar a dupla tributação da renda. Nada afastaria do Poder Judiciário brasileiro a função de decidir se a interpretação conduzida pelas autoridades administrativas seria ou não “correta”. Quando o juiz verificar que as administrações fiscais de fato alcançaram uma interpretação plausível para a convenção fiscal, embora outras também fossem igualmente possíveis, parece prudente privilegiar a versão da norma compreendida bilateralmente pelas autoridades fiscais, para a promoção da interpretação harmônica e do efeito útil da convenção fiscal.

Por sua vez, ao menos no sistema jurídico brasileiro, os procedimentos amigáveis integrativos estão sujeitos a maiores questionamentos, pois exigem a aceitação da tese da delegação de competência atribuída ao Poder Legislativo às autoridades administrativas. Entende-se que a celebração de um acordo de bitributação, contendo cláusula equivalente à segunda parte do art. 25 (3) da CM-OCDE, não atribui às autoridades administrativas um cheque em branco para comprometerem o País em situações diversas daquelas que contaram com a aprovação do Congresso Nacional.

Ao menos no Brasil, a questão dos procedimentos amigáveis ainda é apenas teórica. Há no máximo rumores sobre procedimentos amigáveis conduzidos, mas definitivamente não se trata de uma prática corrente com os seus parceiros internacionais. O sigilo que os Estados geralmente guardam em relação aos procedimentos amigáveis, no entanto, poderia ser ultrapassado no Brasil, tendo em vista a Lei de Acesso à Informação, de 2011. 
A segunda evidência apresentada no Capítulo II sob o escopo do contexto extrínseco primário consiste em práticas seguidas posteriormente na aplicação do tratado. Embora não tenha sido reconhecida pela CVDT a função modificadora de tais práticas subsequentes, lhes foi atribuída a função interpretativa, de forma que podem prover uma clara evidência do que os Estados reconhecem ter acordado, como têm construído e desenvolvido o sentido do acordo internacional e, por consequência, qual a expectativa que nutrem em relação ao comportamento do outro Estado contratante.

Foram analisadas práticas subsequentes conduzidas por autoridades fiscais, judiciárias e legislativas em relação à aplicação de acordos de dupla tributação. $\mathrm{O}$ monopólio da última palavra, geralmente atribuído constitucionalmente ao Poder Judiciário, contribui para a confirmação de que tais práticas do Estado na aplicação de um acordo de dupla tributação observam as suas normas de fundamental relevância (art. 27 e 46 da CVDT) e melhor se prestam à promoção do efeito útil e a interpretação harmônica dos Estados contratantes. A questão da definitividade com que o acordo é aplicado torna necessária a consideração da hierarquia ou competência do Tribunal para julgar questões tributárias em última instância.

É possível compreender que os Estados são obrigados a considerar decisões do outro Estado contratante como evidência do sentido de termos dos acordos de dupla tributação, mas não estão compelidos a concordar e segui-las, caso não as considere plausíveis. No entanto, não se pode ignorar que ainda hoje persistem as dificuldades para o acesso às decisões de Cortes estrangeiras quanto à aplicação de convenções fiscais. Iniciativas como a promovida pelo IBFD, para a composição de um banco de decisões de tribunais de variadas jurisdições, embora absolutamente festejáveis, ainda não se mostram como uma ferramenta sempre eficiente para fornecer evidências quanto ao sentido dos termos dos acordos de dupla tributação. A gradual evolução de bancos de dados como esses deve ser acompanhada da adoção de outras medidas, como a criação de canais de diálogo entre os julgadores de diferentes nações (a exemplo da IATJ) e a ampliação das hipóteses do artigo 2 (2) dos acordos de bitributação, de forma que, além de mudanças significativas nas respectivas legislações fiscais, os Estados contratantes também notifiquem-se mutuamente quanto a qualquer publicação oficial relacionada à aplicação do acordo, incluindo atos declaratórios, regulamentos e decisões judiciais. 
Outras iniciativas também parecem ser possíveis e necessárias, como o estabelecimento de convênios entre os tribunais dos Estados contratantes de convenções fiscais para que se comuniquem diretamente. Seria auspicioso se a adequada interpretação e aplicação de convenções fiscais também entrasse em pauta das Cortes Superiores brasileiras, com o estabelecimento de convênios de troca de informações com todos os países com os quais o Brasil possui acordos de bitributação.

Além das práticas subsequentes conduzidas pelo Poder Judiciário para a aplicação das convenções fiscais, práticas da administração fiscal e do Poder Legislativo também podem ser úteis para a interpretação dos termos dos acordos de bitributação. Cautelas redobradas, no entanto, são indispensáveis.

Não se pode ignorar ser bastante sutil a diferença entre a adoção de medidas legislativas tendentes a alterar o conteúdo de uma convenção fiscal celebrada (treaty override) de outras, que apenas aclarariam o quanto foi acordado internacionalmente. Por hipótese, a produção, em 2015, de uma lei brasileira quanto ao sentido dos termos dos acordos de bitributação celebrados pode não ser reconhecida pelo Japão como a compreensão de seu Estado nos idos de 1967. Em vez de evidência útil aos operadores japoneses para a interpretação do acordo Brasil-Japão a partir de seu "contexto", tal lei brasileira poderia dar causa à renúncia ou ao pedido de renegociação por parte do Japão.

Por sua vez, a consideração de práticas administrativas de um Estado (“A”) por outro Estado contratante ("B") como evidência para interpretação de uma convenção fiscal (“A-B”) depende do status de tais elementos em sua própria jurisdição, o que pode demandar a análise do Direito interno de importância fundamental e manifesta de cada um dos Estados contratantes (CVDT, art. 27 e 46) e, em especial, da precariedade de tal interpretação naquele sistema ("A").

Para que se tornem evidências que realmente contribuem para a interpretação de uma convenção fiscal pelos operadores de um Estado (“A”), quaisquer das práticas subsequentes de outros Estados (“B”), sejam elas judiciais, legislativas ou administrativas, devem passar pelo crivo do exame da plausividade. Tal exercício dialético parece ser bastante saudável ao desenvolvimento do Direito tributário internacional, pois ainda que o juiz de um Estado (“A”) não concorde com as razões aduzidas por agentes administrativos, 
legislativos ou mesmo juízes de um outro Estado contratante (“B”), certamente poderá aprender muito com a análise de questões complexas, que já terá tomado tempo desses intérpretes estrangeiros.

O parallel treaty foi a terceira evidência apresentada no Capítulo II sob o escopo do contexto extrínseco primário. A adoção de outros acordos internacionais como pares de comparação pode ser meio hábil para fornecer evidências quanto ao sentido de termos de uma específica convenção fiscal.

Com vistas à diversidade de possibilidades que o tema enseja, este estudo distinguiu os parallel treaties próprios de outros, chamados impróprios, por não envolverem outros acordos internacionais efetivamente celebrados por um dos Estados contratantes, mas modelos de convenções, a exemplo da CM-OCDE, CM-ONU e CMEUA. Os parallel treaties próprios englobariam outros tratados celebrados por um ou por ambos os Estados contratantes, sejam eles acordos de bitributação ou relacionados a outras matérias tributárias ou mesmo não tributárias.

Foram analisados exemplos do efetivo recurso a parallel treaties para a interpretação de acordos de bitributação. No entanto, não se pôde deixar de observar o extremo cuidado que tal recurso exige. Diferenças na redação de um acordo não necessariamente significam que substantivas alterações em seu sentido foram pretendidas por seus negociadores, bem como é razoável que os Estados contratantes de um acordo tenham desejado esclarecimentos que não foram reclamados pelas partes de outro tratado, sem que, com isso, tenham sido celebradas normas diversas.

O Capítulo IV, que antecedeu as presentes conclusões, abordou o chamado contexto extrínseco secundário. As evidências analisadas nesse capítulo possuem a função de confirmar ou infirmar determinado sentido construído a partir de evidências intrínsecas ou evidências extrínsecas secundárias, como contraprovas que podem ser lançadas por advogados do físco ou do contribuinte. A única e combinada operação de interpretação ("a closely integrated single rule of interpretation") requerida pela CVDT não exclui o acesso a evidências do contexto extrínseco, mas regulamenta a sua utilização. Caso evidências sob o escopo do art. 31 (3) "c" da CVDT cumulado com o art. 38 (1) "c" do ECIJ ou, ainda, do art. 32 da CVDT, apresentem mensagens plausíveis e úteis, poderiam 
ser utilizadas para confirmar ou mesmo infirmar o sentido construído a partir de evidências intrínsecas ou de evidências extrínsecas primárias. Considerado em conjunto com o contexto intrínseco, extrínseco primário e extrínseco secundário, a questão se resolveria em favor da evidência dotada de argumento mais plausível.

Suscitou-se, contudo, que evidências do contexto intrínseco ou do contexto extrínseco primário podem se mostrar tão plausíveis quanto aquelas fornecidas pelo contexto extrínseco secundário. Em tais casos, então, deveriam ser adotados os critérios de desempate de evidências disciplinados pela CVDT: os sentidos fornecidos por evidências intrínsecas e extrínsecas primárias teriam preferência em relação àqueles construídos a partir do contexto extrínseco secundário.

As primeiras evidências analisadas no Capítulo IV foram as decisões de Cortes nacionais de terceiros Estados. Foi possível concluir que, no caso de coincidência de resultados obtidos por Tribunais de terceiros Estados, o sentido construído a partir de evidências intrínsecas ou evidências extrínsecas secundárias pode ganhar força argumentativa e mais aparência de credibilidade. A plausividade da decisão de um terceiro Estado pode abrir os olhos do intérprete para sentidos que já lhe seriam possíveis ainda que não as tivesse acessado, podendo, inclusive, infirmar interpretações construídas a partir de outras evidências ou, ainda, suprir a ausência de quaisquer outras evidências no contexto internacional, evitando, assim, o reenvio ao Direito doméstico.

A segunda evidência analisada no Capítulo IV foi a doutrina dos publicistas mais qualificados das diferentes Nações. Produzida por indivíduos ou por instituições, trata-se de evidência que se adequa perfeitamente na função desempenhada pelo contexto extrínseco secundário, com potencial para preencher os critérios formais, funcionais e materiais adotados nesta tese.

Em especial, a plausividade de suas posições e a coerência com as suas premissas parecem ser fundamentais para o reconhecimento de doutrina como evidência do contexto extrínseco secundário. A reputação de um acadêmico sem dúvida é relevante, inclusive por alçá-lo entre os publicistas mais qualificados das diferentes Nações, mas o argumento de autoridade é suficiente. 
Como terceira evidência no âmbito do contexto extrínseco secundário analisado no Capítulo IV, foram analisadas a CM-OCDE os seus respectivos Comentários. Foram analisados, ainda, outros modelos de acordos de bitributação, especialmente a CM-ONU e a CM-EUA.

Nesse seguir, investigou-se o recurso ao parallel treaty impróprio, adotando-se como par de comparação a CM-OCDE ou outros modelos de acordos de bitributação ou, ainda, modelos de outras espécies de convenções internacionais em matéria tributária, como "Estate and Inheritance Draft Model Convention" e "Estate, Inheritance and Gift Model Convention".

$\mathrm{O}$ recurso à CM-OCDE como par de comparação é cada vez mais comum nos tribunais de variadas jurisdições. No entanto, como se pôde observar, é necessário distinguir situações em que: (a) ambos os Estados contratantes são membros da OCDE; $(b)$ ao menos um dos Estados contratantes não é membro da OCDE, mas observador convidado (como se dá com o Brasil em relação à OCDE) ou; (c) se ao menos um dos Estados contratantes não é membro e nem observador convidado.

Em relação aos Comentários à CM-OCDE, não menos do que onze teorias foram identificadas quanto ao seu status perante o Direito Internacional. Tais materiais, concluiuse, parecem assumir o status de doutrina dos publicistas mais qualificados das diferentes nações.

Os Comentários à CM-OCDE, tal como a doutrina: (i) não criam o sentido dos termos dos acordos de dupla tributação, mas apenas descrevem interpretações que o CAFOCDE compreende possíveis; (ii) são atemporais, pois as interpretações descritas em tais materiais poderiam ser consideradas plausíveis ou refutadas por Cortes nacionais, independentemente do momento de sua produção; (iii) requerem o recurso à analogia (iv) trata-se de uma instituição que congrega especialistas; $(v)$ promovem o critério funcional como meio auxiliar para a determinação de sentido; e (vi) requerem critérios materiais de reconhecimento, como perícia, reputação e plausibilidade. 
Como se pôde observar, em relação aos Estados membros da OCDE, por força do 18 do regulamento daquela organização, os Comentários funcionam como doutrina de consideração obrigatória e de observação dependente de sua plausividade.

Infelizmente, os Comentários à CM-OCDE têm pecado justamente em relação à sua plausividade. A política de revisões constantes, com frequente alteração ou mesmo flutuação de posições, desacompanhadas da justificativas claras, enfraquece o seu potencial para colaborar na interpretação dos acordos de bitributação.

Também foi suscitado o fenômeno da mutação da natureza jurídica dos Comentários à CM-OCDE. Tal mutação, contudo, não soluciona por si a questão da admissibilidade de tais evidências para a solução de um caso concreto. Ocorre que se torna necessário o enfrentamento de todas as questões suscitadas em relação ao seu novo status (critério formal) e, qualquer um que este seja, está sujeito ao questionamento de sua aptidão para a promoção do efeito útil e da interpretação harmônica do acordo (critério funcional), bem como dependente de sua plausividade (critério material).

A quarta evidência analisada no Capítulo IV foram os trabalhos preparatórios. Compreende-se que estes sempre podem ser acessados pelo operador, não apenas quando as evidências intrínsecas ou extrínsecas primárias conduzirem à ambiguidade, obscuridade, manifesto absurdo ou ausência de razoabilidade. Os trabalhos preparatórios podem dar ensejo a argumentos plausíveis, capazes de iluminar, inclusive, a compreensão de outras evidências componentes do contexto. Por se tratar de meio suplementar, contudo, jamais prevalecerá no embate com outros argumentos igualmente plausíveis.

Trata-se, no entanto, de evidência marginalizada e de pouca utilidade prática. Ocorre que a ausência de publicidade em geral impossibilita que os operadores do Direito tributário internacional os acessem. No Brasil, contudo, tal situação foi alterada com a Lei de Acesso à Informação, o que foi demonstrado pelo projeto "História das políticas e das negociações das convenções internacionais em matéria tributária celebradas pelo Brasil", promovido pelo IBDT. Quaisquer interessados podem ter acesso aos trabalhos preparatórios dos acordos de bitributação celebrados pelo Brasil, provavelmente sob a guarda da CORIN. 
A quinta evidência analisada no Capítulo IV foram os atos unilaterais quanto à intenção dos Estados contratantes. Embora não vinculantes, tais elementos do contexto extrínseco secundário podem ser úteis como guia para a interpretação harmônica entre os Estados. A transposição da teoria consensualista das fontes ao Direito tributário internacional legitima que um Estado, por ato unilateral, se comprometa a determinada forma de interpretar os seus acordos de bitributação. No entanto, tais atos unilaterais têm eficácia para vincular parceiros internacionais, de tal forma que não teriam o condão de suprimir ou reduzir a porção assegurada a outros Estados por meio de tratado internacional.

Sob essa perspectiva, embora seja correto distinguir atos unilaterais dos trabalhos preparatórios, que pressupõem bilateralidade, não se pode recusar a priori que aqueles também possam configurar evidências quanto ao sentido dos termos dos acordos de dupla tributação, sob o escopo do contexto extrínseco secundário, e com a eficácia limitada para vincular apenas o Estado do qual tais atos unilaterais tenham sido emanados.

Por fim, também sob o escopo do contexto extrínseco secundário, o Capítulo IV tratou das circunstâncias relacionadas à conclusão da convenção fiscal, em especial: (i) Circunstâncias fáticas ocorridas no período das negociações e da celebração do acordo de dupla tributação; (ii) acordos de dupla tributação anteriormente celebrados entre os mesmos Estados; (iii) o Direito doméstico dos Estados contratantes no momento da celebração da convenção fiscal; (iv) a origem histórica do termo utilizado no acordo de dupla tributação; (v) a participação de um ou de ambos os Estados contratantes em grupos econômicos; (vi) a celebração de acordos entre países industrializados e países em desenvolvimento; (vi) a política adotada por parte dos Estados contratantes em relação aos acordos de dupla tributação e; (vii) o idioma no qual as negociações foram conduzidas.

Como última conclusão, é possível afirmar que a interpretação do Direito tributário internacional não é ofício para leigos. Análises superficiais não são suficientes para cumprir a função dos acordos de bitributação. Investigações aprofundadas conduzidas por especialistas em Direito tributário internacional, habituados com a variedade de evidências que podem ser úteis para cada caso 


\section{concreto, são essenciais para o adequado cumprimentos das obrigações mutuamente estabelecidas pelos Estados contratantes.}

Bem compreendidas, as decisões de tribunais nacionais e estrangeiros analisadas nesta tese apresentam o esforço de advogados (dos contribuintes e do fisco) para o convencimento de juízes quanto ao sentido dos termos de convenções fiscais. O passo antecedente consiste na investigação de evidências que lhes possam servir de argumento nessa disputa: quanto mais evidências do contexto intrínseco e extrínseco sejam levantadas por uma das partes em litígio, maior o seu potencial argumentativo.

Decisões de tribunais estrangeiros, produzidas décadas atrás, já apresentavam a preocupação em interpretar convenções fiscais a partir de seu "contexto", com a consideração de evidências que the foram apresentadas ou mesmo pela investigação proativa de outras mais, com a seleção dos argumentos que melhor se harmonizassem com as normas do Direito Internacional, especialmente à CVDT.

Os tribunais brasileiros apenas nos últimos anos passaram a dar os seus primeiros passos para a aplicação de acordos de bitributação. Duas das mais importantes decisões enunciadas pelo STJ sobre o tema - casos Falcão e Copesul - sequer fazem referência à CVDT ou à cláusula do "contexto" do art. 3 (2) da CM-OCDE.

Há, assim, um inevitável reclamo: se a experiência jurisprudencial brasileira nesse campo é tardia, é preciso que seja rápida a compreensão por parte dos tribunais das peculiaridades que o Direito tributário internacional assume diante da legislação puramente doméstica e das consequências interpretatidas decorrentes.

Os advogados brasileiros assumem um papel essencial nesse processo: embora os juízes não estejam de mãos atadas para conhecer o Direito, é função do advogado investigar exaustivamente evidências legitimadas pelo Direito tributário internacional para a construção de sentido dos termos dos acordos de bitributação, bem como adotar estratégias argumentativas hábeis para explorá-las perante os tribunais.

Nesse cenário, a presente tese pode auxiliar os operadores do Direito tributário internacional na seleção de argumentos qualitativamente mais apurados, aptos a satisfazer 
critérios formais, funcionais e materiais para a construção de sentido dos termos das convenções fiscais. Um salto quantitativo nas evidências manejadas por tais profissionais também seria auspicioso quando se constata que, embora não hajam fórmulas, quanto mais elementos apontarem para um mesmo sentido, mais convincente pode se tornar a argumentação e a decisão adotada.

Aos julgadores cabe um apelo final, para que assumam a vocação de guardiões do Direito tributário internacional e do cumprimento com boa-fé dos compromissos assumidos por seu país perante outros Estados. Em última análise, depende deles que convenções fiscais não se tornem letra morta, aplicadas ao gosto de seus intérpretes e à revelia de seu real sentido contextualizado e consentido por ambos os Estados contratantes sob promessas de cooperação, coordenação e reciprocidade. 
APÊNDICE 01.

\section{A REDAÇÃO DO “ART. 3 (2)" NOS MODELOS DE CONVENÇÕES FISCAIS E NOS ACORDOS DE BITRIBUTAÇÃO BRASILEIROS}

\section{1. $O$ "ART. 3 (2)" NOS VARIADOS MODELOS DE CONVENÇÕES}

\section{FISCAIS.}

\begin{tabular}{|c|c|c|c|}
\hline \multicolumn{4}{|c|}{$\begin{array}{l}\text { MODELOS DE CONVENÇÃO PARA EVITAR A DUPLA TRIBUTAÇÃO ADOTADOS POR } \\
\text { INSTITUIÇÕES }\end{array}$} \\
\hline INSTITUIÇÃO & REDAÇÃO DO DISPOSITIVO & PADRÃO & ANO \\
\hline OCDE & $\begin{array}{l}3 \text { (2). As regards the application of the Convention at } \\
\text { any time by a Contracting State, any term not defined } \\
\text { therein shall, unless the context otherwise requires, } \\
\text { have the meaning that it has at that time under the law } \\
\text { of that State for the purposes of the taxes to which the } \\
\text { Convention applies, any meaning under the applicable } \\
\text { tax laws of that State prevailing over a meaning } \\
\text { given to the term under other laws of that State. }\end{array}$ & $\begin{array}{l}\text { CM-OCDE } \\
(1995)\end{array}$ & $\begin{array}{c}1995 \\
\text { até } \\
\text { hoje. }\end{array}$ \\
\hline OCDE & $\begin{array}{l}3 \text { (2) As regards the application of the Convention by a } \\
\text { Contracting State any term not defined therein shall, } \\
\text { unless the context otherwise requires, have the } \\
\text { meaning which it has under the law of that State } \\
\text { concerning the taxes to which the Convention applies. }\end{array}$ & $\begin{array}{l}\text { CM-OCDE } \\
\quad(1977)\end{array}$ & 1977 \\
\hline OCDE & $\begin{array}{l}3 \text { (2). As regards the application of the Convention by } \\
\text { a Contracting State any term not otherwise defined } \\
\text { shall, unless the context otherwise requires, have the } \\
\text { meaning which it has under the laws of that } \\
\text { Contracting State relating to the taxes which are the } \\
\text { subject of the Convention." }\end{array}$ & $\begin{array}{l}\text { CM-OCDE } \\
\quad(1963)\end{array}$ & 1963 \\
\hline $\mathrm{ONU}$ & $\begin{array}{l}3 \text { (2). As regards the application of the Convention at } \\
\text { any time by a Contracting State, any term not defined } \\
\text { therein shall, unless the context otherwise requires, } \\
\text { have the meaning that it has at that time under the law } \\
\text { of that State for the purposes of the taxes to which the } \\
\text { Convention applies, any meaning under the applicable } \\
\text { tax laws of that State prevailing over a meaning given } \\
\text { to the term under other laws of that State. }\end{array}$ & $\begin{array}{l}\text { CM-OCDE } \\
(1995)\end{array}$ & 2011 \\
\hline ONU & $\begin{array}{l}3 \text { (2).As regards the application of the Convention by a } \\
\text { Contracting State, any term not defined therein shall, } \\
\text { unless the context otherwise requires, have the } \\
\text { meaning which it has under the law of that State } \\
\text { concerning the taxes to which the Convention applies. }\end{array}$ & $\begin{array}{l}\text { CM-OCDE } \\
(1963)\end{array}$ & 1980 \\
\hline
\end{tabular}




\begin{tabular}{|c|c|c|c|}
\hline INSTITUIÇÃO & REDAÇÃO DO DISPOSITIVO & PADRÃO & ANO \\
\hline $\begin{array}{l}\text { Andean Community } \\
\text { (Bolivia, Colombia, } \\
\text { Ecuador e Peru) }\end{array}$ & $\begin{array}{l}\text { 3. Any term that is not defined in this agreement shal } \\
\text { have the meaning given to it in the effective legislation } \\
\text { of each Contracting State. }\end{array}$ & - & 1971 \\
\hline $\begin{array}{c}\text { Intra-Asean Model } \\
\text { Double Taxation } \\
\text { Convention } \\
\text { on Income }\end{array}$ & $\begin{array}{l}3 \text { (2). As regards the application of the Convention by } \\
\text { a Contracting State, any term not defined therein shall } \\
\text { unless the context otherwise requires, have the } \\
\text { meaning which it has under the law of that Stat } \\
\text { concerning the taxes to which the Convention applies. }\end{array}$ & $\begin{array}{l}\text { CM-OCDE } \\
(1963 / 77)\end{array}$ & \\
\hline $\begin{array}{l}\text { SADC Model Tax } \\
\text { Agreement on } \\
\text { Income }\end{array}$ & $\begin{array}{l}3 \text { (2). As regards the application of the provisions o } \\
\text { the Agreement at any time by a Contracting State, any } \\
\text { term not defined therein shall, unless the contex } \\
\text { otherwise requires, have the meaning that it has at tha } \\
\text { time under the law of that State for the purposes of the } \\
\text { taxes to which the Agreement applies, any meaning } \\
\text { under the applicable tax laws of that State prevailing } \\
\text { over a meaning given to the term under other laws o } \\
\text { that State. }\end{array}$ & $\begin{array}{l}\text { CM-OCDE } \\
\quad(1995)\end{array}$ & 2011 \\
\hline ILADT & $\begin{array}{l}4 \text { (2). Any term included in the Convention shall b } \\
\text { interpreted, unless the context requires a differen } \\
\text { interpretation, in the light of the definitions providec } \\
\text { by the Convention, as well as of its objective anc } \\
\text { purpose, in accordance with the provisions of th } \\
\text { Vienna Convention on the Law of Treaties. Th } \\
\text { interpretation in accordance with domestic law shall be } \\
\text { only possible as a supplementary means o } \\
\text { interpretation. } \\
4 \text { (3). Any term or expression not defined by th } \\
\text { Convention or whose meaning cannot be determined in } \\
\text { the light of the Convention shall, unless the contex } \\
\text { requires a different interpretation, have the meaning } \\
\text { that it has at that time under the law of the source Stat } \\
\text { for the purposes of the taxes covered by th } \\
\text { Convention with any meaning under the applicable tax } \\
\text { laws of that State prevailing over a meaning given to } \\
\text { the term under other laws of that State. }\end{array}$ & . & 2012 \\
\hline \multicolumn{4}{|c|}{$\begin{array}{l}\text { MODELOS DE CONVENÇÃO PARA EVITAR A DUPLA TRIBUTAÇÃO ADOTADOS POR } \\
\text { PAÍSES }\end{array}$} \\
\hline PAÍS & \begin{tabular}{|c|c|} 
REDAÇÃO DO DISPOSITIVO \\
\end{tabular} & PADRÃO & ANO \\
\hline Bélgica & $\begin{array}{l}3 \text { (2). As regards the application of the Convention at } \\
\text { any time by a Contracting State, any term not defined } \\
\text { therein shall, unless the context otherwise requires, } \\
\text { have the meaning that it has at that time under the } \\
\text { law of that State for the purposes of the taxes to } \\
\text { which the Convention applies, any meaning under the } \\
\text { applicable tax laws of that State prevailing over a } \\
\text { meaning given to the term under other laws of that } \\
\text { State. }\end{array}$ & $\begin{array}{l}\text { CM-OCDE } \\
(1995)\end{array}$ & 2010 \\
\hline
\end{tabular}




\begin{tabular}{|c|c|c|c|}
\hline PAÍS & REDAÇÃO DO DISPOSITIVO & PADRÃO & ANO \\
\hline EUA & $\begin{array}{l}3 \text { (2). As regards the application of the Convention at } \\
\text { any time by a Contracting State any term not defined } \\
\text { therein shall, unless the context otherwise requires, or } \\
\text { the competent authorities agree to a common } \\
\text { meaning pursuant to the provisions of Article } 25 \\
\text { (Mutual agreement procedure), have the meaning } \\
\text { which it has at that time under the law of that State } \\
\text { for the purposes of the taxes to which the Convention } \\
\text { applies, any meaning under the applicable tax laws of } \\
\text { that State prevailing over a meaning given to the term } \\
\text { under other laws of that State. }\end{array}$ & $\begin{array}{l}\text { CM-EUA } \\
(1996)\end{array}$ & 1996 \\
\hline EUA & $\begin{array}{l}3 \text { (2). As regards the application of the Convention } \\
\text { by a Contracting State any term not defined therein } \\
\text { shall, unless the context otherwise requires or the } \\
\text { competent authorities agree to a common meaning } \\
\text { pursuant to the provisions of Article } 25 \text { (Mutual } \\
\text { agreement procedure), have the meaning which it has } \\
\text { under the laws of that State concerning the taxes to } \\
\text { which the Convention applies. }\end{array}$ & $\begin{array}{l}\text { CM-EUA } \\
(1981)\end{array}$ & 1981 \\
\hline Alemanha & $\begin{array}{l}3 \text { (2). As regards the application of the Agreement at } \\
\text { any time by a Contracting State, any term not defined } \\
\text { therein shall, unless the context otherwise requires, } \\
\text { have the meaning that it has at that time under the } \\
\text { law of that State for the purposes of the taxes to } \\
\text { which the Agreement applies, any meaning under the } \\
\text { applicable tax laws of that State prevailing over a } \\
\text { meaning given to the term under other laws of that } \\
\text { State. }\end{array}$ & $\begin{array}{l}\text { CM-OCDE } \\
\quad(1995)\end{array}$ & 2013 \\
\hline \multicolumn{4}{|c|}{ ACORDOS MULTILATERAIS PARA EVITAR A DUPLA TRIBUTAÇÃO } \\
\hline INSTITUIÇÃO & \begin{tabular}{|l} 
REDAÇÃO DO DISPOSITIVO \\
\end{tabular} & PADRÃO & ANO \\
\hline $\begin{array}{l}\text { CARICOM Income } \\
\text { Tax Agreement }\end{array}$ & $\begin{array}{l}3 \text { (2). In the application of this Agreement by a } \\
\text { Member State any word or term not defined in this } \\
\text { Agreement shall, unless the context otherwise } \\
\text { requires, have the meaning which it has under the } \\
\text { laws of that Member State relating to the taxes } \\
\text { which are the subject of this Agreement. }\end{array}$ & $\begin{array}{l}\text { CM-OCDE } \\
(1963 / 77)\end{array}$ & 1994 \\
\hline
\end{tabular}




\section{O “ART. 3 (2)" NOS ACORDOS DE BITRIBUTAÇÃO}

\section{CELEBRADOS PELO BRASIL.}

\begin{tabular}{|c|c|c|c|c|}
\hline & $\begin{array}{c}\text { OUTRO } \\
\text { ESTADO }\end{array}$ & REDAÇÃO DO DISPOSITIVO & PADRÃO & ANO \\
\hline 1 & África do Sul & $\begin{array}{l}3 \text { (2). Para a aplicação das disposições da Convenção a } \\
\text { qualquer tempo por um Estado Contratante, qualquer termo ou } \\
\text { expressão que nela não se encontrem definidos terá, a não ser } \\
\text { que o contexto exija interpretação diferente, o significado que a } \\
\text { esse tempo the for atribuído pela legislação desse Estado } \\
\text { relativa aos impostos que são objeto da Convenção, } \\
\text { prevalecendo os efeitos atribuídos a esse termo ou expressão } \\
\text { pela legislação tributária desse Estado sobre o significado que } \\
\text { lhe atribuam outras leis desse Estado. }\end{array}$ & $\begin{array}{c}\text { CM-OCDE } \\
\quad(1995)\end{array}$ & 2003 \\
\hline 2 & $\begin{array}{l}\text { Alemanha } \\
\text { (sem efeito) }\end{array}$ & $\begin{array}{l}3 \text { (2). Para a aplicação do presente acordo por um Estado } \\
\text { Contratante, qualquer expressão que não se encontre de outro } \\
\text { modo definida terá o significado que lhe é atribuído pela } \\
\text { legislação desse Estado Contratante relativa aos impostos que } \\
\text { são objeto do presente Acordo, a não ser que o contexto } \\
\text { imponha interpretação diferente. }\end{array}$ & $\begin{array}{c}\text { CM-OCDE } \\
\quad(1963)\end{array}$ & 1975 \\
\hline 3 & Argentina & $\begin{array}{l}3 \text { (2). Para a aplicação da presente Convenção por um Estado } \\
\text { Contratante, qualquer expressão que não se encontre de outro } \\
\text { modo definida terá o significado que lhe é atribuído pela } \\
\text { legislação desse Estado Contratante relativa aos impostos que } \\
\text { são objeto da presente Convenção, a não ser que o contexto } \\
\text { imponha interpretação diferente. Caso os sentidos resultantes } \\
\text { sejam opostos ou antagônicos, as autoridades competentes dos } \\
\text { Estados Contratantes estabelecerão, de comum acordo, a } \\
\text { interpretação a ser dada. }\end{array}$ & $\begin{array}{c}\text { CM-EUA } \\
(1981)\end{array}$ & 1980 \\
\hline 4 & Áustria & $\begin{array}{l}3 \text { (2). Para a aplicação da presente Convenção por um Estado } \\
\text { Contratante, qualquer expressão que não se encontre de outro } \\
\text { modo definida terá o significado que lhe é atribuído pela } \\
\text { legislação desse Estado Contratante relativa aos impostos que } \\
\text { são objetos da Convenção, a não ser que o contexto imponha } \\
\text { interpretação diferente. }\end{array}$ & $\begin{array}{c}\text { CM-OCDE } \\
(1963)\end{array}$ & 1975 \\
\hline 5 & Bélgica & $\begin{array}{l}3 \text { (2). Para aplicação da Convenção por um Estado Contratante, } \\
\text { qualquer expressão não definida de outro modo terá, a não ser } \\
\text { que o contexto exija interpretação diferente, o significado que } \\
\text { lhe é atribuído pela legislação desse Estado Contratante } \\
\text { relativo aos impostos que são objeto da Convenção. }\end{array}$ & $\begin{array}{c}\text { CM-OCDE } \\
\quad(1963)\end{array}$ & 1972 \\
\hline 6 & Canadá & $\begin{array}{l}3 \text { (2). Para a aplicação da presente Convenção por um Estado } \\
\text { Contratante, qualquer expressão que não se encontre de outro } \\
\text { modo definida terá o significado que lhe é atribuído pela } \\
\text { legislação desse Estado Contratante relativa aos impostos que } \\
\text { são objeto da presente Convenção, a não ser que o contexto } \\
\text { imponha interpretação diferente. }\end{array}$ & $\begin{array}{c}\text { CM-OCDE } \\
(1963 / 77)\end{array}$ & 1984 \\
\hline
\end{tabular}




\begin{tabular}{|c|c|c|c|c|}
\hline & $\begin{array}{c}\text { OUTRO } \\
\text { ESTADO }\end{array}$ & REDAÇÃO DO DISPOSITIVO & PADRÃO & ANO \\
\hline 7 & Chile & $\begin{array}{l}3 \text { (2). Para a aplicação da Convenção em um dado momento } \\
\text { por um Estado Contratante, qualquer termo ou expressão que } \\
\text { nela não se encontrem definidos terá, a não ser que de seu } \\
\text { contexto se infira uma interpretação diferente, o significado } \\
\text { que nesse momento lhe for atribuído pela legislação desse } \\
\text { Estado relativa aos impostos que são objeto da Convenção, } \\
\text { prevalecendo o significado atribuído pela legislação tributária } \\
\text { aplicável nesse Estado sobre o significado atribuído por outras } \\
\text { leis desse Estado. }\end{array}$ & $\begin{array}{c}\text { CM-OCDE } \\
(1995)\end{array}$ & 2001 \\
\hline 8 & China & $\begin{array}{l}3 \text { (2). Para a aplicação deste Acordo por um Estado } \\
\text { Contratante, qualquer termo que não esteja aí definido terá, a } \\
\text { menos que seu contexto exija de forma diversa, o sentido dado } \\
\text { pela respectiva legislação tributária, aplicável aos impostos } \\
\text { abrangidos por este Acordo. }\end{array}$ & $\begin{array}{c}\text { CM-OCDE } \\
(1963 / 77)\end{array}$ & 1991 \\
\hline 9 & Coréia & $\begin{array}{l}3 \text { (2). Para a aplicação da Convenção por um Estado } \\
\text { Contratante, qualquer expressão que não se encontre de outro } \\
\text { modo definida tem o sentido que lhe é atribuído pela legislação } \\
\text { desse Estado relativa aos impostos que são objeto da } \\
\text { Convenção, a não ser que o contexto imponha uma } \\
\text { interpretação diferente. }\end{array}$ & $\begin{array}{c}\text { CM-OCDE } \\
(1963 / 77)\end{array}$ & 1989 \\
\hline 10 & Dinamarca & $\begin{array}{l}3 \text { (2). Para a aplicação da presente Convenção por um Estado } \\
\text { Contratante, qualquer expressão que não se encontre de outro } \\
\text { modo definida terá o significado que lhe é atribuído pela } \\
\text { legislação desse Estado Contratante relativa aos impostos que } \\
\text { são objeto da Convenção, a não ser que o contexto imponha } \\
\text { interpretação diferente. }\end{array}$ & $\begin{array}{c}\text { CM-OCDE } \\
(1963)\end{array}$ & 1974 \\
\hline 11 & Equador & $\begin{array}{l}3 \text { (2). Para a aplicação da presente Convenção por um Estado } \\
\text { Contratante, qualquer expressão ou termo que se encontre de } \\
\text { outro modo definido terá o significado que lhe é atribuído pela } \\
\text { legislação desse Estado Contratante no que respeita aos } \\
\text { impostos que são objeto da presente Convenção, a não ser que } \\
\text { o contexto imponha uma interpretação diferente. Caso os } \\
\text { sentidos resultantes sejam opostos ou antagônicos, as } \\
\text { autoridades competentes dos Estados Contratantes } \\
\text { estabelecerão, de comum acordo, a interpretação a ser dada. }\end{array}$ & $\begin{array}{c}\text { CM-EUA } \\
(1981)\end{array}$ & 1983 \\
\hline 12 & Espanha & $\begin{array}{l}3 \text { (2). Para a aplicação da presente Convenção por um Estado } \\
\text { Contratante, qualquer expressão que não se encontre de outro } \\
\text { modo definida terá o significado que lhe é atribuído pela } \\
\text { legislação desse Estado Contratante relativa aos impostos que } \\
\text { são objeto da Convenção, a não ser que o contexto imponha } \\
\text { interpretação diferente. }\end{array}$ & $\begin{array}{c}\text { CM-OCDE } \\
(1963)\end{array}$ & 1974 \\
\hline 13 & Filipinas & $\begin{array}{l}3 \text { (2). Para a aplicação da presente Convenção por um Estado } \\
\text { Contratante, qualquer expressão que não se encontre de outro } \\
\text { modo definida tem o sentido que lhe é atribuído pela legislação } \\
\text { desse Estado Contratante no que respeita aos impostos a que se } \\
\text { aplica a Convenção a não ser que o contexto imponha uma } \\
\text { interpretação diferente. }\end{array}$ & $\begin{array}{c}\text { CM-OCDE } \\
(1963 / 77)\end{array}$ & 1983 \\
\hline
\end{tabular}




\begin{tabular}{|c|c|c|c|c|}
\hline & $\begin{array}{c}\text { OUTRO } \\
\text { ESTADO } \\
\end{array}$ & REDAÇÃO DO DISPOSITIVO & PADRÃO & ANO \\
\hline 14 & Finlândia & $\begin{array}{l}3 \text { (2). Para a aplicação do presente Acordo por um dos Estados } \\
\text { Contratantes, qualquer expressão que não se encontre nele } \\
\text { definida terá o sentido que lhe é atribuído pela legislação desse } \\
\text { Estado Contratante relativa aos impostos que são objeto do } \\
\text { Acordo, a não ser que o contexto imponha uma interpretação } \\
\text { diferente. }\end{array}$ & $\begin{array}{c}\text { CM-OCDE } \\
(1963 / 77)\end{array}$ & 1996 \\
\hline 15 & França & $\begin{array}{l}3 \text { (2). Para aplicação da Convenção por um Estado Contratante, } \\
\text { qualquer expressão não definida de outro modo terá, a não ser } \\
\text { que o contexto exija interpretação diferente, o significado que } \\
\text { lhe é atribuído pela legislação desse Estado Contratante } \\
\text { relativa aos impostos que são objeto da Convenção. }\end{array}$ & $\begin{array}{c}\text { CM-OCDE } \\
(1963)\end{array}$ & 1971 \\
\hline 16 & Hungria & $\begin{array}{l}3 \text { (2). Para a aplicação da presente Convenção por um Estado } \\
\text { Contratante, qualquer expressão que não se encontre de outro } \\
\text { modo definida tem o sentido que lhe é atribuído pela legislação } \\
\text { desse Estado Contratante relativa aos impostos que são objeto } \\
\text { da presente Convenção, a não ser que o contexto imponha uma } \\
\text { interpretação diferente. }\end{array}$ & $\begin{array}{c}\text { CM-OCDE } \\
(1963 / 77)\end{array}$ & 1986 \\
\hline 17 & Índia & $\begin{array}{l}3 \text { (3). Para aplicação da Convenção por um Estado Contratante } \\
\text { qualquer expressão que não se encontre nela definida tem o } \\
\text { sentido que lhe é atribuído pela legislação desse Estado } \\
\text { relativo aos impostos que são objeto da Convenção, a não ser } \\
\text { que o contexto imponha uma interpretação diferente. }\end{array}$ & $\begin{array}{c}\text { CM-OCDE } \\
(1963 / 77)\end{array}$ & 1988 \\
\hline 18 & Israel & $\begin{array}{l}3 \text { (2). Para a aplicação da Convenção, a qualquer tempo, por } \\
\text { um Estado Contratante, qualquer termo aqui não definido terá, } \\
\text { a não ser que o contexto exija interpretação diferente, o } \\
\text { significado que a esse tempo lhe for atribuído pela legislação } \\
\text { desse Estado relativa aos impostos que são objeto da presente } \\
\text { Convenção, prevalecendo o significado atribuído a esse termo } \\
\text { pela legislação tributária vigente nesse Estado sobre o } \\
\text { significado que lhe atribuam outras leis desse Estado. }\end{array}$ & $\begin{array}{l}\text { CM-OCDE } \\
\quad(1995)\end{array}$ & 2002 \\
\hline 19 & Itália & $\begin{array}{l}3 \text { (2). Para a aplicação da presente Convenção por um Estado } \\
\text { Contratante, qualquer expressão que não se encontre de outro } \\
\text { modo definida terá o significado que lhe é atribuído pela } \\
\text { legislação desse Estado Contratante relativa aos impostos que } \\
\text { são objeto da presente Convenção, a não ser que o contexto } \\
\text { exija interpretação diferente. }\end{array}$ & $\begin{array}{c}\text { CM-OCDE } \\
(1963 / 77)\end{array}$ & 1978 \\
\hline 20 & Japão & $\begin{array}{l}2 \text { (2) Para a aplicação desta Convenção por um dos Estados } \\
\text { Contratantes qualquer expressão que não se encontre definida } \\
\text { tem sentido que lhe é atribuído pela legislação dêsse Estado } \\
\text { Contratante relativa aos impostos a que esta Convenção se } \\
\text { aplique, a não ser que o contexto imponha uma interpretação } \\
\text { diferente. }\end{array}$ & $\begin{array}{c}\text { CM-OCDE } \\
\quad(1963)\end{array}$ & 1967 \\
\hline 21 & Luxemburgo & $\begin{array}{l}3 \text { (2). Para a aplicação da Convenção por um Estado } \\
\text { Contratante, qualquer expressão que não se encontre de outro } \\
\text { modo definida terá o significado que lhe é atribuído pela } \\
\text { legislação desse Estado Contratante relativa aos impostos que } \\
\text { são objeto da Convenção, a não ser que o contexto imponha } \\
\text { interpretação diferente. }\end{array}$ & $\begin{array}{c}\text { CM-OCDE } \\
(1963 / 77)\end{array}$ & 1978 \\
\hline
\end{tabular}




\begin{tabular}{|c|c|c|c|c|}
\hline & $\begin{array}{c}\text { OUTRO } \\
\text { ESTADO }\end{array}$ & REDAÇÃO DO DISPOSITIVO & PADRÃO & ANO \\
\hline 22 & México & $\begin{array}{l}3 \text { (2). Para a aplicação da presente Convenção em qualquer } \\
\text { momento por um Estado Contratante, qualquer expressão não } \\
\text { definida na mesma terá, a menos que do seu contexto se } \\
\text { infira uma interpretação diferente, o significado que nesse } \\
\text { momento lhe atribua a legislação desse Estado Contratante } \\
\text { relativa aos impostos aos quais se aplica a presente Convenção. } \\
\text { Qualquer termo sob a legislação aplicável desse Estado } \\
\text { Contratante prevalecerá sobre o significado previsto para dito } \\
\text { termo sob outras leis desse Estado Contratante. }\end{array}$ & $\begin{array}{c}\text { CM-OCDE } \\
(1995)\end{array}$ & 2003 \\
\hline 23 & Noruega & $\begin{array}{l}3 \text { (2). Para a aplicação da presente Convenção por Estado } \\
\text { Contratante, qualquer expressão que não se encontre de outro } \\
\text { modo definida, terá o significado que lhe é atribuído pela } \\
\text { legislação desse Estado relativa aos impostos que são objeto da } \\
\text { Convenção, a não ser que o contexto imponha interpretação } \\
\text { diferente. }\end{array}$ & $\begin{array}{c}\text { CM-OCDE } \\
(1963 / 77)\end{array}$ & 1980 \\
\hline 24 & $\begin{array}{l}\text { Países } \\
\text { Baixos }\end{array}$ & $\begin{array}{l}3 \text { (2). Para a aplicação desta Convenção por um Estado } \\
\text { Contratante, qualquer expressão que nela não esteja definida } \\
\text { terá o significado que lhe é atribuído pela legislação desse } \\
\text { Estado, relativamente aos impostos aos quais se aplica a } \\
\text { Convenção, a não ser que o contexto imponha interpretação } \\
\text { diversa. }\end{array}$ & $\begin{array}{c}\text { CM-OCDE } \\
(1963 / 77)\end{array}$ & 1990 \\
\hline 25 & Peru & $\begin{array}{l}3 \text { (2). Para a aplicação da Convenção em um dado momento } \\
\text { por um Estado Contratante, qualquer termo ou expressão que } \\
\text { nela não se encontrem definidos terá, a não ser que o contexto } \\
\text { exija interpretação diferente, o significado que nesse momento } \\
\text { lhe for atribuído pela legislação desse Estado relativa aos } \\
\text { impostos que são objeto da Convenção, prevalecendo o } \\
\text { significado atribuído pela legislação tributária sobre o } \\
\text { significado que lhe atribuiriam os demais ramos do Direito } \\
\text { desse Estado. }\end{array}$ & $\begin{array}{c}\text { CM-OCDE } \\
(1995)\end{array}$ & 2006 \\
\hline 26 & Portugal & $\begin{array}{l}3 \text { (2). No que se refere à aplicação da Convenção, num dado } \\
\text { momento, por um Estado Contratante, qualquer termo ou } \\
\text { expressão que nela não se encontre definido terá, a não ser que } \\
\text { o contexto exija interpretação diferente, o significado que lhe } \\
\text { for atribuído nesse momento pela legislação desse Estado que } \\
\text { regula os impostos a que a Convenção se aplica, prevalecendo } \\
\text { a interpretação resultante desta legislação fiscal, na definição } \\
\text { dos respectivos efeitos tributários, sobre a que decorra de outra } \\
\text { legislação deste Estado. }\end{array}$ & $\begin{array}{c}\text { CM-OCDE } \\
(1995)\end{array}$ & 2001 \\
\hline 27 & $\begin{array}{l}\text { República } \\
\text { Eslovaca }\end{array}$ & $\begin{array}{l}3 \text { (2). Para a aplicação da presente Convenção por um Estado } \\
\text { Contratante, qualquer expressão que não se encontre de outro } \\
\text { modo definida tem o sentido que lhe é atribuído pela legislação } \\
\text { desse Estado relativa aos impostos que são objeto da presente } \\
\text { Convenção, a não ser que o contexto imponha uma } \\
\text { interpretação diferente. }\end{array}$ & $\begin{array}{c}\text { CM-OCDE } \\
(1963 / 77)\end{array}$ & 1986 \\
\hline
\end{tabular}




\begin{tabular}{|c|c|c|c|c|}
\hline & $\begin{array}{c}\text { OUTRO } \\
\text { ESTADO } \\
\end{array}$ & REDAÇÃO DO DISPOSITIVO & PADRÃO & ANO \\
\hline 28 & $\begin{array}{l}\text { República } \\
\text { Tcheca }\end{array}$ & $\begin{array}{l}3 \text { (2). Para a aplicação da presente Convenção por um Estado } \\
\text { Contratante, qualquer expressão que não se encontre de outro } \\
\text { modo definida tem o sentido que lhe é atribuído pela legislação } \\
\text { desse Estado relativa aos impostos que são objeto da presente } \\
\text { Convenção, a não ser que o contexto imponha uma } \\
\text { interpretação diferente. }\end{array}$ & $\begin{array}{c}\text { CM-OCDE } \\
(1963 / 77)\end{array}$ & 1986 \\
\hline 29 & Suécia & $\begin{array}{l}3 \text { (2). Para aplicação da presente convenção por um estado } \\
\text { contratante, qualquer expressão que não se encontre de outro } \\
\text { modo definida terá o sentido que lhe é atribuído pela legislação } \\
\text { desse estado contratante relativa aos impostos que são objeto } \\
\text { da convenção, a não ser que o contexto imponha interpretação } \\
\text { diferente. }\end{array}$ & $\begin{array}{c}\text { CM-OCDE } \\
(1963 / 77)\end{array}$ & 1975 \\
\hline 30 & $\begin{array}{c}\text { Trinidad e } \\
\text { Tobago }\end{array}$ & $\begin{array}{l}3 \text { (2). No que se refere à aplicação desta Convenção a qualquer } \\
\text { tempo por um Estado Contratante, qualquer termo ou } \\
\text { expressão que nela não se encontrem definidos terá, a não ser } \\
\text { que o contexto exija interpretação diferente, o significado que a } \\
\text { esse tempo lhe for atribuído pela legislação desse Estado } \\
\text { relativa aos impostos que são objeto da Convenção, qualquer } \\
\text { significado sob as leis tributárias aplicáveis desse Estado tendo } \\
\text { prevalência sobre o significado dado ao termo sob outras leis } \\
\text { desse Estado. }\end{array}$ & $\begin{array}{c}\text { CM-OCDE } \\
(1995)\end{array}$ & 2008 \\
\hline 31 & Turquia & $\begin{array}{l}3 \text { (2). Para a aplicação deste Acordo, a qualquer tempo, por um } \\
\text { Estado Contratante, qualquer termo ou expressão que nele não } \\
\text { se encontre definido terá, a não ser que o contexto exija } \\
\text { interpretação diferente, o significado que, a esse tempo, for-lhe } \\
\text { atribuído pela legislação desse Estado relativa aos impostos } \\
\text { que são objeto do Acordo, prevalecendo o significado atribuído } \\
\text { a esse termo ou expressão pela legislação tributária desse } \\
\text { Estado sobre o significado que lhe atribuírem outras leis desse } \\
\text { Estado. }\end{array}$ & $\begin{array}{c}\text { CM-OCDE } \\
\quad(1995)\end{array}$ & 2010 \\
\hline 32 & Ucrânia & $\begin{array}{l}3 \text { (2). No que se refere à aplicação da Convenção, a qualquer } \\
\text { tempo, por um Estado Contratante, qualquer termo aqui não } \\
\text { definido terá, a não ser que o contexto exija interpretação } \\
\text { diferente, o significado que, naquele momento, a ele for } \\
\text { atribuído pela legislação daquele Estado para fins dos impostos } \\
\text { aos quais se aplica a Convenção, sendo que qualquer } \\
\text { significado a ele atribuído em conformidade com a legislação } \\
\text { tributária vigente naquele Estado prevalecerá sobre outro } \\
\text { significado atribuído ao termo por outras leis daquele Estado. }\end{array}$ & $\begin{array}{c}\text { CM-OCDE } \\
\quad(1995)\end{array}$ & 2002 \\
\hline 33 & Venezuela & $\begin{array}{l}3 \text { (2). Para a aplicação da Convenção em um dado momento } \\
\text { por um Estado Contratante, qualquer termo ou expressão que } \\
\text { nela não se encontrem definidos terá, a não ser que o contexto } \\
\text { exija interpretação diferente, o significado que nesse momento } \\
\text { lhe for atribuído pela legislação desse Estado Contratante } \\
\text { relativa aos impostos que são objeto da presente Convenção, } \\
\text { prevalecendo os efeitos atribuídos a esse termo ou expressão } \\
\text { pela legislação tributária desse Estado Contratante sobre o } \\
\text { significado que lhe atribuam os demais ramos do direito desse } \\
\text { Estado Contratante. }\end{array}$ & $\begin{array}{l}\text { CM-OCDE } \\
(1963 / 77) \\
\text { acrescida } \\
\text { do reenvio } \\
\text { ao Direito } \\
\text { privado. }\end{array}$ & 2005 \\
\hline
\end{tabular}




\section{APÊNDICE 02.}

\section{DESCRIÇÃO DE CASOS DE APLICAÇÃO DE ACORDOS DE DUPLA TRIBUTAÇÃO POR TRIBUNAIS BRASILEIROS CITADOS NO TRABALHO.}

\section{1. "CASO ALUBAR".}

Brasil. Conselho Administrativo de Recursos Fiscais. Alubar Metais S.A vs. Fazenda Nacional. Processo n. 10280.004154/2001-14. Julgamento de 12/08/2004. Fatos em discussão ocorridos entre 1998 e 1999. Acordo de dupla tributação Brasil-Portugal celebrado em 1971.

“Alubar”, uma pessoa jurídica residente no Brasil, contratou os serviços de consultoria tecnológica (sem transferência de tecnologia) de "Hodler”, uma pessoa jurídica residente na Ilha da Madeira (Portugal). O pagamento de tais serviços foi realizado por "Soinco", uma pessoa jurídica residente em Bahamas. O quadro a seguir ilustra o caso:

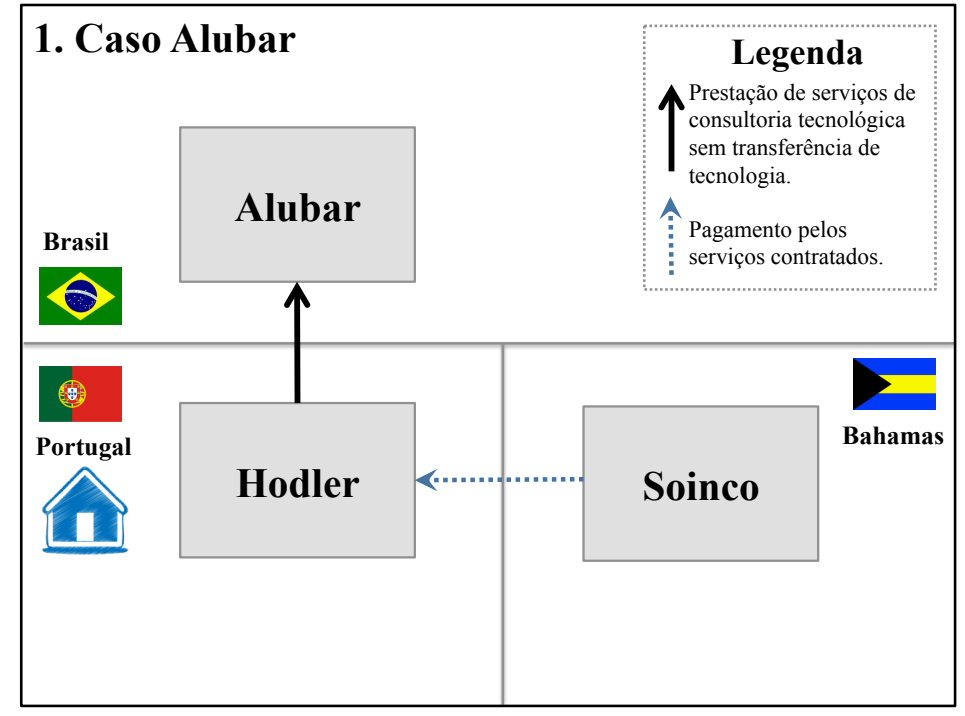

Diante da ausência de retenção e recolhimento de $25 \%$ sobre tais pagamentos, as autoridades fiscais brasileiras autuaram Alubar.

O contribuinte se opos à exigência do físco brasileiro, alegando, em especial, que: 
- $\mathrm{O}$ art. 7 do acordo Brasil-Portugal (equivalente à CM-OCDE) seria aplicável ao caso, de forma que apenas o Estado de residência da empresa prestadora dos serviços (Portugal) poderia tributar os seus lucros. Não haveria qualquer estabelecimento permanente de "Hodler" no Brasil que justificariam a tributação nesse País;

- O art. 14 do acordo Brasil-Portugal (excluído da CM-OCDE) seria aplicável ao caso, de forma que apenas o Estado de residência dos prestadores de atividades independentes (Portugal) poderia tributar tais rendimentos;

- Caso tais rendimentos fossem qualificados como royalties, o art. 12 do acordo Brasil-Portugal (equivalente à CM-OCDE) limitaria a tributação brasileira a 15\%.

O CARF decidiu, contudo, que os referidos rendimentos estariam sob o escopo do art. 21 do acordo Brasil-Portugal (outros rendimentos), de forma o Brasil estaria livre para tributá-los, cabendo a Portugal conceder o crédito.

Entre as evidências utilizadas pelo tribunal para a interpretação do acordo, destacam-se: Direito doméstico; comparação de diferentes dispositivos do acordo; parallel treaties.

\section{2. "CASO BBA".}

Brasil. Conselho Administrativo de Recursos Fiscais. Creditanstalt Finanças $e$ Representações Ltda vs. Fazenda Nacional. Processo n. 16327.003372/2003-04. Julgamento de 26/04/2006. Fatos em discussão ocorridos entre 1996 e 1998. Acordo de dupla tributação Brasil-Portugal celebrado em 1971.

"PPL", pessoa jurídica residente no Brasil, seria controlada por três outras pessoas jurídicas também residentes no Brasil, quais sejam, " $B B A$ ", " $S P$ " e " $S P H$ ". "PPL”, por sua vez, detinha $100 \%$ do capital de "PIS", uma pessoa jurídica residente na Ilha da Madeira, em Portugal. É o que se pode observar na ilustração a seguir: 


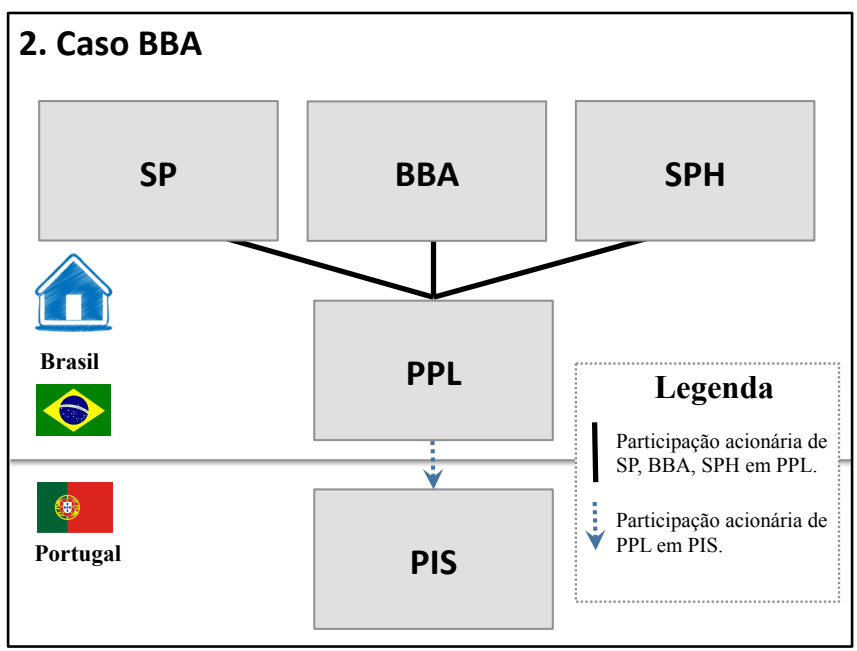

Nos anos de 1996 e 1997, PIS acumulou lucros e não os distribuiu a PPL. Em 1998, PPL transferiu toda a participação que detinha em PIS para BBA, SP e SPH, em decorrência de redução de capital. O quadro a seguir ilustra o caso:

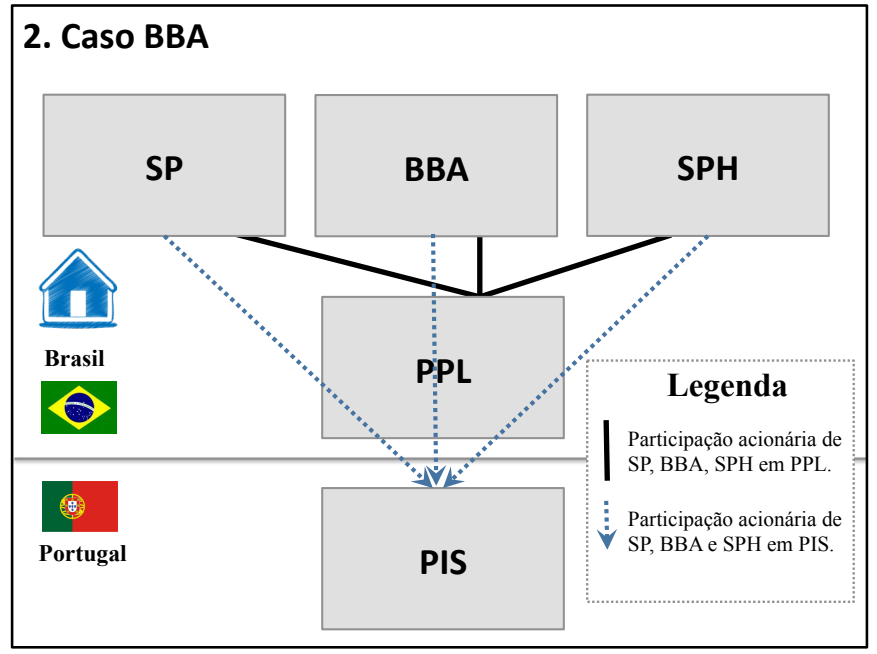

As autoridades fiscais brasileiras, no entanto, consideraram que a transferência de tais participações sociais configuraria pagamento de dividendos, bem como que estes seriam tributáveis pela legislação doméstica. Nesse cenário, PPL estaria sujeita ao pagamento de imposto de renda sobre tais dividendos. Como tal empresa já havia sido extinta, as autoridades fiscais autuaram $B B A, S P$ e $S P H$.

Os contribuintes alegaram, então, que o art. 7 do acordo Brasil-Portugal (equivalente à CM-OCDE) afastaria a tributação brasileira sobre os lucros auferidos por PIS. 
O CARF, no entanto, decidiu que seria aplicável o art. 10 do acordo Brasil-Portugal (equivalente à CM-OCDE), sob o fundamento de que a legislação brasileira ${ }^{900}$ atribui aos lucros não distribuídos mas empregados pela investida no exterior em favor da investidora no Brasil o sentido de dividendos. Sob a égide do art. 10 da convenção fiscal, então, seria legítima a tributação brasileira.

Como o termo distribuição, utilizado pelo art. 10 da referida convenção e não definido em seu texto, concluíram os julgadores que deveria ser construído a partir do Direito brasileiro. Assim, "dividendos" seriam equivalentes a "lucros disponibilizados", bem como a transferência de ações de uma empresa estaria sob o seu escopo de "lucros distribuídos".

Entre as evidências utilizadas pelo tribunal para a interpretação do acordo, destacam-se: Direito doméstico; doutrina.

\section{3. "CASO AIR FRANCE".}

Brasil. Tribunal Regional Federal da $2^{a}$ Região. Compagnie Nationale Air France vs. Fazenda Nacional. Recurso de Apelação n. 1998.51.01.023848-8. Julgamento de 22/02/2008. Acordo de dupla tributação Brasil-França celebrado em 1971.

“Air France”, uma empresa de aviação residente na França, possuía subsidiária no Brasil.

O contribuinte ajuizou ação judicial para que fosse reconhecido que os termos "impostos futuros de natureza idêntica ou análoga", presentes no art. 2 (2) da convenção Brasil-França (equivalente ao art. 2 (3) e (4) da CM-OCDE).

O quadro a seguir ilustra o caso:

${ }^{900}$ Os dispositivos citados foram: art. $2^{\circ}, \S 2^{\circ}$, "b", 4 da Lei $9.532 / 97$ ou do art. $2^{\circ}, \S 2^{\circ}$, alínea "d", da IN $38 / 96$. 


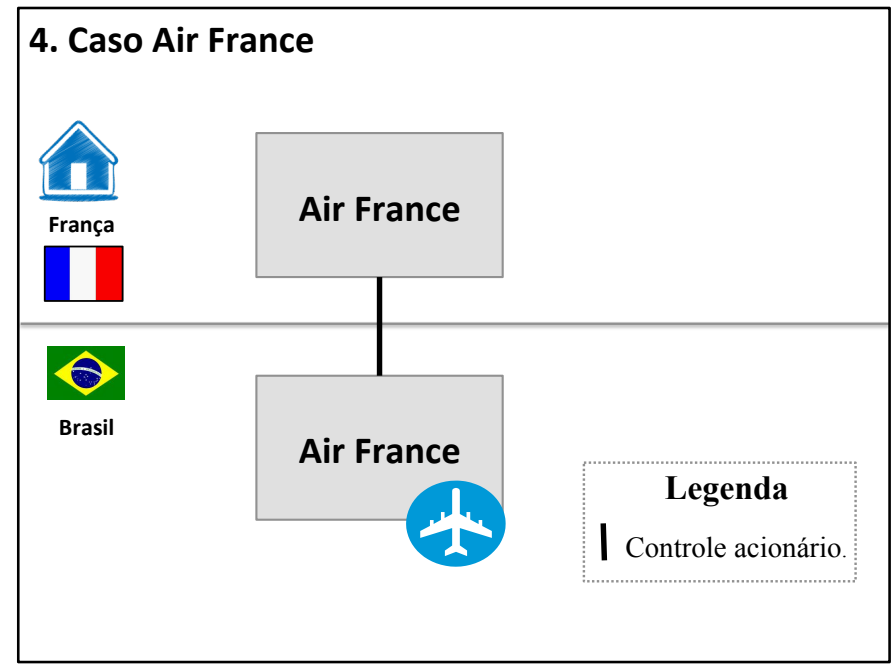

Com base no art. 111 e 175 do CTN, o TRF-2, no entanto, considerou que o acordo Brasil-França deveria ser interpretado de forma estrita e não extensiva. O acordo BrasilFrança se refere apenas ao imposto de renda, que incide sobre a renda, enquanto que a COFINS incide sobre a receita bruta ou faturamento.

Air France recorreu ao STJ e ao STF em face de tal decisão, os quais ainda não julgaram o caso.

Entre as evidências utilizadas pelo tribunal para a interpretação do acordo, destacam-se: Direito doméstico.

\section{4. "CASO COPESUL".}

Brasil. Superior Tribunal de Justiça. Copesul Companhia Petroquímica do Sul vs. Fazenda Nacional. Recurso Especial n. 1.161.467-RS. Julgamento de 01/06/2012. Acordos de dupla tributação Brasil-Alemanha de 1975 e Brasil-Canadá celebrado em 1984.

Copesul, pessoa jurídica residente no Brasil, contratou os serviços de beneficiamento em tubos e conexões de um forno de etano prestados por "Surface", pessoa jurídica residente no Canadá, bem como os serviços de retífica de maquinários prestados por "Siemens", pessoa jurídica residente na Alemanha. Tais serviços teriam sido prestados no exterior, não envolveriam a transferência de tecnologia e não estavam relacionados a quaisquer estabelecimentos permanentes das empresas estrangeiras que os teriam prestado. 
Ao realizar as remessas ao exterior para o pagamento por tais serviços, Copesul realizou a retenção e o recolhimento de $25 \%$ a título de imposto de renda brasileiro.

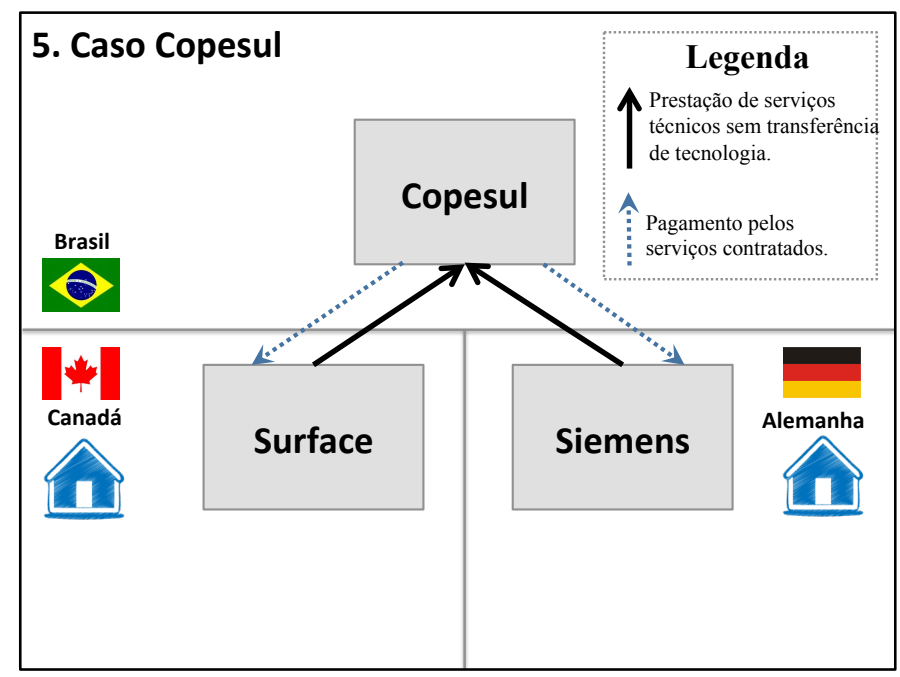

No entanto, após o recolhimento de tais valores, Copesul propôs ação judicial para requerer a repetição do indébito tributário, bem como a declaração de inexistência de relação jurídico-tributária que lhe obrigasse a realizar a retenção e o recolhimento de tributos em operações futuras. Como fundamento, Copesul argumentou que o art. 7 dos acordos de dupla tributação Brasil-Canadá e Brasil-Alemanha (equivalents à CM-OCDE) afastariam a tributação brasileira (Estado da fonte), de modo que apenas aqueles outros Estados poderiam tributar os rendimentos ("lucros") de seus residentes.

O fisco brasileiro, por sua vez, sustentou que deveria ser observado o Ato Declaratório COSIT n. 1/2000, no sentido de que remessas decorrentes de contratos de prestação de assistência técnica e de serviços técnicos sem transferência de tecnologia não estariam compreendidos no sentido do termo "lucros das empresas" geralmente referido no art. 7 dos acordos de dupla tributação celebrados pelo Brasil, mas sim no art. 21 (“Rendimentos não Expressamente Mencionados”), sujeitando-se à tributação na fonte. Diferente da CM-OCDE, os acordos celebrados pelo Brasil tradicionalmente permitem que o Estado da fonte tribute os rendimentos sob o escopo do art. 21.

No Parecer PGFN/CAT n. 776/2011, elaborado para ser apresentado ao STJ como memorial para o julgamento deste caso, compreendeu-se que, para a interpretação dos termos do art. $7^{\circ}$ "lucros da empresa”, seria inevitável e necessário o reenvio ao conceito 
de "lucro" na legislação brasileira. Tal definição dependeria "assim, única $e$ exclusivamente do conceito de lucro dentro da legislação pátria”

O STJ, por sua vez, confirmou a anterior decisão do "TRF-4", no sentido de que os pagamentos realizados pela Copesul estariam compreendidos no conceito de "lucros da empresa", de forma a ser aplicável o art. 7 das convenções fiscais. Compreendeu-se que os termos "lucro da empresa" deveria ser equivalente ao que os arts. 11 e 12 do Decreto-lei n. 1.598/77 teriam delineado como "lucro operacional", calculado a partir da receita bruta da venda de bens e da prestação de serviços. Ao contrário do que vinha sendo sustentado pelo fisco brasileiro, os termos "lucro da empresa" não seria equivalente a "lucro real" ou a "lucro líquido do exercício", definidos no art. $6^{\circ}$ do do Decreto-lei n. 1.598/77.

Entre as evidências utilizadas pelo tribunal para a interpretação do acordo, destacam-se: Texto do acordo.

\section{5. “CASO FALCÃO”.}

Brasil. Superior Tribunal de Justiça. Paulo Roberto Falcão vs. Fazenda Nacional. Recurso Especial n. 882.785. Julgamento de 13/02/2009. Fatos em discussão ocorridos em 1994. Acordo de dupla tributação Brasil-Japão celebrado em 1967.

Em 1994, "Falcão" trabalhou durante oito meses no Japão, como técnico de um time de futebol, embora jamais tenha abandonado a condição de residente no Brasil. Os seus rendimentos recibidos por tal atividade sofreram a retenção de $20 \%$ a título de imposto de renda japonês.

O fisco brasileiro, por sua vez, também exigiu o recolhimento de imposto de renda sobre tais rendimentos, possibilitando o creditamento do imposto pago ao Japão. Falcão, por sua vez, ajuizou ação anulatória em relação a tal cobrança, alegando, além de questões relacionadas à legislação doméstica brasileira (Lei 7.713/1988, art. $8^{\circ}$ ), a aplicação do art. 15 do acordo Brasil-Japão (equivalente ao art. 17 da CM-OCDE). 
O quadro a seguir ilustra o caso:

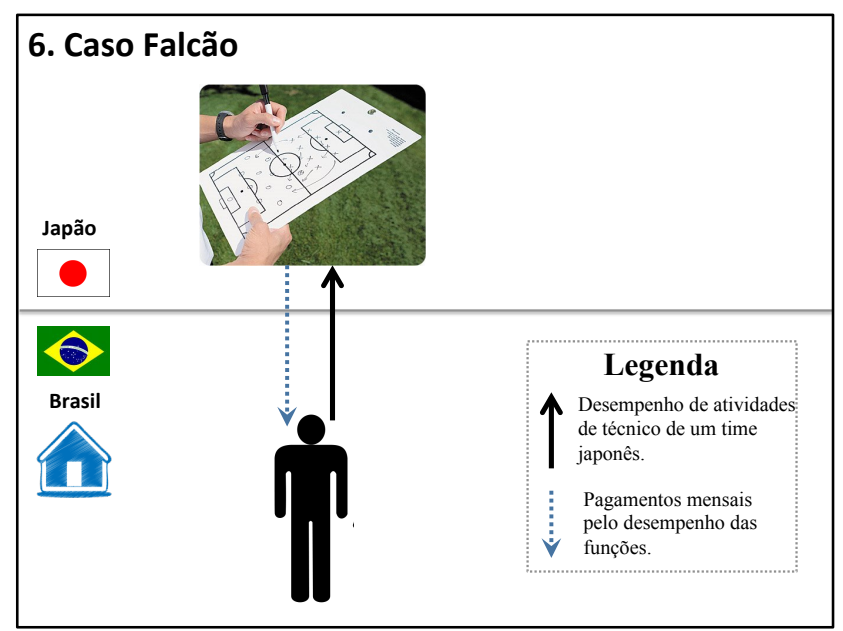

O STJ, por maioria, julgou que técnicos de futebol estariam compreendidos sob o escopo dos termos "participantes em diversões públicas" utilizados no art. 15 do acordo Brasil-Japão.

Entre as evidências utilizadas pelo tribunal para a interpretação do acordo, destacam-se: elementos textuais. 


\section{APÊNDICE 03. \\ DESCRIÇÃO DE CASOS DE APLICAÇÃO DE ACORDOS \\ DE DUPLA TRIBUTAÇÃO POR TRIBUNAIS \\ ESTRANGEIROS CITADOS NO TRABALHO.}

\section{AUSTRÁlia.}

\section{1. "Caso Thiel".}

Austrália. High Court of Australia. Thiel v. Federal Commissioner of Taxation. Julgamento de 22/08/1990. Fatos em discussão ocorridos em 1985. Acordo de dupla tributação Austrália-Suiça celebrado em 1980.

Thiel, uma pessoa física residente na Suíça, aquiriu participações em um trust de tecnologia estabelecido na Austrália, no valor de $\$ 100.000$, entre 25/1/84 e 25/05/84. Em 22/10/84, o trust foi incorporado como companhia (Energy Research Group Australia Ltd). Em 9/11/84, Thiel realizou a sua participação naquele trust, recebendo o equivalente a \$300.000 em ações da companhia. Com a oferta pública inicial de ações dessa companhia na bolsa de valores, Thiel vendeu parte de sua participação entre 7/2/85 e 6/3/85, ao valor de aproximadamente $\$ 600.000$.

Após ser autuado pelo fisco australiano para o pagamento de imposto sobre o ganho de capital obtido com a venda dessas ações, Thiel reclamou os benefícios da convenção físcal Austrália-Suíça, especialmente de seu art. 7. O Fisco contestou a aplicação do art. 7, sob a alegação de que, no Direito interno australiano, a expressão “carried on", que antecede o termo "business" na definição estabelecida no art. 3 (1) do acordo, exigiria frequência e repetição das atividades, o que não seria o caso de Thiel.

Os quadros a seguir ilustram o caso: 

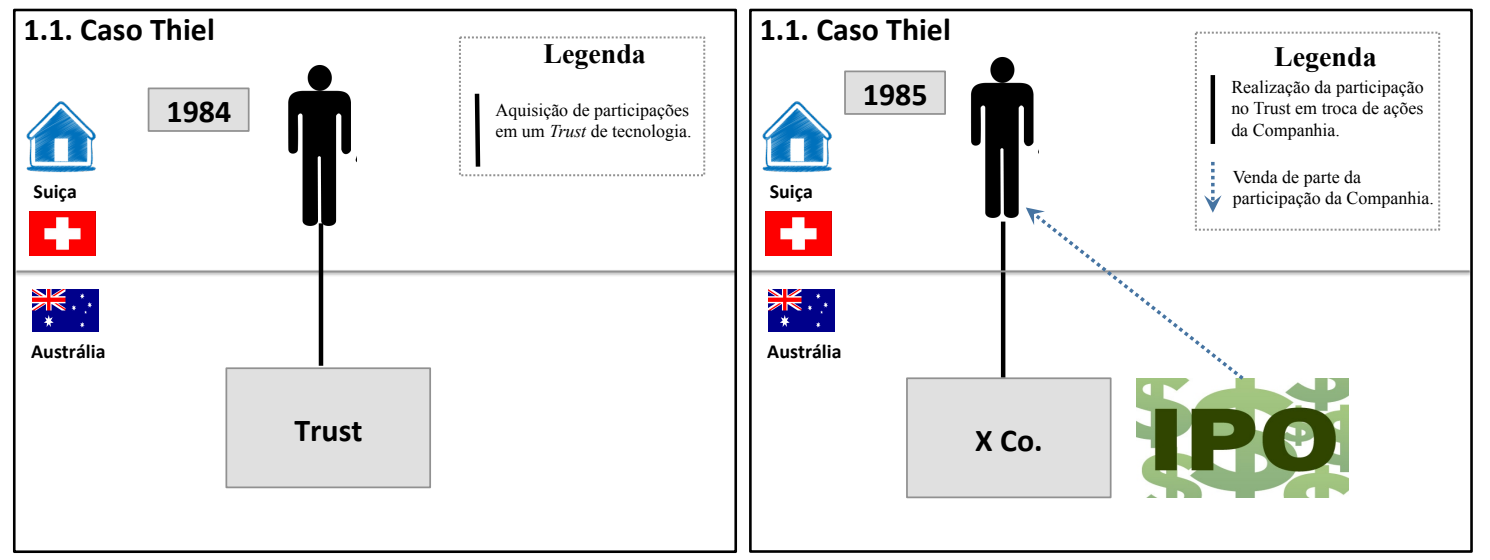

Para o tribunal australiano, Thiel teria adquirido a participação no trust como parte de suas atividades empresariais e com o propósito de obter lucros. A alienação das ações não teria gerado, então, ganho de capital, mas lucros da atividade empresarial (art. 7). O argumento de que a cláusula do "an enterprise carried on" exigiria certa frequência no desempenho das atividades não prosperou.

Entre as evidências utilizadas pelo tribunal para a interpretação dos termos em questão destacam-se: comparação de diferentes dispositivos do acordo; Comentários à $C M-O C D E$. Também foram feitas referências ao preâmbulo e aos anexos do acordo de dupla tributação, mas nenhuma consequência prática lhes foram atribuídas a tal constatação.

\section{2. "Caso Lamesa".}

Austrália. Federal Court of Australia. Commissioner of Taxation v Lamesa Holdings BV. Julgamento de 20/08/1997. Fatos em discussão ocorridos entre 1993 e 1996. Acordo de dupla tributação Austrália-Países Baixos celebrado em 1976.

O caso envolve a interposição de uma série de empresas: "LGA" seria uma partnership constituída nos EUA. "Arimco" seria residente na Austrália, a qual possuia como subsidiária Arimco Mining, também residente na Austrália e detentora de direitos de exploração de minas de ouro naquele país. Inicialmente, "LGA" teria utilizado "GEILP", outra partnership residente nos EUA, para a aquisição de 18,10\% de "Arimco". Em seguida, "GEILP" teria adquirido a empresa "ARL" (Austrália), que teria adquirido “ARM" (Austrália). Após, "GEILP” teria adquirido "LAMESA" (Holanda), integralizando 
nesta a sua participação em "ARL". Na sequência, então, "ARM" teria adquirido “ARIMCO”. A estrutura pode ser representada da seguinte forma:

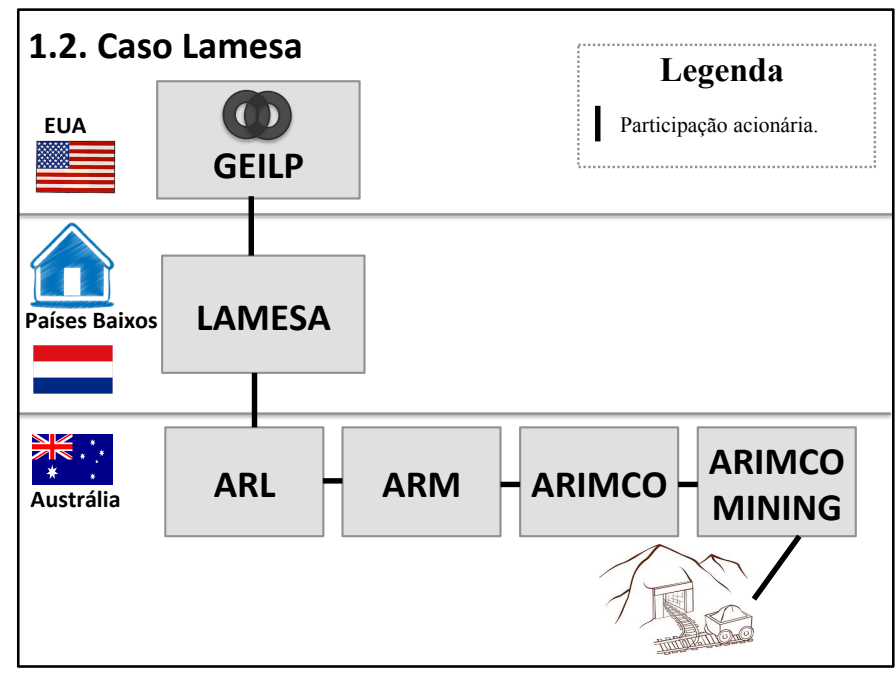

Entre 1993 e 1996, "LAMESA" teria realizado a venda de sua participação em "ARL".

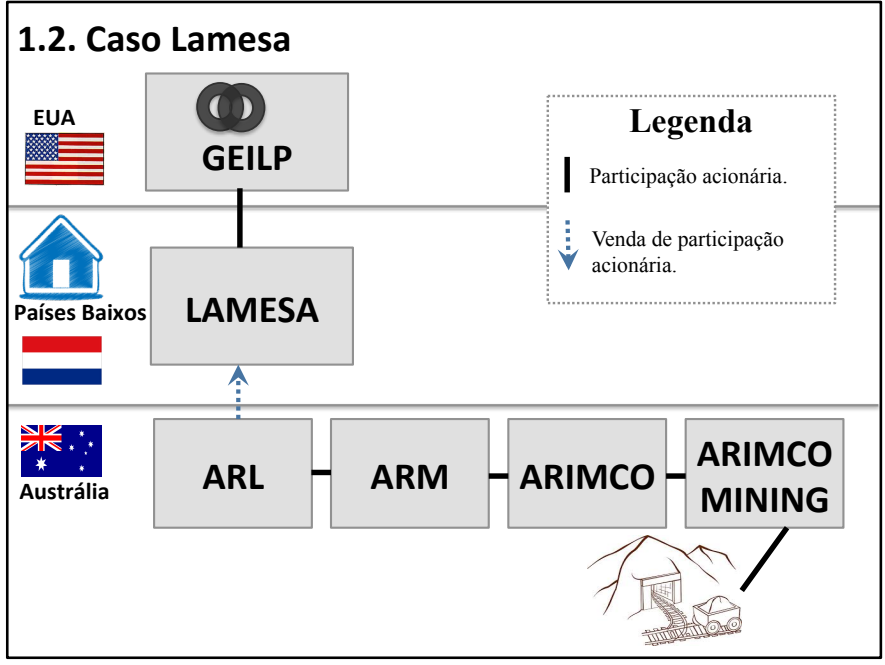

O Fisco australiano exigiu tributos com base no art. 13 (2) do acordo AustraliaPaíses Baixos. O art. 13 distribui ao Estado em que a "real property" estivesse localizada e a alínea "a", "iii" deste dispositivo equipara a "real property" quaisquer "shares or comparable interests in a company, the assets of which consist wholly or principally of direct interests in or over land in one of the State or of rights to exploit, or to explore for, natural resources in one of the States". 
Por sua vez, LAMESA sustentou que deveria ser aplicado ao caso o art. 7 do acordo Australia-Países Baixos, pois tais rendimentos estariam suportados pelo conceito de "business profits". Sob tal perspectiva, apenas os Países Baixos poderiam exercer a tributação sobre tais rendimentos, o que, na verdade, não ocorria na legislação interna daquele país.

O tribunal compreendeu que o art. 13 (2) “a" "iii”" não seria aplicável, devendo ser adotado o art. 7, de forma que apenas os Países Baixos poderiam tributar os lucros obtidos na alienação da participação em ARL. Ocorre que o "ARL" possuia em seus ativos apenas ações de outras empresas e não direitos de exploração de minas (tais direitos eram detidos por "ARIMCO MINING", controlada indireta de "ARL”). Para tanto, o Tribunal interpretou a expressão "the assets of which" de forma a se referir apenas aos ativos detidos diretamente por ARL, desconsiderando os ativos de suas subsidiárias.

\section{Entre as evidências utilizadas pelo tribunal para a interpretação do acordo,} destacam-se: os objetivos e propósitos da convenção e de seus dispositivos, a partir de evidências textuais ("four corners of the actual text"), decisões judiciais do outro Estado contratante e Comentários à CM-OCDE.

\section{3. "Caso McDermott".}

Austrália. Federal Court of Australia. McDermott Industries (Aust) Pty Ltd v. Federal Commissioner of Taxation. Julgamento de 29/04/2005. Fatos em discussão ocorridos entre 1993 e 1997. Acordo de dupla tributação Austrália-Singapura celebrado em 1989.

“CCS”, uma empresa residente em Singapura, não conduzia negócios (“carry on business") e nem possuía escritório ou funcionários na Austrália. "McDermott", uma empresa residente na Austrália, teria arrendado de CCS embarcações vazias (“barges” e não "ships"), as quais foram utilizadas apenas em território australiano. 
O quadro a seguir ilustra o caso:

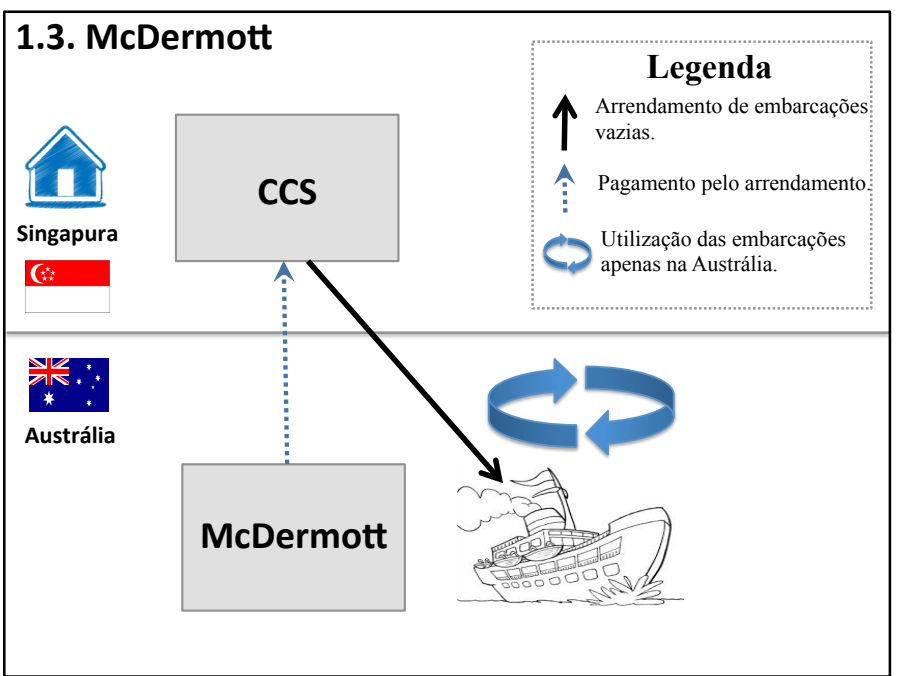

$\mathrm{O}$ art. 4 (3) do acordo Austrália-Singapura, embora semelhante ao art. 5 da CMOCDE, previa a presença de um estabelecimento permanente no caso de "substantial equipment".

Para o Fisco australiano, McDermott deveria reter 10\% sobre os valores brutos pagos a título de royalties, sob o escopo do art. 10 do acordo Austrália-Singapura (semelhante ao art. 12 da CM-OCDE). Para o contribuinte, não deveria haver retenção alguma, devendo CCS ser tributada por seus lucros em Singapura, conforme o art. 7 daquela convenção (equivalente ao art. 7 da CM-OCDE).

Para o tribunal australiano, o art. 7 e não o art. 12 seria aplicável. Contudo, "CCS" possuiria um estabelecimento permanente na Austrália, em razão de "substantial equipment" de sua propriedade que permaneceram no território australiano em função do contrato de arrendamento firmado com McDermott.

Entre as questões envolvidas, foi discutido se o termo "used", referido no art. 4 (3) "b" do acordo ("substantial equipment is being used in that other State by, for or under contract with the enterprise") alcançaria o uso passivo ou apenas o uso ativo?

Para o fisco: (i) o art. 4 (1) comandaria a interpretação do art. 4 (3), exigindo "significant presence" para a caracterização de um estabelecimento permanente; (ii) tal 
como no caso de royalties, o uso passivo estaria fora do escopo do art. 4 (3) no escopo do art. 10. Também foi preciso que o tribunal interpretasse "substantial equipment" e declarasse o preenchimento ou não do requisito.

Entre as evidências utilizadas pelo tribunal para a interpretação do acordo, destacam-se: os objetivos e propósitos da convenção e de seus dispositivos, a partir de evidências textuais ("four corners of the actual text").

\section{CANADÁ}

\section{1. "Caso Saunders".}

Canadá. Tax Appeal Board. Saunders v. Her Majesty the Queen. Julgamento de 30/11/1954. Fatos em discussão ocorridos entre 1951 e 1952. Acordo de dupla tributação Canadá-EUA celebrado em 1942.

Sr. Saunders serviu a Marinha dos EUA por muitos anos. Em 1947, Saunders voluntariamente aposentou-se e, com a autorização prévia da Marinha, mudou-se para o Canadá com a sua família para trabalhar em uma empresa privada. Todos os anos, Saunders recebia um pagamento do governo americano entitulado "retired pay", sobre o qual recolhia imposto de renda nos EUA.

O quadro a seguir ilustra o caso:

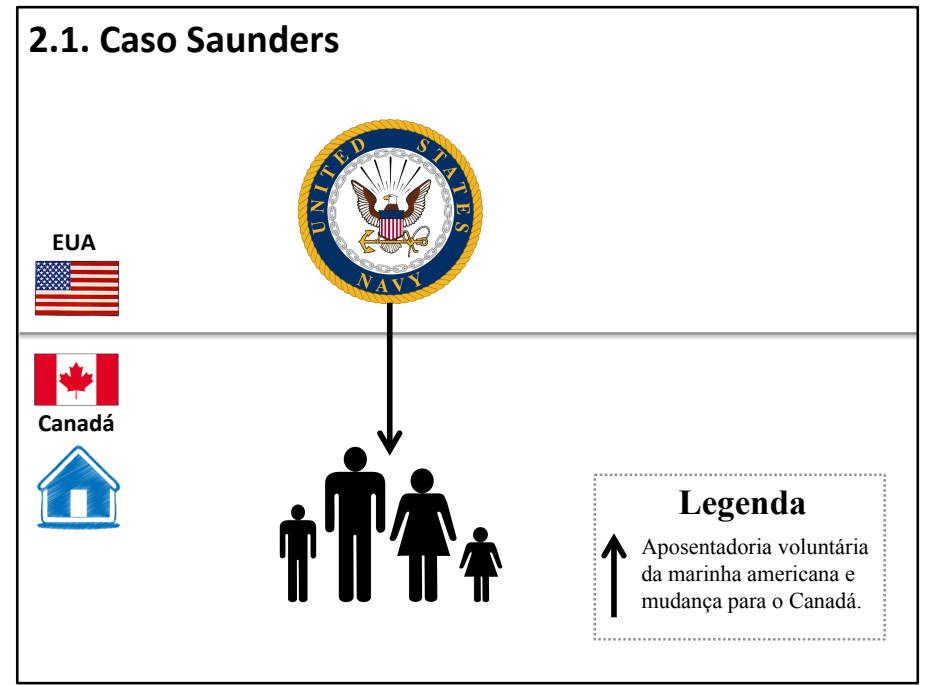


O tribunal canadense precisou analisar se tais pagamentos recebidos por Saunders estaria sob o escopo do termo: (i) "pension", referido no art. 6-A do acordo Canadá-EUA (equivalente ao art. 18 da CM-OCDE), de forma que a tributação poderia ser exercida exclusivamente pelo Estado de residência (Canadá), ou; (ii) "Remuneration, wages or salary (other than pensions)", que, conforme o art. 6 da mesma convenção (equivalente ao art. 19 da CM-OCDE), somente poderia ser tributado pelo Estado da fonte (EUA).

Para o tribunal canadense, os rendimentos em questão apenas poderiam ser considerados como pensão caso a aposentadoria houvesse sido concedida em função da finalização de seu tempo de trabalho ("wholly retired"). Ocorre que, com vistas ao Direito norte-americano que regula a concessão do benefício recebido em questão, este seria concedido em outras condições ("merely 'retired").

\section{Entre as evidências utilizadas pelo tribunal para a interpretação do acordo,} destacam-se: o texto do acordo, incluindo o seu protocolo, parecer de experts ("Mr. Sullivan") sobre o Direito do outro Estado contratante, práticas da administração fiscal canadense na aplicação do acordo e decisões judiciais do outro Estado contratante.

\section{2. "Caso Ezra".}

Canadá. Ezra Shahmoon v. Her Majesty the Queen. Tax Review Board. Julgamento de 30/09/1975. Fatos em discussão ocorridos entre 1968 e 1973. Acordo de dupla tributação Canadá-EUA celebrado em 1942.

Ezra Shahmoon ("Ezra”), residente nos EUA, obteve rendimentos com a alienação de bens imóveis no Canadá.

Conforme o art. 1 do antigo acordo Canadá-EUA (em alguma medida equivalente ao art. 7 da CM-OCDE), os lucros de atividades empresariais apenas seriam tributáveis no Estado de residência, salvo se tais rendimentos pudessem ser atribuídos a um estabelecimento permanente no Estado da fonte. Por sua vez, o art. 8 daquela convenção (em alguma medida equivalente ao art. 13 da CM-OCDE), também reservava ao Estado de residência a tributação sobre ganhos de capital, salvo se estes pudessem ser atribuídos a estabelecimento permanente no outro Estado contratante. 
Tendo em vista que Ezra possuía um imóvel no Canadá, o fisco considerou que haveria um estabelecimento permanente naquele país, exigindo o recolhimento de tributos.

O quadro a seguir ilustra o caso:

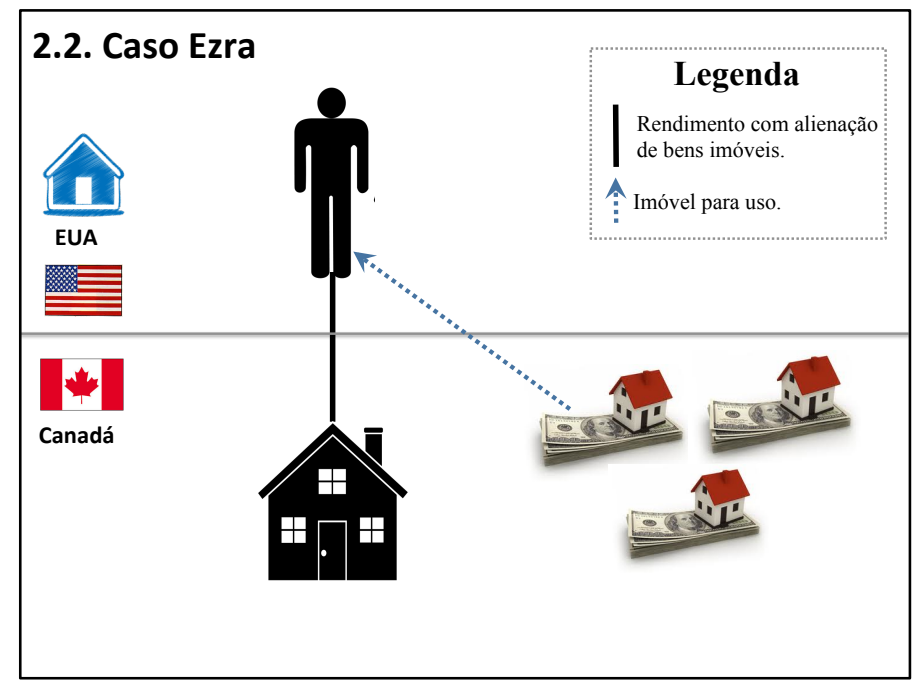

O tribunal canadense, contudo, considerou que o imóvel referido pelo fisco estava alugado e era utilizado pelo contribuinte esporadicamente, não constituindo um estabelecimento permanente utilizado para a condução dos negócios que teriam ensejado os rendimentos em questão. Para os juízes, considerar o imóvel em questão como um estabelecimento permanente seria contraditório com as práticas seguidas por ambos os países, em que não se considerava que residentes do Canadá, que possuíam imóveis nos EUA para férias, teriam estabelecimento permanente naquele país.

Entre as evidências utilizadas pelo tribunal para a interpretação do acordo, destacam-se: o Direito doméstico existente no momento em que a convenção físcal foi celebrada, com a recusa a alterações unilaterais no acordo pela consideração de legislações supervenientes; práticas seguidas pelos Estados na aplicação do acordo. 


\section{3. "Caso Cruikshank"}

Canadá. Federal Court - Trial Division. Cruikshank v. Her Majesty the Queen. Julgamento de 09/06/1977. Fatos em discussão ocorridos nos anos de 1974. Acordo de dupla tributação Canadá-França celebrado em 1951.

O Sr. Cruikshank, residente na França, recebeu um pagamento único (“lump sum payment") de um fundo de previdência privada, constituído no Canadá, em razão do fim deste plano de pensão. Tal pagamento foi realizado como substituição aos pagamentos periódicos que lhe seriam feitos caso o fundo de pensão permanecesse em funcionamento.

Conforme o art. 11 acordo de bitributação Canadá-França (equivalente ao art. 18 da CM-OCDE), as pensões apenas seriam tributáveis no Estado de residência. Contudo, como nem o acordo Canadá-França e nem o Direito canadense possuíam a definição de "pensão", o fisco canadense sustentou que nos dicionários o sentido do termo não comportaria pagamentos únicos, de forma que o acordo não seria aplicável.

O quadro a seguir ilustra o caso:

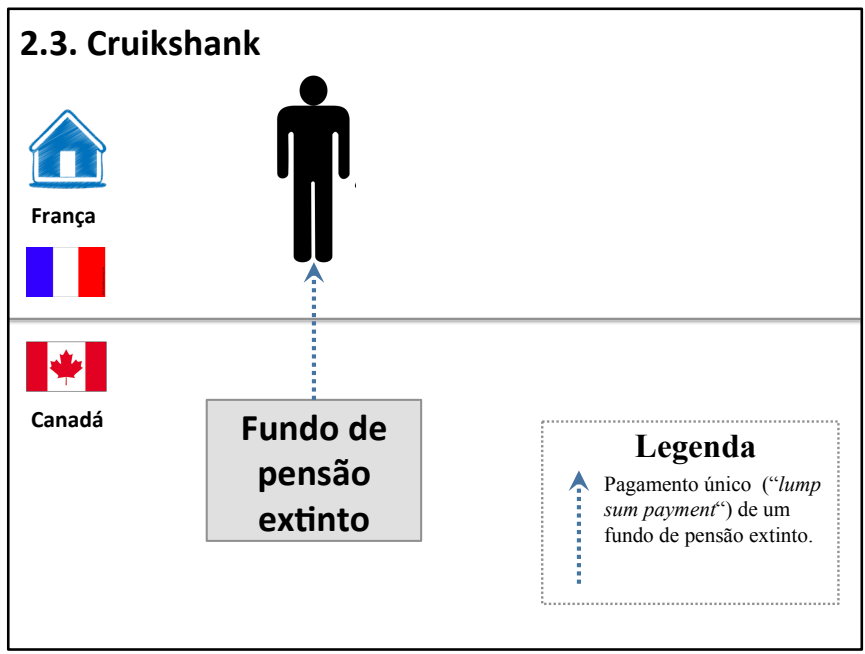

O tribunal canadense, por sua vez, compreendeu que o termo "pensão" deveria ser interpretado de forma mais ampla do que o seu sentido lexical colhido em dicionários, de forma a incluir quaisquer "superannuation or pension benefit", inclusive "lump sum payments". Dessa forma, o acordo Canadá-França seria aplicável e apenas o Estado de residência (França) teria competência para tributar a pensão em questão. 
Embora o tribunal tenha recusado a utilização de dicionários, bem como tenha consignado a inexistência de definição no Direito doméstico para o termo "pensão", não indicou a quais outras evidências teria recorrido para julgar que uma interpretação mais compreensiva deveria ser utilizada no caso.

\section{4. "Caso Melford".}

Canadá. Melford v. Her Majesty the Queen. Supreme Court. Julgamento de 28/09/1982. Fatos em discussão ocorridos entre 1975 e 1977. Acordo de dupla tributação CanadáAlemanha celebrado em 1956.

Para a obtenção de um empréstimo do Bank of Nova Scotia (Canadá), Melford (Canadá) obteve uma garantia com outro banco, Vereinsbank, o qual era residente na Alemanha e não possuía estabelecimento permanente no Canadá. Para a obtenção de tal garantia, Melford se comprometeu a pagar 1\% ao ano sobre o valor afiançado ("garantee fee").

O fisco canadense considerou que tais pagamentos seriam "juros" pagos por Melford. Como a legislação canadense da época exigia a renteção de imposto de renda pelo remetente dos juros ao exterior, foi exigido de Melford os valores que deixara de reter, ainda que com a alíquota reduzida prevista no acordo Canadá-Alemanha (15\%).

Melford, por sua vez, alegou que tais rendimentos seriam suportados pelo conceito de "industrial or commercial profits" referidos no art. 3 (1) da convenção fiscal (semelhante ao art. 7 da CM-OCDE) e, dessa forma, somente poderiam ser tributados na Alemanha. 
O quadro a seguir ilustra o caso:

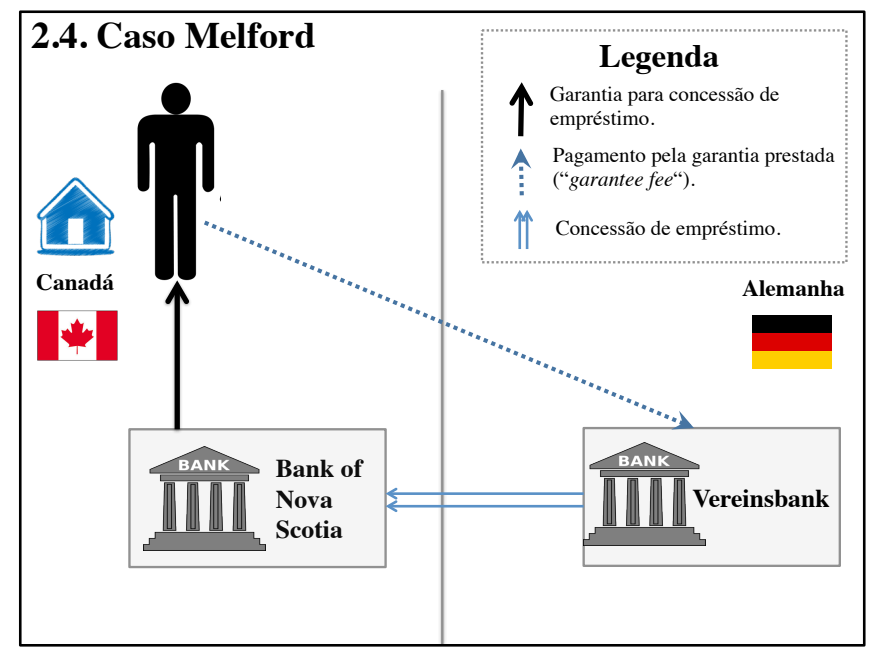

A Suprema Corte canadense decidiu que os pagamentos realizados a título de "guarantee fee" não poderiam ser qualificados como "interest", devendo ser qualificados como "industrial or commercial profits" e, portanto, apenas tributáveis no Estado de residência (Alemanha).

Entre as evidências utilizadas pelo tribunal para a interpretação do acordo, destacam-se: análise sintática e semântica do texto do acordo; comparação de diferentes dispositivos do acordo; o Direito doméstico existente no momento em que a convenção fiscal foi celebrada, com a recusa a alterações unilaterais no acordo pela consideração de legislações supervenientes; uso comercial ordinário ("ordinary commercial usage”) dos termos à época em que o acordo foi celebrado; decisões judiciais de terceiros Estados.

É curioso notar que, em razão dessa decisão, foi introduzido no Direito canadense (“Canada's Income Tax Conventions Interpretation Act”) norma que expressamente determina a adoção dinâmica das de normas domésticas para a interpretação dos acordos de dupla tributação. 


\section{5. "Caso Gladden".}

Canadá. Federal Court - Trial Division. Gladden v. Her Majesty the Queen. Julgamento de 22/01/1985. Fatos em discussão ocorridos entre 1960 e 1964. Acordo de dupla tributação Canadá-EUA celebrado em 1942.

O Sr. "Gladden", residente nos EUA, possuía participação em duas empresas no Canadá. Em 1977, o Sr. Gladden faleceu, o que, conforme a legislação canadense, configuraria fato gerador do imposto de renda sobre o ganho de capital apurado na sucessão.

O acordo Canadá-EUA reservava a competência para a tributação do ganho de capital apenas ao Estado de residência. O fisco canadense, no entanto, exerceu tal tributação, sob a alegação de que o acordo Canadá-EUA não seria aplicável, já que (i) o Canadá não tributava o ganho de capital à época da celebração do acordo e, portanto, não teria sido a sua intenção incluí-la no acordo; (ii) o art. VIII do acordo Canadá-EUA faria referência à tributação sobre "sale or exchange", o que não seria o caso; (iii) os EUA não teriam tributado os rendimentos em questão, de modo que não haveria dupla tributação capaz de justificar a aplicação do acordo internacional.

O quadro a seguir ilustra o caso:

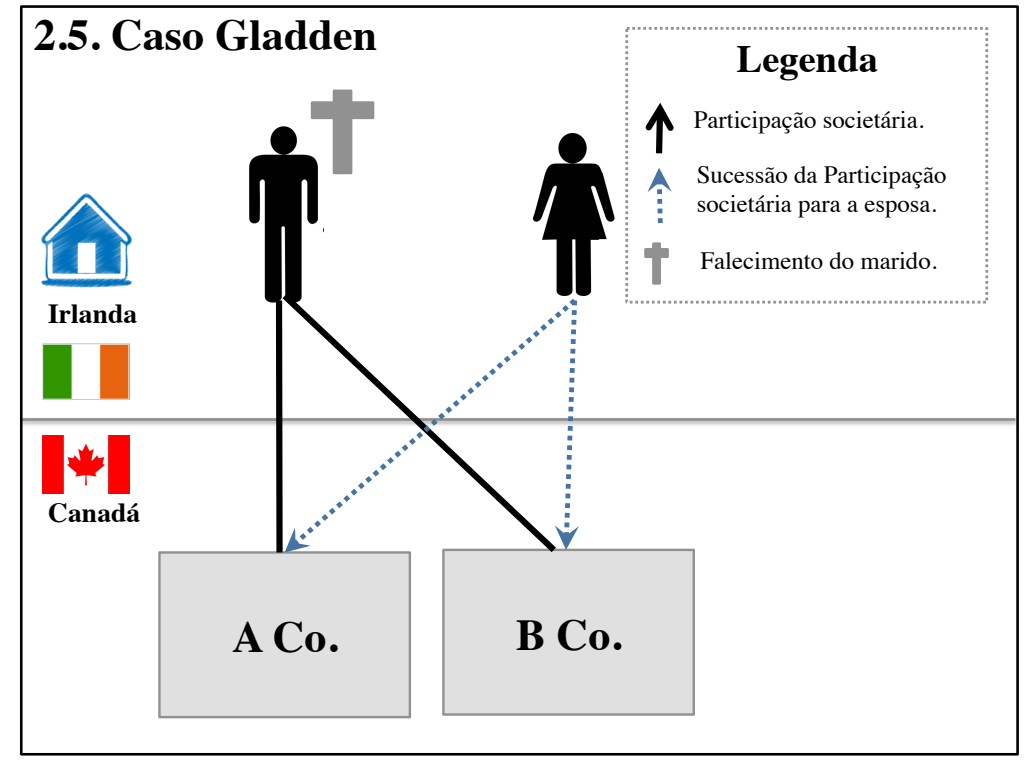

O tribunal canadense compreendeu que o acordo seria aplicável, de forma que apenas o Estado de residência (EUA) poderia tributar o ganho de capital. Se os EUA exerceriam de fato tal competência não seria relevante para a interpretação do acordo. 
Entre as evidências utilizadas pelo tribunal para a interpretação do acordo, destacam-se: análise sintática e semântica do texto do acordo; os objetivos e propósitos da convenção e de seus dispositivos, a partir de evidências textuais; decisões judiciais do outro Estado contratante; comparação de diferentes dispositivos do acordo; o Direito doméstico existente no momento em que a convenção fiscal foi celebrada.

\section{6. "Caso Crown Forest".}

Canadá. Supreme Court of Canada. Crown Forest Industries Ltd. v. Her Majesty the Queen. Julgamento de 22/06/1995. Fatos em discussão ocorridos entre 1987 e 1989. Acordo de dupla tributação Canadá-EUA celebrado em 1980.

Entre 1987 e 1989, "Fletcher" uma holding residente na Nova Zelândia, possuía uma subsidiária constituída no Canadá (“Crown Forest”), que se dedicava ao transporte marítimo de lascas de madeira para fábricas de celulose, bem como de produtos destas fábricas ao Canadá e aos EUA. Fletcher possuía também outra subsidiária (“Norsk”), em Bahamas, a qual realizava a locação das embarcações (“barges”) utilizadas por Crown Forest, bem como o transporte internacional de papel para impressão de jornais.

Norsk não possuía estrutura física em Bahamas, mas um escritório com 19 funcionários nos EUA, de onde a empresa era administrada ("sole office and place of business"). A única declaração fiscal apresentada por Norsk nesse período foi aos EUA, na condição de "não residente". Norsk não era tributada nos EUA ou em Bahamas, em razão de isenção recíproca concedida nesses países. Ao realizar o pagamento pelo fretamento das embarcações, Crown Forest realizou a retenção de 10\% a título de imposto de renda canadense (e não 25\%, conforme previsto pela legislação doméstica), baseando-se no acordo Canadá-EUA. 
O quadro a seguir ilustra o caso:

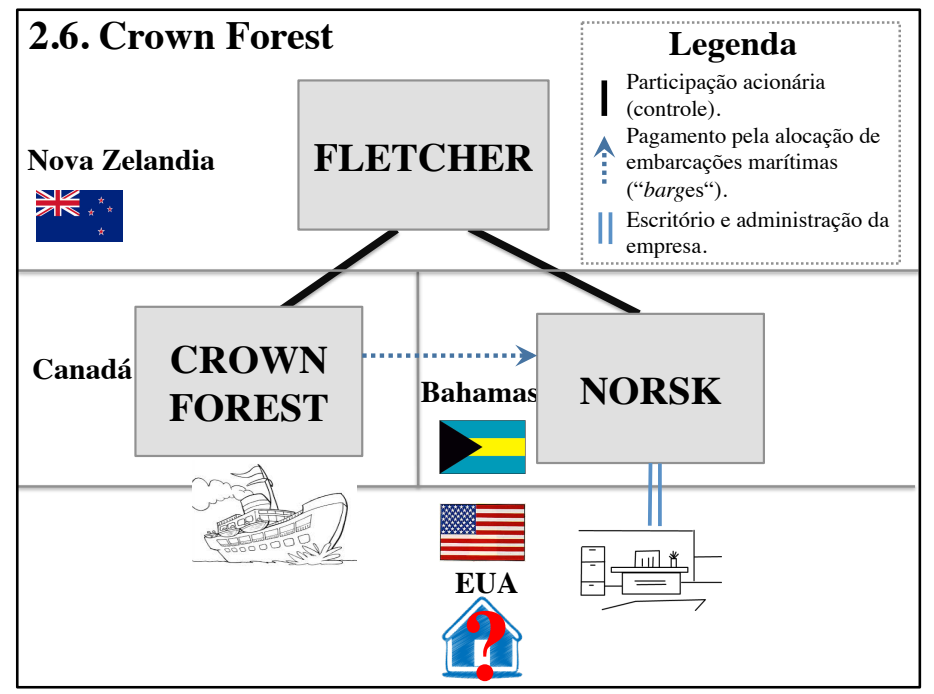

O fisco canadense, no entanto, rejeitou a aplicação do acordo internacional, sob a alegação de que Norsk não poderia ser considerada residente nos EUA, exigindo que Crown Forest recolhesse a diferença dos tributos que deixou de reter.

Nas instâncias anteriores, os julgadores consideraram que Norsk seria residente nos EUA, pois preencheria o requisito do art. 4 quanto ao "place of management". A Suprema Corte canadense, no entanto, considerou que o acordo Canadá-EUA não seria aplicável, especialmente porque, na legislação dos EUA, o "place of management" não seria um fator que, por si só, determinaria se as rendas de uma empresa estariam efetivamente conectadas com aquele país. Embora os tribunais a quo tenham considerado corretamente que o "place of management" estaria nos EUA e este seria um fator relevante para ser liable to tax naquele país, teriam interpretado de forma equivocada os termos "by reason of": dizer que o "place of management" é fundamental para que Norsk seja considerado residente nos EUA não significa que apenas e diretamente por essa razão (“by reason of”) tal empresa já poderia ser considerada residente naquele país.

Entre as evidências utilizadas pelo tribunal para a interpretação do acordo, destacam-se: a intenção dos Estados contratantes, delineada a partir de materiais unilaterais ("U.S. Senate (Foreign Relations Committee), Tax Convention and Proposed Protocols with Canada"); circunstâncias fáticas ocorridas no período das negociações da 
convenção fiscal; decisões judiciais do outro Estado contratante; a CM-OCDE, a CMONU e os seus respectivos Comentários.

\section{7. "Caso Beame".}

Canadá. Federal Court of Appeal. Beame v. Her Majesty the Queen. Julgamento de 04.02.2004. Fatos em discussão ocorridos em 1997. Acordo de dupla tributação CanadáIrlanda celebrado em 1966.

O Sr. Beame, residente na Irlanda, alienou ações que possuia em uma empresa residente no Canadá. O quadro a seguir ilustra o caso:

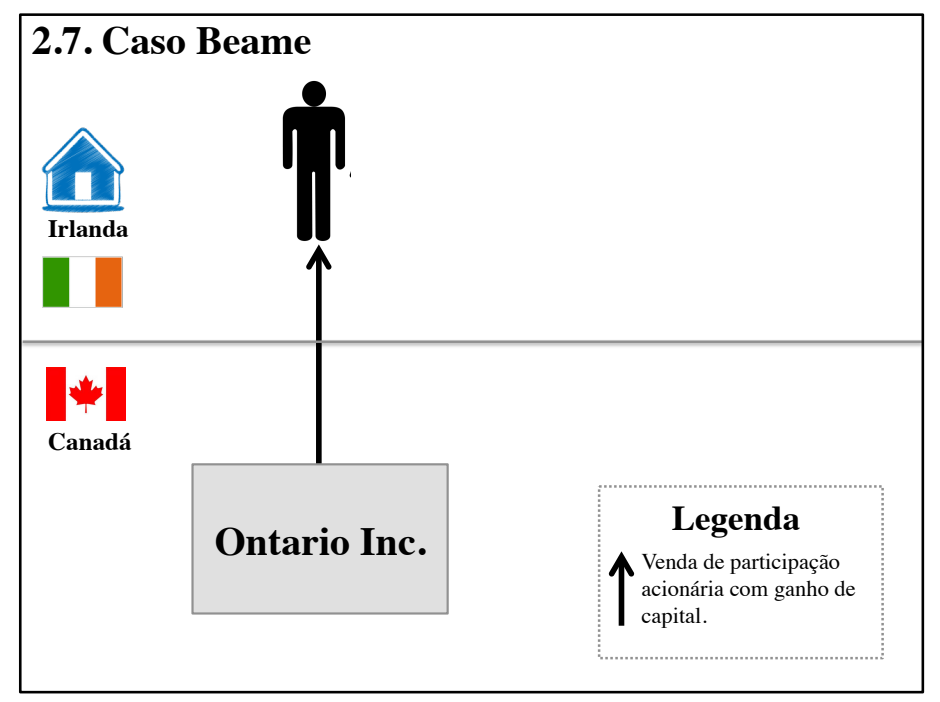

O acordo Canadá-Irlanda previa, em seu article 6 (1), que "the rate of Canadian tax on income (other than income from carrying on business in Canada or from performing duties in Canada) derived from sources within Canada by a resident of Ireland shall not exceed 15 per cent”. Como Direito canadence tributa o "taxable capital gain", que equivale a $3 / 4$ do "capital gain" efetivamente obtido, o Sr. Beame sustentou que a base tributável, sobre a qual seria aplicável a alíquota reduzida de $15 \%$, seria o referido "taxable capital gain". O fisco canadense, contudo, sustentou que a base de cálculo seria todo o ganho de capital auferido.

O tribunal canadense, por sua vez, decidiu que: (i) há no Direito canadense norma que estabelece que aos termos não definidos no acordo internacional sejam atribuídos os sentidos existentes no Income Tax Act de forma dinâmica ("Section 3 of Canada's Income 
Tax Conventions Interpretation Act"); (ii) tal norma é aceita pelo Poder Judiciário, inclusive com o escopo de reverter o julgamento da Suprema Corte no Caso Melford; (iii) bem como que tal definição doméstica prevê a tributação sobre o "taxable capital gains", então o Sr. Beame somente poderia ser tributado sobre $3 / 4$ de seu ganho de capital ("taxable capital gain").

Entre as evidências utilizadas pelo tribunal para a interpretação do acordo, destacam-se: o Direito doméstico existente no momento da aplicação do acordo.

\subsection{Caso Pacific Network}

Canadá. Federal Court of Canada. Pacific Network Services Ltd v. Minister of National Revenue. Julgamento de 08.11.2002. Acordo de dupla tributação Canadá-França

No caso, com base no art. 26 (1) da convenção Canadá-França, as autoridades fiscais francesas requereram às autoridades canadenses informações a respeito da empresa Pacific Network, em especial quanto à natureza de seus negócios, o nome e endereço de seus sócios, incluindo a participação de cada um em seu capital social.

O art. 26 do acordo de dupla tributação Canadá-França possuía a seguinte redação:

\section{Article 26 - Exchange of information}

1. The competent authorities of the Contracting States shall exchange such information as is necessary for carrying out the provisions of this Convention or of the domestic laws of the Contracting States concerning taxes covered by the Convention insofar as the taxation thereunder is not contrary to the Convention. The exchange of information is not restricted by Article 1 . Any information received by a Contracting State shall be treated as secret in the same manner as information obtained under the domestic laws of that State and shall be disclosed only to persons or authorities (including courts and administrative bodies) involved in the assessment or collection of, the enforcement in respect of, or the determination of appeals in relation to, the taxes covered by the Convention. Such persons or authorities shall use the information only for such purposes. They may disclose the information in public court proceedings or in judicial decisions.

2.In no case shall the provisions of paragraph 1 be construed so as to impose on a Contracting State the obligation:

(a) to carry out administrative measures at variance with the laws and administrative practice of that or of the other Contracting State;

(b) to supply information which is not obtainable under the laws or in the normal course of the administration of that or of the other Contracting 
State;

(c) to supply information which would disclose any trade, business, industrial, commercial or professional secret or trade process, or information, the disclosure of which would be contrary to public policy (ordre public)

A fim de evitar o fornecimento de tais informações às autoridades fiscais francesas, o contribuinte interpôs ação judicial perante os tribunais canadenses, alegando, em especial, que o termo "exchange", presente no artigo 26 do acordo Canadá-França, deveria ser interpretado em seu sentido literal (contexto intrínseco), de tal modo que as autoridades fiscais canadenses apenas poderiam fornecer informações que já estivessem em seu poder; para que as autoridade fiscais canadenses pudessem ou tivessem que empreender esforços especialmente para a coleta de tais informações, tal fator deveria estar expresso no texto do acordo internacional.

Para atribuir peso a tal argumento, Pacific Network levou à análise do tribunal canadense evidências do contexto extrínseco, a exemplo de parallel treaties, adotando como par de comparação o acordo Canadá-EUA, que previa expressamente o dever dos Estados de empenhar esforços para a obtenção de informações ("endeavour to obtain the information") sob a sua jurisdição, na mesma intensidade caso o interesse arrecadatório do próprio Estado estivesse em jogo. Diante da ausência de tal cláusula no acordo CanadáFrança, que simplesmente previa a troca ("exchange") de informações e não o empenho de esforços ("endeavour"), os Estados apenas deveriam fornecer informações que já detivessem.

No entanto, o Tribunal canadense compreendeu que a presença de cláusula semelhante à do art. 26 (2) do acordo Canadá-EUA no texto do acordo Canadá-França não seria decisiva para que ambos fossem aplicados na mesma forma no que concerne à troca de informações. Consignou-se, ainda, que o exercício realizado pelo contribuinte a partir de parallel treaties não trariam evidências tão persuasivas quanto aquelas providas pela CM-OCDE ou por seus Comentários.

O Tribunal canadense consignou que acordos de dupla tributação demandariam interpretação liberal e não literal. No caso, então, o contexto intrínseco não seria suficiente para prover um sentido plausível, conduzindo à conclusões contraditórias, enquanto que o contexto extrínseco primário seria menos convincente que o contexto 
extrínseco secundário, fundamentando que se apoiariam basicamente nas evidências levantadas a partir deste último.

Entre as evidências utilizadas pelo tribunal para a interpretação do acordo, destacam-se: protocolos do acordo; outros acordos de bitributação (parallel treaties); a CM-OCDE e os seus respectivos Comentários.

\section{ESPANHA}

\section{1. "Caso Halcón".}

Espanha. Tribunal Supremo, Sala de lo Contencioso. Viajes Halcón SA vs. Administración General del Estado. Julgamento de 11/06/2008. Fatos em discussão ocorridos 1995. Acordo de dupla tributação Espanha-Países Baixos, celebrado em 1971.

Uma empresa residente na Espanha ("Halcón"), contratou o cantor Juan Manuel, residente nos Estados Unidos, para espetáculos em território espanhol. Foram assinados dois contratos: um diretamente com o referido artista e, o outro, com uma empresa residente nos Países Baixos ("ITCON BV"), a qual detinha os direitos de imagem do cantor. Considerou-se que os pagamentos realizados por Halcón à ITCON estariam sob o escopo do termo royalties, referidos no art. 12 (3) da convenção Espanha-Países Baixos, sujeitos à retenção de $6 \%$ a título de imposto de renda espanhol.

O quadro a seguir ilustra o caso:

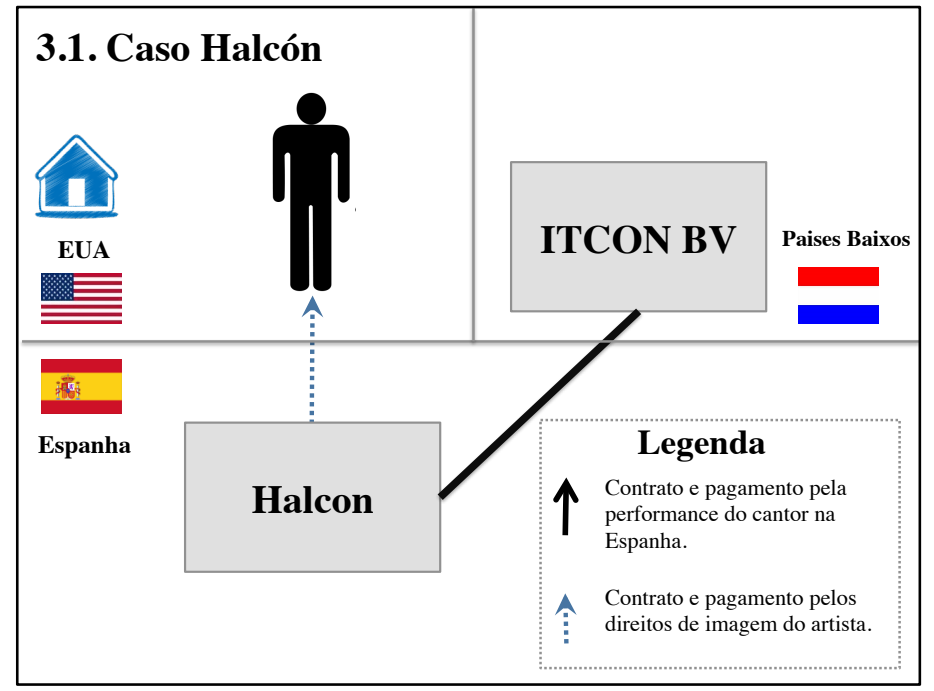


No entanto, após o recolhimento de tais valores, Hálcon requereu a sua devolução alegando que, conforme o art. 7 da convenção fiscal, os rendimentos da ITCON somente poderiam ser tributados nos Países Baixos. As autoridades fiscais, no entanto, discordaram da qualificação empreendida pelo contribuinte e compreenderam que tais pagamentos estariam compreendidos no escopo do art. 18 do Tratado Espanha-Países Baixos (correspondente ao art. 17 da CM-OCDE), sujeitos, então, à retenção fiscal ainda mais gravosa, de $24 \%$.

O Tribunal Supremo considerou que os valores pagos à ITCON estariam sob o escopo do artigo 18 do Tratado Espanha-Países Baixos, tendo em vista a estreita ligação entre os direitos de imagem explorados por essa star company e a própria atividade desempenhada pelo cantor, conhecido mundialmente. $\mathrm{O}$ tribunal considerou presente a norma do parágrafo $2^{\circ}$ do art. 17 da $\mathrm{CM}$ - OCDE, ainda que aquele dispositivo não constasse expressamente no acordo.

Entre as evidências utilizadas pelo tribunal para a interpretação do acordo, destacam-se: comparação de diferentes dispositivos do acordo; outros acordos de bitributação (parallel treaties); Direito doméstico, considerado de forma dinâmica; Comentários à CM-OCDE, considerados de forma dinâmica.

\section{2. "Caso U2"}

Espanha. Tribunal Supremo. Sala de lo Contencioso. Stage Enterteinment S.L. vs. Administración General del Estado. Julgamento de 07/12/2012. Fatos em discussão ocorridos 1997. Acordo de dupla tributação Espanha-Irlanda, celebrado em 1994.

“Stage Enterteinment S.L.”, empresa espanhola, promotora de eventos, contratou a banda irlandesa U2 para a realização de dois shows no ano de 1997, em Madri e em Barcelona. Para a contratação da banda, foram assinados oito contratos com três diferentes empresas: (i) Eventcorp Ltd, à qual, de modo geral, competiria fornecer a performance da banda U2, (ii) Remond Ltd, responsável pelo fornecimento dos equipamentos utilizados nos espetáculos, como som, iluminação, decoração etc.; (iii) Brenwel Ltd., à qual caberia a atividade de gerenciamento e consultoria para os shows. 
O quadro a seguir ilustra o caso:

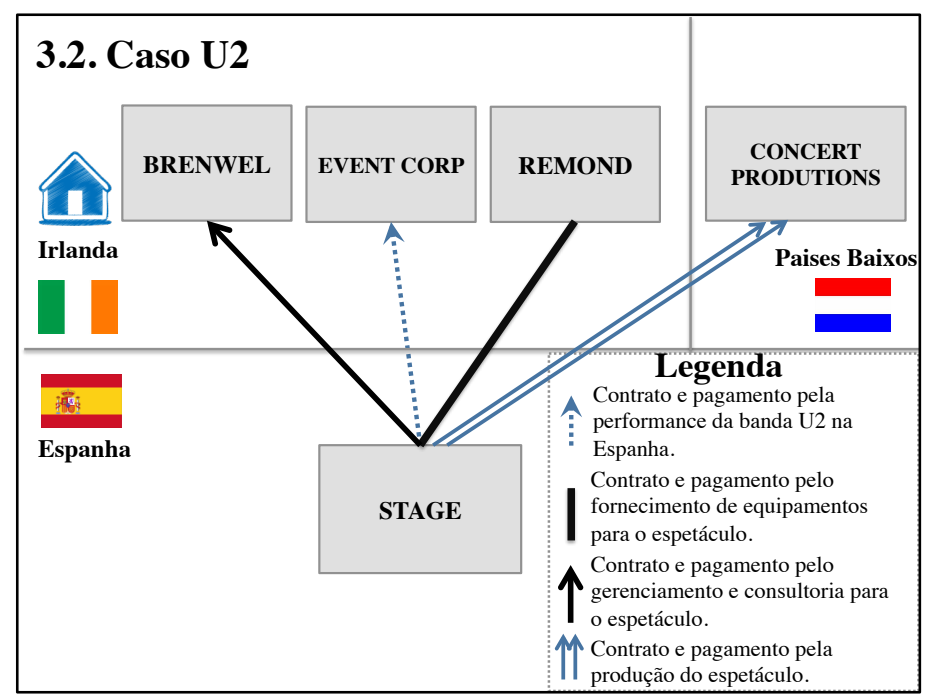

Em razão dos pagamentos contratados, a empresa espanhola promotora dos eventos apenas realizou a retenção do imposto de renda espanhol, à alíquota de $24 \%$, em relação à Eventcorp, já que os rendimentos de Remond e Brenwel, conforme o art. $7^{\circ}$ do Tratado Espanha-Irlanda, somente seriam tributáveis nesse último Estado.

Em 2001, contudo, as autoridades fiscais espanholas autuaram a empresa promotora dos eventos, sob a justificativa de que todos os pagamentos realizados a tais empresas, da mesma forma que aqueles realizados à Eventcorp, também estariam no escopo do art. 17 do Tratado Espanha-Irlanda, tendo em vista a conexão com o espetáculo. O promotor de eventos espanhol, então, refutou a autuação, destacando que os serviços prestados por Remond e Brenwel, embora relacionados com o show da banda U2, não se misturavam com os serviços prestados por esta e não estariam abrangidos pelo escopo desse dispositivo, e sim no art. 7 da Convenção. Além disso, o promotor de eventos sustentou que, tratando-se o parágrafo $2^{\circ}$ do art. 17 de uma norma de combate ao planejamento tributário abusivo, seria necessário ao Fisco espanhol demonstrar o abuso em questão, na mesma linha dos Comentários da OCDE à Convenção Modelo de 1977.

O Tribunal Supremo, revertendo a anterior decisão da Audiencia Nacional, decidiu que todos os pagamentos em questão estariam sob o escopo do art. 17 (2) do acordo Espanha-Irlanda, de forma que poderiam ser tributados pelo fisco espanhol. 
Entre as evidências utilizadas pelo tribunal para a interpretação do acordo, destacam-se: elementos textuais; outros acordos de bitributação (parallel treaties); CMOCDE e os seus respectivos Comentários.

\section{3. "Caso Barcelona".}

Espanha. Audiencia Nacional, Sala de lo Contencioso-Administrativo. Orotava Rocky Stone Media vs. Administración General del Estado. Julgamento de 26.09.2013. Fatos em discussão ocorridos entre 2004 e 2007. Acordo de dupla tributação Espanha-Países Baixos celebrado em 1971.

O Fútbol Club Barcelona e a Televisió de Catalunya, ambas residentes na Espanha, realizaram pagamentos à Orotava Rocky Stone Media, residente nos Países Baixos, em função de contratos para cessão de direitos de imagens de diversos jogadores. Foi realizada retenção de impostos ao Governo espanhol a título de "cánones" (“royalties”).

O quadro a seguir ilustra o caso:

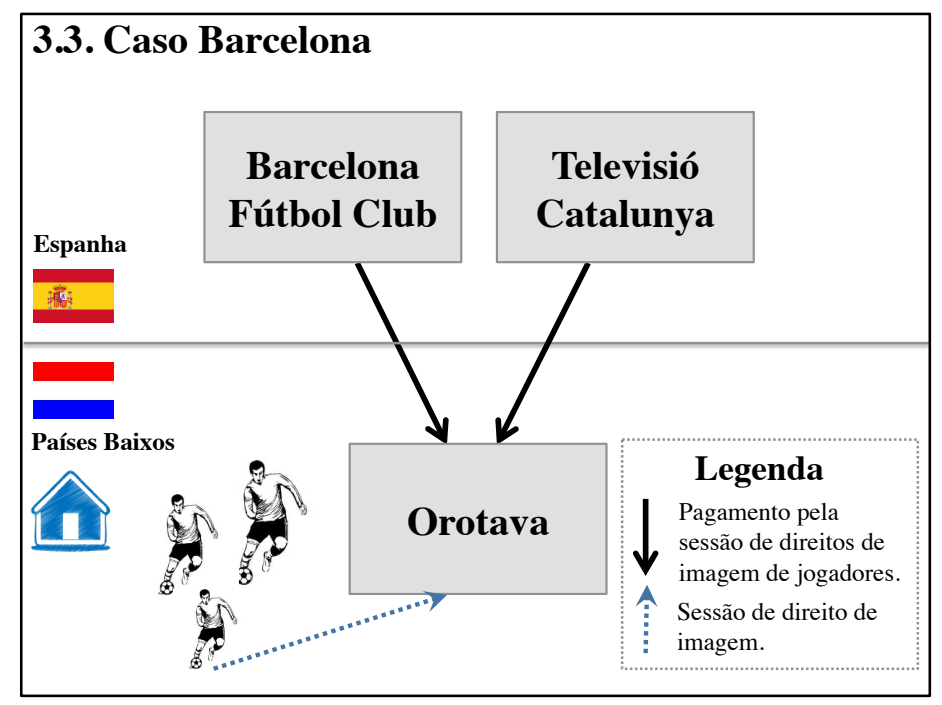

Após as referidas retenções, o tribunal espanhol havia decidido que os pagamentos de direitos de imagens realizados pelo Barcelona não se sujeitariam à retenção de imposto de renda, pois não estariam sob o escopo do termo “cánones” (“royalties”). Seria aplicável o art. 7 da convenção fiscal Espanha-Países baixos (equivalente à CM-OCDE), de forma que apenas seria possível a tributação pelo outro Estado.

Diante de tal decisão, a empresa Orotava requereu a restituição de impostos 
anteriormente retidos por aquele time de futebol, o que foi indeferido pelo fisco espanhol.

Ao analisar o caso, o tribunal espanhol também rejeitou tal pedido de restituição, sob o fundamento de que, desde a edição da Ley 46/2002, que teria reformulado parcialmente o imposto de renda espanhol, o conceito de "cánones" ("royalties") teria sido alterado, de forma a incluir pagamentos pela cessão de direitos de imagem.

$\mathrm{O}$ art. 3 (2) do acordo de dupla tributação Espanha-Países Baixos representaria, conforme a fundamentação apresentada pelo juiz FRANCISCO JOSE NAVARRO SANCHIS, um chamado para que o sistema jurídico espanhol estabelecesse o conceito de "cánones" (“royalties”). A Ley 46/2002, por sua vez, deveria ser compreendida como a interpretação autêntica do legislador espanhol e "integrada” ao art. 12 do acordo Espanha-Países Baixos, o qual deveria "interpretarse rectamente conforme a las definiciones legales contenidas en la legislación interna del Estado contratante (art. 3.2 del Convenio)”.

Entre as evidências utilizadas pelo tribunal para a interpretação do acordo, destacam-se: Direito doméstico, considerado de forma dinâmica; Comentários à CMOCDE, considerados de forma dinâmica.

\section{4. "Caso Televisió de Catalunya".}

Espanha. Supremo Tribunal, Sala de lo Contencioso. Televisió de Catalunya, S.A vs. Administración General del Estado. Julgamento de 13/04/2011. Fatos em discussão ocorridos 1999. Acordo de dupla tributação Espanha-Países Baixos, celebrado em 1971.

Televisió de Catalunya, uma emissora espanhola, teria realizado diversos pagamentos a empresas residentes nos Países Baixos pela utilização de direitos de imagens cedidos por elas. Considerou-se aplicável o art. 12 do acordo Espanha-Países Baixos, de forma que seria devida a retenção do imposto espanhol a título de royalties. 
O quadro a seguir ilustra o caso:

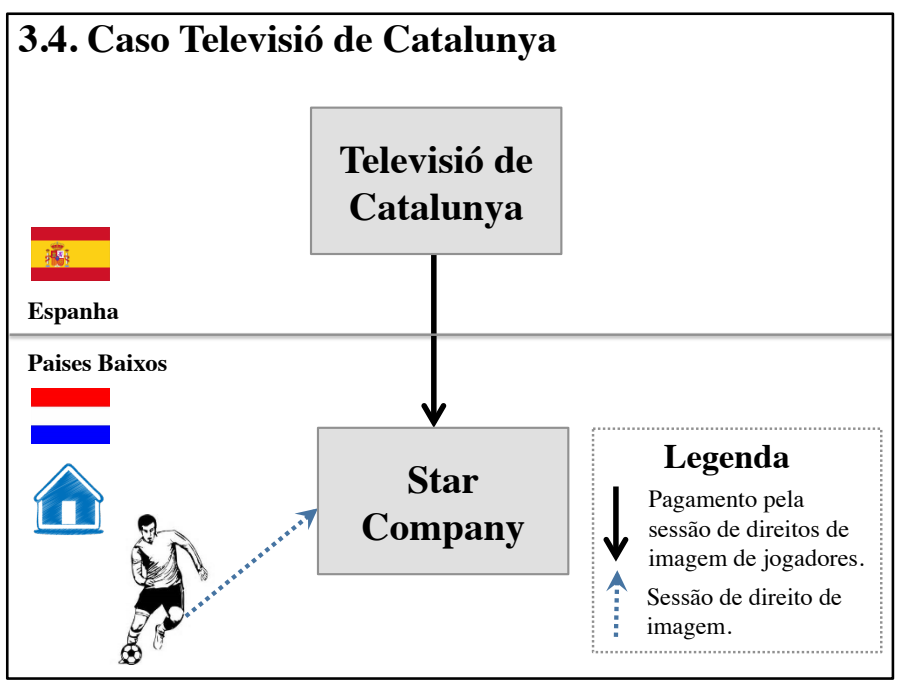

No entanto, após o recolhimento de tais valores, Televisió de Catalunya requereu a sua devolução, a justificativa de que, conforme o art. 7 da convenção fiscal, os rendimentos em questão somente poderiam ser tributados nos Países Baixos.

A Suprema Corte julgou que a retenção do imposto espanhol seria realmente devida, não sob o escopo do art. 12 (royalties), mas sim do art. 18 (artistas e esportistas) do Tratado Espanha-Países Baixos.

Entre as evidências utilizadas pelo tribunal para a interpretação do acordo, destacam-se: comparação de diferentes dispositivos do acordo; outros acordos de bitributação (parallel treaties); Direito doméstico, considerado de forma dinâmica; Comentários à CM-OCDE, considerados de forma dinâmica. 


\section{ESTADOS UNIDOS DA AMÉRICA (EUA)}

\section{1. "Caso Maximov".}

Estados Unidos da América. Suprema Corte. Andre Maximov v. United States. Julgamento de 29.04.1963. Fatos em discussão ocorridos nos anos de 1954 e 1955. Acordo de dupla tributação EUA-Reino Unido de 1945.

O Sr. "Maximov", residente do Reino Unido, constituiu um trust nos EUA, estabelecendo que benefícios deste se voltariam para si e, após a sua morte, aos seus familiares. $\mathrm{O}$ administrador do trust também seria residente nos EUA.

O trust realizou ganhos de capital na venda de alguns dos seus ativos entre os anos de 1954 e 1955, os quais não foram foram distribuídos. Tais ganhos de capital foram declarados aos EUA como parte da renda do trust, com o recolhimento de imposto de renda.

O quadro a seguir ilustra o caso:

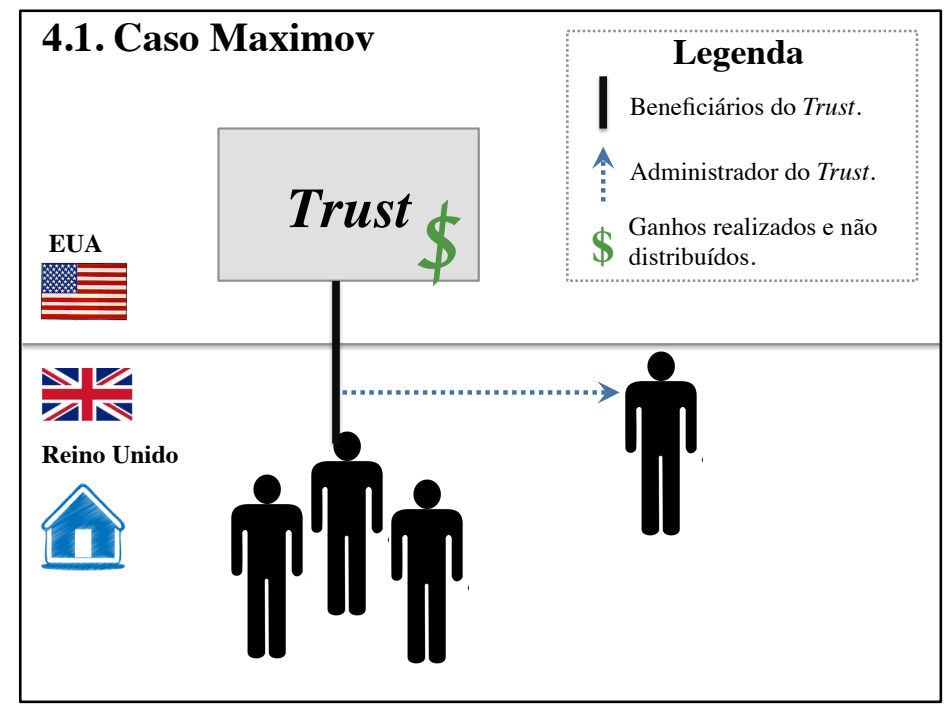

Após o recolhimento de impostos sobre os referidos ganhos de capital, foi requerida a sua restituição, com base no acordo de bitributação Reino Unido-EUA. 
$\mathrm{O}$ art. 14 do acordo EUA-Reino Unido previa que:

"A resident of the United Kingdom not engaged in trade or business in the United States shall be exempt from United States tax on gains from the sale or exchange of capital assets."

O art. II (1) (g) do acordo, por sua vez, definiu "resident" como "any person (other than a citizen of the United States or a United States corporation) who is resident in the United Kingdom for the purposes of the United Kingdom tax and not resident in the United States for purposes of the United States tax".

A questão girou em torno do conceito do termo "person", não definido no texto do acordo: os juízes foram provocados a julgar se o trust estaria compreendido no sentido de tal termo. Decidiu, então, que seria irrelevante a residência do Sr. Maximov ou dos demais beneficiários, considerando o trust, constituído sob as leis norte-americanas, "person" para fins da convenção fiscal.

Julgou-se, então, que a tributação nos EUA seria legítima e não contrariaria o acordo de bitributação, inclusive porque não haveria, de fato, tributação no outro Estado contratantes, o que afastaria o risco da dupla tributação a que o acordo se propunha a combater.

Entre as evidências utilizadas pelo tribunal para a interpretação do acordo, destacam-se: preâmbulo do acordo, para a identificação de seus objetivos e propósitos; sistema jurídico dos Estados contratantes; outros acordos de bitributação (parallel treaties); atos unilaterais da administração fiscal; testemunho dos negociadores; circunstâncias em que o foi celebrado (embora não esteja claro quais seriam elas). 


\section{2. "Caso Johansson".}

EUA. Court of Appeals, Fifth Circuit. Johansson v. United States. Julgamento de 02/09/1964. Fatos em discussão ocorridos entre 1960 e 1961. Acordo de dupla tributação EUA-Suiça celebrado em 1951.

O Sr. Jens Ingemar Johansson, famoso boxeador suéco campeão dos pesos pesados, competiu e recebeu prêmios por três lutas ocorridas nos EUA, entre 1960 e 1961.

O quadro a seguir ilustra o caso:

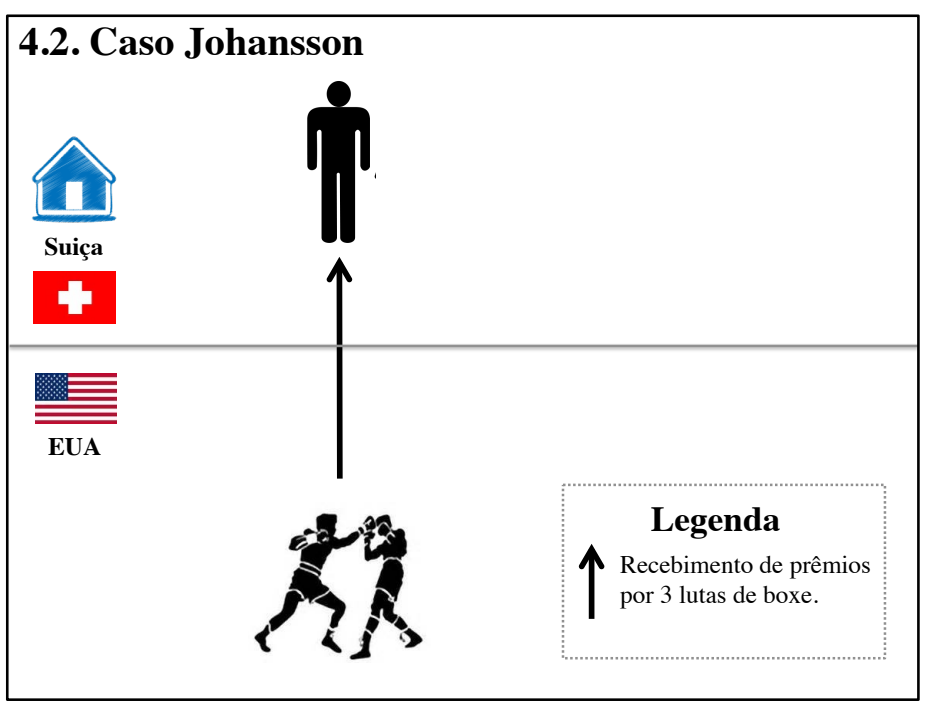

Para evitar o recolhimentos de impostos aos EUA, o boxeador reclamou a aplicação do art. 10 (1) do acordo de dupla tributação EUA-Suíça, de 1951 (até certo ponto equivalente ao art. 15 da CM-OCDE):

"Article X. 1.An individual resident of Switzerland shall be exempt from United States tax upon compensation for labor or personal services performed in the United States (including the practice of the liberal professions and rendition of services as director) if he is temporarily present in the United States for a period or periods not exceeding a total of 183 days during the taxable year and either of the following conditions is met:

(a) his compensation is received for such labor or personal services performed as an employee of, or under contract with, a resident or corporation or other entity of Switzerland, or

(b) his compensation received for such labor or personal services does not exceed \$10.000." (grifamos) 
O fisco norte-americano, contudo, recusou a aplicação dos benefícios EUA-Suíça a Johansson. Embora não houvesse dúvidas que o boxeador não havia permanecido nos EUA por período inferior a 183 dias, as autoridades fiscais contestavam: i) que Johansson fosse residente suíço; ii) a substância econômica da empresa "Scanart", residente na Suíça, da qual Johansson era sócio e pela qual desempenhou as atividades relacionadas às remunerações recebidas de fontes norte-americanas.

Em especial, para a solução daquela primeira questão, foi necessário ao Tribunal norte-americano interpretar o termo "resident", presente no início do art. 10 (2) do acordo EUA-Suíça, mas não definido expressamente naquele acordo, o qual não continha cláusula semelhante ao art. 4 da CM-OCDE. Note-se, contudo, que aquela convenção fiscal de 1951 já possuía cláusula semelhante ao art. 3 (2) da CM-OCDE:

\footnotetext{
"Art. 2 (2). In the application of the provisions of the present Convention by one of the contracting States any term not otherwise defined shall, unless the context otherwise requires, have the meaning which such term has under its own tax laws".
}

Conforme os argumentos de Johansson, diante deste art. 2 (2), a atribuição da condição de "residente" suíço caberia à legislação suíça e, a fim de cumprir com tal condição, o boxeador apresentou ao julgador um certificado de residência fornecido pelas autoridades fiscais suíças.

O tribunal norte-americano acolheu a mensagem do Caso Maximov para que não se examinasse apenas a linguagem dos acordos de dupla tributação, mas todo o seu contexto. Compreendeu o Juiz RIVES, acompanhado de seus pares, que seria necessário considerar o objetivo e propósito do acordo de eliminar os impedimentos ao comércio internacional criados pela dupla tributação da renda em, estabelecendo-se, para tanto, padrões para a mais apropriada alocação da tributação em cada transação envolvendo os dois países contratantes. Entre tais padrões, deveria ser observado que os serviços seriam tributados no Estado em que são prestados, admitindo-se exceções como às do art. 10 (equivalente ao art. 15 da CM-OCDE). O referido art. 10 seria uma "commercial traveler provision", vocacionada a assegurar que empresas de ambos os Estados contratantes possam enviar seus empregados e agentes ao outro Estado sem, contudo, sujeita-los à tributação neste. Quando as condições para a aplicação desta exceção não estivessem presentes, deveria ser 
aplicada a regra geral, tributando-se da renda no Estado em que os respectivos serviços houverem sido prestados.

O tribunal julgou, então, que aquele boxeador não poderia ser compreendido como residente suíço para os propósitos do art. 10 em questão. O fato de seu centro de interesses sociais e econômicos se localizar na Suécia foi decisivo para excluir a residência suíça.

Entre as evidências utilizadas pelo tribunal para a interpretação do acordo, destacam-se: os objetivos e propósitos da convenção e de seus dispositivos; atos da administração fiscal do outro Estado contratante.

\section{3. "Caso Great-West".}

Estados Unidos da América. Court of Claims. The Great-West Life Assurance Company v. EUA. Julgamento de 05.05.1982. Fatos em discussão ocorridos nos anos de 1967 a 1969. Acordo de dupla tributação EUA-Canadá celebrado em 1942, com as alterações do protocolo de 1951.

Great-West Life Assurance Company, uma empresa de seguros de vida incorporada e residente no Canadá, possuia licença para operar em diversos Estados dos EUA. Em função de regulamentos norte-americanos, Great-West deveria reservar parcela de seus ativos em um trust constituído nos EUA. Para cumprir tal exigência, o referido trust foi constituído basicamente com diversos títulos de origem canadense, muitos deles públicos. O quadro a seguir ilustra o caso:

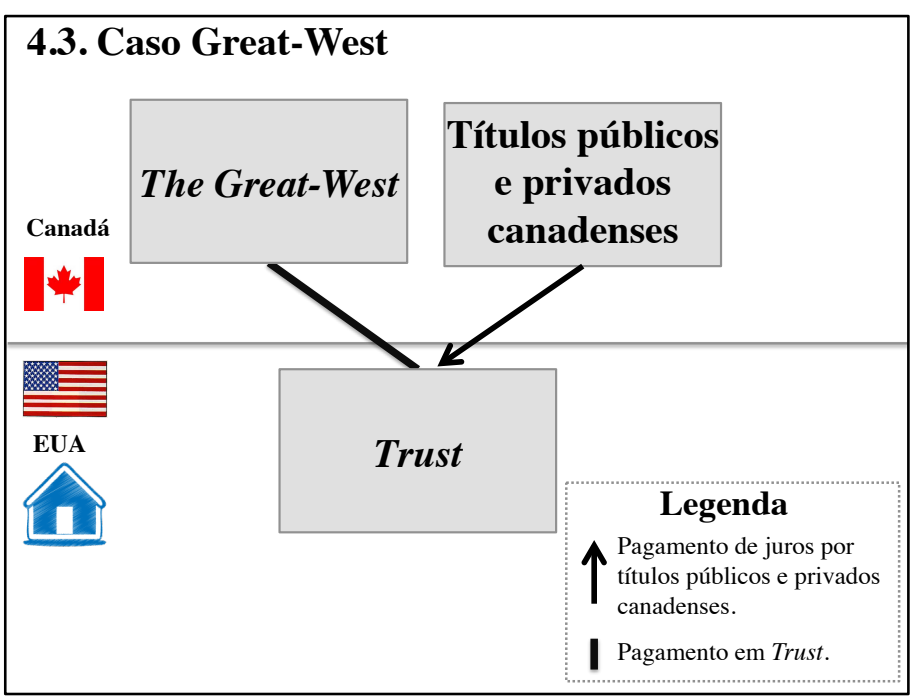


Conforme a legislação norte-americana da época, companhias estrangeiras de seguro de vida seriam tributáveis nos EUA em relação a todos os redimentos "effectively connected" com tais atividades. Inicialmente, Great-West submeteu os juros obtidos pelo trust à tributação dos EUA, considerando que estariam efetivamente conectados ("effectively connected") com a sua atividade de seguradora, como "gross investment income".

No entanto, após realizar o recolhimento de tais tributos, Great-West concluiu que não seriam devidos, por força do art. 12 do acordo EUA-Canadá:

"Dividends and interest paid by a corporation organized under the laws of Canada to a recipient, other than a citizen or resident of the United States of America or a corporation organized under the laws of the United States of America, shall be exempt from all income taxes imposed by the United States of America.

Dividends and interest paid by a corporation organized under the laws of the United States of America whose business is not managed and controlled in Canada to a recipient, other than a resident of Canada or a corporation whose business is managed and controlled in Canada, shall be exempt from all taxes imposed by Canada".

Nesse seguir, Great-West requereu a devolução dos valores pagos, alegando, em especial, que os termos "exempt from all income taxes" possuiria um sentido bastante amplo, conduzindo à isenção completa dos juros pagos por fontes canadenses pagas para sujeitos não descritos naquele dispositivo. Assim, juros pagos a empresas presentes nos EUA por fontes canadenses não estariam sujeitos a quaisquer impostos norte-americanos:

\footnotetext{
"Plaintiff continues, though, that Article XII had other purposes as well. It was to reflect all such purposes, plaintiff says, that Article XII's broad operative phrase "exempt from all income taxes" was chosen. The result, plaintiff's argument finishes, is a complete exemption for Canadian corporate interest when paid to persons not described in the Article. Under plaintiff's view, whether the interest was paid to a corporation not present in the United States and whether the interest would be subject to a United States tax solely through the deeming provisions is therefore irrelevant. Although the language of Article XII could be read as broadly as plaintiff suggests, we are compelled to a more restricted reading".
}

O tribunal, contudo, recusou o pedido do contribuinte. Os juízes consideraram que, embora os literais requerimentos do art. 12 do acordo internacional tivessem sido 
preenchidos, seria necessário interpretá-los conforme a intenção dos Estados contratantes, à qual não seria isentar empresas canadenses com presença nos EUA

Entre as evidências utilizadas pelo tribunal para a interpretação do acordo, destacam-se: comparação de diferentes dispositivos do acordo; atos legislativos subsequentes à celebração do acordo; outros acordos de bitributação (parallel treaties); materiais unilaterais, como registros do processo legislativo.

\section{4. "Caso Stuart".}

Estados Unidos da América. Suprema Corte. United States v. Philip Stuart Julgamento de 28.02.1989. Fatos em discussão ocorridos entre os anos de 1980 e 1982. Acordo de dupla tributação EUA-Canadá celebrado em 1942.

O Sr. "Stuart" era residente no Canadá e mantinha contas bancárias nos EUA. Em face um procedimemto de investigação criminal, as autoridades fiscais canadenses requisitaram informações a respeito de tais contas bancárias às autoridades fiscais norteamericanas, com fundamento no 19 e 21 da convenção fiscal EUA-Canadá (equivalentes ao art. 26 da CM-OCDE).

A fim de obstar o fornecimento de tais informações às autoridades fiscais canadenses, o Sr. Stuart ajuizou ação judicial nos EUA, valendo-se do argumento de que as autoridades fiscais norte-americanas apenas poderiam fornecer informações às quais elas próprias estivessem legitimadas a obter conforme a legislação norte-americana. Ocorre que, como havia uma investigação criminal em andamento no Canadá, as autoridades fiscais estariam impedidas de acessar tais informações, tendo em vista que, em caso de persecução criminal nos EUA, tal agência governamental sairia de cena.

Em situações puramente domésticas, sob o precedente United States v. Powell, caberia às autoridades fiscais demonstrar que as investigações seriam conduzidas por propósitos legítimos, que tais informações seriam relevantes e, ainda, que ainda não teriam sido obtidas, bem como que todos os estágios requeridos pela legislação norte-americana teriam sido observados, em especial que a autoridade fiscal ("Secretary or his delegate"), após examinar o caso, tenha concluído como relevante a obtenção de tais informações e 
notificado o contribuinte a esse respeito. Ainda sob o contexto doméstico norte-americano, um procedimento que observasse todos esses requisitos apenas poderia ser impugnado pelo contribuinte, caso este demonstrasse abuso por parte da autoridade fiscal. Tal abuso se daria a evidência de propósitos espúrios, como para pressioná-lo em relação a disputas paralelas ou qualquer outra razão que não reflita a boa-fé da investigação em questão. A Corte compreendeu que, no caso, os requisitos exigidos no precedente caso United States v. Powell para o acesso às informações estariam cumpridos.

A decisão do Caso Stuart foi unânime quanto à autorização para a obtenção e transmissão das informações, mas não quanto aos materiais que deveriam ser consultados para chegar a essa conclusão. Destacaram-se nesse sentido os votos dos juízes BRENNAN e SCALIA.

Entre as evidências utilizadas pelo tribunal para a interpretação do acordo, destacam-se: elementos textuais; práticas subsequentes a um acordo de dupla tributação, em especial a sua aplicação por parte das autoridades físcais; outros acordos de bitributação (parallel treaties); Direito doméstico do outro Estado contratante e de terceiros Estados.

\section{MÉXICO}

\section{1. "Caso Intercontinental".}

México. Tribunal Fiscal de la Federación. Operadora y Controladora Intercontinental, S.A. vs. Administración Especial de Recaudación de la SHCP. Julgamento de 24/02/1998. Fatos em discussão ocorridos entre 1994 e 1995. Acordo de dupla tributação MéxicoReino Unido, celebrado em 1994.

"Intercontinental”, pessoa jurídica residente no México, possuía uma linha de crédito com “ $U D P$ ”, pessoa jurídica residente na Inglaterra. Os juros de tais empréstimos deveriam ser pagos à Guinness (“collecting agent”), também residente na Inglaterra.

O quadro a seguir ilustra o caso: 


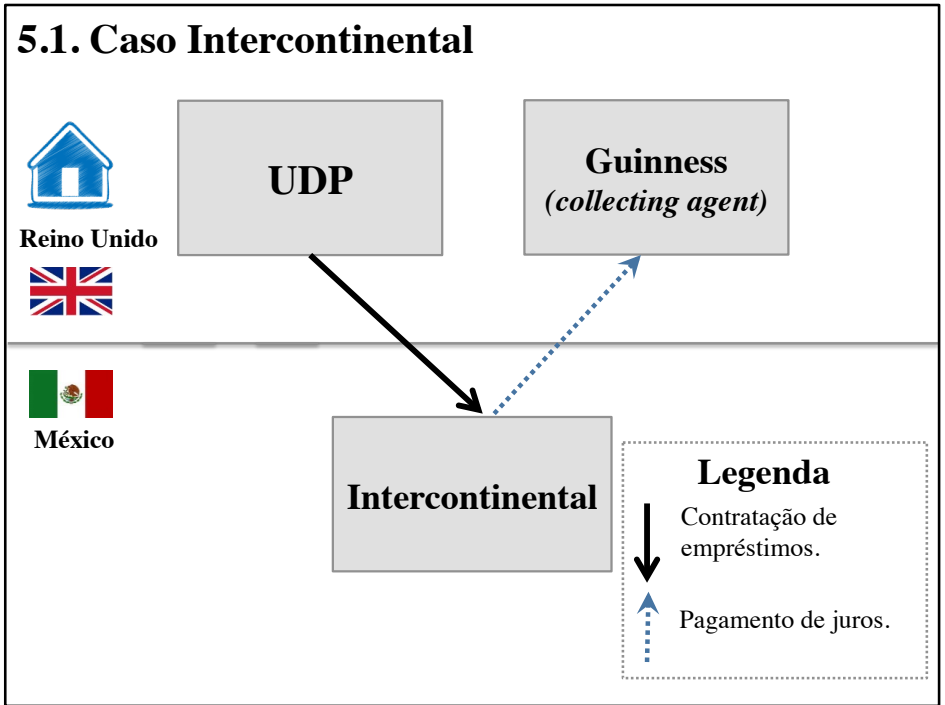

Ao realizar o pagamento de tais juros à Guinness, Intercontinental realizou a retenção do imposto de renda mexicano equivalente a 35\% dos valores remetidos. No entanto, após o recolhimento destes, foi requerida a sua devolução, sob a justificativa de que, conforme o art. 11 (2) da convenção fiscal (equivalente à CM-OCDE), o México apenas os poderia tributar até o limite de $15 \%$.

As autoridades fiscais mexicanas, no entanto, negaram a restituição de tais valores, sob o argumento de que Guinness não estaria compreendida no conceito de beneficial owner, conforme exigido pela convenção fiscal.

O tribunal mexicano, contudo, compreendeu que Guinness não estaria excluído do conceito de beneficiário efetivo, pois não seria residente de um terceiro Estado. Ocorre que, conforme os Comentários à CM-OCDE, tal instituto procura afastar planejamentos tributários abusivos realizados pela interposição de empresas em terceiros Estados. No caso, contudo, tanto UDP quanto Guinness seriam residentes no Reino Unido, de forma que a interposição desta última não afastaria a aplicação da convenção fiscal.

Entre as evidências utilizadas pelo tribunal para a interpretação do acordo, destacam-se: Direito doméstico; normas produzidas pela administração fiscal; considerado; Comentários à CM-OCDE, considerados vinculantes pela legislação doméstica. 


\section{REINO UNIDO.}

\section{1. "Caso Lord Strathalmond".}

Reino Unido. High Court, London, Chancery Division. Lord Strathalmond $v$. Commissioners of Inland Revenue. Julgamento de 23/06/1972. Fatos em discussão ocorridos nos anos de 1968 a 1969. Acordo de dupla tributação Reino Unido-EUA celebrado em 1945 com as alterações do protocolo de 1966.

"Lord Strathalmond" representou sua esposa na discussão deste caso, à qual era uma cidadã norte-americana que residia no Reino Unido e considerada residente para fins fiscais nesse país. Sua esposa havia recebido dividendos e juros pagos por uma companhia residente nos EUA, os quais foram tributados na fonte.

Lord Strathalmond reclamou a aplicação do art. 15 do acordo Reino Unido-EUA, com a redação que lhe havia sido dada pelo protocolo de 1966:

"Dividends and interest paid by a Corporation of one Contracting Party shall be exempt from tax by the other Contracting Party except where the recipient is a citizen, resident, or corporation of that other Contracting Party. This exemption shall not apply if the corporation paying such dividend or interest is a resident of the other Contracting Party."

Conforme a sua interpretação, os termos "citizen, resident, or corporation of that other Contracting Party" haviam sido expressamente definidos no art. 2 (1) "g" e " $\mathrm{h}$ " daquela convenção fiscal. Em especial, o referido inciso "g" estabelecia que:

'The term 'resident of the United Kingdom' means any person (other than a citizen of the United States or a United States corporation) who is resident in the United Kingdom for the purposes of United Kingdom tax and not resident in the United States for the purposes of United States tax. A corporation is to be regarded as resident in the United Kingdom if its business is managed and controlled in the United Kingdom".

Nesse seguir, como sua esposa era cidadã e, portanto, residente dos EUA para fins fiscais, não seria considerada, para os propósitos específicos da convenção fiscal, "resident of the United Kingdom", bem como também não seria cidadã inglesa ("citizen") ou uma 
companhia ("corporation of that other Contracting Party"), de modo que o art. 15 afastaria a tributação sobre os aludidos juros e dividendos.

O fisco inglês, contudo, sustentou que os termos "citizen, resident, or corporation of that other Contracting Party" não teriam sido definidos expressamente no texto do acordo Reino Unido-EUA, concluindo que, diante do art. 2 (3) daquela convenção (equivamente ao art. 3 (2) da CM-OCDE), deveriam ser compreendidos conforme as definições existentes no Direito doméstico inglês.

Foi necessário ao tribunal, então, decidir se os termos "citizen, resident, or corporation of that other Contracting Party", utilizados no art. 15 do antigo acordo de bitributação Reino Unido-EUA assumiriam o sentido da definição estabelecida no art. 2 (1) "g" e " $\mathrm{h}$ " daquela convenção para os termos "resident of the United Kingdom" e "resident of the United States".

Decidiu-se, então, que os argumentos de Lord Strathalmond estariam corretos, considerando clara a redação da convenção fiscal.

Entre as evidências utilizadas pelo tribunal para a interpretação do acordo, destacam-se: Texto do acordo; acordos de dupla tributação anteriormente celebrados entre os mesmos Estados.

\section{2. "Caso Ostime".}

Reino Unido. House of Lords. Ostime (H M Inspector of Taxes) v. Australian Mutual Provident Society. Julgamento de 16.07.1959. Fatos em discussão ocorridos nos anos de 1947 a 1954. Acordo de dupla tributação Reino Unido-Austrália celebrado em 1946.

Uma companhia de seguros, residente na Austrália, possuía uma filial no Reino Unido. Com base na legislação interna aplicável a esse tipo de atividade, o fisco inglês lhe exigiu o pagamento de imposto de renda calculado a partir de uma fórmula que considerava a totalidade dos fundos mantidos pela companhia e dos prêmios recebidos. 
A companhia, então, contestou a exigência do fisco inglês, sob o argumento de que o art. 3 do acordo Reino Unido-Austrália (equivalente ao art. 7 da CM-OCDE, mas diverso deste) restringiria a tributação ao Estado de residência:

"(2) ...the industrial or commercial profits of an Australian enterprise shall not be subject to United Kingdom tax unless the enterprise is engaged in trade or business in the United Kingdom through a permanent establishment situated therein. If it is so engaged, tax may be imposed on those profits by the United Kingdom, but only on so much of them as is attributable to that permanent establishment".

(3) Where an enterprise of one of the territories is engaged in trade or business in the other territory through a permanent establishment situated therein, there shall be attributed to that permanent establishment the industrial or commercial profits which it might be expected to derive in that other territory if it were an independent enterprise engaged in the same or similar activities and its dealings with the enterprise of which it is a permanent establishment were dealings at arm's length with that enterprise or an independent enterprise; and the profits so attributed shall be deemed to be income derived from sources in that other territory...".

Para a solução do caso, o juiz RADCLIFFE, da House of Lords, consignou que:

"For our purpose it is convenient to note that the language employed in this Agreement is what may be called international tax language and that such categories as 'enterprise', 'industrial or commercial profits' and 'permanent establishment' have no exact counterpart in the taxing code of the United Kingdom".

Decidiu o tribunal, então, que apenas a porção dos lucros atribuíveis às atividades desempenhadas pela filial inglesa da companhia seguradora poderiam ser tributadas naquele país, conforme estabelecido na convenção fiscal.

Entre as evidências utilizadas pelo tribunal para a interpretação do acordo,

destacam-se: Texto do acordo; Direito doméstico; linguagem tributária internacional. 


\section{3. “Caso Exxon”.}

Reino Unido. High Court of Justice (Chancery Division). Exxon Corporation v. Commissioners of Inland Revenue. Julgamento de 01/03/1982. Fatos em discussão ocorridos nos anos de 1972 e 1973. Acordo de dupla tributação Reino Unido-EUA celebrado em 1945, com redação dada por protocolo de 1966.

"Exxon”, uma pessoa jurídica incorporada e residente nos EUA, possuía como subsidiária integral "Esso Holding", também residente nos EUA. Para a legislação doméstica inglesa, contudo, Esso Holding seria igualmente considerada residente no Reino Unido. Em 1973, Esso Holding fez o pagamento de dividendos para Exxon, retendo a 15\% a título de imposto de renda inglês.

Em 1978, contudo, Exxon requereu a restituição do imposto de renda que havia retido, sob o argumento de que seria aplicável a isenção prevista no art. 15 do acordo Reino Unido-EUA (transcrito no Caso Lord Strathalmond acima).

Para as autoridades fiscais, por força do art. 2 (3) da convenção fisscal (equivalente ao art. 3 (2) da CM-OCDE), deveria haver o reenvio ao Direito doméstico do Reino Unido para a interpretação dos termos "resident of the other Contracting Party", de forma a não ser aplicável as definições presentes naquele acordo de bitributação.

Nesse caso, o tribunal julgou que os termos "resident of a Contracting State", presente na segunda sentença do art. 15 da convenção Reino Unido-EUA, não obedeceria à definição estabelecida pelo art. 2, (1) "g" e "h". O juiz GoULDING declarou-se convencido de que, por mais estranho que isso lhe parecesse, palavras semelhantes adotadas na mesma convenção fiscal teriam sentidos diversos.

Entre as evidências utilizadas pelo tribunal para a interpretação do acordo, destacam-se: Texto do acordo; decisões do outro Estado contratante; Direito doméstico dos Estados contratantes. 


\section{4. "Caso Vas".}

Reino Unido. High Court, London, Chancery Division. Vas v. Inland Revenue Commissioners. Julgamento de 08.12.1989. Fatos em discussão ocorridos nos anos de 1981 a 1982. Acordo de dupla tributação Reino Unido-Hungria celebrado em 1977.

O Sr. "Vaz", um professor residente na Hungria, passou três temporadas como "research associate" do Departamento de Engenharia Eletrônica e Elétrica da Universidade de Newcastle (Reino Unido): $21 / 1 / 79$ a $22 / 01 / 81 ; 19 / 02 / 81$ a $28 / 01 / 82$; $30 / 03 / 82$, por mais dois anos.

O quadro a seguir ilustra o caso:

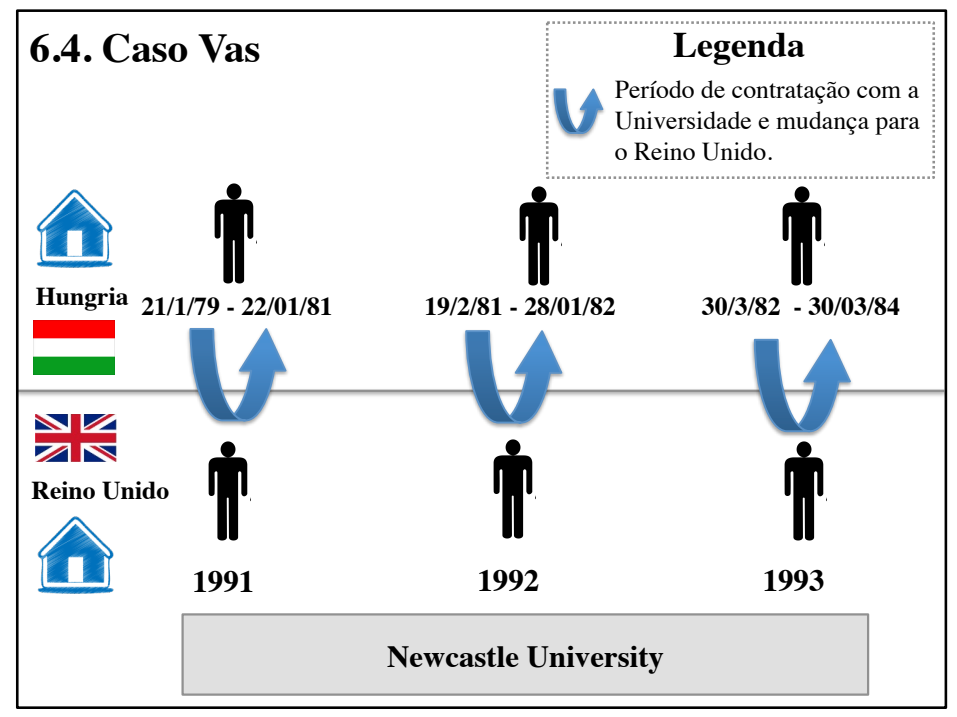

O tribunal inglês precisou analisar se os rendimentos recebidos por Vas e pagos pela Universidade de Newcastle seriam abrangidos pela isenção prevista no acordo Reino Unido-Hungria, para professores e pesquisadores residentes na Hungria, que visitassem a Inglaterra por período não superior a 2 anos.

O fisco inglês sustentou que a contagem de tal prazo começaria a partir da primeira chegada do professor, enquanto que o contribuinte sustentou que tal contagem recomeçaria a cada nova chegada.

O Tribunal inglês decidiu que não teria sido a intenção dos negociadores afastar indefinidamente a tributação inglesa em casos como este, em que o professor deixou a 
Inglaterra e retornou de formas sucessivas (permanecendo pouco tempo na Hungria e retornando em seguida para mais um contrato). Dessa forma, os benefícios do acordo não foram aplicados.

Entre as evidências utilizadas pelo tribunal para a interpretação do acordo, destacam-se: Texto do acordo; outros acordos de bitributação (parallel treaties); Direito doméstico dos Estados contratantes.

\section{5. "Caso Sportsman".}

Reino Unido. Special Commissioners (Edinburgh). Sportsman vs. Commissioners of Inland Revenue. Julgamento de 23/09/1998. Fatos em discussão ocorridos nos anos de 1992 a 1994. Acordo de dupla tributação Reino Unido-França celebrado em 1968.

Um jogador de futebol inglês foi contratado por um time de futebol francês, para as temporadas de 1991, 1992 e 1993. Nessas três temporadas, o jogador deixou a Inglaterra no meio de um ano e retornou no meio do outro, não abandonando a residência inglesa conforme o critério temporal adotado por aquele país.

Por sua vez, sob o Direito francês, o indivíduo que habitasse a França para o desempenho de suas atividades profissionais seria considerado residente fiscal. Os rendimentos daí decorrentes não estariam sujeitos à retenção de imposto de renda pelo empregador. Nos anos de 1992 e 1993, nem o time de futebol realizou a retenção do imposto (porque não teria tal dever) e nem o jogador declarou e recolheu à França impostos sobre os valores recebidos. O quadro a seguir ilustra o caso:

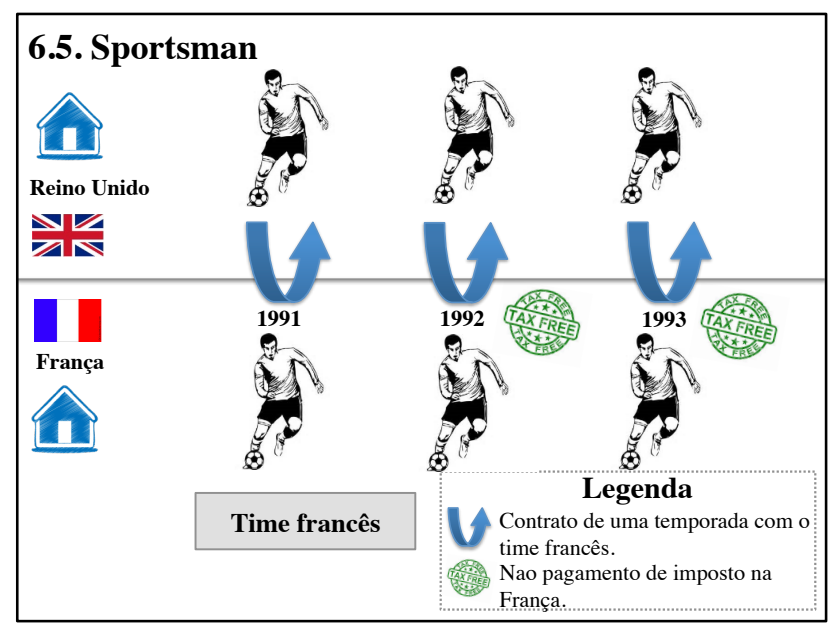


Em relação ao ano de 1991, o fisco inglês reconheceu como crédito, para a compensação com o imposto a ser pago sobre tais rendimentos ao Reino Unido, o imposto recolhido à França, conforme o art. 24 do acordo Reino Unido-França (aquivalente ao art. 23 da CM-OCDE). No entanto, embora o contribuinte tenha requerido a aplicação da mesma regra nos anos de 1992 e 1993, o fisco inglês recusou o aproveitamento de tais créditos, sob o fundamento de que este dependia do efetivo pagamento do imposto à França, o que não teria ocorrido.

Para a solução do litígio, o tribunal inglês precisou interpretar o termo "payable", presente no art. 24 do acordo Reino Unido-França, decidindo que teria o sentido de pago (“paid”). Nesse seguir, não haveria créditos a serem concedidos ao jogador para a compensação com o imposto inglês, pois não teriam sido efetivamente pagos impostos à França.

Entre as evidências utilizadas pelo tribunal para a interpretação do acordo, destacam-se: Texto do acordo, inclusive o seu preâmbulo; jurisprudência doméstica; CMOCDE; dicionários.

\section{6. "Caso Banco do Brasil/Commerzbank".}

Reino Unido. High Court, London, Chancery Division. Inland Revenue Commissioners v. Banco do Brasil SA e Commerzbank AG. Julgamento 09/02/1990. Fatos em discussão ocorridos nos anos de 1973 a 1976. Acordo de dupla tributação Reino Unido-EUA celebrado em 1945 com as alterações do protocolo de 1966.

O "Banco do Brasil", residente no Brasil, e o "Commerzbank", residente na Alemanha, possuíam filiais no Reino Unido, por meio das quais operavam empréstimos a diversas empresas residentes nos EUA, recebendo, então, o pagamento de juros. 
O quadro a seguir ilustra o caso:

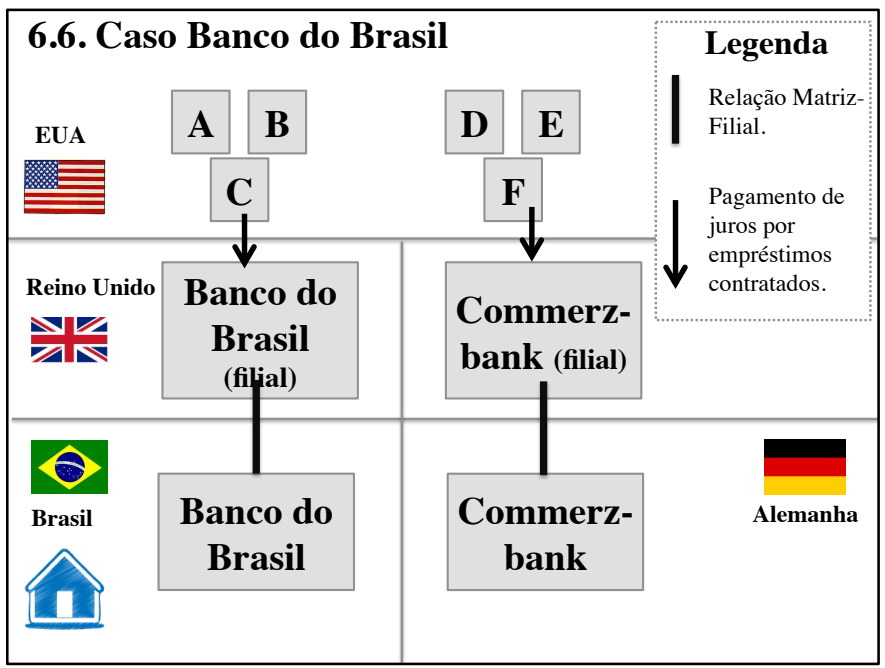

Com base no art. 15 do acordo Reino Unido-EUA (transcrito no Caso Lord Strathalmond acima), Banco do Brasil e o Commerzbank questionaram a cobrança de imposto de renda pelo fisco inglêses. Com seriam residentes ingleses para fins do tratado, estariam isentas de imposto de renda em relação aos juros pagos por empresas norteamericanas.

O fisco britânico, por sua vez, se opôs à concessão dos benefícios do art. 15 do acordo Reino Unido-EUA. Entre os seus argumentos, suscitou-se que o acordo Reino Unido-EUA não possuía em seu texto a cláusula "this Convention shall apply to persons who are residents of one or both of the Contracting States", presente na CM-OCDE de 1977. Como consequência, a convenção fiscal apenas seria aplicável àqueles que não fossem residentes nem dos EUA e nem do Reino Unido.

O tribunal decidiu que o art. 15 do acordo Reino Unido-EUA afastava a tributação inglesa em relação a todos os juros recebidos de fontes norte-americanas, estabelecendo como única exceção a hipóteses de tais pagadores se qualificarem como cidadãos, residentes ou companhias inglesas. A pretenção do fisco inglês, para os julgadores, ampliaria o rol de exceções de uma forma que não havia sido acordada entre ambos os Estados contratantes, o que não se poderia admitir.

Entre as evidências utilizadas pelo tribunal para a interpretação do acordo, destacam-se: Texto do acordo; acordos de dupla tributação anteriormente celebrados 
entre os mesmos Estados; CM-OCDE e os seus Comentários; decisões judiciais do outro Estado contratante.

\section{7. "Caso Squirrell"}

Reino Unido. Peter John Squirrell v. HM Revenue and Customs. Julgamento de 23/06/2005. Fatos em discussão ocorridos em 2000. Acordo de dupla tributação Reino Unido-EUA celebrado em 1975.

O Sr. "Squirrell”, um cidadão inglês, viveu e trabalhou no Reino Unido até outubro de 2000, quando deixou aquele país para viver nos EUA com a sua esposa, uma cidadã norte-americana.

Até próximo de deixar o Reino Unido, Squirrell trabalhou para a companhia aérea British Airways, residente ingles. Naquele ano, contudo, recebeu £92,957.89 a título de aviso prévio ("payment in lieu of notice"), os quais foram tributados na fonte à alíquota de $23 \%$.

Por sua vez, perante o fisco norte-americano, Squirrell elegeu a opção de apresentar declaração de imposto de renda com a sua esposa naquele país, de forma a ser considerado residente nos EUA para fins fiscais em relação a todo o ano de 2000.

O quadro a seguir ilustra o caso:

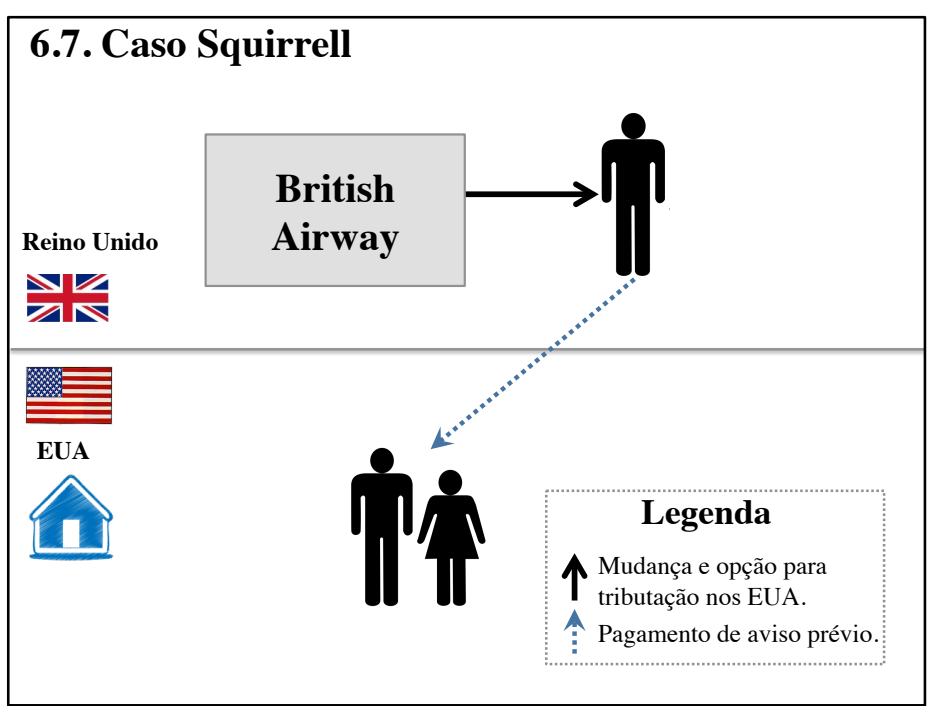


O tribunal inglês concluiu que, como os termos "salaries, wages and other remuneration" referidos no art. 15 do acordo Reino Unido-EUA não haviam sido definidos em seu texto, deveriam ser compreendidos conforme o Direito inglês. Embora não tenha apresentado maiores justificativas, o julgador indicou que o "contexto" não ajudaria na solução do caso. Julgou-se, então, que o Reino Unido poderia tributar tais rendimentos, restando ao contrinbuinte o opção de requerer crédito aos EUA.

\section{Entre as evidências utilizadas pelo tribunal para a interpretação do acordo,} destacam-se: Texto do acordo; Direito doméstico (inglês).

\section{8. "Caso Tomislav".}

Reino Unido. First-tier Tribunal (Tax Chamber). Tomislav Kljun v. Commissioners for Her Majesty's Revenue and Customs. 03/06/2011. Fatos em discussão ocorridos de 2006 a 2009. Acordo de dupla tributação Reino Unido-Croácia (Iugoslávia) celebrado em 1981.

Em breve resumo do caso, que envolve uma série de detalhes, o Sr. "Tomislav" (contribuinte), residente na Croácia, foi contratado como empregado da empresa "BCL", incorporada em Chipre, para a prestação de serviços à empresa "VOSL", residente no Reino Unido. Em especial, Tomislav seria o engenheiro chefe a bordo de embarcações da indústria de óleo e gás que transitariam apenas dentro do território marinho do Reino Unido.

Após receber os seus rendimentos com a retenção de imposto de renda supostamente devido ao Reino Unido, o Sr. Tomislav requereu a restituição deste montante, sob o argumento de que os seus rendimentos apenas poderiam ser tributados em seu Estado de residência (Croácia), com base no art. 15 (2) do acordo de dupla tributação Reino Unido-Croácia: 
"Article 15 - Dependent personal services

1. Subject to the provisions of Articles 16, 17, 18, 19 and 20 salaries, wages and other similar remuneration derived by a resident of a Contracting State in respect of an employment shall be taxable only in that State unless the employment is exercised in the other Contracting State. If the employment is so exercised, such remuneration as is derived therefrom may be taxed in that other State.

2. Notwithstanding the provisions of paragraph 1 of this Article, remuneration derived by a resident of a Contracting State in respect of an employment exercised in the other Contracting State shall be taxable only in the first-mentioned State if:

(a) the recipient is present in the other State for a period or periods not exceeding in the aggregate 183 days in the fiscal year concerned; and

(b) the remuneration is paid by, or on behalf of, a person to whom, or for whose benefit, the relevant dependent personal services are rendered and who is not a resident of the other State;

(c) the remuneration is not borne by a permanent establishment or a fixed base which the person to whom, or for whose benefit, the relevant dependent personal services are rendered has in that other State". (grifamos)

Conforme os argumentos do Sr. Tomislav, o benefício da isenção deveria ser concedido e o imposto pago ao Reino Unido restituído, pois todos os requisitos previstos no teste no art. 15 (2) teriam sido cumpridas: o contribuinte beneficiário dos rendimentos não teria permanecido no Reino Unido por um período ou períodos que excedessem 183 dias do ano físcal em questão; as remunerações foram pagas por um empregador ou em nome de um empregador não residente do Reino Unido, qual seja, BCL; o encargo das remunerações não couberam a um estabelecimento permanente de BCL no Reino Unido.

As autoridades fiscais britânicas, por sua vez, compreenderam que a relação de emprego seria mantida entre o Sr. Tomislav e VOSL (residente no Reino Unido), mas não com BCL (não residente no Reino Unido). Sob tal pressuposto, recusou-se a concessão do benefício da isenção ao contribuinte, já que o requisito previsto pelo art. 15 (2) do acordo de dupla tributação Reino Unido-Croácia não teria sido cumprido.

Cumpria ao Tribunal, então, julgar o caso e, atribuir sentido a termos não definidos naquele acordo internacional, como "person" e "exercised", atribuindo razão às autoridades fiscais. 
Entre as evidências utilizadas pelo tribunal para a interpretação do acordo, destacam-se: Texto do acordo, inclusive o seu preâmbulo; CM-OCDE e os seus respectivos comentários. 


\section{REFERÊNCIAS BIBLIOGRÁFICAS}

AMARAL JÚNIOR, Alberto do. Curso de Direito Internacional Público. Atlas : São Paulo, 2013

ANDRADE, José Maria Arruda de. Interpretação da norma tributária. São Paulo: MP Editora, 2006.

ARNOLD, J. Brian. The interpretation of tax treaties: myth or reality, in Bulletin for International Taxation (tax treaty monitor) - january of 2010. IBFD : Amsterdã, 2010, p. $2-11$.

AVERY JONES, John et al., The interpretation of tax treaties with particular reference to article 3(2) of the OECD Model - I. British Tax Review,1984

, The interpretation of tax treaties with particular reference to article 3(2) of the OECD Model - II. British Tax Review, 1984.

AVERY JONES, John F; BROE, Luc De, ELLIS, Maarten J.; RAAD, and Kees van; GALL, Jean-Pierre Le; TORRIONE, Henri, MIYATAKE, Toshio; ROBERTS, Sidney I.; GOLDBERG, Sanford H.; KILLIUS, Jürgen; MAISTO, Guglielmo; GIULIANI, Federico; VANN, Richard J., WARD, David A.; WIMAN, Bertil . Treaty Conflicts in Categorizing Income as Business Profits Caused by Differences in Approach between Common Law and Civil Law, in Bulletin for International Taxation vol. 57, n. 6. Amsterdã : IBFD, 2013.

AVERY JONES, John F; LÜDICKE, Jürgen. The Origins of Article 5(5) and 5(6) of the OECD Model, in World Tax Journal v. 6, n. 3. Amsterdam: IBFD, 2014. 
. The Definitions of Dividends and Interest in the OECD Model: Something Lost in Translation?, in World Tax Journal v.1, n. 1. Amsterdam: IBFD, 2009.

AVERY JONES, John F. Avoiding Double Taxation: Credit versus Exemption - The Origins, in Bulletin for International Taxation v.66, n. 2. Amsterdam: IBFD, 2012.

. The "one true meaning" of a Tax Treaty, in 55 Bulletin for International Fiscal Documentation - Tax Treaty Monitor - Junho 2001. IBFD : Amsterdã, p. 220-224 . 2008 OECD Model: place of effective management - what one can learn from the history, in Bulletin for International Taxation v. 63, n. 5. Amsterdam: IBFD, 2009.

AVI-YONAH, Reuven. International Tax as International Law - an analysis of the international tax regime. New York, Cambridge University Press, 2007.

BAISTROCCHI, Eduardo A., The Use and Interpretation of Tax Treaties in the Emerging World: Theory and Implications. British Tax Review n. 4. Londres : Thomson, 2008.

BAKER, Philip. A tributação internacional no século XXI. Direito tributário atual n. 19. São Paulo : IBDT/Dialética, 2005, p. 41-51.

. Double taxation conventions and international tax law. Londres : Sweet \& Maxwell, 1994.

BARRETO, Paulo Ayres. Imposto sobre a renda e preços de transferência. São Paulo : Dialética, 2001. 
BEDERMAN, David. The Spirit of International Law. The University of Georgia Press : Athens, Georgia : 2002.

BELLAN, Daniel Vitor. Direito tributário internacional. Rendimentos de pessoas físicas nos tratados internacionais contra a dupla tributação. Saraiva : São Paulo, 2010.

BERTIN, Olivier. Tax treaty interpretation in Belgium, in Tax treaty interpretation. LANG, Michael (ed). LINDE : Vienna, 2001.

BIANCO, João Francisco. A CIDE sobre royalties e os tratados internacionais contra a dupla tributação, in Grandes Questões Atuais do Direito Tributário vol. 8 (Coord. Valdir de Oliveira Rocha). São Paulo : Dialética, 2004. . Transparência fiscal internacional. São Paulo : Dialética, 2007.

BIANCO, João Francisco. NEWTON, Raquel. Beneficiário efetivo, in Revista Direito Tributário Atual n. 26. São Paulo : IBDT/Dialética, 2011.

BIERLAAGH, Huub M.M. The CARICOM Income Tax Agreement for the Avoidance of (Double) Taxation?, in Bulletin - Tax Treaty Monitor - January. Amsterdã : IBFD, 2000.

BIFANO, Elidie Palma. O Planejamento Tributário Internacional e as Boas Práticas de Governança Corporativa nas Empresas, in Revista de Direito Tributário Internacional - ano 2 - n. 5 - São Paulo : Quartier Latin, 2007. 
BRAUNER, Yariv. Por que os Estados Unidos firmam Tratados Tributários? E por que não têm Tratado Tributário com o Brasil?, in Revista Direito Tributário Atual n. 26. São Paulo : IBDT/Dialética, 2011,

BROE, Luc De. International tax planning and prevention of abuse (doctoral series n. 14). Amsterdã : IBFD, 2007.

BROEKHUIJSEN, Dirk M. A Modern Understanding of Article 31(3)(c) of the Vienna Convention (1969): A New Haunt for the Commentaries to the OECD Model?, in Bulletin for International Taxation, volume 67, n. 9. Amsterdã : IBFD, 2013.

BROWNLIE, IAN. Principles of public international law. Clarendon : Oxford, 1998.

BRUGGEN, Edwin van der. Unless the Vienna Convention Otherwise Requires: notes on the relationship between Art. 3 (2) of the OECD Model Tax Convention and art. 31 and 32 of the Vienna Convention on the Law of Treaties, in European Taxation of May 2003. IBFD : Amsterdam, 2003.

BRUNSCHOT, Frank van. The Judiciary and the OECD Model Tax Convention and its Commentaries, in Bulletin - Tax Treaty Monitor of January 2005. IBFD, 2005, p. 5-11.

CARVALHO, Paulo de Barros. Curso de Direito Tributário. São Paulo : Saraiva, 2000.

CASELLA, Paulo Borba. Direito internacional tributário brasileiro. São Paulo : LTR, 1995. 
CORREA, Walter B. "Subsídios para o Estudo da História Legislativa do Imposto de Renda no Brasil". In MARTINS, Ives G. S. (coord.). Estudos sobre o Imposto de Renda (em memória de Henry Tilbery). S. Paulo: Resenha Tributária. 1994. p. 247- 260

DALLARI, Pedro Bohomoletz de Abreu. Constituição e tratados internacionais. São Paulo : Saraiva, 2003.

DINH, Nguyen Quoc; DAILLER, Patrick; PELLET, Alain. Direito Internacional Público. Lisboa : Fundação Calouste Gulbenkian, 2003.

DINH, Nguyen Quoc; DAILLER, Patrick; PELLET, Alain. Direito Internacional Público. Lisboa : Fundação Calouste Gulbenkian, 2003.

DINIZ, Maria Helena. Dicionário jurídico, São Paulo: Saraiva, 1998.

DÖRR, Oliver. "Introduction: on the role of treaties in the development of international law", in "Vienna Convention on the Law of Treaties: a Commentary". DÖRR, Oliver; SCHMALENBACH, Kirsten (Editors). Springer, 2012.

DZIURDŹ, Kasper; PÖTGENS, Frank. Cross-Border Short-Term Employment, Bulletin for International Taxation Vol. 68, n. 8 (agosto). Amsterdã : IBFD, 2014

EDWARDES-KER, Michael. Tax Treaty Interpretation - The International Tax Treaties Service. In-Depth Publishing : Athlone, 1995.

ENGELEN, Frank; DOUME, Sjoerd. Conference position paper: the quest for the holy grail in international tax law - the legal status of the Commentaries on the OECD Model Tax Convention on Income and on Capital, in The legal status of the OECD Commentaries. Amsterdã : IBFD, 2008.

ENGELEN, Frank. Interpretation of Tax Treaties under International Law. Doctoral series n. 7. IBFD : Amsterdam, 2004. 
FERRAZ JÚNIOR, Tercio Sampaio. Introdução ao Estudo de Direito - Técnica, Decisão, Dominação. 4a ed. São Paulo: Ed. Atlas, 2003.

FITZMAURICE, Malgosia. "The Practical Working of the Law of Treaties", in International Law, 3rd ed. Ed. Evans, Malcolm. Oxford, 2010.

GARDINER, Richard K. International Law. Pearson : Harlaw, 2003.

GOTHENBURG, K. Ahlm. National Report of Sweden. Cahiers de Droit Fiscal International by the International Fiscal Association (studies on international tax law), volume XLII - Subject II: The interpretation of the Double Taxation Convention. / IFA : Rotterdam, 1960.

GROSSFELD, Bernhard; BRYCE, James. A Brief Comparative History of the Origins of the Income Tax in Great Britain, Germany and the United States, in The American Journal of Tax Policy. p. 211-251.

GRUPENMACHER, Betina Treiger. Tratados internacionais em matéria tributária e ordem interna. São Paulo : Dialética.

GUTMANN, Daniel. Tax treaty interpretation in France, in Tax treaty interpretation (Org.: Michael Lang). Viena : Linde, 2001.

HILÚ Neto, Miguel. Imposto sobre importações e imposto sobre exportações. São Paulo : Quartier Latin, 2003.

HOFBAUER, Ines. Tax treaty interpretation in Austria, in Tax treaty interpretation. LANG, Michael (ed). LINDE : Vienna, 2001. 
HOLLIS, Duncan B. Defining treaties, in The Oxford Guide to Treaties (Ed. HOLLIS, Duncan B.). Oxford University Press : Oxford, 2012.

JIMÉNEZ, Adolfo J. Martín. Defining the objective scope of income tax treaties: the impact of the other treaties and EC Law on the Concept of Tax in the OCED Model, in Bulletin - Tax Treaty Monitor - October 2005. Amsterdã : IBFD, 2005, p. 432-444.

JOGARAJAN, Sunita. The conclusion and termination of the 'first' double taxation treaty, in British Tax Review, Vol. 3, 2012.

LANG, Michael. Introduction to the law of double taxation conventions. Vienna : Linde, 2013.

LANG, Michael. The application of the OECD Model Tax Convention to Partnerships - A critical Analysis of the Report Prepared by the OECD Committee on Fiscal Affairs. Viena : Linde, 2000.

Lang, Michael. 2008 OECD Model : conflicts of qualification and double non-taxation, in Bulletin for International Taxation Vol. 63, n. 5. Amsterdã : IBFD, 2009

Lang, Michael. Taxes Covered" - What is a "Tax" according to Article 2 of the OECD Model?, in Bulletin for International Taxation, n. 6. Amsterdã : IBFD, 2005.

LEHNER, Moris. Consideração econômica e tributação conforme a capacidade contributiva. Sobre a possibilidade de uma interpretação teleológica de normas com finalidades arrecadatórias. In: SCHOUERI, Luís Eduardo; ZILVETI, Fernando Aurélio (coords.). Direito tributário: estudos em homenagem a Brandão Machado. São Paulo: Dialética, 2001, p. 143-54. 
LENZ, Raoul. General Report. Cahiers de Droit Fiscal International by the International Fiscal Association (studies on international tax law), volume XLII - Subject II: The interpretation of the Double Taxation Convention. / IFA : Rotterdam, 1960.

MACHADO DE MELLO, Nivaldo Edson. O uso impróprio das convenções bilaterais de dupla tributação, in Revista de Direito Tributário Internacional - ano 1 - n. 2. São Paulo : Quartier Latin, 2006.

MAISTO, Guglielmo. The Observations on the OECD Commentaries in the Interpretation of Tax Treaties, in Bulletin for International Taxation - Agosto, vol. 59, n. 1. Amsterdã : IBFD, 2005.

MARTINS, Ives Gandra da Silva. Revista Dialética de Direito Tributário n ${ }^{\circ}$ 54, Orientação da União para não-pagamento de imposto de renda antes de processo de privatização e ação fiscal posterior à privatização - Princípio da eficácia dos tratados internacionais Princípio da convivência de leis especiais e gerais. Dialética : São Paulo, 2000.

MCDOUGAL, Myres S. The International Law Commission's Draft Articles Upon Interpretation: Textuality Redivivus, in Faculty Scholarship Series - paper 2581. Yale : Yale Law School Legal Scholarship Repository, 1967.

MEIRELLES, Hely Lopes. Direito Administrativo Brasileiro. São Paulo : Edtora Revista dos Tribunais, 1979

MENEZES CORDEIRO, António Manuel da Rocha e. "Introdução à edição portuguesa", in Pensamento sistemático e conceito de sistema na ciência do Direito (Claus-Wilhelm Canaris). Lisboa : Fundação Calouste Gulbenkian, 2008. 
MERKOURIS, Panos. Introduction: Interpretation is a Science, is an Art, is a Science, in Treaty Interpretation and the Vienna Convention on the Law of Treaties. Leiden : Martinus Nijhoff, 2010.

MORENO, Andrés Báez. Contract Splitting and Article 17 of the OECD Model: Is Source Taxation of Artistes and Sportsmen a New Dummensteuer?, in Bulletin for International Taxation vol. 68, n. 3. Amsterdã : 2014.

NAVARRO COELHO, Sacha Calmon. Direito tributário internacional aplicado - volume II. Coordenação Heleno Taveira Tôrres - São Paulo : Quartier Latin, 2004.

NETO, Luís Flávio. A tolerância e a intolerância ao treaty shopping: os casos Prévost, Indofood, Eagle I e Eagle II. Direito Tributário Atual, v. 23, São Paulo : Dialética/IBDT, p. 321-340, 2009.

NOGUEIRA, Ruy Barbosa. Curso de Direito Tributário. São Paulo, Saraiva, 1995.

OCDE. Modelo de Convenção Fiscal sobre o Rendimento e o Patrimônio - Comitê dos Assuntos Fiscais da OCDE. Lisboa : Centro de Estudos Fiscais, 2008.

OCDE. Modelo de Convenção Tributária sobre o Rendimento e o Capital. Versão Condensada, de 22 de julho de 2010. Tradução: Demarest \& Almeida Advogados.

OECD, The Application of the OECD Model Tax Convention to Partnerships, in Issues in International Taxation n. 6. Paris : OECD Publishing, 1999.

OECD, Model Tax Convention on Income and on Capital 2010 (Full Version), OECD Publishing, 2010.

OECD, Model Tax Convention on Income and on Capital 2014 (Full Version), OECD Publishing, 2014. 
ONU. International Law Commission Fifty-Eighth Session. Geneva, 2006. Fragmentation Of International Law: Difficulties Arising From The Diversification and Expansion of International Law - Report of the Study Group of the International Law Commission

ONU. Yearbook of the International Law Commission. Documents of the fourteenth session including the report of the Commission to the General Assembly. ONU, 1962.

ONU. Yearbook of the International Law Commission. 1966. Records on the 866th meeting. ONU, 1966.

ONU. Yearbook of the International Law Commission. 1964, vol. II. Records on the 866th meeting. ONU, 1964.

OPPENHEIM, Lassa. International Law. A treatise. Volume I (of 2) - Peace. Longmans : Londres, 1912.

RAAD, Kees van. International coordination of tax treaty interpretation and application, in International and comparative taxation - essays in honour of Klaus Vogel. KIRCHHOF, Paul et. al. eds London : Kluwer, 2002.

RAAD, Kees van. Interpretation and Application of Tax Treaties by Tax Courts, in European Taxation - January 1996. IBFD : Amsterdã, 1996.

. Nondiscrimination in international tax law. Deventer : Kluwer, 1986

. The term 'Enterprise' in the Model Double Taxation Conventions - Seventy Years of Confusion, in Intertax 1994/11, Intertax, 1994.

. Materials on International, TP and EU Tax Law 2014-2015. Leiden : International Tax Centre Leiden, 2014. 
REALE, Miguel. Lições Preliminares de Direito. São Paulo : Saraiva, 1995.

REIMER, Ekkehart. Interpretation of tax treaties - Germany. European Taxation. IBFD, 1999 (December),

REZEK, José Francisco. Direito internacional público. São Paulo : Saraiva, 2000.

RIBEIRO, Ricardo Lodi. Justiça, Interpretação e Elisão Tributária. Rio de Janeiro: Editora Lumen Juris, 2003

ROCHA, Sergio André. Interpretação dos tratados para evitar a dupla tributação. São Paulo : Quartier Latin, 2013.

ROHATGI, Roy. Basic International taxation. Volume 1: principles. Nova Deli : Taxmann, 2005.

ROMYN, Marcel. Editorial - Changes to OECD Commentary may affect its credibility, in Intertax 1994/11, Intertax, 1994, p. 470-472.

ROTHMANN, Gerd W. A denúncia do acordo de bitributação Brasil-Alemanha e suas consequências, in Grandes Questões Atuais do Direito Tributário vol. 9 (Coord. Valdir de Oliveira Rocha). Dialética : São Paulo, 2005. 
. Interpretação e aplicação dos acordos internacionais contra a bitributação. Tese de doutorado. São Paulo : Faculdade de Direito da Universidade de São Paulo (USP), 1978.

Prefácio, in Interpretação dos tratados para evitar a dupla tributação (Autor: ROCHA, Sergio André). São Paulo : Quartier Latin, 2013, p. 11-21.

ROTONDARO, Carmine. The Application of Art. 3(2) in case of Differences between Domestic Definitions of "Associated Enterprises" - A Problem of Treaty Interpretation and a Proposed Solution, in International Transfer Princing Journal, vol. 7, n. 5. Amsterdã : IBFD, 2000.

SANTIAGO, Igor Mauler. Método de Solução dos Conflitos fundados em Convenções contra a Dupla Tributação Internacional, in Direito Tributário Internacional Aplicado, vol. III. Tôrres, Heleno Taveira (coord.). São Paulo : Quartier Latin, 2005.

SCHARF, Michael P. Customary International Law in Times of Fundamental Charge recognizing Grotian Moments. Cambridge University Press : Cambridge, 2013 SCHMALENBACH, Kirsten. "Preamble", in "Vienna Convention on the Law of Treaties: a Commentary”, DÖRR, Oliver; SCHMALENBACH, Kirsten (Editors). Springer, 2012,

SCHOUERI, Luís Eduardo; SILVA, Natalie Matos. Brazil, in The Impact of the OECD and UN Model Conventions on Bilateral Tax Treaties. (Editores: LANG, Michael; PISTONE, Pasquale; SCHUCH, Josef; STARINGER, Claus). Cambridge : Cambridge University Press, 2012.

SCHOUERI, Luís Eduardo. "Direito tributário internacional. Acordos de bitributação. Imposto de Renda: Lucros auferidos por controladas e coligadas no exterior. 
Disponibilidade. Efeitos do art. 74 da Medida Provisória n. 2.158-35 - Parecer.”, in Revista de Direito Tributário Atual n. 16. São Paulo : IBDT/Dialética, 2001, p. 161-209.

- Arbitragem no Direito Tributário Internacional, in Revista de Direito Tributário Atual n. 23. São Paulo : IBDT/Dialética, 2009.

. Direito Tributário. Saraiva : São Paulo, 2013.

. O princípio do não retrocesso como nova perspectiva à denúncia de acordos de bitributação, in Revista de Direito Tributário Atual n. 29. São Paulo : IBDT/Dialética, 2013, p. 237-249.

. Planejamento Fiscal Através de Acordos de Bitributação (Treaty Shopping).

São Paulo: Ed. Revista dos Tribunais, 1995.

. Preços de transferência no direito tributário brasileiro. São Paulo: Dialética, 2013.

. Residência fiscal da pessoa física, in Revista de Direito Tributário Atual n. 28. São Paulo : IBDT/Dialética, 2012.

- Tratados e Convenções Internacionais sobre Tributação, in Revista de Direito Tributário Atual n. 17. São Paulo : IBDT/Dialética, 2003, p. 20-50.

SCHOUERI, Pedro. Comparison of the OECD and ILADT Model Conventions, in Bulletin for International Taxation - Agosto, volume 68, n. 9. Amsterdã : IBFD, 2014.

SILVA, Bruno Aniceto. The tie-breaker rule (art. 4 of the OECD MC): relevance of domestic law or autonomous interpretation, in Fundamental issues and practical problems in tax treaty interpretation (Editores: SCHILCHER, Michael; WENINGER, Patrick). Linde : Viena, 2008. 
SILVEIRA, Rodrigo Maitto da. Aplicação de Tratados Internacionais Contra a Bitributação - Qualificação de Partnership Joint Ventures. IBDT/Quartier Latin : São Paulo, 2006

SINCLAIR, Ian M. The Viena Convention on the Law of Treaties. Manchester University Press : Manchester, 1973, p. 72-73.

SOOS, Piroska E. The Origins of Taxation at Source in England. Amsterdam:IBFD. 1997. p. $145-167$.

STARKE, Joseph Gabriel; SHEARER, I.A. Starke's international law. Butterworths : Canada, 1994.

THIRLWAY, Hugh. The Sources of International Law. Oxford : Oxford, 2014.

TIPKE, Klaus; LANG, Joachim. Direito tributário (Steuerrecht). Volume 1. Tradução da 18a edição alemã, totalmente refeita, de Luíz Dória Furquim. Porto Alegre : Sergio Antonio Fabris Editor, 2008

TOIT, Charl du. The Evolution of the Term "Beneficial Ownership" in Relation to International Taxation over the Past 45 Year, in Bulletin for International Taxation Vol. 64, n. 10. Amsterdã : IBFD, 2010.

TÔRRES, Heleno Taveira. O combate à evasão e à elisão tributária de caráter internacional, in Revista Internacional de Direito Internacional - ABRADT, vol. 1, n. 2. Del Rey : Belo Horizonte, 2004, p. 151-175. 
Pluritributação internacional sobre as rendas das empresas. São Paulo : Revista dos Tribunais, 2001

Tratados e convenções internacionais em matéria tributária e o federalismo fiscal brasileiro, in Revista Dialética de Direito Tributário $n^{\circ}$ 86. Dialética : São Paulo, 2002.

UCKMAR, Victor; CORASANITI, Giuseppe; VIMERCATE, Paolo de'Capitani; OLIVA, Caterina Corrado (aspectos gerais); GRECO, Marco Aurélio; ROCHA, Sérgio André (sistema brasileiro). Manual de Direito Tributário Internacional. Dialética : São Paulo, 2012.

UCKMAR, Victor. Double Taxation Conventions, in International Tax Law (Ed. Andrea Amatucci). Klumer : Netherlands, 2006.

VANN, Richard J. International Aspects od Income Tax, in Tax Law Design and Drafting (Ed. THURONYI, Victor). Londres : Kluwer, 1998.

VANONI, Ezio. Natureza e interpretação das leis tributarias. Trad. Rubens Gomes de Souza. Rio de Janeiro : Edições Financeiras, 1932.

VASCONCELLOS, Roberto França. Aspectos Econômicos dos Tratados Internacionais em Matéria Tributária, in Revista de Direito Tributário Internacional n. 1. São Paulo: Quartier Latin, 2005, p. 147-191.

VOGEL, Klaus; PROKISCH, Rainer G. Cahiers de Droit Fiscal International by the International Fiscal Association (studies on international tax law), volume LXXVIIIa Subject I. Interpretation of double taxation conventions. Kluwer Law and Taxation Publishers / IFA : Rotterdam, 1993 
VOGEL, Klaus. Double tax treaties and their interpretation, in Berkeley Journal of International Law v. 4. 1986.

. Klaus Vogel on Double Taxation Convention, Kluwer : London, 1997.

. Klaus Vogel on Double Taxation Conventions. Kluwer : London, 1999.

. Problemas na interpretação de acordos de bitributação, in Direito Tributário

- Homenagem a Alcides Jorge Costa, vol. 2. (Coord. Luis Eduardo Schoueri). São Paulo: Quartier Latin, 2003

. The influence of the OECD Commentaries on Treaty Interpretation, in Bulletin - Tax Treaty Monitor - December 2000. IBFD : Amsterdã, 2000.

WALTON, Douglas. Legal argumentation and evidence. Pennsylvania State Press : Pennsylvania, 2002

WIJNEN, Wim. Some Thoughts on Convergence and Tax Treaty Interpretation, in Tax Treaty Monitor - Bulletin for International Taxation (November 2013). IBFD: Amsterdã, 2013, p. 575-579.

XAVIER, Alberto. Direito tributário internacional do Brasil. Forense : Rio de Janeiro, 2010.

. Tipicidade da tributação, simulação e norma antielisão. São Paulo : Dialética, 2002. 


\section{CONTEÚDOS DA INTERNET}

Receita Federal. Acordos de dupla tributação brasileiros. Último acesso em 29/12/2014, no endereço

eletrônico:

http://www.receita.fazenda.gov.br/Legislacao/AcordosInternacionais/AcordosDuplaTrib.ht m\#Trinidad\%20e\%20Tobago

Acordo de dupla tributação Reino Unido-EUA. Último acesso em 01/11/2014, no endereço eletrônico $\quad \underline{\mathrm{http}} / / /$ online.ibfd.org/kbase/\#topic=doc\&url=/data/treaty/docs/html/tt_ukus_01_eng_1945_tt_td1.html\&WT.z_nav=Navigation\&colid=4932

Andean Community Income and Capital Model Tax Treaty. Último acesso em 01/11/2014, no endereço eletrônico http://online.ibfd.org/kbase/\#topic=doc\&url=/collections/ttmodel/html/tt_a1_02_eng_1971 mo td1.html\&WT.z nav=Navigation\&colid=4933.

Belgium Income and Capital Model Convention. Último acesso em 01/11/2014, no endereço eletrônico http://online.ibfd.org/kbase/\#topic=doc\&url=/collections/ttmodel $/ \mathrm{html} / \mathrm{tt} \_$be_02_eng_2010 mo td1.html\&WT.z_nav=Navigation\& colid=4933.

Cook v. Tait - 265 U.S. 47 (1924). Acesso em: http://supreme.justia.com/cases/federal/us/265/47/

IBFD (decisões de tribunais nacionais, acordos de bitributação entre diversos Estados, modelos de acordos de bitributação, trabalhos acadêmicos). Último acesso em 20.12.2014: www.ibfd.org. 
FONTOURA, Jorge. A era dos tratados. Último acesso em 1/09/2014, por meio do endereço eletrônico http://www.gazetadopovo.com.br/colunistas/conteudo.phtml?id=1421372).

ICJ e PJCJ (decisões). Último acesso em 10.7.2014: http://www.icj-cij.org

Modelo ILADT de Convenio Multilateral de Doble Imposición para América Latina, in Cuaderno Tributario ICDT, Agosto. Santiago de Compostela : ILADT, 2012. Último acesso em 31/10/2014, por meio do endereço eletrônico http://www.iladt.org/frontend/DocumentPage.aspx.

Trabalhos preparatórios do acordo de dupla tributação Brasil-Áustria. Último acesso em 7/10/2014, no endereço eletrônico http://www.ibdt.com.br/p117.

Último acesso em 20/10/2014, no endereço eletrônico http://www.oecd.org/legal/Rules\%20of\%20Procedure\%20OECD\%200ct\%202013.pdf.)

United Nations. Model Double Taxation Convention between Developed and Developing Countries. Nova Iorque : ONU, 2011. Último acesso em 01/11/2014, no endereço eletrônico http://www.un.org/esa/ffd/documents/UN_Model 2011 Update.pdf.

UNITED STATES MODEL INCOME TAX CONVENTION. Último acesso em 01/11/2014, no endereço eletrônico http://www.irs.gov/pub/irs-trty/model006.pdf. 